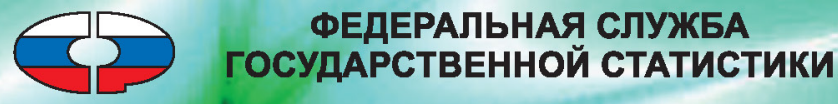

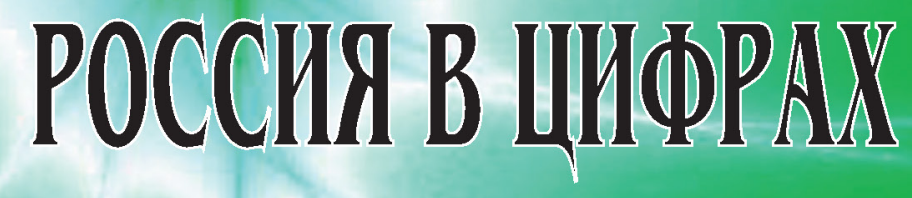

ОФИЦИАЛЬНОЕ ИЗДАНИЕ 
ФЕДЕРАЛЬНАЯ СЛУЖБА

ГОСУДАРСТВЕННОЙ СТАТИСТИКИ

(Росстат)

\section{РОССИЯ В ЦИФРАХ \\ 2018}

Краткий статистический сборник

Москва

2018 
УДК 31(470)

ББК 65.051.5 (2Poc)

P76

Редакционная коллегия:

А.Е. Суринов - Председатель редакционной коллегии

Э.Ф. Баранов, Т.С. Безбородова, С.Н. Бобылев, Н.С. Бугакова, , Л.М. Гохберг, Л.М. Григорьев, С.Н.Егоренко, В.В. Елизаров, В.Б. Житков, Ю.Н. Иванов, А.Л. Кевеш, А.Е. Косарев, К.Э. Лайкам, Т.М. Малева, И.Д. Масакова, В.Н. Нестеров, Г.К. Оксенойт, О.П. Рыбак, Б.Т. Рябушкин, М.А. Сабельникова, А.А. Татаринов, К.А. Тузов, А.В. Хорошилов

Россия в цифрах. 2018: Крат.стат.сб./Росстат- М., P76 $2018-522$ c.

ISBN 978-5-89476-450-4

В сборнике представлена информация о социальноэкономическом положении России в 2017 г. в сравнении с предыдущими годами.

Помещены данные, характеризующие государственное устройство Российской Федерации, производство и использование валового внутреннего продукта. Представлена информация о населении, его занятости и денежных доходах. Публикуются сведения о проблемах социальной сферы, результатах научных разработок и инновационной деятельности, инвестициях, финансовом состоянии, ценах и тарифах. Часть материалов сборника посвящена положению организаций различных видов экономической деятельности. Отражена внешнеэкономическая деятельность Российской Федерации. Приведены отдельные международные сравнения.

Для высшего управленческого персонала, руководителей и работников предприятий и организации, научных, предпринимательских и банковских кругов, профессорскопреподавательского состава, аспирантов и студентов экономических вузов, других заинтересованных пользователей.

Удк 31(470)

ББК 65.051.5 (2Poc)

ISBN 978-5-89476-450-4

(c) Федеральная служба государственной статистики, 2018

E-mail: stat@gks.ru http://www.gks.ru 


\section{ПРЕДИСЛОВИЕ}

В кратком статистическом сборнике публикуются основные показатели, характеризующие социально-экономическое положение России в 2017 г. в сравнении с рядом предшествующих лет.

Сборник подготовлен Федеральной службой государственной статистики на основе данных, получаемых органами государственной статистики от предприятий, организаций, населения в ходе проведения статистических наблюдений, переписей, выборочных обследований, данных министерств и ведомств Российской Федерации, а также информации, получаемой от организаций, которые проводят обследования, опросы по сбору сведений экономического и социального характера, и материалов международных организаций.

Открывают сборник основные социально-экономические характеристики Российской Федерации, информация, содержащая описание географического положения Российской Федерации, сведения о природных ресурсах, национальном богатстве и окружающей среде.

В тематических разделах приведены данные, отражающие демографические процессы, проблемы занятости и безработицы, денежные доходы населения. Представлены сведения о производстве валового внутреннего продукта и его использовании. Помещена информация о социальной сфере, науке, инновациях и информационных технологиях, инвестициях, финансовом состоянии, ценах и тарифах. Один из разделов сборника содержит общую характеристику предприятий и организаций, информацию о малом и индивидуальном предпринимательстBe.

Значительная часть материалов сборника освещает положение в организациях отдельных видов экономической деятельности - промышленности, сельского, лесного хозяйства, рыболовства и рыбоводства, строительства, транспорта, в организациях, обслуживающих население.

Внешнеэкономическая деятельность представлена данными о внешней торговле. Приведена информация по международным сравнениям России с некоторыми зарубежными странами.

В связи с переходом с 1 января 2017 года на новые редакции общероссийских классификаторов видов экономической деятельности (ОКВЭД2) ОК 029-2014 и продукции по видам 
экономической деятельности (ОКПД2) ОК 034-2014 описание структуры российской экономики представлено в сборнике в соответствии с группировками этих классификаторов, которые разработаны Минэкономразвития России во исполнение «Плана мероприятий по формированию методологии систематизации и кодирования информации, а также совершенствованию и актуализации общероссийских классификаторов, реестров и информационных ресурсов».

ОКВЭД2 и ОКПД2 приняты и введены в действие приказом Росстандарта от 31.01.2014 № 14-ст (с изменениями).

В ОКВЭД2 по сравнению с ОКВЭД-2007 добавились следующие новые разделы:

«Е» «Водоснабжение; водоотведение, организация сбора и утилизации отходов, деятельность по ликвидации загрязнений»;

«J» «Деятельность в области информации и связи» (издательская, телекоммуникационная, программное обеспечение, радио, телевидение, кино);

«N» «Деятельность административная и сопутствующие дополнительные услуги» (аренда, лизине, трудоустройство, туризм, услуги охранных служб, детективов);

«R» «Деятельность в области культуры, спорта, организации досуга и развлечений».

В связи с тем, что результатами экономической деятельности хозяйствующих субъектов являются произведенные товары и услуги, аналогичные изменения произошли также в структуре ОКПД2.

В качестве справочного инструмента могут использоваться переходные ключи между старыми и новыми версиями ОКВЭД и ОКПД, разработанные Минэкономразвития России, и размещенные на его официальном сайте в сети Интернет по адресу: http://economy.gov.ru/minec/activity/sections/classificators.

ОКВЭД2 и ОКПД2 гармонизированы с европейскими классификациями NACE Rev.2 и CPA 2008, а также с международными классификациями Статистической комиссии ОOH: ISIC Rev.4 и CPC Ver.2, что позволяет проводить статистические сопоставления на международном и национальном уровнях.

По показателям в разрезе видов экономической деятельности в сборнике приводится статистическая информация за 2017 г. в соответствии с Общероссийским классификатором ОКВЭД2. Данные по видам экономической деятельности за предыдущие периоды в соответствии с ОКВЭД2 будут публико- 
ваться по мере проведения в 2018-2019 годах Росстатом по согласованию с Минэкономразвития России соответствующих пересчетов ретроспективных динамических рядов статистических показателей.

Аналогичные сведения за период до 2016 г. включительно, разработанные в соответствии с ранее действовавшим Общероссийским классификатором видов экономической деятельности (ОКВЭД-2007) ОК 029-2007 и Общероссийским классификатором продукции по видам экономической деятельности (ОКПД) (КПЕС 2002) ОК 034-2007, опубликованы в кратком статистическом сборнике «Россия в цифрах. 2017», электронная версия которого размещена на официальном Интернет-портале Росстата в разделе «Публикации».

По отдельным показателям данные за 2016 г. уточнены по сравнению с опубликованными ранее, за 2017 г. в ряде случаев являются предварительными. По некоторым показателям последние данные приведены за 2016 г. в сравнении с предыдущими годами, за 2017 г. - будут представлены в «Российском статистическом ежегоднике. 2018» и тематических сборниках.

Более подробные данные о социально-экономическом положении России за ряд лет будут опубликованы в «Российском статистическом ежегоднике» и других официальных статистических изданиях Росстата, перечень которых приведен в Плане выпуска публикаций в 2018 году, размещенном на официальном Интернет-портале Росстата. 


\section{ОТВЕТСТВЕННЫЕ ЗА РАЗДЕЛЫ СБОРНИКА}

Государственное устройство

Российской Федерации

Национальное богатство

Охрана окружающей среды

Население

Труд

Уровень жизни населения

Образование

Здравоохранение

Культура, отдых и туризм

Общественные объединения и религиозные организации

Правонарушения

Производство и использование валового внутреннего продукта Инвестиции

Предприятия и организации

Промышленное производство

Сельское, лесное хозяйство, рыболовство и рыбоводство

Строительство

Торговля и услуги населению

Транспорт

Информационные и коммуникационные технологии

Наука и инновации

Финансы

Цены и тарифы

Внешнеэкономическая

деятельность

Международные сравнения
3.Ж. Зайнуллина

Л.Б. Кузьмичева

Е.В. Зарубина

H.В. Шашлова

Н.В. Шашлова

С.Ю. Никитина

3.Ж. Зайнуллина

Е.Б. Фролова

3.Ж. Зайнуллина

Н.А. Власенко

О.Ю. Дудорова

С.Ю. Никитина

О.Ю. Дудорова

Л.Б. Кузьмичева

Л.Б. Кузьмичева

3.Ж. Зайнуллина

Е.Б. Фролова

Л.Б. Кузьмичева

Е.В. Зарубина

Н.А. Власенко

Л.Н. Кобринская

Н.В. Воробьева

Е.А. Шустова

Н.В. Шашлова

Е.А. Шустова

Н.В. Шашлова

Е.А. Шустова

Л.Б. Кузьмичева

Н.А. Власенко

Л.Б. Кузьмичева

Л.Б. Кузьмичева

О.Ю. Дудорова

О.Ю. Дудорова

Л.Н. Кобринская

Л.Н. Кобринская

Л.Б. Кузьмичева

И.Е. Харитонов

Е.В. Зарубина
Телефоны

(495) 607-4117

607-2785

$607-4256$

607-2862

607-2862

607-2605

$607-4117$

607-4801

$607-4117$

$607-4780$

$607-4585$

607-2605

607-4585

607-2785

607-2785

$607-4117$

607-4801

607-2785

607-4256

$607-4780$

$607-4447$

632-9192

$607-2220$

607-2862

607-2220

607-2862

$607-2220$

$607-2785$

$607-4780$

607-2785

607-2785

607-4585

607-4585

607-4447

607-4447

607-2785

607-2620

$607-4256$ 


\section{УСЛОВНЫЕ ОБОЗНАЧЕНИЯ ЕДИНИЦ ИЗМЕРЕНИЯ}

\begin{tabular}{|c|c|}
\hline тыс. & - тысяча \\
\hline млн. & - миллион \\
\hline млрд. & - миллиард \\
\hline трлн. & - триллион \\
\hline MM & - миллиметр \\
\hline M & - метр \\
\hline погг. м & - погонный метр \\
\hline $\mathrm{M}_{3}^{2}$ & - квадратный метр \\
\hline$M^{3}$ & - кубический метр \\
\hline $\mathrm{KM}$ & - километр \\
\hline $\mathrm{KM}_{3}^{2}$ & - квадратный километр \\
\hline $\mathrm{KM}^{3}$ & - кубический километр \\
\hline$\Gamma$ & - грамм \\
\hline КГ & - килограмм \\
\hline $\mathrm{T}$ & - тонна \\
\hline $\mathrm{T} \cdot \mathrm{KM}$ & - тонно-километр \\
\hline$ת$ & - литр \\
\hline дкл & - декалитр \\
\hline га & - гектар \\
\hline КВт & - киловатт \\
\hline кВт.ч & - киловатт-час \\
\hline ккал & - килокалория \\
\hline Гкал & - гигакалория \\
\hline л.с. & - лошадиная сила \\
\hline Г. & - год \\
\hline долл. & - доллар \\
\hline руб. & - рубль \\
\hline p. & - раз \\
\hline ШТ. & - штука \\
\hline ЭКЗ. & - экземпляр \\
\hline
\end{tabular}

\section{СПИСОК СОКРАЩЕНИЙ}

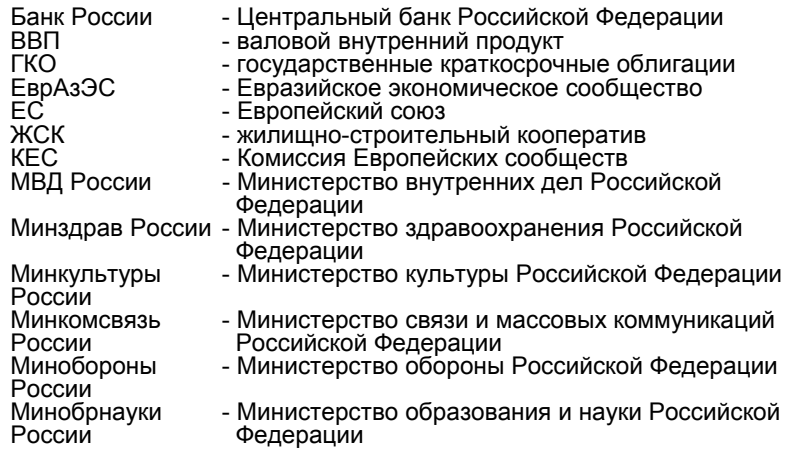




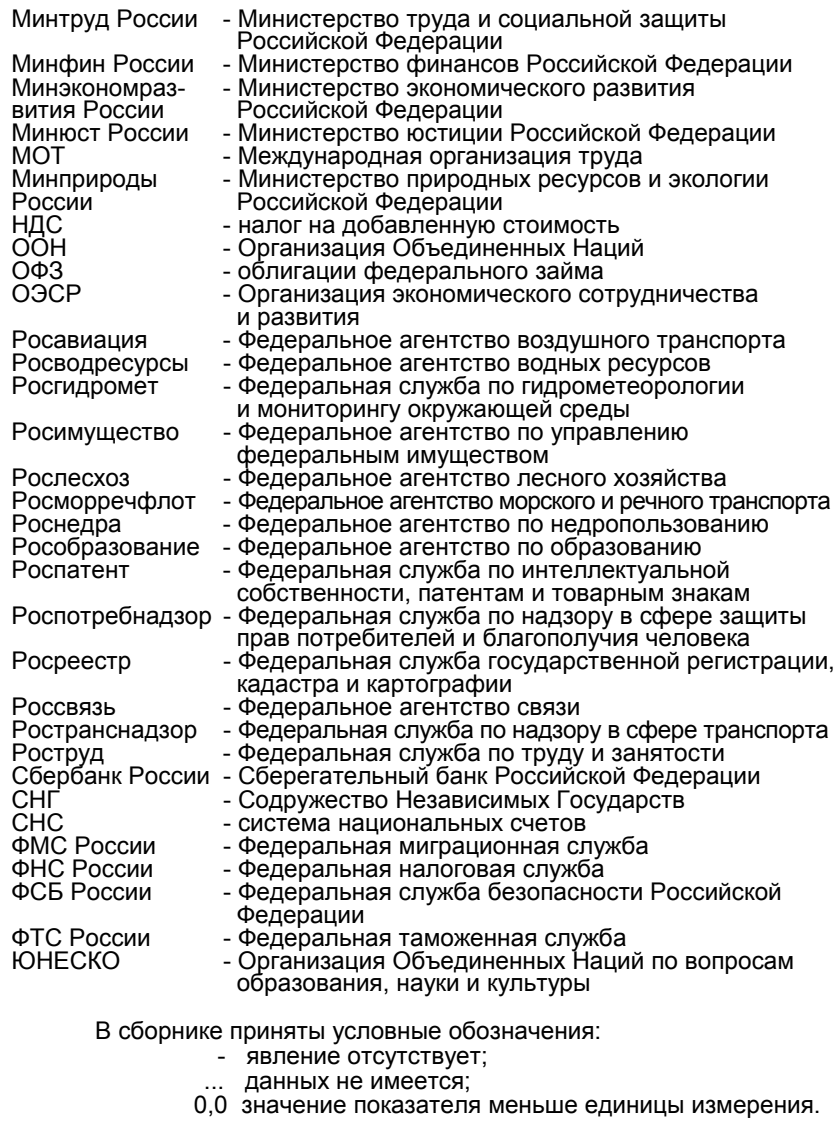

В отдельных случаях незначительные расхождения между итогом и суммой слагаемых объясняются округлением данных.

Значения стоимостных показателей начиная с 1998 г. приведены с учетом изменения нарицательной стоимости российских денежных знаков (уменьшение в 1000 раз) и в масштабе цен, действующем с 1 января 1998 г., за остальные годы - в нарицательной стоимости денежных знаков соответствующих лет. 


\section{СОДЕ Р Ж А И Е}

Предисловие

1. ОСНОВНЫЕ СОЦИАЛЬНО-ЭКОНОМИЧЕСКИЕ ХАРАКТЕРИСТИКИ РОССИЙСКОЙ ФЕДЕРАЦИИ

1.1. Основные социально-экономические показатели .....

1.2. Динамика основных социально-экономических показателей

1.3. Основные социально-экономические показатели по субъектам Российской Федерации в 2017 г.

\section{2. ГОСУДАРСТВЕННОЕ УСТРОЙСТВО РОССИЙСКОЙ ФЕДЕРАЦИИ}

2.1. Государственное устройство Российской Федерации

2.2. Муниципальные образования на 1 января 2018 г.

2.3. Характеристики муниципальных образований в субъектах Российской Федерации в 2017 г.

2.4. Численность работников государственных органов и органов местного самоуправления по ветвям власти и уровням управления

2.5. Состав Федерального Собрания Российской Федерации

\section{3. НАЦИОНАЛЬНОЕ БОГАТСТВО}

\section{Национальное богатство}

3.1. Баланс активов и пассивов

3.2. Индексы изменения стоимости, коэффициенты обновления и выбытия основных фондов

по видам экономической деятельности в 2017 г. ....

3.3. Наличие и степень износа основных фондов по видам экономической деятельности на конец 2017 г.

Природные ресурсы

3.4. Земельная площадь ............................................... 66

3.5. Водные ресурсы ............................................. 67

3.6. Среднемноголетние запасы (объем) воды в крупнейших озерах и водохранилищах 


\section{4. ОХРАНА ОКРУЖАЮЩЕЙ СРЕДЫ}

4.1. Основные показатели, характеризующие воздействие хозяйственной деятельности на окружающую среду и природные ресурсы ....................... 70

4.2. Особо охраняемые природные территории .......... 70

4.3. Государственные природные заповедники и национальные парки

4.4. Инвестиции в основной капитал, направленные на охрану окружающей среды и рациональное использование природных ресурсов

4.5. Ввод в действие мощностей по охране водных ресурсов и атмосферного воздуха от загрязнения

4.6. Экологические инновации

\section{5. НАСЕЛЕНИЕ}

5.1. Численность населения

5.2. Распределение численности населения по возрастным группам

5.3. Возрастно-половая структура населения на 1 января 2017 г. (диаграмма)

5.4. Естественное движение населения

5.5. Общие коэффициенты естественного движения населения

5.6. Браки и разводы

5.7. Коэффициенты смертности по основным классам причин смерти

5.8. Ожидаемая продолжительность жизни при рождении

5.9. Международная миграция

5.10. Численность вынужденных мигрантов

\section{6. ТРУД}

6.1. Численность и состав рабочей силы

6.2. Уровень участия в рабочей силе, уровень занятости и уровень безработицы населения

6.3. Численность населения по статусу участия в составе рабочей силы в 2017 г. 
6.4. Среднегодовая численность занятых по видам экономической деятельности в 2017 г.

6.5. Темпы роста (снижения) производительности труда по видам экономической деятельности

6.6. Численность занятых по полу и занятиям в 2017 г.

6.7. Распределение численности занятых по возрастным группам и уровню образования в 2017 г.

6.8. Численность занятых в России и некоторых зарубежных странах по видам экономической деятельности

6.9. Численность иностранных граждан, получивших разрешительные документы на работу в России .... 100

6.10. Численность иностранных граждан, имевших действующее разрешение на работу

6.11. Численность иностранных граждан, имевших действующий патент на осуществление трудовой деятельности

6.12. Численность безработных 103

6.13. Распределение численности безработных по возрастным группам и уровню образования в 2017 г.

6.14. Распределение численности занятых и безработных по семейному положению в 2017 г. 105

6.15. Распределение численности безработных по наличию прошлого опыта работы и обстоятельствам незанятости в 2017 г.

6.16. Трудоустройство населения органами службы занятости населения

6.17. Забастовки 107

6.18. Травматизм на производстве 108

6.19. Профессиональные заболевания (отравления) 108

\section{7. УРОВЕНЬ ЖИЗНИ НАСЕЛЕНИЯ}

\section{Индикаторы уровня жизни населения}

7.1. Основные социально-экономические индикаторы уровня жизни населения

7.2. Фактическое конечное потребление домашних хозяйств

7.3. Фактическое конечное потребление домашних хозяйств (диаграмма) 
7.4. Изменение фрактического конечного потребления домашних хозяйств

Доходы и расходы населения

7.5. Состав и использование денежных доходов населения

7.6. Структура денежных доходов и расходов населения

7.7. Среднемесячная номинальная начисленная заработная плата работников организаций по видам экономической деятельности в 2017 г. ... 123

7.8. Среднемесячная начисленная заработная плата работников организаций

7.9. Распределение населения по величине среднедушевых денежных доходов

7.10. Распределение общего объема денежных доходов населения

7.11. Величина прожиточного минимума 126

7.12. Состав потребительских расходов домашних хозяйств

7.13. Структура потребительских расходов домашних хозяйств

7.14. Наличие предметов длительного пользования в домашних хозяйствах

\section{Жилищные условия населения}

7.15. Жилищный фонд

7.16. Приватизация жилищного фонда

7.17. Предоставление жилых помещений гражданам

7.18. Развитие инфраструктуры сельской местности

7.19. Число зарегистрированных прав на жилые помещения на основании договоров куплипродажи гражданам и юридическим лицам

\section{8. ОБРАЗОВАНИЕ}

8.1. Организации, осуществляющие образовательную деятельность по образовательным программам дошкольного образования, присмотр и уход за детьми

8.2. Организации, осуществляющие образовательную деятельность по образовательным программам начального, основного и среднего общего образования 
8.3. Сменность занятий в организациях, осуществляющих образовательную деятельность по образовательным программам начального, основного и среднего общего образования

8.4. Образовательные организации, осуществляющие образовательную деятельность по программам подготовки квалифицированных рабочих, служащих специалистов среднего звена

8.5. Образовательные организации высшего образования и научные организации, осуществляющие образовательную деятельность по программам бакалавриата, специалитета, магистратуры

8.6. Прием на обучение по программам бакалавриата, специалитета, магистратуры и выпуск бакалавров, специалистов, магистров

8.7. Численность иностранных студентов, обучающихся по образовательным программам высшего образования - программам бакалавриата, программам специалитета, программам магистратуры в государственных и муниципальных организациях

8.8. Численность иностранных студентов, обучающихся по образовательным программам высшего образования - программам бакалавриата, программам специалитета, программам магистратуры в частных организациях

8.9. Конкурс на вступительных экзаменах в государственных и муниципальных профессиональных образовательных организациях, образовательных организациях высшего образования и научных организациях (диаграмма)

\section{9. ЗДРАВООХРАНЕНИЕ}

9.1. Основные показатели здравоохранения

9.2. Заболеваемость населения по основным классам болезней в 1992-1998 гг.

9.3. Заболеваемость населения по основным классам болезней в 2000-2016 гг.

9.4. Численность лиц в возрасте 18 лет и старше, впервые признанных инвалидами

9.5. Санаторно-курортные организации и организации отдыха 


\section{0. КУЛЬТУРА, ОТДЫХ И ТУРИЗм}

10.1. Общедоступные библиотеки .................................. 156

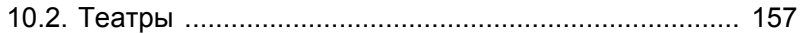

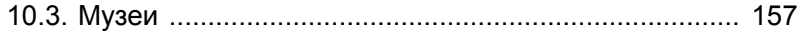

10.4. Число организаций культурно-досугового типа ...... 158

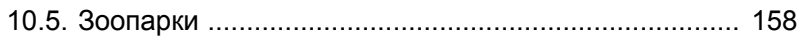

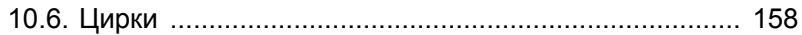

10.7. Выпуск книг и брошюр, журналов и газет .............. 159

10.8. Охват населения теле- и радиовещанием в 2016 г. ..... 160

10.9. Детские оздоровительные лагеря ......................... 161

10.10. Число гостиниц и аналогичных средств размещения ...... 161

10.11. Число въездных туристских поездок иностранных граждан в Россию ................................................ 162

10.12. Число выездных туристских поездок граждан России в зарубежные страны

\section{1. ОБЩЕСТВЕННЫЕ ОБЪЕДИНЕНИЯ И РЕЛИГИОЗНЫЕ ОРГАНИЗАЦИИ}

11.1. Число общественных объединений, политических партий и некоммерческих организаций, зарегистрированных в Российской Федерации, на конец 2017 г.

11.2. Среднесписочная численность и среднемесячная начисленная заработная плата работников общественных объединений

11.3. Число некоммерческих организаций по видам ....... 165

11.4. Число религиозных организаций, зарегистрированных в Российской Федерации, на конец 2017 г.

11.5. Участие населения в деятельности общественных, добровольных и благотворительных организаций (движений) в 2016 г.

\section{2. ПРАВОНАРУШЕНИЯ}

12.1. Число зарегистрированных преступлений

12.2. Состав лиц, совершивших преступления, по полу, возрасту и виду занятий

12.3. Распределение осужденных по основным мерам наказания, назначенным судами 
12.4. Численность осужденных по приговорам судов, вступившим в законную силу, по отдельным видам преступлений

12.5. Состав осужденных 173

\section{3. ПРОИЗВОДСТВО И ИСПОЛЬЗОВАНИЕ ВАЛОВОГО ВНУТРЕННЕГО ПРОДУКТА}

13.1. Производство валового внутреннего продукта ....... 179

13.2. Структура выпуска по отраслям экономики ............ 179

13.3. Структура валовой добавленной стоимости по отраслям экономики

13.4. Валовой внутренний продукт по источникам доходов

13.5. Валовой внутренний продукт по источникам доходов (в процентах)

13.6. Использование валового внутреннего продукта 182

13.7. Использование валового внутреннего продукта (в процентах) 183

\section{4. ИНВЕСТИЦИИ}

\section{Инвестиции в нефинансовые активы}

14.1. Инвестиции в нефинансовые активы 186

14.2. Инвестиции в основной капитал 186

14.3. Инвестиции в основной капитал по формам собственности

14.4. Инвестиции в основной капитал по формам собственности (в процентах)

14.5. Инвестиции в основной капитал по источникам финансирования

14.6. Инвестиции в основной капитал по источникам финансирования (в процентах)

14.7. Инвестиции в основной капитал по видам экономической деятельности в 2017 г.

14.8. Инвестиции в основной капитал по видам основных фондов в 2017 г.

\section{Иностранные инвестиции}

14.9. Прямые иностранные инвестиции в экономику России по основным странам-инвесторам 
14.10. Прямые инвестиции из России в экономику стран - крупнейших получателей прямых инвестиций

Финансовые вложения

14.11. Финансовые вложения организаций по видам экономической деятельности в 2017 г. 196

\section{5. ПРЕДПРИЯТИЯ И ОРГАНИЗАЦИИ}

\section{Общая характеристика предприятий и организаций}

15.1. Число организаций по видам экономической деятельности

15.2. Распределение предприятий и организаций по формам собственности

15.3. Оборот организаций по видам экономической деятельности

\section{Малое предпринимательство}

15.4. Число малых предприятий (без микропредприятий) по видам экономической деятельности в 2017 г.

15.5. Численность работников малых предприятий (без микропредприятий) по видам экономической деятельности в 2017 г.

15.6. Оборот малых предприятий (без микропредприятий) по видам экономической деятельности в 2017 г.

15.7. Удельный вес крестьянских (фермерских) хозяйств в общем объеме производства основных видов сельскохозяйственной продукции (диаграмма)

Индивидуальное предпринимательство

15.8. Основные показатели деятельности индивидуальных предпринимателей по видам экономической деятельности в 2016 г.

16. ПРОМЫШЛЕННОЕ ПРОИЗВОДСТВО

Общеэкономические показатели организаций по видам экономической деятельности в сфере промышленного производства

16.1. Основные экономические показатели деятельности организаций 
16.2. Структура объема отгруженных товаров собственного производства, выполненных работ и услуг собственными силами по видам экономической деятельности

\section{Основные показатели работы организаций отдельных видов экономической деятельности}

16.3. Основные показатели работы организаций по виду экономической деятельности «Добыча полезных ископаемых»

16.4. Добыча и переработка основных видов полезных ископаемых

16.5. Основные показатели работы организаций по виду экономическои деятельности «Обрабатывающие производства»

16.6. Основные показатели работы организаций по виду экономической деятельности «Производство пищевых продуктов»

16.7. Производство основных видов пищевых продуктов

16.8. Основные показатели работы организаций по виду экономической деятельности «Производство напитков»

16.9. Производство напитков

16.10. Основные показатели работы организаций по виду экономическои деятельности «Производство табачных изделий»

16.11. Производство табачных изделий 228

16.12. Основные показатели работы организаций по виду экономической деятельности «Производство текстильных изделий»

16.13. Производство основных видов текстильных изделий

16.14. Основные показатели работы организаций по виду экономическои деятельности «Производство одежды»

16.15. Производство основных видов одежды 230

16.16. Основные показатели работы организаций по виду экономическои деятельности «Производство кожи и изделий из кожи»

16.17. Производство основных видов кожи и изделий из кожи 
16.18. Основные показатели работы организаций по виду экономическои деятельности «Обработка древесины и производство изделий из дерева и пробки, кроме мебели, производство изделий из соломки и материалов для плетения».

16.19. Производство основных видов продукции деревообработки

16.20. Основные показатели работы организаций по виду экономической деятельности «Производство бумаги и бумажных изделий»

16.21. Производство основных видов бумаги и изделий из бумаги

16.22. Основные показатели работы организаций по виду экономическои деятельности «Производство кокса и нефтепродуктов»

16.23. Производство кокса и основных видов нефтепродуктов

16.24. Основные показатели работы организаций по виду экономическои деятельности «Производство химических веществ и химических продуктов»

16.25. Производство основных видов химических веществ и химических продуктов

16.26. Основные показатели работы организаций по виду экономическои деятельности «Производство резиновых и пластмассовых изделий»

16.27. Производство основных видов резиновых и пластмассовых изделий

16.28. Основные показатели работы организаций по виду экономическои деятельности «Производство прочей неметаллической минеральной продукции»

16.29. Производство основных видов прочей неметаллической минеральной продукции

16.30. Основные показатели работы организаций по виду экономической деятельности «Производство металлургическое»

16.31. Производство основных видов продукции металлургического производства 
16.32. Основные показатели работы организаций по виду экономическои деятельности «Производство готовых металлических изделий, кроме машин и оборудования»

16.33. Производство основных видов готовых металлических изделий, кроме машин и оборудования

16.34. Основные показатели работы организаций по виду экономическои деятельности «Производство машин и оборудования, не включенных в другие группировки»

16.35. Производство основных видов машин и оборудования, не включенных в другие группировки

16.36. Основные показатели работы организаций по виду экономическои деятельности «Производство компьютеров, электронных и оптических изделий»

16.37. Производство основных видов компьютеров, электронных и оптических изделий

16.38. Основные показатели работы организаций по виду экономическои деятельности «Производство электрического оборудования»

16.39. Производство основных видов электрического оборудования

16.40. Основные показатели работы организаций по виду экономической деятельности «Производство автотранспортных средств, прицепов и полуприцепов»

16.41. Производство основных видов автотранспортных средств и оборудования, прицепов и полуприцепов

16.42. Основные показатели работы организаций по виду экономическои деятельности «Производство прочих транспортных средств и оборудования»

16.43. Производство основных видов прочих транспортных средств и оборудования

16.44. Основные показатели работы организаций по виду экономическои деятельности «Обеспечение электрической энергией, газом и паром; кондиционирование воздуха»

16.45. Производство электроэнергии и теплоэнергии 245 


\section{7. СЕЛЬСКОЕ, ЛЕСНОЕ ХОЗЯЙСТВО, РЫБОЛОВСТВО И РЫБОВОДСТВО}

\section{Сельское хозяйство}

Основные показатели сельского хозяйства

17.1. Продукция сельского хозяйства по категориям хозяйств

17.2. Продукция сельского хозяйства по категориям хозяйств (в процентах)

17.3. Индексы производства продукции сельского хозяйства по категориям хозяйств

17.4. Производство основных видов сельскохозяйственной продукции по категориям хозяйств

17.5. Основные показатели производственной деятельности сельскохозяйственных организаций

17.6. Производство основных видов сельскохозяйственной продукции в хозяйствах населения

17.7. Производство основных видов сельскохозяйственной продукции крестьянскими (фермерскими) хозяйствами

17.8. Парк основных видов техники в сельскохозяйственных организациях

17.9. Обеспеченность сельскохозяйственных организаций тракторами и комбайнами

17.10. Внесение минеральных удобрений под посевы в сельскохозяйственных организациях

17.11. Внесение органических удобрений под посевы в сельскохозяйственных организациях

\section{Растениеводство}

17.12. Посевные площади сельскохозяйственных культур

17.13. Посевные площади сельскохозяйственных культур по категориям хозяйств в 2017 г.

17.14. Валовой сбор и урожайность основных сельскохозяйственных культур

17.15. Валовой сбор и урожайность отдельных зерновых и зернобобовых культур

17.16. Производство зерна по видам культур (диаграмма) 


\section{Животноводство}

17.17. Поголовье скота 265

17.18. Поголовье скота по категориям хозяйств на конец 2017 г.

17.19. Производство основных продуктов животноводства

17.20. Производство скота и птицы на убой по отдельным видам 266

17.21. Продуктивность скота и птицы 266

\section{Продовольственные ресурсы и их использование}

17.22. Ресурсы и использование мяса и мясопродуктов .. 267

17.23. Ресурсы и использование молока и молокопродуктов

\section{Лесное хозяйство}

17.24. Лесные ресурсы 268

17.25. Лесовосстановление 268

17.26. Лесные пожары на землях лесного фонда и землях иных категорий

17.27. Основные показатели работы организаций по виду экономическои деятельности «Лесозаготовки»

17.28. Производство продукции лесозаготовок 269

\section{Рыболовство и рыбоводство}

17.29. Основные показатели работы организаций по виду экономическои деятельности «Рыболовство, рыбоводство»

17.30. Добыча (производство) основных видов продукции рыболовства

17.31. Розничная продажа рыбы, ракообразных и моллюсков и продуктов из них

17.32. Экспорт и импорт Российской Федерации рыбы, рыбопродуктов и морепродуктов

17.33. Выпуск молоди водных биологических ресурсов в водные объекты рыбохозяйственного значения 273 


\section{8. СТРОИТЕЛЬСТВО}

\section{Строительная деятельность}

18.1. Объем работ, выполненных по виду экономической деятельности «Строительство»

18.2. Объем работ, выполненных по виду экономической деятельности «Строительство» организациями различных форм собственности

18.3. Инвестиции в основной капитал организаций, осуществляющих деятельность в строительстве ... 277

18.4. Основные фонды организаций, осуществляющих деятельность в строительстве

18.5. Наличие и состояние основных строительных машин в строительных организациях на 1 января 2018 г.

18.6. Ввод в действие зданий 278

18.7. Ввод в действие отдельных производственных мощностей

\section{Жилищное и социально-культурное строительство}

18.8. Ввод в действие жилых домов

18.9. Индексы ввода в действие жилых домов (график)

18.10. Ввод в действие жилых домов организациями различных форм собственности и населением

18.11. Ввод в действие жилых домов на 1000 человек населения (график)

18.12. Ввод в действие жилых домов в городах и поселках городского типа и сельской местности .... 286

18.13. Основные характеристики построенных квартир .... 287

18.14. Ввод в действие мощностей и объектов социально-культурного назначения

18.15. Ввод в действие мощностей образовательных организаций высшего образования, профессиональных образовательных организаций

18.16. Ввод в действие домов-интернатов для престарелых, инвалидов (взрослых и детей)

18.17. Ввод в действие объектов, связанных с охраной материнства и детства

18.18. Ввод в действие санаториев и домов отдыха 289 


\section{9. ТОРГОВЛЯ И УСЛУГИ НАСЕЛЕНИЮ}

19.1. Число хозяйствующих субъектов торговли по видам экономической деятельности

19.2. Оборот и среднегодовая численность работников организаций торговли

\section{Розничная торговля}

19.3. Оборот и товарные запасы розничной торговли .... 294

19.4. Индексы физического объема оборота розничной торговли

19.5. Распределение оборота розничной торговли по формам собственности

19.6. Оборот розничной торговли отдельными товарами

19.7. Число розничных рынков и торговых мест на них

19.8. Число проведенных розничных ярморок и торговых мест на них

19.9. Удельный вес продажи товаров на рынках и ярмарках в обороте розничной торговли (диаграмма)

19.10. Индексы физического объема розничной продажи отдельных товаров

19.11. Продажа отдельных пищевых продуктов 302

19.12. Товарные ресурсы розничной торговли 302

19.13. Качество товаров, поступивших на потребительский рынок

\section{Оптовая торговля}

19.14. Оборот оптовой торговли 304

19.15. Основные показатели деятельности бирж 305

\section{Услуги населению}

19.16. Объем платных услуг населению 306

19.17. Индексы физического объема платных услуг населению

19.18. Распределение платных услуг населению по видам

19.19. Объем бытовых услуг населению ......................... 308

19.20. Индексы физического объема бытовых услуг населению 
19.21. Распределение бытовых услуг населению по видам

\section{0. ТРАНСПОРТ}

\section{Грузовые перевозки}

20.1. Перевозки грузов по видам транспорта ................. 314

20.2. Грузооборот по видам транспорта ......................... 314

\section{Пассажирские перевозки}

20.3. Перевозки пассажиров по видам транспорта общего пользования

20.4. Пассажирооборот по видам транспорта общего пользования

20.5. Протяженность путей сообщения 316

\section{Аварийность на транспорте}

20.6. Число происшествий и численность пострадавших в происшествиях с подвижным составом

\section{1. ИНФОРМАЦИОННЫЕ И КОММУНИКАЦИОННЫЕ ТЕХНОЛОГИИ}

21.1. Использование инфрормационных и коммуникационных технологий в организациях

21.2. Использование информационных и коммуникационных технологий в организациях по видам экономической деятельности в 2016 г.

21.3. Персональные компьютеры в организациях .......... 324

21.4. Организации, имевшие Web-сайт, по видам экономической деятельности

21.5. Распределение затрат организаций на информационные и коммуникационные технологии по видам

21.6. Распределение затрат организаций на информационные и коммуникационные технологии по видам экономической деятельности в 2016 г

21.7. Основные показатели развития фиксированного и мобильного доступа к сети Интернет

21.8. Домашние хозяйства, имеющие доступ к сети Интернет

21.9. Использование населением сети Интернет 


\section{2. НАУКА И ИННОВАЦИИ}

22.1. Число организаций, выполнявших исследования и разработки

22.2. Численность персонала, занятого исследованиями и разработками

22.3. Основные показатели деятельности аспирантуры

22.4. Выпуск аспирантов по отраслям наук в 2017 г. ...... 343

22.5. Выпуск аспирантов по направлениям подготовки в 2017 r.

22.6. Основные показатели деятельности докторантуры .... 346

22.7. Выпуск докторантов по отраслям наук в 2017 г.

22.8. Финансирование науки из средств федерального бюджета

22.9. Внутренние затраты на исследования и разработки

22.10. Внутренние затраты на исследования и разработки по источникам финансирования

22.11. Внутренние затраты на исследования и разработки по секторам деятельности

22.12. Гранты, субсидии, конкурсное финансирование исследований и разработок в 2016 г.

22.13. Разработанные передовые производственные технологии по группам

22.14. Используемые передовые производственные технологии по группам

22.15. Торговля технологиями с зарубежными странами по объектам сделок в 2017 г.

22.16. Торговля технологиями с зарубежными странами по области назначения предмета соглашения в 2017 г.

22.17. Поступление патентных заявок и выдача патентов в России

22.18. Инновационная активность организаций по видам экономической деятельности

22.19. Затраты на технологические инновации организаций по видам экономической деятельности

22.20. Объем инновационных товаров, работ, услуг организаций по видам экономической деятельности 


\section{3. ФИНАНСЫ}

\section{Государственные финансы}

23.1. Консолидированный бюджет Российской Федерации и бюджетов государственных внебюджетных фондов в 2017 г.

23.2. Отношение профицита (дефицита) консолидированного бюджета Россииской Федерации и бюджетов государственных внебюджетных фрондов к валовому внутреннему продукту (диаграмма)

23.3. Расходы консолидированного бюджета Российской Федерации и бюджетов государственных внебюджетных фондов на социально-культурные мероприятия в 2017 г.

23.4. Исполнение расходной части федерального бюджета Российской Федерации в 2017 г.

23.5. Основные показатели рынка государственных краткосрочных облигаций (ГКО) и облигаций федерального займа (ОФЗ)

\section{Денежно-кредитная система}

23.6. Денежная масса

23.7. Внешний долг Российской Федерации

23.8. Кредитные организации 383

23.9. Группировка действующих кредитных организаций по величине зарегистрированного уставного капитала

23.10. Вклады (депозиты) физических лиц в Сбербанке России

23.11. Вклады (депозиты), кредиты и прочие привлеченные кредитными организациями средства

23.12. Кредиты, депозиты и прочие размещенные средства, предоставленные организациям, кредитным организациям и физическим лицам

23.13. Основные показатели деятельности страховщиков

23.14. Основные показатели работы страховых медицинских организаций в части обязательного медицинского страхования (ОМС)

23.15. Официальные курсы иностранных валют по отношению к российскому рублю 
23.16. Динамика официальных курсов иностранных валют по отношению к российскому рублю

\section{Финансовая деятельность организаций}

23.17. Сальдированный финансовый результат (прибыль минус убыток) деятельности организаций по видам экономической деятельности в 2017 г. ... 392

23.18. Удельный вес убыточных организаций и сумма убытка по видам экономической деятельности в 2017 г.

23.19. Удельный вес прибыльных организаций и сумма прибыли по видам экономической деятельности в 2017 г.

23.20. Затраты на производство и продажу продукции (товаров, работ, услуг) по видам экономической деятельности в 2016 г.

23.21. Структура затрат на производство и продажу продукции (товаров, работ, услуг) по видам экономической деятельности в 2016 г.

23.22. Рентабельность проданных товаров, продукции (работ, услуг) и активов организаций по видам экономической деятельности в 2017 г.

23.23. Задолженность организаций

23.24. Кредиторская и дебиторская задолженность организаций по видам экономической деятельности в 2017 г.

23.25. Задолженность организаций по платежам в бюджет и государственные внебюджетные фонды по видам экономической деятельности в 2017 г.

23.26. Задолженность покупателей и поставщикам организаций по видам экономической деятельности в 2017 г.

23.27. Задолженность организаций по полученным кредитам банков и предоставленным займам по видам экономической деятельности в 2017 г. ... 437

23.28. Распределение организаций, имевших просроченную задолженность покупателей и поставщикам, по видам экономической деятельности в 2017 г.

23.29. Просроченная задолженность по заработной плате работникам организаций по видам экономической деятельности

23.30. Платежно-расчетные отношения организаций России с организациями стран СНГ в 2017 г. 


\section{4. ЦЕНЫ И ТАРИФЫ}

24.1. Индексы цен в секторах экономики 455

\section{Уровень и динамика цен на потребительском рынке}

24.2. Индексы потребительских цен (тарифов) на товары и услуги

24.3. Базовый индекс потребительских цен и индекс потребительских цен в 2017 г. (график)

24.4. Индексы потребительских цен на отдельные группы продовольственных товаров 460

24.5. Индексы потребительских цен на отдельные группы непродовольственных товаров

24.6. Индексы потребительских цен (тарифов) на отдельные группы услуг

24.7. Средние потребительские цены на отдельные виды продовольственных товаров

24.8. Соотношение потребительских цен на основные виды продовольственных товаров с ценой на говядину

24.9. Средние потребительские цены на отдельные виды непродовольственных товаров

24.10. Средние потребительские цены (тарифы) на отдельные виды услуг

\section{Уровень и динамика цен на рынке жилья}

24.11. Индексы цен на первичном и вторичном рынках жилья

24.12. Средние цены на первичном и вторичном рынках жилья

\section{Уровень и динамика цен производителей}

24.13. Индексы цен производителей по видам экономической деятельности

24.14. Индексы цен производителей и приобретения промышленными организациями основных видов топливно-энергетических ресурсов

24.15. Средние цены приобретения и производителей основных видов топливно-энергетических ресурсов и их соотношение

24.16. Индексы цен производителей сельскохозяйственной продукции

24.17. Средние цены производителей сельскохозяйственной продукции 
24.18. Индексы цен на продукцию (затраты, услуги) инвестиционного назначения

24.19. Индексы тарифов на грузовые перевозки основными видами транспорта 478

\section{5. ВНЕШНЕЭКОНОМИЧЕСКАЯ ДЕЯТЕЛЬНОСТЬ}

\section{Внешняя торговля товарами}

25.1. Внешняя торговля Российской Федерации 482

25.2. Экспорт и импорт Российской Федерации 483

25.3. Товарная структура экспорта и импорта Российской Федерации (диаграмма)

25.4. Внешняя торговля Российской Федерации со странами СНГ

25.5. Внешняя торговля Российской Федерации со странами дальнего зарубежья

25.6. Распределение экспорта и импорта Российской Федерации по некоторым зарубежным странам (диаграмма)

25.7. Товарная структура экспорта Российской Федерации

25.8. Товарная структура экспорта Российской Федерации в страны СНГ

25.9. Товарная структура экспорта Российской Федерации в страны дальнего зарубежья

25.10. Товарная структура импорта Российской Федерации

25.11. Товарная структура импорта Российской Федерации из стран СНГ

25.12. Товарная структура импорта Российской Федерации из стран дальнего зарубежья

25.13. Удельный вес потребительских, промежуточных и инвестиционных товаров в общем объеме импорта Российской Федерации

25.14. Экспорт важнейших товаров Российской Федерации 499

25.15. Экспорт важнейших товаров Российской Федерации в страны СНГ 500 
25.16. Экспорт важнейших товаров Российской Федерации в страны дальнего зарубежья

25.17. Импорт важнейших товаров в Российскую Федерацию 503

25.18. Импорт важнейших товаров в Российскую Федерацию из стран СНГ 505

25.19. Импорт важнейших товаров в Российскую Федерацию из стран дальнего зарубежья 506

\section{Цены внешней торговли}

25.20. Средние экспортные цены на основные товары .... 508

25.21. Средние экспортные цены на основные товары в торговле со странами СНГ

25.22. Средние экспортные цены на основные товары в торговле со странами дальнего зарубежья

25.23. Средние импортные цены на основные товары ..... 511

25.24. Средние импортные цены на основные товары в торговле со странами СНГ

25.25. Средние импортные цены на основные товары в торговле со странами дальнего зарубежья

\section{6. МЕЖДУНАРОДНЫЕ СРАВНЕНИЯ}

26.1. Сравнительные данные по некоторым странам мира

26.2. Место, занимаемое Россией в мире по производству отдельных видов промышленной и сельскохозяйственной продукции в 2016 г.

26.3. Ежегодные оценки отдельных показателей ВВП в сопоставимой валюте 


\section{1. ОСНОВНЫЕ СОЦИАЛЬНО- ЭКОНОМИЧЕСКИЕ ХАРАКТЕРИСТИКИ РОССИЙСКОЙ ФЕДЕРАЦИИ}

Столица - Москва

Россия расположена на востоке Европы и севере Азии Общая площадь территории ${ }^{1)}$ $17,1 \mathrm{Mлн.} \mathrm{км}{ }^{2}$

(на 1 января 2017 г. сельскохозяйственные угодья составили $13 \%$, леса $-51 \%$, поверхностные воды, включая болота - 13\%)

Численность населения на 1 января 2018 г. - 146880,4 тыс. человек

Плотность населения на 1 января 2018 г. - 8,6 человека на 1 км

Наибольшая протяженность, тыс. Км:

в меридиональном направлении - 4

в широтном направлении - 9

Россия омывается:

морями Северного Ледовитого

океана (Баренцево, Белое, Карское,

Лаптевых, Восточно-Сибирское,

Чукотское)

морями Тихого океана (Берингово, Охотское, Японское)

морями Атлантического океана

(Балтийское, Черное, Азовское)

Самые большие острова, тыс. км²:

архипелаг Новая Земля

Сахалин

Новосибирский архипелаг

архипелаг Северная Земля

Государственная граница:

на северо-западе - с Норвегией и Финляндией;

на западе - с Польшей, Эстонией, Латвией, Литвой и Беларусью;

на юго-западе - с Украиной;

на юге - с Абхазией, Грузией,

Южной Осетией, Азербайджаном и Казахстаном;

на юго-востоке - с Китаем, Монголией и Корейской НародноДемократической Республикой;

на востоке (морская) - с США и Японией

Самые длинные реки ${ }^{2)}$, тыс.км:

Лена

Иртыш

Обь

Волга

Енисей

Нижняя Тунгуска

\section{4,4}

Амур

Вилюй

Самые крупные озера ${ }^{2)}$, тыс.

$\mathrm{KM}^{2}$ :

Байкал

Ладожское

Онежское

Таймыр

4,2

3,7

Ханка

3,0

2,8

Самые высокие точки, м:

Эльбрус 2,7

\section{(редняя температура ${ }^{2}$ :}

январь от $+4-6^{\circ} \mathrm{C}$ (Черноморское побережье) до $-40^{\circ},-47^{\circ} \mathrm{C}$ (восток Республики Саха (Якутия), где абсолютный минимум температуры составил $-67,7^{\circ} \mathrm{C}$ в Оймяконе);

июль от $+0,5-1^{\circ} \mathrm{C}$ (арктические острова) до $+24-26^{\circ} \mathrm{C}$ (Республика Калмыкия, где абсолютный максимум составил $\left.+45,4^{\circ} \mathrm{C}\right)$.

Российская Федерация занимает 1-е место в мире по территории,
место - по численности населения и 6-е место - по объему ВВП, рас9-е место - по численности населения и 6-е место - по объему ВВП,
считанному в долларах США по паритету покупательной способности ${ }^{3}$.

1) По данным Росреестра.

2) По данным Росгидромета.

3) По результатам международных сопоставлений за 2011 г. 


\section{1. ОСНОВНЫЕ СОЦИАЛЬНО-ЭКОНОМИЧЕСКИЕ} ПОКАЗАТЕЛИ ${ }^{1)}$

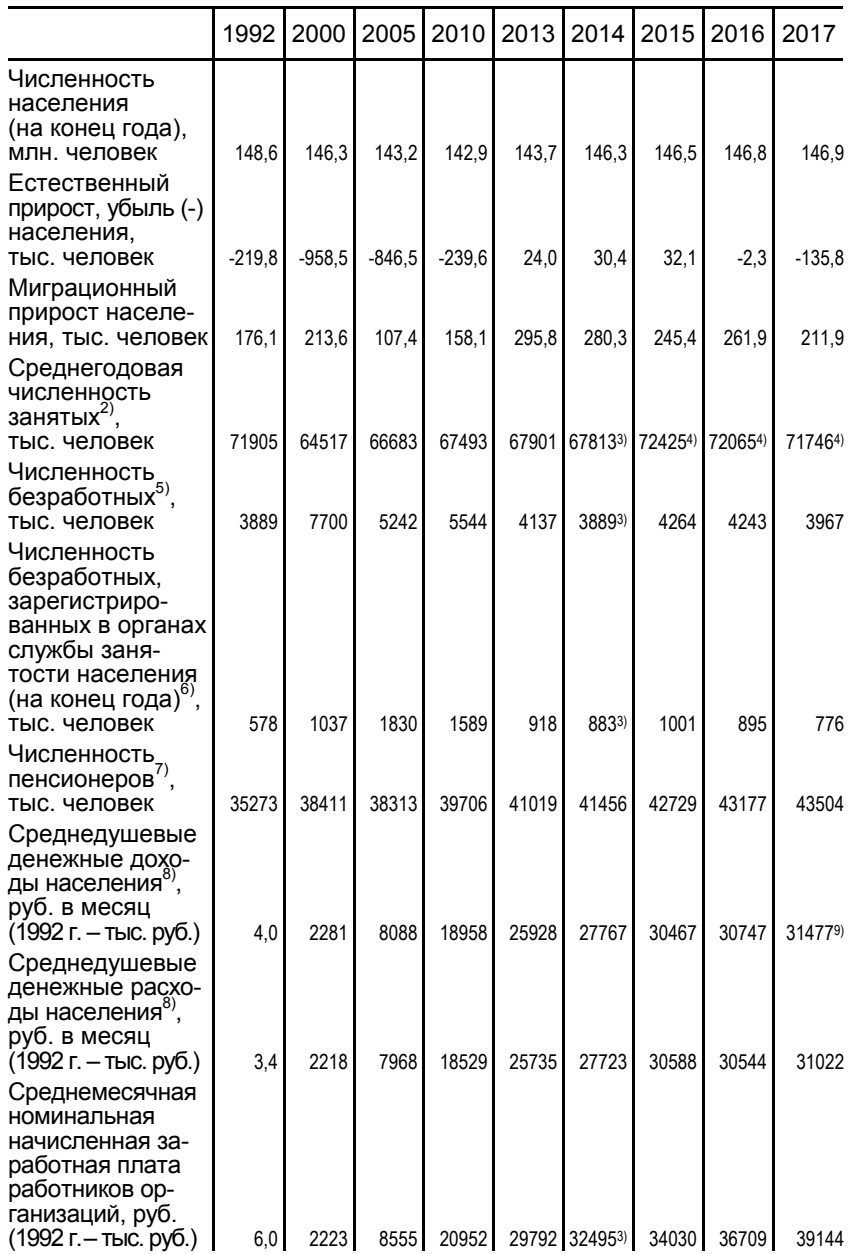


Продолжение табл. 1.1

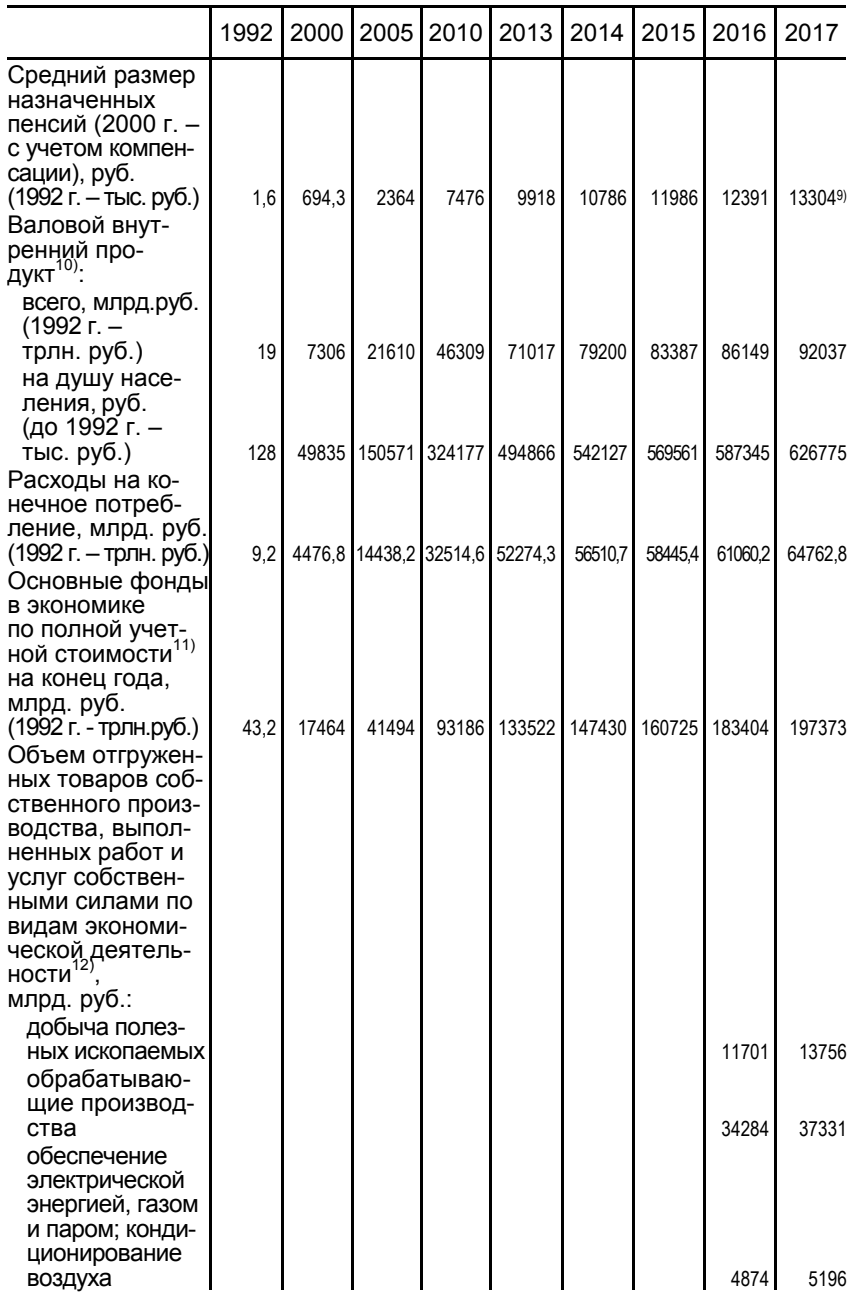


Продолжение табл. 1.1

\begin{tabular}{|c|c|c|c|c|c|c|c|c|c|}
\hline & 1992 & 2000 & 2005 & 2010 & 2013 & 2014 & 2015 & 2016 & 2017 \\
\hline $\begin{array}{l}\text { водоснабжение; } \\
\text { водоотведение, } \\
\text { организация сбо } \\
\text { ра и утилизации } \\
\text { отходов, дея- } \\
\text { тельность по ли- } \\
\text { квидации за- } \\
\text { грязнений }\end{array}$ & & & & & & & & 824 & 921 \\
\hline $\begin{array}{l}\text { Продукция сель- } \\
\text { ского хозяйства, } \\
\text { млрд. рубб. } \\
\text { (1992 г. - трлн. }\end{array}$ & & & & & & & & & \\
\hline $\begin{array}{l}\text { руб.) } \\
\text { Ввод в действие } \\
\text { общей площади }\end{array}$ & 2,7 & 742,4 & 1380,9 & 2587,8 & 3687,1 & 4319,1 & 5164,9 & 5505,7 & 5654,0 \\
\hline $\begin{array}{l}\text { жилых помејще- } \\
\text { ний, млн. м² } \\
\text { Грузооборот }\end{array}$ & 41,5 & 30,3 & 43,6 & 58,4 & 70,5 & 84,2 & 85,3 & 80,2 & 79,2 \\
\hline $\begin{array}{l}\text { транспорта, } \\
\text { трлн. т·км }\end{array}$ & 4,9 & 3,6 & 4,7 & 4,8 & 5,1 & 5,1 & 5,1 & 5,2 & 5,5 \\
\hline $\begin{array}{l}\text { Пассажирооборот } \\
\text { транспорта обще- } \\
\text { го пользования, } \\
\text { млрд. пассажиро- }\end{array}$ & & & & & & & & & \\
\hline $\begin{array}{l}\text { километров } \\
\text { Оборот рознич- } \\
\text { ной торговли, } \\
\text { млрд. руб. } \\
\text { (1992 г. - }\end{array}$ & 681,2 & 496,2 & 473,3 & 484,0 & 547,2 & 556,2 & 530,0 & 519,8 & 560,6 \\
\hline $\begin{array}{l}\text { трлн. руб.) } \\
\text { Платные услуги } \\
\text { населению, } \\
\text { млрд. руб. } \\
\text { (1992 г. - }\end{array}$ & 5,1 & 2352 & 7041 & 16512 & 23686 & 26356 & 27527 & 28306 & 29813 \\
\hline $\begin{array}{l}\text { трлн. руб.) } \\
\text { Доходы консоли- } \\
\text { дированного } \\
\text { бюджета }{ }^{14)}: \\
\text { млрд. руб. } \\
\text { (1992 г. - }\end{array}$ & 0,5 & 603 & 2272 & 4943 & 6927 & 7468 & 8051 & 8636 & $8839^{13)}$ \\
\hline $\begin{array}{l}\text { трлн. руб.) } \\
\text { в процентах } \\
\text { к валовому } \\
\text { внутреннему }\end{array}$ & 5,3 & 2097,7 & 8579,6 & 16031,9 & 24442,7 & 26766,1 & 26922,0 & 28181,5 & 31046,7 \\
\hline $\begin{array}{l}\text { продукту } \\
\text { Расходы консо- } \\
\text { лидированного } \\
\text { бюджета }^{44)}\end{array}$ & 28,0 & 28,7 & 39,7 & 34,6 & 33,4 & 33,8 & 32,3 & 32,7 & 33,7 \\
\hline $\begin{array}{l}\text { млрд. руб. } \\
\text { (1992 г. - } \\
\text { трлн. руб.) }\end{array}$ & 6,0 & 1960,1 & 6820,6 & 17616,7 & |25290,9 & | 27611,7 & 29741,5 & 31323,7 & 32395,7 \\
\hline
\end{tabular}


Продолжение табл. 1.1

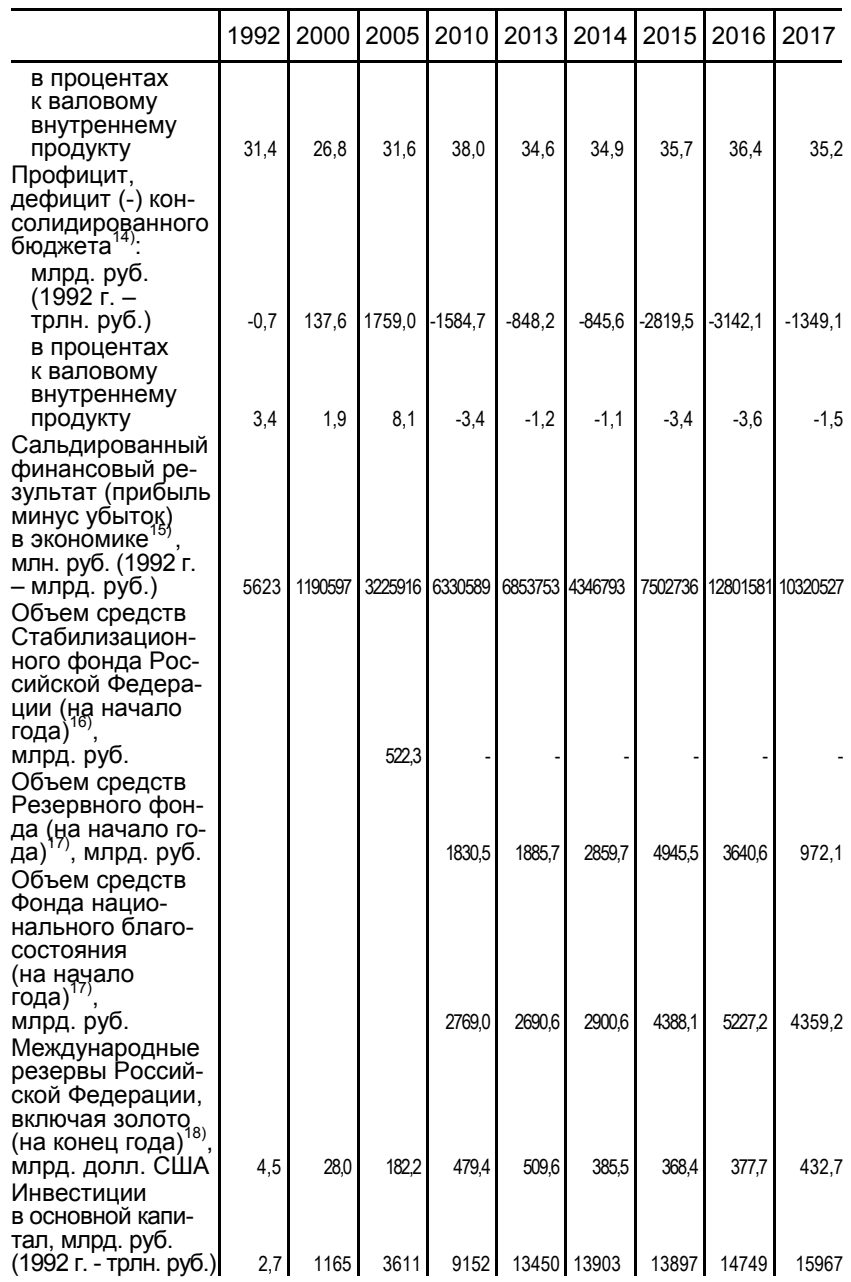


Продолжение табл. 1.1

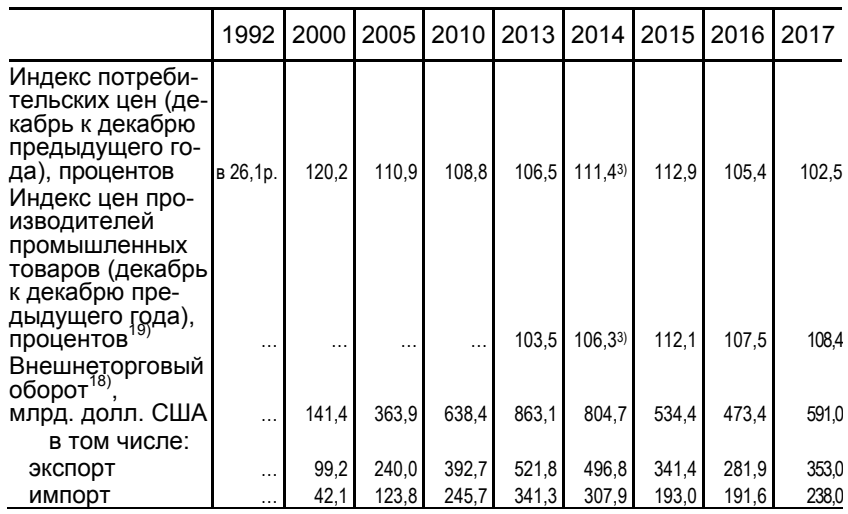

1) Данные в стоимостном выражении приведены в фактически действовавших ценах; с 2000 г. - в масштабе цен, действующем с 1 января 1998 г.

2) На основе баланса трудовых ресурсов; за 2000, 2005 гг. данные приведены без учета Чеченской Республики.

3) Без учета данных по Крымскому федеральному округу.

4) Данные рассчитаны в соответствии с актуализированной методикой расчета баланса трудовых ресурсов и оценки затрат труда.

5) В возрасте 15-72 лет; по материалам выборочного обследования рабочей силы: 1992 г. - на конец октября, 2000-2017 гг. - в среднем за год. До 2006 г. - данные сформированы без учета Чеченской Республики.

6) С 2005 г. - включая данные по Чеченской Республике.

7) 1992-2000 гг. - состоящих на учете в органах социальной защиты населения, с 2005 г. - в системе Пенсионного фонда Российской Федерации. Данные приведены по состоянию на 1 января года, следующего за отчетным.

8) С 2010 г. - включая данные по Чеченской Республике.

9) С учетом единовременной денежной выплаты, назначенной в соответствии с Федеральным законом от 22 ноября 2016 г. № 385-Ф3 в размере 5 тысяч рублей.

10) См. сноску на стр. 179.

11) С учетом проводившихся переоценок.

12) Данные за период по 2015 г., приведенные в соответствии с ранее действовавшим Общероссийским классификатором видов экономической деятельности (ОКВЭД), опубликованы в сборнике «Россия в цифрах. 2017».

13) По данным оперативной отчетности.

14) По данным Федерального казначейства. С 2005 г. данные приведены с учетом бюджетов государственных внебюджетных фондов.

15) 2000-2016 гг. - по данным бухгалтерской отчетности.

16) С 1 февраля 2008 г. Стабилизационный фонд Российской Федерации был разделен на две части: Резервный фонд и Фонд национального благосостояния.

17) На начало 2018 г. - объем средств Резервного фонда составил 0,0 млрд. руб., Фонда национального благосостояния - 3752,9 млрд. руб.

18) По данным Банка России.

19) Данные приведены в соответствии с Общероссийским классификатором видов экономической деятельности (ОКВЭД2). 


\section{2. ДИНАМИКА ОСНОВНЫХ СОЦИАЛЬНО-ЭКОНОМИЧЕСКИХ ПОКАЗАТЕЛЕЙ}

(стоимостные показатели в сопоставимых ценах; в процентах к предыдущему году)

\begin{tabular}{l|r|r|r|r|r|r|r|r|r}
\hline & 1992 & 2000 & 2005 & 2010 & 2013 & 2014 & 2015 & 2016 & 2017 \\
\hline $\begin{array}{l}\text { Численность } \\
\text { населения } \\
\text { Среднегодовая } \\
\text { численность } \\
\text { занятых }\end{array}$ & 100,03 & 99,6 & 99,6 & 100,02 & 100,2 & $100,2^{11}$ & 100,2 & 100,2 & 100,1 \\
$\begin{array}{l}\text { Численность } \\
\text { безработных } \\
\text { (в среднем } \\
\text { за год) }\end{array}$ \\
$\begin{array}{l}\text { Численность } \\
\text { безработных, } \\
\text { зарегистриро- } \\
\text { ванных в органах } \\
\text { службы занято- } \\
\text { сти населения } \\
\text { (на конец года) }\end{array}$
\end{tabular}


Продолжение табл. 1.2

\begin{tabular}{|c|c|c|c|c|c|c|c|c|c|}
\hline & 1992 & 2000 & 2005 & 2010 & 2013 & 2014 & 2015 & 2016 & 2017 \\
\hline \multicolumn{10}{|l|}{$\begin{array}{l}\text { Реальный размер } \\
\text { назначенных }\end{array}$} \\
\hline $\begin{array}{l}\text { назначенных } \\
\text { пенсий }\end{array}$ & 51,9 & 128,0 & 109,6 & 134,8 & 102,8 & $100,9^{1)}$ & $96,2^{1)}$ & 96,6 & $103,6^{8)}$ \\
\hline Вало & & & & & & & & & \\
\hline ренний про- & & & & & & & & & \\
\hline дукт $^{9) ; 10)}$ & 85,5 & 110,0 & 106,4 & 104,5 & 101,3 & 100,7 & 97,5 & 99,8 & 101,5 \\
\hline Расходы на ко- & & & & & & & & & \\
\hline $\begin{array}{l}\text { нечное потреб- } \\
\text { ление }{ }^{9) ; 10)}\end{array}$ & 94,8 & 105,6 & 109,1 & 103,5 & 104,1 & 100,9 & 92,2 & 98,1 & 102,6 \\
\hline Валовое накоп- & & & & & & & & & \\
\hline ление ${ }^{9) ; 10)}$ & 63,1 & 175,2 & 109,5 & 128,5 & 94,4 & 93,9 & 87,7 & 98,1 & 107,4 \\
\hline Основные фонды & & & & & & & & & \\
\hline $\begin{array}{l}\text { в экономике } \\
\text { (на конец года) }\end{array}$ & 102,0 & 100,5 & 101,9 & 103,0 & 104,1 & $103,7^{1)}$ & 103,2 & 103,9 & 103,9 \\
\hline Промышленное & & & & & & & & & \\
\hline производство $^{11)}$ & 84,0 & 108,7 & 105,1 & 107,3 & 100,4 & 102,5 & 99,2 & 101,3 & 101,0 \\
\hline Продукция сель- & & & & & & & & & \\
\hline ского хозяйства & 90,6 & 106,2 & 101,6 & 88,7 & 105,8 & 103,5 & 102,6 & 104,8 & 102,4 \\
\hline Ввод в действие & & & & & & & & & \\
\hline общей площади & & & & & & & & & \\
\hline жилых помеще- & & & & & & & & & \\
\hline ний & 84,0 & 94,6 & 106,1 & 97,6 & 107,2 & $118,2^{1)}$ & 101,4 & 94,0 & 98,7 \\
\hline $\begin{array}{l}\text { Грузооборот } \\
\text { транспорта }\end{array}$ & 86,3 & 105,1 & 102,6 & 106,9 & 100,6 & $99,9^{1)}$ & 100,6 & 101,8 & 105,4 \\
\hline Пассажирообо- & & & & & & & & & \\
\hline $\begin{array}{l}\text { рот транспорта } \\
\text { общего пользо- }\end{array}$ & & & & & & & & & \\
\hline вания & 87,0 & 106,4 & 93,0 & 104,3 & 102,7 & $100,9^{1)}$ & 95,3 & 98,1 & 107,8 \\
\hline Оборот рознич- & & & & & & & & & \\
\hline ной торговли & 100,3 & 109,0 & 112,8 & 106,5 & 103,9 & $102,7^{1)}$ & 90,0 & 95,4 & 101,3 \\
\hline Платные услуги & & & & & & & & & \\
\hline населению & 81,6 & 104,7 & 106,3 & 101,5 & 102,0 & $\left|101,0^{1)}\right|$ & 98,9 & 100,7 & $100,2^{12)}$ \\
\hline
\end{tabular}


Продолжение табл. 1.2

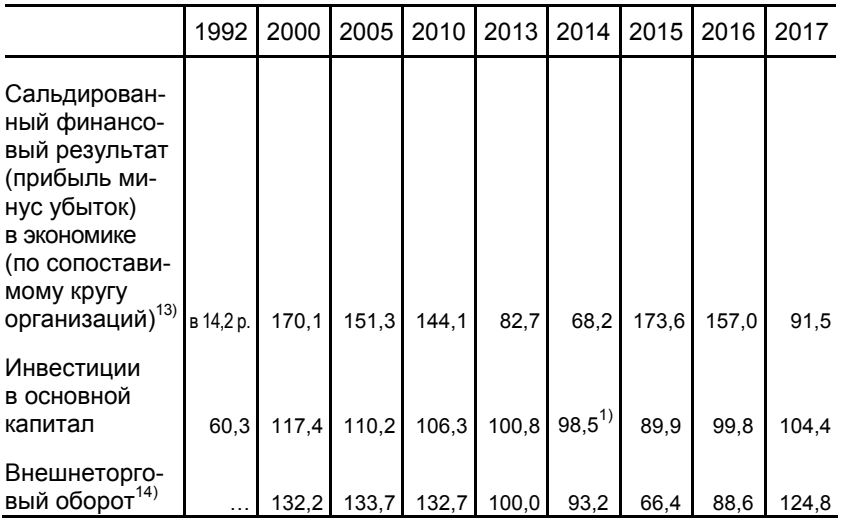

1) В целях обеспечения статистической сопоставимости относительные показатели рассчитаны без учета данных по Республике Крым и г. Севастополю.

2) За 1992 г. сведения отсутствуют из-за несопоставимости данных. С 2010 г. с учетом Чеченской Республики.

3) Данные рассчитаны в соответствии с актуализированной методикой расчета баланса трудовых ресурсов и оценки затрат труда.

4) В возрасте 15-72 лет; по материалам выборочного обследования рабочей силы: 1992 г. - на конец октября, 2000-2017 гг. - в среднем за год. До 2006 г. - данные сформированы без учета Чеченской Республики.

5) С 2005 г. - включая данные по Чеченской Республике.

6) 1992-2000 гг. - состоящих на учете в органах социальной защиты населения, с 2005 г. - в системе Пенсионного фонда Российской Федерации. Данные приведены по состоянию на 1 января года, следующего за отчетным.

7) С 2010 г. - включая данные по Чеченской Республике.

8) С учетом единовременной денежной выплаты, назначенной в соответствии с Федеральным законом от 22 ноября 2016 г. № 385-Ф3 в размере 5 тысяч рублей.

9) См. сноску на стр. 179.

10) В постоянных ценах.

11) До 2013 г. - агрегированный индекс производства по видам экономической деятельности «Добыча полезных ископаемых», «Обрабатывающие производства», «Производство и распределение электроэнергии, газа и воды» (ОКВЭД), с 2014 г. агрегированный индекс производства по видам экономической деятельности «Добыча полезных ископаемых», «Обрабатывающие производства», «Обеспечение электрической энергией, газом и паром; кондиционирование воздуха», «Водоснабжение; водоотведение, организация сбора и утилизации отходов, деятельность по ликвидации загрязнений» (ОКВЭД2).

12) По данным оперативной отчетности.

13) В фактически действовавших ценах, 2000-2016 гг. - по данным бухгалтерской отчетности.

14) По данным Банка России; в фактически действовавших ценах. 
1.3. ОСНОВНЫЕ СОЦИАЛЬНО-ЭКОНОМИЧЕСКИЕ ПОКАЗАТЕЛИ

\begin{tabular}{|c|c|c|c|c|c|c|c|}
\hline & \begin{tabular}{|c|} 
Пло- \\
щадь \\
терри- \\
тории \\
(на 1 \\
января \\
2017 г.) \\
тыс. км
\end{tabular} & \begin{tabular}{|c} 
Числен- \\
ность \\
насе- \\
ле- \\
ния \\
на 1 ян- \\
варя \\
2018 г., \\
тыс. \\
человек
\end{tabular} & $\begin{array}{c}\text { Средне- } \\
\text { годовая } \\
\text { числен- } \\
\text { ность } \\
\text { заня- } \\
\text { тых } \\
\text { тыс. } \\
\text { человек }\end{array}$ & \begin{tabular}{|c} 
Сред- \\
неду- \\
шевые \\
денеж- \\
ные \\
дохо- \\
ды (в (в \\
месяц), \\
руб.
\end{tabular} & \begin{tabular}{|c|} 
Сред- \\
неду- \\
шевые \\
денеж- \\
ные \\
расхо- \\
ды (в $^{4}$ (в \\
месяц), \\
руб. \\
\end{tabular} & \begin{tabular}{|c|} 
Сред- \\
неме- \\
сячная \\
номи- \\
наль- \\
ная на- \\
числен- \\
ная за- \\
работ- \\
ная \\
плата \\
работ- \\
ников \\
органи- \\
заций, \\
руб.
\end{tabular} & $\begin{array}{c}\text { Вало- } \\
\text { вой ре- } \\
\text { гио- } \\
\text { наль- } \\
\text { ный } \\
\text { про- } \\
\text { дукт } \\
\text { (в теку- } \\
\text { щих ос- } \\
\text { новных } \\
\text { ценах) } \\
\text { млрд. } \\
\text { руб. } \\
\end{array}$ \\
\hline оссийская & & & & & & & \\
\hline $\begin{array}{c}\text { Федерация } \\
\text { Центральный } \\
\text { федеральный округ }\end{array}$ & $\begin{array}{l}11,17 \\
650,2\end{array}$ & 39311,4 & $\begin{array}{r}72065,2 \\
21181,9\end{array}$ & $\begin{array}{l}314 / / \\
40594\end{array}$ & 41313 & $\begin{array}{r}39144 \\
48396\end{array}$ & 24135,0 \\
\hline Белгородская & & & & & & & 7306 \\
\hline область & 27,1 & 1549,9 & 756,8 & 30420 & 27479 & 29150 & 730,6 \\
\hline $\begin{array}{l}\text { Брянская область } \\
\text { Владимирская }\end{array}$ & 34,9 & 1211,0 & 540,6 & 26867 & 26012 & 24390 & 285,9 \\
\hline область & 29,1 & 1378,3 & 647,4 & 24003 & 22739 & 27842 & 392,1 \\
\hline Воронежская область & 52,2 & 2333,8 & 1094,8 & 29971 & 29188 & 28339 & 841,4 \\
\hline Ивановская область & 21,4 & 1014,6 & 447,1 & 24959 & 21680 & 23165 & 179,6 \\
\hline Калужская область & 29,8 & 1012,2 & 508,9 & 28722 & 26686 & 33899 & 373,4 \\
\hline Костромская область & 60,2 & 643,3 & 293,2 & 25048 & 22989 & 24296 & 160,7 \\
\hline Курская область & 30,0 & 1115,2 & 520,6 & 27141 & 24810 & 27241 & 364,6 \\
\hline Липецкая область & 24,0 & 1150,2 & 565,4 & 28865 & 26517 & 28492 & 470,2 \\
\hline Московская область & 44,3 & 7503,4 & 3377,0 & 41184 & 36514 & 46697 & 3565,3 \\
\hline Орловская область & 24,7 & 747,2 & 330,2 & 24187 & 22250 & 24652 & 213,9 \\
\hline Рязанская область & 39,6 & 1121,5 & 505,5 & 24893 & 22791 & 29129 & 337,0 \\
\hline Смоленская область & 49,8 & 949,3 & 443,8 & 25460 & 23265 & 26294 & 262,3 \\
\hline Тамбовская область & 34,5 & 1033,6 & 492,1 & 25938 & 23490 & 24196 & 311,4 \\
\hline Тверская область & 84,2 & 1283,9 & 608,5 & 24687 & 23306 & 27387 & 359,3 \\
\hline Тульская область & 25,7 & 1491,8 & 731,5 & 27853 & 25568 & 31302 & 517,7 \\
\hline Ярославская область & 36,2 & 1265,7 & 626,5 & 27329 & 24600 & 30501 & 469,8 \\
\hline г. Москва & 2,6 & 12506,5 & 8692,0 & 61358 & 69509 & 73345 & 14299,8 \\
\hline
\end{tabular}


ПО СУБЪЕКТАМ РОССИЙСКОЙ ФЕДЕРАЦИИ в 2017 г. ${ }^{1)}$

\begin{tabular}{|c|c|c|c|c|c|c|c|c|c|c|}
\hline \multirow{2}{*}{\begin{tabular}{|} 
Основ- \\
ные \\
фонды \\
в эко- \\
номи- \\
ке (по \\
пол- \\
ной \\
учет- \\
ной \\
стои- \\
мос- \\
ти; на \\
конец \\
2016 г..) \\
млрд. \\
руб.
\end{tabular}} & \multicolumn{4}{|c|}{$\begin{array}{c}\text { Объем отгруженных } \\
\text { товаров собственного } \\
\text { производства, } \\
\text { выполненных работ } \\
\text { и услуг собственными } \\
\text { силами, млн. руб. } \\
\end{array}$} & \multirow{2}{*}{$\begin{array}{c}\text { Про- } \\
\text { дукция } \\
\text { сель- } \\
\text { ского } \\
\text { хозяй- } \\
\text { ства, } \\
\text { млн. } \\
\text { руб. }\end{array}$} & \multirow{2}{*}{$\begin{array}{l}\text { Ввод в } \\
\text { дейст- } \\
\text { вие об- } \\
\text { щей } \\
\text { площа- } \\
\text { ди жи- } \\
\text { лых } \\
\text { поме- } \\
\text { щений } \\
\text { тыс.м }\end{array}$} & \multirow{2}{*}{$\begin{array}{c}\text { Обо- } \\
\text { рот } \\
\text { роз- } \\
\text { нич- } \\
\text { ной } \\
\text { торгов- } \\
\text { ли, } \\
\text { млрд. } \\
\text { руб. }\end{array}$} & \multirow{2}{*}{\begin{tabular}{|c} 
Саль- \\
диро- \\
ванный \\
финан- - совый \\
резуль- \\
тат \\
(при- \\
быль \\
минус \\
убы- \\
ток) \\
в эко- \\
номи- \\
ке, \\
млн. \\
руб.
\end{tabular}} & \multirow{2}{*}{\begin{tabular}{|c} 
Индекс \\
потре- \\
битель- \\
ских \\
цен \\
(де- \\
кабрь к \\
декаб- \\
рю \\
преды- \\
дущего \\
года), \\
про- \\
центов
\end{tabular}} & \multirow{2}{*}{$\begin{array}{l}\text { Инвес- } \\
\text { тиции } \\
\text { в } \\
\text { основ- } \\
\text { ной ка- } \\
\text { питал, } \\
\text { млрд. } \\
\text { руб. } \\
\end{array}$} \\
\hline & $\begin{array}{l}\text { добыча } \\
\text { полез- } \\
\text { ных ис- } \\
\text { копа- } \\
\text { емых }\end{array}$ & \begin{tabular}{|c|} 
обраба- \\
ты- \\
ваю- \\
щие \\
произ- \\
водства
\end{tabular} & \begin{tabular}{|c} 
обес- \\
пече- \\
ние \\
элек- \\
триче-- \\
ской \\
энер- \\
гией, \\
газом \\
и па- \\
ром; \\
конди- \\
циони- \\
рова- \\
ние \\
возду- \\
ха
\end{tabular} & \begin{tabular}{|c|} 
водо- \\
снаб- \\
жение; \\
водо- \\
отве- \\
дение, \\
орга- \\
низа- \\
ция \\
сбора \\
и ути- \\
лиза- \\
ции \\
отхо- \\
дов, \\
дея- \\
тель- \\
ность \\
по ли- \\
квида- \\
ции за- \\
гряз- \\
нений
\end{tabular} & & & & & & \\
\hline 183404 & 13755546 & 37330875 & 5195932 & 921149 & 5653953 & 79223,9 & 29813,3 & 10320527 & 102,5 & 15967 \\
\hline 58401 & 1662167 & 12162468 & 1602763 & 257919 & 1385583 & 24284,9 & $\mid 10140,1$ & 4011521 & 103,2 & 4173,0 \\
\hline 1401 & 116280 & 602873 & 25344 & 6283 & 230292 & 1300,5 & 315,4 & 138352 & 101,5 & 139,2 \\
\hline 733 & 216 & 182181 & 16038 & 7058 & 87214 & 558,3 & 234,4 & 16865 & 102,8 & 54,8 \\
\hline 788 & 3917 & 407025 & 39270 & 9897 & 33115 & 695,4 & 211,9 & 34294 & 102,3 & 79,6 \\
\hline 1535 & 5747 & 388429 & 89198 & 8115 & 199863 & 1687,3 & 516,6 & 32701 & 101,5 & 294,2 \\
\hline 553 & 717 & 125536 & 28611 & 3557 & 17239 & 339,8 & 156,9 & 3038 & 102,9 & 27,1 \\
\hline 913 & 3303 & 683966 & 20694 & 6526 & 43070 & 882,3 & 186,0 & 56668 & 103,4 & 81,3 \\
\hline 420 & 355 & 119353 & 37561 & 2972 & 20187 & 310,2 & 97,3 & 8532 & 102,1 & 20,6 \\
\hline 805 & 68123 & 166739 & 58992 & 4490 & 133283 & 590,5 & 197,2 & 61085 & 102,1 & 100,6 \\
\hline 1179 & 5890 & 618965 & 25476 & 10806 & 108868 & 1084,2 & 237,0 & 149367 & 102,3 & 139,9 \\
\hline 7238 & 11752 & 2233754 & 271400 & 62182 & 101472 & 9077,7 & 2093,6 & 442936 & 103,2 & 678,3 \\
\hline 472 & 137 & 94088 & 12491 & 3164 & 61558 & 267,5 & 124,7 & 10754 & 102,0 & 45,3 \\
\hline 927 & 1579 & 266524 & 37947 & 4122 & 57158 & 712,5 & 180,0 & 30091 & 103,3 & 63,8 \\
\hline 829 & 1064 & 177732 & 53884 & 4190 & 25015 & 484,4 & 158,3 & 9870 & 102,4 & 57,5 \\
\hline 798 & 126 & 159334 & 14817 & 3087 & 122151 & 839,4 & 194,7 & 9510 & 102,0 & 111,7 \\
\hline 1213 & 774 & 238728 & 94320 & 5686 & 37477 & 585,2 & 216,1 & 12985 & 102,0 & 100,0 \\
\hline 1033 & 5254 & 576202 & 46643 & 10280 & 64125 & 696,8 & 273,7 & 47579 & 102,6 & 127,1 \\
\hline 1226 & 1055 & 338291 & 40559 & 12400 & 35443 & 753,8 & 224,5 & 34473 & 102,7 & 79,8 \\
\hline 36338 & 1435878 & 4782748 & 689517 & 93104 & 8058 & 3419,0 & 4521,9 & 2912421 & 103,8 & 1972,3 \\
\hline
\end{tabular}




\begin{tabular}{|c|c|c|c|c|c|c|c|}
\hline & \begin{tabular}{|c} 
Пло- \\
щадь \\
терри- \\
тории \\
(на 1 \\
января \\
2017 г.) \\
тыс. км
\end{tabular} & \begin{tabular}{|c} 
Числен- \\
ность \\
насе- \\
ле- \\
ния \\
на 1 ян- \\
варя \\
2018 г., \\
тыс. \\
человек
\end{tabular} & $\begin{array}{c}\text { Средне- } \\
\text { годовая } \\
\text { числен- } \\
\text { ность } \\
\text { заня- } \\
\text { тых }{ }^{3)}, \\
\text { тыс. } \\
\text { человек }\end{array}$ & \begin{tabular}{|c} 
Сред- \\
неду- \\
шевые \\
денеж- \\
ные \\
дохо- \\
ды (в) (в \\
месяц), \\
руб.
\end{tabular} & \begin{tabular}{|c} 
Сред- \\
неду- \\
шевые \\
денеж- \\
ные \\
расхо- \\
ды) (в \\
месяц), \\
руб.
\end{tabular} & \begin{tabular}{|c|} 
Сред- \\
неме- \\
сячная \\
номи- \\
наль- \\
ная на- \\
числен- \\
ная за- \\
работ- \\
ная \\
плата \\
работ- \\
ников \\
органи- \\
заций, \\
руб.
\end{tabular} & \begin{tabular}{|c} 
Вало- \\
вой ре- \\
гио-- \\
наль- \\
ный \\
про- \\
дукт \\
(в теку- \\
щих ос- \\
новных \\
ценах) \\
млр. \\
руб. \\
\end{tabular} \\
\hline $\begin{array}{c}\text { Северо-Западный } \\
\text { федеральный округ }\end{array}$ & 1687,0 & 13952,0 & 7251,1 & 33669 & 33841 & 44696 & 7803,7 \\
\hline Республика Карелия & 180,5 & 622,5 & 283,6 & 26730 & 25193 & 34779 & 233,4 \\
\hline Республика Коми & 416,8 & 840,9 & 421,8 & 30843 & 28321 & 45455 & 546,9 \\
\hline $\begin{array}{l}\text { Архангельская } \\
\text { область }\end{array}$ & 589,9 & 1155,0 & 547,5 & 33475 & 31776 & 43108 & 683,4 \\
\hline $\begin{array}{l}\text { в том числе: } \\
\text { Ненецкий } \\
\text { автономный округ }\end{array}$ & 176,8 & 44,0 & 33,2 & 70587 & 36804 & 74262 & 255,5 \\
\hline $\begin{array}{l}\text { Архангельская } \\
\text { область без } \\
\text { автономного округа }\end{array}$ & 413,1 & 1111,0 & 514,4 & 32013 & 31578 & 40511 & 427,9 \\
\hline Вологодская область & 144,5 & 1176,7 & 556,6 & 26308 & 22666 & 31636 & 486,2 \\
\hline $\begin{array}{l}\text { Калининградская } \\
\text { область }\end{array}$ & 15,1 & 994,6 & 476,9 & 26683 & 26215 & 31296 & 383,1 \\
\hline Ленинградская область & 83,9 & 1813,8 & 820,2 & 28809 & 25274 & 38755 & 913,8 \\
\hline Мурманская область & 144,9 & 753,6 & 379,8 & 37898 & 35827 & 51450 & 425,8 \\
\hline $\begin{array}{l}\text { Новгородская } \\
\text { область }\end{array}$ & 54,5 & 606,5 & 294,0 & 25553 & 25645 & 29204 & 244,5 \\
\hline Псковская область & 55,4 & 636,5 & 291,2 & 23375 & 21955 & 23304 & 144,4 \\
\hline г. Санкт-Петербург & 1,4 & 5351,9 & 3179,4 & 41128 & 45078 & 54353 & 3742,2 \\
\hline
\end{tabular}


Продолжение табл. 1.3

\begin{tabular}{|c|c|c|c|c|c|c|c|c|c|c|}
\hline \multirow{2}{*}{$\begin{array}{c}\text { Основ- } \\
\text { ные } \\
\text { фонды } \\
\text { в эко- } \\
\text { номи- } \\
\text { ке (по } \\
\text { пол- } \\
\text { ной } \\
\text { учет- } \\
\text { ной } \\
\text { стои- } \\
\text { мос- } \\
\text { ти; на } \\
\text { конец } \\
2016 \text { г.), } \\
\text { млрд. } \\
\text { руб. }\end{array}$} & \multicolumn{4}{|c|}{$\begin{array}{c}\text { Объем отгруженных } \\
\text { товаров собственного } \\
\text { производства, } \\
\text { выполненных работ } \\
\text { и услуг собственными } \\
\text { силами, млн. руб. }\end{array}$} & \multirow{2}{*}{$\begin{array}{c}\text { Про- } \\
\text { дукция } \\
\text { сель- } \\
\text { ского } \\
\text { хозяй- } \\
\text { ства, } \\
\text { млн. } \\
\text { руб. }\end{array}$} & \multirow{2}{*}{\begin{tabular}{|c|} 
Ввод в \\
дейст- \\
вие об- \\
щей \\
площа- \\
ди жи- \\
лых \\
поме- \\
щений, \\
тыс.м
\end{tabular}} & \multirow{2}{*}{$\begin{array}{c}\text { Обо- } \\
\text { рот } \\
\text { роз- } \\
\text { нич- } \\
\text { ной } \\
\text { торгов- } \\
\text { ли, } \\
\text { млрд. } \\
\text { руб. }\end{array}$} & \multirow{2}{*}{\begin{tabular}{|c|} 
Саль- \\
диро- \\
ванный \\
финан- \\
совый \\
резуль-- \\
тат \\
(при- \\
быль \\
минус \\
убы- \\
ток) \\
в эко- \\
номи- \\
ке, \\
млн. \\
руб.
\end{tabular}} & \multirow{2}{*}{\begin{tabular}{|c|} 
Индекс \\
потре- \\
битель- \\
ских \\
цен \\
(де- \\
кабрь к \\
декаб- \\
рю \\
преды- \\
дущего \\
года), \\
про- \\
центов
\end{tabular}} & \multirow{2}{*}{\begin{tabular}{|c} 
Инвес- \\
тиции \\
в \\
основ- \\
ной ка- \\
питал, \\
млрд. \\
руб. \\
\end{tabular}} \\
\hline & $\begin{array}{c}\text { добыча } \\
\text { полез- } \\
\text { ных ис- } \\
\text { копа- } \\
\text { емых }\end{array}$ & $\begin{array}{c}\text { обраба- } \\
\text { ты- } \\
\text { ваю- } \\
\text { щие } \\
\text { произ- } \\
\text { водства }\end{array}$ & \begin{tabular}{|c} 
обес- \\
пече- \\
ние \\
элек- \\
триче-- \\
ской \\
энер- \\
гией, \\
газом \\
и па- \\
ром; \\
конди- \\
циони- \\
рова- \\
ние \\
возду- \\
ха
\end{tabular} & \begin{tabular}{|c} 
водо- \\
снаб- \\
жение; \\
водо- \\
отве- \\
дение, \\
орга- \\
низа- \\
ция \\
сбора \\
и ути- \\
лиза- \\
ции \\
отхо- \\
дов, \\
дея- \\
тель- \\
ность \\
по ли- \\
квида- \\
ции за-- \\
гряз- \\
нений \\
\end{tabular} & & & & & & \\
\hline 20330 & 828303 & 5522981 & 558058 & 113127 & 256216 & 8967,2 & 2923,0 & 1388320 & 103,1 & 1872,0 \\
\hline 676 & 71303 & 86261 & 24884 & 2726 & 4769 & 222,3 & 112,6 & 36511 & 102,8 & 41,7 \\
\hline 3052 & 301679 & 170183 & 47429 & 5423 & 10229 & 222,8 & 150,2 & 75996 & 102,4 & 129,3 \\
\hline 1957 & 294223 & 300902 & 34891 & 6147 & 12074 & 422,8 & 252,1 & 52274 & 101,6 & 245,7 \\
\hline 755 & 266745 & 20610 & 3755 & 501 & 1080 & 27,9 & 9,4 & 16215 & 101,7 & 142,1 \\
\hline 1202 & 27478 & 280291 & 31137 & 5646 & 10994 & 394,9 & 242,7 & 36059 & 101,5 & 103,5 \\
\hline 1549 & 623 & 563938 & 39911 & 7210 & 28363 & 542,3 & 172,0 & 200260 & 102,2 & 130,8 \\
\hline 756 & 17643 & 446949 & 26316 & 5423 & 31461 & 902,4 & 157,1 & 34014 & 102,8 & 118,9 \\
\hline 2924 & 11323 & 917490 & 114079 & 14368 & 103483 & 2625,8 & 370,7 & 148101 & 102,7 & 338,6 \\
\hline 1891 & 106157 & 148600 & 59327 & 9176 & 1925 & 59,0 & 163,5 & 59200 & 103,1 & 110,7 \\
\hline 609 & 1465 & 190993 & 21505 & 2779 & 28800 & 231,6 & 111,9 & 21459 & 102,4 & 68,8 \\
\hline 370 & 1307 & 91385 & 9128 & 2502 & 35111 & 202,3 & 106,6 & 7533 & 102,4 & 28,9 \\
\hline 6546 & 22580 & 2606280 & 180587 & 57373 & & 3536,1 & 1326,3 & | 752972 & 103,7 & 658,5 \\
\hline
\end{tabular}




\begin{tabular}{|c|c|c|c|c|c|c|c|}
\hline & \begin{tabular}{|c|} 
Пло- \\
щадь \\
терри- \\
тории \\
$($ на 1 ян- \\
варя \\
2017 г.) $)^{2)}$ \\
тыс. км
\end{tabular} & \begin{tabular}{|c|} 
Числен- \\
ность \\
насе- \\
ле- \\
ния \\
на 1 ян- \\
варя \\
2018 г., \\
тыс. \\
человек
\end{tabular} & $\begin{array}{c}\text { Средне- } \\
\text { годовая } \\
\text { числен- } \\
\text { ность } \\
\text { заня- } \\
\text { тых } \\
\text { тыс. } \\
\text { человек }\end{array}$ & $\begin{array}{c}\text { Сред- } \\
\text { неду- } \\
\text { шевые } \\
\text { денеж- } \\
\text { ные } \\
\text { дохо- } \\
\text { ды }{ }^{4} \text { (в } \\
\text { месяц), } \\
\text { руб. }\end{array}$ & \begin{tabular}{|c} 
Сред- \\
неду- \\
шевые \\
денеж- \\
ные \\
расхо- \\
ды) (в \\
месяц), \\
руб.
\end{tabular} & \begin{tabular}{|c|} 
Сред- \\
неме- \\
сячная \\
номи- \\
наль- \\
ная на- \\
числен- \\
ная за- \\
работ- \\
ная \\
плата \\
работ- \\
ников \\
органи- \\
заций, \\
руб.
\end{tabular} & \begin{tabular}{|c} 
Вало- \\
вой ре- \\
гио-- \\
наль- \\
ный \\
про- \\
дукт \\
(в теку- \\
щих ос- \\
новных \\
ценах), \\
млрд. \\
руб.
\end{tabular} \\
\hline $\begin{array}{c}\text { Южный } \\
\text { федеральный округ }\end{array}$ & 447,8 & 16441,8 & 7402,8 & 27234 & 27238 & 28653 & 4896,3 \\
\hline $\begin{array}{l}\text { Республика Адыгея } \\
\text { Республика }\end{array}$ & 7,8 & 453,4 & 151,1 & 25647 & 21718 & 24247 & 91,4 \\
\hline Калмыкия & 74,7 & 275,4 & 112,3 & 14948 & 12526 & 23043 & 56,0 \\
\hline Республика Крым & 26,1 & 1913,7 & 825,4 & 21363 & 19711 & 26312 & 315,9 \\
\hline Краснодарский край & 75,5 & 5603,4 & 2553,2 & 33224 & 34149 & 30557 & 2015,9 \\
\hline $\begin{array}{l}\text { Астраханская область } \\
\text { Волгоградская }\end{array}$ & 49,0 & 1017,5 & 473,7 & 22503 & 22365 & 29428 & 338,7 \\
\hline область & 112,9 & 2521,3 & 1147,6 & 21689 & 21258 & 27884 & 743,3 \\
\hline Ростовская область & 101,0 & 4220,4 & 1968,2 & 27726 & 27988 & 28083 & 1270,9 \\
\hline $\begin{array}{l}\text { г. Севастополь } \\
\text { Северо-Кавказский } \\
\text { федеральный округ }\end{array}$ & 170,4 & $\begin{array}{r}436,7 \\
9823,5\end{array}$ & $\begin{array}{r}171,3 \\
3778,9\end{array}$ & 24270 & 21400 & 24346 & $\begin{array}{r}64,2 \\
1798,0\end{array}$ \\
\hline Республика Дагестан & 50,3 & 3063,9 & 1066,8 & 29649 & 26007 & 21768 & 597,1 \\
\hline $\begin{array}{l}\text { Республика Ингушетия } \\
\text { Кабардино-Балкар- }\end{array}$ & 3,6 & 488,0 & 162,3 & 15298 & 8623 & 22085 & 50,9 \\
\hline $\begin{array}{l}\text { ская Республика } \\
\text { Карачаево-Черкес- }\end{array}$ & 12,5 & 865,8 & 358,9 & 21568 & 18954 & 22242 & 132,7 \\
\hline $\begin{array}{l}\text { ская Республика } \\
\text { Республика Север- }\end{array}$ & 14,3 & 466,3 & 171,7 & 17436 & 12311 & 22939 & 73,2 \\
\hline $\begin{array}{l}\text { ная Осетия - Алания } \\
\text { Чеченская }\end{array}$ & 8,0 & 701,8 & 287,2 & 22640 & 20006 & 24136 & 125,5 \\
\hline Республика & 15,6 & 1437,0 & 490,0 & 22338 & 14777 & 23171 & 166,7 \\
\hline Ставропольский край & 66,2 & 2800,7 & 1242,0 & 23323 & 24575 & 26892 & 651,9 \\
\hline
\end{tabular}


Продолжение табл. 1.3

\begin{tabular}{|c|c|c|c|c|c|c|c|c|c|c|}
\hline \multirow{2}{*}{$\begin{array}{c}\text { Основ- } \\
\text { ные } \\
\text { фонды } \\
\text { в эко- } \\
\text { номи- } \\
\text { ке (по } \\
\text { пол- } \\
\text { ной } \\
\text { учет- } \\
\text { ной } \\
\text { стои- } \\
\text { мос- } \\
\text { ти; на } \\
\text { конец } \\
2016 \text { г.), } \\
\text { млрд. } \\
\text { руб. }\end{array}$} & \multicolumn{4}{|c|}{$\begin{array}{c}\text { Объем отгруженных } \\
\text { товаров собственного } \\
\text { производства, } \\
\text { выполненных работ } \\
\text { и услуг собственными } \\
\text { силами, млн. руб. }\end{array}$} & \multirow{2}{*}{$\begin{array}{c}\text { Про- } \\
\text { дукция } \\
\text { сель- } \\
\text { ского } \\
\text { хозяй- } \\
\text { ства, } \\
\text { млн. } \\
\text { руб. }\end{array}$} & \multirow{2}{*}{\begin{tabular}{|} 
Ввод в \\
дейст- \\
вие об- \\
щей \\
поща- \\
ди жи- \\
лых \\
поме- \\
щений, \\
тыс.м
\end{tabular}} & \multirow{2}{*}{$\begin{array}{c}\text { Обо- } \\
\text { рот } \\
\text { роз- } \\
\text { нич- } \\
\text { ной } \\
\text { торгов- } \\
\text { ли, } \\
\text { млрд. } \\
\text { руб. }\end{array}$} & \multirow{2}{*}{\begin{tabular}{|c|} 
Саль- \\
диро- \\
ванный \\
финан- \\
совый \\
резуль- \\
тат \\
(при- \\
быль \\
минус \\
убы- \\
ток) \\
в эко- \\
номи- \\
ке, \\
млн. \\
руб.
\end{tabular}} & \multirow{2}{*}{\begin{tabular}{|c} 
Индекс \\
потре- \\
битель- \\
ских \\
цен \\
(де- \\
кабрь к \\
декаб- \\
рю \\
преды- \\
дущего \\
года), \\
про- \\
центов
\end{tabular}} & \multirow{2}{*}{$\begin{array}{l}\text { Инвес- } \\
\text { тиции } \\
\text { в } \\
\text { основ- } \\
\text { ной ка- } \\
\text { питал, } \\
\text { млрд. } \\
\text { руб. } \\
\\
\end{array}$} \\
\hline & \begin{tabular}{|c|} 
добыча \\
полез- \\
ных ис- \\
копа- \\
емых \\
\end{tabular} & $\begin{array}{l}\text { обраба- } \\
\text { ты- } \\
\text { ваю- } \\
\text { щие } \\
\text { произ- } \\
\text { водства }\end{array}$ & \begin{tabular}{|c} 
обес- \\
пече- \\
ние \\
элек- \\
триче-- \\
ской \\
энер- \\
гией, \\
газом \\
и па- \\
ром; \\
конди- \\
циони- \\
рова- \\
ние \\
возду- \\
ха
\end{tabular} & \begin{tabular}{|c} 
водо- \\
снаб- \\
жение; \\
водо- \\
отве- \\
дение, \\
орга- \\
низа- \\
ция \\
сбора \\
и ути- \\
лиза- \\
ции \\
отхо- \\
дов, \\
дея- \\
тель- \\
ность \\
по ли- \\
квида- \\
ции за-- \\
гряз- \\
нений
\end{tabular} & & & & & & \\
\hline 14201 & 335173 & 2461824 & 371825 & 84375 & 996771 & 9622,1 & 3120,2 & 530459 & 102,1 & 1397,3 \\
\hline 183 & 2100 & 49035 & 2345 & 1873 & 21374 & 244,3 & 86,2 & 1136 & 101,7 & 22,9 \\
\hline 196 & ...8) & 933 & 2564 & 419 & 25898 & 96,3 & 19,6 & -273 & 103,3 & 10,4 \\
\hline 2055 & 11498 & 77338 & 34024 & 5761 & 57519 & 833,7 & 229,9 & 62895 & 101,4 & 195,4 \\
\hline 5482 & 24487 & 808811 & 102501 & 27046 & 412367 & 4728,4 & 1306,9 & 265270 & 102,2 & 484,1 \\
\hline 1357 & 220540 & 53568 & 27512 & 4559 & 42363 & 483,5 & 166,8 & 68413 & 102,1 & 144,1 \\
\hline 2070 & 46273 & 710337 & 64404 & 14085 & 144673 & 727,6 & 367,1 & 53785 & 102,4 & 190,8 \\
\hline 2584 & 27222 & 750704 & 131824 & 28985 & 290583 & 2333,9 & 880,4 & 77010 & 101,6 & 319,3 \\
\hline 275 & ...8) & 11099 & 6652 & 1647 & 1995 & 174,3 & 63,3 & 2223 & 103,8 & 30,4 \\
\hline 4516 & 23955 & 388045 & 137498 & 17236 & 463584 & 5081,7 & 1620,8 & 34252 & 102,2 & 503,9 \\
\hline 1571 & 4533 & 40911 & 20071 & 2215 & 123119 & 2000,1 & 690,3 & -5380 & 101,1 & 199,4 \\
\hline 102 & 1164 & 2574 & 2327 & 552 & 8488 & 309,3 & 22,5 & -1206 & 104,0 & 13,6 \\
\hline 253 & 234 & 26568 & 8302 & 963 & 46233 & 426,8 & 124,0 & -1463 & 102,5 & 40,9 \\
\hline 199 & 2583 & 36644 & 9018 & 970 & 32255 & 201,8 & 37,1 & 1027 & 101,9 & 17,8 \\
\hline 248 & 626 & 26423 & 6637 & 1450 & 24748 & 192,2 & 109,7 & -281 & 102,3 & 26,8 \\
\hline 468 & 4482 & 6464 & 13883 & 1164 & 24866 & 1069,3 & 158,4 & -8879 & 102,0 & 65,4 \\
\hline 1675 & 10333 & 248461 & 77261 & 9921 & 203876 & 882,1 & 478,8 & 50434 & 102,9 & 140,0 \\
\hline
\end{tabular}




\begin{tabular}{|c|c|c|c|c|c|c|c|}
\hline & \begin{tabular}{|c} 
Пло- \\
щадь \\
терри- \\
тории \\
(на 1 \\
января \\
2017 г.) $)^{2}$ \\
тыс. км
\end{tabular} & \begin{tabular}{|c|} 
Числен- \\
ность \\
насе- \\
ле- \\
ния \\
на 1 ян- \\
варя \\
2018 г., \\
тыс. \\
человек
\end{tabular} & $\begin{array}{c}\text { Средне- } \\
\text { годовая } \\
\text { числен- } \\
\text { ность } \\
\text { заня- } \\
\text { тых } \\
\text { тыс. } \\
\text { человек }\end{array}$ & \begin{tabular}{|c} 
Сред- \\
неду- \\
шевые \\
денеж- \\
ные \\
дохо- \\
ды ${ }^{4}$ (в \\
месяц), \\
руб.
\end{tabular} & \begin{tabular}{|c} 
Сред- \\
неду- \\
шевые \\
денеж- \\
ные \\
расхо- \\
ды (4) (в \\
месяц), \\
руб.
\end{tabular} & \begin{tabular}{|c|} 
Сред- \\
неме- \\
сячная \\
номи- \\
наль- \\
ная на- \\
числен- \\
ная за- \\
работ- \\
ная \\
плата \\
работ- \\
ников \\
органи- \\
заций, \\
руб.
\end{tabular} & \begin{tabular}{|c} 
Вало- \\
вой ре- \\
гио- \\
наль- \\
ный \\
про- \\
дукт \\
(в теку- \\
щих ос- \\
новных \\
ценах) $)^{5}$, \\
млрд. \\
руб. \\
\end{tabular} \\
\hline Приволжский & & & & & & & \\
\hline $\begin{array}{l}\text { федеральный округ } \\
\text { Республика }\end{array}$ & 1037,0 & 29542,7 & 14116,2 & 25971 & 24637 & 29166 & 10375,9 \\
\hline $\begin{array}{l}\text { Башкортостан } \\
\text { Республика }\end{array}$ & 142,9 & 4063,3 & 1757,5 & 28473 & 26895 & 30149 & 1344,4 \\
\hline $\begin{array}{l}\text { Марий Эл } \\
\text { Республика }\end{array}$ & 23,4 & 682,3 & 300,9 & 18913 & 16803 & 25711 & 160,5 \\
\hline $\begin{array}{l}\text { Мордовия } \\
\text { Республика }\end{array}$ & 26,1 & 805,0 & 387,6 & 18073 & 15928 & 24902 & 198,1 \\
\hline $\begin{array}{l}\text { Татарстан } \\
\text { Удмуртская }\end{array}$ & 67,8 & 3894,3 & 1951,2 & 32199 & 31165 & 32419 & 1937,6 \\
\hline $\begin{array}{l}\text { Республика } \\
\text { Чувашская }\end{array}$ & 42,1 & 1513,0 & 726,5 & 24016 & 21880 & 29008 & 540,1 \\
\hline Республика & 18,3 & 1231,1 & 545,9 & 17835 & 17599 & 24531 & 261,6 \\
\hline Пермский край & 160,2 & 2623,1 & 1204,4 & 28823 & 26982 & 32438 & 1091,3 \\
\hline $\begin{array}{l}\text { Кировская область } \\
\text { Нижегородская }\end{array}$ & 120,4 & 1283,3 & 590,8 & 21519 & 20649 & 24949 & 291,0 \\
\hline $\begin{array}{l}\text { область } \\
\text { Оренбургская }\end{array}$ & 76,6 & 3234,8 & 1644,9 & 30741 & 28998 & 30598 & 1182,3 \\
\hline область & 123,7 & 1977,7 & 935,6 & 23206 & 21901 & 27400 & 772,1 \\
\hline Пензенская область & 43,4 & 1331,7 & 632,6 & 21469 & 20855 & 26619 & 338,6 \\
\hline $\begin{array}{l}\text { Самарская область } \\
\text { Саратовская }\end{array}$ & 53,6 & 3193,5 & 1714,3 & 26803 & 26225 & 30267 & 1275,1 \\
\hline $\begin{array}{l}\text { область } \\
\text { Ульяновская }\end{array}$ & 101,2 & 2463,0 & 1136,9 & 19869 & 18914 & 24715 & 655,0 \\
\hline область & 37,2 & 1246,6 & 587,1 & 23161 & 20683 & 26134 & 328,2 \\
\hline
\end{tabular}


Продолжение табл. 1.3

\begin{tabular}{|c|c|c|c|c|c|c|c|c|c|c|}
\hline \multirow{2}{*}{$\begin{array}{c}\text { Основ- } \\
\text { ные } \\
\text { фонды } \\
\text { в эко- } \\
\text { номи- } \\
\text { ке (по } \\
\text { пол- } \\
\text { ной } \\
\text { учет- } \\
\text { ной } \\
\text { стои- } \\
\text { мос- } \\
\text { ти; на } \\
\text { конец } \\
2016 \text { г.), } \\
\text { млрд. } \\
\text { руб. }\end{array}$} & \multicolumn{4}{|c|}{$\begin{array}{c}\text { Объем отгруженных } \\
\text { товаров собственного } \\
\text { производства, } \\
\text { выполненных работ } \\
\text { и услуг собственными } \\
\text { силами, млн. руб. }\end{array}$} & \multirow{2}{*}{$\begin{array}{c}\text { Про- } \\
\text { дукция } \\
\text { сель- } \\
\text { ского } \\
\text { хозяй- } \\
\text { ства, } \\
\text { млн. } \\
\text { руб. }\end{array}$} & \multirow{2}{*}{\begin{tabular}{|} 
Ввод в \\
дейст- \\
вие об- \\
щей \\
поща- \\
ди жи- \\
лых \\
поме- \\
щений, \\
тыс.м
\end{tabular}} & \multirow{2}{*}{$\begin{array}{c}\text { Обо- } \\
\text { рот } \\
\text { роз- } \\
\text { нич- } \\
\text { ной } \\
\text { торгов- } \\
\text { ли, } \\
\text { млрд. } \\
\text { руб. }\end{array}$} & \multirow{2}{*}{\begin{tabular}{|c} 
Саль- \\
диро- \\
ванный \\
финан- - совый \\
резуль- \\
тат \\
(при- \\
быль \\
минус \\
убы- \\
ток) \\
в эко- \\
номи- \\
ке, \\
млн. \\
руб.
\end{tabular}} & \multirow{2}{*}{$\begin{array}{l}\text { Индекс } \\
\text { потре- } \\
\text { битель- } \\
\text { ских } \\
\text { цен } \\
\text { (де- } \\
\text { кабрь к } \\
\text { декаб- } \\
\text { рю } \\
\text { преды- } \\
\text { дущего } \\
\text { года), } \\
\text { про- } \\
\text { центов }\end{array}$} & \multirow{2}{*}{$\begin{array}{c}\text { Инвес- } \\
\text { тиции } \\
\text { В } \\
\text { основ- } \\
\text { ной ка- } \\
\text { питал, } \\
\text { млрд. } \\
\text { руб. } \\
\\
\end{array}$} \\
\hline & $\begin{array}{c}\text { добыча } \\
\text { полез- } \\
\text { ных ис- } \\
\text { копа- } \\
\text { емых }\end{array}$ & $\begin{array}{c}\text { обраба- } \\
\text { ты- } \\
\text { ваю- } \\
\text { щие } \\
\text { произ- } \\
\text { водства }\end{array}$ & \begin{tabular}{|c} 
обес- \\
пече- \\
ние \\
элек- \\
триче-- \\
ской \\
энер- \\
гией, \\
газом \\
и па- \\
ром; \\
конди- \\
циони- \\
рова- \\
ние \\
возду- \\
ха
\end{tabular} & \begin{tabular}{|c} 
водо- \\
снаб- \\
жение; \\
водо- \\
отве- \\
дение, \\
орга- \\
низа- \\
ция \\
сбора \\
и ути- \\
лиза- \\
ции \\
отхо- \\
дов, \\
дея- \\
тель- \\
ность \\
по ли- \\
квида- \\
ции за-- \\
гряз- \\
нений
\end{tabular} & & & & & & \\
\hline 25330 & 1914711 & 7744413 & 904980 & 191646 & 1343605 & 15640,8 & 5220,0 & 1135529 & 101,9 & 2412,2 \\
\hline 2868 & 227606 & 1067504 & 126451 & 19202 & 171828 & 2460,5 & 841,1 & 264526 & 101,6 & 260,9 \\
\hline 405 & 559 & 143046 & 11556 & 4001 & 43949 & 470,3 & 82,0 & 8581 & 102,5 & 24,0 \\
\hline 600 & 148 & 154354 & 12366 & 2806 & 61114 & 330,1 & 87,4 & 7362 & 101,1 & 59,9 \\
\hline 4256 & 541120 & 1561010 & 126294 & 25756 & 256118 & 2408,1 & 843,9 & 320734 & 102,2 & 637,6 \\
\hline 1170 & 178188 & 311843 & 36525 & 6935 & 71543 & 658,6 & 221,5 & 84715 & 101,4 & 80,0 \\
\hline 761 & 509 & 168635 & 24176 & 5944 & 45224 & 605,0 & 142,2 & -214601 & 101,4 & 51,9 \\
\hline 3205 & 286753 & 952819 & 119340 & 24579 & 44957 & 1101,1 & 502,3 & 187402 & 101,4 & 253,8 \\
\hline 785 & 991 & 195857 & 39035 & 4487 & 40005 & 545,8 & 184,4 & 13105 & 102,0 & 57,0 \\
\hline 2791 & 940 & 1180501 & 97233 & 25854 & 76088 & 1308,1 & 696,9 & 143194 & 103,1 & 244,1 \\
\hline 2040 & 363588 & 294253 & 54012 & 11585 & 130106 & 892,0 & 294,0 & 91474 & 101,9 & 181,7 \\
\hline 930 & 946 & 181920 & 22096 & 5235 & 87359 & 886,9 & 199,2 & 11944 & 101,6 & 72,5 \\
\hline 3012 & 275426 & 938513 & 113685 & 37799 & 96425 & 1787,7 & 613,6 & 165721 & 101,5 & 251,5 \\
\hline 1780 & 31431 & 336660 & 96678 & 9415 & 173761 & 1210,1 & 333,2 & 37003 & 101,2 & 145,5 \\
\hline 728 & 6507 & 257499 & 25532 & 8047 & 45129 & 976,6 & 178,3 & 14369 & 102,5 & 91,8 \\
\hline
\end{tabular}




\begin{tabular}{|c|c|c|c|c|c|c|c|}
\hline & $\begin{array}{c}\text { Пло- } \\
\text { щадь } \\
\text { терри- } \\
\text { тории } \\
\text { (на } 1 \\
\text { января } \\
\text { 2017 г.) } \\
\text { тыс. км }\end{array}$ & \begin{tabular}{|c} 
Числен- \\
ность \\
насе- \\
ле- \\
ния \\
на 1 ян- \\
варя \\
2018 г., \\
тыс. \\
человек
\end{tabular} & $\begin{array}{l}\text { Средне- } \\
\text { годовая } \\
\text { числен- } \\
\text { ность } \\
\text { заня- } \\
\text { тых } \\
\text { тыс. } \\
\text { тыс. } \\
\text { человек } \\
\end{array}$ & \begin{tabular}{|c} 
Сред- \\
неду- \\
шевые \\
денеж- \\
ные \\
дохо- \\
ды (1) (в \\
месяц), \\
руб.
\end{tabular} & \begin{tabular}{|c} 
Сред- \\
неду- \\
шевые \\
денеж- \\
ные \\
расхо- \\
ды (в (в \\
месяц), \\
руб.
\end{tabular} & \begin{tabular}{|c|} 
Сред- \\
неме- \\
сячная \\
номи- \\
наль- \\
ная на- \\
числен- \\
ная за- \\
работ- \\
ная \\
плата \\
работ- \\
ников \\
органи- \\
заций, \\
руб.
\end{tabular} & \begin{tabular}{|c|} 
Вало- \\
вой ре- \\
гио- \\
наль- \\
ный \\
про- \\
дукт \\
(в теку- \\
щих ос- \\
новных \\
ценах), \\
млрд. \\
руб.
\end{tabular} \\
\hline $\begin{array}{c}\text { Уральскии } \\
\text { федеральный округ }\end{array}$ & 1818,5 & 12356,2 & 6347,1 & 32712 & 31342 & 43853 & 9354,7 \\
\hline $\begin{array}{l}\text { Курганская область } \\
\text { Свердловская }\end{array}$ & 71,5 & 845,5 & 348,3 & 21208 & 19336 & 25239 & 193,9 \\
\hline область & 194,3 & 4325,3 & 2093,9 & 35303 & 35564 & 34341 & 1978,0 \\
\hline $\begin{array}{c}\text { Тюменская область } \\
\text { в том числе: } \\
\text { Ханты-Мансийский } \\
\text { автономный округ- }\end{array}$ & 1464,2 & 3692,4 & 2190,8 & 41314 & 38460 & 63796 & 5922,1 \\
\hline $\begin{array}{l}\text { Югра } \\
\text { Ямало-Ненецкий }\end{array}$ & 534,8 & 1655,1 & 1025,4 & 44359 & 39879 & 66376 & 3031,2 \\
\hline $\begin{array}{l}\text { автономный округ } \\
\text { Тюменская область } \\
\text { без автономных }\end{array}$ & 769,3 & 538,5 & 403,0 & 67797 & 46268 & 89834 & 1963,9 \\
\hline округов & 160,1 & 1498,8 & 762,5 & 28377 & 34067 & 40964 & 927,0 \\
\hline $\begin{array}{l}\text { Челябинская область } \\
\text { Сибирский }\end{array}$ & 88,5 & 3493,0 & 1714,0 & 23261 & 21554 & 32196 & 1260,7 \\
\hline федеральный округ & 5145,0 & 19287,5 & 8783,8 & 23860 & 22933 & 33822 & 7133,9 \\
\hline Республика Алтай & 92,9 & 218,1 & 85,0 & 19046 & 15594 & 25903 & 46,1 \\
\hline Республика Бурятия & 351,3 & 984,5 & 391,2 & 24566 & 24953 & 32088 & 199,2 \\
\hline Республика Тыва & 168,6 & 321,7 & 103,2 & 13800 & 10345 & 30760 & 52,2 \\
\hline Республика Хакасия & 61,6 & 537,5 & 233,3 & 21363 & 22280 & 34347 & 182,4 \\
\hline Алтайский край & 168,0 & 2350,1 & 1017,5 & 22238 & 19607 & 22732 & 498,8 \\
\hline Забайкальский край & 431,9 & 1072,8 & 474,5 & 23361 & 22328 & 34875 & 262,8 \\
\hline Красноярский край & 2366,8 & 2876,5 & 1391,3 & 27977 & 26603 & 40929 & 1768,0 \\
\hline Иркутская область & 774,8 & 2404,2 & 1128,0 & 22412 & 21488 & 37589 & 1068,7 \\
\hline $\begin{array}{l}\text { Кемеровская область } \\
\text { Новосибирская }\end{array}$ & 95,7 & 2694,9 & 1220,4 & 21910 & 20187 & 32645 & 858,1 \\
\hline область & 177,8 & 2788,8 & 1338,8 & 25230 & 27310 & 32984 & 1084,7 \\
\hline
\end{tabular}


Продолжение табл. 1.3

\begin{tabular}{|c|c|c|c|c|c|c|c|c|c|c|}
\hline \multirow{2}{*}{$\begin{array}{c}\text { Основ- } \\
\text { ные } \\
\text { фонды } \\
\text { в эко- } \\
\text { номи- } \\
\text { ке (по } \\
\text { пол-- } \\
\text { ной } \\
\text { учет- } \\
\text { ной } \\
\text { стои- } \\
\text { мос- } \\
\text { ти; на } \\
\text { конец } \\
2016 \text { г) } \\
\text { млрд. } \\
\text { руб. }\end{array}$} & \multicolumn{4}{|c|}{$\begin{array}{c}\text { Объем отгруженных } \\
\text { товаров собственного } \\
\text { производства, } \\
\text { выполненных работ } \\
\text { и услуг собственными } \\
\text { силами, млн. руб. }\end{array}$} & \multirow{2}{*}{$\begin{array}{c}\text { Про- } \\
\text { дукция } \\
\text { сель- } \\
\text { ского } \\
\text { хозяй- } \\
\text { ства, } \\
\text { млн. } \\
\text { руб. }\end{array}$} & \multirow{2}{*}{$\begin{array}{l}\text { Ввод в } \\
\text { дейст- } \\
\text { вие об- } \\
\text { щей } \\
\text { площа- } \\
\text { ди жи- } \\
\text { лых } \\
\text { поме- } \\
\text { щений, } \\
\text { тыс.м }\end{array}$} & \multirow{2}{*}{$\begin{array}{c}\text { Обо- } \\
\text { рот } \\
\text { роз- } \\
\text { нич- } \\
\text { ной } \\
\text { торгов- } \\
\text { ли, } \\
\text { млрд. } \\
\text { руб. } \\
\\
\end{array}$} & \multirow{2}{*}{\begin{tabular}{|c} 
Саль- \\
диро- \\
ванный \\
финан- \\
совый \\
резуль- \\
тат \\
(при- \\
быль \\
минус \\
убы- \\
ток) \\
в эко- \\
номи- \\
ке, \\
млн. \\
руб.
\end{tabular}} & \multirow{2}{*}{\begin{tabular}{|c} 
Индекс \\
потре- \\
битель- \\
ских \\
цен \\
(де- \\
кабрь к \\
декаб- \\
рю \\
преды- \\
дущего \\
года), \\
про- \\
центов
\end{tabular}} & \multirow{2}{*}{\begin{tabular}{|c} 
Инвес- \\
тиции \\
в \\
основ- - \\
ной ка- \\
питал, \\
млрд. \\
руб.
\end{tabular}} \\
\hline & $\begin{array}{c}\text { добыча } \\
\text { полез- } \\
\text { ных ис- } \\
\text { копа- } \\
\text { емых }\end{array}$ & $\begin{array}{c}\text { обраба- } \\
\text { ты- } \\
\text { ваю- } \\
\text { щие } \\
\text { произ- } \\
\text { водства }\end{array}$ & $\begin{array}{c}\text { обес- } \\
\text { пече- } \\
\text { ние } \\
\text { элек- } \\
\text { триче-- } \\
\text { ской } \\
\text { энер- } \\
\text { гией, } \\
\text { газом } \\
\text { и па- } \\
\text { ром; } \\
\text { конди- } \\
\text { циони- } \\
\text { рова- } \\
\text { ние } \\
\text { возду- } \\
\text { ха }\end{array}$ & \begin{tabular}{|c|} 
водо- \\
снаб- \\
жение; \\
водо- \\
отве- \\
дение, \\
орга- \\
низа- \\
ция \\
сбора \\
и ути- \\
лиза- \\
ции \\
отхо- \\
дов, \\
дея- \\
тель- \\
ность \\
по ли- \\
квида- \\
ции за- \\
гряз- \\
нений
\end{tabular} & & & & & & \\
\hline 33651 & 5176030 & 4614849 & 671061 & 125826 & 337931 & 6301,7 & 2555,7 & 1551937 & 102,4 & 2870,1 \\
\hline 694 & 3255 & 94807 & 18621 & 2632 & 46826 & 271,8 & 108,7 & 802 & 102,5 & 22,4 \\
\hline $\begin{array}{r}6087 \\
23948\end{array}$ & 68156 & 1650926 & 215852 & 60011 & 77741 & 2144,0 & 1078,2 & 257070 & 102,2 & 337,8 \\
\hline 23948 & 5043153 & 1535456 & 309477 & 34577 & 87256 & 2468,5 & 876,4 & 1124065 & 102,7 & 2315,1 \\
\hline 11654 & 2932921 & 515593 & 212027 & 20137 & 9229 & 812,5 & 394,6 & 518567 & 103,1 & 942,2 \\
\hline 10219 & 1942881 & 351996 & 45841 & 8164 & 2040 & 236,1 & 127,7 & 378836 & 101,5 & 1082,3 \\
\hline 2075 & 167351 & 667866 & 51610 & 6276 & 75987 & 1419,9 & 354,1 & 226661 & 103,4 & 290,7 \\
\hline 2922 & 61466 & 1333661 & 127111 & 28605 & 126108 & 1417,3 & 492,4 & 170000 & 102,3 & 194,7 \\
\hline 15338 & 2182149 & 3767681 & 673017 & 91495 & 673902 & 7332,9 & 2918,5 & 1193935 & 102,0 & 1521,1 \\
\hline 128 & 3477 & 4695 & 2685 & 343 & 13183 & 130,9 & 24,4 & -205 & 101,6 & 13,1 \\
\hline 609 & 21655 & 57252 & 26407 & 1611 & 16761 & 269,2 & 170,9 & 13543 & 102,1 & 41,5 \\
\hline 92 & 22769 & 346 & 4031 & 317 & 6084 & 101,0 & 22,1 & 6189 & 102,7 & 9,3 \\
\hline 418 & 47946 & 85614 & 47625 & 1247 & 16464 & 235,9 & 79,2 & 14096 & 102,0 & 22,1 \\
\hline 872 & 5561 & 291366 & 45028 & 6349 & 150556 & 629,9 & 339,2 & 31585 & 101,8 & 84,2 \\
\hline 924 & 78951 & 23355 & 31344 & 2485 & 21620 & 270,5 & 158,2 & 12816 & 102,5 & 91,3 \\
\hline 3227 & 502967 & 961416 & 160378 & 24827 & 93114 & 1056,5 & 511,0 & 467017 & 101,6 & 424,7 \\
\hline 2529 & 420105 & 463385 & 115333 & 12291 & 65986 & 973,8 & 322,0 & 203618 & 102,7 & 256,9 \\
\hline 2405 & 852129 & 534881 & 93791 & 14302 & 58542 & 1000,3 & 355,0 & 283945 & 102,1 & 208,1 \\
\hline 1944 & 43563 & 420231 & 58296 & 13593 & 98633 & 1729,1 & 473,4 & 75297 & 101,5 & 175,0 \\
\hline
\end{tabular}




\begin{tabular}{|c|c|c|c|c|c|c|c|}
\hline & \begin{tabular}{|c|} 
Пло- \\
щадь \\
терри- \\
тории \\
(на 1 \\
января \\
2017 г.) $)^{2}$ \\
тыс. км²
\end{tabular} & $\begin{array}{c}\text { Числен- } \\
\text { ность } \\
\text { насе- } \\
\text { ле- } \\
\text { ния } \\
\text { на } 1 \text { ян- } \\
\text { варя } \\
2018 \text { г., } \\
\text { тыс. } \\
\text { человек }\end{array}$ & $\begin{array}{c}\text { Средне- } \\
\text { годовая } \\
\text { числен- } \\
\text { ность } \\
\text { заня- } \\
\text { тых } \\
\text { тыс. } \\
\text { человек }\end{array}$ & $\begin{array}{c}\text { Сред- } \\
\text { неду- } \\
\text { шевые } \\
\text { денеж- } \\
\text { ные } \\
\text { дохо- } \\
\text { ды }{ }^{4)} \text { (в } \\
\text { месяц), } \\
\text { руб. }\end{array}$ & \begin{tabular}{|c} 
Сред- \\
неду- \\
шевые \\
денеж- \\
ные \\
расхо- \\
ды) (в \\
месяц), \\
руб.
\end{tabular} & \begin{tabular}{|c} 
Сред- \\
неме- \\
сячная \\
номи- \\
наль- \\
ная на- \\
числен- \\
ная за- \\
работ- \\
ная \\
плата \\
работ-- \\
ников \\
органи- \\
заций, \\
руб.
\end{tabular} & \begin{tabular}{|c} 
Вало- \\
вой ре- \\
гио- \\
наль- \\
ный \\
про- \\
дукт \\
(в теку- \\
щих ос- \\
новных \\
ценах) \\
млр.' \\
руб. \\
\end{tabular} \\
\hline омская область & 141,1 & 1960,1 & 913,0 & 25243 & 23849 & 30160 & 625,9 \\
\hline $\begin{array}{l}\text { Томская область } \\
\text { Дальневосточный }\end{array}$ & 314,4 & 1078,3 & 487,8 & 23543 & 21862 & 38388 & 487,0 \\
\hline $\begin{array}{l}\text { федеральный округ } \\
\text { Республика Саха }\end{array}$ & 6169,3 & 6165,3 & 3203,4 & 37223 & 35799 & 49022 & 3756,6 \\
\hline (Якутия) & 3083,5 & 964,4 & 483,4 & 39765 & 37237 & 62011 & 868,6 \\
\hline Камчатский край & 464,3 & 315,5 & 166,2 & 41457 & 39472 & 65970 & 198,1 \\
\hline Приморский край & 164,7 & 1913,0 & 986,2 & 33469 & 32948 & 37962 & 736,9 \\
\hline Хабаровский край & 787,6 & 1328,3 & 693,9 & 37801 & 37193 & 42912 & 637,7 \\
\hline Амурская область & 361,9 & 798,4 & 395,5 & 31773 & 30963 & 37447 & 287,6 \\
\hline Магаданская область & 462,5 & 144,1 & 92,2 & 50146 & 46398 & 74855 & 146,9 \\
\hline $\begin{array}{l}\text { Сахалинская область } \\
\text { Еврейская }\end{array}$ & 87,1 & 490,2 & 284,4 & 49474 & 47099 & 68827 & 767,8 \\
\hline $\begin{array}{l}\text { автономная область } \\
\text { Чукотский }\end{array}$ & 36,3 & 162,0 & 69,7 & 23386 & 21342 & 34508 & 46,9 \\
\hline автономный округ & 721,5 & 49,4 & 31,9 & 65564 & 40643 & 92368 & 66,1 \\
\hline
\end{tabular}

1) Данные в стоимостном выражении приведены в фактически действовавших ценах.

2) По данным Росреестра.

3) Данные за 2016 г. рассчитаны в соответствии с актуализированной методикой рас-

чета баланса трудовых ресурсов и оценки затрат труда.

4) Сучетом единовременной денежной выплаты, назначенной в соответствии с Федеральным законом от 22 ноября 2016 г. №385-Ф3 в размере 5 тысяч рублей.

5) 2016 г.

6) $\mathrm{C}$ учётом переоценки, проведённой коммерческими организациями на конец отчётного года.

7) Млн. км².

8) Данные не публикуются в целях обеспечения конфиденциальности первичных статистических данных, полученных от организаций, в соответствии с Федеральным законом от 29.11.07 № 282-Ф3 "Об официальном статистическом учете и системе государственной статистики в Российской Федерации" (п.5, ст.4, ч.1, ст,9). 
Продолжение табл. 1.3

\begin{tabular}{|c|c|c|c|c|c|c|c|c|c|c|}
\hline \multirow{2}{*}{\begin{tabular}{|} 
Основ- \\
ные \\
фонды \\
в эко- \\
номи- \\
ке (по \\
пол- \\
ной \\
учет- \\
ной \\
стои- \\
мос- \\
ти; на \\
конец \\
2016 г.) \\
млрд. \\
руб.
\end{tabular}} & \multicolumn{4}{|c|}{$\begin{array}{c}\text { Объем отгруженных } \\
\text { товаров собственного } \\
\text { производства, } \\
\text { выполненных работ } \\
\text { и услуг собственными } \\
\text { силами, млн. руб. }\end{array}$} & \multirow{2}{*}{\begin{tabular}{|c} 
Про- \\
дукция \\
сель- \\
ского \\
хозяй- \\
ства, \\
млн. \\
руб.
\end{tabular}} & \multirow{2}{*}{$\begin{array}{l}\text { Ввод в } \\
\text { дейст- } \\
\text { вие об- } \\
\text { щей } \\
\text { площа- } \\
\text { ди жи- } \\
\text { лых } \\
\text { поме- } \\
\text { щений, } \\
\text { тыс.м }\end{array}$} & \multirow{2}{*}{$\begin{array}{c}\text { Обо- } \\
\text { рот } \\
\text { роз- } \\
\text { нич- } \\
\text { ной } \\
\text { торгов- } \\
\text { ли, } \\
\text { млрд. } \\
\text { руб. }\end{array}$} & \multirow{2}{*}{\begin{tabular}{|c|} 
Саль- \\
диро- \\
ванный \\
финан- \\
совый \\
резуль- \\
тат \\
(при- \\
быль \\
минус \\
убы- \\
ток) \\
в эко- \\
номи- \\
ке, \\
млн. \\
руб.
\end{tabular}} & \multirow{2}{*}{\begin{tabular}{|c} 
Индекс \\
потре- \\
битель- \\
ских \\
цен \\
(де- \\
кабрь к \\
декаб- \\
рю \\
преды- \\
дущего \\
года), \\
про- \\
центов
\end{tabular}} & \multirow{2}{*}{$\begin{array}{l}\text { Инвес- } \\
\text { тиции } \\
\text { В } \\
\text { основ- } \\
\text { ной ка- } \\
\text { питал, } \\
\text { млрд. } \\
\text { руб. } \\
\\
\end{array}$} \\
\hline & $\begin{array}{c}\text { добыча } \\
\text { полез- } \\
\text { ных ис- } \\
\text { копа- } \\
\text { емых }\end{array}$ & \begin{tabular}{|c|} 
обраба- \\
ты- \\
ваю- \\
щие \\
произ- \\
водства
\end{tabular} & $\begin{array}{c}\text { обес- } \\
\text { пече- } \\
\text { ние } \\
\text { элек- } \\
\text { триче- } \\
\text { ской } \\
\text { энер- } \\
\text { гией, } \\
\text { газом } \\
\text { и па- } \\
\text { ром; } \\
\text { конди- } \\
\text { циони- } \\
\text { рова- } \\
\text { ние } \\
\text { возду- } \\
\text { ха }\end{array}$ & \begin{tabular}{|c|} 
водо- \\
снаб- \\
жение; \\
водо- \\
отве- \\
дение, \\
орга- \\
низа- \\
ция \\
сбора \\
и ути- \\
лиза- \\
ции \\
отхо- \\
дов, \\
дея- \\
тель- \\
ность \\
по ли- \\
квида- \\
ции за- \\
гряз- \\
нений
\end{tabular} & & & & & & \\
\hline 1019 & 3355 & 775082 & $\overline{50746}$ & 7942 & 98600 & 458,2 & 316,7 & 34094 & 101,4 & 99,7 \\
\hline 1172 & 179672 & 150058 & 37355 & 6187 & 34359 & 477,6 & 146,4 & 51940 & 102,8 & 95,1 \\
\hline 11637 & 1633058 & 668614 & 276731 & 39525 & 192862 & 1972,6 & 1315,0 & 474574 & 102,1 & 1217,4 \\
\hline 2025 & 620301 & 34179 & 66149 & 3748 & 25067 & 633,8 & 212,7 & 109851 & 104,4 & 384,9 \\
\hline 501 & 18136 & 85209 & 17647 & 2434 & 9880 & 66,7 & 54,0 & 36081 & 102,1 & 37,1 \\
\hline 3126 & 19332 & 217118 & 62713 & 9730 & 48571 & 412,1 & 375,0 & 60317 & 101,8 & 125,7 \\
\hline 1589 & 74897 & 240548 & 53232 & 6229 & 25101 & 269,7 & 307,6 & 23704 & 102,6 & 117,2 \\
\hline 1009 & 65409 & 23486 & 30701 & 2664 & 62225 & 181,6 & 161,6 & 10374 & 101,7 & 186,6 \\
\hline 259 & 109404 & 3995 & 15411 & 898 & 2792 & 6,4 & 30,9 & 28352 & 103,1 & 44,2 \\
\hline 2763 & 653705 & 57730 & 18189 & 13011 & 11901 & 347,7 & 141,5 & 188985 & 102,2 & 299,5 \\
\hline 224 & 7441 & 5539 & 4329 & 469 & 7043 & 50,4 & 22,6 & 255 & 102,5 & 10,5 \\
\hline 141 & 64433 & 810 & 8359 & 343 & 283 & 4,1 & 9,1 & 16655 & 102,8 & 11,8 \\
\hline
\end{tabular}




\section{2. ГОСУДАРСТВЕННОЕ УСТРОЙСТВО РОССИЙСКОЙ ФЕДЕРАЦИИ}

В разделе приводятся краткая характеристика государственного устройства Российской Федерации, сведения о муниципальных образованиях, численности работников, занятых в органах государственной власти и местного самоуправления, содержится статистическая информация о составе Федерального Собрания Российской Федерации.

Данные о числе муниципальных образований получены на основе федерального статистического наблюдения по форме № 1-администрация «Сведения о муниципальных образованиях», предоставляемой органами исполнительной власти субъектов Российской Федерации.

\section{1. ГОСУДАРСТВЕННОЕ УСТРОЙСТВО РОССИЙСКОЙ ФЕДЕРАЦИИ}

Согласно Конституции, Российская Федерация - Россия есть демократическое федеративное правовое государство с республиканской формой правления (ст.1).

Государственную власть в Российской Федерации осуществляют Президент Российской Федерации, Федеральное Собрание (Совет Федерации и Государственная Дума), Правительство Российской Федерации, суды Российской Федерации (ст.11).

Президент Российской Федерации является главой государства, избирается сроком на шесть лет гражданами Российской Федерации на основе всеобщего равного и прямого избирательного права при тайном голосовании (ст.80, 81).

Федеральное Собрание - парламент Российской Федерации - является представительным и законодательным органом Российской Федерации, состоит из двух палат - Совета Федерации и Государственной Думы. (ст.94, 95). 
2.2. МУНИЦИПАЛЬНЫЕ ОБРАЗОВАНИЯ на 1 января 2018 г.

Внутригородская территория (внутри-

городское муниципальное образование)

городов федерального значения

Городские поселения 


\section{3. ХАРАКТЕРИСТИКИ МУНИЦИПАЛЬНЫХ ОБРАЗОВАНИЙ В СУБЪЕКТАХ РОССИЙСКОЙ ФЕДЕРАЦИИ в 2017 г.}

\begin{tabular}{|c|c|c|c|}
\hline & $\begin{array}{c}\text { Число } \\
\text { муниципаль- } \\
\text { ных образо- } \\
\text { ваний } \\
\text { (на } 1 \text { января } \\
2018 \text { г.) }\end{array}$ & $\begin{array}{c}\text { Численность } \\
\text { работников } \\
\text { органов } \\
\text { местного } \\
\text { самоуправ- } \\
\text { ления }{ }^{1)} \\
\text { (на конец } \\
\text { года), } \\
\text { человек }\end{array}$ & $\begin{array}{c}\text { Среднеме- } \\
\text { сячная } \\
\text { начисленная } \\
\text { заработная } \\
\text { плата работ- } \\
\text { ников органов } \\
\text { местного } \\
\text { самоуправ- } \\
\text { ления }{ }^{1)}, \text { руб. }\end{array}$ \\
\hline $\begin{array}{r}\text { Российская Федерация } \\
\text { Центральный }\end{array}$ & 21946 & 472221 & 33953 \\
\hline федеральный округ & 4489 & 90717 & 34352 \\
\hline Белгородская область & 312 & 6875 & 29060 \\
\hline Брянская область & 289 & 4167 & 22706 \\
\hline Владимирская область & 127 & 3099 & 30625 \\
\hline Воронежская область & 479 & 6081 & 33002 \\
\hline Ивановская область & 143 & 3368 & 26898 \\
\hline Калужская область & 304 & 5016 & 28820 \\
\hline Костромская область & 176 & 3009 & 23635 \\
\hline Курская область & 355 & 4303 & 25771 \\
\hline Липецкая область & 313 & 4792 & 29529 \\
\hline Московская область & 227 & 15494 & 57268 \\
\hline Орловская область & 267 & 3392 & 26142 \\
\hline Рязанская область & 295 & 5480 & 25419 \\
\hline Смоленская область & 257 & 4913 & 20544 \\
\hline Тамбовская область & 274 & 4489 & 22186 \\
\hline Тверская область & 322 & 5674 & 31547 \\
\hline Тульская область & 103 & 4222 & 32622 \\
\hline Ярославская область & 100 & 4377 & 33172 \\
\hline г. Москва & 146 & 1966 & 87641 \\
\hline $\begin{array}{c}\text { Северо-Западный } \\
\text { федеральный округ }\end{array}$ & 1419 & 34786 & 39709 \\
\hline Республика Карелия & 126 & 1609 & 38082 \\
\hline Республика Коми & 181 & 4371 & 38471 \\
\hline $\begin{array}{l}\text { Архангельская область } \\
\text { в том числе: }\end{array}$ & 225 & 5214 & 41858 \\
\hline $\begin{array}{l}\text { Ненецкий автономный округ } \\
\text { Архангельская область }\end{array}$ & 21 & 389 & 90508 \\
\hline без автономного округа & 204 & 4825 & 37878 \\
\hline Вологодская область & 209 & 4519 & 29770 \\
\hline Калининградская область & 32 & 2824 & 42608 \\
\hline Ленинградская область & 217 & 6132 & 46491 \\
\hline Мурманская область & 40 & 2111 & 62438 \\
\hline Новгородская область & 142 & 2928 & 27811 \\
\hline Псковская область & 136 & 2662 & 16956 \\
\hline г. Санкт-Петербург & 111 & 2416 & 55577 \\
\hline
\end{tabular}

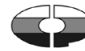


Продолжение табл. 2.3

\begin{tabular}{|c|c|c|c|}
\hline & $\begin{array}{c}\text { Число } \\
\text { муниципаль- } \\
\text { ных образо- } \\
\text { ваний } \\
\text { (на } 1 \text { января } \\
2018 \text { г.) }\end{array}$ & $\begin{array}{c}\text { Численность } \\
\text { работников } \\
\text { органов } \\
\text { местного } \\
\text { самоуправ- } \\
\text { ления }{ }^{1)} \\
\text { (на конец } \\
\text { года), } \\
\text { человек }\end{array}$ & $\begin{array}{c}\text { Среднеме- } \\
\text { сячная } \\
\text { начисленная } \\
\text { заработная } \\
\text { плата работ- } \\
\text { ников органов } \\
\text { местного } \\
\text { самоуправ- } \\
\text { ления }{ }^{1} \text {, руб. }\end{array}$ \\
\hline Южный & & & \\
\hline федеральный округ & 1983 & 53829 & 29308 \\
\hline Республика Адыгея & 60 & 1808 & 26197 \\
\hline Республика Калмыкия & 127 & 1382 & 20490 \\
\hline Республика Крым & 279 & 6058 & 30890 \\
\hline Краснодарский край & 426 & 14230 & 37218 \\
\hline Астраханская область & 143 & 3567 & 23868 \\
\hline Волгоградская область & 475 & 9093 & 25844 \\
\hline Ростовская область & 463 & 17488 & 26128 \\
\hline г. Севастополь & 10 & 203 & 37173 \\
\hline $\begin{array}{c}\text { Северо-Кавказский } \\
\text { федеральный округ }\end{array}$ & 1587 & 29249 & 23649 \\
\hline Республика Дагестан & 760 & 7348 & 21324 \\
\hline Республика Ингушетия & 45 & 817 & 19221 \\
\hline Кабардино-Балкарская & & & \\
\hline Республика & 132 & 2713 & 23475 \\
\hline Карачаево-Черкесская & & & \\
\hline Республика & 100 & 2253 & 18472 \\
\hline Республика Северная & & & \\
\hline Осетия - Алания & 111 & 1749 & 22093 \\
\hline Чеченская Республика & 238 & 4136 & 25343 \\
\hline Ставропольский край & 201 & 10233 & 26232 \\
\hline
\end{tabular}


Продолжение табл. 2.3

\begin{tabular}{|c|c|c|c|}
\hline & $\begin{array}{c}\text { Число } \\
\text { муниципаль- } \\
\text { ных образо- } \\
\text { ваний } \\
\text { (на } 1 \text { января } \\
2018 \text { г.) }\end{array}$ & \begin{tabular}{|c} 
Численность \\
работников \\
органов \\
местного \\
самоуправ- \\
ления ${ }^{1)}$ \\
(на конец \\
года), \\
человек \\
\end{tabular} & $\begin{array}{c}\text { Среднеме- } \\
\text { сячная } \\
\text { начисленная } \\
\text { заработная } \\
\text { плата работ- } \\
\text { ников органов } \\
\text { местного } \\
\text { самоуправ- } \\
\text { ления }{ }^{1}, \text { руб. }\end{array}$ \\
\hline $\begin{array}{c}\text { Приволжский } \\
\text { федеральный округ }\end{array}$ & 5785 & 102902 & 27448 \\
\hline Республика Башкортостан & 895 & 11595 & 30139 \\
\hline Республика Марий Эл & 138 & 2203 & 22105 \\
\hline Республика Мордовия & 377 & 3029 & 23242 \\
\hline Республика Татарстан & 956 & 11011 & 30425 \\
\hline Удмуртская Республика & 333 & 6022 & 26853 \\
\hline Чувашская Республика & 317 & 3415 & 21596 \\
\hline Пермский край & 337 & 11002 & 31501 \\
\hline Кировская область & 364 & 8074 & 19864 \\
\hline Нижегородская область & 380 & 14330 & 28255 \\
\hline Оренбургская область & 489 & 7574 & 26295 \\
\hline Пензенская область & 321 & 5475 & 23154 \\
\hline Самарская область & 342 & 8579 & 32497 \\
\hline Саратовская область & 369 & 7154 & 25179 \\
\hline Ульяновская область & 167 & 3439 & 24794 \\
\hline $\begin{array}{c}\text { Уральский } \\
\text { федеральный округ }\end{array}$ & 1349 & 47147 & 52105 \\
\hline Курганская область & 458 & 4659 & 19913 \\
\hline Свердловская область & 94 & 9139 & 37761 \\
\hline $\begin{array}{l}\text { Тюменская область } \\
\text { в том числе: }\end{array}$ & 478 & 18567 & 86482 \\
\hline $\begin{array}{l}\text { Ханты-Мансийский } \\
\text { автономный округ - Югра }\end{array}$ & 105 & 7604 & 92538 \\
\hline $\begin{array}{l}\text { Ямало-Ненецкий } \\
\text { автономный округ }\end{array}$ & 55 & 5732 & 118741 \\
\hline $\begin{array}{l}\text { Тюменская область } \\
\text { без автономных округов }\end{array}$ & 318 & 5231 & 43081 \\
\hline Челябинская область & 319 & 14782 & 27024 \\
\hline
\end{tabular}


Продолжение табл. 2.3

\begin{tabular}{|c|c|c|c|}
\hline & \begin{tabular}{|c|} 
Число \\
муниципаль- \\
ных образо- \\
ваний \\
(на 1 января \\
2018 г.)
\end{tabular} & $\begin{array}{c}\text { Численность } \\
\text { работников } \\
\text { органов } \\
\text { местного } \\
\text { самоуправ- } \text { ления }{ }^{1)} \\
\text { (на конец } \\
\text { года), } \\
\text { человек }\end{array}$ & $\begin{array}{c}\text { Среднеме- } \\
\text { сячная } \\
\text { начисленная } \\
\text { заработная } \\
\text { плата работ- } \\
\text { ников органов } \\
\text { местного } \\
\text { самоуправ- } \\
\text { ления }{ }^{1}, \text { руб. }\end{array}$ \\
\hline $\begin{array}{c}\text { Сибирский } \\
\text { федеральный округ }\end{array}$ & 4058 & 85622 & 28633 \\
\hline Республика Алтай & 102 & 2027 & 22095 \\
\hline Республика Бурятия & 286 & 3760 & 30338 \\
\hline Республика Тыва & 143 & 2299 & 23649 \\
\hline Республика Хакасия & 100 & 3567 & 24818 \\
\hline Алтайский край & 719 & 9662 & 18627 \\
\hline Забайкальский край & 410 & 6950 & 22620 \\
\hline Красноярский край & 575 & 15989 & 32327 \\
\hline Иркутская область & 464 & 11530 & 39336 \\
\hline Кемеровская область & 210 & 9071 & 21730 \\
\hline Новосибирская область & 490 & 9422 & 28401 \\
\hline Омская область & 424 & 6636 & 30079 \\
\hline Томская область & 135 & 4709 & 37360 \\
\hline $\begin{array}{c}\text { Дальневосточный } \\
\text { федеральный округ }\end{array}$ & 1276 & 27970 & 54675 \\
\hline Республика Саха (Якутия) & 445 & 5375 & 58107 \\
\hline Камчатский край & 65 & 2196 & 70309 \\
\hline Приморский край & 158 & 4951 & 46681 \\
\hline Хабаровский край & 232 & 5767 & 50727 \\
\hline Амурская область & 286 & 4436 & 33150 \\
\hline Магаданская область & 9 & 1479 & 75319 \\
\hline Сахалинская область & 18 & 2135 & 85383 \\
\hline Еврейская автономная область & 33 & 935 & 36985 \\
\hline Чукотский автономный округ & 30 & 696 & 90092 \\
\hline
\end{tabular}

${ }^{1)}$ Включая избирательные комиссии муниципальных образований. 


\section{4. ЧИСЛЕННОСТЬ РАБОТНИКОВ ГОСУДАРСТВЕННЫХ ОРГАНОВ И ОРГАНОВ МЕСТНОГО САМОУПРАВЛЕНИЯ ПО ВЕТВЯМ ВЛАСТИ И УРОВНЯМ УПРАВЛЕНИЯ}

(на конец года; тысяч человек)

\begin{tabular}{l|r|r|r|r|r|r}
\hline & 2000 & 2005 & 2010 & 2015 & 2016 & 2017 \\
\hline В государственных орга- & & & & & & \\
нах, органах местного & & & & & & \\
самоуправления Россий- \\
ской Федерации и избира- \\
тельных комиссиях му-
\end{tabular}

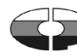


Продолжение табл. 2.4

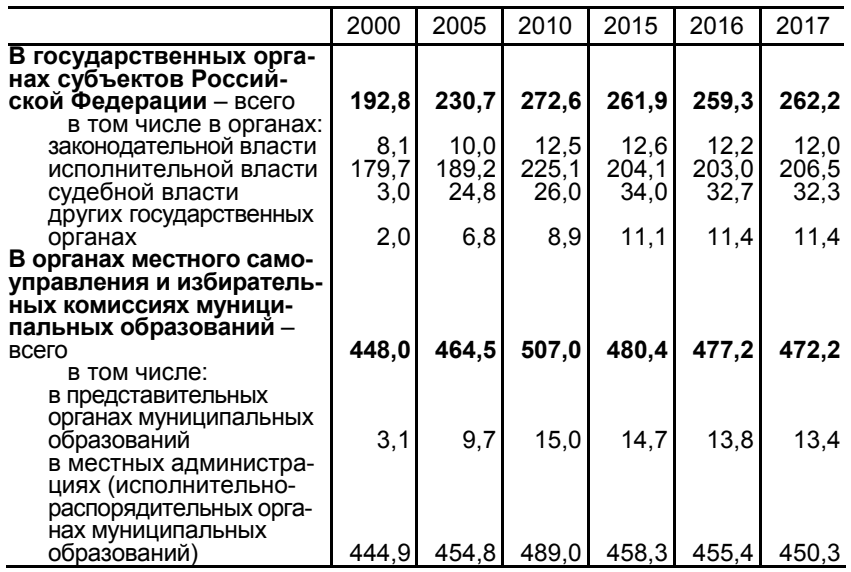

Для объединенных (по выполняемым функциям) группировок государственных органов и органов местного самоуправления используются термины:

законодательные органы - группировка включает органы законодательной власти Российской Федерации (федеральные и субъектов Российской Федерации) и представительные органы муниципальных образований;

исполнительные органы - группировка включает органы исполнительной власти Российской Федерации (федеральные и субъектов Российской Федерации) и местные администрации (исполнительнораспорядительные органы муниципальных образований);

другие - другие государственные органы Российской Федерации и субъектов Российской Федерации (образованные в соответствии с Конституцией Российской Федерации и нормативными правовыми актами субъектов Российской Федерации для решения вопросов государственного значения), контрольно-счетные органы муниципальных образований, иные органы местного самоуправления и избирательные комиссии муниципальных образований (образованные в соответствии с нормативными правовыми актами субъектов Российской Федерации и местного самоуправления для решения вопросов местного значения).

1) Данные приведены с органами, обеспечивающими правопорядок (с 2014 г.) и охрану безопасности государства.

2) Включая: на федеральном уровне - Администрацию Президента Российской Федерации, на региональном уровне - аппараты полномочных представителей Президента Российской Федерации в федеральных округах.

3) Данные о помощниках депутатов палат Федерального Собрания Российской Федерации учтены на региональном уровне. 


\section{5. СОСТАВ ФЕДЕРАЛЬНОГО СОБРАНИЯ РОССИЙСКОЙ ФЕДЕРАЦИИ ${ }^{1)}$}

(по состоянию на 1 января 2018 г.; человек)

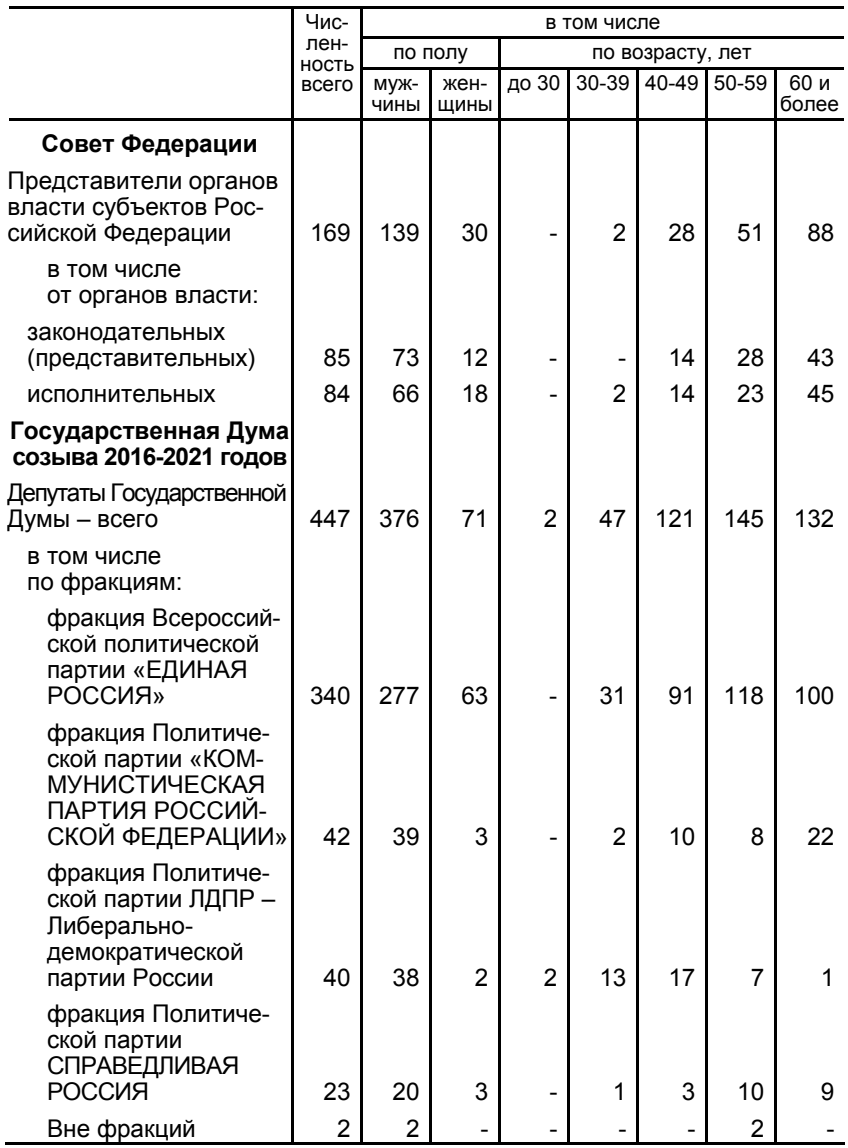

1) По данным Аппарата Государственной Думы и Аппарата Совета Федерации Федерального Собрания Российской Федерации.

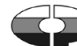




\section{3. НАЦИОНАЛЬНОЕ БОГАТСТВО}

В данном разделе публикуются данные баланса активов и пассивов Российской Федерации, об основных фондах по видам экономической деятельности, о земельных и водных ресурсах.

Данные в таблицах, содержащих показатели по видам экономической деятельности, приводятся за 2017 год в соответствии с Общероссийским классификатором видов экономической деятельности (ОКВЭД 2) ОК 029-2014, введенным в действие с 1 января 2017 г.

Аналогичные сведения за период до 2016 г. включительно, разработанные в соответствии с ранее действовавшим Общероссийским классификатором видов экономической деятельности (ОКВЭД-2007) ОК 029-2007, опубликованы в кратком статистическом сборнике «Россия в цифрах. 2017», электронная версия которого размещена на официальном Интернет-портале Росстата в разделе «Публикации».

Национальное богатство представляет совокупную стоимость всех экономических активов (нефинансовых и финансовых) в рыночных ценах, находящихся на ту или иную дату в собственности резидентов данной страны, за вычетом их финансовых обязательств, как резидентам, так и нерезидентам.

Баланс активов и пассивов - это таблица, отражающая текущую рыночную стоимость экономических активов и пассивов на начало и конец года (начальный и заключительный баланс).

Актив - это накопленный запас стоимости, приносящий экономическую выгоду или ряд экономических выгод экономическому собственнику актива как следствие владения им или использования его в течение некоторого периода времени.

Нефинансовые активы. Различают две категории нефинансовых активов: произведенные активы и непроизведенные активы:

- произведенные активы - это нефинансовые активы, которые возникли в результате процессов производства, подпадающих под определение границ сферы производства в СНС;

- непроизведенные активы - это нефинансовые активы, которые возникли иным образом, нежели в результате процесса производства.

Финансовые активы - включают все финансовые требования, акции или другие виды участия в капитале корпораций, золото в слитках, держателями которого в качестве резервного актива являются органы денежно-кредитного регулирования. 
Финансовое обязательство возникает, когда одна единица (дебитор) обязуется при определенных обстоятельствах произвести платеж или ряд платежей другой единице (кредитоpy).

Основной капитал (основные фонды) - это произведенные активы, подлежащие использованию неоднократно или постоянно в течение длительного периода, но не менее одного года, для производства товаров, оказания рыночных и нерыночных услуг, для управленческих нужд либо для представления другим организациям за плату во временное владение и пользование или во временное пользование.

К основному капиталу (основным фондам) относятся здания, сооружения, машины и оборудование, транспортные средства, культивируемые биологические ресурсы и другие виды основных фондов. В таблице 3.1. основные фонды приведены в границах СНC 2008.

Текущая рыночная стоимость активов - это стоимость, по которой активы могут быть реализованы на открытом рынке в условиях конкуренции, когда стороны сделки действуют разумно, располагая достаточной информацией, а на величине сделки не отражаются какие-либо чрезвычайные обстоятельства. При этом запасы экономических активов на начало года («начальный баланс») отражаются в ценах по состоянию на начало года, а запасы на конец года («заключительный баланс») - в ценах конца года.

Стоимость материальных оборотных средств, ценностей, относящихся к произведенным нефинансовым активам, и непроизведенных нефинансовых активов (природных ресурсов, контрактов, договоров аренды и лицензий, приобретенного гудвилла и маркетинговых активов) в составе баланса активов и пассивов не учтена вследствие отсутствия их оценки по текущей рыночной стоимости.

Сведения о наличии природных ресурсов приведены в натуральном выражении.

В таблице 3.2 приведены индексы физического объема и коэффициенты обновления и выбытия основных фондов в сопоставимых ценах, рассчитанные индексным методом. В таблице 3.3 приводятся данные на основе бухгалтерского учета об основных фондах по полной учетной стоимости в смешанных ценах и степени их износа (соотношение накопленного износа к полной учетной стоимости, в процентах).

Среднемноголетний объем речного стока - средняя арифметическая величина объема стока воды для определенного створа реки за многолетний период наблюдения.

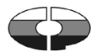




\section{НАЦИОНАЛЬНОЕ БОГАТСТВО}

3.1. БАЛАНС АКТИВОВ И ПАССИВОВ

(в ценах на конец соответствующего года; млрд. рублей)

\begin{tabular}{|c|c|c|c|c|c|c|}
\hline & 2011 & 2012 & 2013 & 2014 & 2015 & 2016 \\
\hline Активы & 447255 & 518381 & 585883 & 691133 & 787077 & 817360 \\
\hline Нефинансовые активы & 224091 & 256262 & 275962 & 302799 & 340334 & 361430 \\
\hline Основной капитал & 224091 & 256262 & 275962 & 302799 & 340334 & 361430 \\
\hline жилые здания & 103365 & 118524 & 120156 & 131437 & 138764 & 142216 \\
\hline нежилые здания & 35228 & 39382 & 46090 & 47928 & 56596 & 61306 \\
\hline сооружения & 55472 & 62590 & 68124 & 73597 & 83426 & 92106 \\
\hline $\begin{array}{l}\text { машины и оборудо- } \\
\text { вание }\end{array}$ & 19748 & 22874 & 25872 & 28961 & 36701 & 37978 \\
\hline транспортные средства & 5886 & 7087 & 8426 & 11705 & 13084 & 13908 \\
\hline прочие виды основного & & & & & & \\
\hline капи & 4392 & 5805 & 7294 & 9171 & 11763 & 13916 \\
\hline $\begin{array}{c}\text { Финансовые активы } \\
\text { Монетарное золото } \\
\text { и специальные права }\end{array}$ & 223164 & 262119 & 309921 & 388334 & 446743 & 455931 \\
\hline заимс & 1720 & 1816 & 1596 & 3057 & 4114 & 4045 \\
\hline $\begin{array}{l}\text { Налич } \\
\text { и депо }\end{array}$ & 48052 & 53897 & 61306 & 78320 & 86472 & 84818 \\
\hline ценные бумаги & 20921 & 22487 & 24008 & 31642 & 38559 & 34085 \\
\hline Креди & 39122 & 50041 & 63061 & 88379 & 96541 & 95628 \\
\hline $\begin{array}{l}\text { Акции } \\
\text { участь }\end{array}$ & 67668 & 77048 & 88253 & 99548 & 118188 & 129255 \\
\hline $\begin{array}{l}\text { Страховые и пенсионные } \\
\text { резервы }\end{array}$ & 1674 & 2043 & 2657 & 2948 & 3682 & 4379 \\
\hline Дебиторская & & & & & & \\
\hline задолу & 44007 & 54787 & 69040 & 84440 & 99187 & 103721 \\
\hline $\begin{array}{l}\text { Обязательства } \\
\text { Монетарное золото } \\
\text { и специальные права }\end{array}$ & 218353 & 257796 & 305610 & 370888 & 422421 & 442459 \\
\hline заимс & 281 & 265 & 286 & 462 & 573 & 463 \\
\hline Налич & & & & & & \\
\hline и депо & 46694 & 53033 & 60056 & 74787 & 81888 & 79262 \\
\hline Долговые ценные бумаги & 8945 & 10810 & 12252 & 15135 & 16737 & 17997 \\
\hline Кредиты и займы & 41552 & 53001 & 67953 & 94757 & 103040 & 99411 \\
\hline Акци & & & & & & \\
\hline участ & 75770 & 84731 & 94705 & 100397 & 119920 & 138707 \\
\hline & & & & & & \\
\hline и пенсионные резервы & 1640 & 2006 & 2602 & 2871 & 3623 & 4290 \\
\hline $\begin{array}{l}\text { Кредиторская } \\
\text { задолженность }\end{array}$ & 43471 & 53950 & 67756 & 82479 & 96640 & 102329 \\
\hline Национальное богатство & 228902 & 260585 & 280273 & 320245 & 364656 & 374901 \\
\hline
\end{tabular}




\section{2. ИНДЕКСЫ ИЗМЕНЕНИЯ СТОИМОСТИ, КОЭФФИЦИЕНТЫ ОБНОВЛЕНИЯ И ВЫБЫТИЯ ОСНОВНЫХ ФОНДОВ ПО ВИДАМ ЭКОНОМИЧЕСКОЙ ДЕЯТЕЛЬНОСТИ В 2017 г.}

(в сопоставимых ценах)

\begin{tabular}{|c|c|c|c|}
\hline & $\begin{array}{c}\text { Индексы } \\
\text { физиче- } \\
\text { ского } \\
\text { объема, } \\
\text { в процен- } \\
\text { тах к кон- } \\
\text { цу преды- } \\
\text { дущего } \\
\text { года }\end{array}$ & $\begin{array}{c}\text { Коэффицци- } \\
\text { ент обнов- } \\
\text { ления } \\
\text { (ввод в } \\
\text { действие } \\
\text { основных } \\
\text { фондов } \\
\text { в процентах } \\
\text { от общей } \\
\text { стоимости } \\
\text { основных } \\
\text { фондов на } \\
\text { конец года) }\end{array}$ & \begin{tabular}{|c} 
Коэфффи- \\
циент вы- \\
бытия \\
(ликвида- \\
ция основ- \\
ных фон- \\
дов в про- \\
центах \\
от общей \\
стоимости \\
основных \\
фондов \\
на начало \\
года)
\end{tabular} \\
\hline $\begin{array}{l}\text { Все основные фонды } \\
\text { в том числе по видам экономической } \\
\text { деятельности: } \\
\text { сельское, лесное хозяйство, охота, }\end{array}$ & 103,9 & 4,4 & 0,8 \\
\hline $\begin{array}{l}\text { рыболовство и рыбоводство } \\
\text { добыча полезных ископаемых } \\
\text { обрабатывающие производства }\end{array}$ & $\begin{array}{l}104,0 \\
108,5 \\
1044\end{array}$ & $\begin{array}{l}5,7 \\
8,8 \\
48\end{array}$ & $\begin{array}{l}1,9 \\
1,1 \\
07\end{array}$ \\
\hline $\begin{array}{l}\text { обрабатывающие производства } \\
\text { обеспечение электрической энергией, } \\
\text { газом и паром; кондиционирование }\end{array}$ & 104,4 & & 0,7 \\
\hline $\begin{array}{l}\text { воздуха } \\
\text { водоснабжение; водоотведение, органи- } \\
\text { зация сбора и утилизации отходов, дея- }\end{array}$ & 104,6 & 5,0 & 0,6 \\
\hline $\begin{array}{l}\text { тельность по ликвидации загрязнений } \\
\text { строительство }\end{array}$ & $\begin{array}{l}103,7 \\
103,0\end{array}$ & $\begin{array}{l}3,9 \\
3,4\end{array}$ & $\begin{array}{l}0,3 \\
0,7\end{array}$ \\
\hline $\begin{array}{l}\text { торговля оптовая и розничная; ремонт } \\
\text { автотранспортных средств и мотоциклов }\end{array}$ & 104.1 & 4,7 & \\
\hline $\begin{array}{l}\text { транспортировка и хранение } \\
\text { деятельность гостиниц и предприятий }\end{array}$ & 103,0 & 3,2 & 0,3 \\
\hline $\begin{array}{l}\text { общественного питания } \\
\text { деятельность в области информации и }\end{array}$ & 103,7 & 4,1 & 0,7 \\
\hline связи & 104,6 & 5,6 & 1,4 \\
\hline $\begin{array}{l}\text { деятельность финансовая и страховая } \\
\text { деятельность по операциям с недвижи- }\end{array}$ & 116,6 & 16,2 & 1,6 \\
\hline Мым имуществом & 100,9 & 2,0 & 1,2 \\
\hline $\begin{array}{l}\text { деятельность профессиональная, научная } \\
\text { и техническая }\end{array}$ & 107,5 & 7,4 & 0,4 \\
\hline $\begin{array}{l}\text { деятельность административная и сопут- } \\
\text { ствующие дополнительные услуги } \\
\text { государственное управление и обеспече- } \\
\text { ние военной безопасности; социальное }\end{array}$ & 102,1 & 2,2 & 0,2 \\
\hline $\begin{array}{l}\text { обеспечение } \\
\text { образование }\end{array}$ & $\begin{array}{l}105,5 \\
102,0\end{array}$ & $\begin{array}{l}5,7 \\
2,4\end{array}$ & $\begin{array}{l}1,0 \\
0,6\end{array}$ \\
\hline $\begin{array}{l}\text { деятельность в области здравоохранения } \\
\text { и социальных услуг } \\
\text { деятельность в области культуры, спор- }\end{array}$ & 101,8 & 2,7 & 0,9 \\
\hline $\begin{array}{l}\text { та, организации досуга и развлечений } \\
\text { предоставление прочих видов услуг }\end{array}$ & $\begin{array}{l}103,7 \\
100,9\end{array}$ & $\begin{array}{l}4,3 \\
1,7\end{array}$ & $\begin{array}{l}0,5 \\
1,2\end{array}$ \\
\hline
\end{tabular}

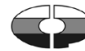


3.3. НАЛИЧИЕ И СТЕПЕНЬ ИЗНОСА ОСНОВНЫХ ФОНДОВ ПО ВИДАМ ЭКОНОМИЧЕСКОЙ ДЕЯТЕЛЬНОСТИ на КОНец 2017 г. (по полной учетной стоимости)

\begin{tabular}{|c|c|c|c|}
\hline & \multicolumn{2}{|c|}{$\begin{array}{l}\text { Наличие основных } \\
\text { фондов }\end{array}$} & \multirow{2}{*}{$\begin{array}{c}\text { Степень } \\
\text { износа ос- } \\
\text { новных } \\
\text { фондов, в } \\
\text { процентах }\end{array}$} \\
\hline & млрд. руб. & \begin{tabular}{|c|} 
в процен- \\
тах \\
к итогу \\
\end{tabular} & \\
\hline $\begin{array}{l}\text { Все основные фонды } \\
\text { в том числе по видам экономической } \\
\text { деятельности: }\end{array}$ & 197373 & 100 & 48,1 \\
\hline $\begin{array}{l}\text { сельское, лесное хозяйство, охота, } \\
\text { рыболовство и рыбоводство }\end{array}$ & 4860 & 2,5 & 41,3 \\
\hline добыча полезных ископаемых & 21830 & 11,1 & 56,4 \\
\hline $\begin{array}{l}\text { обрабатывающие производства } \\
\text { обеспечение электрической энергией, } \\
\text { газом и паром; кондиционирование }\end{array}$ & 20009 & 10,1 & 49,1 \\
\hline $\begin{array}{l}\text { воздуха } \\
\text { водоснабжение; водоотведение, } \\
\text { организация сбора и утилизации }\end{array}$ & 13636 & 6,9 & 43,7 \\
\hline $\begin{array}{l}\text { отходов, деятельность по ликвидации } \\
\text { загрязнений }\end{array}$ & 2546 & 1,3 & 45,4 \\
\hline строительство & 1742 & 0,9 & 49,7 \\
\hline $\begin{array}{l}\text { торговля оптовая и розничная; ремонт } \\
\text { автотранспортных средств и мотоциклов }\end{array}$ & 3589 & 1,8 & 38,8 \\
\hline транспортировка и хранение & 47657 & 24,2 & 56,5 \\
\hline $\begin{array}{l}\text { деятельность гостиниц и предприятий } \\
\text { общественного питания }\end{array}$ & 582 & 0,3 & 32,9 \\
\hline $\begin{array}{l}\text { деятельность в области информации } \\
\text { и связи }\end{array}$ & 5159 & 2,6 & 61,4 \\
\hline деятельность финансовая и страховая & 4259 & 2,2 & 38,5 \\
\hline $\begin{array}{l}\text { деятельность по операциям } \\
\text { с недвижимым имуществом }\end{array}$ & 34039 & 17,2 & 35,6 \\
\hline $\begin{array}{l}\text { деятельность просрессиональная, научная } \\
\text { и техническая }\end{array}$ & 6595 & 3,3 & 41,4 \\
\hline $\begin{array}{l}\text { деятельность административная } \\
\text { и сопутствующие дополнительные услуги }\end{array}$ & 2569 & 1,3 & 76,2 \\
\hline $\begin{array}{l}\text { государственное управление и обеспече- } \\
\text { ние военной безопасности; социальное } \\
\text { обеспечение }\end{array}$ & 16824 & 8,5 & 41,6 \\
\hline образование & 5302 & 2,7 & 49,1 \\
\hline $\begin{array}{l}\text { деятельность в области здравоохранения } \\
\text { и социальных услуг }\end{array}$ & 4035 & 2,0 & 54,1 \\
\hline $\begin{array}{l}\text { деятельность в области культуры, спор- } \\
\text { та, организации досуга и развлечений }\end{array}$ & 1817 & 0,9 & 39,1 \\
\hline предоставление прочих видов услуг & 323 & 0,2 & 46,9 \\
\hline
\end{tabular}




\section{ПРИРОДНЫЕ РЕСУРСЫ}

\section{4. ЗЕМЕЛЬНАЯ ПЛОЩАДЬ}

(на начало года)

\begin{tabular}{|c|c|c|c|c|c|}
\hline & 2001 & 2006 & 2015 & 2016 & 2017 \\
\hline \multirow[b]{2}{*}{ Всего земель } & \multicolumn{5}{|c|}{ Млн. га } \\
\hline & 1709,8 & 1709,8 & $1712,5^{2)}$ & 1712,5 & 1712,5 \\
\hline в том числе ${ }^{3)}$ : & & & & & \\
\hline сельскохозяйственные & & & & & \\
\hline угодья & 221,1 & 220,7 & 220,2 & 222,1 & 222,0 \\
\hline лесные земли & 871,5 & 870,6 & 871,8 & 870,7 & 870,7 \\
\hline $\begin{array}{l}\text { поверхностные воды, } \\
\text { включая болота }\end{array}$ & 219,0 & 225,1 & 225,0 & 226,8 & 226,8 \\
\hline другие земли ${ }^{4)}$ & 398,2 & 393,4 & 392,9 & 392,9 & 393,0 \\
\hline & \multicolumn{5}{|c|}{ В процентах от общей площади } \\
\hline Всего земель & 100 & 100 & 100 & 100 & 100 \\
\hline в том числе ${ }^{3)}$ : & & & & & \\
\hline сельскохозяйственные & & & & & \\
\hline угодья & 12,9 & 12,9 & 12,9 & 13,0 & 13,0 \\
\hline лесные земли & 51,0 & 50,9 & 51,0 & 50,8 & 50,8 \\
\hline $\begin{array}{l}\text { поверхностные воды, } \\
\text { включая болота }\end{array}$ & 12,8 & 13,2 & 13,2 & 13.2 & 13,2 \\
\hline другие земли ${ }^{4)}$ & 23,3 & 23,0 & 22,9 & 23,0 & 23,0 \\
\hline
\end{tabular}

1) По данным Росреестра.

2) Включая сведения по г. Севастополю, с учетом данных Министерства имущественных и земельных отношений Республики Крым о площади территории Республики Крым.

3) На начало 2015 г. - без учета данных по Республике Крым.

4) Земли под древесно-кустарниковой растительностью, земли застройки, земли под дорогами, нарушенные земли и прочие. 
3.5. ВОДНЫЕ РЕСУРСЫ ${ }^{1)}$

(кубических километров в год)

\begin{tabular}{l|r|c}
\hline & 2016 & $\begin{array}{c}\text { Среднемного- } \\
\text { летний объем }\end{array}$ \\
\hline Всего по рекам Российской Федерации & $\mathbf{4 4 4 1 , 0}$ & $\mathbf{4 2 6 0 , 3}$ \\
Волга & 265 & 238 \\
Дон & 13,9 & 25,5 \\
Амур & 426 & 378 \\
Лена & 642 & 537 \\
Енисей & 536 & 635 \\
Обь & 460 & 405 \\
Северная Двина & 97,4 & 101 \\
Печора & 130 & 129 \\
\hline
\end{tabular}

Основная величина речного стока с территории России формируется в пределах страны и только около $5 \%$ поступает с территорий сопредельных государств.

1) По данным Росгидромета.

\section{6. СРЕДНЕМНОГОЛЕТНИЕ ЗАПАСЫ (ОБЪЕМ) ВОДЫ В КРУПНЕЙШИХ ОЗЕРАХ И ВОДОХРАНИЛИЩАХ ${ }^{1)}$}

\begin{tabular}{l|r|l|r}
\hline & $\begin{array}{r}\text { Кубических } \\
\text { километров }\end{array}$ & $\begin{array}{r}\text { Кубических } \\
\text { километров }\end{array}$ \\
\hline Озера & 911 & $\begin{array}{l}\text { Водохранилища } \\
\text { Рыбинское }\end{array}$ & 26,3 \\
Лндожское & 292 & Куйбышевское & 58,0 \\
Байкал & 23000 & Волгоградское & 31,5 \\
Ханка & 18,3 & Цимлянское & 23,7 \\
& & $\begin{array}{l}\text { Саяно- } \\
\text { Шушенское }\end{array}$ & 31,3 \\
& & Красноярское & 73,3 \\
& & Братское & 170 \\
\hline
\end{tabular}

В европейской части России находятся 7 крупных озер, ка-

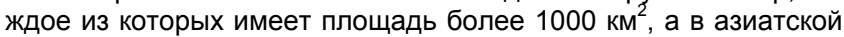
части расположено самое крупное в Азии озеро Байкал, площадь которого составляет около 32 тыс. км².

1) По данным Росгидромета. 


\section{4. ОХРАНА ОКРУЖАЮЩЕЙ СРЕДЫ}

В разделе содержатся данные о воздействии хозяйственной деятельности на окружающую среду и природные ресурсы. Приведены сведения об охране водных ресурсов, атмосферного воздуха, а также особо охраняемых природных территориях.

Забор воды из природных водных объектов для использования - объем изъятия водных ресурсов из поверхностных (включая моря) водоемов и подземных горизонтов с целью дальнейшего потребления воды. В общий объем забора входят используемые шахтно-рудничные воды, получаемые при добыче полезных ископаемых. В этот показатель не включается объем пропуска воды через гидроузлы для производства электроэнергии, шлюзования судов, пропуска рыбы, поддержания судоходных глубин и др. Не учитывается объем забора транзитной воды для подачи в крупные каналы.

Загрязненные сточные воды - производственные и бытовые (коммунальные) стоки, сброшенные в поверхностные водные объекты без очистки (или после недостаточной очистки) и содержащие загрязняющие вещества в количествах, превышающих утвержденный предельно допустимый сброс. Сюда не включаются коллекторно-дренажные воды, отводимые с орошаемых земель после полива.

Стационарный источник загрязнения атмосфреры - непередвижной технологический агрегат (установка, устройство, аппарат и т.п.), выделяющий в процессе эксплуатации загрязняющие атмосферу вещества. Сюда же относятся другие объекты (терриконы, резервуары и т.д.).

Отходы производства и потребления - вещества или предметы, которые образованы в процессе производства, выполнения работ, оказания услуг или в процессе потребления, которые удаляются, предназначены для удаления или подлежат удалению.

Особо охраняемые природные территории - участки земли, водной поверхности и воздушного пространства над ними, где располагаются природные комплексы и объекты, которые имеют особое природоохранное, научное, культурное, эстетическое, рекреационное и оздоровительное значение, которые

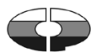


изъяты решениями органов государственной власти полностью или частично из хозяйственного использования и для которых установлен режим особой охраны.

Особо охраняемые природные территории могут иметь федеральное, региональное или местное значение и находиться в ведении соответственно федеральных органов исполнительной власти, органов исполнительной власти субъектов Российской Федерации и органов местного самоуправления, а также в ведении государственных научных организаций и государственных образовательных организаций высшего образования.

Государственные природные заповедники и национальные парки относятся к особо охраняемым природным территориям федерального значения.

Экологические инновации - новые или значительно усовершенствованные товары, работы, услуги, производственные процессы, организационные или маркетинговые методы, способствующие повышению экологической безопасности, улучшению или предотвращению негативного воздействия на окружающую среду. Начиная с отчета за 2016 год, статистическая информация об экологических инновациях разрабатывается с периодичностью раз в два года, за нечетные года.

По инновационной деятельности организаций приведены данные по организациям, осуществляющим экономическую деятельность в сфере растениеводства, животноводства, растениеводства в сочетании с животноводством (смешанное сельское хозяйство), предоставления услуг в области растениеводства, декоративного садоводства и животноводства, кроме ветеринарных услуг (начиная с 2016 г.); в сфере добычи полезных ископаемых; обрабатывающих производств; производства и распределения электроэнергии, газа и воды (за исключением торговли электроэнергией; торговли газообразным топливом, подаваемым по распределительным сетям); начиная с 2015 года - монтажа зданий и сооружений из сборных конструкций, устройства покрытий зданий и сооружений, производства прочих строительных работ; связи; деятельности, связанной с использованием вычислительной техники и информационных технологий; научных исследований и разработок; предоставления прочих видов услуг в соответствии с Общероссийским классификатором видов экономической деятельности (ОКВЭД ОК 029-2007 (КДЕС Ред. 1.1.). 
4.1. ОСНОВНЫЕ ПОКАЗАТЕЛИ, ХАРАКТЕРИЗУЮЩИЕ ВОЗДЕЙСТВИЕ ХОЗЯЙСТВЕННОЙ ДЕЯТЕЛЬНОСТИ НА ОКРУЖАЮЩУЮ СРЕДУ И ПРИРОДНЫЕ РЕСУРСЫ

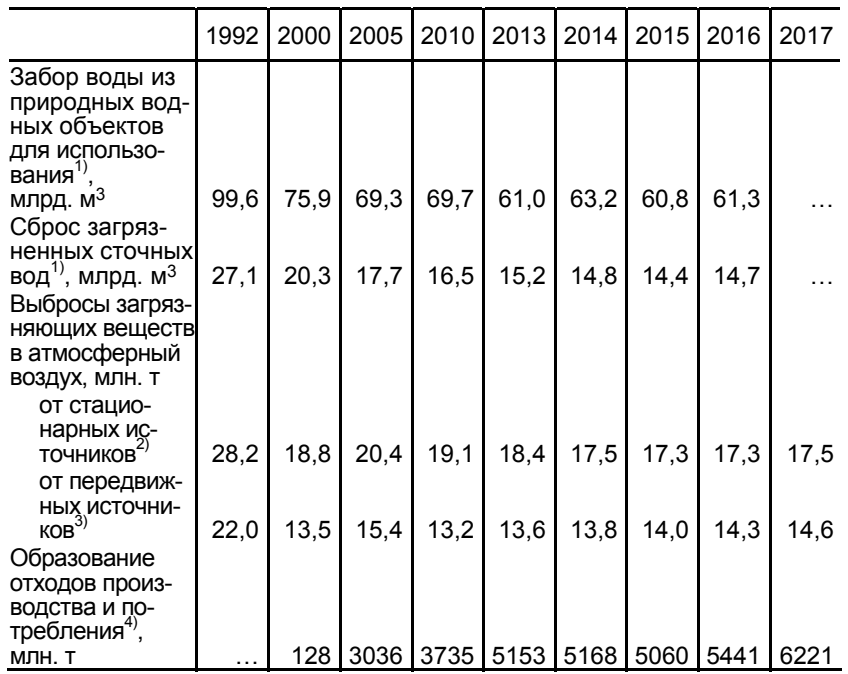

1) По данным Росводресурсов.

2) С 2013 г. - включая индивидуальных предпринимателей.

3) С 2010 г. - по данным Росприроднадзора; выбросы от автомобильного и железнодорожного транспорта, 1992, 2000, 2005 гг. - по данным бывш. Министерства природных ресурсов Российской Федерации; выбросы от автомобильного транспорта.

4) С 2010 г. - по данным Росприроднадзора; 2005 г. - по данным Ростехнадзора. С 2005 г. - отходы производства и потребления; 2000 г. - токсичные отходы.

4.2. ОСОБО ОХРАНЯЕМЫЕ ПРИРОДНЫЕ ТЕРРИТОРИИ

\begin{tabular}{c|c|c|r|r|r|r|r|r}
\hline \multirow{2}{*}{ Годы } & \multicolumn{2}{|c|}{ Всего } & \multicolumn{6}{c}{ в том числе } \\
\cline { 3 - 8 } & \multicolumn{2}{|c|}{} & \multicolumn{2}{c|}{$\begin{array}{c}\text { федерального } \\
\text { значения }\end{array}$} & $\begin{array}{c}\text { регионального } \\
\text { значения }\end{array}$ & \multicolumn{2}{|c}{$\begin{array}{c}\text { местного } \\
\text { значения }\end{array}$} \\
\cline { 3 - 8 } & число & $\begin{array}{c}\text { пло- } \\
\text { щадь, } \\
\text { млн. га }\end{array}$ & число & $\begin{array}{c}\text { пло- } \\
\text { щадь, } \\
\text { млн. га }\end{array}$ & число & $\begin{array}{c}\text { пло- } \\
\text { щадь, } \\
\text { млн. га }\end{array}$ & число & $\begin{array}{c}\text { пло- } \\
\text { щадь, } \\
\text { млн. га }\end{array}$ \\
\hline 2014 & 12942 & 202,3 & 280 & 59,4 & 11474 & 116,4 & 1188 & 26,5 \\
2015 & 12993 & 206,6 & 277 & 60,1 & 11466 & 120,9 & 1250 & 25,7 \\
2016 & 11935 & 211,7 & 272 & 62,3 & 10473 & 122,0 & 1190 & 27,5 \\
2017 & 11995 & 213,6 & 272 & 62,9 & 10473 & 123,9 & 1250 & 26,7 \\
\hline
\end{tabular}


4.3. ГОСУДАРСТВЕННЫЕ ПРИРОДНЫЕ ЗАПОВЕДНИКИ И НАЦИОНАЛЬНЫЕ ПАРКИ

\begin{tabular}{l|r|r|r|r|r|r|r|r|r}
\hline & 1992 & 2000 & 2005 & 2010 & 2013 & 2014 & 2015 & 2016 & 2017 \\
\hline Число государствен- & & & & & & & & & \\
ных природных запо- & 79 & 100 & 100 & 101 & 102 & 103 & 103 & 103 & 105 \\
ведников & 20,4 & 33,3 & 33,7 & 33,8 & 33,8 & 33,8 & 33,9 & 33,8 & 34,5 \\
Их площадь, млн. га & & & & & & & & & \\
Число национальных & 22 & 35 & 35 & 40 & 44 & 47 & 48 & 50 & 52 \\
парков & 4,0 & 6,8 & 6,9 & 7,8 & 11,5 & 12,8 & 13,9 & 21,4 & 21,6 \\
Их площадь, млн. га &
\end{tabular}

4.4. ИНВЕСТИЦИИ В ОСНОВНОЙ КАПИТАЛ, НАПРАВЛЕННЫЕ НА ОХРАНУ ОКРУЖАЮЩЕЙ СРЕДЫ И РАЦИОНАЛЬНОЕ ИСПОЛЬЗОВАНИЕ ПРИРОДНЫХ РЕСУРСОВ ${ }^{1)}$

(в фактически действовавших ценах; млн.рублей; 1992 г. - млрд.руб.)

\begin{tabular}{l|r|r|r|r|r|r|r|r|r}
\hline & 1992 & 2000 & 2005 & 2010 & 2013 & 2014 & 2015 & 2016 & 2017 \\
\hline $\begin{array}{l}\text { Всего } \\
\quad \begin{array}{l}\text { из них } \\
\text { на охрану: }\end{array}\end{array}$ & $\mathbf{5 3}$ & $\mathbf{2 2 3 3 9}$ & $\mathbf{5 8 7 3 8}$ & $\mathbf{8 9 0 9 4}$ & $\mathbf{1 2 3 8 0 7}$ & $\mathbf{1 5 8 6 3 6}$ & $\mathbf{1 5 1 7 8 8}$ & $\mathbf{1 3 9 6 7 7}$ & $\mathbf{1 5 2 9 9 6}$ \\
$\begin{array}{l}\text { водных } \\
\text { ресурсов } \\
\text { атмосферного }\end{array}$ & 33 & 8251 & 26143 & 46025 & 59505 & 76315 & 78962 & 67469 & 65863 \\
$\begin{array}{l}\text { воздуха } \\
\text { земель }\end{array}$ & 9,2 & 7946 & 19839 & 26127 & 41196 & 55587 & 40120 & 40340 & 59827 \\
\hline
\end{tabular}

1) С 2005 г. - без НДС.

4.5. ВВОД В ДЕЙСТВИЕ МОЩНОСТЕЙ ПО ОХРАНЕ ВОДНЫХ РЕСУРСОВ И АТМОСФЕРНОГО ВОЗДУХА ОТ ЗАГРЯЗНЕНИЯ

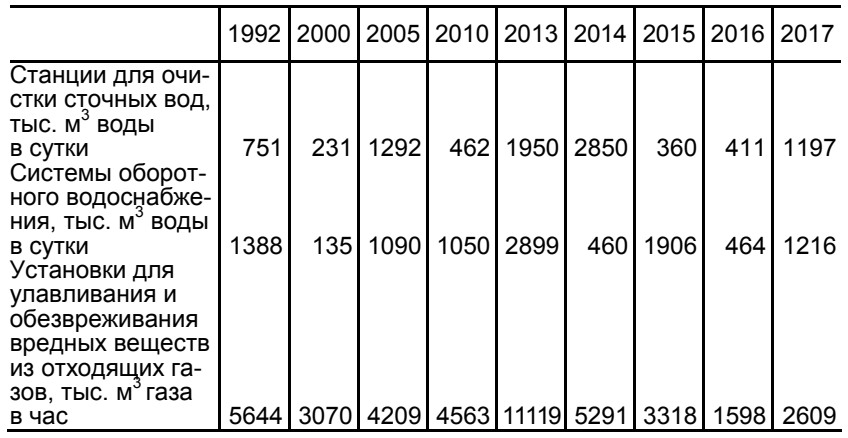


4.6. ЭКОЛОГИЧЕСКИЕ ИННОВАЦИИ ${ }^{1)}$

\begin{tabular}{|c|c|c|c|}
\hline & 2013 & 2014 & 2015 \\
\hline $\begin{array}{l}\text { Удельный вес организаций, осуществ- } \\
\text { лявших экологические инновации, в об- } \\
\text { щем числе организаций, имевших за- } \\
\text { вершенные инновации в течение по- } \\
\text { следних трех лет, процентов } \\
\text { добывающие, обрабатывающие про- } \\
\text { изводства, производство и распреде- } \\
\text { ление электроэнергии, газа и воды } \\
\text { связь, деятельность связанная } \\
\text { с использованием вычислительной } \\
\text { техники и информационных техноло- } \\
\text { гий, научные исследования и разра- } \\
\text { ботки, предоставление прочих видов } \\
\text { услуг } \\
\text { Специальные затраты, связанные } \\
\text { с экологическими инновациями, } \\
\text { млрд. руб. } \\
\text { добывающие, обрабатывающие про- } \\
\text { изводства, производство и распреде- } \\
\text { ление электроэнергии, газа и воды } \\
\text { связь, деятельность связанная } \\
\text { с использованием вычислительной } \\
\text { техники и информационных техноло- } \\
\text { гий, научные исследования и разра- } \\
\text { ботки, предоставление прочих видов } \\
\text { услуг } \\
\text { Удельный вес организаций, использую- } \\
\text { щих систему контроля за загрязнением } \\
\text { окружающей среды, в общем числе об- } \\
\text { следованных организаций, процентов } \\
\text { добывающие, обрабатывающие про- } \\
\text { изводства, производство и распреде- } \\
\text { ление электроэнергии, газа и воды } \\
\text { связь, деятельность связанная } \\
\text { с использованием вычислительной } \\
\text { техники и информационных техноло- } \\
\text { гий, научные исследования и разра- } \\
\text { ботки, предоставление прочих видов } \\
\text { услуг }\end{array}$ & 15,3 & 16,0 & 22,0 \\
\hline
\end{tabular}

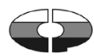




\section{5. НАСЕЛЕНИЕ}

В разделе приведены данные о численности населения, рождаемости, смертности, а также о миграционных процессах.

Первоисточником получения сведений о населении являются переписи населения. Последняя Всероссийская перепись населения проведена в 2010 году по состоянию на 14 октября.

Сведения об общей численности жителей приведены по постоянному населению, к которому относятся лица, постоянно проживающие на данной территории, включая временно отсутствующих на момент переписи.

Распределение населения на городское и сельское производится по месту проживания, при этом городскими населенными пунктами считаются населенные пункты, отнесенные в установленном законодательством порядке к категории городских. Все остальные населенные пункты являются сельскими.

Сведения о рождениях, смертях, браках, разводах получаются на основании ежегодной статистической разработки данных, содержащихся в записях актов гражданского состояния соответственно о рождении, смерти, заключении и расторжении брака, составляемых органами ЗАГС. В число родившихся включены только родившиеся живыми.

С апреля 2012 года, в связи с изменениями (приказ Минздрава России от 16.01.2013 № 7н) к приказу Минздравсоцразвития России от 27.12.2011 г. № 1687н «О медицинских критериях рождения, форме документа о рождении и порядке его выдачи» в органах ЗАГС подлежат регистрации рождения и смерти новорожденных с экстремально низкой массой тела (менее 500 грамм), если они прожили более 168 часов после рождения (7 суток).

Минимальный возраст вступления в брак в Российской Федерации, установленный законом, - 18 лет для мужчин и для женщин. В отдельных случаях, по решению местных органов власти, он может быть снижен, но не более чем на 2 года.

Датой заключения брака считается дата его регистрации в органах ЗАГС. Брак считается расторгнутым с момента регистрации его расторжения.

Источником информации о причинах смерти являются записи в медицинских свидетельствах о смерти, составляемых 
врачом относительно заболевания, несчастного случая, убийства, самоубийства и другого внешнего воздействия (повреждения в результате действий, предусмотренных законом, повреждения без уточнения их случайного или преднамеренного характера, повреждения в результате военных действий), послуживших причиной смерти.

До 1 января 1999 г. разработка данных по причинам смерти производилась согласно Краткой номенклатуре причин смерти (1981 г.), основанной на Международной статистической классификации болезней, травм и причин смерти (IX пересмотр Всемирной организации здравоохранения 1975 г.). С 1 января 1999 г. разработка производится по Краткой номенклатуре причин смерти (1997г.), основанной на Международной статистической классификации болезней и проблем, связанных со здоровьем (X пересмотр Всемирной организации здравоохранения 1989 г.). С 1 января 2011 г. разработка записей актов о смерти по причинам производится применительно к Краткой номенклатуре причин смерти 2010, основанной на Международной статистической классификации болезней и проблем, связанных со здоровьем, X пересмотра (1989 г.).

Общие коэффициенты рождаемости и смертности - отношение соответственно числа родившихся (живыми) и числа умерших в течение календарного года к среднегодовой численности населения. Исчисляются в промилле (на 1000 человек населения).

Коэффициент естественного прироста - разность общих коэффицциентов рождаемости и смертности. Исчисляется в промилле (на 1000 человек населения).

Общие коэффицииенты брачности и разводимости - отношение числа зарегистрированных в течение календарного года браков и разводов к среднегодовой численности населения. Как и общие коэффициенты рождаемости и смертности, они исчисляются в промилле (на 1000 человек населения).

Среднегодовая численность населения - средняя арифметическая значений численности населения на начало и конец соответствующего года.

Общие показатели естественного движения используются, как правило, для оценки текущих изменений в развитии населения в целом. Для развернутой (полной) характеристики демографической ситуации наряду с общими коэфрфициентами используются и специальные коэффициенты.

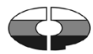


Среди них:

ожидаемая продолжительность жизни при рождении число лет, которое в среднем предстояло бы прожить человеку из поколения родившихся при условии, что на протяжении всей жизни этого поколения повозрастная смертность останется на уровне того года, для которого исчислен показатель;

коэффициенты смертности по причинам смерти - отношение числа умерших от указанных причин смерти к среднегодовой численности населения по текущей оценке. Исчисляются на 100000 человек населения;

коэффициент младенческой смертности исчисляется как сумма двух составляющих, первая из которых - отношение числа умерших в возрасте до одного года из поколения, родившегося в том году, для которого исчисляется коэффициент, к общему числу родившихся в том же году; а вторая - отношение числа умерших в возрасте до одного года из поколения, родившегося в предыдущем году, к общему числу родившихся в предыдущем году. Исчисляется в промилле (на 1000 родившихся живыми).

Данные о международной миграции получены в результате разработки поступающих от территориальных органов Министерства внутренних дел Российской Федерации документов статистического учета прибытия и убытия, которые составляются при регистрации или снятии с регистрационного учета населения по месту жительства.

С 2011 года в статистический учет долгосрочной миграции населения включены также лица, зарегистрированные по месту пребывания на срок 9 месяцев и более, и лица, снятые с регистрационного учета по месту пребывания в связи с окончанием срока пребывания.

Понятия "прибывшие" и "выбывшие" характеризуют миграцию с некоторой условностью, так как одно и то же лицо может в течение года менять место постоянного жительства не один раз.

Информация о вынужденных мигрантах публикуется по данным МВД России о численности граждан Российской Федерации и иностранных граждан, получивших временное убежище, статус беженца или вынужденного переселенца и состоящих на учете в территориальных органах МВД России по состоянию на 1 января. 
5.1. ЧИСЛЕННОСТЬ НАСЕЛЕНИЯ

(оценка на 1 января соответствующего года)

\begin{tabular}{|c|c|c|c|c|c|}
\hline \multirow[t]{2}{*}{ Годы } & \multirow{2}{*}{$\begin{array}{c}\text { Все } \\
\text { население, } \\
\text { млн. } \\
\text { человек }\end{array}$} & \multicolumn{2}{|c|}{ в том числе } & \multicolumn{2}{|c|}{$\begin{array}{l}\text { В общей численности } \\
\text { населения, процентов }\end{array}$} \\
\hline & & городское & сельское & городское & сельское \\
\hline 1993 & 148,6 & 108,7 & 39,9 & 73 & 27 \\
\hline 1996 & 148,3 & 108,3 & 40,0 & 73 & 27 \\
\hline 2001 & 146,3 & 107,1 & 39,2 & 73 & 27 \\
\hline 2002 & & & & & \\
\hline на 1 января & 145,6 & 106,7 & 38,9 & 73 & 27 \\
\hline на 9 октября ${ }^{1)}$ & 145,2 & 106,4 & 38,8 & 73 & 27 \\
\hline 2005 & 143,8 & 105,2 & 38,6 & 73 & 27 \\
\hline 2010 & & & & & \\
\hline на 1 января & 142,8 & 105,0 & 37,8 & 74 & 26 \\
\hline на 14 октября ${ }^{1)}$ & 142,9 & 105,3 & 37,6 & 74 & 26 \\
\hline 2013 & 143,3 & 106,1 & 37,2 & 74 & 26 \\
\hline 2014 & 143,7 & 106,6 & 37,1 & 74 & 26 \\
\hline 2015 & 146,3 & 108,3 & 38,0 & 74 & 26 \\
\hline 2016 & 146,5 & 108,6 & 37,9 & 74 & 26 \\
\hline 2017 & 146,8 & 109,0 & 37,8 & 74 & 26 \\
\hline 2018 & 146,9 & 109,3 & 37,6 & 74 & 26 \\
\hline
\end{tabular}

${ }^{1)}$ По данным Всероссийских переписей населения. 


\section{2. РАСПРЕДЕЛЕНИЕ ЧИСЛЕННОСТИ НАСЕЛЕНИЯ ПО ВОЗРАСТНЫМ ГРУППАМ ${ }^{1)}$}

\begin{tabular}{|c|c|c|c|c|c|c|c|c|c|}
\hline & \multicolumn{3}{|c|}{ Тыс. человек } & \multicolumn{3}{|c|}{$\begin{array}{c}\text { В процентах } \\
\text { к итогу }\end{array}$} & \multicolumn{3}{|c|}{$\begin{array}{l}\text { На } 1000 \text { мужчин соот- } \\
\text { ветствующего возрас- } \\
\text { та приходится женщин }\end{array}$} \\
\hline & 2002 & 2016 & 2017 & 2002 & 2016 & 2017 & 2002 & 2016 & 2017 \\
\hline $\begin{array}{l}\text { Все } \\
\text { население } \\
\text { в том } \\
\text { числе в } \\
\text { возрасте, } \\
\text { лет: }\end{array}$ & 145167 & 146545 & 146804 & 100 & 100 & 100 & 1147 & 1158 & 1157 \\
\hline $0-4$ & 6399 & 9512 & 9582 & 4,4 & 6,5 & 6,5 & 953 & 946 & 946 \\
\hline $5-9$ & 6941 & 8218 & 8558 & 4,8 & 5,6 & 5,8 & 956 & 951 & 950 \\
\hline $10-14$ & 10407 & 7254 & 7408 & 7,2 & 4,9 & 5,1 & 959 & 954 & 954 \\
\hline $15-19$ & 12800 & 6731 & 6690 & 8,8 & 4,6 & 4,6 & 968 & 955 & 957 \\
\hline $20-24$ & 11466 & 8445 & 7828 & 7,9 & 5,8 & 5,3 & 983 & 960 & 960 \\
\hline $25-29$ & 10613 & 12412 & 11879 & 7,3 & 8,4 & 8,1 & 997 & 974 & 968 \\
\hline $30-34$ & 9835 & 12219 & 12537 & 6,8 & 8,3 & 8,5 & 1001 & 1002 & 1000 \\
\hline $35-39$ & 10217 & 11098 & 11194 & 7,0 & 7,6 & 7,6 & 1033 & 1038 & 1033 \\
\hline $40-44$ & 12547 & 10220 & 10381 & 8,6 & 7,0 & 7,1 & 1062 & 1070 & 1073 \\
\hline $45-49$ & 11606 & 9193 & 9280 & 8,0 & 6,3 & 6,3 & 1113 & 1095 & 1091 \\
\hline $50-54$ & 10072 & 10356 & 9835 & 6,9 & 7,1 & 6,7 & 1170 & 1166 & 1164 \\
\hline $55-59$ & 5347 & 11093 & 11155 & 3,7 & 7,6 & 7,6 & 1260 & 1264 & 1255 \\
\hline $60-64$ & 7983 & 9445 & 9610 & 5,5 & 6,4 & 6,6 & 1456 & 1430 & 1425 \\
\hline $65-69$ & 6345 & 7263 & 7637 & 4,4 & 5,0 & 5,2 & 1596 & 1594 & 1595 \\
\hline $\begin{array}{l}70 \text { и более } \\
\text { возраст } \\
\text { не указан }\end{array}$ & 12469 & 13086 & 13230 & 8,6 & 8,9 & 9,0 & $\begin{array}{r}2477 \\
986\end{array}$ & 2441 & 2415 \\
\hline $\begin{array}{l}\text { Из общей } \\
\text { численности } \\
\text { население } \\
\text { в возрасте: }\end{array}$ & & & & & & & & & \\
\hline $\begin{array}{l}\text { моложе } \\
\text { трудоспо- } \\
\text { собного }\end{array}$ & 26327 & 26360 & 26895 & 18,1 & 18,0 & 18,3 & 957 & 950 & 950 \\
\hline $\begin{array}{l}\text { трудоспо- } \\
\text { собном }^{2)}\end{array}$ & 88942 & 84199 & 83224 & 61,3 & 57,4 & 56,7 & 985 & 918 & 915 \\
\hline $\begin{array}{l}\text { старше } \\
\text { трудоспо- } \\
\text { собного }\end{array}$ & 29778 & 35986 & 36685 & 20,5 & 24,6 & 25,0 & 2209 & 2431 & 2403 \\
\hline
\end{tabular}




\section{3. ВОЗРАСТНО-ПОЛОВАЯ СТРУКТУРА НАСЕЛЕНИЯ на 1 января 2017 г.}

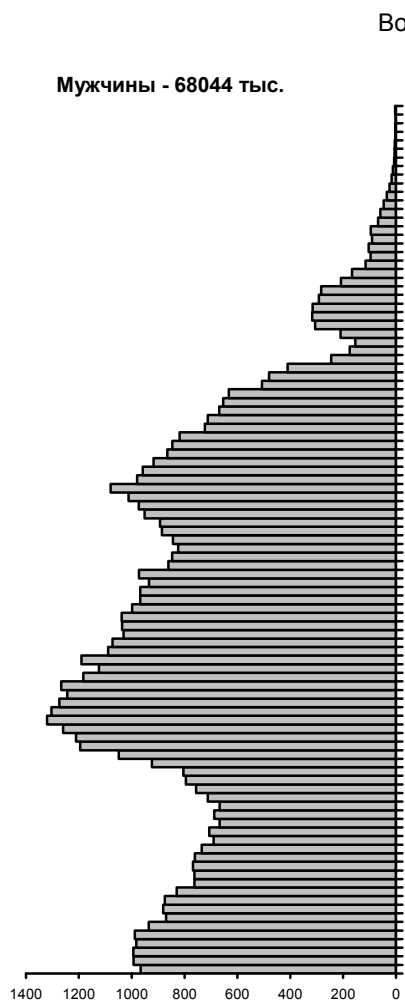

Возраст,
лет

Мужчины - 68044 тыс. $\quad$ Женщины - 78760 тыс.

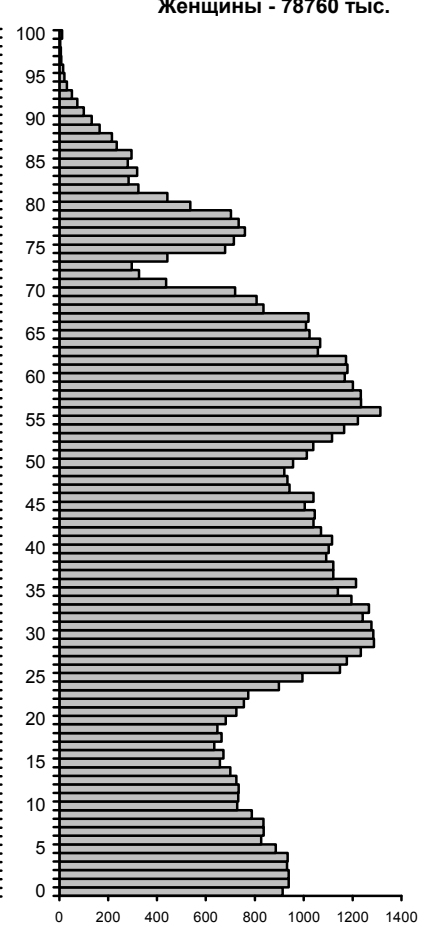


5.4. ЕСТЕСТВЕННОЕ ДВИЖЕНИЕ НАСЕЛЕНИЯ (человек)

\begin{tabular}{c|c|c|c|c}
\hline Годы & Родившиеся & Умершие & $\begin{array}{c}\text { Естественный } \\
\text { прирост, } \\
\text { убыль (-) }\end{array}$ & $\begin{array}{c}\text { Умершие в воз- } \\
\text { расте до одного } \\
\text { года }\end{array}$ \\
\hline 1992 & 1587644 & 1807441 & -219797 & 29208 \\
2000 & 1266800 & 2225332 & -958532 & 19286 \\
2005 & 1457376 & 2303935 & -846559 & 16073 \\
2010 & 1788948 & 2028516 & -239568 & 13405 \\
2013 & 1895822 & 1871809 & 24013 & 15477 \\
2014 & 1942683 & 1912347 & 30336 & 14322 \\
2015 & 1940579 & 1908541 & 32038 & 12664 \\
2016 & 1888729 & 1891015 & -2286 & 11428 \\
2017 & 1690307 & 1826125 & -135818 & 9577 \\
\hline
\end{tabular}

5.5. ОБЩИЕ КОЭФФИЦИЕНТЫ ЕСТЕСТВЕННОГО ДВИЖЕНИЯ НАСЕЛЕНИЯ

\begin{tabular}{c|c|c|c|c}
\hline \multirow{2}{*}{ Годы } & \multicolumn{2}{|c|}{ На 1000 человек населения } & $\begin{array}{c}\text { Число детей, } \\
\text { умерших в } \\
\text { возрасте до } \\
\text { одного года, } \\
\text { на 1000 ро- } \\
\text { дившихся } \\
\text { живыми }\end{array}$ \\
\cline { 2 - 4 } 1992 & 10,7 & 12,2 & $-1,5$ & 18,0 \\
2000 & 8,7 & 15,3 & $-6,6$ & 15,3 \\
2005 & 10,2 & 16,1 & $-5,9$ & 11,0 \\
2010 & 12,5 & 14,2 & $-1,7$ & 7,5 \\
2013 & 13,2 & 13,0 & 0,2 & 8,2 \\
2014 & 13,3 & 13,1 & 0,2 & 7,4 \\
2015 & 13,3 & 13,0 & 0,3 & 6,5 \\
2016 & 12,9 & 12,9 & $-0,01$ & 6,0 \\
2017 & 11,5 & 12,4 & $-0,9$ & 5,6 \\
\hline
\end{tabular}


5.6. БРАКИ И РАЗВОДЫ

\begin{tabular}{c|r|c|c|c}
\hline Годы & \multirow{2}{*}{$\begin{array}{c}\text { Число } \\
\text { браков }\end{array}$} & \multirow{2}{*}{$\begin{array}{c}\text { Число } \\
\text { разводов }\end{array}$} & \multicolumn{2}{|c}{ На 1000 человек населения } \\
\cline { 4 - 5 } & & & браков & разводов \\
\hline 1992 & 1053717 & 639248 & 7,1 & 4,3 \\
2000 & 897327 & 627703 & 6,2 & 4,3 \\
2005 & 1066366 & 604942 & 7,4 & 4,2 \\
2010 & 1215066 & 639321 & 8,5 & 4,5 \\
2013 & 1225501 & 667971 & 8,5 & 4,7 \\
2014 & 1225985 & 693730 & 8,4 & 4,7 \\
2015 & 1161068 & 611646 & 7,9 & 4,2 \\
2016 & 985836 & 608336 & 6,7 & 4,1 \\
2017 & 1049735 & 611436 & 7,1 & 4,2 \\
\hline
\end{tabular}

\section{7. КОЭФФИЦИЕНТЫ СМЕРТНОСТИ} ПО ОСНОВНЫМ КЛАССАМ ПРИЧИН СМЕРТИ

(число умерших на 100000 человек населения)

\begin{tabular}{|c|c|c|c|c|c|c|c|c|c|}
\hline & 1992 & 2000 & 2005 & 2010 & 2013 & $2014^{1)}$ & 2015 & 2016 & 2017 \\
\hline $\begin{array}{l}\text { мершиие } \\
\text { тт всех причи }\end{array}$ & 1217 & 1529 & 1605 & 1420 & 1304 & 1306 & 1304 & 1289 & 1244 \\
\hline $\begin{array}{l}\text { в том числе: } \\
\text { от болезней } \\
\text { системы крово- }\end{array}$ & & & & & & & & & \\
\hline $\begin{array}{l}\text { обрац } \\
\text { от но }\end{array}$ & 647 & 846 & 905 & 806 & 698 & 654 & 635 & 616 & 588 \\
\hline & 202 & 205 & 201 & 205 & 203 & 202 & 205 & 204 & 197 \\
\hline $\begin{array}{l}\text { от вне } \\
\text { причи }\end{array}$ & 173 & 219 & 220 & 152 & 129 & 130 & 121 & 114 & 104 \\
\hline $\begin{array}{l}\text { из } \\
\text { от тр } \\
\text { ных }\end{array}$ & & & & & & & & & \\
\hline & 30 & 27 & 28 & 20 & 20 & 20 & 17 & 15 & 14 \\
\hline & 18 & 26 & 28 & 13 & 10 & 11 & 10 & 10 & 8 \\
\hline & 9 & 11 & 10 & & 5 & 5 & 4 & 4 & 3 \\
\hline OT & 31 & 39 & 32 & 23 & 20 & 18 & 17 & 16 & 14 \\
\hline от y & 23 & 28 & 25 & 13 & 10 & 9 & 8 & 7 & 6 \\
\hline $\begin{array}{l}\text { от боле } \\
\text { ганов }\end{array}$ & 58 & 70 & 66 & 52 & 52 & 54 & 52 & 48 & 42 \\
\hline $\begin{array}{l}\text { от бол } \\
\text { НОв пи }\end{array}$ & 33 & 44 & 65 & 64 & 62 & 67 & 70 & 67 & 63 \\
\hline $\begin{array}{l}\text { от некоторых } \\
\text { инфекциионных } \\
\text { и паразитарных } \\
\text { болезней }\end{array}$ & 13 & 25 & 27 & 24 & 22 & 22 & 23 & 24 & 24 \\
\hline
\end{tabular}

1) Без учета данных по Крымскому федеральному округу. 
5.8. ОЖИДАЕМАЯ ПРОДОЛЖИТЕЛЬНОСТЬ ЖИЗНИ ПРИ РОЖДЕНИИ (число лет)

\begin{tabular}{c|c|c|c}
\hline Годы & Всего & Мужчины & Женщины \\
\hline 1992 & 67,8 & 61,9 & 73,7 \\
2000 & 65,3 & 59,0 & 72,3 \\
2005 & 65,4 & 58,9 & 72,5 \\
2010 & 68,9 & 63,1 & 74,9 \\
2013 & 70,8 & 65,1 & 76,3 \\
2014 & 70,9 & 65,3 & 76,5 \\
2015 & 71,4 & 65,9 & 76,7 \\
2016 & 71,9 & 66,5 & 77,1 \\
2017 & 72,7 & 67,5 & 77,6 \\
\hline
\end{tabular}

5.9. МЕЖДУНАРОДНАЯ МИГРАЦИЯ

(человек)

\begin{tabular}{l|r|r|r|r|r|r|r|r}
\hline & 2000 & 2005 & 2010 & 2013 & 2014 & 2015 & 2016 & 2017 \\
\hline $\begin{array}{l}\text { Прибывшие } \\
\text { в Российскую } \\
\text { Федерацию - } \\
\text { всего }\end{array}$ & & & & & & & & \\
в том числе: & & & & & & & & \\
из стран Снг & 326561 & 163101 & 171940 & 422738 & 529448 & 536157 & 511773 & 524452 \\
Азербай- & & & & & & & & \\
джан & 14906 & 4600 & 14500 & 23453 & 26367 & 24326 & 24109 & 25602 \\
Армения & 15951 & 7581 & 19890 & 42361 & 46568 & 45670 & 43929 & 46898 \\
Беларусь & 10274 & 6797 & 4894 & 15748 & 17931 & 17741 & 14590 & 21282 \\
Казахстан & 124903 & 51945 & 27862 & 51958 & 59142 & 65750 & 69356 & 71680 \\
Киргизия & 15536 & 15592 & 20901 & 30388 & 28543 & 26045 & 28202 & 41165 \\
Республика & & & & & & & & \\
Молдова & 11652 & 6569 & 11814 & 28666 & 32107 & 34026 & 32418 & 31369 \\
Таджикистан & 11043 & 4717 & 18188 & 51011 & 54658 & 47638 & 52676 & 63467 \\
Туркмения & 6738 & 4104 & 2283 & 5986 & 6038 & 6539 & 7242 & 8734 \\
Узбекистан & 40810 & 30436 & 24100 & 118130 & 131275 & 74242 & 60977 & 64073 \\
Украина & 74748 & 30760 & 27508 & 55037 & 126819 & 194180 & 178274 & 150182
\end{tabular}


Продолжение табл. 5.9

\begin{tabular}{|c|c|c|c|c|c|c|c|c|}
\hline & 2000 & 2005 & 2010 & 2013 & 2014 & 2015 & 2016 & 2017 \\
\hline $\begin{array}{l}\text { из стран EC - } \\
\text { всего }\end{array}$ & 6259 & 5386 & 6394 & 12423 & 11264 & 11496 & 10809 & 8672 \\
\hline $\begin{array}{l}\text { в том числе } \\
\text { по отдельным } \\
\text { странам: }\end{array}$ & & & & & & & & \\
\hline Болгария & 245 & 118 & 214 & 419 & 346 & 392 & 293 & 238 \\
\hline Германия & 1753 & 3025 & 2621 & 4166 & 3743 & 3976 & 4153 & 3704 \\
\hline Греция & 182 & 200 & 298 & 995 & 694 & 557 & 450 & 419 \\
\hline Испания & 10 & 49 & 140 & 364 & 303 & 279 & 218 & 227 \\
\hline Италия & 47 & 46 & 163 & 426 & 494 & 425 & 376 & 453 \\
\hline Латвия & 1785 & 726 & 811 & 1484 & 1520 & 1533 & 1428 & 1432 \\
\hline Литва & 945 & 360 & 433 & 892 & 764 & 790 & 802 & 756 \\
\hline Финляндия & 83 & 129 & 178 & 429 & 468 & 401 & 393 & 345 \\
\hline Швеция & 14 & 23 & 44 & 88 & 77 & 116 & 64 & 84 \\
\hline Эстония & 786 & 432 & 637 & 1475 & 1323 & 1283 & 1163 & 1014 \\
\hline другие страны & 26510 & 8743 & 13322 & 47080 & 50112 & 50964 & 50168 & 55909 \\
\hline Австралия & 27 & 30 & 49 & 113 & 71 & 89 & 82 & 123 \\
\hline Афрганистан & 288 & 60 & 236 & 799 & 776 & 831 & 846 & 1183 \\
\hline Вьетнам & 182 & 114 & 921 & 3852 & 3854 & 4012 & 3735 & 3912 \\
\hline Грузия & 20213 & 5497 & 5245 & 7665 & 7756 & 7038 & 6511 & 6809 \\
\hline Израиль & 1508 & 1004 & 814 & 1132 & 1139 & 1077 & 900 & 805 \\
\hline Канада & 50 & 99 & 110 & 226 & 171 & 189 & 193 & 240 \\
\hline Китай & 1121 & 432 & 1380 & 8149 & 10563 & 9043 & 8027 & 8237 \\
\hline США & 439 & 396 & 653 & 954 & 1000 & 1084 & 1137 & 1240 \\
\hline Турция & 164 & 86 & 562 & 2755 & 2631 & 2091 & 1626 & 1600 \\
\hline
\end{tabular}


Продолжение табл. 5.9

\begin{tabular}{|c|c|c|c|c|c|c|c|c|}
\hline & 2000 & 2005 & 2010 & 2013 & 2014 & 2015 & 2016 & 2017 \\
\hline $\begin{array}{l}\text { Выбывшие } \\
\text { из Российской } \\
\text { Федерации - } \\
\text { всего }\end{array}$ & 145720 & 69798 & 33578 & 186382 & 310496 & 353233 & 313210 & 377155 \\
\hline в том числе: & & & & & & & & \\
\hline в страны СНГ & 80510 & 35418 & 21206 & 147853 & 259213 & 298828 & 256480 & 321018 \\
\hline Азербайджан & 3187 & 1274 & 1111 & 6207 & 13973 & 13666 & 13670 & 17003 \\
\hline Армения & 1519 & 620 & 698 & 10182 & 22562 & 25137 & 31936 & 32899 \\
\hline Беларусь & 13276 & 6034 & 2899 & 12031 & 11174 & 12832 & 12463 & 9512 \\
\hline Казахстан & 17913 & 12437 & 7329 & 11802 & 18328 & 30983 & 32226 & 38944 \\
\hline Киргизия & 1857 & 473 & 641 & 10576 & 13284 & 16110 & 17159 & 21810 \\
\hline $\begin{array}{l}\text { Республика } \\
\text { Молдова }\end{array}$ & 2237 & 786 & 617 & 8038 & 14533 & 16646 & 18054 & 21764 \\
\hline $\begin{array}{l}\text { Таджики- } \\
\text { стан }\end{array}$ & 1158 & 434 & 694 & 17362 & 35296 & 36276 & 25388 & 28828 \\
\hline Туркмения & 676 & 125 & 105 & 2165 & 3435 & 4219 & 4824 & 5861 \\
\hline Узбекистан & 3086 & 595 & 834 & 50864 & 94179 & 94910 & 41305 & 41906 \\
\hline Украина & 35601 & 12640 & 6278 & 18626 & 32449 & 48049 & 59455 & 102491 \\
\hline $\begin{array}{l}\text { в страны ЕС - } \\
\text { всего }\end{array}$ & 45064 & 25236 & 7185 & 9384 & 12326 & 11533 & 11534 & 9133 \\
\hline $\begin{array}{l}\text { в том числе } \\
\text { по отдельным } \\
\text { странам: }\end{array}$ & & & & & & & & \\
\hline Болгария & 180 & 124 & 110 & 268 & 373 & 297 & 292 & 269 \\
\hline Германия & 40443 & 21458 & 3725 & 3979 & 4792 & 4531 & 4694 & 4372 \\
\hline Греция & 314 & 155 & 92 & 226 & 306 & 291 & 478 & 357 \\
\hline Испания & 160 & 320 & 296 & 403 & 438 & 411 & 388 & 427 \\
\hline Италия & 273 & 249 & 300 & 390 & 473 & 534 & 392 & 418 \\
\hline Латвия & 365 & 211 & 139 & 556 & 904 & 946 & 926 & 999 \\
\hline Литва & 376 & 213 & 153 & 339 & 597 & 604 & 579 & 591 \\
\hline Финляндия & 1142 & 737 & 517 & 715 & 1016 & 664 & 578 & 593 \\
\hline Швеция & 195 & 110 & 128 & 122 & 160 & 161 & 135 & 112 \\
\hline Эстония & 385 & 225 & 206 & 726 & 1011 & 1000 & 1089 & 995 \\
\hline другие страны & 20146 & 9144 & 5187 & 29145 & 38957 & 42872 & 45196 & 47004 \\
\hline Австралия & 176 & 209 & 184 & 255 & 308 & 226 & 183 & 222 \\
\hline Афрганистан & 25 & 11 & 14 & 181 & 499 & 612 & 576 & 546 \\
\hline Вьетнам & 33 & 45 & 32 & 2355 & 3282 & 3008 & 3341 & 2718 \\
\hline Грузия & 1802 & 691 & 459 & 1553 & 3538 & 3729 & 4217 & 4223 \\
\hline Израиль & 9407 & 1745 & 947 & 1090 & 1151 & 1050 & 1142 & 1044 \\
\hline Канада & 841 & 628 & 497 & 536 & 692 & 457 & 396 & 392 \\
\hline Китай & 658 & 456 & 248 & 7527 & 8607 & 9821 & 8837 & 7600 \\
\hline США & 4793 & 4040 & 1461 & 1485 & 1947 & 1610 & 1404 & 1452 \\
\hline Турция & 104 & 85 & 147 & 1494 & 2397 & 2199 & 1314 & 1219 \\
\hline
\end{tabular}




\subsection{0. ЧИСЛЕННОСТЬ ВЫНУЖДЕННЫХ МИГРАНТОВ}

(на 1 января; человек)

\begin{tabular}{|c|c|c|c|c|c|c|c|c|c|}
\hline & \multicolumn{3}{|c|}{$\begin{array}{c}\text { Лица получившие } \\
\text { временное } \\
\text { убежище } \\
\end{array}$} & \multicolumn{3}{|c|}{ Беженцы } & \multicolumn{3}{|c|}{$\begin{array}{c}\text { Вынужденные } \\
\text { переселенцы }\end{array}$} \\
\hline & 2016 & 2017 & 2018 & 2016 & 2017 & 2018 & 2016 & 2017 & 2018 \\
\hline $\begin{array}{l}\text { Всего } \\
\text { из них ранее } \\
\text { постоянно } \\
\text { проживали } \\
\text { на территории: }\end{array}$ & 313707 & 228392 & 125442 & 770 & 598 & 592 & 25359 & 19327 & 13795 \\
\hline Абхазии & 2 & 1 & 1 & - & - & - & 94 & 77 & 59 \\
\hline Азербайджана & 9 & 10 & 8 & 9 & 8 & 7 & 263 & 189 & 138 \\
\hline Армении & 3 & 1 & 1 & - & - & - & 17 & 11 & 6 \\
\hline Афрганистана & 572 & 417 & 356 & 352 & 292 & 305 & - & - & - \\
\hline Беларуси & & & & - & - & - & - & - & - \\
\hline Грузии & 292 & 226 & 167 & 52 & 34 & 31 & 6527 & 6242 & 5611 \\
\hline Казахстана & 4 & 3 & 4 & 1 & 1 & 1 & 6244 & 4366 & 3014 \\
\hline Киргизии & 48 & 21 & 22 & 3 & 2 & 3 & 406 & 311 & 192 \\
\hline Латвии & 4 & 4 & 1 & 2 & 2 & 2 & 49 & 38 & 30 \\
\hline Литвы & - & 1 & 2 & 3 & 3 & 3 & 12 & 12 & 6 \\
\hline $\begin{array}{l}\text { Республики } \\
\text { Молдова }\end{array}$ & 14 & 7 & 6 & 10 & 9 & 15 & 122 & 85 & 45 \\
\hline России & & - & - & - & - & & 7301 & 4643 & 2279 \\
\hline Сирии & 1302 & 1317 & 1128 & 2 & 2 & 2 & 63 & 62 & 58 \\
\hline Таджикистана & 14 & 26 & 16 & 10 & 7 & 7 & 1031 & 819 & 611 \\
\hline Туркмении & 12 & 8 & 5 & - & - & - & 115 & 120 & 72 \\
\hline Узбекистана & 79 & 82 & 60 & 19 & 18 & 19 & 2730 & 1973 & 1388 \\
\hline Украины & 311134 & 226044 & 123434 & 273 & 188 & 166 & 244 & 243 & 184 \\
\hline Эстонии & - & - & & - & - & - & 26 & 30 & 10 \\
\hline Южной Осетии & & & & - & - & - & 108 & 99 & 85 \\
\hline $\begin{array}{l}\text { другая терри- } \\
\text { тория или } \\
\text { территория }\end{array}$ & & & & & & & & & \\
\hline не указана & 218 & 224 & 231 & 34 & 32 & 31 & 7 & 7 & 7 \\
\hline
\end{tabular}




\section{6. ТРУД}

Раздел представляет данные о численности и составе рабочей силы, занятых и безработных, иностранных трудовых мигрантов, а также о профессиональных заболеваниях и травматизме на производстве.

Данные в таблицах, содержащих показатели по видам экономической деятельности, приводятся за 2017 год в соответствии с Общероссийским классификатором видов экономической деятельности (ОКВЭД 2) ОК 029-2014, введенным в действие с 1 января 2017 г.

Аналогичные сведения за период до 2016 г. включительно, разработанные в соответствии с ранее действовавшим Общероссийским классификатором видов экономической деятельности (ОКВЭД-2007) ОК 029-2007, опубликованы в кратком статистическом сборнике «Россия в цифрах. 2017», электронная версия которого размещена на официальном Интернет-портале Росстата в разделе «Публикации».

Данные за 2014 г. приведены без учета сведений по Республике Крым и г. Севастополю в табл. 6.1, 6.2, 6.12.

Данные о численности рабочей силы, занятых и безработных сформированы по материалам выборочных обследований рабочей силы: 1992 г. - на конец октября; 2000-2017 гг. - в среднем за год. Обследование проводится во всех субъектах Российской Федерации на основе выборочного метода наблюдения с последующим распространением итогов на всю численность населения обследуемого возраста. В Чеченской Республике обследование проводится с 2006 г.

До 2017 года обследование проводилось в отношении лиц 15-72 лет, с 2017 года - 15 лет и старше.

Рабочая сила - лица в возрасте 15 лет и старше, которые в рассматриваемый период считаются занятыми или безработными.

Уровень участия в рабочей силе - отношение численности рабочей силы определенной возрастной группы к общей численности населения соответствующей возрастной группы, рассчитанное в процентах.

К занятым относятся лица, в возрасте 15 лет и старше, которые в течение обследуемой недели осуществляли любую 
деятельность, связанную с производством товаров или оказанием услуг за оплату или прибыль. В численность занятых включаются также лица, временно отсутствующие на рабочем месте в течение короткого промежутка времени и сохранившие связь с рабочим местом во время отсутствия.

Лица, не входящие в состав рабочей силы - лица в возрасте 15 лет и старше, которые не являются занятыми экономической деятельностью или безработными в течение короткого учетного периода (обследуемой недели).

Потенциальная рабочая сила - незанятые лица, которые выражают заинтересованность в получении работы за оплату или прибыль, однако сложившиеся условия ограничивают их активные поиски работы или их готовность приступить к работе.

Уровень занятости - отношение численности занятого населения определенной возрастной группы к общей численности населения соответствующей возрастной группы, рассчитанное в процентах.

Данные о среднегодовой численности занятых формируются по основной работе гражданского населения один раз в год при составлении баланса трудовых ресурсов на основе сведений организаций, материалов выборочного обследования рабочей силы, данных органов исполнительной власти. В среднегодовую численность занятых включаются работающие иностранные граждане, как постоянно проживающие, так и временно находящиеся на территории Российской Федерации.

Динамика производительности труда оценена Федеральной службой государственной статистики в целом по экономике и видам экономической деятельности, продукция которых реализуется преимущественно по рыночным ценам.

Индекс изменения производительности труда по экономике в целом рассчитан как частное от деления индексов физического объема ВВП и изменения совокупных затрат труда, по видам экономической деятельности до 2010 г. - как частное от деления индексов физического объема выпуска и изменения совокупных затрат труда по «чистым» видам деятельности, начиная с 2010 г. - как частое от деления индексов физического объема добавленной стоимости и изменения совокупных затрат труда по «хозяйственным» видам деятельности.

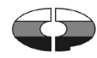


Индексы изменения ВВП, выпуска и добавленной стоимости рассчитаны исходя из абсолютных значений этих показателей в постоянных ценах.

Индексы изменения совокупных затрат труда определены на основе трудовых затрат на всех видах работ, включая дополнительную работу и производство продукции для собственного потребления.

К безработным, применительно к стандартам Международной организации труда (МОТ), относятся лица в возрасте 15 лет и старше, которые в рассматриваемый период одновременно удовлетворяли следующим критериям:

не имели работы (доходного занятия);

занимались поиском работы в течение последних четырех недель, используя при этом любые способы;

были готовы приступить к работе в течение обследуемой недели.

Обучающиеся, студенты, пенсионеры и инвалиды учитываются в качестве безработных, если они не имели работы, занимались поиском работы и были готовы приступить к ней.

Совокупный показатель безработицы и потенциальной рабочей силы - отношение суммы численности безработных и потенциальной рабочей силы к расширенной концепции рабочей силы, рассчитанной в процентах. Расширенная концепции рабочей силы включает в себя занятых, безработных и потенциальную рабочую силу.

К безработным, зарегистрированным в органах службы занятости населения, относятся трудоспособные граждане, не имеющие работы и заработка (трудового дохода), проживающие на территории Российской Федерации, зарегистрированные в органах службы занятости населения по месту жительства в целях поиска подходящей работы, ищущие работу и готовые приступить к ней.

Уровень безработицы - отношение численности безработных определенной возрастной группы к численности рабочей силы соответствующей возрастной группы (в процентах).

Продолжительность безработицы (продолжительность поиска работы) - это промежуток времени, в течение которого лицо, будучи незанятым, ищет работу, используя при этом любые способы. 
Сведения об иностранных гражданах, осуществлявших трудовую деятельность в России, приведены по данным Министерства внутренних дел Российской Федерации.

C 2011 г. данные разрабатывались на основании:

выданных разрешений на работу - для иностранных граждан и лиц без гражданства, прибывших в визовом и безвизовом порядке въезда;

выданных патентов на осуществление трудовой деятельности у фризических лиц - для иностранных граждан и для лиц без гражданства, прибывших в порядке, не требующем получения визы.

С 2015 г. данные разрабатываются на основании:

выданных разрешений на работу - для иностранных граждан, прибывших в визовом порядке въезда;

выданных патентов на осуществление трудовой деятельности у физических и юридических лиц, индивидуальных предпринимателей и иных лиц, чья деятельность подлежит регистрации - для иностранных граждан, прибывших в порядке, не требующем получения визы.

В сведения об иностранных гражданах не включаются граждане Республики Беларусь, в отношении которых порядок регулирования привлечения иностранной рабочей силы не применяется.

С 2015 г. граждане Республики Казахстан, Республики Армения, Киргизской Республики также осуществляют трудовую деятельность без разрешительных документов (разрешений на работу, патентов). По данным странам приводится численность по тем гражданам, которым выдается разрешение на работу или патент (являются высококвалифицированными специалистами или студентами, работающими во время обучения).

С 2015 г. в численность иностранных граждан, получивших патент, включается численность иностранных граждан, переоформивших патент.

К числу пострадавших при несчастных случаях на производстве $с$ утратой трудоспособности на один рабочий день и более и со смертельным исходом относятся лица, пострадавшие при исполнении ими трудовых обязанностей или работ на территории организации и в других случаях, предусмотренных законодательством Российской Федерации, и подлежащие учету на основании нормативных документов.

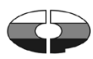




\section{1. ЧИСЛЕННОСТЬ И СОСТАВ РАБОЧЕЙ СИЛЫ' ${ }^{1)}$}

(тыс. человек)

\begin{tabular}{l|r|r|r|r|r|r|r|r|r}
\hline & 1992 & 2000 & 2005 & 2010 & 2013 & 2014 & 2015 & 2016 & 2017 \\
\hline $\begin{array}{l}\text { Численность } \\
\text { рабочей силы - }\end{array}$ & & & & & & & & & \\
всего & 75060 & 72770 & 73581 & 75478 & 75529 & 75428 & 76588 & 76636 & 76109 \\
в том числе: & & & & & & & & & \\
занятые & 71171 & 65070 & 68339 & 69934 & 71391 & 71539 & 72324 & 72393 & 72142 \\
безработные & 3889 & 7700 & 5242 & 5544 & 4137 & 3889 & 4264 & 4243 & 3967 \\
Мужчины & 39197 & 37631 & 37311 & 38601 & 38720 & 38729 & 39433 & 39470 & 39210 \\
в том числе: & & & & & & & & & \\
занятые & 37161 & 33574 & 34584 & 35566 & 36478 & 36605 & 37136 & 37201 & 37108 \\
безработные & 2036 & 4057 & 2727 & 3034 & 2242 & 2123 & 2296 & 2269 & 2102 \\
Женщины & 35863 & 35139 & 36270 & 36877 & 36809 & 36700 & 37155 & 37166 & 36899 \\
в том числе: & & & & & & & & & \\
занятые & 34010 & 31496 & 33755 & 34367 & 34913 & 34934 & 35187 & 35192 & 35034 \\
безработные & 1853 & 3643 & 2515 & 2510 & 1896 & 1766 & 1968 & 1975 & 1865 \\
\hline
\end{tabular}

1) Здесь и в табл. 6.2 - в возрасте 15-72 лет; по данным выборочного обследования рабочей силы.

\section{2. УРОВЕНЬ УЧАСТИЯ В РАБОЧЕЙ СИЛЕ, УРОВЕНЬ ЗАНЯТОСТИ И УРОВЕНЬ БЕЗРАБОТИЦЫ НАСЕЛЕНИЯ}

(в процентах)

\begin{tabular}{l|r|r|r|r|r|r|r|r|r}
\hline & 1992 & 2000 & 2005 & 2010 & 2013 & 2014 & 2015 & 2016 & 2017 \\
\hline $\begin{array}{l}\text { Уровень участия } \\
\text { в рабочей силе }\end{array}$ & & & & & & & & & \\
всего & 70,7 & 65,5 & 66,0 & 67,7 & 68,5 & 68,9 & 69,1 & 69,5 & 69,1 \\
$\quad$ мужчины & 78,2 & 71,5 & 71,1 & 73,8 & 74,7 & 75,1 & 75,5 & 75,9 & 75,6 \\
$\quad$ женщины & 64,1 & 60,0 & 61,5 & 62,2 & 63,0 & 63,3 & 63,4 & 63,8 & 63,3 \\
Уровень занятости & 67,1 & 58,5 & 61,3 & 62,7 & 64,8 & 65,3 & 65,3 & 65,7 & 65,5 \\
всего & & & & & & & & & \\
$\quad$ мужчины & 74,1 & 63,8 & 65,9 & 68,0 & 70,4 & 71,0 & 71,1 & 71,6 & 71,5 \\
$\quad$ женщины & 60,8 & 53,8 & 57,2 & 58,0 & 59,8 & 60,3 & 60,1 & 60,4 & 60,1 \\
Уровень безрабо- & & & & & & & & & \\
тицы & 5,2 & 10,6 & 7,1 & 7,3 & 5,5 & 5,2 & 5,6 & 5,5 & 5,2 \\
всего & & & & & & & & & \\
$\quad$ мужчины & 5,2 & 10,8 & 7,3 & 7,9 & 5,8 & 5,5 & 5,8 & 5,7 & 5,4 \\
женщины & 5,2 & 10,4 & 6,9 & 6,8 & 5,2 & 4,8 & 5,3 & 5,3 & 5,1 \\
\hline
\end{tabular}




\section{3. ЧИСЛЕННОСТЬ НАСЕЛЕНИЯ ПО СТАТУСУ УЧАСТИЯ В СОСТАВЕ РАБОЧЕЙ СИЛЫ В 2017 г. ${ }^{1)}$}

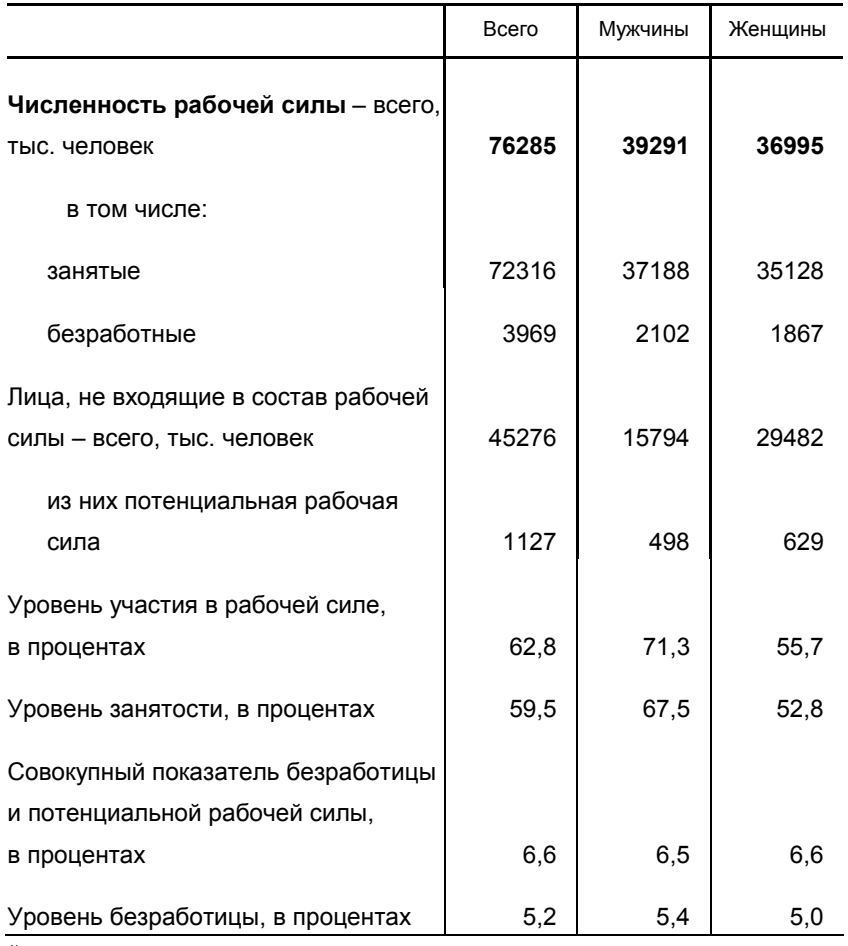

1) Здесь и в табл. 6.7, 6.13-6.15 - в возрасте 15 лет и старше; по данным выборочного обследования рабочей силы. 


\section{4. СРЕДНЕГОДОВАЯ ЧИСЛЕННОСТЬ ЗАНЯТЫХ} ПО ВИДАМ ЭКОНОМИЧЕСКОЙ ДЕЯТЕЛЬНОСТИ В 2017 Г.

\begin{tabular}{|c|c|c|}
\hline & Тыс. человек & $\begin{array}{c}\text { В процентах } \\
\text { к итогу }\end{array}$ \\
\hline Всего & 71746,2 & 100 \\
\hline $\begin{array}{l}\text { из них по видам экономической } \\
\text { деятельности: }\end{array}$ & & \\
\hline $\begin{array}{l}\text { сельское, лесное хозяйство, охота, рыбо- } \\
\text { ловство и рыбоводство }\end{array}$ & 5059,3 & 7,1 \\
\hline добыча полезных ископаемых & 1119,0 & 1,6 \\
\hline обрабатывающие производства & 10258,8 & 14,3 \\
\hline $\begin{array}{l}\text { обеспечение электрической энергией, га- } \\
\text { зом и паром; кондиционирование воздуха }\end{array}$ & 1612,8 & 2,2 \\
\hline $\begin{array}{l}\text { водоснабжение; водоотведение, организа- } \\
\text { ция сбора и утилизации отходов, деятель- } \\
\text { ность по ликвидации загрязнений }\end{array}$ & 644,9 & 0,9 \\
\hline строительство & 6414,4 & 8,9 \\
\hline $\begin{array}{l}\text { торговля оптовая и розничная; ремонт } \\
\text { автотранспортных средств и мотоциклов }\end{array}$ & 13867,0 & 19,3 \\
\hline транспортировка и хранение & 5253,6 & 7,3 \\
\hline $\begin{array}{l}\text { деятельность гостиниц и предприятий } \\
\text { общественного питания }\end{array}$ & 1730,1 & 2,4 \\
\hline $\begin{array}{l}\text { деятельность в области информации } \\
\text { и связи }\end{array}$ & 1435,5 & 2,0 \\
\hline деятельность финансовая и страховая & 1347,6 & 1,9 \\
\hline $\begin{array}{l}\text { деятельность по операциям с недвижимым } \\
\text { имуществом }\end{array}$ & 1928,1 & 2,7 \\
\hline $\begin{array}{l}\text { деятельность профессиональная, научная } \\
\text { и техническая }\end{array}$ & 2718,9 & 3,8 \\
\hline $\begin{array}{l}\text { деятельность административная и сопут- } \\
\text { ствующие дополнительные услуги }\end{array}$ & 1991,7 & 2,8 \\
\hline $\begin{array}{l}\text { государственное управление и обеспече- } \\
\text { ние военной безопасности; социальное } \\
\text { обеспечение }\end{array}$ & 3735,8 & 5,2 \\
\hline образование & 5439,2 & 7,6 \\
\hline $\begin{array}{l}\text { деятельность в области здравоохранения } \\
\text { и социальных услуг }\end{array}$ & 4443,1 & 6,2 \\
\hline $\begin{array}{l}\text { деятельность в области культуры, спорта, } \\
\text { организации досуга и развлечений }\end{array}$ & 1163,3 & 1,6 \\
\hline предоставление прочих видов услуг & 1515,2 & 2,1 \\
\hline
\end{tabular}




\section{5. ТЕМПЫ РОСТА (СНИЖЕНИЯ) ПРОИЗВОДИТЕЛЬНОСТИ ТРУДА} ПО ВИДАМ ЭКОНОМИЧЕСКОЙ ДЕЯТЕЛЬНОСТИ

(в процентах к предыдущему году)

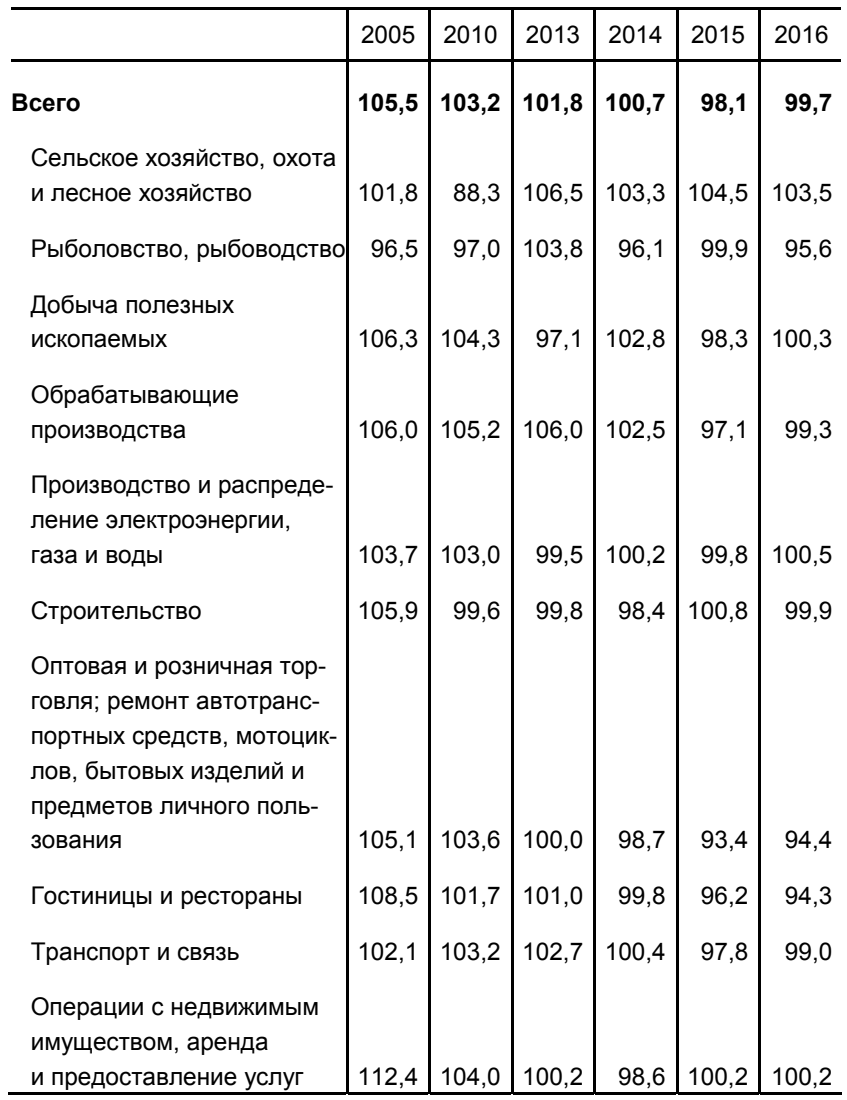


6.6. ЧИСЛЕННОСТЬ ЗАНЯТЫХ ПО ПОЛУ И ЗАНЯТИЯМ в 2017 г. ${ }^{1)}$ (в среднем за год; тыс. человек)

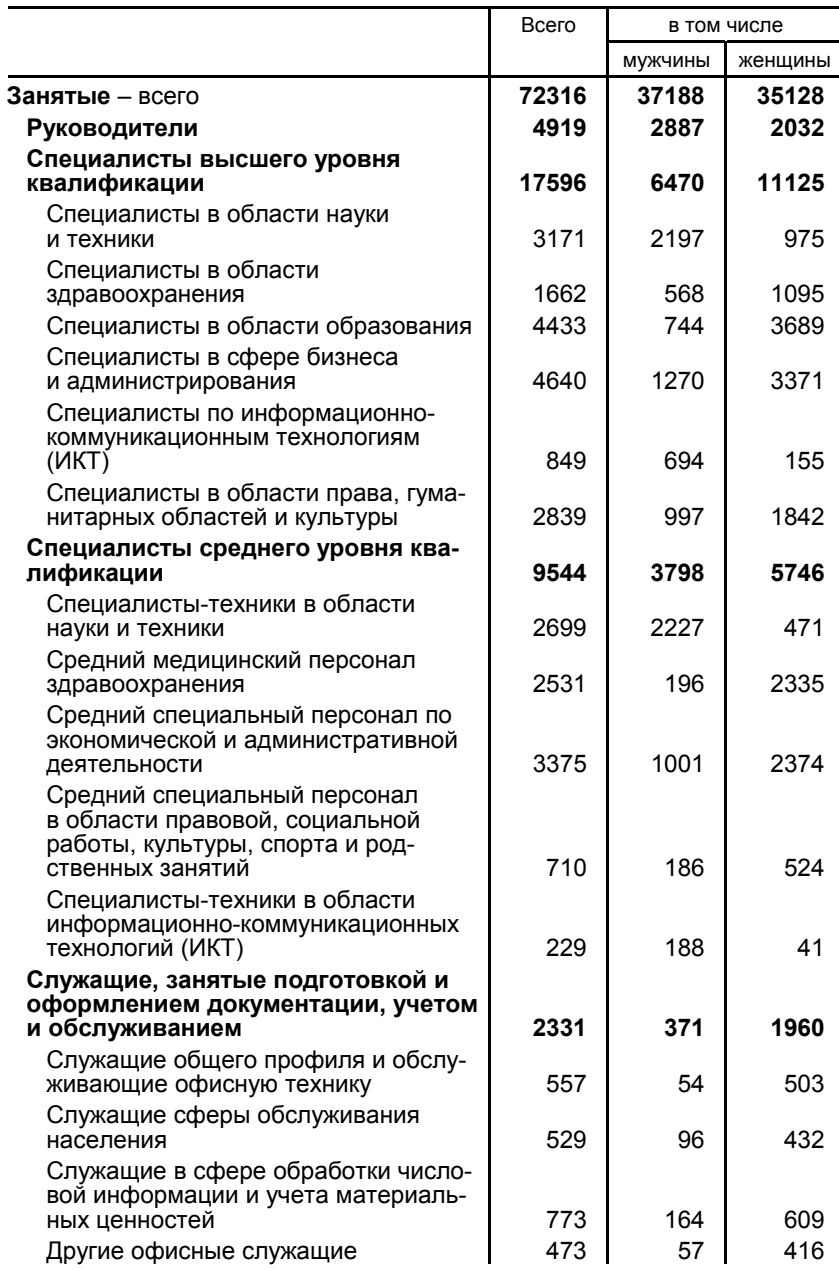


Продолжение табл. 6.6

\begin{tabular}{|c|c|c|c|}
\hline & \multirow[t]{2}{*}{ Всего } & \multicolumn{2}{|c|}{ в том числе } \\
\hline & & мужчины & женщины \\
\hline $\begin{array}{l}\text { Работники сферы обслуживания и } \\
\text { торговли, охраны граждан и собст- }\end{array}$ & & & \\
\hline Венности & 11383 & 3494 & 7889 \\
\hline $\begin{array}{l}\text { Работники сферы индивидуальных } \\
\text { услуг }\end{array}$ & 2614 & 406 & 2208 \\
\hline Продавцы & 5586 & 933 & 4653 \\
\hline Работники, оказывающие услуги по & & & \\
\hline индивидуальному уходу & 809 & 39 & 770 \\
\hline $\begin{array}{l}\text { Работники служб, осуществляющих } \\
\text { охрану граждан и собственности }\end{array}$ & 2374 & 2116 & 258 \\
\hline Квалифицированные работники & & & \\
\hline $\begin{array}{l}\text { сельского и лесного хозяйства, } \\
\text { рыбоводства и рыболовства }\end{array}$ & 1814 & 960 & 854 \\
\hline $\begin{array}{l}\text { Квалифицированные рабочие } \\
\text { промышленности, строительства, } \\
\text { транспорта и рабочие родственных }\end{array}$ & & & \\
\hline занятий & 9573 & 7923 & 1650 \\
\hline $\begin{array}{l}\text { Рабочие, занятые в строительстве, } \\
\text { и рабочие родственных занятий } \\
\text { (за исключением электриков) }\end{array}$ & 2568 & 2290 & 278 \\
\hline $\begin{array}{l}\text { Рабочие, занятые в металлообраба- } \\
\text { тывающем и машиностроительном }\end{array}$ & & & \\
\hline производстве, механики и ремонтники & 4088 & 3890 & 197 \\
\hline $\begin{array}{l}\text { Рабочие, занятые изготовлением пре- } \\
\text { цизионных инструментов и приборов, } \\
\text { рабочие художественных промыслов }\end{array}$ & & & \\
\hline и полиграфического производства & 225 & 146 & 79 \\
\hline $\begin{array}{l}\text { Рабочие в области электротехники } \\
\text { и электроники }\end{array}$ & 908 & 826 & 82 \\
\hline $\begin{array}{l}\text { Рабочие пищевой, деревообрабаты- } \\
\text { вающей, текстильной и швейной про- }\end{array}$ & & & \\
\hline $\begin{array}{l}\text { мышленности и рабочие родственных } \\
\text { занятий }\end{array}$ & 1784 & 770 & 1013 \\
\hline $\begin{array}{l}\text { Операторы производственных уста- } \\
\text { новок и машин, сборщики и водители }\end{array}$ & 9150 & 8155 & 995 \\
\hline Операторы промышленных установок & & & \\
\hline и стационарного оборудования & 1983 & 1233 & 750 \\
\hline Сборщики & 229 & 176 & 53 \\
\hline $\begin{array}{l}\text { Водители и операторы подвижного } \\
\text { оборудования }\end{array}$ & 6938 & 6746 & 192 \\
\hline Неквалифицированные рабочие & 6006 & 3130 & 2876 \\
\hline $\begin{array}{l}\text { Уборщики и прислуга } \\
\text { Неквалифицированные рабочие }\end{array}$ & 1172 & 73 & 1099 \\
\hline $\begin{array}{l}\text { сельского и лесного хозяйства, } \\
\text { рыбоводства и рыболовства }\end{array}$ & 432 & 294 & 138 \\
\hline
\end{tabular}


Продолжение табл. 6.6

\begin{tabular}{|c|c|c|c|}
\hline & \multirow[t]{2}{*}{ Всего } & \multicolumn{2}{|c|}{ в том числе } \\
\hline & & мужчины & женщины \\
\hline $\begin{array}{l}\text { Неквалифицированные рабочие, за- } \\
\text { нятые в горнодобывающей промыш- } \\
\text { ленности, строительстве, обрабаты- } \\
\text { вающей промышленности и на транс- } \\
\text { порте } \\
\text { Помощники в приготовлении пищи } \\
\text { Уличные торговцы и другие неквали- } \\
\text { фицированные работники, оказываю- } \\
\text { щие различные уличные услуги } \\
\text { Неквалифицированные работники } \\
\text { по сбору мусора и другие неквалифи- } \\
\text { цированные работники }\end{array}$ & $\begin{array}{r}1639 \\
138 \\
25 \\
\\
2599\end{array}$ & $\begin{array}{r}1103 \\
18 \\
\\
11\end{array}$ & $\begin{array}{l}536 \\
120\end{array}$ \\
\hline
\end{tabular}

6.7. РАСПРЕДЕЛЕНИЕ ЧИСЛЕННОСТИ ЗАНЯТЫХ ПО ВОЗРАСТНЫМ ГРУППАМ И УРОВНЮ ОБРАЗОВАНИЯ в 2017 г.

(в среднем за год; в процентах к итогу)

\begin{tabular}{|c|c|c|c|}
\hline & Всего & Мужчины & Женщины \\
\hline Занятые - всего & 100 & 100 & 100 \\
\hline в том числе в возрасте, лет: & & & \\
\hline $\begin{array}{l}15-19 \\
20-24\end{array}$ & $\begin{array}{l}0,5 \\
5,7\end{array}$ & $\begin{array}{l}0,6 \\
6,2\end{array}$ & $\begin{array}{l}0,4 \\
5,1\end{array}$ \\
\hline $25-29$ & 14,4 & 15,4 & 13,4 \\
\hline $30-34$ & 14,5 & 15,1 & 13,9 \\
\hline $35-39$ & 13,6 & 13,4 & 13,7 \\
\hline $40-44$ & 12,7 & 12,1 & 13,3 \\
\hline $45-49$ & 11,4 & 10,6 & 12,1 \\
\hline $50-54$ & 12,1 & 11,1 & 13,2 \\
\hline $55-59$ & 9,6 & 10,0 & 9,2 \\
\hline $60-69$ & 5,2 & 5,1 & 5,3 \\
\hline 70 лет и старше & 0,4 & 0,3 & 0,4 \\
\hline Средний возраст занятых, лет & 40,9 & 40,4 & 41,3 \\
\hline Занятые - всего & 100 & 100 & 100 \\
\hline в том числе имеют образование: & & & \\
\hline высшее & 34,2 & 29,9 & 38,8 \\
\hline среднее профессиональное - всего & 44,8 & 44,8 & 44,8 \\
\hline $\begin{array}{l}\text { по программе подготовки специа- } \\
\text { листов среднего звена }\end{array}$ & 25,6 & 22,2 & 29,3 \\
\hline по программе подготовки квалифи- & & & \\
\hline цированных рабочих (служащих) ${ }^{1)}$ & 19,2 & 23,8 & 14,3 \\
\hline среднее общее & 17,4 & 19,7 & 14,9 \\
\hline основное общее & 3,3 & 4,1 & 2,5 \\
\hline $\begin{array}{l}\text { не имеют основного общего } \\
\text { образования }\end{array}$ & 0,2 & 0,3 & 0,1 \\
\hline
\end{tabular}




\section{8. ЧИСЛЕННОСТЬ ЗАНЯТЫХ В РОССИИ И ПО ВИДАМ ЭКОНОМИЧЕСКОЙ}

(в процентах

\begin{tabular}{|c|c|c|c|c|c|c|c|c|c|}
\hline & Poc- & & & & Стран & ы СНГ & & & \\
\hline & 2017 & $\begin{array}{c}\text { Азер- } \\
\text { бай- } \\
\text { джан } \\
2016\end{array}$ & \begin{tabular}{|} 
Арме- \\
ния \\
2016
\end{tabular} & $\begin{array}{l}\text { Бела- } \\
\text { русь } \\
2016\end{array}$ & $\begin{array}{c}\text { Казах- } \\
\text { стан } \\
2017\end{array}$ & $\begin{array}{c}\text { Кирги- } \\
\text { зия } \\
2016\end{array}$ & $\begin{array}{l}\text { Рес- } \\
\text { пуб- } \\
\text { лика } \\
\text { Мол- } \\
\text { дова } \\
2017\end{array}$ & \begin{tabular}{|c|} 
Тад- \\
жики- \\
стан \\
2016
\end{tabular} & $\begin{array}{c}\text { Украи- } \\
\text { на } \\
2016\end{array}$ \\
\hline $\begin{array}{l}\text { Всего } \\
\text { в том числе } \\
\text { по видам } \\
\text { экономической } \\
\text { деятельности: } \\
\text { сельское, лесное } \\
\text { хозяйство, охота, } \\
\text { рыболовство }\end{array}$ & 100 & 100 & 100 & 100 & 100 & 100 & 100 & 100 & 100 \\
\hline $\begin{array}{l}\text { и рыбоводство } \\
\text { добыча полезных }\end{array}$ & 5,9 & 36,3 & 33,6 & 9,6 & 15,4 & 26,8 & 32,3 & 45,8 & 17,6 \\
\hline $\begin{array}{l}\text { ископаемых } \\
\text { обрабатывающие }\end{array}$ & 2,2 & 0,8 & 0,9 & 0,2 & 3,3 & 0,4 & 0,3 & 0,4 & $\ldots$ \\
\hline $\begin{array}{l}\text { производства } \\
\text { обеспечение } \\
\text { электрической } \\
\text { энергией, газом } \\
\text { и паром; конди- } \\
\text { ционирование }\end{array}$ & 14,2 & 5,1 & 8,3 & 19,8 & 6,8 & 7,6 & 9,6 & 5,4 & $\ldots$ \\
\hline $\begin{array}{l}\text { воздуха } \\
\text { водоснабжение; } \\
\text { водоотведение, } \\
\text { организация сбо- } \\
\text { ра и утилизации } \\
\text { отходов, деятель-- } \\
\text { ность по ликвида- } \\
\text { ции загрязнений }\end{array}$ & 2,6 & 0,6 & 2,4 & 2,3 & 1,8 & 1,2 & 1,3 & 0,6 & $15,3^{3)}$ \\
\hline $\begin{array}{l}\text { строительство } \\
\text { торговля, транс- } \\
\text { порт и хранение, } \\
\text { гостиницы и } \\
\text { предприятия } \\
\text { общественного } \\
\text { питания, инфор- } \\
\text { мация и связь }\end{array}$ & 28,8 & 21,6 & 19,0 & 25,5 & 26,6 & 12,0 & 23,3 & 17,6 & 4,0 \\
\hline
\end{tabular}

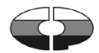




\section{НЕКОТОРЫХ ЗАРУБЕЖНЫХ СТРАНАХ ДЕЯТЕЛЬНОСТИ'}

к итогу)

\begin{tabular}{|c|c|c|c|c|c|c|c|c|}
\hline \multicolumn{7}{|c|}{ Страны ЕС } & \multirow{2}{*}{\begin{tabular}{|c|} 
Другие \\
страны \\
США \\
2016
\end{tabular}} & \\
\hline $\begin{array}{c}\text { Герма- } \\
\text { ния } \\
2016\end{array}$ & \begin{tabular}{|c|} 
Поль- \\
ша \\
2016
\end{tabular} & \begin{tabular}{|c|} 
Соеди- \\
ненное \\
Коро- \\
лев- \\
ство \\
(Вели- \\
ко- \\
брита- \\
ния) \\
2016 \\
\end{tabular} & \begin{tabular}{|c|} 
Фин- \\
ляндия \\
2016 \\
\\
\\
\end{tabular} & $\begin{array}{c}\text { Фран- } \\
\text { ция } \\
2016\end{array}$ & $\begin{array}{c}\text { Шве- } \\
\text { ция } \\
2016\end{array}$ & $\begin{array}{c}\text { Эсто- } \\
\text { ния } \\
2016\end{array}$ & & \\
\hline 100 & 100 & 100 & 100 & 100 & 100 & 100 & 100 & $\begin{array}{l}\text { Всего } \\
\text { в том числе } \\
\text { по видам } \\
\text { экономической } \\
\text { деятельности: } \\
\text { сельское, лесное } \\
\text { хозяйство, охота, } \\
\text { рыболовство }\end{array}$ \\
\hline 1,3 & 10,5 & 1,1 & 3,8 & 2,8 & 1,9 & 3,9 & 1,6 & $\begin{array}{l}\text { и рыбоводство } \\
\text { добыча полезных }\end{array}$ \\
\hline 0,2 & 1,4 & 0,4 & 0,2 & 0,1 & 0,2 & 0,5 & 0,5 & $\begin{array}{l}\text { ископаемых } \\
\text { обрабатывающие }\end{array}$ \\
\hline 19,2 & 20,2 & 9,5 & 13,4 & 12,2 & 10,2 & 18,8 & 10,2 & $\begin{array}{l}\text { производства } \\
\text { обеспечение } \\
\text { электрической } \\
\text { энергией, газом } \\
\text { и паром; конди- } \\
\text { ционирование }\end{array}$ \\
\hline $0,6^{4)}$ & $1,1^{4)}$ & $0,7^{4)}$ & $0,5^{4)}$ & $0,7^{4)}$ & $0,4^{4)}$ & $0,5^{4)}$ & $0,0^{4)}$ & $\begin{array}{l}\text { воздуха } \\
\text { водоснабжение; } \\
\text { водоотведение, } \\
\text { организация сбо- } \\
\text { ра и утилизации } \\
\text { отходов, деятель- } \\
\text { ность по ликвида- } \\
\text { ции загрязнений }\end{array}$ \\
\hline 25,9 & 25,1 & 27,7 & 25,2 & 25,0 & 24,2 & 29,5 & 26,9 & $\begin{array}{l}\text { строительство } \\
\text { торговля, транс- } \\
\text { порт и хранение, } \\
\text { гостиницы и } \\
\text { предприятия } \\
\text { общественного } \\
\text { питания, инфор- } \\
\text { мация и связь }\end{array}$ \\
\hline
\end{tabular}




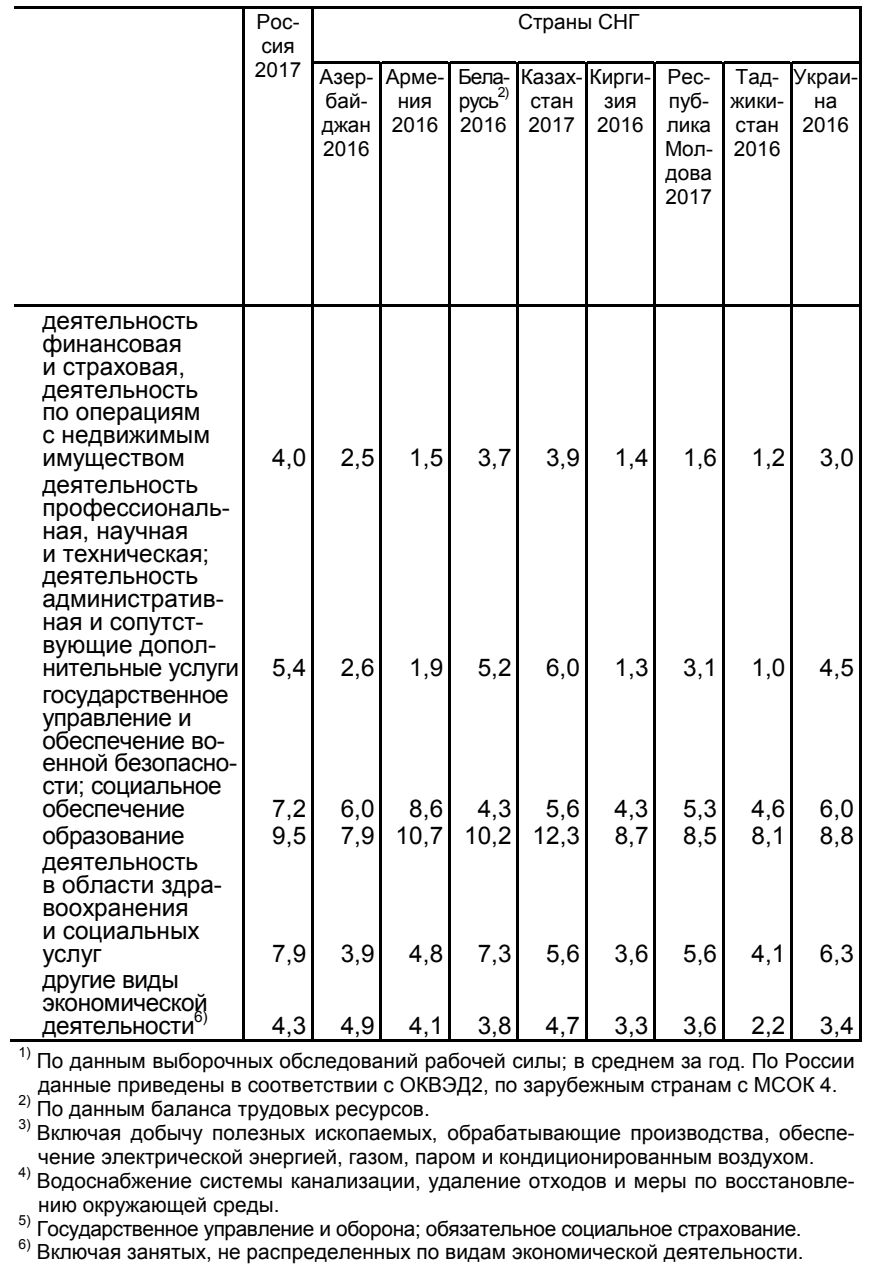


Продолжение табл. 6.8

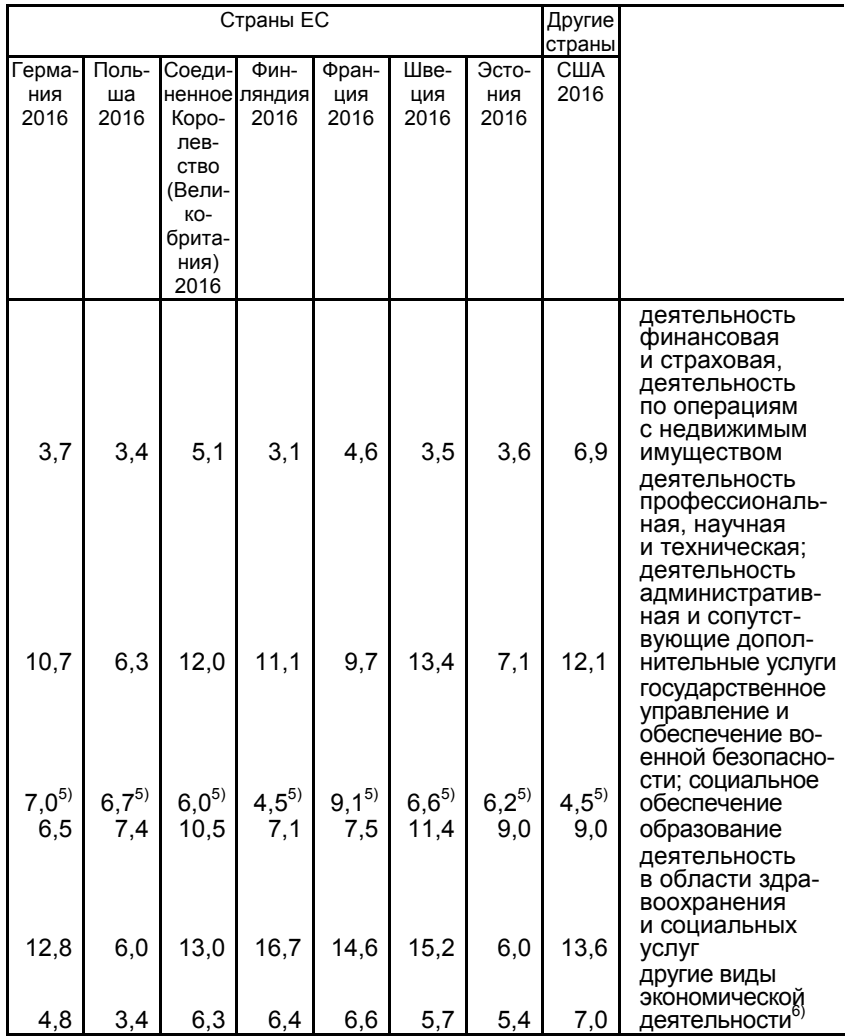




\section{9. ЧИСЛЕННОСТЬ ИНОСТРАННЫХ ГРАЖДАН, ПОЛУЧИВШИХ} РАЗРЕШИТЕЛЬНЫЕ ДОКУМЕНТЫ НА РАБОТУ В РОССИИ ${ }^{1)}$

\begin{tabular}{|c|c|c|c|c|c|c|c|c|c|c|}
\hline & \multicolumn{5}{|c|}{ Тыс. человек } & \multicolumn{5}{|c|}{$\begin{array}{c}\text { В процентах от общей } \\
\text { численности }\end{array}$} \\
\hline & 2013 & 2014 & 2015 & 2016 & 2017 & 2013 & 2014 & 2015 & 2016 & 2017 \\
\hline Bcero $^{2)}$ & 2529,0 & 3306,3 & 1868,7 & 1686,3 & 1773,9 & 100 & 100 & 100 & 100 & 100 \\
\hline в том числе: & & & & & & & & & & \\
\hline из стран СНГ & 2365,0 & 3101,1 & 1713,4 & 1581,1 & 1679,4 & 93,5 & 93,8 & 91,7 & 93,8 & 94,7 \\
\hline Азербайджан & 75,2 & 110,7 & 50,5 & 49,0 & 54,1 & 3,0 & 3,3 & 2,7 & 2,9 & 3,0 \\
\hline Армения & 127,2 & 181,3 & 0,2 & 0,0 & 0,0 & 5,0 & 5,5 & 0,0 & 0,0 & 0,0 \\
\hline Казахстан & 1,1 & 1,1 & 0,3 & 0,2 & 0,1 & 0,0 & 0,0 & 0,0 & 0,0 & 0,0 \\
\hline Киргизия & 167,7 & 227,1 & 33,2 & 0,1 & 0,1 & 6,6 & 6,9 & 1,8 & 0,0 & 0,0 \\
\hline $\begin{array}{l}\text { Республика } \\
\text { Молдова }\end{array}$ & 94,9 & 224,1 & 98,3 & 65,4 & 52,0 & 3,8 & 6,8 & 5,3 & 3,9 & 2,9 \\
\hline Таджикистан & 472,2 & 603,1 & 428,3 & 403,8 & 442,4 & 18,7 & 18,2 & 22,9 & 23,9 & 24,9 \\
\hline Туркмения & 0,3 & 0,5 & 0,3 & 0,3 & 0,2 & 0,0 & 0,0 & 0,0 & 0,0 & 0,0 \\
\hline Узбекистан & 1254,0 & 1341,4 & 893,2 & 894,5 & 997,0 & 49,6 & 40,6 & 47,8 & 53,0 & 56,2 \\
\hline Украина & 172,3 & 411,7 & 209,1 & 167,9 & 133,5 & 6,8 & 12,5 & 11,2 & 10,0 & 7,5 \\
\hline из других стран & 162,5 & 202,6 & 154,4 & 104,5 & 94,2 & 6,4 & 6,1 & 8,3 & 6,2 & 5,3 \\
\hline Вьетнам & 10,0 & 14,9 & 12,9 & 8,0 & 11,5 & 0,4 & 0,5 & 0,7 & 0,5 & 0,6 \\
\hline Китай & 77,9 & 84,1 & 53,6 & 40,1 & 35,7 & 3,1 & 2,5 & 2,9 & 2,4 & 2,0 \\
\hline $\begin{array}{l}\text { Корейская } \\
\text { Народно- } \\
\text { Демократическая }\end{array}$ & & & & & & & & & & \\
\hline Республика & 25,1 & 32,7 & 33,1 & 33,1 & 27,2 & 1,0 & 1,0 & 1,8 & 2,0 & 1,5 \\
\hline США & 0,5 & 1,1 & 0,7 & 0,1 & 0,1 & 0,0 & 0,0 & 0,0 & 0,0 & 0,0 \\
\hline Турция & 26,3 & 29,9 & 23,7 & 8,7 & 5,9 & 1,0 & 0,9 & 1,3 & 0,5 & 0,3 \\
\hline
\end{tabular}




\subsection{0. ЧИСЛЕННОСТЬ ИНОСТРАННЫХ ГРАЖДАН, ИМЕВШИХ ДЕЙСТВУЮЩЕЕ РАЗРЕШЕНИЕ НА РАБОТУ')}

(на конец года)

\begin{tabular}{|c|c|c|c|c|c|c|c|c|c|c|}
\hline & \multicolumn{5}{|c|}{ Тыс. человек } & \multicolumn{5}{|c|}{$\begin{array}{c}\text { В процентах от общей } \\
\text { численности }\end{array}$} \\
\hline & 2013 & 2014 & 2015 & 2016 & 2017 & 2013 & 2014 & 2015 & 2016 & 2017 \\
\hline $\begin{array}{c}\text { Bсего }^{2)} \\
\text { в том } \\
\text { числе: }\end{array}$ & 1111,5 & 1043,8 & 182,4 & 143,9 & 114,9 & 100 & 100 & 100 & 100 & 100 \\
\hline $\begin{array}{l}\text { из стран } \\
\text { СНГ }\end{array}$ & 947,3 & 866,0 & 33,5 & 25,0 & 19,9 & 85,2 & 83,0 & 18,4 & 17,4 & 17,3 \\
\hline $\begin{array}{l}\text { из них: } \\
\text { Азер- } \\
\text { байджан }\end{array}$ & 18,1 & 14,1 & 2,5 & 2,0 & 1,9 & 1,6 & 1,3 & 1,3 & 1,4 & 1,6 \\
\hline Армения & 35,5 & 30,3 & 1,5 & 1,5 & 1,4 & 3,2 & 2,9 & 0,8 & 1,0 & 1,2 \\
\hline $\begin{array}{l}\text { Казах- } \\
\text { стан }\end{array}$ & 0,7 & 0,5 & 0,2 & 0,2 & 0,2 & 0,1 & 0,0 & 0,1 & 0,1 & 0,1 \\
\hline Киргизия & 82,7 & 72,9 & 2,5 & 1,1 & 1,1 & 7,4 & 7,0 & 1,4 & 0,8 & 1,0 \\
\hline $\begin{array}{l}\text { Респуб- } \\
\text { лика }\end{array}$ & & & & & & & & & & \\
\hline Молдова & 45,5 & 40,4 & 1,5 & 0,9 & 0,9 & 4,1 & 3,9 & 0,8 & 0,6 & 0,8 \\
\hline $\begin{array}{l}\text { Таджи- } \\
\text { кистан }\end{array}$ & 162,8 & 145,7 & 10,7 & 8,3 & 4,4 & 14,6 & 14,0 & 5,9 & 5,8 & 3,8 \\
\hline $\begin{array}{l}\text { Туркме- } \\
\text { ния }\end{array}$ & 0,5 & 0,5 & 0,4 & 0,5 & 0,3 & 0,0 & 0,0 & 0,2 & 0,3 & 0,3 \\
\hline $\begin{array}{l}\text { Узбеки- } \\
\text { стан }\end{array}$ & 476,6 & 422,0 & 10,0 & 7,8 & 7,7 & 42,9 & 40,4 & 5,5 & 5,4 & 6,7 \\
\hline Украина & 124,9 & 139,5 & 4,2 & 2,7 & 2,0 & 11,2 & 13,4 & 2,3 & 1,9 & 1,8 \\
\hline $\begin{array}{l}\text { из других } \\
\text { стран }\end{array}$ & 162,5 & 176,8 & 148,6 & 118,6 & 94,9 & 14,6 & 16,9 & 81,5 & 82,5 & 82,5 \\
\hline из них: & & & & & & & & & & \\
\hline Вьетнам & 10,3 & 13,5 & 14,1 & 12,5 & 13,0 & 0,9 & 1,3 & 7,7 & 8,7 & 11,3 \\
\hline $\begin{array}{l}\text { Китай } \\
\text { Корей- } \\
\text { ская На- } \\
\text { родно- } \\
\text { Демо- } \\
\text { кра- } \\
\text { тическая } \\
\text { Респуб- }\end{array}$ & 71,3 & 71,7 & 49,4 & 40,5 & 34,4 & 6,4 & 6,9 & 27,1 & 28,1 & 29,9 \\
\hline лика & 27,2 & 30,7 & 30,4 & 29,1 & 24,1 & 2,4 & 2,9 & 16,7 & 20,2 & 21,0 \\
\hline США & 0,6 & 1,1 & 1,2 & 1,0 & 0,5 & 0,1 & 0,1 & 0,6 & 0,7 & 0,4 \\
\hline Турция & 27,7 & 24,1 & 19,3 & 9,9 & 5,4 & 2,5 & 2,3 & 10,6 & 6,9 & 4,7 \\
\hline
\end{tabular}

1) По данным МВД России. С 2015 г. изменен порядок осуществления трудовой деятельности иностранными гражданами, прибывшими в безвизовом режиме.

2) Включая лиц без гражданства. 


\subsection{1. ЧИСЛЕННОСТЬ ИНОСТРАННЫХ ГРАЖДАН, ИМЕВШИХ ДЕЙСТВУЮЩИЙ ПАТЕНТ НА ОСУЩЕСТВЛЕНИЕ ТРУДОВОЙ ДЕЯТЕЛЬНОСТИ ${ }^{1)}$}

\begin{tabular}{|c|c|c|c|c|c|c|c|c|c|c|}
\hline & \multicolumn{5}{|c|}{ Тыс. человек } & \multicolumn{5}{|c|}{$\begin{array}{c}\text { В процентах от общей } \\
\text { численности }\end{array}$} \\
\hline & 2013 & 2014 & 2015 & 2016 & 2017 & 2013 & 2014 & 2015 & 2016 & 2017 \\
\hline $\begin{array}{l}\text { Bcero }^{2)} \\
\qquad \begin{array}{l}\text { в том } \\
\text { числе } \\
\text { из стран }\end{array}\end{array}$ & 1117,8 & 2079,8 & 1656,3 & 1543,4 & 1649,1 & 100 & 100 & 100 & 100 & 100 \\
\hline $\begin{array}{l}\text { СНГ } \\
\text { из них: }\end{array}$ & 1117,8 & 2077,6 & 1655,4 & 1542,6 & $\mid 1648,7$ & 100 & 99,9 & 99,9 & 99,9 & 100 \\
\hline $\begin{array}{l}\text { Азербай- } \\
\text { джан }\end{array}$ & 45,3 & 93,2 & 48,8 & 48,2 & 53,7 & 4,0 & 4,5 & 2,9 & 3,1 & 3,3 \\
\hline Армения & 80,1 & 145,9 & 0,2 & 0,0 & 0,0 & 7,2 & 7,0 & 0,0 & 0,0 & 0,0 \\
\hline Казахстан & 1,5 & 1,5 & 0,4 & 0,2 & 0,2 & 0,1 & 0,1 & 0,0 & 0,0 & 0,0 \\
\hline Киргизия & 67,2 & 151,9 & 31,0 & 0,2 & 0,1 & 6,0 & 7,3 & 1,9 & 0,0 & 0,0 \\
\hline $\begin{array}{l}\text { Республи- } \\
\text { ка Молдо- } \\
\text { ва }\end{array}$ & 40,4 & 175,1 & 96,4 & 64,3 & 52,0 & 3,6 & 8,4 & 5,8 & 4,2 & 3,2 \\
\hline $\begin{array}{l}\text { Таджики- } \\
\text { стан }\end{array}$ & 252,2 & 432,5 & 416,8 & 393,4 & 432,8 & 22,6 & 20,8 & 25,2 & 25,5 & 26,2 \\
\hline $\begin{array}{l}\text { Узбеки- } \\
\text { стан }\end{array}$ & 595,0 & 824,8 & 859,2 & 871,7 & 976,9 & 53,2 & 39,7 & 51,9 & 56,5 & 59,2 \\
\hline Украина & 36,3 & 252,6 & 202,7 & 164,6 & 132,8 & 3,2 & 12,1 & 12,2 & 10,7 & 8,1 \\
\hline
\end{tabular}

1) По данным МВД России. С 2015 г. изменен порядок осуществления трудовой деятельности иностранными гражданами, прибывшими в безвизовом режиме.

${ }^{2)}$ Включая лиц без гражданства. 
6.12. ЧИСЛЕННОСТЬ БЕЗРАБОТНЫХ

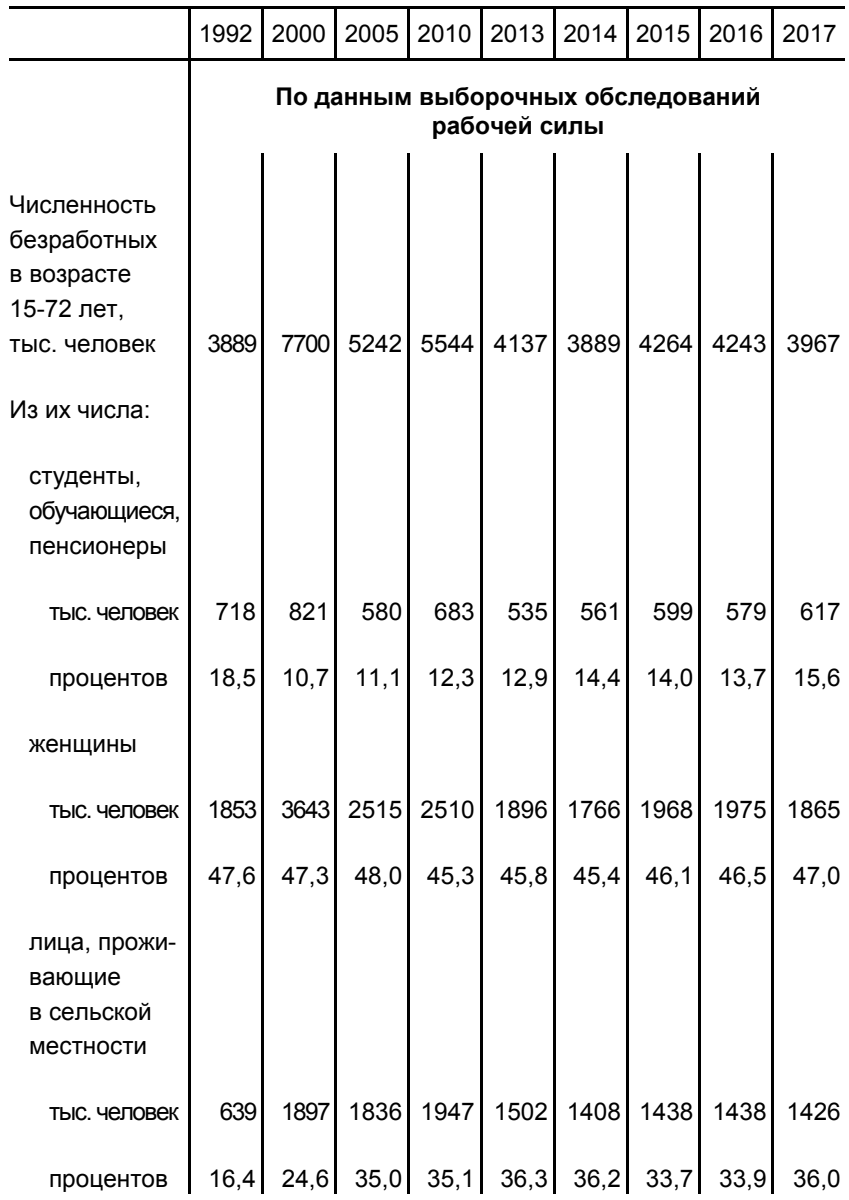


Продолжение табл. 6.12

\begin{tabular}{|c|c|c|c|c|c|c|c|c|c|}
\hline & 1992 & 2000 & 2005 & 2010 & 2013 & 2014 & 2015 & 2016 & 2017 \\
\hline $\begin{array}{l}\text { Численность } \\
\text { безработных, } \\
\text { зарегистриро- } \\
\text { ванных в орга- } \\
\text { нах службы } \\
\text { занятости } \\
\text { населения }{ }^{1)} \text {, } \\
\text { тыс. человек }\end{array}$ & 578 & $\Pi$ & о данн & $\begin{array}{r}\text { ым Ф } \\
\text { о труд } \\
\text { (на к }\end{array}$ & $\begin{array}{l}\text { едера } \\
\text { у и за } \\
\text { онец г }\end{array}$ & $\begin{array}{l}\text { Іьной } \\
\text { нятост } \\
\text { ода) }\end{array}$ & $\begin{array}{l}\text { служб } \\
\text { и }\end{array}$ & b & 776 \\
\hline $\begin{array}{c}\text { Из их числа: } \\
\text { женщины }\end{array}$ & & & & & & & & & \\
\hline тыс. человек & 417 & 715 & 1200 & 891 & 502 & 480 & 535 & 469 & 411 \\
\hline $\begin{array}{l}\text { процентов } \\
\text { лица, прожи- } \\
\text { вающие } \\
\text { в сельской } \\
\text { местности }\end{array}$ & 72,2 & 68,9 & 65,5 & 56,1 & 54,7 & 54,3 & 53,5 & 52,4 & 53,0 \\
\hline тыс. человек & 102 & 325 & 891 & 699 & 425 & 382 & 377 & 336 & 306 \\
\hline процентов & 17,6 & 31,4 & 48,7 & 44,0 & 46,3 & 43,3 & 37,7 & 37,6 & 39,5 \\
\hline $\begin{array}{l}\text { Отношение чис- } \\
\text { ленности безра- } \\
\text { ботных, зареги- } \\
\text { стрированных } \\
\text { в органах служ- } \\
\text { бы занятости } \\
\text { населения, к } \\
\text { общей числен- } \\
\text { ности безработ- }\end{array}$ & & & & & & & & & \\
\hline ных, процентов & 14,9 & 13,5 & 34,9 & 28,7 & 22,2 & 22,7 & 23,5 & 21,1 & 19,6 \\
\hline
\end{tabular}

${ }^{1)}$ С 2005 г. - включая данные по Чеченской Республике. 
6.13. РАСПРЕДЕЛЕНИЕ ЧИСЛЕННОСТИ БЕЗРАБОТНЫХ ПО ВОЗРАСТНЫМ ГРУППАМ И УРОВНЮ ОБРАЗОВАНИЯ в 2017 г.

(в среднем за год; в процентах к итогу)

\begin{tabular}{|c|c|c|c|}
\hline & Всего & Мужчины & Женщины \\
\hline Безработные - всего & 100 & 100 & 100 \\
\hline в том числе в возрасте, лет: & & & \\
\hline $\begin{array}{l}15-19 \\
20-24\end{array}$ & $\begin{array}{r}3,8 \\
17,9\end{array}$ & $\begin{array}{r}3,9 \\
18,5\end{array}$ & $\begin{array}{r}3,7 \\
17,2\end{array}$ \\
\hline $25-29$ & 16,4 & 15,7 & 17,3 \\
\hline $30-34$ & 13,1 & 12,4 & 13,9 \\
\hline $35-39$ & 10,7 & 10,4 & 11,1 \\
\hline $40-44$ & 9,3 & 9,5 & 9,0 \\
\hline $45-49$ & 8,4 & 8,0 & 8,9 \\
\hline $50-54$ & 9,4 & 9,4 & 9,3 \\
\hline $55-59$ & 7,4 & 8,8 & 5,8 \\
\hline $60-69$ & 3,4 & 3,3 & 3,4 \\
\hline 70 лет и старше & 0,1 & 0,1 & 0,2 \\
\hline $\begin{array}{l}\text { Средний возраст безработных, лет } \\
\text { Безработные - всего }\end{array}$ & $\begin{array}{r}36,4 \\
100\end{array}$ & $\begin{array}{r}36,5 \\
100\end{array}$ & $\begin{array}{r}36,1 \\
100\end{array}$ \\
\hline В том числе имеют образование: & & & \\
\hline высшее & 20,6 & 17,0 & 24,8 \\
\hline $\begin{array}{l}\text { среднее профессиональное - } \\
\text { всего }\end{array}$ & 40,1 & 40,3 & 39,9 \\
\hline по программе подготовки специа- & & & \\
\hline листов среднего звена & 20,0 & 17,1 & 23,3 \\
\hline по программе подготовки & & & \\
\hline $\begin{array}{l}\text { квалифицированных рабочих } \\
(\text { служащих) })^{1)}\end{array}$ & 20,1 & 23,1 & 16,6 \\
\hline среднее общее & 29,1 & 30,8 & 27,2 \\
\hline основное общее & 9,1 & 10,6 & 7,4 \\
\hline $\begin{array}{l}\text { не имеют основного общего } \\
\text { образования }\end{array}$ & 1.0 & 14 & 0.7 \\
\hline
\end{tabular}

1) Включая начальное профессиональное образование.

6.14. РАСПРЕДЕЛЕНИЕ ЧИСЛЕННОСТИ ЗАНЯТЫХ И БЕЗРАБОТНЫХ ПО СЕМЕЙНОМУ ПОЛОЖЕНИЮ В 2017 r.

(в среднем за год; в процентах к итогу)

\begin{tabular}{l|c|c|c|c|c}
\hline & Bсего & \multicolumn{4}{|c}{ в том числе } \\
\cline { 3 - 6 } & & $\begin{array}{c}\text { состоят в } \\
\text { браке }\end{array}$ & $\begin{array}{c}\text { холосты, } \\
\text { не замужем }\end{array}$ & $\begin{array}{c}\text { вдовцы, } \\
\text { вдовы }\end{array}$ & $\begin{array}{c}\text { разведены, } \\
\text { разошлись }\end{array}$ \\
\hline Занятые - всего & 100 & 69,6 & 15,9 & 3,1 & 11,4 \\
мужчины & 100 & 73,6 & 18,6 & 1,0 & 6,8 \\
женщины & 100 & 65,4 & 13,1 & 5,2 & 16,2 \\
Безработные - всего & 100 & 51,1 & 33,9 & 3,0 & 12,0 \\
мужчины & 100 & 47,1 & 41,2 & 1,1 & 10,7 \\
женщины & 100 & 55,6 & 25,7 & 5,1 & 13,6 \\
\hline
\end{tabular}




\subsection{5. РАСПРЕДЕЛЕНИЕ ЧИСЛЕННОСТИ БЕЗРАБОТНЫХ} ПО НАЛИЧИЮ ПРОШЛОГО ОПЫТА РАБОТЫ И ОБСТОЯТЕЛЬСТВАМ НЕЗАНЯТОСТИ в 2017 Г.

(в среднем за год; в процентах к итогу)

\begin{tabular}{l|r|r|r}
\hline & Всего & Мужчины & Женщины \\
\hline $\begin{array}{l}\text { Безработные - всего } \\
\text { в том числе: }\end{array}$ & 100 & 100 & 100 \\
имеют опыт трудовой деятельности & 74,0 & 75,8 & 72,0 \\
из них оставили прежнее место & & & \\
работы (деятельности) по причинам: & & & \\
высвобождение, сокращение & & & \\
штатов, ликвидация предприятия, & 16,3 & 16,6 & 16,0 \\
собственного дела & & & \\
окончание срока действия срочного & & & \\
трудового договора, договора & 5,1 & 6,4 & 3,7 \\
гражданско-правового характера & 25,2 & 27,1 & 23,0 \\
по собственному желанию & 27,4 & 25,7 & 29,3 \\
другие причины & 26,0 & 24,2 & 28,0 \\
не имеют опыта работы & & & \\
\hline
\end{tabular}

\subsection{6. ТРУДОУСТРОЙСТВО НАСЕЛЕНИЯ ОРГАНАМИ СЛУЖБЫ ЗАНЯТОСТИ НАСЕЛЕНИЯ ${ }^{1)}$}

\begin{tabular}{|c|c|c|c|c|c|c|c|c|}
\hline & \multicolumn{4}{|c|}{$\begin{array}{c}\text { Обратились по вопросу } \\
\text { трудоустройства }\end{array}$} & \multicolumn{4}{|c|}{ Трудоустроены } \\
\hline & 2000 & 2005 & 2016 & 2017 & 2000 & 2005 & 2016 & 2017 \\
\hline & \multicolumn{8}{|c|}{ Тысяч человек } \\
\hline Bcero & 4745,9 & 6438,0 & 4002,3 & 3761,0 & 3199,4 & 4075,8 & 2577,4 & 2511,9 \\
\hline в том числе: & & & & & & & & \\
\hline $\begin{array}{l}\text { занятые тру- } \\
\text { довой дея- }\end{array}$ & & & & & & & & \\
\hline $\begin{array}{l}\text { тельностью и } \\
\text { учебой }\end{array}$ & 1462,9 & 1397,7 & 777,9 & 768,0 & 1339,2 & 1310,8 & 706,9 & 693,8 \\
\hline $\begin{array}{l}\text { незанятые } \\
\text { трудовой дея- }\end{array}$ & & & & & & & & \\
\hline тельностью2) & 3283,0 & 5040,3 & 3224,4 & 2993,1 & 1860,2 & 2765,0 & 1870,5 & 1818,1 \\
\hline $\begin{array}{l}\text { из них ищу- } \\
\text { щие первую } \\
\text { работу } \\
\text { (ранее не } \\
\text { приступав- } \\
\text { шие к трудо- } \\
\text { вой деятель- }\end{array}$ & & & & & & & & \\
\hline ности) & 2049,1 & 2470,5 & 592,3 & 593,3 & 1622,5 & 1828,9 & 368,8 & 392,2 \\
\hline
\end{tabular}

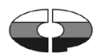


Продолжение табл. 6.16

\begin{tabular}{|c|c|c|c|c|c|c|c|c|}
\hline & \multicolumn{4}{|c|}{$\begin{array}{c}\text { Обратились по вопросу } \\
\text { трудоустройства }\end{array}$} & \multicolumn{4}{|c|}{ Трудоустроены } \\
\hline & 2000 & 2005 & 2016 & 2017 & 2000 & 2005 & 2016 & 2017 \\
\hline $\begin{array}{l}\text { Всего } \\
\text { в том числе: } \\
\text { занятые трудо- } \\
\text { вой деятельно- }\end{array}$ & 100 & 100 & $\begin{array}{r}\text { B n } \\
100\end{array}$ & $\begin{array}{r}\text { ооцент } \\
100\end{array}$ & $\begin{array}{r}a \times k \text { K } \\
100\end{array}$ & ory 100 & 100 & 100 \\
\hline $\begin{array}{l}\text { стью и учебой } \\
\text { незанятые }\end{array}$ & 30,8 & 21,7 & 19,4 & 20,4 & 41,9 & 32,2 & 27,4 & 27,6 \\
\hline $\begin{array}{c}\text { трудовой дея- } \\
\text { тельностью2) } \\
\text { из них ищу- } \\
\text { щие первую } \\
\text { работу (ра- } \\
\text { нее не при- } \\
\text { ступавшие } \\
\text { к трудовой }\end{array}$ & 69,2 & 78,3 & 80,6 & 79,6 & 58,1 & 67,8 & 72,6 & 72,4 \\
\hline $\begin{array}{l}\text { деятельно- } \\
\text { сти) }\end{array}$ & 43,2 & 38,4 & 14,8 & 15,8 & 50,7 & 44,9 & 14,3 & 15,6 \\
\hline
\end{tabular}

Заявленная работодателями в органы службы занятости населения потребность в работниках на конец 2017 г. составила 1392,2 тыс. человек.

Численность не занятых трудовой деятельностью граждан, обратившихся за содействием в поиске подходящей работы в органы службы занятости населения, в расчете на одну заявленную вакансию составила на конец 2017 г. 0,6 человека.

1) По данным Роструда; 2000 г. - без данных по Чеченской Республике.

2) Включая пенсионеров.

\subsection{7. ЗАБАСТОВКИ}

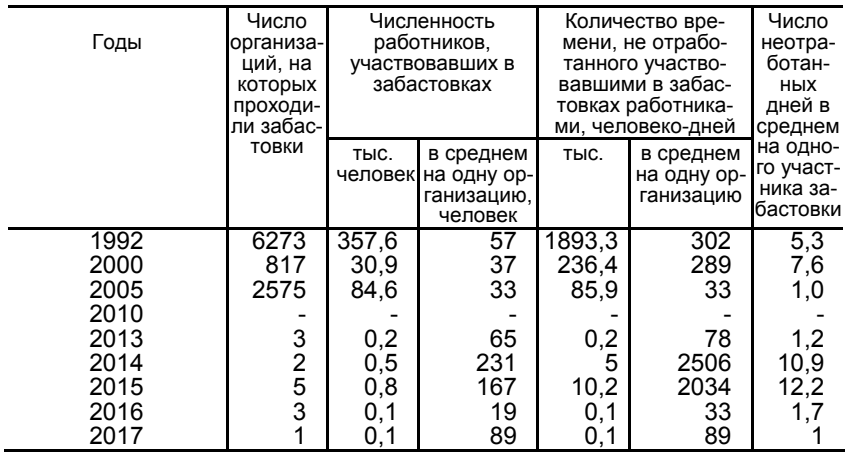




\subsection{8. ТРАВМАТИЗМ НА ПРОИЗВОДСТВЕ} (человек)

\begin{tabular}{|c|c|c|c|c|c|c|c|c|c|}
\hline & 1992 & 2000 & 2005 & 2010 & 2013 & 2014 & 2015 & 2016 & 2017 \\
\hline $\begin{array}{l}\text { Численность постра- } \\
\text { давших при несчастных } \\
\text { случаях на производст- } \\
\text { ве с утратой трудоспо- } \\
\text { собности на один рабо- } \\
\text { чий день и более и со } \\
\text { смертельным исходом: }\end{array}$ & & & & & & & & & \\
\hline всего, тыс. & 364 & 152 & 78 & 48 & 36 & 31 & 28 & 27 & 25 \\
\hline $\begin{array}{l}\text { на } 1000 \text { работающих } \\
\text { Численность постра- } \\
\text { давших при несчаст- } \\
\text { ных случаях на произ- } \\
\text { водстве со смертель- } \\
\text { ным исходом: }\end{array}$ & 6,2 & 5,1 & 3,1 & 2,2 & 1,8 & 1,5 & 1,3 & 1,3 & 1,3 \\
\hline всего & 7655 & 4404 & 3091 & 2004 & 1699 & 1447 & 1288 & 1290 & 1138 \\
\hline на 1000 работающих & 0,131 & 0,149 & 0,124 & 0,094 & 0,080 & 0,067 & 0,062 & 0,062 & 0,056 \\
\hline
\end{tabular}

Потери рабочего времени от несчастных случаев на производстве составили в 2017 г. 1,2 млн. человеко-дней.

\subsection{9. ПРОФЕССИОНАЛЬНЫЕ ЗАБОЛЕВАНИЯ (ОТРАВЛЕНИЯ)}

(человек)

\begin{tabular}{l|c|c|c|c|c|c|c|c|c}
\hline & 1992 & 2000 & 2005 & 2010 & 2013 & 2014 & 2015 & 2016 & 2017 \\
\hline $\begin{array}{l}\text { Численность лиц } \\
\text { с впервые уста- } \\
\begin{array}{l}\text { новленным про- } \\
\text { фессиональным } \\
\text { заболеванием } \\
\text { (отравлением): }\end{array}\end{array}$ & & & & & & & & \\
$\begin{array}{l}\text { всего } \\
\text { на 10 000 } \\
\text { работающих }\end{array}$ & 10624 & 9280 & 8156 & 7671 & 6993 & 6718 & 6334 & 5520 & 4756 \\
\hline
\end{tabular}

1) По данным Роспотребнадзора.

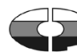




\section{7. УРОВЕНЬ ЖИЗНИ НАСЕЛЕНИЯ}

Раздел содержит информацию об объеме, составе, направлениях использования и дифференциации распределения денежных доходов населения; о структуре потребительских расходов домашних хозяйств. Публикуется информация о жилищном фонде и жилищных условиях населения.

Данные в таблицах, содержащих показатели по видам экономической деятельности, приводятся за 2017 год в соответствии с Общероссийским классификатором видов экономической деятельности (ОКВЭД 2) ОК 029-2014, введенным в действие с 1 января 2017 г.

Аналогичные сведения за период до 2016 г. включительно, разработанные в соответствии с ранее действовавшим Общероссийским классификатором видов экономической деятельности (ОКВЭД-2007) ОК 029-2007, опубликованы в кратком статистическом сборнике «Россия в цифрах. 2017», электронная версия которого размещена на официальном Интернет-портале Росстата в разделе «Публикации».

Реальные размеры денежных доходов населения, начисленной заработной платы, назначенных пенсий - относительные показатели, исчисленные путем деления индексов номинальных размеров ${ }^{1)}$ денежных доходов населения, начисленной заработной платы, назначенных пенсий на индекс потребительских цен за соответствующий временной период.

Денежные доходы населения включают доходы лиц, занятых предпринимательской деятельностью, выплаченную заработную плату наемных работников, социальные выплаты (пенсии, пособия, стипендии, страховые возмещения и прочие выплаты), доходы от собственности в виде процентов по вкладам, ценным бумагам, дивидендов и другие доходы. Денежные доходы за вычетом обязательных платежей и взносов представляют собой располагаемые денежные доходы населения.

1) Под номинальным понимается фактически сложившийся в отчетном периоде размер доходов, заработной платы, пенсий соответственно. 
Среднедушевые денежные доходы (в месяц) исчисляются делением годового объема денежных доходов на 12 и на численность населения.

Среднемесячная номинальная начисленная заработная плата работников организаций исчисляется делением годового фонда начисленной заработной платы работников на среднесписочную численность работников и на 12. Пособия, получаемые работниками из государственных внебюджетных фондов, не включаются в фронд заработной платы и среднемесячную заработную плату.

Средний размер назначенных пенсий определяется делением общей суммы назначенных пенсий на численность пенсионеров, состоящих на учете в системе Пенсионного фонда Российской Федерации.

К пенсионерам относятся лица, реализовавшие право на получение пенсии в соответствии с законодательством Российской Федерации и межгосударственными соглашениями, постоянно проживающие в Российской Федерации.

Денежные расходы населения включают расходы на покупку товаров и оплату услуг, включая платежи за товары (работы, услуги) с использованием банковских карт за рубежом, обязательные платежи и разнообразные взносы (налоги и сборы, платежи по страхованию, взносы в общественные и кооперативные организации, проценты за кредиты и др.), сбережения. Сбережения состоят из прироста (уменьшения) вкладов на счетах граждан, покупки иностранной валюты, расходов на приобретение ценных бумаг, недвижимости, скота и птицы, изменения средств на счетах индивидуальных предпринимателей, задолженности по кредитам, прироста (уменьшения) наличных денег на руках у населения.

Величина прожиточного минимума в соответствии с Федеральным законом от 24 октября 1997 г. №134-Ф3 “О прожиточном минимуме в Российской Федерации" представляет собой стоимостную оценку потребительской корзины, а также обязательные платежи и сборы, определяется ежеквартально и устанавливается: в целом по Российской Федерации - Правительством Российской Федерации (с января 2018 г. - Минтрудом России) .

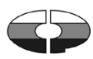


С 2013 г. Федеральным законом от 3 декабря 2012 г. № 233-Ф3 "О внесении изменений в Федеральный закон "О прожиточном минимуме в Российской Федерации" изменен порядок определения потребительской корзины и прожиточного минимума в целом по Российской Федерации и в субъектах Российской Федерации.

Согласно Федеральному закону от 3 декабря 2012 г. № 227-Ф3 "О потребительской корзине в целом по Российской Федерации" потребительская корзина включает минимальные наборы продуктов питания (в натуральных показателях), а также непродовольственные товары и услуги, стоимость которых определяется в соотношении со стоимостью минимального набора продуктов питания (в объеме по 50 \% от стоимости продуктов питания), необходимого для сохранения здоровья человека и обеспечения его жизнедеятельности. Наблюдение за уровнем потребительских цен на продукты питания и индексах потребительских цен на продукты питания, непродовольственные товары и услуги для исчисления величины прожиточного минимума в целом по Российской Федерации осуществляется органами государственной статистики во всех субъектах Российской Федерации по Перечню продуктов питанияпредставителей, включающему 42 наименования.

В 2000-2012 гг. величина прожиточного минимума определялась на основании потребительской корзины, установленной федеральным законом, и данных Росстата об уровне потребительских цен на продукты питания, непродовольственные товары и услуги.

В 1992-1999 гг. расчет величины прожиточного минимума производился на основе методических рекомендаций Минтруда России от 10 ноября 1992 г., разработанных в соответствии с Указом Президента Российской Федерации от 2 марта 1992 г. № 210 "О системе минимальных потребительских бюджетов населения Российской Федерации".

Численность населения с денежными доходами ниже величины прожиточного минимума определяется на основе данных о распределении населения по величине среднедушевых денежных доходов и является результатом их соизмерения С величиной прожиточного минимума. 
Дефицит денежного дохода определяется как сумма денежных средств, необходимая для доведения доходов населения с денежными доходами ниже прожиточного минимума до величины прожиточного минимума.

Распределение населения по величине среднедушевых денежных доходов характеризует дифференциацию населения по уровню материального достатка и представляет собой показатели численности (или долей) постоянного населения, сгруппированные в заданных интервалах по уровню среднедушевых денежных доходов.

Расчеты распределения населения по величине среднедушевых денежных доходов осуществляются в соответствии с методикой, утвержденной постановлением Госкомстата России от 16 июля 1996 г. № 61 по согласованию с рядом заинтересованных министерств и ведомств. Ряды распределения строятся с применением метода имитационного моделирования путем преобразования эмпирического распределения, полученного на основе данных выборочного обследования бюджетов домашних хозяйств, в ряд распределения, соответствующий значению группировочного признака в генеральной совокупности (среднедушевому денежному доходу, полученному по данным баланса денежных доходов и расходов населения).

Распределение общего объема денежных доходов по различным группам населения выражается через долю общего объема денежных доходов, которая приходится на каждую из 20-процентных групп населения, ранжированного по мере возрастания среднедушевых денежных доходов.

Коэффициент фондов (коэффициент дифференциации доходов) характеризует степень социального расслоения и определяется как соотношение между средними уровнями денежных доходов $10 \%$ населения с самыми высокими доходами и $10 \%$ населения с самыми низкими доходами.

Коэффициент Джини (индекс концентрации доходов) характеризует степень отклонения линии фрактического распределения общего объема доходов населения от линии их равномерного распределения. Величина коэффициента может варьироваться от 0 до 1, при этом чем выше значение показателя, тем более неравномерно распределены доходы в обществе.

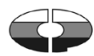


Фактическое конечное потребление домашних хозяйств включает их расходы на покупку потребительских товаров и услуг, а также стоимость потребления товаров и услуг в натуральной форме - произведенных для себя, полученных в качестве оплаты труда и в виде социальных трансфертов в натуральной форме, т.е. бесплатных или льготных индивидуальных товаров и услуг, полученных от сектора государственного управления и некоммерческих организаций, обслуживающих домашние хозяйства.

Выборочное обследование бюджетов домашних хозяйств является методом государственного статистического наблюдения за уровнем жизни населения. Область изучения и распространения данных бюджетного обследования определяется целями: получения данных о распределении населения по уровню материального благосостояния; получения весовых показателей для расчета индекса потребительских цен; обеспечения данных для составления счетов сектора домашних хозяйств в системе национальных счетов.

Обследование бюджетов домашних хозяйств проводится ежеквартально во всех субъектах Российской Федерации и охватывает 48,5 тыс. домашних хозяйств. Итоги обследования разрабатываются ежеквартально и за год в целом.

Начиная с 1997 г. для формирования выборочной совокупности домашних хозяйств применяется двухступенчатая случайная выборка, построенная по территориальному принципу. Конечной единицей отбора является домашнее хозяйство. В выборку не включаются коллективные домашние хозяйства, состоящие из лиц, долговременно находящихся в больницах, домах-интернатах для престарелых, школах-интернатах и других институциональных заведениях. Единицами обследования выступают домашние хозяйства и их отдельные члены.

Потребительские расходы домашних хозяйств являются частью денежных расходов, которые направляются на приобретение потребительских товаров и услуг. В их составе не учитываются расходы на покупку произведений искусства, антиквариата и ювелирных изделий, приобретенных в качестве капиталовложений, оплату материалов и работ по строительству и 
капитальному ремонту жилых или подсобных помещений, являющихся инвестициями.

Жилищный фонд - совокупность всех жилых помещений, находящихся на территории Российской Федерации.

Жилым помещением признается изолированное помещение, которое является недвижимым имуществом и пригодно для постоянного проживания граждан (отвечает установленным санитарным и техническим правилам и нормам, иным требованиям законодательства).

В составе жилищного фонда не учитываются дачи, летние садовые домики, спортивные и туристские базы, мотели, кемпинги, санатории, дома отдыха, пансионаты, дома для приезжих, гостиницы, казармы, кельи, железнодорожные вагончики и другие строения.

Общая площадь жилого помещения состоит из суммы площади всех частей такого помещения, включая площадь помещений вспомогательного использования, предназначенных для удовлетворения гражданами бытовых и иных нужд, связанных с их проживанием в жилом помещении, за исключением балконов, лоджий, веранд и террас. 


\section{ИНДИКАТОРЫ УРОВНЯ ЖИЗНИ НАСЕЛЕНИЯ}

\section{1. ОСНОВНЫЕ СОЦИАЛЬНО-ЭКОНОМИЧЕСКИЕ ИНДИКАТОРЫ УРОВНЯ ЖИЗНИ НАСЕЛЕНИЯ}

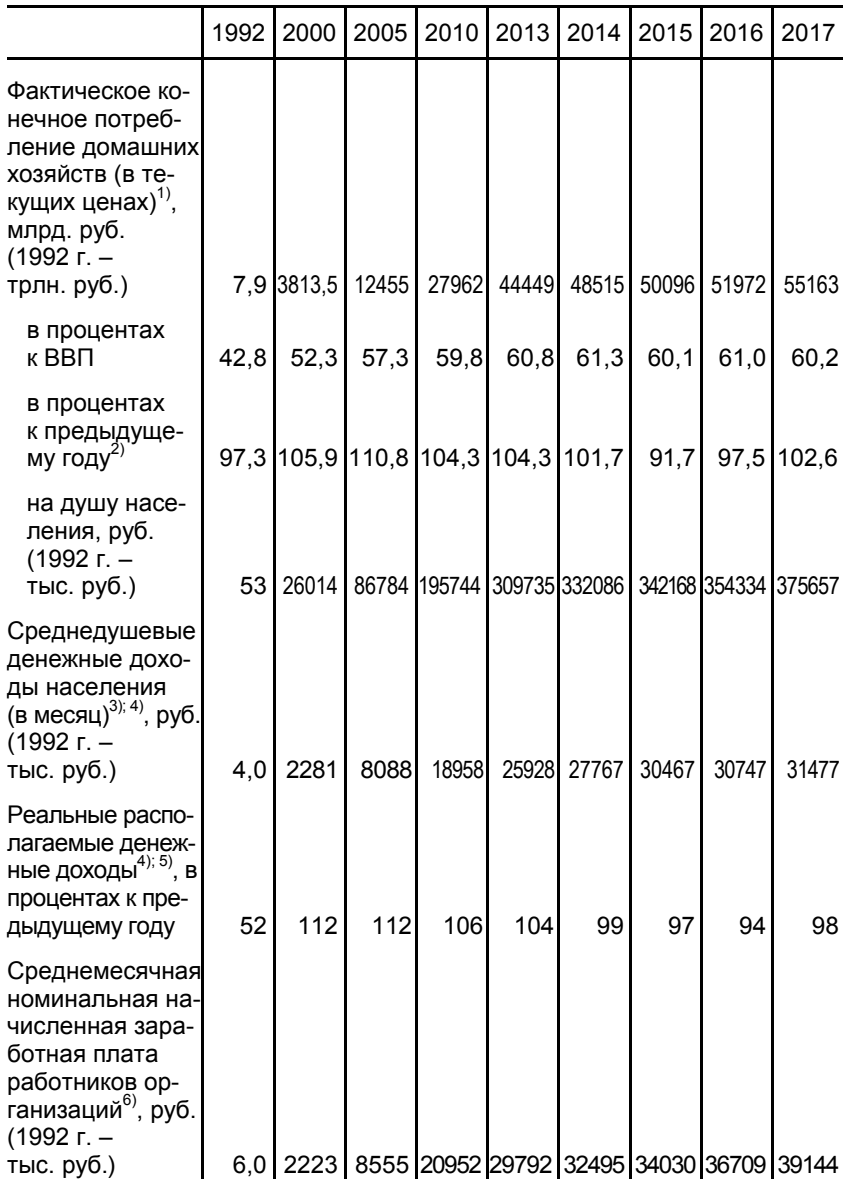


Продолжение табл. 7.1

\begin{tabular}{|c|c|c|c|c|c|c|c|c|c|}
\hline & 1992 & 2000 & 2005 & 2010 & 2013 & 2014 & 2015 & 2016 & 2017 \\
\hline $\begin{array}{l}\text { Реальная на- } \\
\text { численная зара- } \\
\text { ботная плата } \\
\text { работников ор- } \\
\text { ганизаций, в } \\
\text { процентах к пре- } \\
\text { дыдущему году }\end{array}$ & 67 & 121 & 113 & 105 & 105 & 101 & 91 & 101 & 103 \\
\hline $\begin{array}{l}\text { Средний размер } \\
\text { назначенных } \\
\text { пенсий }{ }^{4)} \\
\text { (2000 г. - с уче- } \\
\text { том компенса- } \\
\text { ции), руб. } \\
\text { (1992 г. - }\end{array}$ & & & & & & & & & \\
\hline $\begin{array}{l}\text { тыс. руб.) } \\
\text { Реальный раз- } \\
\text { мер назначен- } \\
\text { ных пенсий }{ }^{4} \text {, в } \\
\text { процентах к пре- }\end{array}$ & 1,6 & 694,3 & 2364 & 7476 & 9918 & 10786 & 11986 & 12391 & 13304 \\
\hline $\begin{array}{l}\text { дыдущему году } \\
\text { Величина про- } \\
\text { житочного ми- } \\
\text { нимума (в сред- } \\
\text { нем на душу } \\
\text { населения): }\end{array}$ & 52 & 128 & 110 & 135 & 103 & 101 & 96 & 97 & 104 \\
\hline $\begin{array}{l}\text { руб. в месяц } \\
\text { (1992 г. - }\end{array}$ & & & & & & & & & \\
\hline $\begin{array}{l}\text { тыс. руб.) } \\
\text { в процентах } \\
\text { к предыдуще- } \\
\text { му году }\end{array}$ & 1,9 & $120^{10)}$ & $119^{10)}$ & 5688 & $108^{10)}$ & 8050 & 121 & 101 & 10088 \\
\hline $\begin{array}{l}\text { Величина про- } \\
\text { житочного ми- } \\
\text { нимума пенсио- } \\
\text { нера в целях ус- } \\
\text { тановления со- } \\
\text { циальной доп- } \\
\text { латы к пенсии }{ }^{11)} \text {, } \\
\text { руб. в месяц }\end{array}$ & & & & 4780 & 6131 & 6354 & 7161 & 8803 & 8540 \\
\hline
\end{tabular}


Продолжение табл. 7.1

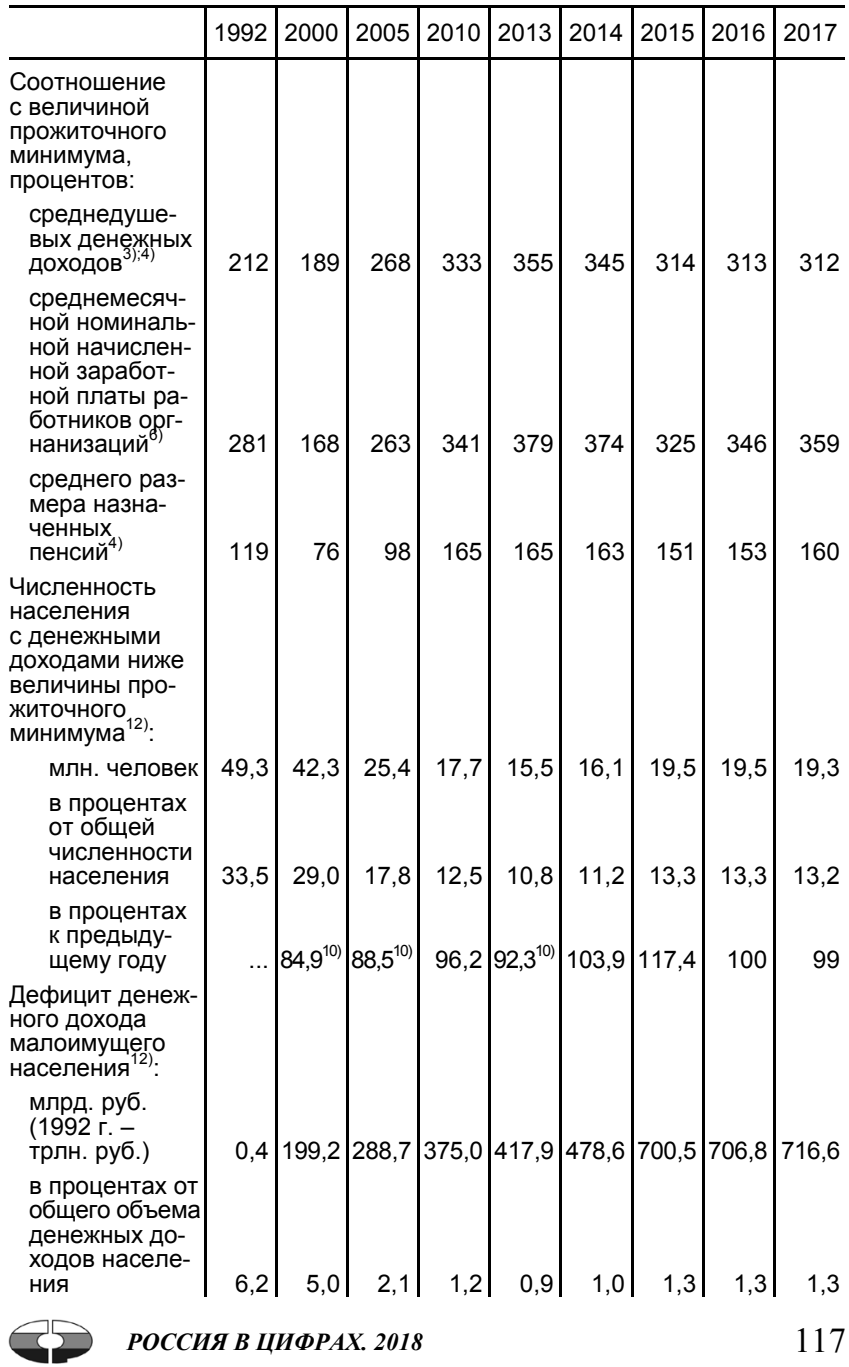


Продолжение табл. 7.1

\begin{tabular}{|c|c|c|c|c|c|c|c|c|c|}
\hline & 1992 & 2000 & 2005 & 2010 & 2013 & 2014 & 2015 & 2016 & 2017 \\
\hline $\begin{array}{l}\text { Коэффициент } \\
\text { фондов (коэф- } \\
\text { фициент диф- } \\
\text { ференциации } \\
\text { доходов) }{ }^{12)} \text {, в } \\
\text { разах } \\
\text { Минимальный } \\
\text { размер оплаты } \\
\text { труда (в среднем } \\
\text { за год) })^{6}, \text { руб. } \\
\text { (1992 г. - } \\
\text { Тыс. руб.) } \\
\text { Реальный раз- } \\
\text { мер минималь- } \\
\text { ной оплаты тру- } \\
\text { да, в процентах } \\
\text { к предыдущему } \\
\text { году }\end{array}$ & 41,5 & 107,8 & 746,7 & 4330 & 5205 & 5554 & 5965 & 6852 & 7650 \\
\hline
\end{tabular}

1) См. сноску на стр.179.

2) В постоянных ценах.

3) С 2010 г. - включая данные по Чеченской Республике.

4) 2017 г. - с учетом единовременной денежной выплаты, назначенной в соответствии с Федеральным законом от 22 ноября 2016 г. № 385-Ф3 в размере 5 тысяч рублей.

5) С 2011 г. - включая данные по Чеченской Республике.

6) Данные за 2014 г. приведены без учета сведений по Крымскому федеральному округу.

7) С 2000 г. в связи с изменением нормативной правовой базы и методологии расчета величины прожиточного минимума (см. методологические пояснения) публикуется оценка на основе данных, установленных Правительством Российской Федерации за I-IV кварталы соответствующего года. В 2017 г. приведена оценка на основе данных, установленных Правительством Российской Федерации за I-III кварталы, Минтрудом России - за IV квартал.

8) На основании Федерального закона от 24 октября 1997 г. №134-Ф3 «О прожиточном минимуме в Российской Федерации» с 2005 г. изменен состав потребительской корзины для определения величины прожиточного минимума.

9) На основании Федерального закона от 3 декабря 2012 г. № 233-Ф3 «О внесении изменений в Федеральный закон «О прожиточном минимуме в Российской Федерации» с 2013 г. изменен порядок расчета величины прожиточного минимума.

10) В сопоставимой методологии исчисления величины прожиточного минимума.

11) Согласно Федеральному закону от 24 июля 2009 г. №213-Ф3 с 1 января 2010 г. с целью доведения материального обеспечения пенсионера до величины прожиточного минимума пенсионера, установленной в субъекте Российской Федерации, предусматривается установление социальных доплат к пенсии.

12) С 2013 г. - включая данные по Чеченской Республике.

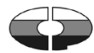




\section{2. ФАКТИЧЕСКОЕ КОНЕЧНОЕ ПОТРЕБЛЕНИЕ ДОМАШНИХ ХОЗЯЙСТВ ${ }^{1)}$}

(в текущих ценах; млрд. рублей)

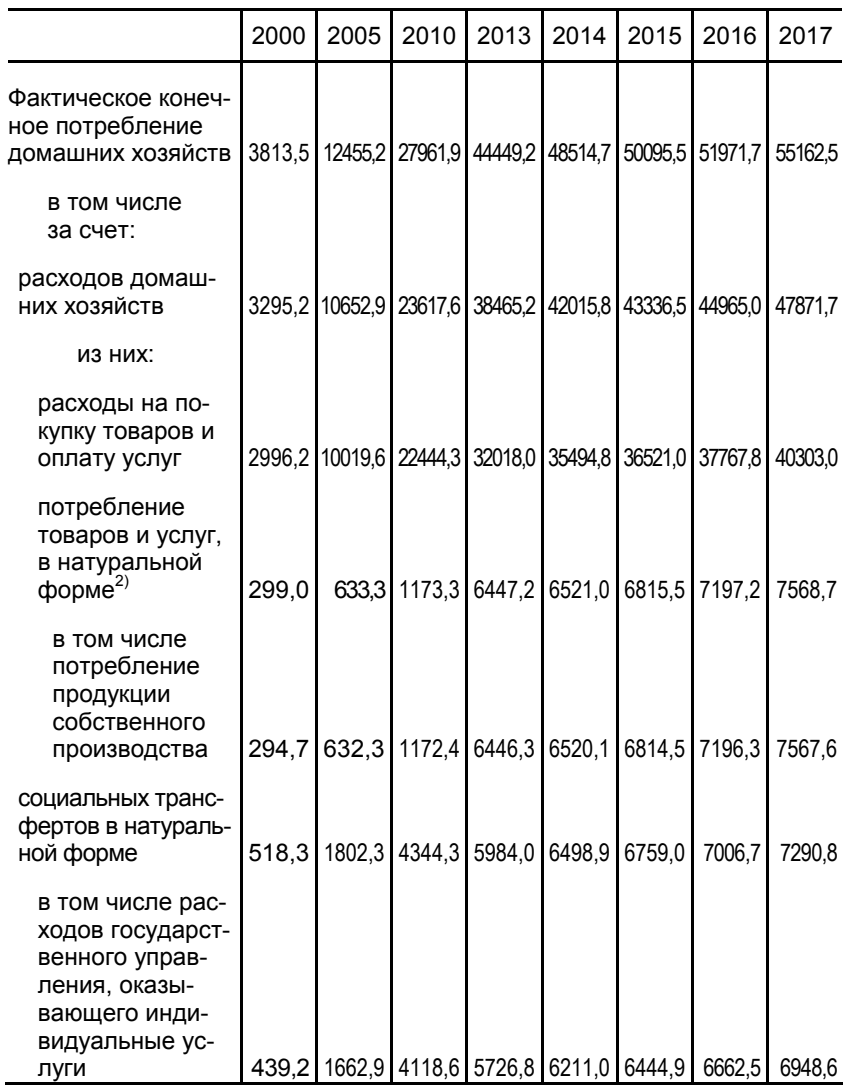

1) За 2013-2016 гг. данные актуализированы (см. сноску на стр. 179).

2) За исключением социальных трансфертов в натуральной форме. 


\section{3. ФАКТИЧЕСКОЕ КОНЕЧНОЕ ПОТРЕБЛЕНИЕ ДОМАШНИХ ХОЗЯЙСТВ}

(в процентах к итогу)

2005

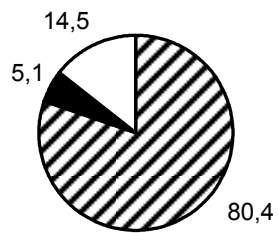

$2017^{1)}$

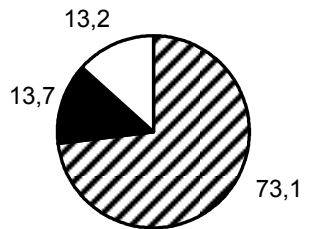

$\boldsymbol{\Xi}$ Покупка товаров и оплата услуг

— Поступление товаров и услуг в натуральной форме

$\square$ Социальные трансферты в натуральной форме

${ }^{1)}$ См. сноску на стр. 179.

\section{4. ИЗМЕНЕНИЕ ФАКТИЧЕСКОГО КОНЕЧНОГО} ПОТРЕБЛЕНИЯ ДОМАШНИХ ХОЗЯЙСТВ ${ }^{1)}$

(в постоянных ценах; в процентах к предыдущему году)

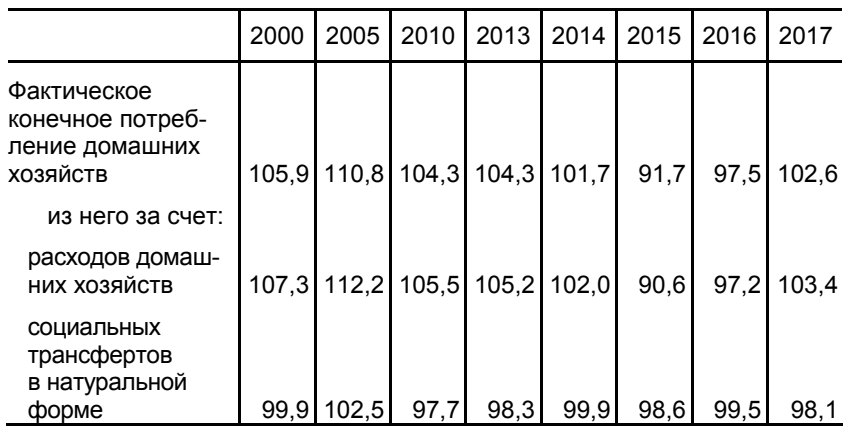

1) См. сноску на стр.179. 


\section{ДОХОДЫ И РАСХОДЫ НАСЕЛЕНИЯ}

\section{5. СОСТАВ И ИСПОЛЬЗОВАНИЕ ДЕНЕЖНЫХ ДОХОДОВ НАСЕЛЕНИЯ}

(1992 г. - трлн. руб.; млрд. рублей)

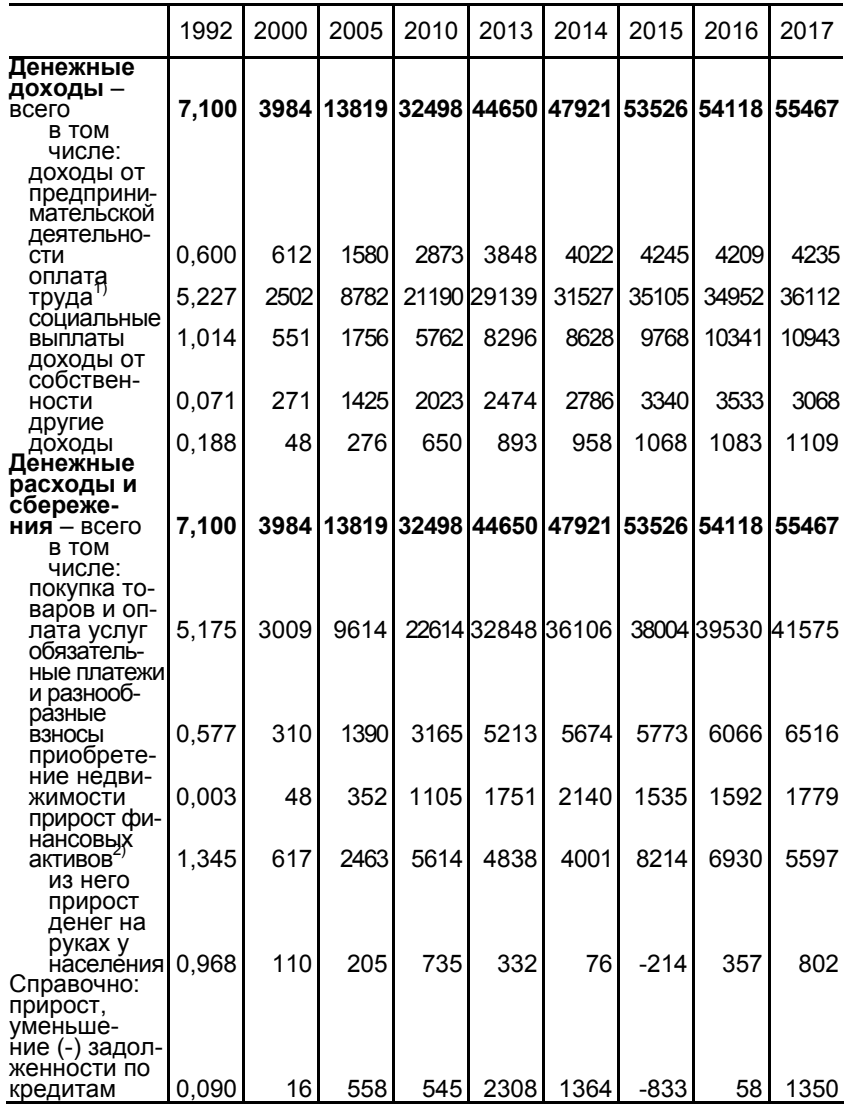

1) Включая скрытую (официально не учтенную) заработную плату.

2) За минусом изменения задолженности по кредитам. 
7.6. СТРУКТУРА ДЕНЕЖНЫХ ДОХОДОВ И РАСХОДОВ НАСЕЛЕНИЯ (в процентах от общего объема)

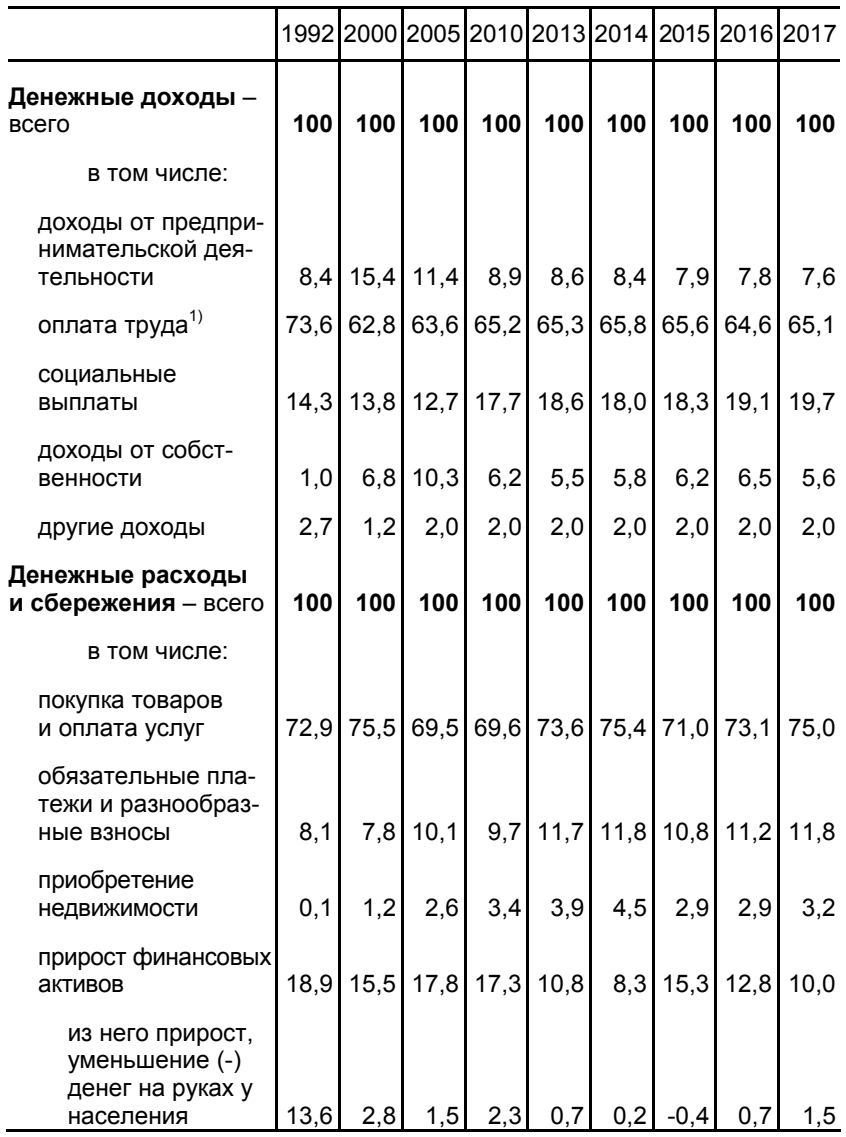

1) Включая скрытую (официально не учтенную) заработную плату. 


\section{7. СРЕДНЕМЕСЯЧНАЯ НОМИНАЛЬНАЯ НАЧИСЛЕННАЯ ЗАРАБОТНАЯ ПЛАТА РАБОТНИКОВ ОРГАНИЗАЦИЙ ПО ВИДАМ ЭКОНОМИЧЕСКОЙ ДЕЯТЕЛЬНОСТИ В 2017 Г.}

\begin{tabular}{|c|c|}
\hline & Руб. \\
\hline Bcero & 39144 \\
\hline $\begin{array}{l}\text { Сельское, лесное хозяйство, охота, рыболовство и } \\
\text { рыбоводство }\end{array}$ & 25156 \\
\hline Добыча полезных ископаемых & 74417 \\
\hline добыча угля & 53185 \\
\hline добыча сырой нефти и природного газа & 103849 \\
\hline добыча металлических руд & 60788 \\
\hline Обрабатывающие производства & 38517 \\
\hline производство пищевых продуктов & 29939 \\
\hline производство напитков & 38083 \\
\hline производство табачных изделий & 95629 \\
\hline производство текстильных изделий & 22174 \\
\hline производство одежды & 19776 \\
\hline производство кожи и изделий из кожи & 20997 \\
\hline $\begin{array}{l}\text { обработка древесины и производство изделий из } \\
\text { дерева и пробки, кроме мебели, производство } \\
\text { изделий из соломки и материалов для плетения }\end{array}$ & 25522 \\
\hline производство бумаги и бумажных изделий & 39473 \\
\hline $\begin{array}{l}\text { деятельность полиграфическая } \\
\text { и копирование носителей информации }\end{array}$ & 32399 \\
\hline производство кокса и нефтепродуктов & 95345 \\
\hline $\begin{array}{l}\text { производство химических веществ } \\
\text { и химических продуктов }\end{array}$ & 45936 \\
\hline $\begin{array}{l}\text { производство лекарственных средств и } \\
\text { материалов, применяемых в медицинских целях }\end{array}$ & 54454 \\
\hline производство резиновых и пластмассовых изделий & 30130 \\
\hline $\begin{array}{l}\text { производство прочей неметаллической } \\
\text { минеральной продукции }\end{array}$ & 31080 \\
\hline производство металлургическое & 49280 \\
\hline $\begin{array}{l}\text { производство готовых металлических изделий, } \\
\text { кроме машин и оборудования }\end{array}$ & 36368 \\
\hline $\begin{array}{l}\text { производство компьютеров, электронных и } \\
\text { оптических изделий }\end{array}$ & 46352 \\
\hline производство электрического оборудования & 34880 \\
\hline $\begin{array}{l}\text { производство машин и оборудования, не включен- } \\
\text { ных в другие группировки }\end{array}$ & 37117 \\
\hline
\end{tabular}


Продолжение табл. 7.7

\begin{tabular}{|c|c|}
\hline & Руб. \\
\hline $\begin{array}{l}\text { производство автотранспортных средств, } \\
\text { прицепов и полуприцепов }\end{array}$ & 38357 \\
\hline $\begin{array}{l}\text { производство прочих транспортных средств и } \\
\text { оборудования }\end{array}$ & 44600 \\
\hline производство мебели & 21988 \\
\hline производство прочих готовых изделий & 29697 \\
\hline ремонт и монтаж машин и оборудования & 44614 \\
\hline $\begin{array}{l}\text { Обеспечение электрической энергией, газом и па- } \\
\text { ром; кондиционирование воздуха }\end{array}$ & 44536 \\
\hline $\begin{array}{l}\text { Водоснабжение; водоотведение, организация сбора } \\
\text { и утилизации отходов, деятельность по ликвидации } \\
\text { загрязнений }\end{array}$ & 29023 \\
\hline Строительство & 34450 \\
\hline $\begin{array}{l}\text { Торговля оптовая и розничная; ремонт автотранс- } \\
\text { портных средств и мотоциклов }\end{array}$ & 31373 \\
\hline Транспортировка и хранение & 44522 \\
\hline $\begin{array}{l}\text { из нее деятельность почтовой связи и курьерская } \\
\text { деятельность }\end{array}$ & 22939 \\
\hline $\begin{array}{l}\text { Деятельность гостиниц и предприятий общественно- } \\
\text { го питания }\end{array}$ & 24122 \\
\hline Деятельность в области информации и связи & 57659 \\
\hline Деятельность финансовая и страховая & 85519 \\
\hline $\begin{array}{l}\text { Деятельность по операциям с недвижимым } \\
\text { имуществом }\end{array}$ & 31417 \\
\hline $\begin{array}{l}\text { Деятельность профессиональная, научная и } \\
\text { техническая }\end{array}$ & 56293 \\
\hline научные исследования и разработки & 65969 \\
\hline $\begin{array}{l}\text { Деятельность административная и сопутствующие } \\
\text { дополнительные услуги }\end{array}$ & 27310 \\
\hline $\begin{array}{l}\text { Государственное управление и обеспечение военной } \\
\text { безопасности; социальное обеспечение }\end{array}$ & 43476 \\
\hline Образование & 30260 \\
\hline $\begin{array}{l}\text { Деятельность в области здравоохранения } \\
\text { и социальных услуг }\end{array}$ & 31834 \\
\hline $\begin{array}{l}\text { Деятельность в области культуры, спорта, } \\
\text { организации досуга и развлечений }\end{array}$ & 37682 \\
\hline
\end{tabular}

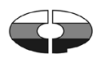




\section{8. СРЕДНЕМЕСЯЧНАЯ НАЧИСЛЕННАЯ ЗАРАБОТНАЯ ПЛАТА РАБОТНИКОВ ОРГАНИЗАЦИЙ ${ }^{1)}$}

\begin{tabular}{|c|c|c|c|}
\hline \multirow[t]{2}{*}{ Годы } & \multicolumn{2}{|c|}{$\begin{array}{c}\text { Среднемесячная начисленная } \\
\text { заработная плата (в ценах } \\
\text { соответствующего года) }\end{array}$} & \multirow{2}{*}{$\begin{array}{c}\text { Отношение среднеме- } \\
\text { сячной заработной } \\
\text { платы и выплат соци- } \\
\text { ального характера к } \\
\text { величине прожиточно- } \\
\text { го минимума трудосп- } \\
\text { собного населения, } \\
\text { процентов }\end{array}$} \\
\hline & руб. & $\begin{array}{l}\text { долл. США (ис- } \\
\text { ходя из средне- } \\
\text { годового офици- } \\
\text { ального курса } \\
\text { доллара США) }\end{array}$ & \\
\hline $\begin{array}{l}2000 \\
2005 \\
2010 \\
2013 \\
2014 \\
2015 \\
2016 \\
2017\end{array}$ & $\begin{array}{r}2223 \\
8555 \\
20952 \\
29792 \\
32495 \\
34030 \\
36709 \\
39144 \\
\end{array}$ & $\begin{array}{r}79 \\
303 \\
690 \\
936 \\
856 \\
561 \\
549 \\
671\end{array}$ & $\begin{array}{l}172 \\
268 \\
347 \\
384 \\
379 \\
331 \\
351 \\
364\end{array}$ \\
\hline
\end{tabular}

${ }^{1)}$ Данные за 2014 г. приведены без учета сведений по Крымскому федеральному округу.

7.9. РАСПРЕДЕЛЕНИЕ НАСЕЛЕНИЯ ПО ВЕЛИЧИНЕ СРЕДНЕДУШЕВЫХ ДЕНЕЖНЫХ ДОХОДОВ ${ }^{1)}$

(в процентах к итогу)

\begin{tabular}{|c|c|c|c|c|c|c|}
\hline & 2010 & 2012 & 2014 & 2015 & 2016 & 2017 \\
\hline $\begin{array}{l}\text { Все население } \\
\text { в том числе со } \\
\text { среднедушевыми } \\
\text { денежными дохо- } \\
\text { дами в месяц, руб.: }\end{array}$ & 100 & 100 & 100 & 100 & 100 & 100 \\
\hline до 7000,0 & 18,8 & 12,6 & 8,1 & 6,2 & 6,0 & 5,5 \\
\hline $7000,1-10000,0$ & 14,6 & 11,9 & 9,4 & 8,0 & 7,8 & 7,4 \\
\hline $10000,1-14000,0$ & 16,6 & 15,3 & 13,4 & 12,2 & 12,0 & 11,7 \\
\hline $14000,1-19000,0$ & 15,2 & 15,5 & 15,0 & 14,4 & 14,4 & 14,2 \\
\hline $19000,1-27000,0$ & 14,7 & 16,7 & 17,8 & 18,1 & 18,2 & 18,3 \\
\hline $27000,1-45000,0$ & 13,3 & 17,2 & 20,7 & 22,5 & 22,7 & 23,2 \\
\hline $45000,1-60000,0$ & 6,8 & 5,4 & 7,3 & 8,4 & 8,5 & 8,8 \\
\hline свыше 60000,0 & . & 5,4 & 8,3 & 10,2 & 10,4 & 10,9 \\
\hline $\begin{array}{l}\text { Справочно: } \\
\text { Медианное значение } \\
\text { среднедушевого де- } \\
\text { нежного дохода насе- }\end{array}$ & & & & & & \\
\hline $\begin{array}{l}\text { ления (в месяц), руб. } \\
\text { Модальное значение } \\
\text { среднедушевого } \\
\text { денежного дохода на- } \\
\text { селения (в месяц), } \\
\text { руб. }\end{array}$ & 14000 & 17131 & 20593,8 & 22713,2 & 22948,4 & 23592,4 \\
\hline
\end{tabular}

1) Оценка на основе материалов выборочного обследования бюджетов домашних хозяйств и макроэкономического показателя среднедушевых денежных доходов населения. 
7.10. РАСПРЕДЕЛЕНИЕ ОБЩЕГО ОБЪЕМА ДЕНЕЖНЫХ ДОХОДОВ НАСЕЛЕНИЯ ${ }^{1)}$

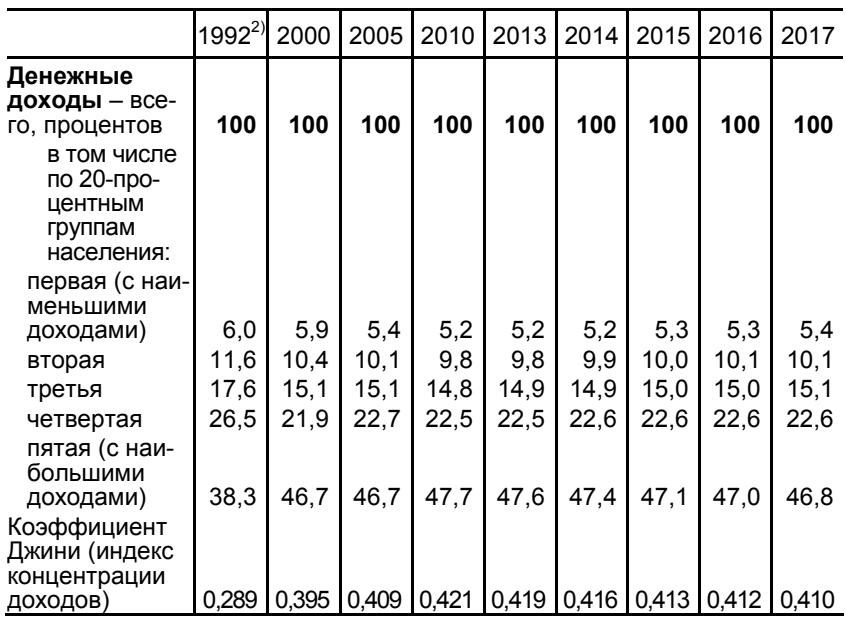

1) Оценка на основе материалов выборочного обследования бюджетов домашних хозяйств и макроэкономического показателя среднедушевых денежных доходов населения.

2) Совокупный доход (с учетом стоимости чистой продукции личных подсобных хозяйств населения).

7.11. ВЕЛИЧИНА ПРОЖИТОЧНОГО МИНИМУМА ${ }^{1)}$

(в среднем на душу населения; рублей в месяц)

\begin{tabular}{l|c|c|c|c}
\hline & $\begin{array}{c}\text { Все } \\
\text { население }\end{array}$ & \multicolumn{3}{|c}{$\begin{array}{c}\text { из него по социально-демографическим } \\
\text { группам }\end{array}$} \\
\cline { 3 - 5 } & & $\begin{array}{c}\text { трудоспособное } \\
\text { население }\end{array}$ & пенсионеры & дети \\
\hline $\mathbf{2 0 0 0}$ & $\mathbf{1 2 1 0}$ & $\mathbf{1 3 2 0}$ & $\mathbf{9 0 9}$ & $\mathbf{1 2 0 8}$ \\
I квартал & 1138 & 1232 & 851 & 1161 \\
II квартал & 1185 & 1290 & 894 & 1182 \\
III квартал & 1234 & 1350 & 930 & 1218 \\
IV квартал & 1285 & 1406 & 962 & 1272 \\
2005 & 3018 & 3255 & $\mathbf{2 4 1 8}$ & $\mathbf{2 8 9 6}$ \\
I квартал & 2910 & 3138 & 2332 & 2795 \\
II квартал & 3053 & 3290 & 2449 & 2937 \\
III квартал & 3047 & 3288 & 2440 & 2921 \\
IV квартал & 3060 & 3302 & 2450 & 2931
\end{tabular}

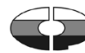


Продолжение табл. 7.11

\begin{tabular}{|c|c|c|c|c|}
\hline & $\begin{array}{c}\text { Bce } \\
\text { население }\end{array}$ & из него по & $\begin{array}{c}\text { циально-демо } \\
\text { группам }\end{array}$ & ическим \\
\hline & & $\begin{array}{l}\text { трудоспособ- } \\
\text { ное население }\end{array}$ & пенсионеры & дети \\
\hline 2010 & 5688 & 6138 & 4521 & 5489 \\
\hline I квартал & 5518 & 5956 & 4395 & 5312 \\
\hline II квартал & 5625 & 6070 & 4475 & 5423 \\
\hline III квартал & 5707 & 6159 & 4532 & 5510 \\
\hline IV квартал & 5902 & 6367 & 4683 & 5709 \\
\hline $2013^{2)}$ & 7306 & 7871 & 5998 & 7022 \\
\hline I квартал & 7095 & 7633 & 5828 & 6859 \\
\hline II квартал & 7372 & 7941 & 6043 & 7104 \\
\hline III квартал & 7429 & 8014 & 6097 & 7105 \\
\hline IV квартал & 7326 & 7896 & 6023 & 7021 \\
\hline 2014 & 8050 & 8683 & 6617 & 7752 \\
\hline I квартал & 7688 & 8283 & 6308 & 7452 \\
\hline II квартал & 8192 & 8834 & 6717 & 7920 \\
\hline III квартал & 8086 & 8731 & 6656 & 7738 \\
\hline IV квартал & 8234 & 8885 & 6785 & 7899 \\
\hline 2015 & 9701 & 10455 & 7965 & 9472 \\
\hline I квартал & 9662 & 10404 & 7916 & 9489 \\
\hline II квартал & 10017 & 10792 & 8210 & 9806 \\
\hline III квартал & 9673 & 10436 & 7951 & 9396 \\
\hline IV квартал & 9452 & 10187 & 7781 & 9197 \\
\hline 2016 & 9828 & 10598 & 8081 & 9660 \\
\hline I квартал & 9776 & 10524 & 8025 & 9677 \\
\hline II квартал & 9956 & 10722 & 8163 & 9861 \\
\hline III квартал & 9889 & 10678 & 8136 & 9668 \\
\hline IV квартал & 9691 & 10466 & 8000 & 9434 \\
\hline 2017 & 10088 & 10899 & 8315 & 9925 \\
\hline I квартал & 9909 & 10701 & 8178 & 9756 \\
\hline II квартал & 10329 & 11163 & 8506 & 10160 \\
\hline III квартал & 10328 & 11160 & 8496 & 10181 \\
\hline IV квартал & 9786 & 10573 & 8078 & 9603 \\
\hline
\end{tabular}

1) За I-IV кварталы приведены данные, установленные Правительством Российской Федерации в соответствии с Федеральным законом от 24 октября 1997 г. № 134Ф3 “О прожиточном минимуме в Российской Федерации”; в 2017 г. за I-ІІІ кварталы приведены данные, установленные Правительством Российской Федерации, за IV квартал - Минтрудом России; за год - оценка на основе указанных данных. C 2005 г. изменен состав потребительской корзины для определения величины прожиточного минимума.

2) На основании Федерального закона от 3 декабря 2012 г. № 233-Ф3 «О внесении изменений в Федеральный закон «О прожиточном минимуме в Российской Федерации» с 2013 г. изменен порядок расчета величины прожиточного минимума. 


\subsection{2. СОСТАВ ПОТРЕБИТЕЛЬСКИХ РАСХОДОВ ДОМАШНИХ ХОЗЯЙСТВ ${ }^{1)}$}

(по материалам выборочного обследования бюджетов домашних хозяйств; в среднем на члена домашнего хозяйства; рублей в месяц)

\begin{tabular}{|c|c|c|c|c|c|c|c|}
\hline & 2001 & 2005 & 2010 & 2014 & 2015 & 2016 & 2017 \\
\hline $\begin{array}{l}\text { Потребительские } \\
\text { расходы - всего } \\
\text { в том числе по целям } \\
\text { потребления: }\end{array}$ & 1659,9 & 4239,2 & 10121,5 & 14629,6 & 14712,7 & 16085,7 & 16535,2 \\
\hline продукты питания & 760,6 & 1406,2 & 2999,2 & 4171,2 & 4719,1 & 5193,0 & 5230,5 \\
\hline $\begin{array}{l}\text { алкогольные напитки, } \\
\text { табачные изделия }\end{array}$ & 59,1 & 114,7 & 247,7 & 407,5 & 436,3 & 493,3 & 495,3 \\
\hline одежда и обувь & 226,1 & 452,9 & 1094,9 & 1300,1 & 1352,9 & 1478,2 & 1470,7 \\
\hline $\begin{array}{l}\text { жилищно-коммунальные } \\
\text { услуги, топливо }\end{array}$ & 118,5 & 480,7 & 1142,2 & 1511,6 & 1589,6 & 1816,1 & 1600,4 \\
\hline $\begin{array}{l}\text { предметы домашнего } \\
\text { обихода, бытовая }\end{array}$ & & & & & & & \\
\hline техника, уход за домом & 101,7 & 305,6 & 626,9 & 915,9 & 811,8 & 952,3 & 891,2 \\
\hline здравоохранение & 34,4 & 104,8 & 327,3 & 525,6 & 537,9 & 586,2 & 636,5 \\
\hline транспорт & 127,5 & 516,3 & 1511,7 & 2597,8 & 2124,9 & 2135,8 & 2686,8 \\
\hline связь & 22,9 & 155,3 & 384,2 & 492,8 & 483,8 & 525,3 & 526,7 \\
\hline $\begin{array}{l}\text { организация отдыха } \\
\text { и культурных }\end{array}$ & & & & & & & \\
\hline мероприятий & 78,1 & 299,2 & 683,7 & 1042,1 & 988,4 & 1076,1 & 1162,4 \\
\hline образование & 20,1 & 77,6 & 131,9 & 147,2 & 131,1 & 132,6 & 128,7 \\
\hline гостиницы, кафе & & & & & & & \\
\hline $\begin{array}{l}\text { и рестораны } \\
\text { другие товары и услуги }\end{array}$ & $\begin{array}{l}42,8 \\
68,1\end{array}$ & $\begin{array}{l}124,5 \\
201,4\end{array}$ & $\begin{array}{l}340,7 \\
6311\end{array}$ & $\begin{array}{r}523,0 \\
994.8\end{array}$ & $\begin{array}{l}515,8 \\
1021.0\end{array}$ & $\begin{array}{r}560,3 \\
1136,5\end{array}$ & $\begin{array}{r}549,7 \\
1156,2\end{array}$ \\
\hline
\end{tabular}

1) В соответствии с Классификатором индивидуального потребления домашних хозяйств по целям (КИПЦ-ДХ).

\subsection{3. СТРУКТУРА ПОТРЕБИТЕЛЬСКИХ РАСХОДОВ ДОМАШНИХ ХОЗЯЙСТВ}

(по материалам выборочного обследования бюджетов домашних хозяйств; в процентах к итогу)

\begin{tabular}{|c|c|c|c|c|c|c|c|c|}
\hline & 2000 & 2005 & 2010 & 2013 & 2014 & 2015 & 2016 & 2017 \\
\hline $\begin{array}{l}\text { Потребительские } \\
\text { расходы - всего }\end{array}$ & 100 & 100 & 100 & 100 & 100 & 100 & 100 & 10 \\
\hline в том числе: & & & & & & & & \\
\hline $\begin{array}{l}\text { расходы ю } \\
\text { дуктов дл }\end{array}$ & & & & & & & & \\
\hline питания & 47,6 & 33,2 & 29,6 & 27,7 & 28,4 & 32,1 & 32,3 & 31 \\
\hline $\begin{array}{l}\text { из них на покупку: } \\
\text { хлеба и хлебных }\end{array}$ & & & & & & & & \\
\hline & 8,1 & 5,6 & 4,5 & 4,2 & 4,3 & 4,9 & 4,9 & 4 \\
\hline картофеля & 0,9 & 0,5 & 0,5 & 0,4 & 0,4 & 0,4 & 0,4 & 0 \\
\hline $\mathrm{OB}$ & 2,5 & 2,0 & 2,1 & 1,8 & 2,0 & 2,2 & 2,2 & 2 \\
\hline фруктов и ягод & 2,4 & 2,0 & 2,1 & 2,0 & 2,0 & 2,3 & 2,3 & \\
\hline
\end{tabular}

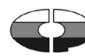


Продолжение табл. 7.13

\begin{tabular}{|c|c|c|c|c|c|c|c|c|}
\hline & 2000 & 2005 & 2010 & 2013 & 2014 & 2015 & 2016 & 2017 \\
\hline мяса и мясных продуктов & 13,1 & 10,1 & 8,8 & 8,2 & 8,5 & 9,3 & 9,2 & 8,8 \\
\hline рыбы и рыбных продуктов & 2,5 & 2,0 & 1,8 & 1,8 & 1,9 & 2,0 & 2,1 & 2,1 \\
\hline $\begin{array}{l}\text { молока и молочных } \\
\text { продуктов }\end{array}$ & 6,4 & 4,6 & 4,4 & 4,3 & 4,6 & 5,2 & 5,3 & 5,2 \\
\hline $\begin{array}{l}\text { сахара и кондитерских } \\
\text { изделий }\end{array}$ & 5,9 & 2,3 & 2,1 & 1,8 & 1,7 & 2,1 & 2,1 & 1,9 \\
\hline яиц & 1,2 & 0,6 & 0,4 & 0,4 & 0,4 & 0,5 & 0,5 & 0,5 \\
\hline $\begin{array}{l}\text { масла растительного } \\
\text { и других жиров }\end{array}$ & 1,5 & 0,7 & 0,5 & 0,5 & 0,4 & 0,5 & 0,5 & 0,5 \\
\hline $\begin{array}{l}\text { чая, кофе, безалко- } \\
\text { гольных напитков и } \\
\text { других продуктов }\end{array}$ & 31 & 28 & 24 & 23 & 27 & 27 & 28 & 26 \\
\hline расходы на питание & & & 2,4 & $2, v$ & & & 2,0 & 2,0 \\
\hline вне дома & 1,8 & 2,9 & 3,3 & 3,5 & 3,4 & 3,3 & 3,2 & 3,1 \\
\hline $\begin{array}{l}\text { расходы на покупку } \\
\text { алкогольных напитков }\end{array}$ & 2,5 & 1,9 & 1,7 & 1,7 & 1,7 & 1,8 & 1,7 & 1,6 \\
\hline $\begin{array}{l}\text { расходы на покупку } \\
\text { непродовольственных }\end{array}$ & & & & & & & & \\
\hline $\begin{array}{l}\text { непродовольственных } \\
\text { товаров } \\
\text { из них на покупку: }\end{array}$ & 34,3 & 38,5 & 38,7 & 40,8 & 40,1 & 36,4 & 35,5 & 37,1 \\
\hline $\begin{array}{l}\text { одежды, обуви, } \\
\text { белья, тканей }\end{array}$ & 15,5 & 10,5 & 10,6 & 9,4 & 8,7 & 9,0 & 9,0 & 8,6 \\
\hline $\begin{array}{l}\text { телерадиоаппаратуры, } \\
\text { предметов для отдыха }\end{array}$ & & & & & & & & \\
\hline и увлечений & 3,2 & 5,2 & 3,5 & 3,3 & 3,3 & 2,8 & 2,6 & 2,6 \\
\hline $\begin{array}{l}\text { транспортных средств } \\
\text { товаров и принадлеж- } \\
\text { ностей по ведению }\end{array}$ & 2,8 & 6,7 & 8,1 & 10,2 & 10,4 & 6,8 & 5,3 & 8,1 \\
\hline хозяйства, мебели & 4,5 & 6,3 & 5,3 & 5,6 & 5,2 & 4,5 & 4,9 & 4,3 \\
\hline $\begin{array}{l}\text { строительных } \\
\text { материалов }\end{array}$ & & & & & & & & \\
\hline $\begin{array}{l}\text { материал } \\
\text { топлива }\end{array}$ & $\begin{array}{l}1,0 \\
1,5\end{array}$ & $\begin{array}{l}1,9 \\
2,1\end{array}$ & $\begin{array}{l}1,4 \\
2,9\end{array}$ & $\begin{array}{l}1,3 \\
3,8\end{array}$ & $\begin{array}{l}1,0 \\
4,0\end{array}$ & $\begin{array}{l}1,0 \\
4,4\end{array}$ & $\begin{array}{l}1,0 \\
4,5\end{array}$ & $\begin{array}{l}1,0 \\
4,5\end{array}$ \\
\hline табачных изделий & 1,2 & 0,8 & 0,8 & 0,9 & 1,1 & 1,2 & 1,3 & 1,3 \\
\hline $\begin{array}{l}\text { предметов личной ги- } \\
\text { гиены, фармацевтиче- } \\
\text { ских и медицинских }\end{array}$ & & & & & & & & \\
\hline товаров и др. & 3,9 & 3,9 & 4,5 & 4,8 & 4,7 & 5,0 & 5,2 & 5,1 \\
\hline $\begin{array}{l}\text { других непродовольст- } \\
\text { венных товаров }\end{array}$ & 0,7 & 1,1 & 1,6 & 1,5 & 1,7 & 1,7 & 1,7 & 1,6 \\
\hline $\begin{array}{c}\text { расходы на оплату услуг } \\
\text { из них на оплату: }\end{array}$ & 13,8 & 23,5 & 26,7 & 26,3 & 26,4 & 26,4 & 27,3 & 27,0 \\
\hline $\begin{array}{l}\text { жилищно-коммуналь- } \\
\text { ных услуг }\end{array}$ & 4,6 & 8,3 & 9,2 & 8,8 & 8,9 & 9,5 & 10,1 & 9,6 \\
\hline $\begin{array}{l}\text { в том числе: } \\
\text { жилья }\end{array}$ & & 1,4 & & & 1.5 & 1. & 1.6 & 1.6 \\
\hline электроэнергии & & 1,0 & 1,2 & 1,3 & 1,3 & 1,4 & 1,4 & 1,4 \\
\hline $\begin{array}{l}\text { газа } \\
\text { центр }\end{array}$ & 0,6 & 0,7 & 0,9 & 0,9 & 0,9 & 1,0 & 1,0 & 0,9 \\
\hline отопления & 0,7 & 1,9 & 2,2 & 2,0 & 2,0 & 2,1 & 2,2 & 2,2 \\
\hline $\begin{array}{l}\text { прочих коммуналь- } \\
\text { ных услуг }\end{array}$ & 1,3 & 3,3 & 3,7 & 3,2 & 3,2 & 3,4 & 3,9 & 3,5 \\
\hline
\end{tabular}


Продолжение табл. 7.13

\begin{tabular}{|c|c|c|c|c|c|c|c|c|}
\hline & 2000 & 2005 & 2010 & 2013 & 2014 & 2015 & 2016 & 2017 \\
\hline $\begin{array}{c}\text { бытовых услуг } \\
\text { в том числе } \\
\text { по ремонту: }\end{array}$ & 1,8 & 2,8 & 3,1 & 3,0 & 2,8 & 3,0 & 3,2 & 3,2 \\
\hline одежды и обуви & 0,2 & 0,2 & 0,1 & 0,1 & 0,1 & 0,1 & 0,1 & 0,1 \\
\hline $\begin{array}{l}\text { транспортных } \\
\text { средств }\end{array}$ & 0,3 & 0,5 & 0,8 & 0,7 & 0,7 & 0,8 & 0,9 & 0,8 \\
\hline $\begin{array}{l}\text { квартир, домов } \\
\text { и других построек }\end{array}$ & 0,5 & 1,0 & 0,6 & 0,4 & 0,4 & 0,3 & 0,2 & 0,3 \\
\hline $\begin{array}{l}\text { услуг учреждений } \\
\text { культуры }\end{array}$ & & 2,1 & 2,8 & 3,6 & 3,6 & 3,6 & 3,6 & 3,9 \\
\hline $\begin{array}{l}\text { услуг в системе } \\
\text { образования }\end{array}$ & & 2,2 & 1,7 & 1,6 & 1,6 & 1,5 & 1,4 & 1,4 \\
\hline $\begin{array}{l}\text { в том числе в систе- } \\
\text { ме дошкольного } \\
\text { воспитания }\end{array}$ & & 0,2 & 0,1 & 0,1 & 0,1 & 0,5 & 0,4 & 0,4 \\
\hline медицинских услуг & & 1,0 & 1,3 & 1,4 & 1,4 & 1,4 & 1,3 & 1,4 \\
\hline санаторно-оздорови- & & 0,4 & 0,5 & 0,4 & 0,4 & 0,4 & 0,5 & 0,6 \\
\hline $\begin{array}{l}\text { услуг правового } \\
\text { характера }\end{array}$ & & 0,1 & 0,1 & 0,1 & 0,0 & 0,0 & 0,1 & 0,1 \\
\hline $\begin{array}{l}\text { услуг пассажирского } \\
\text { транспорта }\end{array}$ & & 2,9 & 3,1 & 2,7 & 2,6 & 2,3 & 2,4 & 2,3 \\
\hline услуг связи & & 2,7 & 3,3 & 2,9 & 2,8 & 2,8 & 2,7 & 2,5 \\
\hline прочих услуг & & 1,0 & 1,6 & 1,9 & 2,3 & 1,9 & 2,0 & 2,0 \\
\hline
\end{tabular}

\subsection{4. НАЛИЧИЕ ПРЕДМЕТОВ ДЛИТЕЛЬНОГО ПОЛЬЗОВАНИЯ В ДОМАШНИХ ХОЗЯЙСТВАХ}

(по материалам выборочного обследования бюджетов домашних хозяйств; на конец года; на 100 домохозяйств; штук)

\begin{tabular}{|c|c|c|c|c|c|c|c|c|}
\hline & 2000 & 2005 & 2010 & 2013 & 2014 & 2015 & 2016 & 2017 \\
\hline Телевизоры ${ }^{1)}$ & 124 & 138 & 164 & 178 & 184 & 197 & 193 & 190 \\
\hline Видеокамеры & 48 & 66 & 49 & 47 & 44 & 61 & 46 & 39 \\
\hline Персональные & & & & & & & & \\
\hline компьютеры & 6 & 26 & 63 & 100 & 113 & 125 & 127 & 124 \\
\hline Мобильные телефоны & & 104 & 228 & 250 & 257 & 256 & 245 & 245 \\
\hline Музыкальные центры & 12 & 34 & 39 & 39 & 38 & 35 & 31 & 28 \\
\hline $\begin{array}{l}\text { Холодильники, моро- } \\
\text { зильники }\end{array}$ & 113 & 117 & 121 & 126 & 128 & 129 & 132 & 133 \\
\hline Стиральные машины & 98 & 97 & 99 & 101 & 103 & 100 & 100 & 100 \\
\hline Электропылесосы & 82 & 84 & 92 & 95 & 96 & 96 & 96 & 95 \\
\hline Микроволновые печи & & 25 & 61 & 72 & 75 & 79 & 106 & 108 \\
\hline $\begin{array}{l}\text { Посудомоечные } \\
\text { машины }\end{array}$ & 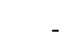 & 1 & 3 & 7 & 8 & 9 & 10 & 10 \\
\hline Кондиционеры & & 3 & 8 & 17 & 20 & 21 & 24 & 23 \\
\hline Легковые автомобили & 27 & 33 & 48 & 57 & 61 & 60 & 58 & 58 \\
\hline
\end{tabular}

1) Начиная с 2015 г. телевизор всех типов, видеопроектор, домашний кинотеатр, мультимедиа плеер и т. п.

2) Начиная с 2015 г. включая кинокамеры.

3) Начиная с 2017 г. включая мультиварки.

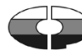




\section{ЖИЛИЩНЫЕ УСЛОВИЯ НАСЕЛЕНИЯ}

\subsection{5. Жилищный Фонд ${ }^{1)}$}

(на конец года; общая площадь жилых помещений)

\begin{tabular}{l|l|l|l|l|l|l|l|l|l}
\hline & 1992 & 2000 & 2005 & 2010 & 2013 & 2014 & 2015 & 2016 & $2017^{2}$ \\
\hline $\begin{array}{l}\text { Весь жилищный } \\
\text { фонд: }\end{array}$ & & & & & & & & & \\
всего, млн. м & 2492 & 2787 & 2955 & 3231 & 3359 & 3473 & 3581 & 3653 & 3724 \\
в среднем на од- \\
ного жителя, м
\end{tabular}

1) В связи с отсутствием нормативно-правового акта, устанавливающего порядок государственного учета жилищного фонда в Российской Федерации, в том числе его государственного технического учета (включая техническую инвентаризацию), официальная статистическая информация с 2013 г. формируется по неполному кругу единиц учёта.

2) Расчетные данные.

7.16. ПРИВАТИЗАЦИЯ ЖИЛИЩНОГО ФОНДА

\begin{tabular}{|c|c|c|c|c|c|c|c|c|c|c|}
\hline & 1992 & 2000 & 2005 & 2010 & 2013 & 2014 & 2015 & 2016 & 2017 & $\begin{array}{c}\text { Всего с } \\
\text { начала } \\
\text { прива- } \\
\text { тизации } \\
\text { по со- } \\
\text { стоя- } \\
\text { нию } \\
\text { на } 1 \text { ян- } \\
\text { варя } \\
2018 \text { г. }\end{array}$ \\
\hline $\begin{array}{l}\text { Число приватизи- } \\
\text { рованных жилых } \\
\text { помещений, тыс. }\end{array}$ & 2631 & 922 & 1822 & 885 & 766 & 359 & 449 & 225 & 165 & 30901 \\
\hline $\begin{array}{l}\text { Общая площадь } \\
\text { приватизирован- } \\
\text { ных жилых поме- } \\
\text { щений, млн. м² }\end{array}$ & 132 & 42 & 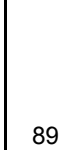 & 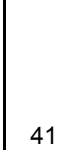 & 35 & 16 & 21 & 10 & 7 & 1525 \\
\hline
\end{tabular}


7.17. ПРЕДОСТАВЛЕНИЕ ЖИЛЫХ ПОМЕЩЕНИЙ ГРАЖДАНАМ

\begin{tabular}{l|r|r|r|r|r|r|r|r}
\hline & 1992 & 2000 & 2005 & 2010 & 2013 & 2014 & 2015 & 2016 \\
\hline $\begin{array}{l}\text { Число семей (включая } \\
\text { одиноких), состоявших } \\
\text { на учете в качестве } \\
\text { нуждающихся в жилых }\end{array}$ & & & & & & & & \\
$\begin{array}{l}\text { помещениях (на конец } \\
\text { года): }\end{array}$ & & & & & & & & \\
тыс. \\
$\begin{array}{l}\text { в процентах } \\
\text { от общего числа } \\
\text { семей (включая } \\
\text { одиноких) }\end{array}$ \\
$\begin{array}{l}\text { Число семей (включая } \\
\text { одиноких), получивших } \\
\text { жилые помещения и } \\
\text { улучшиших жилищные } \\
\text { условия за год: }\end{array}$
\end{tabular}




\subsection{8. РАЗВИТИЕ ИНФРАСТРУКТУРЫ СЕЛЬСКОЙ МЕСТНОСТИ}

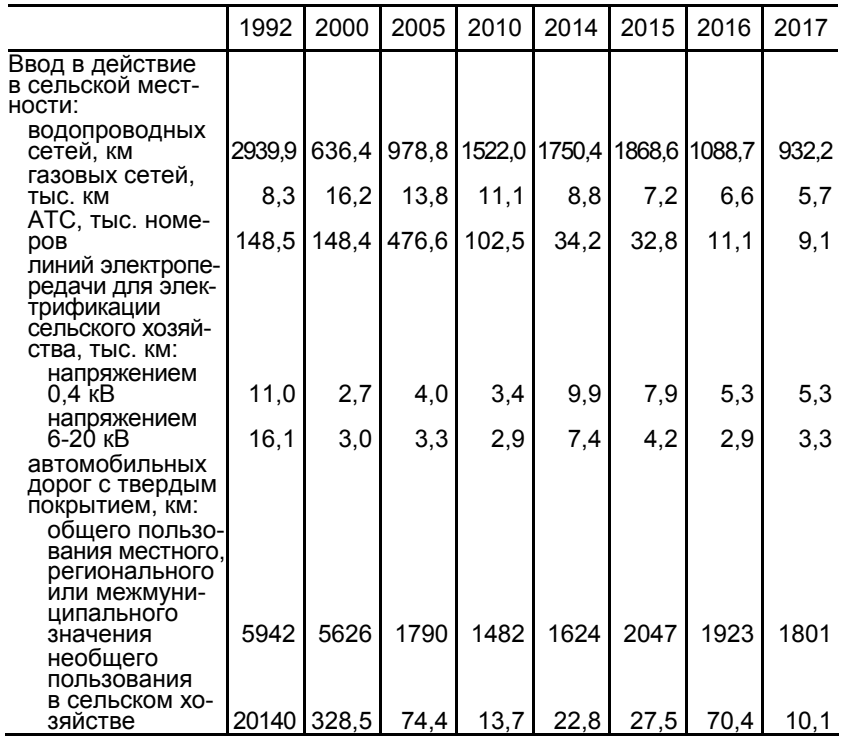

7.19. ЧИСЛО ЗАРЕГИСТРИРОВАННЫХ ПРАВ НА ЖИЛЫЕ ПОМЕЩЕНИЯ НА ОСНОВАНИИ ДОГОВОРОВ КУПЛИ-ПРОДАЖИ ГРАЖДАНАМ И ЮРИДИЧЕСКИМ ЛИЦАМ ${ }^{1)}$

\begin{tabular}{l|c|c|c|c|c}
\hline & 2005 & 2010 & 2015 & 2016 & 2017 \\
\hline $\begin{array}{l}\text { Число зарегистрирован- } \\
\text { ных прав на жилые по- } \\
\text { мещения на основании } \\
\text { договоров купли-продажи } \\
\text { в том числе населению }\end{array}$ & 1831838 & 2442509 & 3203046 & 3286213 & 3301735 \\
Общая площадь жилых & & & & & \\
помещений, на которые \\
зарегистрированы права \\
на основании договоров \\
купли-продажи, тыс. м
\end{tabular}

1) Статистическое наблюдение осуществляется с 2005 г. 


\section{8. ОБРАЗОВАНИЕ}

Раздел представляет данные о деятельности организаций, осуществляющих образовательную деятельность по образовательным программам дошкольного образования, присмотр и уход за детьми; образовательным программам начального, основного и среднего общего образования; образовательным программам среднего профессионального образования; образовательным программам высшего образования - программам бакалавриата, программам специалитета, программам магистратуры.

По данным Росстата приведена официальная статистическая информация по организациям, осуществляющим образовательную деятельность по образовательным программам дошкольного образования, присмотр и уход за детьми; по данным Минобрнауки России - по организациям осуществляющим образовательную деятельность по образовательным программам начального, основного и среднего общего образования и профессиональным образовательным организациям, осуществляющим подготовку квалифицированных рабочих, служащих (начиная с 2011 г.); по профессиональным образовательным организациям, осуществляющим подготовку специалистов среднего звена и образовательным организациям высшего образования (с 2013 г.).

К организациям, осуществляющим образовательную деятельность по образовательным программам дошкольного образования, присмотр и уход за детьми относятся организации:

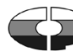


дошкольные образовательные, общеобразовательные, профессиональные образовательные, высшего образования, дополнительного образования детей, иные юридические лица (организации здравоохранения, социального обслуживания, науки, культуры и др., осуществляющие образовательную деятельность по образовательным программам дошкольного образования, присмотр и уход за детьми в качестве дополнительной к своей основной деятельности).

К воспитанникам относятся лица, осваивающие образовательную программу дошкольного образования, а также лица, в отношении которых установлен только присмотр и уход.

Общее образование может быть получено в общеобразовательных организациях, профессиональных образовательных организациях, образовательных организациях высшего образования, иных организациях. К иным организациям относятся организации, осуществляющие обучение по образовательным программам начального, основного и среднего общего образования в качестве дополнительной к своей основной деятельности.

Среднее профессиональное образование по программам подготовки квалифицированных рабочих, служащих и программам подготовки специалистов среднего звена может быть получено в профессиональных образовательных организациях и образовательных организациях высшего образования, осуществляющих образовательную деятельность по образовательным программам среднего профессионального образования программам подготовки квалифицированных рабочих, служащих; и программам подготовки специалистов среднего звена. 
Высшее образование по программам бакалавриата, специалитета и магистратуры может быть получено в образовательных организациях высшего образования и научных организациях по программам магистратуры; высшее образование по подготовке кадров высшей квалификации по программам подготовки научно-педагогических кадров в аспирантуре - в образовательных организациях высшего образования, организациях дополнительного профессионального образования и научных организациях (информация размещена в разделе 23 "Наука и инновации").

Информация о числе организаций приведена без учета обособленных структурных подразделений (филиалов).

В численность студентов, приема и выпуска по образовательным программам среднего профессионального образования и образовательным программам высшего образования, программам бакалавриата, программам специалитета, программам магистратуры включены граждане иностранных государств и лица без гражданства, обучающиеся на условиях общего приема.

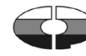




\section{1. ОРГАНИЗАЦИИ, ОСУЩЕСТВЛЯЮЩИЕ ОБРАЗОВАТЕЛЬНУЮ ДЕЯТЕЛЬНОСТЬ ПО ОБРАЗОВАТЕЛЬНЫМ ПРОГРАММАМ ДОШКОЛЬНОГО ОБРАЗОВАНИЯ, ПРИСМОТР И УХОД ЗА ДЕТЬМИ} (на конец года)

\begin{tabular}{|c|c|c|c|c|}
\hline & 2014 & 2015 & 2016 & 2017 \\
\hline Число организаций²), тыс. & 51,0 & 50,1 & 49,4 & 48,6 \\
\hline В них воспитанников, тыс. человек & 6813,6 & 7160,0 & 7342,9 & 7477,9 \\
\hline Из общего числа организаций - дошко- & & & & \\
\hline $\begin{array}{l}\text { льные образовательные организации, } \\
\text { тыс. }\end{array}$ & 41,3 & 39,5 & 38,4 & 37,3 \\
\hline В них воспитанников, тыс. человек & 6068,3 & 6347,9 & 6508,7 & 6600,1 \\
\hline $\begin{array}{l}\text { Обеспеченность детей дошкольного } \\
\text { возраста местами в организациях, осу- } \\
\text { ществляющих образовательную дея- } \\
\text { тельность по образовательным про- } \\
\text { граммам дошкольного образованиях, } \\
\text { присмотр и уход за детьми, приходится }\end{array}$ & & & & \\
\hline мест на 1000 детей, человек & 612 & 626 & 635 & $\ldots$ \\
\hline $\begin{array}{l}\text { Охват детей дошкольным образовани- } \\
\text { ем, процентов }\end{array}$ & 64,6 & 66,2 & 66,5 & $\ldots$ \\
\hline
\end{tabular}

В 2017 г. в организациях, осуществляющих образовательную деятельность по образовательным программам дошкольного образования, присмотр и уход за детьми, работало 12,5 тыс. групп кратковременного пребывания, которые посещали 175,1 тыс. воспитанников.

1) Сведения за 1993-2013 гг. опубликованы в статистическом сборнике "Россия в цифрах. 2015".

2) Включая организации, находящиеся на капитальном ремонте и организации, деятельность которых приостановлена. 


\section{2. ОРГАНИЗАЦИИ, ОСУЩЕСТВЛЯЮЩИЕ ОБРАЗОВАТЕЛЬНУЮ ДЕЯТЕЛЬНОСТЬ ПО ОБРАЗОВАТЕЛЬНЫМ ПРОГРАММАМ НАЧАЛЬНОГО, ОСНОВНОГО И СРЕДНЕГО ОБЩЕГО ОБРАЗОВАНИЯ}

(на начало учебного года)

\begin{abstract}
Число организаций, осуществляющих образовательную деятельность по образовательным программам начального, основного и среднего общего образования, тыс. человек
\end{abstract}

Численность обучающихся по образовательным программам начального, основного и среднего общего образования,

тыс. человек

Численность обучающихся, получивших аттестат об основном общем образовании ${ }^{1)}$, тыс. человек

Численность обучающихся, получивших аттестат о среднем общем образовании ${ }^{1)}$, тыс. человек Численность учителей в организациях, осуществляющих образовательную деятельность по образовательным программам начального, основного и среднего общего образования ${ }^{2)}$, тыс. человек

\begin{tabular}{|l|l|l|l|l}
$2005 / 2006$ & $2010 / 2011$ & $2015 / 2016$ & $2016 / 2017$ & $2017 / 2018$ \\
\hline
\end{tabular}

15630,9

1466,0
1944,1

\section{4,2}

14770,4

15219,0

\section{5,9}

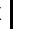

(

1) Соответственно в 2005, 2010, 2015, 2016, 2017 гг.

2) С 2010 г. - без руководителей и внешних совместителей. 


\section{3. СМЕННОСТЬ ЗАНЯТИЙ В ОРГАНИЗАЦИЯХ, ОСУЩЕСТВЛЯЮЩИХ ОБРАЗОВАТЕЛЬНУЮ ДЕЯТЕЛЬНОСТЬ ПО ОБРАЗОВАТЕЛЬНЫМ ПРОГРАММАМ НАЧАЛЬНОГО, ОСНОВНОГО И СРЕДНЕГО ОБЩЕГО ОБРАЗОВАНИЯ ${ }^{1 / 2)}$}

(на начало учебного года)

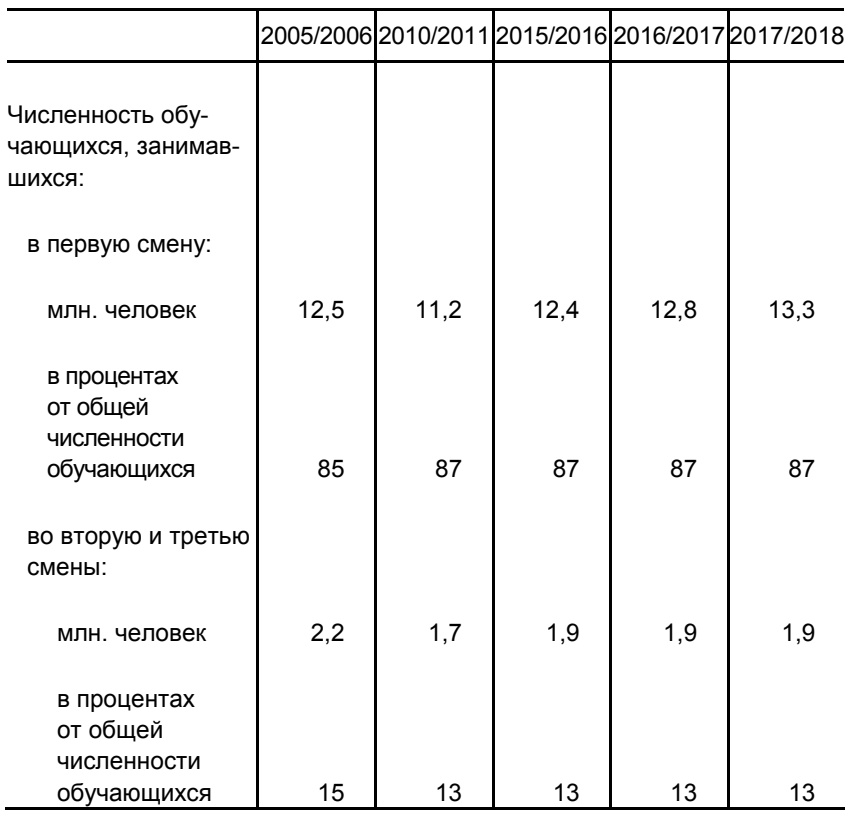

1) До 2016/2017 учебного года информация приведена без учета отдельных общеобразовательных организаций и классов для обучающихся с ограниченными возможностями здоровья; специальных учебно-воспитательных учреждений для обучающихся с девиантным (общественно опасным) поведением; санаторных образовательных организаций для обучающихся, нуждающихся в длительном лечении; организаций для обучающихся, нуждающихся в психолого-педагогической, медицинской и социальной помощи; без вечерних (сменных) общеобразовательных организаций. За 2016/2017 и 2017/2018 учебные годы информация приведена по классам очного обучения без учета отдельных организаций и классов для обучающихся с ограниченными возможностями здоровья.

2) За 2005/2006 и 2010/2011 учебные годы информация приведена только по государственным и муниципальным общеобразовательным организациям. 


\section{4. ОБРАЗОВАТЕЛЬНЫЕ ОРГАНИЗАЦИИ, ОСУЩЕСТВЛЯЮЩИЕ ОБРАЗОВАТЕЛЬНУЮ ДЕЯТЕЛЬНОСТЬ ПО ПРОГРАММАМ ПОДГОТОВКИ КВАЛИФИЦИРОВАННЫХ РАБОЧИХ, СЛУЖАЩИХ СПЕЦИАЛИСТОВ СРЕДНЕГО ЗВЕНА}

(на начало учебного года)

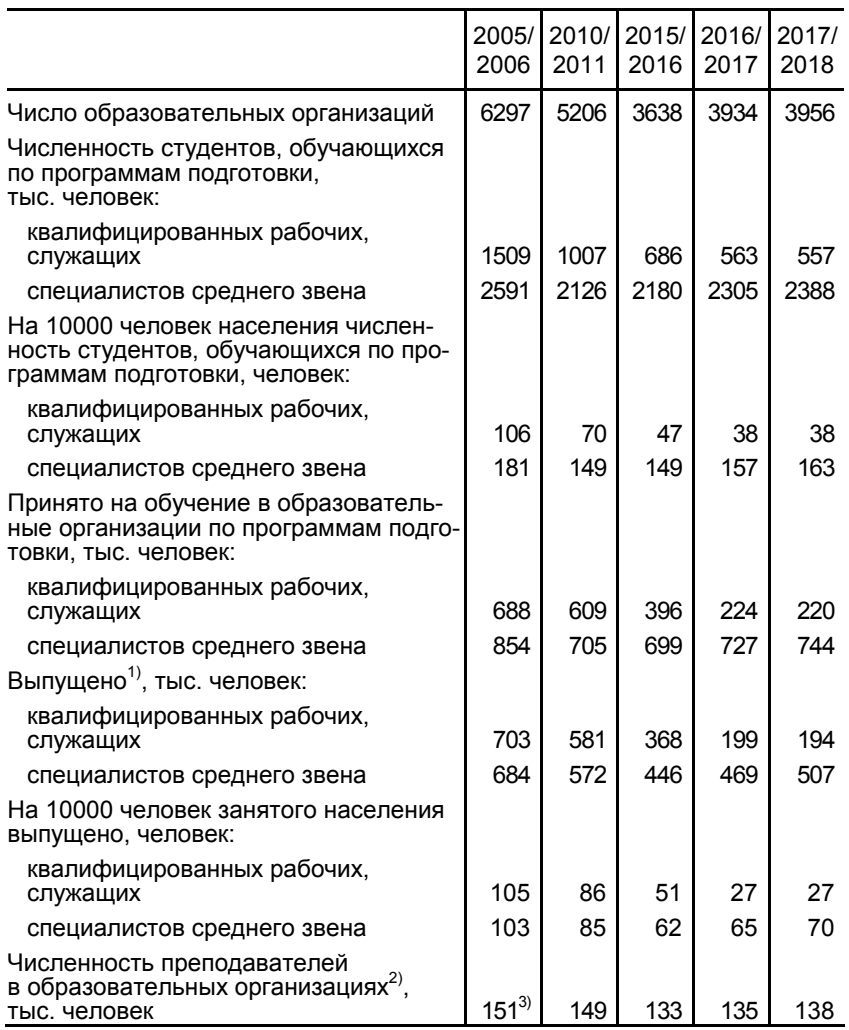

1) Соответственно в 2005, 2010, 2015, 2016, 2017 гг.

2) Без учета внешних совместителей. Включая преподавателей профессиональных образовательных организаций, осуществляющих подготовку квалифицированных рабочих, служащих и подготовку специалистов среднего звена.

3) Преподаватели профессиональных организаций, осуществляющих подготовку специалистов среднего звена.

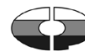


8.5 ОБРАЗОВАТЕЛЬНЫЕ ОРГАНИЗАЦИИ ВЫСШЕГО ОБРАЗОВАНИЯ И НАУЧНЫЕ ОРГАНИЗАЦИИ, ОСУЩЕСТВЛЯЮЩИЕ ОБРАЗОВАТЕЛЬНУЮ ДЕЯТЕЛЬНОСТЬ ПО ПРОГРАММАМ БАКАЛАВРИАТА, СПЕЦИАЛИТЕТА, МАГИСТРАТУРЫ

(на начало учебного года)

\begin{tabular}{|c|c|c|c|c|c|c|c|c|c|}
\hline & $\begin{array}{l}1993 / \\
1994\end{array}$ & $\begin{array}{l}2000 / \\
2001\end{array}$ & 2005 & $2010 /$ & 2013/ & $\begin{array}{l}2014 / \\
2015\end{array}$ & 2015 & $2016 / 2$ & $\begin{array}{l}2017 / \\
2018\end{array}$ \\
\hline Число организаций ${ }^{1)}$ & 626 & 965 & 1068 & 1115 & 969 & 950 & 896 & 818 & 766 \\
\hline $\begin{array}{l}\text { Численность студентов } \\
\text { тыс. человек }\end{array}$ & 2613 & 4741 & 7064 & 7050 & 5647 & 5209 & 4766 & 4399 & 4246 \\
\hline $\begin{array}{l}\text { Численность студен- } \\
\text { тов, обучающихся по } \\
\text { программам бакалав- } \\
\text { риата, специалитета, } \\
\text { магистратуры, } \\
\text { на } 10000 \text { человек }\end{array}$ & & & & & & & & & \\
\hline населения, человек & 176 & 324 & 493 & 493 & 393 & 356 & 325 & 300 & 289 \\
\hline $\begin{array}{l}\text { Из общей численно- } \\
\text { сти студентов - жен- } \\
\text { щины, тыс. человек }\end{array}$ & 1347 & 2686 & 4114 & 4030 & 3054 & 2813 & 2549 & 2358 & 2280 \\
\hline $\begin{array}{l}\text { Численность профес- } \\
\text { сорско-преподаватель- } \\
\text { ского персонала орга- } \\
\text { низаций }{ }^{2}, \text { тыс. человек } \\
\end{array}$ & 43,6 & 307,4 & 387,3 & 356,8 & & & & 261,0 & 245,1 \\
\hline
\end{tabular}

1) До 2016/2017 учебного года - число образовательных организаций высшего образования.

2) Без внешних совместителей.

8.6. ПРИЕМ НА ОБУЧЕНИЕ ПО ПРОГРАММАМ

БАКАЛАВРИАТА, СПЕЦИАЛИТЕТА, МАГИСТРАТУРЫ И ВЫПУСК БАКАЛАВРОВ, СПЕЦИАЛИСТОВ, МАГИСТРОВ

\begin{tabular}{|c|c|c|c|c|c|c|c|c|c|}
\hline & 1993 & 2000 & 2005 & 2010 & 2013 & 2014 & 2015 & 2016 & 2017 \\
\hline $\begin{array}{l}\text { Принято студентов, } \\
\text { тыс. человек }\end{array}$ & 590 & 1292 & 1640 & 1399 & 1247 & 1192 & 1222 & 1158 & 1142 \\
\hline $\begin{array}{l}\text { Выпущено бакалав- } \\
\text { ров, специалистов, } \\
\text { магистров, } \\
\text { тыс. человек }\end{array}$ & 445 & 635 & 1151 & 1468 & 1291 & 1226 & 1300 & 1161 & 969 \\
\hline $\begin{array}{l}\text { Выпущено бакалавров, } \\
\text { специалистов, маги- } \\
\text { стров на } 10000 \text { заня- } \\
\text { того населения, } \\
\text { человек }\end{array}$ & 63 & 99 & 172 & 217 & 181 & 171 & 180 & 160 & 134 \\
\hline
\end{tabular}


8.7. ЧИСЛЕННОСТЬ ИНОСТРАННЫХ СТУДЕНТОВ, ОБУЧАЮЩИХСЯ ПО ОБРАЗОВАТЕЛЬНЫМ ПРОГРАММАМ ВЫСШЕГО ОБРАЗОВАНИЯ - ПРОГРАММАМ БАКАЛАВРИАТА, ПРОГРАММАМ СПЕЦИАЛИТЕТА, ПРОГРАММАМ МАГИСТРАТУРЫ В ГОСУДАРСТВЕННЫХ И МУНИЦИПАЛЬНЫХ ОРГАНИЗАЦИЯХ (на начало учебного года)

\begin{tabular}{|c|c|c|c|c|c|c|c|c|}
\hline & \multicolumn{2}{|c|}{2000} & \multicolumn{2}{|c|}{2005} & \multicolumn{2}{|c|}{2016} & \multicolumn{2}{|c|}{2017} \\
\hline & Всего & $\begin{array}{l}\text { в том } \\
\text { числе } \\
\text { по } \\
\text { очной } \\
\text { форме } \\
\text { обуче- } \\
\text { ния }\end{array}$ & Всего & $\begin{array}{l}\text { в том } \\
\text { числе } \\
\text { по } \\
\text { очной } \\
\text { форме } \\
\text { обуче- } \\
\text { ния }\end{array}$ & Всего & $\begin{array}{l}\text { в том } \\
\text { числе } \\
\text { по } \\
\text { очной } \\
\text { форме } \\
\text { обуче- } \\
\text { ния }\end{array}$ & Всего & $\begin{array}{l}\text { в том } \\
\text { числе } \\
\text { по } \\
\text { очной } \\
\text { форме } \\
\text { обуче- } \\
\text { ния }\end{array}$ \\
\hline $\begin{array}{l}\text { Численность } \\
\text { иностранных } \\
\text { студентов, обу- } \\
\text { чающихся на ус- } \\
\text { ловиях общего } \\
\text { приема - } \\
\text { всего, человек }\end{array}$ & 58992 & 40479 & 78139 & 60969 & 175412 & 130806 & 198295 & 153586 \\
\hline $\begin{array}{l}\text { из них гражда- } \\
\text { не стран СНГ, } \\
\text { Балтии, Абха- } \\
\text { зии и Южной }\end{array}$ & & & & & & & & \\
\hline $\begin{array}{l}\text { Осетии } \\
\text { в том числе } \\
\text { из стран: }\end{array}$ & 34510 & 19963 & 40636 & 25985 & 134500 & 90690 & 147080 & 103978 \\
\hline Азербайджан & 1248 & 494 & 1367 & 1019 & 8944 & 3247 & 8056 & 3010 \\
\hline Армения & 1097 & 598 & 1393 & 1006 & 2201 & 1178 & 2087 & 1111 \\
\hline Беларусь & 3368 & 893 & 5527 & 1947 & 7263 & 3472 & 7324 & 3779 \\
\hline Казахстан & 16665 & 11724 & 17204 & 12632 & 50653 & 34711 & 52714 & 37519 \\
\hline Киргизия & 1230 & 519 & 825 & 713 & 4591 & 4018 & 5472 & 4717 \\
\hline $\begin{array}{l}\text { Республика } \\
\text { Молдова }\end{array}$ & 1047 & 527 & 1443 & 852 & 2234 & 1574 & 2165 & 1507 \\
\hline Таджикистан & 324 & 221 & 1172 & 845 & 11980 & 10155 & 14309 & 12415 \\
\hline Туркмения & 540 & 383 & 1065 & 930 & 15936 & 13068 & 20368 & 17414 \\
\hline Узбекистан & 3221 & 1162 & 4099 & 2003 & 16760 & 11051 & 20283 & 13998 \\
\hline Украина & 4953 & 2786 & 5473 & 3162 & 12121 & 7110 & 12445 & 7342 \\
\hline $\begin{array}{l}\text { Удельный вес } \\
\text { иностранных } \\
\text { студентов в } \\
\text { общей числен- } \\
\text { ности студентов, } \\
\text { процентов }\end{array}$ & 1,4 & 1,7 & 1,3 & 1,9 & 4,5 & 5,7 & 5,2 & 6,7 \\
\hline
\end{tabular}

1) На начало 2000, 2005 учебного года - включая Грузию. 


\section{8. ЧИСЛЕННОСТЬ ИНОСТРАННЫХ СТУДЕНТОВ,} ОБУЧАЮЩИХСЯ ПО ОБРАЗОВАТЕЛЬНЫМ ПРОГРАММАМ ВЫСШЕГО ОБРАЗОВАНИЯ - ПРОГРАММАМ БАКАЛАВРИАТА, ПРОГРАММАМ СПЕЦИАЛИТЕТА, ПРОГРАММАМ МАГИСТРАТУРЫ

В ЧАСТНЫХ ОРГАНИЗАЦИЯХ

(на начало учебного года)

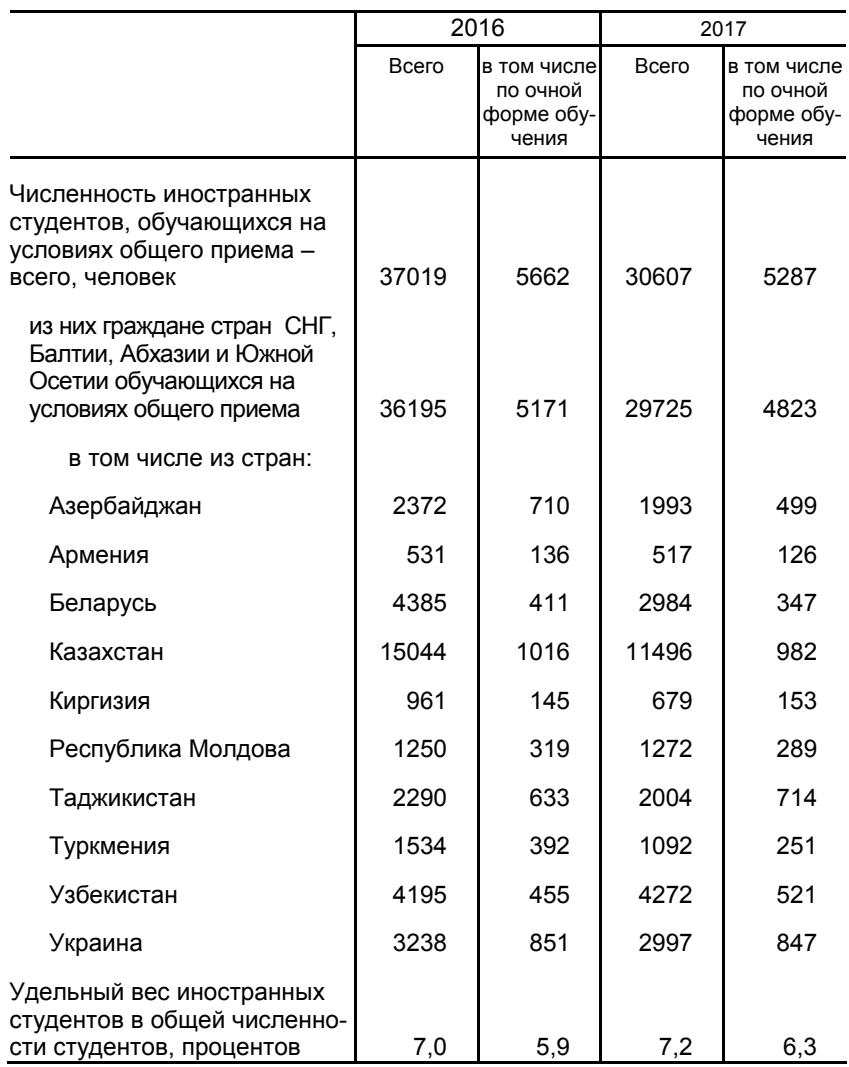




\section{9. КОНКУРС НА ВСТУПИТЕЛЬНЫХ ЭКЗАМЕНАХ}

В ГОСУДАРСТВЕННЫХ И МУНИЦИПАЛЬНЫХ

ПРОФЕССИОНАЛЬНЫХ ОБРАЗОВАТЕЛЬНЫХ ОРГАНИЗАЦИЯХ, ОБРАЗОВАТЕЛЬНЫХ ОРГАНИЗАЦИЯХ ВЫСШЕГО ОБРАЗОВАНИЯ И

НАУЧНЫХ ОРГАНИЗАЦИЯХ

(на 100 мест подано заявлений о приеме)

Программы подготовки
специалистов среднего звена

число заявлений

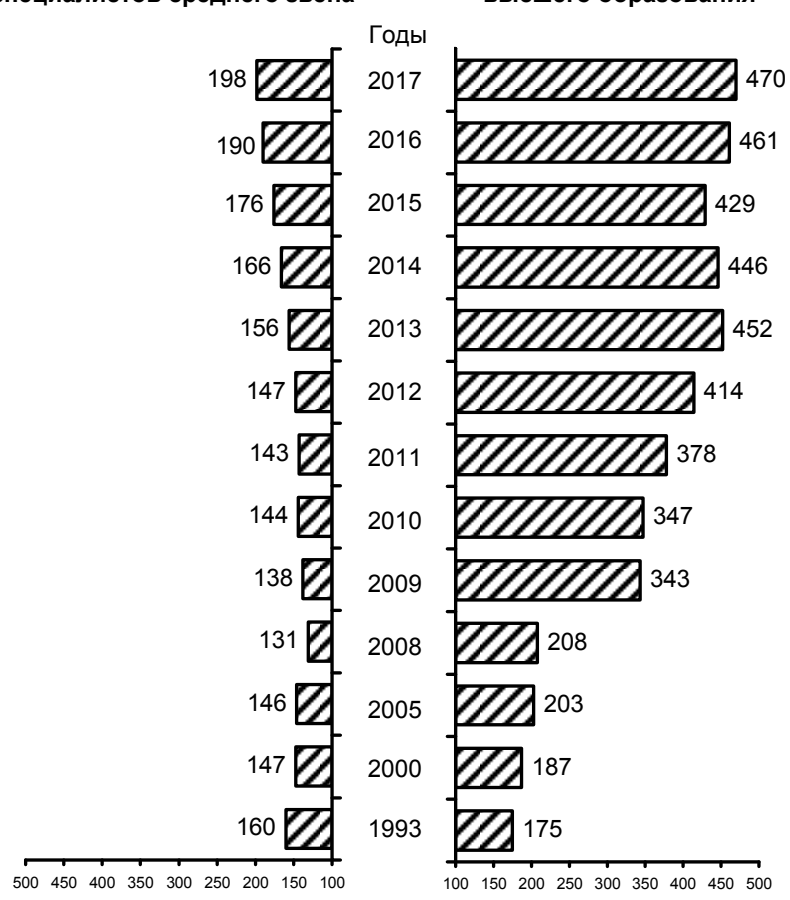

Образовательные программы высшего образования

число заявлений 


\section{9. ЗДРАВООХРАНЕНИЕ}

В разделе приведены данные о сети и кадрах медицинских организаций, о заболеваемости и инвалидности населения.

В общую численность врачей и среднего медицинского персонала включаются лица с высшим медицинским образованием и со средним медицинским образованием соответственно, занятые в лечебно-профилактических организациях, организациях служб по надзору в сфере защиты прав потребителей и благополучия человека, учреждениях социального обеспечения, клиниках ВУЗов и НИИ, дошкольных учреждениях, школах, домах ребенка и др.

В больничных организациях учету подлежат койки, оборудованные необходимым инвентарем.

В число амбулаторно-поликлинических организаций включаются все медицинские организации, которые ведут амбулаторный прием (поликлиники, амбулатории, диспансеры, поликлинические отделения в составе больничных организаций и др.).

Для статистической разработки данных о заболеваемости населения до 1999 г. применялась Международная статистическая классификация болезней, травм и причин смерти (IX пересмотр Всемирной организации здравоохранения 1975 г.), с 1999 г. - Международная статистическая классификация болезней и проблем, связанных со здоровьем (X пересмотр Всемирной организации здравоохранения 1989 г.).

Санаторно-курортные организации - лечебно-профилактические организации, оснащенные койками и обеспечивающие реабилитационное лечение, главным образом, на основе использования целебных свойств природных факторов. К ним относятся санатории, санатории-профилактории и др. 
Организации отдыха - оздоровительные организации, предназначенные для отдыха. К ним относятся дома, базы отдыха, кемпинги и другие организации отдыха, туристские базы. В 1992 г. включались туристские гостиницы, мотели.

Санаторно-курортные организации и организации отдыха расположены, как правило, в пределах курортов, лечебнооздоровительных местностей, в пригородных зонах. 


\section{1. ОСНОВНЫЕ ПОКАЗАТЕЛИ ЗДРАВООХРАНЕНИЯ}

(на конец года)

\begin{tabular}{|c|c|c|c|c|c|c|c|c|}
\hline & 1992 & 2000 & 2005 & 2010 & 2013 & 2014 & 2015 & 2016 \\
\hline \multicolumn{9}{|l|}{$\begin{array}{l}\text { Численность врачей"), } \\
\text { человек: }\end{array}$} \\
\hline $\begin{array}{l}\text { всего, тыс. } \\
\text { на } 10000 \text { человек }\end{array}$ & 637 & 680 & 690 & 716 & 703 & 709 & 673 & 681 \\
\hline населения & 42,9 & 46,8 & 48,2 & 50,1 & 48,9 & 48,5 & 45,9 & 46,4 \\
\hline $\begin{array}{l}\text { Численность среднего } \\
\text { медицинского } \\
\text { персонала человек: }\end{array}$ & & & & & & & & \\
\hline $\begin{array}{l}\text { всего, тыс. } \\
\text { на } 10000 \text { человек }\end{array}$ & 1709 & 1564 & 1530 & 1509 & 1518 & 1525 & 1550 & 1538 \\
\hline населения & 115 & 108 & 107 & 106 & 106 & 104 & 106 & 105 \\
\hline $\begin{array}{l}\text { Число больничных } \\
\text { организаций, тыс. }\end{array}$ & 12,6 & 10,7 & 9,5 & 6,3 & 5,9 & 5,6 & 5,4 & 5,4 \\
\hline $\begin{array}{l}\text { Числоо больничных } \\
\text { коек }^{2)} \text { : }\end{array}$ & & & & & & & & \\
\hline $\begin{array}{l}\text { всего, тыс. } \\
\text { на } 10000 \text { человек }\end{array}$ & 1940 & 1672 & 1575 & 1339 & 1302 & 1267 & 1222 & 1197 \\
\hline населения & 131 & 115 & 110 & 94 & 91 & 87 & 83 & 82 \\
\hline $\begin{array}{l}\text { Число амбулаторно- } \\
\text { поликлинических }\end{array}$ & & & & & & & & \\
\hline $\begin{array}{l}\text { организаций, тыс. } \\
\text { Мощность амбулаторно- } \\
\text { поликлинических орга- } \\
\text { низаций, посещений } \\
\text { в смену: }\end{array}$ & 20,7 & 21,3 & 21,8 & 15,7 & 16,5 & 17,1 & 18,6 & 19,1 \\
\hline $\begin{array}{l}\text { всего, тыс. } \\
\text { на } 10000 \text { человек }\end{array}$ & 3321 & 3534 & 3638 & 3685 & 3799 & 3859 & 3861 & 3914 \\
\hline населения & 224 & 243 & 254 & 258 & 265 & 264 & 264 & 267 \\
\hline $\begin{array}{l}\text { Число женских консуль- } \\
\text { таций, детских поликли- } \\
\text { ник, амбулаторий (само- } \\
\text { стоятельных) и органи- } \\
\text { заций, имеющих жен- } \\
\text { ские консультации и }\end{array}$ & & & & & & & & \\
\hline $\begin{array}{l}\text { Тис. } \\
\text { Число коек для } \\
\text { беременных женщин }\end{array}$ & 14,1 & 16,0 & 15,0 & 17,0 & 17,8 & 17,8 & 14,3 & 17,4 \\
\hline $\begin{array}{l}\text { и рожениц, тыс. } \\
\text { Число фельдшерско- }\end{array}$ & 113 & 91 & 82 & 80 & 75 & 72 & 69 & 67 \\
\hline $\begin{array}{l}\text { акушерских пунктов, } \\
\text { тыс. }\end{array}$ & 46,8 & 44,6 & 43,1 & 37,8 & 34,8 & 35,0 & 34,3 & 34,0 \\
\hline
\end{tabular}

1) 2015 г. - изменение методологии Минздрава России.

2) С 2010 г. - койки круглосуточных стационаров (без коек в дневных стационарах).

3) С 2010 г. - число женских консультаций, детских поликлиник, амбулаторий (самостоятельных и входящих в состав других организаций). 


\section{2. ЗАБОЛЕВАЕМОСТЬ НАСЕЛЕНИЯ}

ПО ОСНОВНЫМ КЛАССАМ БОЛЕЗНЕЙ в 1992 - 1998 гг.

(зарегистрировано пациентов с диагнозом, установленным впервые в жизни)

\begin{tabular}{|c|c|c|c|c|c|c|c|}
\hline & 1992 & 1993 & 1994 & 1995 & 1996 & 1997 & 1998 \\
\hline & \multicolumn{7}{|c|}{ Всего, тыс. человек } \\
\hline Все болезни & 91296 & 96932 & 96000 & 100306 & 95013 & 98520 & 97710 \\
\hline из них: & & & & & & & \\
\hline $\begin{array}{l}\text { инфекционные и па- } \\
\text { разитарные болезни }\end{array}$ & 5175 & 5719 & 6492 & 6983 & 6399 & 6157 & 6415 \\
\hline новообразования & 882 & 910 & 954 & 974 & 1029 & 1020 & 1116 \\
\hline $\begin{array}{l}\text { болезни эндокринной } \\
\text { системы, расстрой- } \\
\text { ства питания, нару- } \\
\text { шения обмена ве-- }\end{array}$ & & & & & & & \\
\hline ществ и иммунитета & 617 & 672 & 770 & 817 & 908 & 979 & 1114 \\
\hline $\begin{array}{l}\text { болезни крови и кро- } \\
\text { ветворных органов }\end{array}$ & 282 & 326 & 363 & 402 & 420 & 441 & 462 \\
\hline $\begin{array}{l}\text { болезни нервной } \\
\text { системы и органов }\end{array}$ & & & & & & & \\
\hline чувств & 7507 & 8042 & 8303 & 8589 & 8847 & 8830 & 9106 \\
\hline кровообращения & 1703 & 1752 & 1900 & 1960 & 2057 & 2101 & 2227 \\
\hline $\begin{array}{l}\text { болезни органов } \\
\text { дыхания }\end{array}$ & 42966 & 45800 & 41622 & 43636 & 39058 & 43538 & 41092 \\
\hline $\begin{array}{l}\text { болезни органов } \\
\text { пищеварения }\end{array}$ & 4620 & 4787 & 4879 & 5357 & 4978 & 4566 & 4748 \\
\hline $\begin{array}{l}\text { болезни мочеполо- } \\
\text { вой системы }\end{array}$ & 3314 & 3571 & 3957 & 4276 & 4523 & 4611 & 4905 \\
\hline $\begin{array}{l}\text { осложнения } \\
\text { беременности, } \\
\text { родов и после- } \\
\text { родового периода }\end{array}$ & 1263 & 1289 & 1394 & 1444 & 1541 & 1573 & 1669 \\
\hline $\begin{array}{l}\text { болезни кожи и под- } \\
\text { кожной клетчатки }\end{array}$ & 5299 & 5912 & 6700 & 7113 & 6773 & 6421 & 6298 \\
\hline $\begin{array}{l}\text { болезни костно- } \\
\text { мышечной системы } \\
\text { и соединительной }\end{array}$ & & & & & & & \\
\hline ткани & 3793 & 3836 & 3960 & 3953 & 4120 & 4128 & 4236 \\
\hline $\begin{array}{l}\text { врожденные анома- } \\
\text { лии (пороки развития) }\end{array}$ & 131 & 136 & 146 & 156 & 170 & 179 & 193 \\
\hline $\begin{array}{l}\text { травмы и } \\
\text { отравления }\end{array}$ & $\mid 12295$ & $|12652|$ & | 12965 & $\mid$ & $|12521|$ & 12294 & 12355 \\
\hline
\end{tabular}

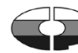


Продолжение табл. 9.2

\begin{tabular}{|c|c|c|c|c|c|c|c|}
\hline & 1992 & 1993 & 1994 & 1995 & 1996 & 1997 & 1998 \\
\hline & \multicolumn{7}{|c|}{ На 1000 человек населения } \\
\hline $\begin{array}{c}\text { Bсе болезни } \\
\text { из них: }\end{array}$ & 614,6 & 652,9 & 646,9 & 676,0 & 646,5 & 671,4 & 666,9 \\
\hline $\begin{array}{l}\text { инфекционные и па- } \\
\text { разитарные болезни }\end{array}$ & 34,8 & 38,5 & 43,7 & 47,1 & 43,5 & 42,0 & 43,8 \\
\hline $\begin{array}{l}\text { новообразования } \\
\text { болезни эндокрин- } \\
\text { ной системы, рас- } \\
\text { стройства питания, } \\
\text { нарушения обмена } \\
\text { веществ и иммуни- }\end{array}$ & 5,9 & 6,1 & 6,4 & 6,6 & 7,0 & 6,9 & 7,6 \\
\hline тета & 4,2 & 4,5 & 5,2 & 5,5 & 6,2 & 6,7 & 7,6 \\
\hline $\begin{array}{l}\text { болезни крови и кро- } \\
\text { ветворных органов }\end{array}$ & 1,9 & 2,2 & 2,4 & 2,7 & 2,9 & 3,0 & 3,2 \\
\hline $\begin{array}{l}\text { болезни нервной } \\
\text { системы и органов }\end{array}$ & & & & & & & \\
\hline чувств & 50,5 & 54,2 & 55,9 & 57,9 & 60,2 & 60,2 & 62,2 \\
\hline $\begin{array}{l}\text { болезни системы } \\
\text { кровообращения }\end{array}$ & 11,5 & 11,8 & 12,8 & 13,2 & 14,0 & 14,3 & 15,2 \\
\hline болезни органов & & & & & & & \\
\hline дыхания & 289,3 & 308,5 & 280,5 & 294,1 & 265,8 & 296,7 & 280,5 \\
\hline $\begin{array}{l}\text { болезни органов } \\
\text { пищеварения }\end{array}$ & 31,1 & 32,2 & 32,9 & 36,1 & 33,9 & 31,1 & 32,4 \\
\hline $\begin{array}{l}\text { болезни мочеполо- } \\
\text { вой системы }\end{array}$ & 22,3 & 24,1 & 26,7 & 28,8 & 30,8 & 31,4 & 33,5 \\
\hline $\begin{array}{l}\text { осложнения } \\
\text { беременности, } \\
\text { родов и послеродо- } \\
\text { вого периода }\end{array}$ & 34,8 & 35,0 & 37,1 & 37,7 & 40,0 & 40,6 & 42,7 \\
\hline $\begin{array}{l}\text { болезни кожи и под- } \\
\text { кожной клетчатки }\end{array}$ & 35,7 & 39,8 & 45,1 & 47,9 & 46,1 & 43,8 & 43,0 \\
\hline $\begin{array}{l}\text { болезни костно- } \\
\text { мышечной системы } \\
\text { и соединительной }\end{array}$ & & & & & & & \\
\hline ткани & 25,5 & 25,8 & 26,7 & 26,6 & 28,0 & 28,1 & 28,9 \\
\hline $\begin{array}{l}\text { врожденные анома- } \\
\text { лии (пороки развития) }\end{array}$ & 0,9 & 0,9 & 1,0 & 1,1 & 1,2 & 1,2 & 1,3 \\
\hline $\begin{array}{l}\text { травмы и отравле- } \\
\text { ния }\end{array}$ & 82,8 & 85,2 & 87,4 & 87,7 & 85,2 & 83,8 & 84,3 \\
\hline
\end{tabular}

1) На 1000 женщин в возрасте 15-49 лет. 


\section{3. ЗАБОЛЕВАЕМОСТЬ НАСЕЛЕНИЯ ПО ОСНОВНЫМ КЛАССАМ БОЛЕЗНЕЙ в 2000-2016 гг.}

(зарегистрировано пациентов с диагнозом, установленным впервые в жизни)

\begin{tabular}{|c|c|c|c|c|c|c|c|}
\hline & 2000 & 2005 & 2010 & 2013 & 2014 & 2015 & 2016 \\
\hline & \multicolumn{7}{|c|}{ Всего, тыс. человек } \\
\hline Все болезни & 106328 & 105886 & 111428 & 114721 & 114989 & 113927 & 115187 \\
\hline из них: & & & & & & & \\
\hline $\begin{array}{l}\text { некоторые инфек- } \\
\text { ционные и парази- }\end{array}$ & & & & & & & \\
\hline тарные болезни & 6448 & 5312 & 4690 & 4434 & 4504 & 4116 & 4086 \\
\hline новообразования & 1226 & 1357 & 1540 & 1629 & 1693 & 1672 & 1668 \\
\hline $\begin{array}{l}\text { болезни крови, кро- } \\
\text { ветворных органов } \\
\text { и отдельные нару- } \\
\text { шения, вовлекаю- } \\
\text { щие иммунный }\end{array}$ & & & & & & & \\
\hline механизм & 551 & 647 & 705 & 668 & 688 & 692 & 688 \\
\hline $\begin{array}{l}\text { болезни эндокрин- } \\
\text { ной системы, рас- } \\
\text { стройства питания, } \\
\text { нарушения обмена }\end{array}$ & & & & & & & \\
\hline веществ & 1234 & 1361 & 1461 & 1527 & 1636 & 1953 & 2038 \\
\hline $\begin{array}{l}\text { болезни нервной } \\
\text { системы }\end{array}$ & 2227 & 2178 & 2345 & 2364 & 2370 & 2257 & 2231 \\
\hline $\begin{array}{l}\text { болезни глаза и его } \\
\text { придаточного аппа- } \\
\text { рата }\end{array}$ & 4638 & 4778 & 4715 & 5023 & 5067 & 4878 & 4787 \\
\hline $\begin{array}{l}\text { болезни уха и сос- } \\
\text { цевидного отростка }\end{array}$ & 3191 & 3425 & 3867 & 4014 & 4050 & 3893 & 3863 \\
\hline $\begin{array}{l}\text { болезни системы } \\
\text { кровообращения }\end{array}$ & 2483 & 3278 & 3743 & 4285 & 4205 & 4563 & 4649 \\
\hline $\begin{array}{l}\text { болезни органов } \\
\text { дыхания }\end{array}$ & 46170 & 41915 & 46281 & 48568 & 48708 & 49464 & 51573 \\
\hline $\begin{array}{l}\text { болезни органов } \\
\text { пищеварения }\end{array}$ & 4698 & 5034 & 4778 & 5055 & 5342 & 5163 & 5229 \\
\hline $\begin{array}{l}\text { болезни кожи и под- } \\
\text { кожной клетчатки }\end{array}$ & 6407 & 7073 & 6886 & 6740 & 6767 & 6437 & 6241 \\
\hline $\begin{array}{l}\text { болезни костно- } \\
\text { мышечной системы } \\
\text { и соединительной }\end{array}$ & & & & & & & \\
\hline ткани & 4452 & 4746 & 4789 & 4634 & 4647 & 4410 & 4332 \\
\hline $\begin{array}{l}\text { болезни мочеполо- } \\
\text { вой системы }\end{array}$ & 5470 & 6560 & 6842 & 7147 & 7164 & 6793 & 6689 \\
\hline
\end{tabular}


Продолжение табл. 9.3

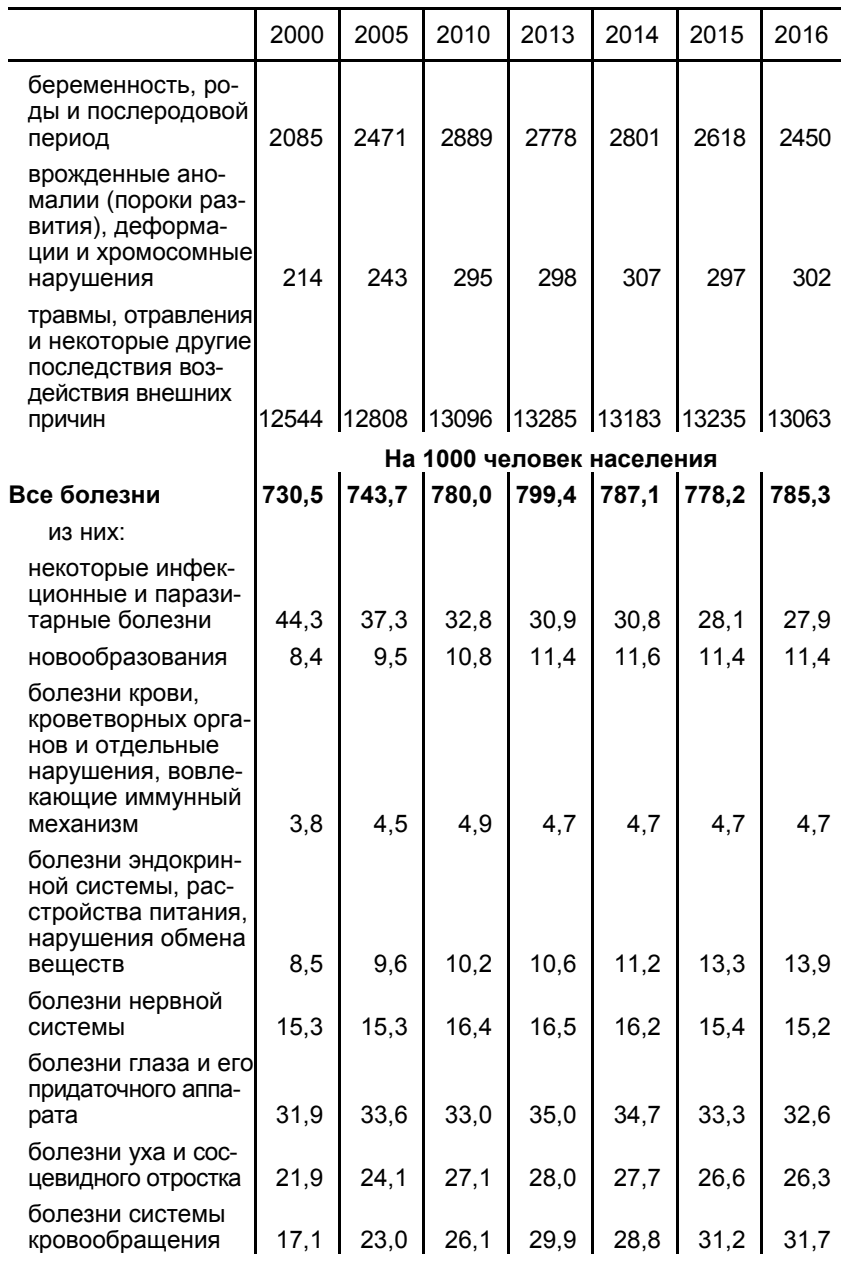


Продолжение табл. 9.3

\begin{tabular}{|c|c|c|c|c|c|c|c|}
\hline & 2000 & 2005 & 2010 & 2013 & 2014 & 2015 & 2016 \\
\hline $\begin{array}{l}\text { болезни органов } \\
\text { дыхания }\end{array}$ & 317,2 & 294,4 & 324,0 & 338,4 & 333,4 & 337,9 & 351,6 \\
\hline $\begin{array}{l}\text { болезни органов } \\
\text { пищеварения }\end{array}$ & 32,3 & 35,4 & 33,4 & 35,2 & 36,6 & 35,3 & 35,6 \\
\hline $\begin{array}{l}\text { болезни кожи и под- } \\
\text { кожной клетчатки }\end{array}$ & 44,0 & 49,7 & 48,2 & 47,0 & 46,3 & 44,0 & 42,5 \\
\hline $\begin{array}{l}\text { болезни костно- } \\
\text { мышечной системы } \\
\text { и соединительной } \\
\text { ткани }\end{array}$ & 30,6 & 33,3 & 33,5 & 32,3 & 31,8 & 30,1 & 29,5 \\
\hline $\begin{array}{l}\text { болезни мочеполо- } \\
\text { вой системы }\end{array}$ & 37,6 & 46,1 & 47,9 & 49,8 & 49,0 & 46,4 & 45,6 \\
\hline $\begin{array}{l}\text { беременность, ро- } \\
\text { ды и послеродовой } \\
\text { период } 1 \text { ) }\end{array}$ & 52,9 & 63,0 & 77,2 & 77,6 & 77,3 & 73,6 & 69,5 \\
\hline $\begin{array}{l}\text { врожденные ано- } \\
\text { малии (пороки раз- } \\
\text { вития), деформа- } \\
\text { ции и хромосомные }\end{array}$ & & & & & & & \\
\hline $\begin{array}{l}\text { нарушения } \\
\text { травмы, отравле- } \\
\text { ния и некоторые } \\
\text { другие последст- } \\
\text { вия воздействия }\end{array}$ & 1,5 & 1,7 & 2,1 & 2,1 & 2,1 & 2,0 & 2,1 \\
\hline Внешних причин & 86,2 & 90,0 & 91,7 & 92,6 & 90,2 & 90,4 & 89,1 \\
\hline
\end{tabular}

1) На 1000 женщин в возрасте 15-49 лет.

9.4. ЧИСЛЕННОСТЬ ЛИЦ в возрасте 18 лет и старше, ВПЕРВЫЕ ПРИЗНАННЫХ ИНВАЛИДАМИ

\begin{tabular}{|c|c|c|c|c|c|c|c|c|}
\hline & $1992^{1)}$ & 2000 & 2005 & 2010 & 2013 & $2014^{2)}$ & 2015 & 2016 \\
\hline $\begin{array}{l}\text { Всего }{ }^{3)} \text {, } \\
\text { тыс. человек }\end{array}$ & 1113 & 1109 & 1799 & 893 & 754 & 729 & 695 & 666 \\
\hline $\begin{array}{l}\text { На } 10000 \text { человек } \\
\text { населения соот- } \\
\text { ветствующего } \\
\text { возраста }\end{array}$ & 74,9 & 98,5 & 156,9 & 76,6 & 64,8 & 62,7 & 59,0 & 56,8 \\
\hline
\end{tabular}

1) В возрасте 16 лет и более.

2) Без учёта сведений по Крымскому федеральному округу.

3) Данные Минтруда России. 
9.5. САНАТОРНО-КУРОРТНЫЕ ОРГАНИЗАЦИИ И ОРГАНИЗАЦИИ ОТДЫХА

\begin{tabular}{l|l|l|l|l|l|l|l|l}
\hline & 1992 & 2000 & 2005 & 2010 & 2013 & 2014 & 2015 & 2016 \\
\hline $\begin{array}{l}\text { Число санаторно- } \\
\text { курортных органи- } \\
\text { заций и организа- } \\
\text { ций отдыха }\end{array}$ & 6931 & 4876 & 4457 & 3886 & 3630 & 3776 & 3689 & 5075 \\
В них мест (коек), \\
тыс.
\end{tabular}

1) 2010-2015 гг. - без учета микропредприятий. 


\section{0. КУЛЬТУРА, ОТДЫХ И ТУРИЗМ}

Раздел представляет данные о библиотеках, театрах, музеях, выпуске печатной продукции, организациях культурно-досугового типа, зоопарках, цирках, санаторно-курортных организациях и организациях отдыха, числе гостиниц и аналогичных средств размещения, о въезде в Россию иностранных граждан и выезде российских граждан за границу по целям поездок.

Сведения о библиотеках, театрах, музеях, организациях культурно-досугового типа, зоопарках и цирках приводятся по данным Минкультуры России, о печати - филиала «Российская книжная палата» ФГУП ИТАР-ТАСС, ТАСС.

К числу общедоступных (публичных) библиотек отнесены библиотеки, имеющие универсальные книжные фонды и удовлетворяющие массовые запросы населения на литературу. Кроме того, на территории Российской Федерации осуществляют деятельность научные, учебные, технические и другие специальные библиотеки. Учет таких библиотек осуществляется путем проведения переписей, последняя библиотечная перепись проведена в 2011 году.

К числу организаций культурно-досугового типа отнесены клубы; центры культуры и досуга; дома и дворцы культуры; дома интеллигенции, книги, кино, эстетического воспитания детей, женщин, молодежи, пенсионеров; национальные культурные центры; центры традиционной культуры; дома ремесел и фольклора; автоклубы, агиткультбригады, плавучие культбазы; культурно-спортивные и социально-культурные комплексы и др.

В показатели по театрам не включены данные по народным, любительским коллективам.

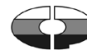


Гостиницы и аналогичные средства размещения - организации, которые предоставляют помещение для временного проживания. К ним относятся гостиницы, мотели, пансионаты, хостелы, другие организации гостиничного типа.

Въездная туристская поездка - поездка, совершенная в отчетном периоде иностранным гражданином в Российскую Федерацию, с любой главной целью (деловая поездка, отдых или иная личная цель), за исключением цели трудоустройства на предприятие, зарегистрированное в Российской Федерации, прохождения долгосрочного курса обучения в Российской Федерации. Не учитываются в числе въездных туристских поездок поездки иностранного обслуживающего персонала (экипажа/команды) общественных видов транспорта, дипломатов, сотрудников консульств, военнослужащих и их иждивенцев.

Выездная туристская поездка - поездка, совершенная в отчетном периоде гражданином Российской Федерации в зарубежные страны, с любой главной целью (деловая поездка, отдых или иная личная цель), за исключением цели трудоустройства на предприятие, зарегистрированное в посещаемой стране, прохождения долгосрочного курса обучения в посещаемой стране. Не учитываются в числе выездных туристских поездок поездки российского обслуживающего персонала (экипажа/команды) общественных видов транспорта, дипломатов, сотрудников консульств, военнослужащих и их иждивенцев.

Поездки охватывают деятельность лиц, которые путешествуют в какую-либо страну, не являющуюся страной их обычного местожительства, на срок, не превышающий 6 месяцев, с целью отдыха, деловыми или прочими целями.

Охват населения телевизионным и радиовещанием исчисляется как отношение числа жителей, имеющих возможность принимать телевизионные и радиопрограммы, к общей численности населения Российской Федерации. 
10.1. ОБЩЕДОСТУПНЫЕ БИБЛИОТЕКИ

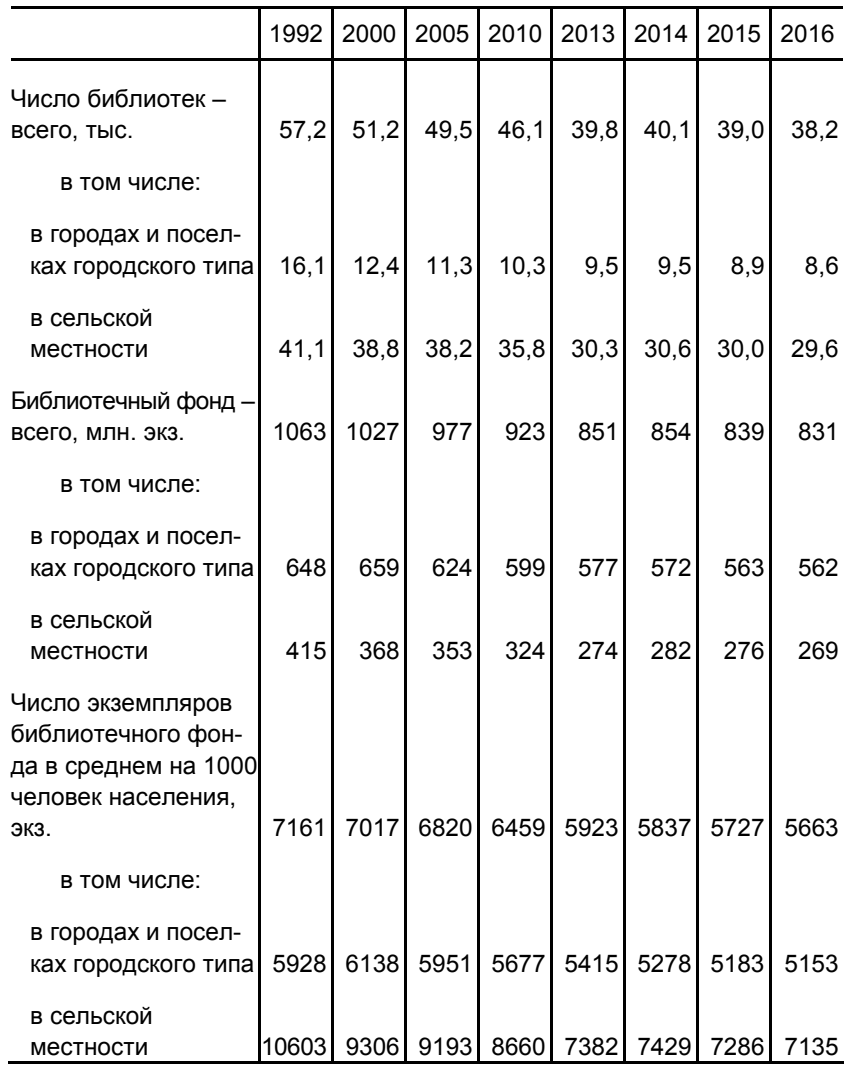


10.2. TEATPЫ

\begin{tabular}{l|r|r|r|r|r|r|r|r}
\hline & 1992 & 2000 & 2005 & 2010 & 2013 & 2014 & 2015 & 2016 \\
\hline $\begin{array}{l}\text { Число просресио- } \\
\text { нальных театров - } \\
\text { всего }\end{array}$ & 421 & 547 & 588 & 604 & 658 & 661 & 665 & 651 \\
$\quad$ в том числе: & & & & & & & & \\
оперы и балета & 31 & 65 & 72 & 74 & 75 & 78 & 77 & 76 \\
$\begin{array}{l}\text { драмы, комедии } \\
\text { и музыкальные }\end{array}$ & 260 & 318 & 335 & 344 & 377 & 376 & 376 & 367 \\
$\begin{array}{l}\text { детские и юного } \\
\text { зрителя }\end{array}$ & 130 & 151 & 165 & 170 & 184 & 183 & 185 & 183 \\
$\begin{array}{l}\text { прочие } \\
\text { Численность }\end{array}$ & - & 13 & 16 & 16 & 22 & 24 & 27 & 25 \\
зрителей театров, \\
млн. человек
\end{tabular}

10.3. МУЗЕИ

\begin{tabular}{l|r|r|r|r|r|r|r}
\hline & 2000 & 2005 & 2010 & 2013 & 2014 & 2015 & 2016 \\
\hline Число музеев - всего & 2047 & 2285 & 2578 & 2727 & 2731 & 2758 & 2742 \\
$\quad$ в том числе: & & & & & & & \\
искусствоведческие & 301 & 316 & 320 & 352 & 345 & 346 & 339 \\
исторические & & & & & & & \\
и археологические & 465 & 492 & 522 & 516 & 522 & 525 & 518 \\
краеведческие & 908 & 1085 & 1332 & 1403 & 1410 & 1421 & 1416 \\
естественнонаучные & 38 & 39 & 39 & 48 & 49 & 49 & 43 \\
научно-технические & 10 & 13 & 21 & 22 & 23 & 24 & 23 \\
комплексные & 155 & 179 & 190 & 225 & 224 & 231 & 244 \\
отраслевые, специали- & 170 & 161 & 154 & 161 & 158 & 162 & 159 \\
зированные и прочие & & & & & & & \\
Число посещений & 73,2 & 75,6 & 81,0 & 95,8 & 102,7 & 119,0 & 123,6 \\
музеев, млн. &
\end{tabular}


10.4. ЧИСЛО ОРГАНИЗАЦИЙ КУЛЬТУРНО-ДОСУГОВОГО ТИПА

\begin{tabular}{l|r|r|r|r|r|r|r|r}
\multicolumn{1}{|c|}{} & 1992 & 2000 & 2005 & 2010 & 2013 & 2014 & 2015 & 2016 \\
\hline Всего & 66,0 & 54,8 & 51,4 & 46,6 & 42,4 & 42,1 & 40,3 & 41,3 \\
$\quad$ в том числе: & & & & & & & & \\
в городах и поселках \\
городского типа
\end{tabular}

10.5. ЗООПАРКИ

\begin{tabular}{l|r|r|r|r|r|r|r|r}
\hline & 2000 & 2005 & 2010 & 2013 & 2014 & 2015 & 2016 & 2017 \\
\hline Число зоопарков & 20 & 23 & 29 & 30 & 30 & 31 & 31 & 31 \\
Площадь территории & & & & & & & & \\
зоопарков, га & 298 & 327 & 673 & 640 & 640 & 634 & 570 & 490 \\
Численность животных - & & & & & & & \\
всего, экземпляров & 39849 & 50190 & 66043 & 66284 & 68966 & 69633 & 75168 & 81695 \\
$\quad$ & & & & & & & & \\
из них: & 5131 & 8306 & 12169 & 15084 & 16688 & 17034 & 22896 & 24978 \\
беспозвоночные & 13815 & 15521 & 17990 & 20391 & 19099 & 19971 & 20299 & 23347 \\
рыбы & 570 & 673 & 1381 & 995 & 1047 & 877 & 822 & 1031 \\
земноводные & 3718 & 5025 & 4381 & 3594 & 3591 & 3578 & 3615 & 3679 \\
пресмыкающиеся & 8930 & 10124 & 14421 & 11815 & 11854 & 12505 & 12006 & 12181 \\
птицы & 7685 & 9691 & 14860 & 12664 & 14058 & 13022 & 12737 & 14651 \\
$\quad$ млекопитающие & & & & & & & & \\
Число посещений, & 6,4 & 7,4 & 9,5 & 7,6 & 8,3 & 8,7 & 8,8 & 8,5 \\
\hline млн.
\end{tabular}

10.6. ЦИРКИ

\begin{tabular}{l|r|r|r|r|r|r|r|r}
\hline & 2000 & 2005 & 2010 & 2013 & 2014 & 2015 & 2016 & 2017 \\
\hline Число цирков & 62 & 67 & 68 & 67 & 63 & 67 & 65 & 66 \\
$\begin{array}{l}\text { Численность зрителей } \\
\text { цирков }{ }^{1)} \text {, млн. человек }\end{array}$ & 8,6 & 6,8 & 11,3 & 5,6 & 5,1 & 4,2 & 4,2 & 5,8 \\
\hline
\end{tabular}

1) С 2010 г. - с учетом гастрольной деятельности. 
10.7. ВЫПУСК КНИГ И БРОШЮР, ЖУРНАЛОВ И ГАЗЕТ

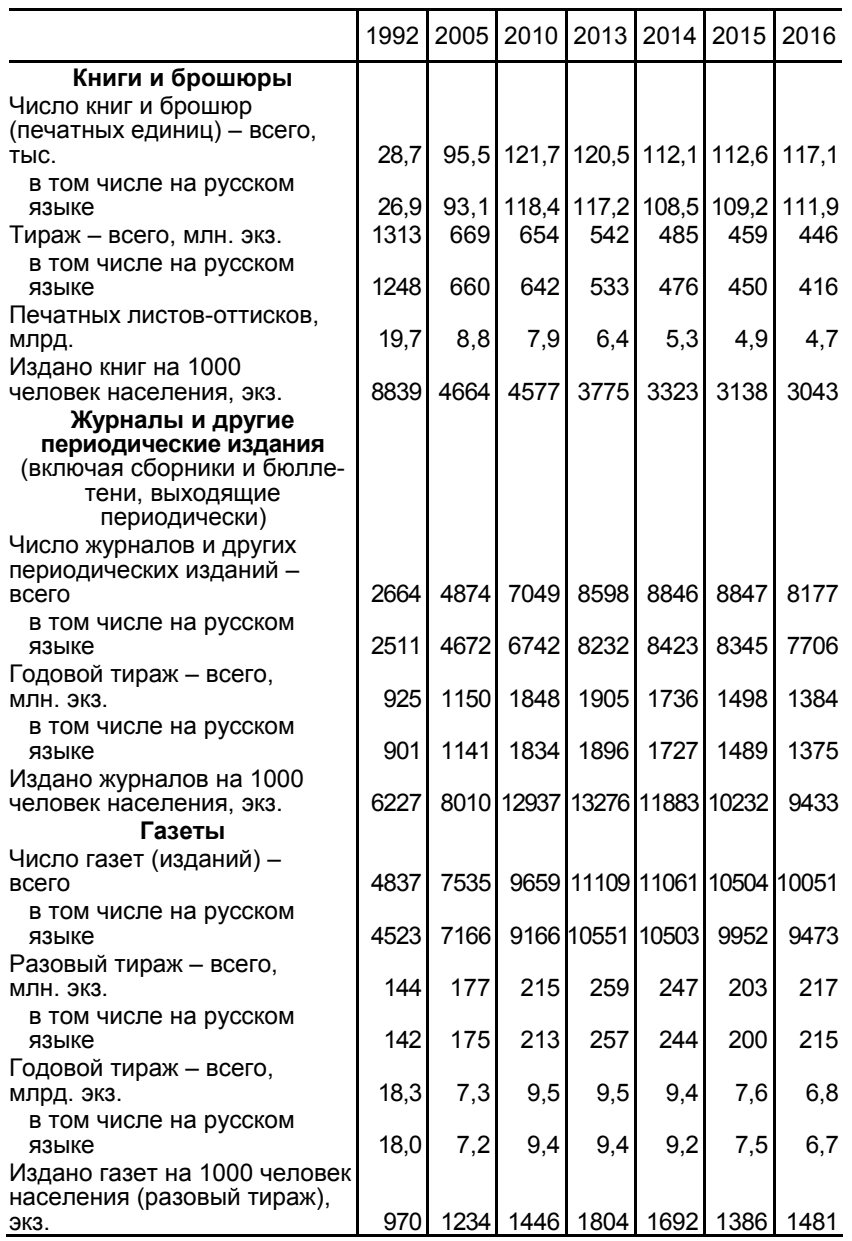


10.8. ОХВАТ НАСЕЛЕНИЯ ТЕЛЕ - И РАДИОВЕЩАНИЕМ В 2016 г. ${ }^{1)}$

(в процентах от общей численности соответствующего населения)

\begin{tabular}{|c|c|c|}
\hline & $\begin{array}{l}\text { Городское } \\
\text { население }\end{array}$ & $\begin{array}{l}\text { Сельское } \\
\text { население }\end{array}$ \\
\hline \multicolumn{3}{|l|}{$\begin{array}{l}\text { Имеют возможность принимать наземное } \\
\text { эфирное аналоговое телевещание: }\end{array}$} \\
\hline одну телевизионную программу & 98,3 & 95,6 \\
\hline \multicolumn{3}{|l|}{$\begin{array}{l}\text { общероссийские обязательные общедос- } \\
\text { тупные телеканалы: }\end{array}$} \\
\hline Телеканал «Россия» (Россия 1) & 96,4 & 87,0 \\
\hline Телеканал «Россия-Культура» (Россия-К) & 63,6 & 24,5 \\
\hline $\begin{array}{l}\text { Российский информационный канал } \\
\text { «Россия-24» (Россия-24) }\end{array}$ & 43,2 & 9,8 \\
\hline Первый канал & 97,8 & 93,1 \\
\hline Телекомпания НТВ & 77,7 & 34,3 \\
\hline Петербург - 5 канал & 72,8 & 31,0 \\
\hline Детско - юношеский канал «Карусель» & 6,8 & 1,7 \\
\hline Телеканал «Россия-2» (Россия-2) & 56,7 & 24,3 \\
\hline $\begin{array}{l}\text { Телеканал «Общественное телевидение } \\
\text { России» }\end{array}$ & 5,4 & $\cdots$ \\
\hline ТВ-Центр - Москва & 56,6 & 19,6 \\
\hline \multicolumn{3}{|l|}{$\begin{array}{l}\text { Имеют возможность принимать } \\
\text { радиовещание: }\end{array}$} \\
\hline одну радиопрограмму & 89,7 & 77,8 \\
\hline $\begin{array}{l}\text { три общероссийских обязательных } \\
\text { общедоступных радиоканала: }\end{array}$ & 49,8 & 11,7 \\
\hline Радио России & 85,9 & 73,1 \\
\hline Маяк & 66,7 & 25,5 \\
\hline Вести FM & 55,3 & 14,1 \\
\hline
\end{tabular}

1) По данным Минкомсвязи России. 
10.9. ДЕТСКИЕ ОЗДОРОВИТЕЛЬНЫЕ ЛАГЕРЯ

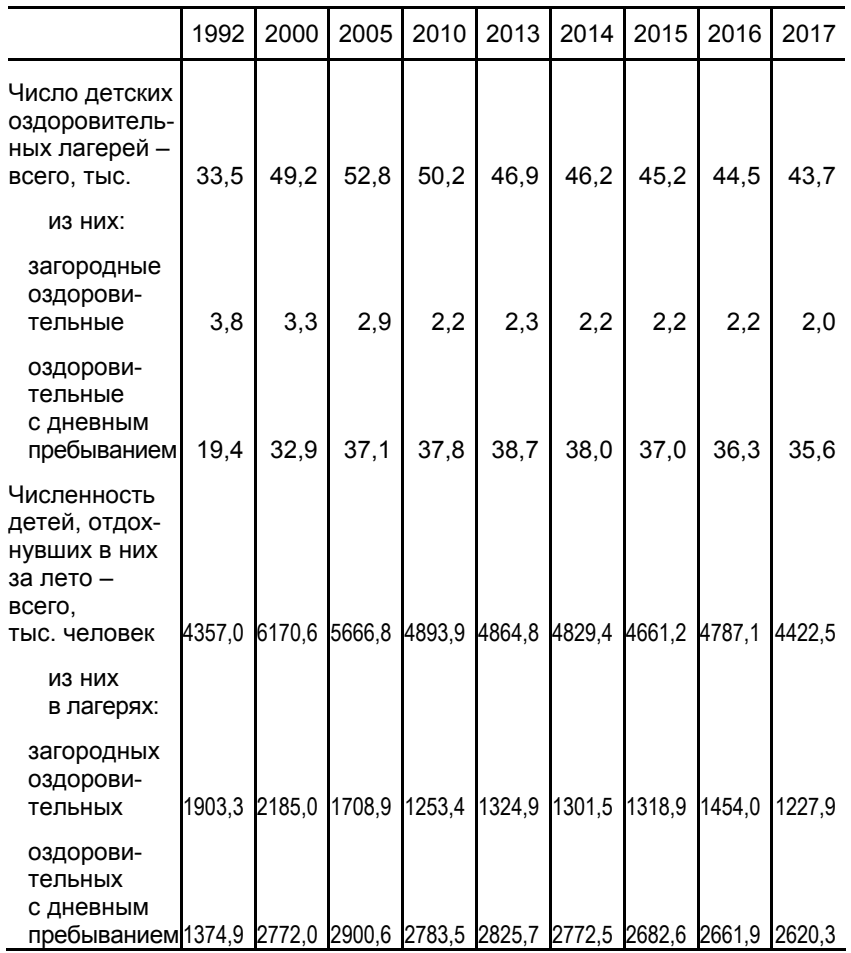

10.10. ЧИСЛО ГОСТИНИЦ И АНАЛОГИЧНЫХ СРЕДСТВ

РАЗМЕЩЕНИЯ

(на конец года)

\begin{tabular}{l|l|l|l|l|l|l|l|l}
\hline & 1993 & 2000 & 2005 & 2010 & 2013 & 2014 & 2015 & 2016 \\
\hline Всего & 6258 & 4182 & 4812 & 7866 & 9869 & 10714 & 13957 & 14948 \\
\hline
\end{tabular}




\subsection{1. ЧИСЛО ВЪЕЗДНЫХ ТУРИСТСКИХ ПОЕЗДОК ИНОСТРАННЫХ ГРАЖДАН В РОССИЮ}

(тысяч)

\begin{tabular}{|c|c|c|c|c|c|c|c|}
\hline & 2015 & 2016 & 2017 & & 2015 & 2016 & 2017 \\
\hline Всего & 26852 & 24571 & 24390 & Азия & & & \\
\hline из них из & & & & Абхазия & 417 & 411 & 432 \\
\hline стран: & & & & Азербайджан & 856 & 898 & 876 \\
\hline Европа & & & & Армения & 552 & 596 & 584 \\
\hline Австрия & 51 & 49 & 52 & Вьетнам & 30 & 36 & 43 \\
\hline Беларусь & 249 & 134 & 152 & Гонконг & 12 & 13 & 18 \\
\hline Бельгия & 31 & 35 & 36 & Грузия & 47 & 65 & 79 \\
\hline Болгария & 24 & 27 & 27 & Израиль & 162 & 179 & 182 \\
\hline Босния и & & & & Индия & 51 & 59 & 71 \\
\hline Герцеговина & 7 & 6 & 6 & Индонезия & 7 & 8 & 10 \\
\hline Венгрия & 20 & 21 & 21 & Исламская & & & \\
\hline Германия & 553 & 566 & 580 & Республика & & & \\
\hline Греция & 25 & 27 & 27 & Иран & 41 & 70 & 80 \\
\hline Дания & 23 & 19 & 19 & Казахстан & 4711 & 3564 & 3485 \\
\hline Ирландия & 11 & 11 & 12 & Киргизия & 374 & 398 & 421 \\
\hline Испания & 104 & 109 & 110 & Китай & 1122 & 1289 & 1478 \\
\hline Италия & 191 & 192 & 189 & Монголия & 378 & 522 & 396 \\
\hline Латвия & 278 & 289 & 261 & Республика & & & \\
\hline Литва & 237 & 249 & 226 & Корея & 136 & 161 & 254 \\
\hline Нидерланды & 55 & 57 & 60 & Сирийская & & & \\
\hline Норвегия & 48 & 45 & 51 & Арабская & & & \\
\hline Польша & 1725 & 1017 & 714 & Республика & 6 & 4 & 5 \\
\hline Португалия & 13 & 15 & 16 & Таджикистан & 458 & 410 & 360 \\
\hline Республика & & & & Таиланд & 25 & 28 & 45 \\
\hline Молдова & 491 & 409 & 519 & Турция & 239 & 43 & 80 \\
\hline Румыния & 16 & 15 & 17 & Узбекистан & 797 & 597 & 425 \\
\hline Сербия & 58 & 50 & 55 & Филиппины & 6 & 7 & 10 \\
\hline Словакия & 18 & 21 & 22 & Япония & 86 & 85 & 102 \\
\hline Словения & 10 & 9 & 9 & Афррика & & & \\
\hline Соединенное & & & & Алжир & 4 & 4 & 5 \\
\hline Королевство & & & & Египет & 15 & 11 & 10 \\
\hline (Великобри- & & & & Марокко & 3 & 4 & 4 \\
\hline тания) & 180 & 177 & 178 & Тунис & 3 & 4 & 3 \\
\hline Украина & 8912 & 8569 & 8723 & Южно- & & & \\
\hline Финляндия & 1416 & 1319 & 1017 & Афрриканская & & & \\
\hline Франция & 171 & 177 & 185 & Республика & 8 & 7 & 11 \\
\hline Хорватия & 9 & 9 & 9 & Америка & & & \\
\hline Черногория & 4 & 4 & 4 & Аргентина & 17 & 19 & 24 \\
\hline Чешская & & & & Бразилия & 34 & 27 & 35 \\
\hline Республика & 40 & 40 & 41 & Канада & 42 & 40 & 51 \\
\hline Швейцария & 42 & 48 & 49 & Колумбия & 10 & 10 & 12 \\
\hline Швеция & 37 & 36 & 34 & Куба & 12 & 26 & 29 \\
\hline Эстония & 357 & 414 & 415 & Мексика & 22 & 20 & 26 \\
\hline Австралия и & & & & США & 233 & 239 & 282 \\
\hline Океания & & & & & & & \\
\hline Австралия & 38 & 42 & 47 & & & & \\
\hline $\begin{array}{l}\text { НОвая } \\
\text { Зеландия }\end{array}$ & 6 & 7 & 8 & & & & \\
\hline
\end{tabular}


10.12. ЧИСЛО ВЫЕЗДНЫХ ТУРИСТСКИХ ПОЕЗДОК ГРАЖДАН РОССИИ В ЗАРУБЕЖНЫЕ СТРАНЫ

(Тысяч)

\begin{tabular}{|c|c|c|c|c|c|c|c|}
\hline & 2015 & 2016 & 2017 & & 2015 & 2016 & 2017 \\
\hline Всего & 34390 & 31659 & 39629 & Азия & & & \\
\hline из них в & & & & Абхазия & 3824 & 4257 & 4344 \\
\hline страны: & & & & Азербайджан & 584 & 627 & 736 \\
\hline Европа & & & & Армения & 266 & 288 & 368 \\
\hline Австрия & 223 & 183 & 248 & Вьетнам & 321 & 392 & 512 \\
\hline Бельгия & 73 & 71 & 85 & Гонконг & 34 & 22 & 19 \\
\hline Болгария & 413 & 535 & 482 & Грузия & 651 & 742 & 1003 \\
\hline Венгрия & 95 & 95 & 112 & Израиль & 299 & 303 & 359 \\
\hline Германия & 1111 & 1057 & 1229 & Индия & 118 & 169 & 219 \\
\hline Греция & 634 & 782 & 856 & Казахстан & 3125 & 2850 & 2978 \\
\hline Дания & 45 & 35 & 32 & Катар & 53 & 66 & 87 \\
\hline Испания & 693 & 790 & 929 & Кипр & 550 & 813 & 869 \\
\hline Италия & 662 & 710 & 893 & Киргизия & 250 & 240 & 248 \\
\hline Латвия & 312 & 339 & 379 & Китай & 1284 & 1676 & 2003 \\
\hline Литва & 743 & 693 & 638 & Мальдивы & 19 & 23 & 30 \\
\hline Мальта & 12 & 6 & 8 & Монголия & 57 & 72 & 91 \\
\hline Нидерланды & 175 & 177 & 219 & Объединенные & & & \\
\hline Норвегия & 112 & 103 & 115 & Арабские & & & \\
\hline Польша & 1322 & 1104 & 1230 & Эмираты & 472 & 499 & 766 \\
\hline Португалия & 24 & 25 & 47 & Республика & & & \\
\hline Республика & & & & Корея & 166 & 199 & 232 \\
\hline Молдова & 224 & 200 & 249 & Сингапур & 20 & 29 & 26 \\
\hline Румыния & 13 & 12 & 13 & Таджикистан & 98 & 110 & 116 \\
\hline Сербия & 73 & 73 & 76 & Таиланд & 675 & 867 & 1094 \\
\hline Словакия & 3 & 29 & 29 & Турция & 3460 & 797 & 4520 \\
\hline Словения & 16 & 16 & 19 & Узбекистан & 98 & 98 & 120 \\
\hline Соединенное & & & & Япония & 46 & 47 & 65 \\
\hline Королевство & & & & Африка & & & \\
\hline (Великобри- & & & & Египет & 2244 & 0,3 & 0,4 \\
\hline тания) & 247 & 215 & 255 & Марокко & 8 & 33 & 20 \\
\hline Украина & 1657 & 1804 & 2283 & Тунис & 49 & 624 & 520 \\
\hline Финляндия & 3067 & 2894 & 3333 & Америка & & & \\
\hline Франция & 408 & 393 & 471 & Доминиканская & & & \\
\hline Хорватия & 49 & 56 & 58 & Республика & 36 & 132 & 230 \\
\hline Черногория & 252 & 283 & 305 & Канада & 8 & - & - \\
\hline Чешская & & & & Куба & 32 & 45 & 75 \\
\hline Республика & 361 & 367 & 499 & Мексика & 32 & 4 & 1 \\
\hline Швейцария & 234 & 229 & 239 & США & 237 & 225 & 238 \\
\hline Швеция & 55 & 41 & 56 & & & & \\
\hline Эстония & 1477 & 1511 & 1728 & & & & \\
\hline
\end{tabular}




\section{1. ОБЩЕСТВЕННЫЕ ОБЪЕДИНЕНИЯ И РЕЛИГИОЗНЫЕ ОРГАНИЗАЦИИ}

В разделе приведены данные по некоммерческим, общественным и религиозным организациям, зарегистрированным в реестре Министерства юстиции Российской Федерации.

11.1. ЧИСЛО ОБЩЕСТВЕННЫХ ОБЪЕДИНЕНИЙ, ПОЛИТИЧЕСКИХ ПАРТИЙ И НЕКОММЕРЧЕСКИХ ОРГАНИЗАЦИЙ, ЗАРЕГИСТРИРОВАННЫХ В РОССИЙСКОЙ ФЕДЕРАЦИИ, на конец 2017 г.

\begin{tabular}{|c|c|c|}
\hline & $\begin{array}{c}\text { Всего } \\
\text { зарегистрировано }\end{array}$ & $\begin{array}{c}\text { в том числе } \\
\text { зарегистрировано } \\
\text { в 2017 г. }\end{array}$ \\
\hline $\begin{array}{c}\text { Общественные объединения - всего } \\
\text { в том числе: }\end{array}$ & 95204 & 4841 \\
\hline общественные организации & 55771 & 3874 \\
\hline из них благотворительные & 1599 & 51 \\
\hline общественные движения & 1442 & 118 \\
\hline из них благотворительные & 12 & 1 \\
\hline общественные фонды & 3531 & 25 \\
\hline из них благотворительные & 1556 & 6 \\
\hline общественные учреждения & 681 & 9 \\
\hline из них благотворительные & 4 & - \\
\hline $\begin{array}{l}\text { органы общественной самодея- } \\
\text { тельности }\end{array}$ & 172 & 2 \\
\hline $\begin{array}{l}\text { иные виды общественных } \\
\text { объединений }\end{array}$ & 33607 & 813 \\
\hline из них: & & \\
\hline профессиональные союзы & 22241 & 207 \\
\hline $\begin{array}{l}\text { национально-культурные } \\
\text { автономии }\end{array}$ & 1248 & 92 \\
\hline Политические партии & 70 & 1 \\
\hline Некоммерческие организации - всего & 90852 & 8854 \\
\hline $\begin{array}{l}\text { в том числе благотворительные } \\
\text { фонды }\end{array}$ & 8549 & 1074 \\
\hline $\begin{array}{l}\text { Филиалы и представительства иност- } \\
\text { ранных некоммерческих неправи- } \\
\text { тельственных организаций }\end{array}$ & 127 & 2 \\
\hline
\end{tabular}

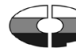


11.2. СРЕДНЕСПИСОЧНАЯ ЧИСЛЕННОСТЬ

И СРЕДНЕМЕСЯЧНАЯ НАЧИСЛЕННАЯ ЗАРАБОТНАЯ ПЛАТА

РАБОТНИКОВ ОБЩЕСТВЕННЫХ ОБЪЕДИНЕНИЙ

\begin{tabular}{c|c|c}
\hline Годы & $\begin{array}{c}\text { Среднесписочная численность } \\
\text { работников, тыс. человек }\end{array}$ & $\begin{array}{c}\text { Среднемесячная начисленная } \\
\text { заработная плата, руб. }\end{array}$ \\
\hline 2010 & 82,5 & 20536 \\
2013 & 80,4 & 28884 \\
2014 & 83,8 & 30843 \\
2015 & 87,2 & 32365 \\
2016 & 89,3 & 36371 \\
2017 & 91,7 & 37330 \\
\hline
\end{tabular}

11.3. ЧИСЛО НЕКОММЕРЧЕСКИХ ОРГАНИЗАЦИЙ ПО ВИДАМ

(на конец года)

\begin{tabular}{|c|c|c|c|c|c|}
\hline & 2013 & 2014 & 2015 & 2016 & 2017 \\
\hline $\begin{array}{c}\text { Некоммерческие } \\
\text { организации - всего } \\
\text { из них: }\end{array}$ & 89617 & 90155 & 90464 & 91285 & 90852 \\
\hline фонды & 16425 & 16637 & 17395 & 18126 & 18339 \\
\hline $\begin{array}{l}\text { некоммерческие } \\
\text { партнерства }\end{array}$ & 23170 & 22158 & 20004 & 17441 & 14422 \\
\hline $\begin{array}{l}\text { автономные некоммерче- } \\
\text { ские организации }\end{array}$ & 18152 & 19008 & 20658 & 22231 & 23915 \\
\hline $\begin{array}{l}\text { объединения юридических } \\
\text { лиц (ассоциации, союзы) }\end{array}$ & 4871 & 5067 & 6703 & 8205 & 9963 \\
\hline учреждения & 17071 & 16900 & 16519 & 15951 & 14753 \\
\hline $\begin{array}{l}\text { территориальные общест- } \\
\text { венные самоуправления }\end{array}$ & 2119 & 2218 & 905 & 840 & 820 \\
\hline коллегии адвокатов & 2402 & 2490 & 2542 & 2648 & 2732 \\
\hline $\begin{array}{l}\text { общины малочисленных } \\
\text { народов }\end{array}$ & 1261 & 1288 & 1348 & 1413 & 1481 \\
\hline казачьи общества & 2201 & 2410 & 2577 & 2653 & 2688 \\
\hline
\end{tabular}


11.4. ЧИСЛО РЕЛИГИОЗНЫХ ОРГАНИЗАЦИЙ, ЗАРЕГИСТРИРОВАННЫХ В РОССИЙСКОЙ ФЕДЕРАЦИИ, на конец 2017 г. ${ }^{1)}$

\begin{tabular}{|c|c|c|c|c|c|c|}
\hline & \multirow{2}{*}{$\begin{array}{l}\text { Всего } \\
\text { заре- } \\
\text { гистри- } \\
\text { ровано }\end{array}$} & \multicolumn{5}{|c|}{ в том числе по видам } \\
\hline & & \begin{tabular}{|c} 
центра- \\
пизован- \\
ные \\
религи- \\
озные \\
органи- \\
зации \\
\end{tabular} & $\begin{array}{c}\text { местные } \\
\text { религи- } \\
\text { озные } \\
\text { органи- } \\
\text { зации }\end{array}$ & $\begin{array}{c}\text { духов- } \\
\text { ные } \\
\text { образо- } \\
\text { ватель- } \\
\text { ные } \\
\text { органи- } \\
\text { зации } \\
\end{array}$ & $\begin{array}{l}\text { мона- } \\
\text { стыри }\end{array}$ & $\begin{array}{l}\text { иные } \\
\text { религи- } \\
\text { озные } \\
\text { органи- } \\
\text { зации }\end{array}$ \\
\hline Все религиозные & & & & & & \\
\hline $\begin{array}{l}\text { организации } \\
\text { в том числе } \\
\text { по конфессиям: }\end{array}$ & 30193 & 601 & 28370 & 173 & 498 & 551 \\
\hline $\begin{array}{l}\text { Русская православная } \\
\text { церковь }\end{array}$ & 18191 & 198 & 16931 & 60 & 484 & 518 \\
\hline Российская православ- & 27 & 3 & 1000 & & 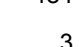 & 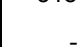 \\
\hline Русская православная & & & & & & \\
\hline $\begin{array}{l}\text { церковь за границей } \\
\text { Истинно-православная }\end{array}$ & 9 & - & 8 & - & 1 & - \\
\hline церковь & 35 & 4 & 27 & - & 3 & 1 \\
\hline $\begin{array}{l}\text { Россииская православ- } \\
\text { ная свободная церковь }\end{array}$ & 5 & - & 5 & - & - & - \\
\hline $\begin{array}{l}\text { Украинская православ- } \\
\text { ная церковь (Киевский } \\
\text { патриархат) }\end{array}$ & 8 & 1 & 7 & - & - & - \\
\hline $\begin{array}{l}\text { Старообрядцы } \\
\text { в том числе: } \\
\text { Русская православная } \\
\text { старообрядческая }\end{array}$ & 378 & 9 & 358 & 1 & 7 & 3 \\
\hline $\begin{array}{l}\text { церковь } \\
\text { Древлеправославная }\end{array}$ & 197 & 1 & 193 & - & 1 & 2 \\
\hline церковь & 111 & 4 & 100 & 1 & 5 & 1 \\
\hline $\begin{array}{l}\text { Поморская церковь } \\
\text { Федосеевское }\end{array}$ & 48 & 2 & 46 & - & - & - \\
\hline согласие & 11 & 2 & 8 & - & 1 & - \\
\hline $\begin{array}{c}\text { другие согласия } \\
\text { Римско-католическая }\end{array}$ & 11 & - & 11 & - & - & - \\
\hline церковь & 235 & 9 & 215 & 1 & - & 10 \\
\hline $\begin{array}{l}\text { Греко-католическая } \\
\text { церковь } \\
\text { Армянская апостольская }\end{array}$ & 8 & 1 & 7 & - & - & - \\
\hline церковь & 104 & 2 & 102 & - & - & $=$ \\
\hline Ислам & 5663 & 90 & 5490 & 78 & - & 5 \\
\hline Буддизм & 265 & 12 & 251 & 2 & - & - \\
\hline $\begin{array}{l}\text { Иудаизм } \\
\text { в том числе: }\end{array}$ & 269 & 10 & 256 & 1 & - & 2 \\
\hline ортодоксальный & 220 & 8 & 209 & 1 & - & 2 \\
\hline современный & 49 & 2 & 47 & - & - & - \\
\hline Евангельские христиане- & & & & & & \\
\hline баптисты & 888 & 51 & 830 & 6 & - & 1 \\
\hline 166 & & POCC & СЯ В & $\Phi P A X$ & 2018 & \\
\hline
\end{tabular}


Продолжение табл. 11.4

\begin{tabular}{|c|c|c|c|c|c|c|}
\hline & \multirow{2}{*}{$\begin{array}{l}\text { Bсего } \\
\text { заре- } \\
\text { гистри- } \\
\text { ровано }\end{array}$} & \multicolumn{5}{|c|}{ в том числе по видам } \\
\hline & & \begin{tabular}{|c} 
центра- \\
лизован- \\
ные \\
религи- \\
озные \\
органи- \\
зации
\end{tabular} & $\begin{array}{c}\text { местные } \\
\text { религи- } \\
\text { озные } \\
\text { органи- } \\
\text { зации }\end{array}$ & \begin{tabular}{|c} 
духов- \\
ные \\
образо- \\
ватель- \\
ные \\
органи- \\
зации
\end{tabular} & $\begin{array}{l}\text { мона- } \\
\text { стыри }\end{array}$ & $\begin{array}{l}\text { иные } \\
\text { религи- } \\
\text { озные } \\
\text { органи- } \\
\text { зации }\end{array}$ \\
\hline $\begin{array}{l}\text { Христиане веры } \\
\text { евангельской }\end{array}$ & 671 & 49 & 614 & 8 & - & - \\
\hline $\begin{array}{l}\text { Евангельские христиане } \\
\text { Евангельские христиане }\end{array}$ & 720 & 36 & 677 & 4 & - & 3 \\
\hline в духе апостолов & 21 & 1 & 20 & - & - & - \\
\hline $\begin{array}{l}\text { Христиане веры еван- } \\
\text { гельской-пятидесятники }\end{array}$ & 1171 & 57 & 1108 & 3 & - & 3 \\
\hline $\begin{array}{l}\text { Церковь полного } \\
\text { Евангелия }\end{array}$ & 27 & 2 & 25 & - & - & - \\
\hline $\begin{array}{l}\text { Евангельские христиане- } \\
\text { трезвенники }\end{array}$ & 4 & - & 4 & - & - & - \\
\hline Адвентисты седьмого дня & 573 & 19 & 553 & 1 & - & - \\
\hline $\begin{array}{l}\text { Лютеране } \\
\text { в том числе: } \\
\text { Евангедическо- }\end{array}$ & 223 & 11 & 209 & 3 & - & - \\
\hline $\begin{array}{l}\text { лютеранская церковь } \\
\text { Единая евангелическо- } \\
\text { лютеранская церковь } \\
\text { России }\end{array}$ & 168 & 9 & 157 & 2 & - & - \\
\hline Церковь Ингрии & 43 & 1 & 41 & 1 & - & - \\
\hline $\begin{array}{l}\text { другие евангелическо- } \\
\text { лютеранские церкви }\end{array}$ & 8 & 1 & 7 & - & - & - \\
\hline $\begin{array}{l}\text { Новоапостольская } \\
\text { церковь }\end{array}$ & 46 & 4 & 42 & - & - & - \\
\hline Методистская церковь & 93 & 2 & 89 & 1 & - & 1 \\
\hline $\begin{array}{l}\text { Реформатская церковь } \\
\text { Пресвитерианская }\end{array}$ & 4 & - & 4 & - & - & - \\
\hline церковь & 191 & 8 & 179 & 3 & - & 1 \\
\hline Англиканская церковь & 1 & - & 1 & - & - & - \\
\hline Меннониты & 7 & 1 & 6 & - & - & - \\
\hline $\begin{array}{l}\text { Армия спасения } \\
\text { Церковь Иисуса Христа }\end{array}$ & 13 & 1 & 12 & - & - & - \\
\hline $\begin{array}{l}\text { святых последних дней } \\
\text { (мормоны) }\end{array}$ & 57 & 1 & 56 & - & - & - \\
\hline $\begin{array}{l}\text { Церковь объединения } \\
\text { (Муна) }\end{array}$ & 6 & 1 & 5 & - & - & - \\
\hline $\begin{array}{l}\text { Церковь Божьей матери } \\
\text { “Державная” }\end{array}$ & 17 & 1 & 16 & - & - & - \\
\hline
\end{tabular}


Продолжение табл. 11.4

\begin{tabular}{|c|c|c|c|c|c|c|}
\hline & \multirow{2}{*}{$\begin{array}{c}\text { Всего } \\
\text { заре- } \\
\text { гистри- } \\
\text { ровано }\end{array}$} & \multicolumn{5}{|c|}{ в том числе по видам } \\
\hline & & \begin{tabular}{|c} 
центра- \\
лизован- \\
ные \\
религи- \\
озные \\
органи- \\
зации \\
\end{tabular} & \begin{tabular}{|c|} 
местные \\
религи- \\
озные \\
органи- \\
зации
\end{tabular} & \begin{tabular}{|c|} 
духов- \\
ные \\
образо- \\
ватель- \\
ные \\
органи- \\
зации \\
\end{tabular} & $\begin{array}{l}\text { мона- } \\
\text { стыри }\end{array}$ & $\begin{array}{c}\text { иные } \\
\text { религи- } \\
\text { озные } \\
\text { органи- } \\
\text { зации }\end{array}$ \\
\hline Молокане & 19 & 1 & 18 & - & - & - \\
\hline $\begin{array}{l}\text { Церковь последнего } \\
\text { завета }\end{array}$ & 2 & - & 2 & - & - & - \\
\hline Церковь Христа & 18 & 1 & 17 & - & - & - \\
\hline $\begin{array}{l}\text { Христиане иудействую- } \\
\text { щие }\end{array}$ & 2 & - & 2 & - & - & - \\
\hline $\begin{array}{l}\text { Неденоминированные } \\
\text { христианские церкви }\end{array}$ & 21 & 7 & 12 & 1 & - & 1 \\
\hline $\begin{array}{l}\text { Саентологическая } \\
\text { церковь }\end{array}$ & 1 & - & 1 & - & - & - \\
\hline Индуизм & 4 & - & 4 & - & - & - \\
\hline $\begin{array}{l}\text { Сознание Кришны } \\
\text { (вайшнавы) }\end{array}$ & 82 & 2 & 80 & - & - & - \\
\hline Вера Бахаи & 16 & 1 & 15 & - & - & - \\
\hline Ассирийская церковь & 6 & 1 & 5 & - & - & - \\
\hline Сикхи & 1 & - & 1 & - & - & - \\
\hline Шаманизм & 30 & - & 30 & - & - & - \\
\hline Караимы & 7 & 1 & 6 & - & - & - \\
\hline Зороастризм & 2 & - & 2 & - & - & - \\
\hline $\begin{array}{l}\text { Духовное единство } \\
\text { (толстовцы) }\end{array}$ & 1 & - & 1 & - & - & - \\
\hline Языческие верования & 17 & 1 & 16 & - & - & - \\
\hline Иные вероисповедания & 34 & 2 & 30 & - & - & 2 \\
\hline
\end{tabular}




\section{5. УЧАСТИЕ НАСЕЛЕНИЯ В ДЕЯТЕЛЬНОСТИ ОБЩЕСТВЕННЫХ, ДОБРОВОЛЬНЫХ И БЛАГОТВОРИТЕЛЬНЫХ ОРГАНИЗАЦИЙ (ДВИЖЕНИЙ) в 2016 r.}

(по итогам Комплексного наблюдения условий жизни населения; в процентах)

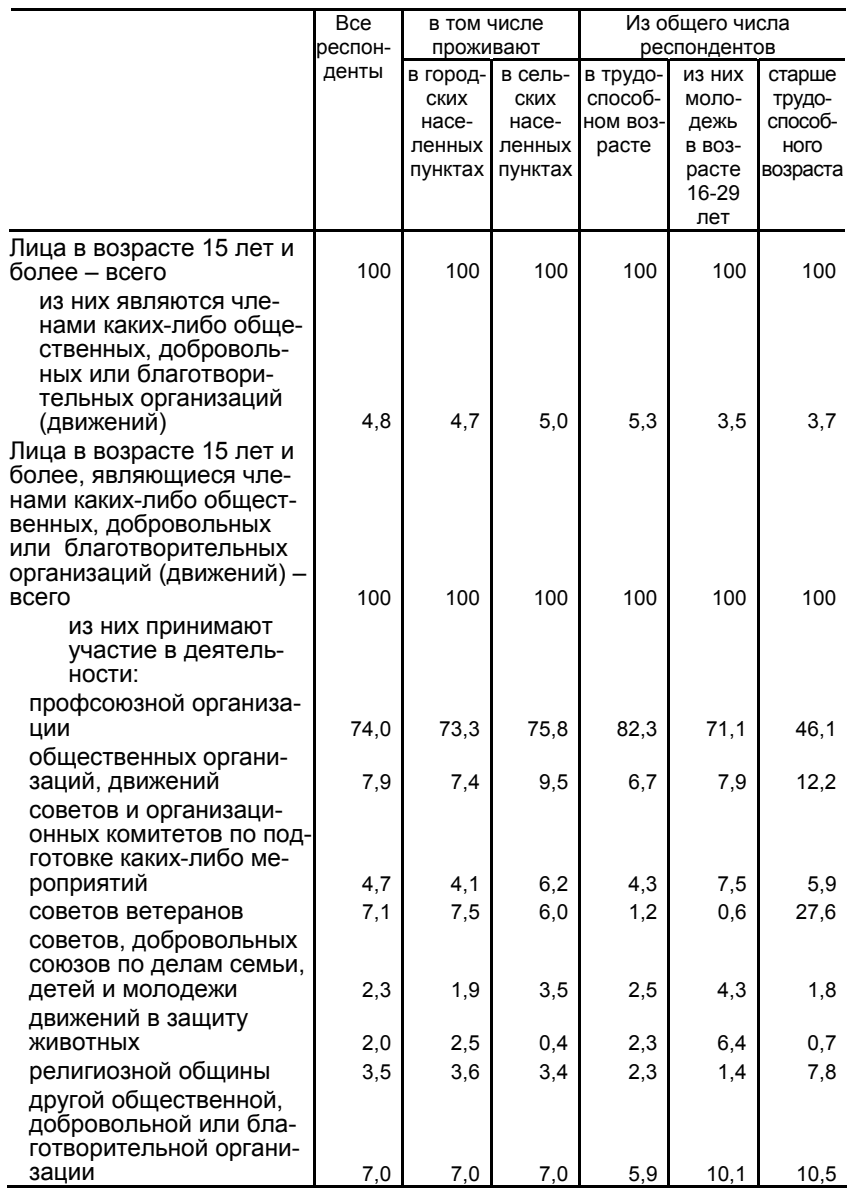




\section{2. ПРАВОНАРУШЕНИЯ}

Раздел содержит данные о состоянии преступности и судимости, в том числе по отдельным видам наиболее опасных или распространенных преступлений. Публикуются сведения о выявленных лицах, совершивших преступления. Представлены данные о численности, составе и распределении осужденных по основным мерам наказания.

Информация приводится по данным Генеральной прокуратуры Российкой Федерации, Следственного комитета Россииской Федерации, Министерства внутренних дел Российской Федерации, Министерства Российскои Федерации по делам гражданской обороны, чрезвычайным ситуациям и ликвидации последствий стихийных бедствий, Федеральной службы исполнения наказаний, Федеральной службы судебных приставов, Федеральной службы безопасности Российской Федерации, Федеральной таможенной службы и Судебного департамента при Верховном Суде Российской Федерации.

Зарегистрированное преступление - выявленное и официально взятое на учет общественно опасное деяние, предусмотренное уголовным законодательством. Регистрация преступлений и лиц, их совершивших, осуществляется всеми правоохранительными органами, осуществляющими в пределах своей компетенции уголовное преследование.

В численность осужденных входят лица, в отношении которых судами вынесены обвинительные приговоры, вступившие в законную силу.

\section{1. ЧИСЛО ЗАРЕГИСТРИРОВАННЫХ ПРЕСТУПЛЕНИЙ}

(тысяч)

\begin{tabular}{l|r|r|r|r|r|r|r|r|r}
\hline & 1992 & 2000 & 2005 & 2010 & 2013 & 2014 & 2015 & 2016 & 2017 \\
\hline $\begin{array}{l}\text { Зарегистрировано } \\
\text { преступлений - всего }\end{array}$ & $\mathbf{2 7 6 1}$ & $\mathbf{2 9 5 2}$ & $\mathbf{3 5 5 5}$ & $\mathbf{2 6 2 9}$ & $\mathbf{2 2 0 6}$ & $\mathbf{2 1 9 1}$ & $\mathbf{2 3 8 8}$ & $\mathbf{2 1 6 0}$ & $\mathbf{2 0 5 8}$ \\
$\begin{array}{l}\text { в том числе: } \\
\text { убийство и покуше- } \\
\text { ние на убийство } \\
\text { умышленное причи- }\end{array}$ & 23,0 & 31,8 & 30,8 & 15,6 & 12,4 & 11,9 & 11,5 & 10,4 & 9,7 \\
нение тяжкого вреда & & & & & & & & & \\
здоровью & 53,9 & 49,8 & 57,9 & 39,7 & 34,8 & 32,9 & 30,2 & 27,4 & 24,6 \\
изнасилование & & & & & & & & & \\
и покушение на & & & & & & & & \\
изнасилование & 13,7 & 7,9 & 9,2 & 4,9 & 4,2 & 4,2 & 3,9 & 3,9 & 3,5 \\
разбой & 30,4 & 39,4 & 63,7 & 24,5 & 16,4 & 14,3 & 13,6 & 11,4 & 9,1 \\
грабеж & 165 & 132 & 344 & 165 & 92,1 & 77,7 & 72,7 & 61,5 & 56,9 \\
кража & 1651 & 1310 & 1573 & 1108 & 923 & 909 & 1018 & 871 & 789 \\
террористический & & 135 & 203 & 31 & 31 & 33 & 8 & 25 & 37 \\
акт), единиц & $\ldots$ & 135
\end{tabular}

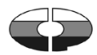


Продолжение табл. 12.1

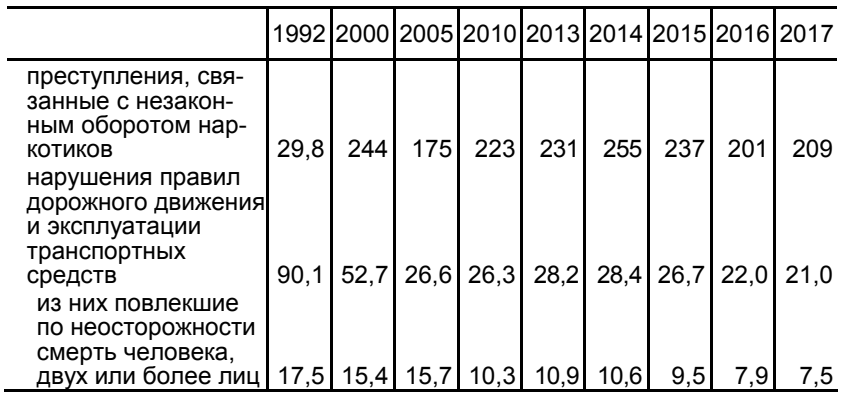

${ }^{1)}$ До 2010 г. - терроризм.

12.2. СОСТАВ ЛИЦ, СОВЕРШИВШИХ ПРЕСТУПЛЕНИЯ, ПО ПОЛУ, ВОЗРАСТУ И ВИДУ ЗАНЯТИЙ

(тыс. человек)

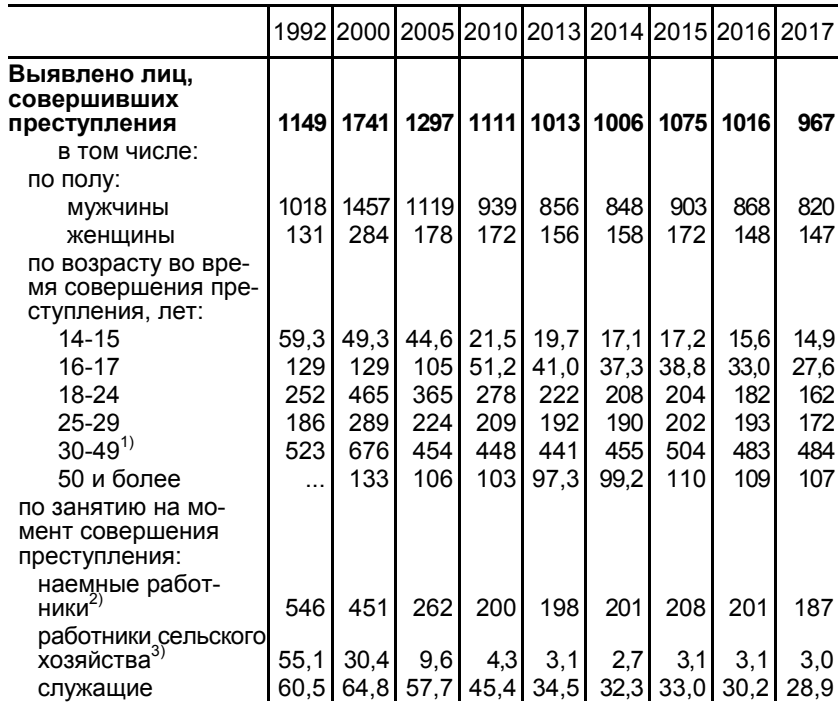


Продолжение табл. 12.2

\begin{tabular}{l|r|r|r|r|r|r|r|r|r}
\hline & 1992 & 2000 & 2005 & 2010 & 2013 & 2014 & 2015 & 2016 & 2017 \\
\hline $\begin{array}{l}\text { учащиеся и студен- } \\
\text { ты }\end{array}$ & 104 & 101 & 87,1 & 72,0 & 60,9 & 54,9 & 56,0 & 50,0 & 45,5 \\
лица без постоянно- \\
го источника дохо- \\
да
\end{tabular}

1) 1992 г. - 30 лет и старше.

2) До 2010 г. - рабочие.

3) 1992 г. - колхозники.

4) До 2010 г. - учащиеся.

5) До 2016 г. - с учетом безработных.

12.3. РАСПРЕДЕЛЕНИЕ ОСУЖДЕННЫХ ПО ОСНОВНЫМ МЕРАМ НАКАЗАНИЯ, НАЗНАЧЕННЫМ СУДАМИ

(в процентах к итогу)

\begin{tabular}{l|r|r|r|r|r|r|r|r|r}
\hline & 1992 & 2000 & 2005 & 2010 & 2013 & 2014 & 2015 & 2016 & 2017 \\
\hline $\begin{array}{l}\text { Осуждено - всего } \\
\text { в том числе по } \\
\text { мерам наказания: }\end{array}$ & $\mathbf{1 0 0}$ & $\mathbf{1 0 0}$ & $\mathbf{1 0 0}$ & $\mathbf{1 0 0}$ & $\mathbf{1 0 0}$ & $\mathbf{1 0 0}$ & $\mathbf{1 0 0}$ & $\mathbf{1 0 0}$ & $\mathbf{1 0 0}$ \\
$\begin{array}{l}\text { лишение свободы } \\
\text { исправительные }\end{array}$ & 34,2 & 29,9 & 34,9 & 31,5 & 28,5 & 29,1 & 28,8 & 27,8 & 28,7 \\
работы & 18,3 & 4,3 & 4,9 & 4,9 & 10,3 & 10,4 & 8,3 & 7,0 & 7,9 \\
условное & & & & & & & & & \\
$\begin{array}{l}\text { осуждение к } \\
\text { лишению свободы } \\
\text { и к иным мерам }\end{array}$ & 11,2 & 45,9 & 48,4 & 38,1 & 30,3 & 30,4 & 25,4 & 26,8 & 27,2 \\
штраф & 9,5 & 5,3 & 10,3 & 14,6 & 15,8 & 15,5 & 11,8 & 13,5 & 13,0 \\
другие меры & 6,5 & 14,6 & 1,5 & 10,9 & 15,0 & 14,5 & 13,0 & 24,8 & 23,2 \\
наказания &
\end{tabular}

12.4. ЧИСЛЕННОСТЬ ОСУЖДЕННЫХ ПО ПРИГОВОРАМ СУДОВ, ВСТУПИВШИМ В ЗАКОННУЮ СИЛУ, ПО ОТДЕЛЬНЫМ ВИДАМ ПРЕСТУПЛЕНИЙ

(тыс. человек)

\begin{tabular}{|c|c|c|c|c|c|c|c|c|c|}
\hline & 1992 & 2000 & 2005 & 2010 & 2013 & 2014 & 2015 & 2016 & 20 \\
\hline $\begin{array}{r}\text { Гсужде } \\
\text { из } \\
\text { стуг }\end{array}$ & 661 & 1184 & 879 & 845 & 736 & 719 & 734 & 740 & 69 \\
\hline $\begin{array}{l}\text { убийство } \\
\text { умышленное при- } \\
\text { чинение тяжкого }\end{array}$ & 12,4 & 19,4 & 20,3 & 12,4 & 9,3 & 9,2 & 9,1 & 8,9 & \\
\hline & $\begin{array}{l}23,1 \\
115\end{array}$ & $\begin{array}{r}35,0 \\
6.4\end{array}$ & $\begin{array}{r}43,0 \\
6.6\end{array}$ & $\begin{array}{r}33,8 \\
4,0\end{array}$ & $\begin{array}{r}30,2 \\
2,9\end{array}$ & $\begin{array}{r}28,8 \\
29\end{array}$ & $\begin{array}{r}26,9 \\
27\end{array}$ & $\begin{array}{r}25,2 \\
25\end{array}$ & 22 \\
\hline & & & & & & 2,9 & & 2,5 & \\
\hline
\end{tabular}

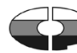


Продолжение табл. 12.4

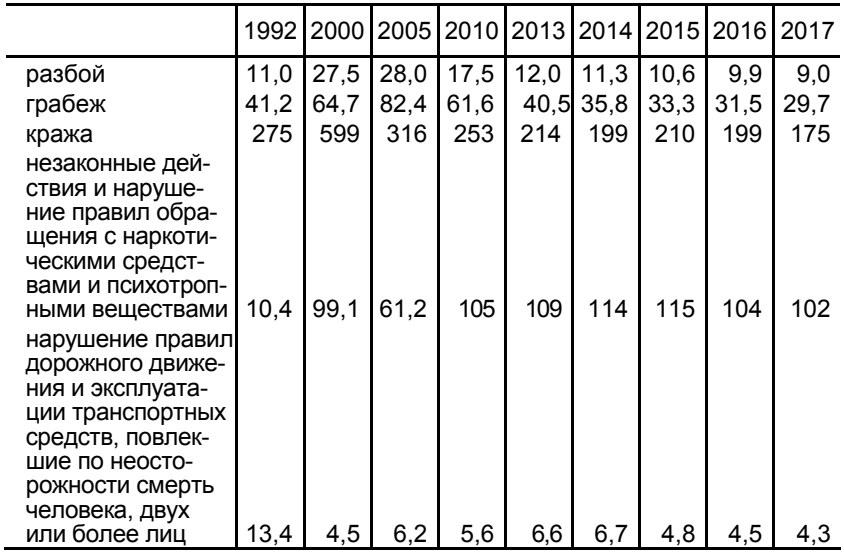

12.5. СОСТАВ ОСУЖДЕННЫХ

(в процентах)

\begin{tabular}{|c|c|c|c|c|c|c|c|c|c|}
\hline & 1992 & 2000 & 2005 & 2010 & 2013 & 2014 & 2015 & 2016 & 2017 \\
\hline $\begin{array}{l}\text { Осуждено - } \\
\text { всего }\end{array}$ & 100 & 100 & 100 & 100 & 100 & 100 & 100 & 100 & 100 \\
\hline $\begin{array}{l}\text { из них в воз- } \\
\text { расте, лет: }\end{array}$ & & & & & & & & & \\
\hline 14-17 & 13,8 & 12,6 & 11,3 & 5,5 & 4,0 & 3,3 & 3,1 & 3,2 & 3,0 \\
\hline $18-24$ & 23,6 & 31,3 & 29,5 & 27,0 & 23,5 & 22,1 & 20,7 & 19,0 & 17,7 \\
\hline $25-29$ & 17,7 & 16,3 & 17,9 & 19,5 & 19,7 & 19,9 & 19,9 & 20,2 & 19,3 \\
\hline $30-49$ & 39,5 & 34,9 & 35,1 & 40,5 & 44,9 & 46,6 & 48,4 & 48,7 & 51,0 \\
\hline $\begin{array}{l}50 \text { и } \\
\text { более }\end{array}$ & 5,4 & 4,9 & 6,2 & 7,5 & 7,9 & 8,1 & 7,9 & 8,8 & 9,1 \\
\hline $\begin{array}{l}\text { Из общей чис- } \\
\text { ленности осу- } \\
\text { жденных: }\end{array}$ & & & & & & & & & \\
\hline женщины & 7,2 & 13,0 & 13,2 & 15,2 & 14,9 & 14,4 & 14,0 & 13,3 & 13,5 \\
\hline $\begin{array}{l}\text { ранее суди- } \\
\text { мые }^{1)}\end{array}$ & 38,8 & 35,0 & 40,8 & 42,9 & 45,4 & 44,2 & 43,8 & 42,2 & 43,9 \\
\hline $\begin{array}{l}\text { трудоспособ- } \\
\text { ные лица без }\end{array}$ & & & & & & & & & \\
\hline $\begin{array}{l}\text { определенных } \\
\text { занятий }\end{array}$ & 26,1 & 50,1 & 57,2 & 60,3 & 62,0 & 63,0 & 64,0 & 63,3 & 63,4 \\
\hline
\end{tabular}

${ }^{1)}$ Включены лица, имеющие неснятые и непогашенные судимости, а также юридически ранее не судимые лица, имеющие снятые и погашенные судимости. 


\section{3. ПРОИЗВОДСТВО И ИСПОЛЬЗОВАНИЕ ВАЛОВОГО ВНУТРЕННЕГО ПРОДУКТА}

В данном разделе публикуются важнейшие показатели системы национальных счетов России за 2000-2016 гг.

Система национальных счетов $(\mathrm{CHC})$ представляет собой систему взаимосвязанных показателей, применяемых для описания и анализа макроэкономических процессов более чем в 150 странах мира с рыночной экономикой.

Данные о ВВП, публикуемые в данном сборнике за 2010-2015 гт., отличаются от опубликованных ранее. Уточнения связаны с получением информации по ряду федеральных статистических наблюдений, данных об исполнении государственного бюджета, актуализации платежного баланса.

Ключевым показателем системы является валовой внутренний продукт (ВВП), характеризующий стоимость товаров и услуг, произведенных в стране во всех отраслях экономики и предназначенных для конечного потребления, накопления и экспорта (за вычетом импорта).

ВВП может быть рассчитан тремя методами: производственным, методом использования доходов и методом формирования ВВП по источникам доходов.

При расчете производственным методом ВВП определяется как разность между выпуском товаров и услуг в целом по стране, с одной стороны, и промежуточным потреблением с другой, или как сумма добавленных стоимостей, создаваемых в отраслях экономики. При этом объемы добавленной стоимости по отраслям рассчитываются в основных ценах, т.е. не включают налоги на продукты, но включают субсидии на продукты. Для расчета ВВП в рыночных ценах необходимо добавить чистые (за вычетом субсидий) налоги на продукты.

Валовой внутренний продукт, рассчитанный методом использования доходов, представляет сумму расходов всех институциональных единиц - резидентов данной страны на конечное потребление, валовое накопление и чистый экспорт.

Формирование валового внутреннего продукта по источникам доходов отражает первичные доходы, созданные в процессе производства всеми институциональными единицами, сгруппированными в сектора экономики. В этом расчете валовая прибыль (валовой смешанный доход) является балансирующей статьей и определяется как разница между валовым

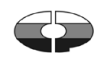


внутренним продуктом, рассчитанным производственным методом в рыночных ценах, оплатой труда наемных работников и чистыми налогами на производство и импорт.

Данный метод используется Росстатом только для анализа стоимостной структуры ВВП, а не для определения его номинального объема или динамики.

В границы производства в СНС включается скрытое производство (экономическая деятельность, разрешенная законом, но скрываемая или преуменьшаемая с целью уклонения от налогов и др.), а также неформальное производство - производственная деятельность некорпорированных предприятий домашних хозяйств, не подпадающая под прямое статистическое наблюдение. В настоящее время в состав неформального производства включается производство некорпорированными предприятиями рыночной продукции и продукции для собственного использования.

Производство в СНС характеризуется показателями выпуска, промежуточного потребления и валовой добавленной стоимости.

Выпуск представляет собой суммарную стоимость товаров и услуг, являющихся результатом производственной деятельности единиц - резидентов экономики в отчетном периоде.

Текущие цены могут быть основными и рыночными. Основными называются цены, включающие субсидии на продукты, но не включающие налоги на продукты. В основных ценах принято исчислять выпуск в отраслевом разрезе. Рыночные цены, наоборот, включают в себя налоги на продукты, но не включают субсидии. В рыночных ценах исчисляются показатели выпуска и валового внутреннего продукта на уровне экономики в целом.

Промежуточное потребление состоит из стоимости товаров и услуг, которые трансформируются или полностью потребляются в процессе производства в отчетном периоде.

Валовая добавленная стоимость исчисляется на уровне отраслей экономики как разность между выпуском товаров и услуг и промежуточным потреблением. Термин "валовая" указывает на то, что показатель определен до вычета потребления основного капитала.

Чистые налоги на производство и импорт включают в себя налоги на продукты и импорт и другие налоги на производство. Термин "чистые" в данном случае означает, что налоги показаны за вычетом соответствующих субсидий. Субсидии текущие некомпенсируемые выплаты из государственного бюджета предприятиям при условии производства ими определенного вида продукции или услуг.

Налоги на продукты включают в себя налоги, размер которых прямо зависит от стоимости произведенной продукции и оказанных услуг. К налогам на продукты относятся: налог 
на добавленную стоимость, акцизы, налоги на импортируемые товары и услуги и некоторые другие.

Другие налоги на производство - это налоги, связанные с использованием факторов производства (труда, земли, капитала), а также платежи за лицензии и разрешение заниматься какой-либо деятельностью или другие обязательные платежи, уплата которых необходима для деятельности производящей единицы - резидента. Они не включают в себя любые налоги на прибыль или иные доходы, получаемые предприятием. К ним относятся: налог на имущество предприятий, земельный налог, транспортный налог (юридических лиц и индивидуальных предпринимателей), лицензионные сборы и некоторые другие.

Валовой внутренний продукт на стадии производства получается путем суммирования валовой добавленной стоимости по отраслям в основных ценах плюс чистые налоги на продукты.

Оплата труда наемных работников представляет собой вознаграждение в денежной или натуральной форме, выплачиваемое работодателем наемному работнику за работу, выполненную в отчетном периоде.

Она учитывается на основе начисленных сумм и включает в себя налоги на доходы и другие выплаты, которые подлежат уплате наемными работниками, даже если они фактически удерживаются нанимателями в административных интересах или по иным причинам, и выплачиваются непосредственно органам социального страхования, налоговым службам от лица наемного работника.

Особенностью расчета оплаты труда наемных работников в российских национальных счетах является то, что она включает помимо оплаты труда наемных работников, не наблюдаемой прямыми статистическими методами, и ненаблюдаемые смешанные доходы.

Оплата труда наемных работников и смешанные доходы, не наблюдаемые прямыми статистическими методами, определяются балансовым путем условно как разница между суммарными расходами на все нужды домашних хозяйств, включая прирост их финансовых активов, и формально зарегистрированными доходами. Расчеты по определению оплаты труда и смешанных доходов, не наблюдаемых прямыми статистическими методами, производятся по экономике в целом без разбивки по отраслям, видам деятельности и территориям.

Показатель ненаблюдаемых смешанных доходов связан с информационными проблемами отнесения институциональных единиц к сектору домашних хозяйств с точки зрения их производственной деятельности.

Ненаблюдаемые смешанные доходы имеют место в тех случаях, когда доходы от производственной деятельности до-

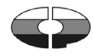


машних хозяйств учтены не в секторе домашних хозяйств, а в секторе нефинансовых корпораций, либо, наоборот, доходы от производства сектора нефинансовых корпораций учтены в секторе домашних хозяйств. В этих случаях при сопоставлении суммарных расходов домашних хозяйств с их формально зарегистрированными доходами производится корректировка смешанных доходов домашних хозяйств и обратная корректировка валовой прибыли сектора нефинансовых корпораций на эту же величину.

Валовая (чистая) прибыль и валовые (чистые) смешанные доходы представляют собой ту часть добавленной стоимости, которая остается у производителей после вычета расходов, связанных с оплатой труда наемных работников, и чистых налогов на производство и импорт. Эта статья измеряет прибыль (или убыток), полученную от производства, до учета доходов от собственности. Валовая прибыль в СНС в отличие от показателя прибыли от реализации, отражаемой в бухгалтерском учете, не содержит элементов оплаты труда, сверхнормативных выплат по командировочным, представительских и других расходов, прибыли, образующейся у владельцев активов в результате роста цен, и включает в себя потребление основного капитала, равного стоимостной оценке величины снижения в течение отчетного периода текущей стоимости основных фондов, находящихся в собственности и пользовании производителей, в результате физического износа, нормального устаревания или естественных случайных повреждений.

Чистая прибыль равняется валовой прибыли за вычетом потребления основного капитала.

Для некорпорированных предприятий, принадлежащих домашним хозяйствам, эта статья содержит элемент вознаграждения за работу, который не может быть отделен от дохода владельца или предпринимателя. В этом случае она называется смешанным доходом.

Конечное потребление складывается из расходов на конечное потребление домашних хозяйств, расходов государственного управления на индивидуальные товары и услуги и на коллективные услуги, расходов на конечное потребление некоммерческих организаций, обслуживающих домашние хозяйства.

Расходы на конечное потребление домашних хозяйств включают расходы домашних хозяйств на приобретение потребительских товаров и услуг во всех торговых организациях, на рынках и через неорганизованную торговлю, организациях бытового и жилищно-коммунального обслуживания населения, пассажирского транспорта, связи, гостиницах, учреждениях культуры, здравоохранения, образования и др., а также стоимость товаров и услуг, потребленных в натуральной форме, произведенных для 
собственного конечного использования, полученных в качестве оплаты труда или гуманитарной помощи.

Расходы государственного управления на индивидуальные товары и услуги состоят из расходов сектора государственного управления на потребительские товары и услуги, предназначенные для индивидуального потребления. Такие расходы финансируются за счет государственного бюджета и внебюджетных фондов из средств, полученных в результате сбора налогов и из других доходов государства. В эти расходы включаются расходы организаций, оказывающих бесплатные (для населения) услуги в области образования, здравоохранения, культуры.

Расходы государственного управления на коллективные услуги. Этот показатель отличается от предыдущего тем, что в нем учитываются услуги, оказываемые за счет государственного бюджета организациями, которые удовлетворяют потребности не отдельных домашних хозяйств, а общества в целом. В этот показатель включаются расходы на оборону, общее государственное управление, а также расходы на нерыночную науку, услуги организаций, обслуживающих сельское хозяйство и другие.

Расходы на конечное потребление некоммерческих организаций, обслуживающих домашние хозяйства, - расходы общественных организаций (политических партий, религиозных организаций, профсоюзов, общественных объединений), в отношении которых условно считается, что они предоставляют только индивидуальные товары и услуги. Сюда же включается стоимость нерыночных услуг, оказываемых самостоятельными социально-культурными подразделениями корпораций и квазикорпораций своим работникам.

Валовое накопление в целом по экономике показывает чистое приобретение резидентными единицами товаров и услуг, произведенных или поступивших по импорту в текущем периоде, но не потребленных в нем. Валовое накопление включает валовое накопление основного капитала, изменение запасов материальных оборотных средств и чистое приобретение ценностей.

Чистый экспорт товаров и услуг рассчитывается как разница между экспортом и импортом и включает в себя оборот российской торговли со странами дальнего зарубежья и СНГ.

Статистическое расхождение между произведенным и использованным валовым внутренним продуктом показывает расхождение между значениями ВВП, рассчитанными различными способами: как суммы валовой добавленной стоимости и как суммы конечного потребления, накопления и чистого экспорта.

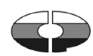




\section{1. ПРОИЗВОДСТВО ВАЛОВОГО ВНУТРЕННЕГО ПРОДУКТА ${ }^{1)}$}

(в текущих ценах; млрд. рублей)

\begin{tabular}{|c|c|c|c|c|c|c|c|c|}
\hline & 2000 & 2005 & 2010 & 2013 & 2014 & 2015 & 2016 & 2017 \\
\hline $\begin{array}{l}\text { Выпуск в основных } \\
\text { ценах }\end{array}$ & 12552 & 37021 & 82055 & |21574 & 133110 & 154822 & 154578 & 166754 \\
\hline $\begin{array}{l}\text { Промежуточное } \\
\text { потребление } \\
\text { Валовая добавлен- } \\
\text { ная стоимость }\end{array}$ & 6080 & 18503 & 42015 & 59822 & 64203 & 71435 & 76970 & 83695 \\
\hline $\begin{array}{l}\text { в основных ценах } \\
\text { Чистые налоги }\end{array}$ & 6472 & 18518 & 40040 & 61752 & 68908 & 74764 & 77607 & 83059 \\
\hline $\begin{array}{l}\text { на продукты } \\
\text { Валовои внутренний }\end{array}$ & 833 & 3092 & 6269 & 9264 & 10292 & 8466 & 8541 & 8978 \\
\hline $\begin{array}{l}\text { продукт в рыночных } \\
\text { ценах }\end{array}$ & 7306 & 21610 & 46309 & 71017 & 79200 & 83387 & 86149 & 92037 \\
\hline
\end{tabular}

1) Данные, начиная с 2011 г. отличаются от данных за предыдущие годы тем, что содержат изменения, связанные с внедрением международной методологии оценки жилищных услуг, производимых и потребляемых собственниками жилья; оценкой потребления основного капитала исходя из его текущей рыночной стоимости; согласованием данных об экспорте и импорте с данными платежного баланса, разработанного по методологии 6 издания «Руководства МВФ по платежному балансу и международной инвестиционной позиции» (ОПБ6); актуализацией данных по итогам разработки базовых таблиц «Затраты-выпуск» за 2011 год, включением оценки услуг домашних работников (домашней прислуги), а также внедрением положений СНС 2008 года относительно учета результатов научных исследований и разработок и систем вооружения.

\section{2. СТРУКТУРА ВЫПУСКА ПО ОТРАСЛЯМ ЭКОНОМИКИ} (в текущих основных ценах; в процентах к итогу)

\begin{tabular}{l|r|r}
\hline & 2016 & 2017 \\
\hline Выпуск в основных ценах & 100 & 100 \\
$\quad$ в том числе по отраслям экономики: & & \\
сельское, лесное хозяйство, охота, & 4,4 & 4,2 \\
рыболовство и рыбоводство & 7,3 & 8,0 \\
добыча полезных ископаемых & 24,5 & 24,7 \\
обрабатывающие производства & & \\
обеспечение электрической энергией, газом & 4,9 & 4,8 \\
и паром; кондиционирование воздуха & & \\
водоснабжение; водоотведение, организация & & \\
сбора и утилизации отходов, деятельность & & \\
по ликвидации загрязнений & 0,6 & 6,9 \\
строительство & 6,9 & 12,9 \\
торговля оптовая и розничная; ремонт & & 7,8 \\
автотранспортных средств и мотоциклов & 13,0 & \\
транспортировка и хранение & 7,7 & \\
деятельность гостиниц и предприятий & & \\
общественного питания & 1,0 & 0,9
\end{tabular}


Продолжение табл. 13.2

\begin{tabular}{|c|c|c|}
\hline & 2016 & 2017 \\
\hline деятельность в области информации и связи & 2,3 & 2,3 \\
\hline деятельность финансовая и страховая & 3,1 & 3,1 \\
\hline деятельность по операциям с недвижимым & & \\
\hline имуществом & 6,6 & 6,4 \\
\hline $\begin{array}{l}\text { деятельность профессиональная, научная } \\
\text { и техническая }\end{array}$ & 4,2 & 4,1 \\
\hline $\begin{array}{l}\text { деятельность административная и сопутст- } \\
\text { вующие дополнительные услуги }\end{array}$ & 1,6 & 1,6 \\
\hline $\begin{array}{l}\text { государственное управление и обеспечение } \\
\text { военной безопасности; социальное обеспечение } \\
\text { образование }\end{array}$ & $\begin{array}{l}6,0 \\
1,6\end{array}$ & $\begin{array}{l}5,8 \\
1,6\end{array}$ \\
\hline $\begin{array}{l}\text { деятельность в области здравоохранения } \\
\text { и социальных услуг }\end{array}$ & 2,8 & 2,7 \\
\hline $\begin{array}{l}\text { деятельность в области культуры, спорта, } \\
\text { организации досуга и развлечений }\end{array}$ & 0,7 & 0,8 \\
\hline предоставление прочих видов услуг & 0,4 & 0,4 \\
\hline $\begin{array}{l}\text { деятельность домашних хозяйств как работо- } \\
\text { дателей; недифференцированная деятель- } \\
\text { ность частных домашних хозяйств по производ- } \\
\text { ству товаров и оказанию услуг для собственно- } \\
\text { го потребления }\end{array}$ & 0,3 & 0,3 \\
\hline
\end{tabular}

\section{3. СТРУКТУРА ВАЛОВОЙ ДОБАВЛЕННОЙ СТОИМОСТИ ПО ОТРАСЛЯМ ЭКОНОМИКИ}

(в текущих основных ценах; в процентах к итогу)

\begin{tabular}{l|r|r}
\hline & 2016 & 2017 \\
\hline $\begin{array}{l}\text { Валовая добавленная стоимость в основных } \\
\text { ценах }\end{array}$ & 100 & 100 \\
$\quad$ в том числе по отраслям экономики: & & \\
сельское, лесное хозяйство, охота, рыболовство & 4,6 & 4,4 \\
и рыбоводство & 9,5 & 10,4 \\
добыча полезных ископаемых & 13,3 & 13,2 \\
обрабатывающие производства & 2,9 & 2,9 \\
обеспечение электрической энергией, газом & & \\
и паром; кондиционирование воздуха & & \\
водоснабжение; водоотведение, организация & & \\
сбора и утилизации отходов, деятельность & 0,5 & 6,4 \\
по ликвидации загрязнений & 6,4 & 14,3 \\
строительство & 14,6 & 6,9 \\
торговля оптовая и розничная; ремонт & 7,0 \\
автотранспортных средств и мотоциклов & & \\
транспортировка и хранение & & \\
деятельность гостиниц и предприятий & 0,9 & 0,9 \\
общественного питания & 2,3 & 2,4 \\
деятельность в области информации и связи & 4,2 & 4,2 \\
деятельность финансовая и страховая &
\end{tabular}


Продолжение табл. 13.3

\begin{tabular}{l|c|c}
\hline & 2016 & 2017 \\
\hline $\begin{array}{l}\text { деятельность по операциям с недвижимым } \\
\text { имуществом }\end{array}$ & 10,1 & 9,9 \\
$\begin{array}{l}\text { деятельность профессиональная, научная } \\
\text { и техническая }\end{array}$ & 4,9 & 4,8 \\
$\begin{array}{l}\text { деятельность административная и сопутст- } \\
\text { вующие дополнительные услуги }\end{array}$ & 2,5 & 2,5 \\
$\begin{array}{l}\text { государственное управление и обеспечение } \\
\text { военнй безопасности; социальное обеспечение }\end{array}$ & 8,1 & 7,9 \\
$\begin{array}{l}\text { образование } \\
\text { деятельность в области здравоохранения }\end{array}$ & 2,6 & 2,6 \\
$\begin{array}{l}\text { и социальных услуг } \\
\text { деятельность в области культуры, спорта, }\end{array}$ & 3,6 & 3,7 \\
$\begin{array}{l}\text { организации досуга и развлечений } \\
\text { педоставление прочих видов услуг }\end{array}$ & 0,9 & 0,9 \\
$\begin{array}{l}\text { деятельность домашних хозяйств как работо- } \\
\text { дателей; недифференцированная деятель- }\end{array}$ & 0,5 & 0,5 \\
$\begin{array}{l}\text { ность частных домашних хозяйств по произ- } \\
\text { водству товаров и оказанию услуг для собст- }\end{array}$ & & \\
венного потребления & 0,7 & 0,6 \\
\hline
\end{tabular}

13.4 ВАЛОВОЙ ВНУТРЕННИЙ ПРОДУКТ ПО ИСТОЧНИКАМ ДОХОДОВ ${ }^{1)}$

(в текущих ценах; млрд. рублей)

\begin{tabular}{|c|c|c|c|c|c|c|c|c|}
\hline & 2000 & 2005 & 2010 & 2013 & 2014 & 2015 & 2016 & 2017 \\
\hline $\begin{array}{c}\text { Валовой внутрен- } \\
\text { ний продукт в ры- } \\
\text { ночных ценах } \\
\text { в том числе: }\end{array}$ & 7306 & 21610 & 46309 & 71017 & 79200 & 83387 & 86149 & 92037 \\
\hline $\begin{array}{c}\text { оплата труда наем- } \\
\text { ных работников } \\
\text { из нее оплата тру- } \\
\text { да наемных ра- } \\
\text { ботников и сме-- } \\
\text { шанные доходы } \\
\text { не наблюдаемые } \\
\text { прямыми стати- } \\
\text { стическими мето- }\end{array}$ & 2937 & 9474 & 22996 & 33144 & 37387 & 39110 & 41277 & 44263 \\
\hline $\begin{array}{l}\text { дами } \\
\text { чистые налоги } \\
\text { на производство }\end{array}$ & 810 & 2551 & 6632 & 8506 & 10536 & 10565 & 10972 & 11727 \\
\hline $\begin{array}{c}\text { на производство } \\
\text { и импорт } \\
\text { в том числе: } \\
\text { чистые налоги }\end{array}$ & 1249 & 4248 & 8219 & 10062 & 11004 & 9270 & 9421 & 9955 \\
\hline $\begin{array}{l}\text { на продукты } \\
\text { другие чистые }\end{array}$ & 834 & 3092 & 6269 & 9264 & 10292 & 8466 & 8541 & 8978 \\
\hline $\begin{array}{l}\text { налоги на произ- } \\
\text { водство } \\
\text { Валовая прибыль }\end{array}$ & 415 & 1156 & 1950 & 798 & 712 & 804 & 880 & 977 \\
\hline $\begin{array}{l}\text { экономики и валовые } \\
\text { смешанные доходы }\end{array}$ & 3120 & 7887 & 15094 & 27811 & 30809 & 35007 & 35451 & 37819 \\
\hline
\end{tabular}

1) См. сноску на стр.179. 
13.5. ВАЛОВОЙ ВНУТРЕННИЙ ПРОДУКТ ПО ИСТОЧНИКАМ ДОХОДОВ ${ }^{1)}$ (в процентах к итогу)

\begin{tabular}{|c|c|c|c|c|c|c|c|c|}
\hline & 2000 & 2005 & 2010 & 2013 & 2014 & 2015 & 2016 & 2017 \\
\hline \multicolumn{9}{|l|}{ Валовой внутренний } \\
\hline ценах & 100 & 100 & 100 & 100 & 100 & 100 & 100 & 100 \\
\hline $\begin{array}{l}\text { оплата труда наемных } \\
\text { работников }\end{array}$ & 40,2 & 43,8 & 49,6 & 46,7 & 47,2 & 46,9 & 47,9 & 48,1 \\
\hline $\begin{array}{l}\text { из нее оплата тру- } \\
\text { да наемных работ- } \\
\text { ников и смешанные } \\
\text { доходы не наблю- } \\
\text { даемые прямыми }\end{array}$ & & & & & & & & \\
\hline $\begin{array}{l}\text { статистическими } \\
\text { методами }\end{array}$ & 11,1 & 11,8 & 14,3 & 12,0 & 13,3 & 12,7 & 12,7 & 12,8 \\
\hline чистые налоги & & & & & & & & \\
\hline $\begin{array}{c}\text { на производство } \\
\text { в том числе: }\end{array}$ & 17,1 & 19,7 & 17,8 & 14,2 & 13,9 & 11,1 & 10,9 & 10,8 \\
\hline $\begin{array}{l}\text { чистые налоги } \\
\text { на продукты }\end{array}$ & 11,4 & 14,3 & 13,6 & 13,1 & 13,0 & 10,2 & 9,9 & 9.8 \\
\hline $\begin{array}{l}\text { другие чистые налоги } \\
\text { на производство }\end{array}$ & 5,7 & 5,4 & 4,2 & 1,1 & 0,9 & 0,9 & 1,0 & 1,0 \\
\hline $\begin{array}{l}\text { валовая прибыль } \\
\text { экономики и валовые }\end{array}$ & & & & & & & & \\
\hline смешанные доходы & 42,7 & 36,5 & 32,6 & 39,1 & 38,9 & 42,0 & 41,2 & 41,1 \\
\hline
\end{tabular}

${ }^{1)}$ См. сноску на стр. 179 .

\section{6. ИСПОЛЬЗОВАНИЕ ВАЛОВОГО ВНУТРЕННЕГО ПРОДУКТА ${ }^{1)}$}

(в текущих ценах; млрд. рублей)

\begin{tabular}{|c|c|c|c|c|c|c|c|c|}
\hline & 2000 & 2005 & 2010 & 2013 & 2014 & 2015 & 2016 & 2017 \\
\hline $\begin{array}{l}\text { Вал̆овой внутрен- } \\
\text { ний продукт } \\
\text { в рыночных ценах }\end{array}$ & 7306 & 21610 & 46309 & 73134 & 79200 & 83387 & 86149 & 92037 \\
\hline $\begin{array}{l}\text { в том числе: } \\
\text { расходы на конеч- } \\
\text { ное потребление }\end{array}$ & 4477 & 14438 & 32514 & 52274 & 56511 & 58445 & 61060 & 64763 \\
\hline $\begin{array}{l}\text { из них: } \\
\text { домашних хозяйств }\end{array}$ & 3295 & 10653 & 23617 & 38465 & 42016 & 43336 & 44965 & 47872 \\
\hline & 1103 & 3646 & 8671 & 13552 & 14207 & 14795 & 15751 & 16549 \\
\hline $\begin{array}{l}\text { в том числе: } \\
\text { на индивиду- } \\
\text { альные товары } \\
\text { и услуги }\end{array}$ & 439 & 1663 & 4118 & 5727 & 6211 & 6445 & 6663 & 6949 \\
\hline $\begin{array}{l}\text { услуги } \\
\text { некоммерческих } \\
\text { организаций, об- }\end{array}$ & 664 & 1983 & 4553 & 7825 & 7996 & 8350 & 9088 & 9600 \\
\hline $\begin{array}{l}\text { служивающих до- } \\
\text { машние хозяйства }\end{array}$ & 79 & 139 & 226 & 257 & 288 & 314 & 344 & 342 \\
\hline $\begin{array}{c}\text { валовое накопление } \\
\text { в том числе: } \\
\text { валовое накопле- }\end{array}$ & 1366 & 4339 & 10473 & 16916 & 17615 & 18241 & 19672 & 21962 \\
\hline $\begin{array}{l}\text { ние оснернооо ка- } \\
\text { питала } \\
\text { изменение запа- }\end{array}$ & 1232 & 3837 & 10015 & 15926 & 16828 & 16942 & 18403 & 19966 \\
\hline $\begin{array}{l}\text { сов материальных } \\
\text { оборотных средств }\end{array}$ & 134 & 502 & 458 & 990 & 787 & 1299 & 1269 & 1996 \\
\hline
\end{tabular}


Продолжение табл. 13.6

\begin{tabular}{l|r|r|r|r|r|r|r|r}
\hline & 2000 & 2005 & 2010 & 2013 & 2014 & 2015 & 2016 & 2017 \\
\hline чистый экспорт & 1463 & 2959 & 3740 & 3944 & 5074 & 6701 & 4456 & 4925 \\
$\begin{array}{l}\text { товаров и услуг } \\
\quad \text { экспорт }\end{array}$ & 3219 & 7607 & 13529 & 18864 & 21426 & 23854 & 22139 & 23966 \\
$\quad \begin{array}{l}\text { импорт } \\
\text { статистическое }\end{array}$ & 1756 & 4648 & 9789 & 14920 & 16352 & 17153 & 17683 & 19041 \\
расхождение & 0 & -126 & -418 & 0 & 0 & 0 & 961 & 387 \\
\hline
\end{tabular}

1) См. сноску на стр. 179 .

${ }^{2)}$ Включая приобретение за вычетом выбытия ценностей.

13.7. ИСПОЛЬЗОВАНИЕ ВАЛОВОГО ВНУТРЕННЕГО ПРОДУКТА ${ }^{1)}$ (в процентах к итогу)

\begin{tabular}{|c|c|c|c|c|c|c|c|c|}
\hline & 2000 & 2005 & 2010 & 2013 & 2014 & 2015 & 2016 & 2017 \\
\hline $\begin{array}{l}\text { Валовой внутрен- } \\
\text { ний продукт в ры- } \\
\text { ночных ценах }\end{array}$ & 100 & 100 & 100 & 100 & 100 & 100 & 100 & 100 \\
\hline $\begin{array}{c}\text { в том числе: } \\
\text { расходы на конеч- }\end{array}$ & & & & & & & & \\
\hline $\begin{array}{l}\text { ное потребление } \\
\text { из них: }\end{array}$ & 61,3 & 66,3 & 69,6 & 71,3 & 71,3 & 70,1 & 71,6 & 70,5 \\
\hline домашних хозяйств & 45,2 & 49,0 & 50,5 & 52,6 & 53,1 & 52,0 & 52,8 & 52,2 \\
\hline $\begin{array}{l}\text { государственного } \\
\text { управления }\end{array}$ & 14,9 & 16,7 & 185 & 185 & 180 & 177 & 185 & 181 \\
\hline $\begin{array}{l}\text { в том числе: } \\
\text { на индивидуаль- }\end{array}$ & & $10, I$ & & & & & & \\
\hline $\begin{array}{l}\text { ные товары и } \\
\text { услуги }\end{array}$ & 5,9 & 7,6 & 8,8 & 7,8 & 7,9 & 7,7 & 7,8 & 7,6 \\
\hline $\begin{array}{l}\text { на коллективные } \\
\text { услуги }\end{array}$ & 9,0 & 9,1 & 9,7 & 10,7 & 10,1 & 10,0 & 10,7 & 10,5 \\
\hline $\begin{array}{l}\text { некоммерческих ор- } \\
\text { ганизаций, обслу- }\end{array}$ & & & & & & & & \\
\hline $\begin{array}{l}\text { живающих домаш- } \\
\text { ние хозяйства }\end{array}$ & 1,2 & 0,6 & 0,6 & 0,2 & 0,2 & 0,4 & 0,3 & 0,2 \\
\hline $\begin{array}{c}\text { валовое накопление } \\
\text { в том числе: } \\
\text { валовое накоп- } \\
\text { ление основного }\end{array}$ & 18,6 & 20,1 & 22,5 & 23,3 & 22,2 & 21,9 & 23,1 & 24,0 \\
\hline капитала & 16,9 & 17,7 & 21,4 & 21,9 & 21,3 & 20,4 & 21,6 & 21,8 \\
\hline $\begin{array}{l}\text { сов материальных } \\
\text { оборотных средств }\end{array}$ & 1,7 & 2,4 & 1,1 & 1,4 & 0,9 & 1,5 & 1,5 & 2,2 \\
\hline чистый экспорт & & & & & & & & \\
\hline товаров и услуг & 20,1 & 13,6 & 7,9 & 5,4 & 6,5 & 8,0 & 5,3 & 5,5 \\
\hline экспорт & 44,1 & 35,0 & 28,9 & 25,8 & 27,1 & 28,6 & 26,0 & 26,2 \\
\hline импорт & 24,0 & 21,4 & 21,0 & 20,4 & 20,6 & 20,6 & 20,7 & 20,7 \\
\hline
\end{tabular}

1) См. сноску на стр. 179 .

2) Включая приобретение за вычетом выбытия ценностей. 


\section{4. ИНВЕСТИЦИИ}

Раздел содержит статистику инвестиций в нефинансовые активы, фринансовых вложений и иностранных инвестиций.

Данные в таблицах, содержащих показатели по видам экономической деятельности, приводятся за 2017 год в соответствии с Общероссийским классификатором видов экономической деятельности (ОКВЭД 2) ОК 029-2014, введенным в действие с 1 января 2017 г.

Аналогичные сведения за период до 2016 г. включительно, разработанные в соответствии с ранее действовавшим Общероссийским классификатором видов экономической деятельности (ОКВЭД-2007) ОК 029-2007, опубликованы в кратком статистическом сборнике «Россия в цифрах. 2017», электронная версия которого размещена на официальном Интернет-портале Росстата в разделе «Публикации».

Инвестиции в нефинансовые активы включают в себя следующие элементы: инвестиции в основной капитал и инвестиции в непроизведенные нефинансовые активы.

Основное место в системе показателей, характеризующих объемы и структуру инвестиций в нефинансовые активы, занимают инвестиции в основной капитал, которые представляют собой совокупность затрат, направленных на строительство, реконструкцию (включая расширение и модернизацию) объектов, которые приводят к увеличению их первоначальной стоимости, приобретение машин, оборудования, транспортных средств, производственного и хозяйственного инвентаря, бухгалтерский учет которых осуществляется в порядке, установленном для учета вложений во внеоборотные активы, инвестиции в объекты интеллектуальной собственности (начиная с 2013 г.), культивируемые биологические ресурсы.

В состав инвестиций в основной капитал включены затраты, осуществленные за счет денежных средств граждан и юридических лиц, привлеченных организациями-застройщиками для долевого строительства.

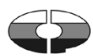


Затраты на приобретение объектов незавершенного строительства и основных средств на вторичном рынке в объеме инвестиций в основной капитал не учитываются.

Распределение инвестиций в основной капитал по видам экономической деятельности осуществляется исходя из назначения основных средств, т.е. той сферы деятельности, в которой они будут функционировать.

За 2017 год данные по инвестициям в основной капитал по видам основных фондов приведены в соответствии с Общероссийским классификатором основных фондов (ОКОФ) ОК 013-2014 (CHC 2008).

Данные по инвестициям в основной капитал приведены в фактически действовавших ценах, индексы физического объема инвестиций в основной капитал рассчитаны в сопоставимых ценах. В качестве сопоставимых цен приняты среднегодовые цены предыдущего года.

С 2005 г. инвестиции в основной капитал приведены без налога на добавленную стоимость.

Прямые инвестиции - это категория трансграничных инвестиций, при которой резидент одной страны осуществляет контроль (более чем $50 \%$ голосов в управлении) или имеет значительную степень влияния (от 10 до 50\%) на управление предприятием, являющимся резидентом другой страны.

Финансовые вложения - государственные и муниципальные ценные бумаги, ценные бумаги других организаций, в том числе долговые ценные бумаги, в которых дата и стоимость погашения определена (облигации, векселя); вклады в уставные (складочные) капиталы других организаций (в том числе дочерних и независимых хозяйственных обществ); вклады организации-товарища по договору простого товарищества; предоставленные другим организациям займы; депозитные вклады в кредитные организации; дебиторская задолженность, приобретенная на основании уступки права требования, и т.д. 


\section{ИНВЕСТИЦИИ В НЕФИНАНСОВЫЕ АКТИВЫ}

\section{1. ИНВЕСТИЦИИ В НЕФИНАНСОВЫЕ АКТИВЫ ${ }^{1)}$}

(в процентах к итогу)

\begin{tabular}{|c|c|c|c|}
\hline \multirow[t]{2}{*}{ Годы } & \multirow{2}{*}{$\begin{array}{l}\text { Инвестиции в } \\
\text { нефинансовые } \\
\text { активы - всего }\end{array}$} & \multicolumn{2}{|c|}{ в том числе } \\
\hline & & $\begin{array}{c}\text { инвестиции } \\
\text { в основной } \\
\text { капитал }\end{array}$ & $\begin{array}{c}\text { инвестиции в } \\
\text { непроизведенные } \\
\text { нефинансовые активы }\end{array}$ \\
\hline 2013 & 100 & 98,7 & 1,3 \\
\hline 2014 & 100 & 98,5 & 1,5 \\
\hline 2015 & 100 & 97,7 & 2,3 \\
\hline 2016 & 100 & 98,7 & 1,3 \\
\hline 2017 & 100 & 99,0 & 1,0 \\
\hline
\end{tabular}

14.2. ИНВЕСТИЦИИ В ОСНОВНОЙ КАПИТАЛ

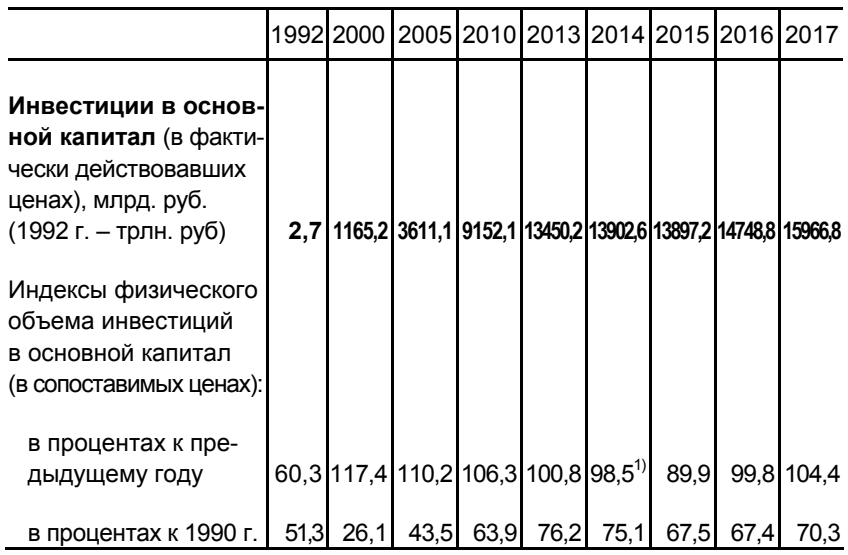

1) В целях обеспечения статистической сопоставимости показатель рассчитан без учета данных по Республике Крым и г. Севастополю. 


\section{3. ИНВЕСТИЦИИ В ОСНОВНОЙ КАПИТАЛ} ПО ФОРМАМ СОБСТВЕННОСТИ

(млрд. рублей)

\begin{tabular}{l|r|r|r|r|r|r|r|r}
\hline & 2000 & 2005 & 2010 & 2013 & 2014 & 2015 & 2016 & 2017 \\
\hline $\begin{array}{l}\text { Инвестиции в ос- } \\
\text { новной капитал - } \\
\text { всего }\end{array}$ & & & & & & & & \\
в том числе \\
$\begin{array}{l}\text { по фрормам } \\
\text { собственности: }\end{array}$
\end{tabular}

1) Статистическое наблюдение ведется с 2010 г. 


\section{4. ИНВЕСТИЦИИ В ОСНОВНОЙ КАПИТАЛ} ПО ФОРМАМ СОБСТВЕННОСТИ

(в процентах к итогу)

\begin{tabular}{l|r|r|r|r|r|r|r|r}
\hline & 2000 & 2005 & 2010 & 2013 & 2014 & 2015 & 2016 & 2017 \\
\hline $\begin{array}{l}\text { Инвестиции в основ- } \\
\text { ной капитал - всего }\end{array}$ & 100 & 100 & 100 & 100 & 100 & 100 & 100 & 100 \\
в том числе & & & & & & & & \\
по фрормам \\
$\begin{array}{l}\text { собственности } \\
\text { инвесторов } \\
\text { (заказчиков): }\end{array}$
\end{tabular}

1) Статистическое наблюдение ведется с 2010 г. 


\section{5. ИНВЕСТИЦИИ В ОСНОВНОЙ КАПИТАЛ ПО ИСТОЧНИКАМ ФИНАНСИРОВАНИЯ ${ }^{1)}$}

(млрд. рублей)

\begin{tabular}{|c|c|c|c|c|c|c|c|c|}
\hline & 2000 & 2005 & 2010 & 2013 & 2014 & 2015 & 2016 & 2017 \\
\hline $\begin{array}{l}\text { Инвестиции в основ- } \\
\text { ной капитал - всего }\end{array}$ & 1053,7 & 2893,2 & 6625,0 & 10065,7 & 10379,6 & 10496,3 & 11282,5 & 12025,6 \\
\hline $\begin{array}{l}\text { в том числе } \\
\text { по источникам } \\
\text { финансирования: }\end{array}$ & & & & & & & & \\
\hline собственные & & & & & & & & \\
\hline средства & 500,0 & 1281,2 & $2 r 15,0$ & 4549,9 & $4 / 42,3$ & $52 / 1,1$ & $5 / 50,1$ & 6268,2 \\
\hline $\begin{array}{l}\text { привлеченные } \\
\text { средства }\end{array}$ & 553,1 & 1606,0 & 3910,0 & 5515,8 & 5637,3 & 5225,2 & 5531,8 & 5757,4 \\
\hline из них: & & & & & & & & \\
\hline кредиты банков & 30,6 & 235,6 & 595,8 & 1003,6 & 1098,7 & 849,9 & 1174,5 & 1308,1 \\
\hline $\begin{array}{l}\text { в том числе ино- } \\
\text { странных банков }\end{array}$ & 6,2 & 27,9 & 150,0 & 107,7 & 265,2 & 183,5 & 329,4 & 655,1 \\
\hline $\begin{array}{l}\text { заемные средства } \\
\text { других организаций }\end{array}$ & 75,6 & 171,1 & 404,7 & 626,1 & 660,1 & 701,0 & 674,4 & 611,4 \\
\hline $\begin{array}{l}\text { инвестиции } \\
\text { из-за рубежа }\end{array}$ & $\cdots$ & & & 76,4 & 88,8 & 120,4 & 86,7 & 83,5 \\
\hline $\begin{array}{l}\text { бюджетные } \\
\text { средства }\end{array}$ & 232,1 & 589,2 & 1294,9 & 1916,3 & 1761,3 & 1922,7 & 1856,7 & 1966,3 \\
\hline $\begin{array}{r}\text { в том числе: } \\
\text { федерального }\end{array}$ & & & & & & & & \\
\hline бюджета & 62,9 & 202,2 & 661,9 & 1009,9 & 933,6 & 1185,7 & 1048,6 & 993,3 \\
\hline $\begin{array}{l}\text { бюджетов } \\
\text { субъектов } \\
\text { Российской }\end{array}$ & & & & & & & & \\
\hline Федерации & 151,2 & 356,1 & 542,8 & 753,3 & 676,6 & 600,3 & 681,3 & 818,6 \\
\hline $\begin{array}{l}\text { средства местных } \\
\text { бюджетов }\end{array}$ & $\cdots$ & $\cdots$ & $\ldots$ & 153,1 & 151,1 & 136,7 & 126,8 & 154,4 \\
\hline $\begin{array}{l}\text { средства внебюд- } \\
\text { жетных фондов }\end{array}$ & 50,3 & 15,6 & 21,0 & 27,9 & 24,0 & 27,3 & 27,8 & 25,8 \\
\hline $\begin{array}{l}\text { средства организа- } \\
\text { ций и населения } \\
\text { на долевое строи- }\end{array}$ & & & & & & & & \\
\hline тельство & $\ldots$ & 108,6 & 144,2 & 294,9 & 367,6 & 334,3 & 340,7 & 321,0 \\
\hline $\begin{array}{l}\text { из них средства } \\
\text { населения }^{2}\end{array}$ & & & 80,5 & 234,7 & 281,7 & 252,3 & 264,6 & 242,4 \\
\hline прочие & 164,5 & 485,9 & 1449,4 & 1570,6 & 1636,8 & 1269,6 & 1371,0 & 1441,3 \\
\hline
\end{tabular}

${ }^{1)}$ Без субъектов малого предпринимательства и объема инвестиций, не наблюдае-

мых прямыми статистическими методами.

2) Статистическое наблюдение ведется с 2006 г. 


\section{6. ИНВЕСТИЦИИ В ОСНОВНОЙ КАПИТАЛ} ПО ИСТОЧНИКАМ ФИНАНСИРОВАНИЯ ${ }^{1)}$

(в процентах к итогу)

\begin{tabular}{|c|c|c|c|c|c|c|c|c|}
\hline & 2000 & 2005 & 2010 & 2013 & 2014 & 2015 & 2016 & 2017 \\
\hline $\begin{array}{l}\text { Инвестиции в основной } \\
\text { капитал - всего } \\
\text { в том числе по источ- } \\
\text { никам финансирова- } \\
\text { ния: }\end{array}$ & 100 & 100 & 100 & 100 & 100 & 100 & 100 & 100 \\
\hline собственные средства & 47,5 & 44,5 & 41,0 & 45,2 & 45,7 & 50,2 & 51,0 & 52,1 \\
\hline $\begin{array}{l}\text { привлеченные средства } \\
\text { их них: }\end{array}$ & 52,5 & 55,5 & 59,0 & 54,8 & 54,3 & 49,8 & 49,0 & 47,9 \\
\hline $\begin{array}{l}\text { кредиты банков } \\
\text { в том числе кредиты } \\
\text { иностранных банков }\end{array}$ & 2,9 & 8,1 & 9,0 & 10,0 & 10,6 & 8,1 & 2,9 & 10,9 \\
\hline $\begin{array}{l}\text { заемные средства } \\
\text { других организаций } \\
\text { инвестиции } \\
\text { из-за рубежа }\end{array}$ & 7,2 & 5,9 & 6,1 & 6,2 & 6,4 & 6,7 & 0,8 & 0,7 \\
\hline $\begin{array}{l}\text { бюджетные средства } \\
\text { в том числе: } \\
\text { из федерального } \\
\text { бюджета }\end{array}$ & 22,0 & 20,4 & 19,5 & 19,0 & 17,0 & 18,3 & 16,4 & 16,3 \\
\hline $\begin{array}{l}\text { из бюджетов субъек- } \\
\text { тов Российской } \\
\text { Федерации }\end{array}$ & 14,3 & 12,3 & 8,2 & 7,5 & 6,5 & 5,7 & 6,0 & 6,8 \\
\hline $\begin{array}{l}\text { из средств местных } \\
\text { бюджетов } \\
\text { средства внебюджет- } \\
\text { ных фондов }\end{array}$ & 4,8 & 0,5 & 0,3 & 1,5 & 1,5 & 1,3 & 1,1 & 1,3 \\
\hline $\begin{array}{l}\text { средства организаций } \\
\text { и населения на доле- } \\
\text { вое строительство }\end{array}$ & $\ldots$ & 3,8 & 2,2 & 2,9 & 3,5 & 3,2 & 3,0 & 2,7 \\
\hline $\begin{array}{l}\text { из них средства } \\
\text { населения }^{2}\end{array}$ & & & 1,2 & 2,3 & 2,7 & 2,4 & 2,3 & 2,0 \\
\hline прочие & 15,6 & 16,8 & 21,9 & 15,6 & 15,7 & 12,1 & 12,2 & 12,0 \\
\hline
\end{tabular}

${ }^{1)}$ Без субъектов малого предпринимательства и объема инвестиций, не наблюдаемых прямыми статистическими методами.

2) Статистическое наблюдение ведется с 2006 г. 
14.7. ИНВЕСТИЦИИ В ОСНОВНОЙ КАПИТАЛ ПО ВИДАМ ЭКОНОМИЧЕСКОЙ ДЕЯТЕЛЬНОСТИ В 2017 г. ${ }^{1)}$

\begin{tabular}{|c|c|c|}
\hline & Млрд. руб. & $\begin{array}{l}\text { В процентах } \\
\text { к итогу }\end{array}$ \\
\hline $\begin{array}{l}\text { Инвестиции в основной капитал - всего } \\
\text { из них: }\end{array}$ & 12025,6 & 100 \\
\hline $\begin{array}{l}\text { сельское, лесное хозяйство, охота, рыболов- } \\
\text { ство и рыбоводство }\end{array}$ & 412,5 & 3,4 \\
\hline из них: & & \\
\hline сельское хозяйство & 374,7 & 3,1 \\
\hline лесоводство и лесозаготовки & 13,7 & 0,1 \\
\hline рыболовство и рыбоводство & 11,9 & 0,1 \\
\hline добыча полезных ископаемых & 3025,5 & 25,1 \\
\hline из нее: & & \\
\hline добыча угля & 114,3 & 1,0 \\
\hline добыча сырой нефти и природного газа & 1872,6 & 15,6 \\
\hline добыча металлических руд & 178,9 & 1,5 \\
\hline добыча прочих полезных ископаемых & 50,8 & 0,4 \\
\hline обрабатывающие производства & 1921,2 & 16,0 \\
\hline из них: & & \\
\hline производство пищевых продуктов & 180,7 & 1,5 \\
\hline производство напитков & 30,1 & 0,3 \\
\hline производство табачных изделий & 10,5 & 0,1 \\
\hline производство текстильных изделий & 7,1 & 0,1 \\
\hline производство одежды & 1,7 & 0,01 \\
\hline производство кожи и изделий из кожи & 1,2 & 0,01 \\
\hline $\begin{array}{l}\text { обработка древесины и производство } \\
\text { изделий из дерева и пробки, кроме мебели, } \\
\text { производство изделий из соломки и мате- } \\
\text { риалов для плетения }\end{array}$ & 64,9 & 0,5 \\
\hline производство бумаги и бумажных изделий & 60,5 & 0,5 \\
\hline $\begin{array}{l}\text { деятельность полиграфическая и копирова- } \\
\text { ние носителей информации }\end{array}$ & 5,5 & 0,05 \\
\hline $\begin{array}{l}\text { производство кокса и нефтепродуктов } \\
\text { в том числе: }\end{array}$ & 381,2 & 3,2 \\
\hline производство кокса & 4,8 & 0,04 \\
\hline производство нефтепродуктов & 376,4 & 3,1 \\
\hline $\begin{array}{l}\text { производство химических веществ } \\
\text { и химических продуктов }\end{array}$ & 396,1 & 3,3 \\
\hline
\end{tabular}


Продолжение табл. 14.7

\begin{tabular}{|c|c|c|}
\hline & Млрд. руб. & $\begin{array}{l}\text { В процентах } \\
\text { к итогу }\end{array}$ \\
\hline $\begin{array}{l}\text { производство лекарственных средств } \\
\text { и материалов, применяемых в медицинских } \\
\text { целях }\end{array}$ & 30,2 & 0,3 \\
\hline $\begin{array}{l}\text { производство резиновых и пластмассовых } \\
\text { изделий }\end{array}$ & 36,2 & 0,3 \\
\hline $\begin{array}{l}\text { производство прочей неметаллической } \\
\text { минеральной продукции }\end{array}$ & 50,8 & 0,4 \\
\hline производство металлургическое & 256,9 & 2,1 \\
\hline $\begin{array}{l}\text { производство готовых металлических } \\
\text { изделий, кроме машин и оборудования }\end{array}$ & 77,2 & 0,6 \\
\hline $\begin{array}{l}\text { производство компьютеров, электронных и } \\
\text { оптических изделий }\end{array}$ & 52,6 & 0,4 \\
\hline производство электрического оборудования & 27,7 & 0,2 \\
\hline $\begin{array}{l}\text { производство машин и оборудования, } \\
\text { не включенных в другие группировки }\end{array}$ & 52,3 & 0,4 \\
\hline $\begin{array}{l}\text { производство автотранспортных средств, } \\
\text { прицепов и полуприцепов }\end{array}$ & 69,0 & 0,6 \\
\hline $\begin{array}{l}\text { производство прочих транспортных средств } \\
\text { и оборудования }\end{array}$ & 101,9 & 0,8 \\
\hline производство мебели & 4,2 & 0,04 \\
\hline производство прочих готовых изделий & 3,7 & 0,03 \\
\hline $\begin{array}{l}\text { обеспечение электрической энергией, } \\
\text { газом и паром; кондиционирование воздуха }\end{array}$ & 820,0 & 6,8 \\
\hline $\begin{array}{l}\text { водоснабжение; водоотведение, организация } \\
\text { сбора и утилизации отходов, деятельность по } \\
\text { ликвидации загрязнений }\end{array}$ & 120,0 & 1,0 \\
\hline строительство & 281,7 & 2,3 \\
\hline $\begin{array}{l}\text { торговля оптовая и розничная; ремонт } \\
\text { автотранспортных средств и мотоциклов }\end{array}$ & 358,5 & 3,0 \\
\hline $\begin{array}{l}\text { в том числе: } \\
\text { торговля оптовая и розничная автотранс- } \\
\text { портными средствами и мотоциклами и их } \\
\text { ремонт }\end{array}$ & 32,1 & 0,3 \\
\hline $\begin{array}{l}\text { торговля оптовая, кроме оптовой торговли } \\
\text { автотранспортными средствами } \\
\text { и мотоциклами }\end{array}$ & 106,5 & 0,9 \\
\hline $\begin{array}{l}\text { торговля розничная, кроме торговли } \\
\text { автотранспортными средствами } \\
\text { и мотоциклами }\end{array}$ & 219,9 & 1,8 \\
\hline
\end{tabular}


Продолжение табл. 14.7

\begin{tabular}{|c|c|c|}
\hline & Млрд. руб. & $\begin{array}{l}\text { В процентах } \\
\text { к итогу }\end{array}$ \\
\hline транспортировка и хранение & 2177,8 & 18,1 \\
\hline $\begin{array}{l}\text { деятельность гостиниц и предприятий обще- } \\
\text { ственного питания }\end{array}$ & 42,7 & 0,4 \\
\hline $\begin{array}{l}\text { деятельность в области информации и связи } \\
\quad \text { из нее: }\end{array}$ & 432,4 & 3,6 \\
\hline деятельность издательская & 0,7 & 0,01 \\
\hline деятельность в сфрере телекоммуникаций & 352,8 & 2,9 \\
\hline $\begin{array}{l}\text { деятельность в области информационных } \\
\text { технологий }\end{array}$ & 19,1 & 0,2 \\
\hline деятельность финансовая и страховая & 315,3 & 2,6 \\
\hline $\begin{array}{l}\text { деятельность по операциям с недвижимым } \\
\text { имуществом }\end{array}$ & 803,1 & 6,7 \\
\hline $\begin{array}{l}\text { деятельность профессиональная, научная } \\
\text { и техническая }\end{array}$ & 355,0 & 3,0 \\
\hline из нее научные исследования и разработки & 120,2 & 1,0 \\
\hline $\begin{array}{l}\text { деятельность административная } \\
\text { и сопутствующие дополнительные услуги }\end{array}$ & 62,4 & 0,5 \\
\hline $\begin{array}{l}\text { государственное управление и обеспечение } \\
\text { военной безопасности; социальное } \\
\text { обеспечение }\end{array}$ & 260,8 & 2,2 \\
\hline образование & 214,5 & 1,8 \\
\hline $\begin{array}{l}\text { деятельность в области здравоохранения } \\
\text { и социальных услуг }\end{array}$ & 194,7 & 1,6 \\
\hline $\begin{array}{l}\text { деятельность в области культуры, спорта, } \\
\text { организации досуга и развлечений }\end{array}$ & 219,7 & 1,8 \\
\hline
\end{tabular}

14.8. ИНВЕСТИЦИИ В ОСНОВНОЙ КАПИТАЛ ПО ВИДАМ ОСНОВНЫХ ФОНДОВ в 2017 г.

\begin{tabular}{l|r|r}
\hline & Млрд. руб. & $\begin{array}{c}\text { В процентах } \\
\text { к итогу }\end{array}$ \\
\hline $\begin{array}{l}\text { Инвестиции в основной капитал } \\
\quad \text { в том числе: }\end{array}$ & $\mathbf{1 5 9 6 6 , 8}$ & $\mathbf{1 0 0}$ \\
$\begin{array}{l}\text { жилые здания и помещения } \\
\text { здания (кроме жилых) и сооружения, }\end{array}$ & $\mathbf{2 2 8 2 , 8}$ & 14,3 \\
расходы на улучшение земель & 7215,1 & 45,2 \\
машины, оборудование, транспортные & & 31,8 \\
средства & 5083,3 & 3,0 \\
объекты интеллектуальной собственности & 478,7 & 5,7 \\
прочие & 906,9 & \\
\hline
\end{tabular}




\section{ИНОСТРАННЫЕ ИНВЕСТИЦИИ}

\section{9. ПРЯМЫЕ ИНОСТРАННЫЕ ИНВЕСТИЦИИ \\ В ЭКОНОМИКУ РОССИИ \\ ПО ОСНОВНЫМ СТРАНАМ-ИНВЕСТОРАМ ${ }^{1)}$}

(сальдо операций платежного баланса Российской Федерации;

млн. долларов США)

\begin{tabular}{|c|c|c|c|c|}
\hline & 2013 & 2014 & 2015 & 2016 \\
\hline $\begin{array}{l}\text { Прямые иностранные } \\
\text { инвестиции - Всего }\end{array}$ & +69219 & +22031 & +6853 & +32539 \\
\hline из них из стран: & & & & \\
\hline Сингапур & -502 & +162 & +185 & +15122 \\
\hline Багамы & +2791 & +3638 & +5108 & +1421 \\
\hline Швейцария & +1086 & +2472 & +203 & +1010 \\
\hline Ирландия & +10399 & -531 & +623 & +784 \\
\hline Джерси & +509 & -717 & +2122 & +711 \\
\hline Бермуды & +404 & +1777 & +2239 & +658 \\
\hline Нидерланды & +5716 & +1102 & -246 & +654 \\
\hline Франция & +2121 & +2224 & +1686 & +438 \\
\hline $\begin{array}{l}\text { Соединенное } \\
\text { Королевство } \\
\text { (Великобритания) }\end{array}$ & +18927 & +120 & +1112 & +422 \\
\hline Австрия & -326 & +841 & +407 & +374 \\
\hline Германия & +335 & +349 & +1483 & +274 \\
\hline Швеция & -1203 & +166 & +122 & +235 \\
\hline Казахстан & +208 & +357 & +433 & +130 \\
\hline $\begin{array}{l}\text { Соединенные Штаты } \\
\text { Америки }\end{array}$ & +485 & +708 & +209 & +125 \\
\hline Финляндия & +216 & +124 & -272 & +86 \\
\hline Япония & +369 & +295 & +447 & +77 \\
\hline Венгрия & +736 & +534 & -452 & +52 \\
\hline Италия & +118 & +158 & +56 & +47 \\
\hline Норвегия & +94 & +51 & -93 & +41 \\
\hline Мальта & +47 & +10 & +41 & +23 \\
\hline Эстония & +47 & +38 & +32 & +20 \\
\hline Чешская Республика & +36 & +109 & +54 & +18 \\
\hline
\end{tabular}

1) По данным Банка России. Данные представлены в соответствии с принципом активов/пассивов. Знак (+) означает рост, знак (-) означает снижение. 
14.10. ПРЯМЫЕ ИНВЕСТИЦИИ ИЗ РОССИИ В ЭКОНОМИКУ СТРАН-КРУПНЕЙШИХ ПОЛУЧАТЕЛЕЙ ПРЯМЫХ ИНВЕСТИЦИЙ ${ }^{1)}$

(сальдо операций платежного баланса Российской Федерации; млн. долларов США)

\begin{tabular}{|c|c|c|c|c|}
\hline & 2013 & 2014 & 2015 & 2016 \\
\hline $\begin{array}{l}\text { Прямые инвестиции - } \\
\text { всего }\end{array}$ & +86507 & +57082 & +22085 & +22314 \\
\hline \multicolumn{5}{|l|}{ из них в страны: } \\
\hline Кипр & +7671 & +23546 & +4249 & +9827 \\
\hline $\begin{array}{l}\text { Виргинские } \\
\text { острова (Брит.) }\end{array}$ & +62223 & +718 & +3301 & +1795 \\
\hline Швейцария & +1358 & +6927 & +203 & +1433 \\
\hline Багамы & +560 & +756 & +1054 & +1205 \\
\hline Турция & +1447 & +1183 & +1475 & +1184 \\
\hline Ирландия & +264 & +91 & +479 & +1139 \\
\hline Сингапур & +304 & +817 & +383 & +888 \\
\hline $\begin{array}{l}\text { Соединенные Штаты } \\
\text { Америки }\end{array}$ & +739 & +1654 & +819 & +873 \\
\hline Нидерланды & -3022 & +2132 & +461 & +841 \\
\hline Украина & +496 & -493 & +595 & +822 \\
\hline Беларусь & +863 & +609 & +736 & +629 \\
\hline Бермуды & +571 & +2997 & -261 & +480 \\
\hline Казахстан & +671 & +657 & +643 & +476 \\
\hline Германия & +1334 & +1016 & +738 & +393 \\
\hline Дания & +752 & 0 & +401 & +307 \\
\hline Канада & +177 & -34 & +41 & +264 \\
\hline Австрия & +5265 & +1135 & +746 & +258 \\
\hline Италия & +538 & +587 & +117 & +165 \\
\hline Киргизия & +11 & +43 & +159 & +125 \\
\hline Испания & +1356 & +1879 & +152 & +125 \\
\hline Франция & +449 & +523 & +74 & +121 \\
\hline Финляндия & +91 & +146 & +1454 & +104 \\
\hline
\end{tabular}

1) По данным Банка России. Данные представлены в соответствии с принципом активов/пассивов. Знак (+) означает рост, знак (-) означает снижение. 


\section{ФИНАНСОВЫЕ ВЛОЖЕНИЯ}

14.11. ФИНАНСОВЫЕ ВЛОЖЕНИЯ ОРГАНИЗАЦИЙ ПО ВИДАМ ЭКОНОМИЧЕСКОЙ ДЕЯТЕЛЬНОСТИ В 2017 г.

(млн. рублей)

\begin{tabular}{|c|c|c|c|}
\hline & \multirow[t]{2}{*}{ Всего } & \multicolumn{2}{|c|}{ в том числе } \\
\hline & & $\begin{array}{c}\text { долгосроч- } \\
\text { ные }\end{array}$ & $\begin{array}{l}\text { кратко- } \\
\text { срочные }\end{array}$ \\
\hline $\begin{array}{l}\text { Финансовые вложения - всего } \\
\text { в том числе по видам экономической } \\
\text { деятельности: }\end{array}$ & 165669181 & 18586505 & 147082676 \\
\hline $\begin{array}{l}\text { сельское, лесное хозяйство, охота, } \\
\text { рыболовство и рыбоводство }\end{array}$ & 944784 & 111250 & 833534 \\
\hline $\begin{array}{l}\text { в том числе: } \\
\text { растениеводство и животноводство, } \\
\text { охота и предоставление соответст- }\end{array}$ & & & \\
\hline вующих услуг в этих областях & 815306 & 89778 & 725528 \\
\hline лесоводство и лесозаготовки & 12789 & 2354 & 10435 \\
\hline рыболовство и рыбоводство & 116689 & 19118 & 97571 \\
\hline $\begin{array}{l}\text { добыча полезных ископаемых } \\
\text { из нее: }\end{array}$ & 13094917 & 5358691 & 7736226 \\
\hline добыча угля & 548081 & 242533 & 305548 \\
\hline $\begin{array}{l}\text { добыча сырой нефти и природного } \\
\text { газа }\end{array}$ & 6178356 & 1124163 & 5054193 \\
\hline добыча металлических руд & 2092940 & 937477 & 1155463 \\
\hline добыча прочих полезных ископаемых & 701799 & 65010 & 636789 \\
\hline обрабатывающие производства & 22632025 & 3577436 & 19054589 \\
\hline $\begin{array}{l}\text { из них: } \\
\text { производство пищевых продуктов }\end{array}$ & 1552969 & 242756 & 1310213 \\
\hline производство напитков & 1017571 & 22437 & 995134 \\
\hline производство табачных изделий & 146273 & 10986 & 135287 \\
\hline производство текстильных изделий & 48282 & 993 & 47289 \\
\hline производство одежды & 20226 & 156 & 20070 \\
\hline производство кожи и изделий из кожи & 6215 & 799 & 5416 \\
\hline $\begin{array}{l}\text { обработка древесины и производство } \\
\text { изделий из дерева и пробки, кроме } \\
\text { мебели, производство изделий из со- }\end{array}$ & & & \\
\hline ломки и материалов для плетения & 74624 & 12172 & 62452 \\
\hline $\begin{array}{l}\text { производство бумаги и бумажных } \\
\text { изделий }\end{array}$ & 260838 & 8849 & 251989 \\
\hline $\begin{array}{l}\text { деятельность полиграфическая и ко- } \\
\text { пирование носителей информации }\end{array}$ & 109349 & 340 & 109009 \\
\hline $\begin{array}{l}\text { производство кокса и нефтепродуктов } \\
\text { из них: }\end{array}$ & 7193169 & 2384876 & 4808293 \\
\hline производство кокса & 33826 & 23592 & 10234 \\
\hline производство нефтепродуктов & 7159343 & 2361284 & 4798059 \\
\hline
\end{tabular}

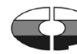


Продолжение табл. 14.11

\begin{tabular}{l}
\hline \\
производство химических веществ и \\
химических продуктов \\
производство лекарственных средств \\
и материалов, применяемых в меди- \\
цинских целях \\
производство резиновых и пластмас- \\
совых изделий \\
производство металлургическое \\
производство готовых металлических \\
изделий, кроме машин и оборудования \\
производство компьютеров, электрон- \\
ных и оптических изделий \\
производство электрического оборудо- \\
вания \\
производство машин и оборудования, \\
не включенных в другие группировки \\
производство автотранспортных \\
средств, прицепов и полуприцепов \\
производство прочих транспортных \\
средств и оборудования \\
производство мебели \\
производство прочих готовых изделий \\
обеспечение электрической энергией, \\
газом и паром; кондиционирование \\
воздуха \\
в том числе: \\
производство, передача и распреде- \\
строительство инженерных сооруже- \\
ний
\end{tabular}

\begin{tabular}{|c|c|c|}
\hline \multirow[t]{2}{*}{ Всего } & \multicolumn{2}{|c|}{ в том числе } \\
\hline & $\begin{array}{c}\text { долгосроч- } \\
\text { ные }\end{array}$ & $\begin{array}{l}\text { кратко- } \\
\text { срочные }\end{array}$ \\
\hline 1235304 & 137353 & 1097951 \\
\hline 246654 & 10111 & 236543 \\
\hline 158343 & 35554 & 122789 \\
\hline 4244274 & 376402 & 3867872 \\
\hline 1371961 & 58374 & 1313587 \\
\hline 636610 & 4797 & 631813 \\
\hline 205062 & 5243 & 199819 \\
\hline 485009 & 41061 & 443948 \\
\hline 1305525 & 33381 & 1272144 \\
\hline 1004094 & 122358 & 881736 \\
\hline 46689 & 2139 & 44550 \\
\hline 170731 & 959 & 169772 \\
\hline 4959613 & 259763 & 4699850 \\
\hline 4341923 & 243399 & 4098524 \\
\hline 467406 & 6283 & 461123 \\
\hline 150284 & 10081 & 140203 \\
\hline 217774 & 8509 & 209265 \\
\hline 4174041 & 211360 & 3962681 \\
\hline 1955925 & 141761 & 1814164 \\
\hline 1723138 & 24930 & 1698208 \\
\hline
\end{tabular}


Продолжение табл. 14.11

\begin{tabular}{|c|c|c|c|}
\hline & \multirow[t]{2}{*}{ Всего } & \multicolumn{2}{|c|}{ в том числе } \\
\hline & & $\begin{array}{c}\text { долгосроч- } \\
\text { ные }\end{array}$ & $\begin{array}{l}\text { кратко- } \\
\text { срочные }\end{array}$ \\
\hline торговля оптовая и розничная; ремонт & & & \\
\hline автотранспортных средств и мотоциклов & 26538491 & 3285854 & 23252637 \\
\hline $\begin{array}{l}\text { в том числе: } \\
\text { торговля оптовая и розничная авто- }\end{array}$ & & & \\
\hline $\begin{array}{l}\text { транспортными средствами и мото- } \\
\text { циклами и их ремонт }\end{array}$ & 1701162 & 199609 & 1501553 \\
\hline $\begin{array}{l}\text { торговля оптовая, кроме оптовой тор- } \\
\text { говли автотранспортными средствами }\end{array}$ & & & \\
\hline и мотоциклами & 23049564 & 2745519 & 20304045 \\
\hline торговля розничная, кроме торговли & & & \\
\hline $\begin{array}{l}\text { автотранспортными средствами и мо- } \\
\text { тоциклами }\end{array}$ & 1787765 & 340726 & 1447039 \\
\hline транспортировка и хранение & 7641268 & 653199 & 6988069 \\
\hline $\begin{array}{l}\text { в том числе: } \\
\text { деятельность сухопутного и трубопро- }\end{array}$ & & & \\
\hline водного транспорта & 3472379 & 367122 & 3105257 \\
\hline в том числе: & & & \\
\hline $\begin{array}{l}\text { деятельность железнодорожного } \\
\text { транспорта: междугородные }\end{array}$ & & & \\
\hline $\begin{array}{l}\text { и международные пассажирские } \\
\text { перевозки }\end{array}$ & 719864 & 21033 & 698831 \\
\hline деятельность железнодорожного & & & \\
\hline транспорта: грузовые перевозки & 204353 & 5866 & 198487 \\
\hline $\begin{array}{l}\text { деятельность прочего сухопутного } \\
\text { пассажирского транспорта }\end{array}$ & 38095 & 1560 & 36535 \\
\hline $\begin{array}{l}\text { деятельность автомобильного гру- } \\
\text { зового транспорта и услуги по пере- }\end{array}$ & & & \\
\hline возкам & 107921 & 2339 & 105582 \\
\hline $\begin{array}{l}\text { деятельность трубопроводного } \\
\text { транспорта }\end{array}$ & 2402146 & 336324 & 2065822 \\
\hline деятельность водного транспорта & 141770 & 3557 & 138213 \\
\hline $\begin{array}{l}\text { деятельность воздушного и космиче- } \\
\text { ского транспорта }\end{array}$ & 2037785 & 157271 & 1880514 \\
\hline $\begin{array}{l}\text { складское хозяйство и вспомогатель- } \\
\text { ная транспортная деятельность }\end{array}$ & 1983783 & 121579 & 1862204 \\
\hline $\begin{array}{l}\text { деятельность почтовой связи и курь- } \\
\text { ерская деятельность }\end{array}$ & 5551 & 3670 & 1881 \\
\hline $\begin{array}{l}\text { деятельность гостиниц и предприятий } \\
\text { общественного питания }\end{array}$ & 335169 & 30099 & 305070 \\
\hline в том числе: & & & \\
\hline $\begin{array}{l}\text { деятельность по предоставлению мест } \\
\text { для временного проживания }\end{array}$ & 198653 & 27063 & 171590 \\
\hline $\begin{array}{l}\text { деятельность по предоставлению про- } \\
\text { дуктов питания и напитков }\end{array}$ & 136516 & 3036 & 133480 \\
\hline
\end{tabular}


Продолжение табл. 14.11

\begin{tabular}{|c|c|c|c|}
\hline & \multirow[t]{2}{*}{ Всего } & \multicolumn{2}{|c|}{ в том числе } \\
\hline & & $\begin{array}{c}\text { долгосроч- } \\
\text { ные }\end{array}$ & $\begin{array}{l}\text { кратко- } \\
\text { срочные }\end{array}$ \\
\hline $\begin{array}{l}\text { деятельность в области информации и } \\
\text { связи }\end{array}$ & 4113986 & 522894 & 3591092 \\
\hline из нее: & & & \\
\hline деятельность издательская & 75552 & 899 & 74653 \\
\hline $\begin{array}{l}\text { деятельность в сфере телеком- } \\
\text { муникаций }\end{array}$ & 3106344 & 476135 & 2630209 \\
\hline $\begin{array}{l}\text { деятельность в области информаци- } \\
\text { онных технологий }\end{array}$ & 213329 & 3182 & 210147 \\
\hline деятельность финансовая и страховая & 65919500 & 1666779 & 64252721 \\
\hline $\begin{array}{l}\text { деятельность по операциям с недвижи- } \\
\text { мым имуществом }\end{array}$ & 4690588 & 1088936 & 3601652 \\
\hline $\begin{array}{l}\text { деятельность профессиональная, } \\
\text { научная и техническая }\end{array}$ & 8772054 & 1333063 & 7438991 \\
\hline из нее: & & & \\
\hline научные исследования и разработки & 2391584 & 86714 & 2304870 \\
\hline $\begin{array}{l}\text { деятельность административная и со- } \\
\text { путствующие дополнительные услуги }\end{array}$ & 1029270 & 430410 & 598860 \\
\hline из нее: & & & \\
\hline $\begin{array}{l}\text { деятельность туристических агентств и } \\
\text { прочих организаций, предоставляющих } \\
\text { услуги в сфрере туризма }\end{array}$ & 7629 & 1953 & 5676 \\
\hline $\begin{array}{l}\text { государственное управление и обеспе- } \\
\text { чение военной безопасности; социаль- }\end{array}$ & & & \\
\hline ное обеспечение & 43912 & 32552 & 11360 \\
\hline образование & 166057 & 241 & 165816 \\
\hline $\begin{array}{l}\text { деятельность в области здравоохране- } \\
\text { ния и социальных услуг }\end{array}$ & 217347 & 9682 & 207665 \\
\hline из нее: & & & \\
\hline $\begin{array}{l}\text { деятельность в области здраво- } \\
\text { охранения }\end{array}$ & 195339 & 9451 & 185888 \\
\hline $\begin{array}{l}\text { деятельность в области культуры, спор- } \\
\text { та, организации досуга и развлечений }\end{array}$ & 75363 & 2505 & 72858 \\
\hline из нее: & & & \\
\hline $\begin{array}{l}\text { деятельность библиотек, архивов, } \\
\text { музеев и прочих объектов культуры }\end{array}$ & 2293 & 14 & 2279 \\
\hline $\begin{array}{l}\text { деятельность в области спорта, отды- } \\
\text { ха и развлечений }\end{array}$ & 64963 & 185 & 64778 \\
\hline предоставление прочих видов услуг & 103022 & 3282 & 99740 \\
\hline
\end{tabular}




\section{5. ПРЕДПРИЯТИЯ И ОРГАНИЗАЦИИ}

В разделе приводятся данные о предприятиях и организациях Российской Федерации, полученные на основе сведений о государственной регистрации юридических лиц.

Налоговыми органами начиная с 11 июля 2016 года при государственной регистрации предприятиям присваиваются коды ОКВЭд2. Предприятиям, которые были зарегистрированы ранее, присвоение кодов ОКВЭД2 осуществлялось с использованием переходных ключей между старыми и новыми версиями ОКВЭД, разработанными Минэкономразвития России и размещенными на его официальном сайте в сети Интернет по адресу: http://economy.gov.ru/minec/activity/sections/ classificators.

В новой редакции ОКВЭД2 по сравнению с его старой версией ОКВЭД-2007 во многих разделах (отраслях экономики) произошли достаточно существенные изменения границ их содержательного наполнения. С целью более точного классифицирования отдельных видов деятельности в разделах ОКВЭД2 произведена их перегруппировка, исходя из классификационных признаков, определяющих принадлежность к разделам ОКВЭД2.

С более подробной информацией об имеющихся различиях между ОКВЭД-2007 и ОКВЭД2 можно ознакомиться в комментариях под таблицей 15.1 «Число организаций по видам экономической деятельности».

Государственной собственностью в Российской Федерации является имущество, принадлежащее на праве собственности Российской Федерации (федеральная собственность), и имущество, принадлежащее на праве собственности субъектам

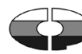


Российской Федерации - республикам, краям, областям, городам федерального значения, автономной области, автономным округам (собственность субъектов Российской Федерации).

Земля и другие природные ресурсы, не находящиеся в собственности граждан, юридических лиц либо муниципальных образований, являются государственной собственностью.

Имущество, принадлежащее на праве собственности городским и сельским поселениям, а также другим муниципальным образованиям, является муниципальной собственностью.

Частной собственностью является имущество, принадлежащее на праве собственности гражданам и юридическим лицам, за исключением отдельных видов имущества, которое в соответствии с законом не может принадлежать гражданам или юридическим лицам.

Собственностью общественных и религиозных организаций (объединений) является имущество, принадлежащее на праве собственности общественным и религиозным организациям (объединениям).

В оборот организаций включается стоимость отгруженных товаров собственного производства, выполненных работ и услуг собственными силами, а также выручка от продажи приобретенных ранее на стороне товаров (без налога на добавленную стоимость, акцизов и аналогичных обязательных платежей). Объем отгруженных товаров собственного производства представляет собой стоимость тех товаров, которые произведены юридическим лицом и фактически в отчетном периоде отгружены или отпущены в порядке продажи, а также прямого обмена на сторону (другим юридическим и физическим лицам), независимо от того, поступили деньги на счет продавца или нет. Данные по этому показателю представляют совокупность организаций с соответствующим основным видом деятельности и отражают коммерческую деятельность организаций. 
Малые предприятия. Условия отнесения к малым предприятиям определены статьей 4 Федерального закона от 24 июля 2007 г. № 209-Ф3 «О развитии малого и среднего предпринимательства в Российской Федерации».

Данные по проводимым Росстатом выборочным обследованиям малых предприятий (без микропредприятий) в 2017 г. сформированы без учета изменений критериев отнесения организаций к субъектам малого и среднего предпринимательства, установленных Федеральными законами от 3 июля 2016 г. № 265-Ф3, от 26 июля 2017 г. № 207-Ф3.

В таблицах 15.4-15.6 приводятся данные по малым предприятиям - юридическим лицам (без микропредприятий) с численностью работников от 16 до 100 человек включительно и с предельным значением дохода, полученного от осуществления предпринимательской деятельности за предшествующий календарный год, от 120 млн. до 800 млн.рублей.

Порядок осуществления выборочных обследований малых предприятий установлен постановлением Правительства Российской Федерации от 16 февраля 2008 г. № 79 «О порядке проведения выборочных статистических наблюдений за деятельностью субъектов малого и среднего предпринимательства». За 2017 г. данные представлены в соответствии с редакцией 2 (ОК 029-2014) Общероссийского классификатора видов экономической деятельности (ОКВЭД2).

Индивидуальное предпринимательство. В таблице 15.8 приведены данные выборочного наблюдения за деятельностью индивидуальных предпринимателей за 2016 год.

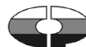




\section{ОБЩАЯ ХАРАКТЕРИСТИКА ПРЕДПРИЯТИЙ И ОРГАНИЗАЦИЙ}
15.1. ЧИСЛО ОРГАНИЗАЦИЙ ПО ВИДАМ ЭКОНОМИЧЕСКОЙ ДЕЯТЕЛЬНОСТИ ${ }^{1)}$
(на конец года; тысяч)

\begin{tabular}{|c|c|c|c|c|}
\hline ОКВЭД2 & $\begin{array}{c}2016 \\
\text { (оценка) }\end{array}$ & 2017 & 2016 & Справочно: ОКВЭД \\
\hline Bcero & 4764,5 & 4561,7 & 4764,5 & Bcero \\
\hline $\begin{array}{l}\text { из них по видам } \\
\text { экономической } \\
\text { деятельности: }\end{array}$ & & & & $\begin{array}{l}\text { из них по видам } \\
\text { экономической } \\
\text { деятельности: }\end{array}$ \\
\hline $\begin{array}{l}\text { сельское, лесное } \\
\text { хозяйство, охота, } \\
\text { рыболовство и } \\
\text { рыбоводство }\end{array}$ & 140,9 & 129,4 & 133,1 & $\begin{array}{l}\text { сельское хозяйст- } \\
\text { во, охота и лесное } \\
\text { хозяйство }\end{array}$ \\
\hline & & & $\begin{array}{l}5,2 \\
2,4\end{array}$ & $\begin{array}{l}\text { рыболовство, } \\
\text { рыбоводство }\end{array}$ \\
\hline $\begin{array}{l}\text { добыча полезных } \\
\text { ископаемых }\end{array}$ & 18,1 & 17,6 & 18,2 & $\begin{array}{l}\text { добыча полезных } \\
\text { ископаемых }\end{array}$ \\
\hline $\begin{array}{l}\text { обрабатывающие } \\
\text { производства }\end{array}$ & 349,7 & 331,6 & 387,1 & $\begin{array}{l}\text { обрабатывающие } \\
\text { производства }\end{array}$ \\
\hline $\begin{array}{l}\text { обеспечение элек- } \\
\text { трической энерги- } \\
\text { ей, газом и паром; } \\
\text { кондиционирова- } \\
\text { ние воздуха }\end{array}$ & 25,2 & 23,9 & 31,8 & $\begin{array}{l}\text { производство и } \\
\text { распределение } \\
\text { электроэнергии, } \\
\text { газа и воды }\end{array}$ \\
\hline $\begin{array}{l}\text { водоснабжение; } \\
\text { водоотведение, } \\
\text { организация сбора } \\
\text { и утилизации от- } \\
\text { ходов, деятель- } \\
\text { ность по ликвида- } \\
\text { ции загрязнений }\end{array}$ & 31,4 & 28,2 & & \\
\hline строительство & 499,2 & 493,2 & 497,8 & строительство \\
\hline $\begin{array}{l}\text { торговля оптовая } \\
\text { и розничная; } \\
\text { ремонт } \\
\text { автотранспортных } \\
\text { средств и мото- } \\
\text { циклов }\end{array}$ & 1577,2 & 1465,1 & 1585,0 & $\begin{array}{l}\text { оптовая и рознич- } \\
\text { ная торговля; ре- } \\
\text { монт автотранс- } \\
\text { портных средств, } \\
\text { мотоциклов, бы- } \\
\text { товых изделий и } \\
\text { предметов лично- } \\
\text { го пользования }\end{array}$ \\
\hline & & & 107,3 & $\begin{array}{l}\text { гостиницы } \\
\text { и рестораны }\end{array}$ \\
\hline $\begin{array}{l}\text { транспортировка } \\
\text { и хранение }\end{array}$ & 257,2 & 256,5 & 325,3 & $\begin{array}{l}\text { транспорт } \\
\text { и связь }\end{array}$ \\
\hline
\end{tabular}


Продолжение табл.15.1

\begin{tabular}{|c|c|c|c|c|}
\hline ОКВЭД2 & $\begin{array}{c}2016 \\
\text { (оценка) } \\
\end{array}$ & 2017 & 2016 & Справочно: ОКВЭД \\
\hline $\begin{array}{l}\text { деятельность } \\
\text { гостиниц и пред- } \\
\text { приятий общест- } \\
\text { венного питания }\end{array}$ & 107,2 & 102,9 & & \\
\hline $\begin{array}{l}\text { деятельность } \\
\text { в области инфор- } \\
\text { мации и связи }\end{array}$ & 137,9 & 134,9 & & \\
\hline $\begin{array}{l}\text { деятельность } \\
\text { финансовая } \\
\text { и страховая }\end{array}$ & 92,2 & 84,2 & 92,4 & $\begin{array}{l}\text { финансовая } \\
\text { деятельность }\end{array}$ \\
\hline $\begin{array}{l}\text { деятельность } \\
\text { по операциям } \\
\text { с недвижимым } \\
\text { имуществом }\end{array}$ & 359,1 & 348,2 & 961,3 & $\begin{array}{l}\text { операции с недви- } \\
\text { жимым имущест- } \\
\text { вом, аренда и пре- } \\
\text { доставление услуг }\end{array}$ \\
\hline $\begin{array}{l}\text { деятельность } \\
\text { профессиональ- } \\
\text { ная, научная и } \\
\text { техническая }\end{array}$ & 391,9 & 382,7 & & \\
\hline $\begin{array}{l}\text { деятельность ад- } \\
\text { министративная и } \\
\text { сопутствующие } \\
\text { дополнительные } \\
\text { услуги }\end{array}$ & 172,8 & 173,1 & & \\
\hline $\begin{array}{l}\text { государственное } \\
\text { управление и } \\
\text { обеспечение во- } \\
\text { енной безопасно- } \\
\text { сти; социальное } \\
\text { обеспечение }\end{array}$ & 96,2 & 94,1 & 96,3 & $\begin{array}{l}\text { государственное } \\
\text { управление и обес- } \\
\text { печение военной } \\
\text { безопасности; соци- } \\
\text { альное страхование }\end{array}$ \\
\hline образование & 141,5 & 136,8 & 141,7 & образование \\
\hline $\begin{array}{l}\text { деятельность } \\
\text { в области здраво- } \\
\text { охранения и соци- } \\
\text { альных услуг }\end{array}$ & 82,0 & 82,8 & 85,9 & $\begin{array}{l}\text { здравоохранение } \\
\text { и предоставление } \\
\text { социальных услуг }\end{array}$ \\
\hline $\begin{array}{l}\text { деятельность в } \\
\text { области культуры, } \\
\text { спорта, организа- } \\
\text { ции досуга и раз- } \\
\text { влечений }\end{array}$ & 81,7 & 80,3 & & \\
\hline $\begin{array}{l}\text { предоставление } \\
\text { прочих видов услуг }\end{array}$ & 198,7 & 193,6 & 291,1 & $\begin{array}{l}\text { предоставление } \\
\text { прочих коммуналь- } \\
\text { ных, социальных и } \\
\text { персональных } \\
\text { услуг }\end{array}$ \\
\hline
\end{tabular}

${ }^{1)}$ По данным государственной регистрации. 
Комментарии к различию между ОКВЭД-2007 и ОКВЭД2.

Отсутствие данных за 2016 год по ОКВЭД-2007 по видам экономической деятельности «Водоснабжение; водоотведение, организация сбора и утилизации отходов, деятельность по ликвидации загрязнений», «Деятельность в области информации и связи», «Деятельность профессиональная, научная и техническая», «Деятельность административная и сопутствующие дополнительные услуги», «Деятельность в области культуры, спорта, организации досуга и развлечений» объясняется отсутствием таких разделов в ОКВЭД-2007.

Имеющееся различие между данными по отдельным разделам ОКВЭД-2007 и ОКВЭД2 объясняется следующим:

- между разделом «К» ОКВЭД-2007 «Операции с недвижимым имуществом, аренда и предоставление услуг (961,3 тыс. организаций в 2016 г.) и разделом «L» ОКВЭД2 «Деятельность по операциям с недвижимым имуществом» (359,1 тыс. организаций в 2016 г. (оценка) тем, что раздел «К» был расформирован по четырем разделам ОКВЭД2: «L» «Деятельность по операциям с недвижимым имуществом», «М» «Деятельность профессиональная, научная и техническая», «N» «Деятельность административная и сопутствующие дополнительные услуги» и «Ј» «Деятельность в области информации и связи»;

- между разделом «|» ОКВЭД-2007 «Транспорт и связь» (325,3 тыс. организаций в 2016 г.) и разделом «Н» ОКВЭД2 «Транспортировка и хранение» (257,2 тыс. организаций в 2016 г. (оценка) тем, что деятельность туристических агентств отнесена в раздел «N» «Деятельность административная и сопутствующие дополнительные услуги», деятельность «связь» перенесена в раздел «Ј» «Деятельность в области информации и связи»;

- между разделом «D» ОКВЭД-2007 «Обрабатывающие 
производства» (387,1 тыс. организаций в 2016 г.) и разделом «С» ОКВЭД2 «Обрабатывающие производства» (349,7 тыс. организаций в 2016 г. (оценка) тем, что издательская деятельность перенесена из раздела «D» в новый раздел «J» «Деятельность в области информации и связи». Обработка вторичного сырья из раздела «D» перенесена в раздел «E» «Водоснабжение; водоотведение, организация сбора и утилизации отходов, деятельность по ликвидации загрязнений»;

- между разделом «О» ОКВЭД-2007 «Предоставление прочих коммунальных, социальных и персональных услуг» $(291,1$ тыс. организаций в 2016 г.) и разделом «S» ОКВЭД2 «Предоставление прочих видов услуг» (198,7 тыс. организаций 2016 г. (оценка) тем, что раздел «О» распределен по трем разделам: «R» «Деятельность в области культуры, спорта, организации досуга и развлечений», «S» «Предоставление прочих видов услуг» и «Ј» «Деятельность в области информации и связи»;

- между разделом «А» ОКВЭД 2007 «Сельское хозяйство, охота и лесное хозяйство» (133,1 тыс. организаций в 2016 г.) и разделом «А» ОКВЭД2 «Сельское, лесное хозяйство, охота, рыболовство и рыбоводство» (140,9 тыс. организаций в 2016 г. (оценка) тем, что раздел «А» ОКВЭД-2007 и раздел «В» ОКВЭД-2007 в ОКВЭД2 объединены в один раздел «А». При этом ландшафртная деятельность из раздела «А» перенесена в раздел «N» «Деятельность административная и сопутствующие дополнительные услуги», а деятельность в области ирригации перенесена в раздел «Е» «Водоснабжение; водоотведение, организация сбора и утилизации отходов, деятельность по ликвидации загрязнений».

Ниже приводится описание прочих различий и совпадений между ОКВЭД-2007 и ОКВЭД2. 
Раздел ОКВЭД-2007 «С» «Добыча полезных ископаемых» преобразован в ОКВЭД2 в одноименный раздел с другим буквенным обозначением - «В», при этом структура этого раздела стала более детализированной.

Раздел «F» «Строительство» не изменился ни по названию, ни по обозначению раздела.

Из раздела ОКВЭД-2007 «Е» «Производство и распределение электроэнергии, газа и воды» в ОКВЭД2 выделились два раздела: «Е» «Водоснабжение; водоотведение, организация сбора и утилизации отходов, деятельность по ликвидации загрязнений» и «D» «Обеспечение электрической энергией, газом и паром; кондиционирование воздуха».

Раздел ОКВЭД-2007 «G» «Оптовая и розничная торговля; ремонт автотранспортных средств, мотоциклов, бытовых изделий и предметов личного пользования» переименован в ОКВЭД2 в раздел «G» в следующей новой редакции: «Торговля оптовая и розничная; ремонт автотранспортных средств и мотоциклов», деятельность по ремонту бытовых изделий и предметов личного пользования перенесена в раздел «S» ОКВЭД2 «Предоставление прочих видов услуг».

Раздел «Р» «Образование» не изменился ни по названию, ни по обозначению раздела.

Раздел ОКВЭД-2007 «N» «Здравоохранение и предоставление социальных услуг» преобразован с более детализированной структурой в раздел ОКВЭД2 с другим буквенным обозначением «Q» «Деятельность в области здравоохранения и социальных услуг».

При этом ветеринарная деятельность перенесена в раздел «М» «Деятельность профессиональная, научная и техническая». 


\section{2. РАСПРЕДЕЛЕНИЕ ПРЕДПРИЯТИЙ И ОРГАНИЗАЦИЙ ПО ФОРМАМ СОБСТВЕННОСТИ ${ }^{1)}$}

(на конец года)

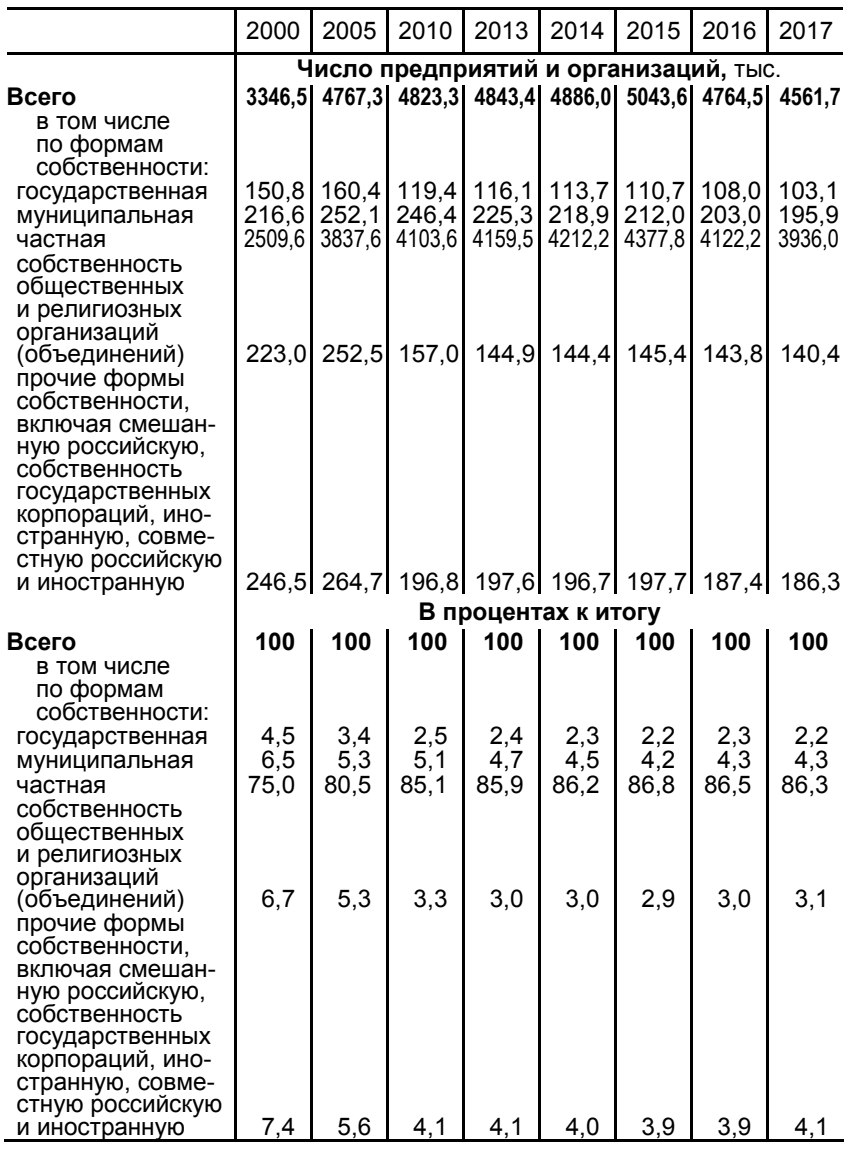

1) По данным государственной регистрации. 
15.3. ОБОРОТ ОРГАНИЗАЦИЙ

ПО ВИДАМ ЭКОНОМИЧЕСКОЙ ДЕЯТЕЛЬНОСТИ ${ }^{1)}$

(в фактически действовавших ценах; млрд. рублей)

\begin{tabular}{|c|c|c|}
\hline & 2016 & 2017 \\
\hline $\begin{array}{l}\text { Всего в экономике } \\
\text { в том числе по видам экономической } \\
\text { деятельности: }\end{array}$ & 146376,8 & 158778,0 \\
\hline $\begin{array}{l}\text { сельское, лесное хозяйство, охота, } \\
\text { рыболовство и рыбоводство }\end{array}$ & 2640,5 & 2720,4 \\
\hline добыча полезных ископаемых & 11688,3 & 13708,3 \\
\hline обрабатывающие производства & 37112,1 & 40502,2 \\
\hline $\begin{array}{l}\text { обеспечение электрической энергией, га- } \\
\text { зом и паром; кондиционирование воздуха }\end{array}$ & 8438,3 & 8995,8 \\
\hline $\begin{array}{l}\text { водоснабжение; водоотведение, органи- } \\
\text { зация сбора и утилизации отходов, дея- } \\
\text { тельность по ликвидации загрязнений }\end{array}$ & 877,9 & 1008,4 \\
\hline строительство & 6522,5 & 6796,2 \\
\hline $\begin{array}{l}\text { торговля оптовая и розничная; ремонт } \\
\text { автотранспортных средств и мотоциклов }\end{array}$ & 54222,2 & 57830,4 \\
\hline транспортировка и хранение & 10031,6 & 10870,7 \\
\hline $\begin{array}{l}\text { деятельность гостиниц и предприятий } \\
\text { общественного питания }\end{array}$ & 966,6 & 1137,6 \\
\hline $\begin{array}{l}\text { деятельность в области информации } \\
\text { и связи }\end{array}$ & 3184,2 & 3437,6 \\
\hline $\begin{array}{l}\text { деятельность по операциям с недвижи- } \\
\text { мым имуществом }\end{array}$ & 2199,5 & 2356,6 \\
\hline $\begin{array}{l}\text { деятельность профессиональная, } \\
\text { научная и техническая }\end{array}$ & 4416,5 & 4826,9 \\
\hline $\begin{array}{l}\text { деятельность административная и сопут- } \\
\text { ствующие дополнительные услуги }\end{array}$ & 971,7 & 1234,0 \\
\hline $\begin{array}{l}\text { государственное управление и обеспече- } \\
\text { ние военной безопасности; социальное } \\
\text { обеспечение }\end{array}$ & 121,4 & 124,8 \\
\hline образование & 487,4 & 534,2 \\
\hline $\begin{array}{l}\text { деятельность в области здравоохранения } \\
\text { и социальных услуг }\end{array}$ & 2005,7 & 2157,0 \\
\hline $\begin{array}{l}\text { деятельность в области культуры, спорта, } \\
\text { организации досуга и развлечений }\end{array}$ & 184,4 & 224,8 \\
\hline предоставление прочих видов услуг & 281,3 & 286,1 \\
\hline
\end{tabular}




\section{МАЛОЕ ПРЕДПРИНИМАТЕЛЬСТВО}

\section{4. ЧИСЛО МАЛЫХ ПРЕДПРИЯТИЙ (без мИкропредПрИЯтиЙ) ПО ВИДАМ ЭКОНОМИЧЕСКОЙ ДЕЯТЕЛЬНОСТИ В 2017 г. \\ (по данным выборочного наблюдения; на конец года)}

\begin{tabular}{|c|c|c|}
\hline & Тысяч & $\begin{array}{l}\text { В процентах } \\
\text { к итогу }\end{array}$ \\
\hline $\begin{array}{l}\text { Bсего } \\
\text { в том числе по видам экономической } \\
\text { деятельности: }\end{array}$ & 256,7 & 100 \\
\hline $\begin{array}{l}\text { сельское, лесное хозяйство, охота, рыболов- } \\
\text { ство и рыбоводство }\end{array}$ & 8,8 & 3,4 \\
\hline добыча полезных ископаемых & 1,3 & 0,5 \\
\hline обрабатывающие производства & 33,2 & 12,9 \\
\hline $\begin{array}{l}\text { обеспечение электрической энергией, газом } \\
\text { и паром; кондиционирование воздуха }\end{array}$ & 2,9 & 1,1 \\
\hline $\begin{array}{l}\text { водоснабжение; водоотведение, организация } \\
\text { сбора и утилизации отходов, деятельность } \\
\text { по ликвидации загрязнений }\end{array}$ & 3,3 & 1,3 \\
\hline строительство & 31,8 & 12,4 \\
\hline $\begin{array}{l}\text { торговля оптовая и розничная; ремонт авто- } \\
\text { транспортных средств и мотоциклов }\end{array}$ & 85,8 & 33,4 \\
\hline транспортировка и хранение & 13,7 & 5,3 \\
\hline $\begin{array}{l}\text { деятельность гостиниц и предприятий обще- } \\
\text { ственного питания }\end{array}$ & 9,8 & 3,8 \\
\hline деятельность в области информации и связи & 7,2 & 2,8 \\
\hline $\begin{array}{l}\text { из нее деятельность в сфере } \\
\text { телекоммуникаций }\end{array}$ & 1,4 & 0,6 \\
\hline $\begin{array}{l}\text { деятельность по операциям с недвижимым } \\
\text { имуществом }\end{array}$ & 18,1 & 7,1 \\
\hline $\begin{array}{l}\text { деятельность профессиональная, научная } \\
\text { и техническая }\end{array}$ & 13,1 & 5,1 \\
\hline из нее научные исследования и разработки & 1,3 & 0,5 \\
\hline $\begin{array}{l}\text { деятельность административная и сопутст- } \\
\text { вующие дополнительные услуги }\end{array}$ & 15,4 & 6,0 \\
\hline $\begin{array}{l}\text { из нее деятельность туристических } \\
\text { агентств и прочих организаций, предостав- } \\
\text { ляющих услуги в сфере туризма }\end{array}$ & 0,7 & 0,3 \\
\hline образование & 0,2 & 0,1 \\
\hline $\begin{array}{l}\text { деятельность в области здравоохранения } \\
\text { и социальных услуг }\end{array}$ & 5,4 & 2,1 \\
\hline $\begin{array}{l}\text { деятельность в области культуры, спорта, } \\
\text { организации досуга и развлечений }\end{array}$ & 1,1 & 0,4 \\
\hline
\end{tabular}


15.5. ЧИСЛЕННОСТЬ РАБОТНИКОВ МАЛЫХ ПРЕДПРИЯТИЙ (без мИкропредПрИЯтИЙ) ПО ВИДАМ ЭКОНОМИЧЕСКОЙ ДЕЯТЕЛЬНОСТИ в 2017 г.

(по данным выборочного наблюдения)

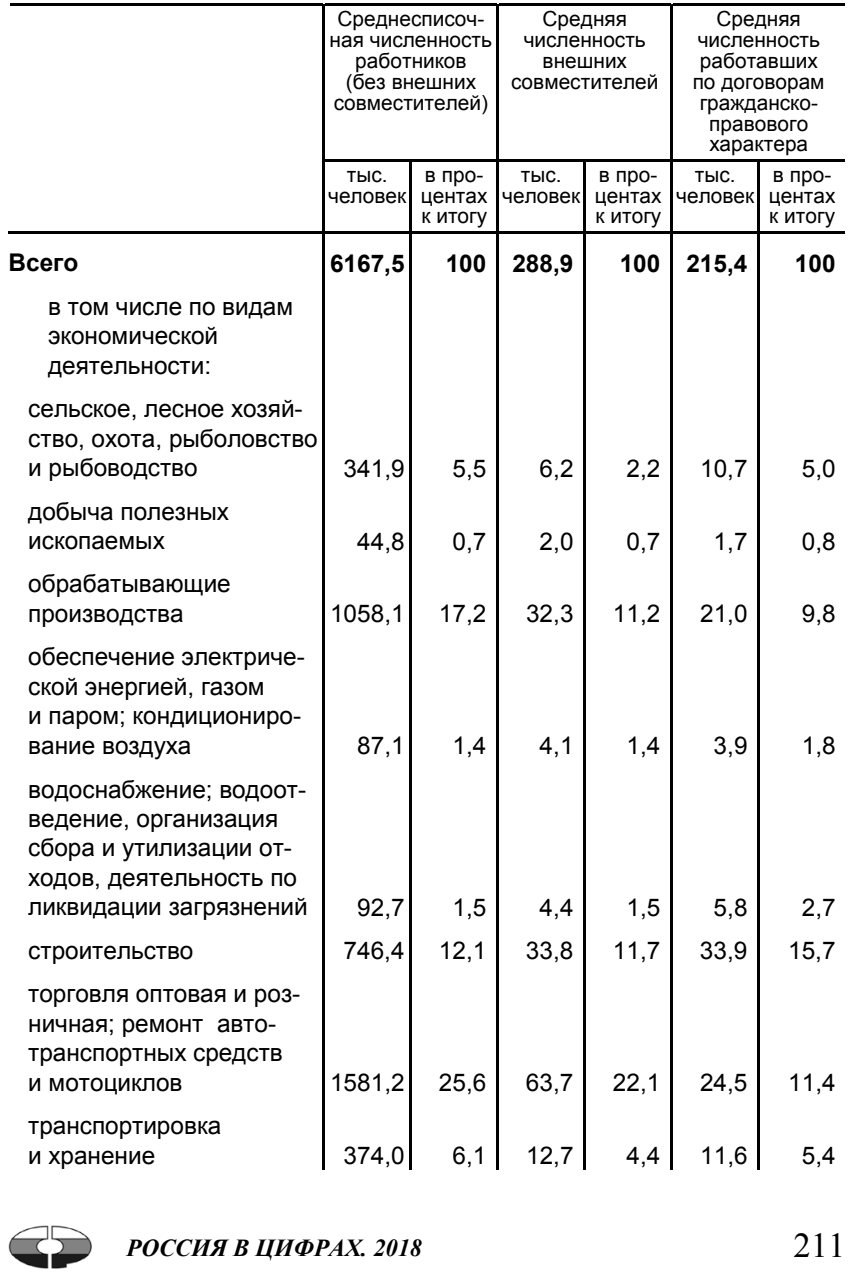


Продолжение табл. 15.5

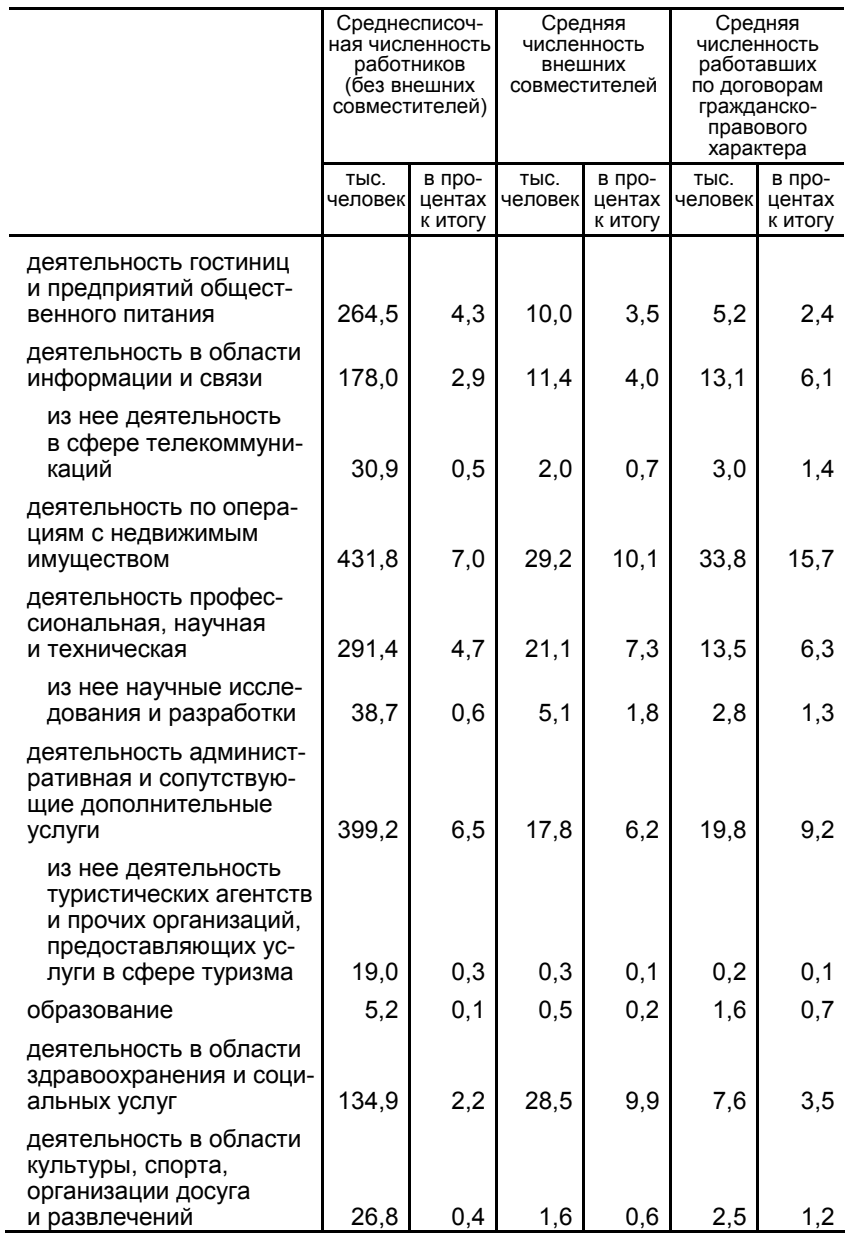


15.6. ОБОРОТ МАЛЫХ ПРЕДПРИЯТИЙ (без мИкропреДпрИЯтИЙ) ПО ВИДАМ ЭКОНОМИЧЕСКОЙ ДЕЯТЕЛЬНОСТИ В 2017 г.

(по данным выборочного наблюдения)

\begin{tabular}{|c|c|c|}
\hline & Млрд. руб. & $\begin{array}{l}\text { В процентах } \\
\text { к итогу }\end{array}$ \\
\hline $\begin{array}{l}\text { Bсего } \\
\text { в том числе по видам экономической } \\
\text { деятельности: }\end{array}$ & 27586,4 & 100 \\
\hline $\begin{array}{l}\text { сельское, лесное хозяйство, охота, } \\
\text { рыболовство и рыбоводство }\end{array}$ & 580,5 & 2,1 \\
\hline добыча полезных ископаемых & 150,2 & 0,5 \\
\hline обрабатывающие производства & 2822,5 & 10,2 \\
\hline $\begin{array}{l}\text { обеспечение электрической энергией, } \\
\text { газом и паром; кондиционирование } \\
\text { воздуха }\end{array}$ & 166,6 & 0,6 \\
\hline $\begin{array}{l}\text { водоснабжение; водоотведение, органи- } \\
\text { зация сбора и утилизации отходов, дея- } \\
\text { тельность по ликвидации загрязнений }\end{array}$ & 203,4 & 0,7 \\
\hline строительство & 3337,1 & 12,1 \\
\hline $\begin{array}{l}\text { торговля оптовая и розничная; ремонт } \\
\text { автотранспортных средств и мотоциклов }\end{array}$ & 15693,2 & 56,9 \\
\hline транспортировка и хранение & 903,5 & 3,3 \\
\hline $\begin{array}{l}\text { деятельность гостиниц и предприятий } \\
\text { общественного питания }\end{array}$ & 433,7 & 1,6 \\
\hline $\begin{array}{l}\text { деятельность в области информации } \\
\text { и связи }\end{array}$ & 452,2 & 1,6 \\
\hline $\begin{array}{l}\text { из нее деятельность в сфрере телеком- } \\
\text { муникаций }\end{array}$ & 86,3 & 0,3 \\
\hline $\begin{array}{l}\text { деятельность по операциям с недвижи- } \\
\text { мым имуществом }\end{array}$ & 1161,3 & 4,2 \\
\hline $\begin{array}{l}\text { деятельность профессиональная, } \\
\text { научная и техническая }\end{array}$ & 912,9 & 3,3 \\
\hline $\begin{array}{l}\text { из нее научные исследования } \\
\text { и разработки }\end{array}$ & 104,5 & 0,4 \\
\hline $\begin{array}{l}\text { деятельность административная и со- } \\
\text { путствующие дополнительные услуги }\end{array}$ & 414,3 & 1,5 \\
\hline $\begin{array}{l}\text { из нее деятельность туристических } \\
\text { агентств и прочих организаций, предос- } \\
\text { тавляющих услуги в сфере туризма }\end{array}$ & 37,4 & 0,1 \\
\hline образование & 4,9 & 0,0 \\
\hline $\begin{array}{l}\text { деятельность в области здравоохране- } \\
\text { ния и социальных услуг }\end{array}$ & 204,1 & 0,7 \\
\hline $\begin{array}{l}\text { деятельность в области культуры, спор- } \\
\text { та, организации досуга и развлечений }\end{array}$ & 50,6 & 0,2 \\
\hline
\end{tabular}


15.7. УДЕЛЬНЫЙ ВЕС КРЕСТЬЯНСКИХ (фермерскИХ) ХОЗЯЙСТВ ${ }^{1)}$ В ОБЩЕМ ОБЪЕМЕ ПРОИЗВОДСТВА ОСНОВНЫХ ВИДОВ СЕЛЬСКОХОЗЯЙСТВЕННОЙ ПРОДУКЦИИ

(в процентах от общего объема производства в хозяйствах всех категорий)

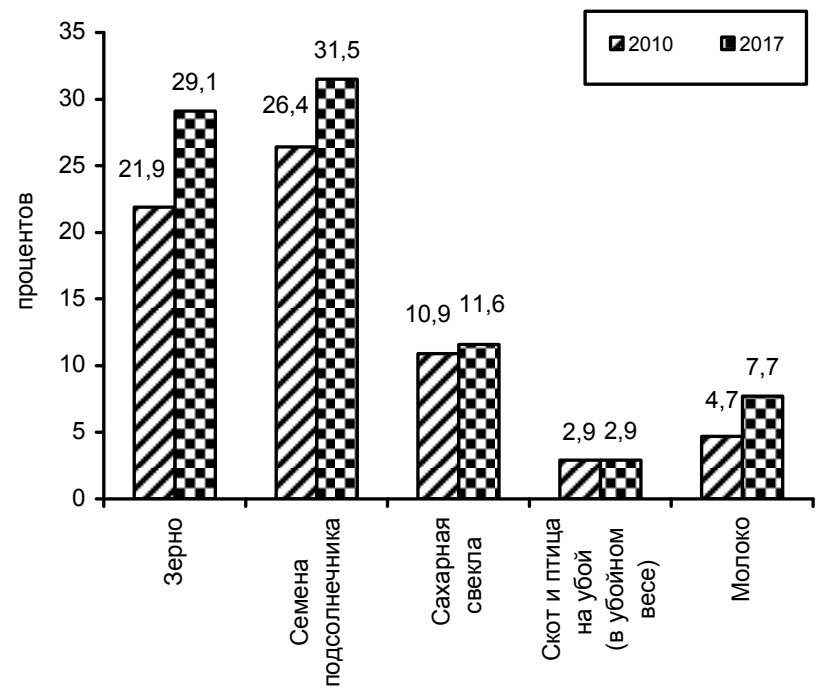

1) Включая индивидуальных предпринимателей. 


\title{
ИНДИВИДУАЛЬНОЕ ПРЕДПРИНИМАТЕЛЬСТВО
}

\author{
15.8. ОСНОВНЫЕ ПОКАЗАТЕЛИ ДЕЯТЕЛЬНОСТИ \\ ИНДИВИДУАЛЬНЫХ ПРЕДПРИНИМАТЕЛЕЙ \\ ПО ВИДАМ ЭКОНОМИЧЕСКОЙ ДЕЯТЕЛЬНОСТИ в 2016 г. ${ }^{1)}$
}

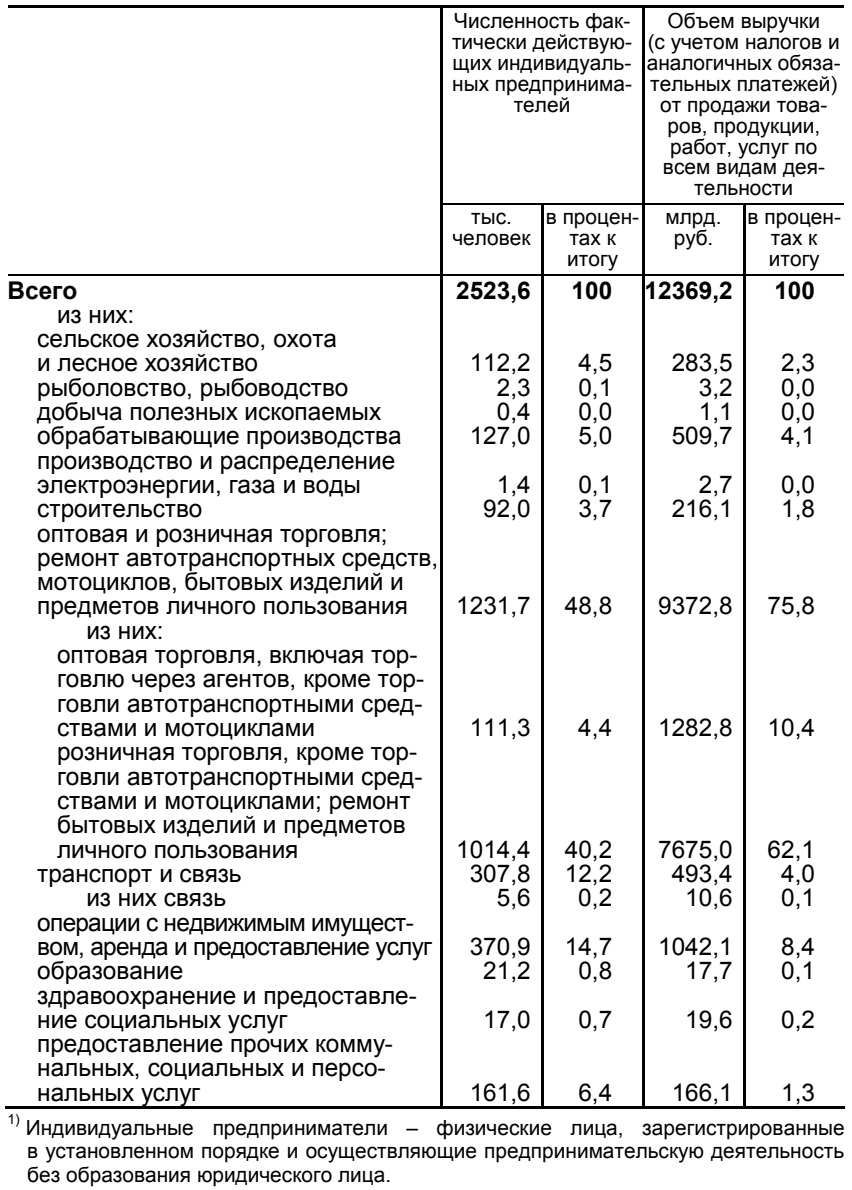




\section{6. ПРОМЫШЛЕННОЕ ПРОИЗВОДСТВО}

В соответствии с Федеральным законом от 31.12.2014 № 488-Ф3 «О промышленной политике в Российской Федерации» промышленное производство - это определенная на основании Общероссийского классификатора видов экономической деятельности совокупность видов экономической деятельности, относящихся к добыче полезных ископаемых, обрабатывающему производству, обеспечению электрической энергией, газом и паром, кондиционированию воздуха, водоснабжению, водоотведению, организации сбора и утилизации отходов, а также ликвидации загрязнений.

В разделе приводится информация о структуре отгруженной продукции (работ, услуг) по видам экономической деятельности, производстве важнейших видов продукции, об отдельных показателях фринансово-хозяйственной деятельности организаций.

Показатели по видам экономической деятельности и по видам продукции приводятся за 2017 год в соответствии с новыми редакциями общероссийских классификаторов видов экономической деятельности (ОКВЭД 2) ОК 029-2014 и продукции по видам экономической деятельности (ОКПД 2) ОК 034-2014, введенных в действие с 1 января 2017 г.

Аналогичные сведения за период до 2016 г. включительно, разработанные в соответствии с ранее действовавшими общероссийскими классификаторами видов экономической деятельности (ОКВЭД-2007) ОК 029-2007 и продукции по видам экономической деятельности (ОКПД) (КПЕС 2002)ОК 034-2007, опубликованы в кратком статистическом сборнике «Россия в цифрах. 2017», электронная версия которого размещена на официальном Интернет-портале Росстата в разделе «Публикации».

Объем отгруженных товаров собственного производства, выполненных работ и услуг собственными силами стоимость отгруженных или отпущенных в порядке продажи, а также прямого обмена (по договору мены) всех товаров собственного производства, работ и услуг, выполненных (оказанных)

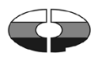


собственными силами. Разработка данного показателя в ОКВЭД2 осуществляется с 2017г. (данные за 2016 год приведены по респондентам, осуществлявшим деятельность в 2017 году).

Объем отгруженных товаров представляет собой стоимость товаров, которые произведены данным юридическим лицом и фактически отгружены (переданы) в отчетном периоде на сторону (другим юридическим и физическим лицам), включая товары, сданные по акту заказчику на месте, независимо от того, поступили деньги на счет продавца или нет.

Объем работ и услуг, выполненных собственными силами, представляет собой стоимость работ и услуг, оказанных (выполненных) организацией другим юридическим и фризическим лицам.

Данные приводятся в фактических отпускных ценах без налога на добавленную стоимость, акцизов и аналогичных обязательных платежей.

Группировки по видам экономической деятельности представляют собой совокупность соответствующих фрактических видов деятельности, осуществляемых организациями, независимо от их основного вида экономической деятельности.

В ряде случаев в соответствии с принятой учетной политикой отдельные организации представляют данные в целом по юридическому лицу по месту его нахождения.

Индекс производства - относительный показатель, характеризующий изменение масштабов производства в сравниваемых периодах. Различают индивидуальные и сводные индексы производства. Индивидуальные индексы отражают изменение выпуска одного продукта и исчисляются как отношение объемов производства данного вида продукта в натуральновещественном выражении в сравниваемых периодах. Сводный индекс производства характеризует совокупные изменения всех видов продукции и отражает изменение создаваемой в процессе производства стоимости в результате изменения только физического объема производимой продукции. Для исчисления сводного индекса производства индивидуальные индексы по конкретным видам продукции поэтапно агрегируются в индексы по видам деятельности, подгруппам, группам, подклассам, классам и разделам ОКВЭД2. 
Индекс промышленного производства - агрегированный индекс производства по видам экономической деятельности "Добыча полезных ископаемых", "Обрабатывающие производства", "Обеспечение электрической энергией, газом и паром; кондиционирование воздуха», «Водоснабжение; водоотведение, организация сбора и утилизации отходов, деятельность по ликвидации загрязнений».

Данные по Российской Федерации по индексу промышленного производства и индексам производства по видам деятельности «Добыча полезных ископаемых», «Обрабатывающие производства», «Обеспечение электрической энергией, газом и паром; кондиционирование воздуха», «Водоснабжение; водоотведение, организация сбора и утилизации отходов, деятельность по ликвидации загрязнений» приведены с учетом поправки на нефрормальную деятельность.

Производство продукции в натуральном выражении включает продукцию, выработанную организацией (независимо от вида основной деятельности) как из собственных сырья и материалов, так и из неоплачиваемых сырья и материалов заказчика (давальческого), предназначенную для отпуска другим юридическим и фризическим лицам, своему капитальному строительству и своим подразделениям, зачисленную в состав основных средств или оборотных активов (например, спецодежда, спецоснастка), выданную своим работникам в счет оплаты труда, а также израсходованную на собственные производственные нужды. Давальческое сырье - это сырье, принадлежащее заказчику и переданное на переработку другим организациям для производства из него продукции в соответствии с заключенными договорами. Данные приводятся в соответствии с Общероссийским классификатором продукции по видам экономической деятельности (ОКПД2).

Среднегодовая численность работников организаций определяется путем суммирования среднесписочной численности организаций за все месяцы года и деления полученной суммы на 12. Среднесписочная численность исчисляется путем суммирования численности работников списочного состава за каждый календарный день месяца и деления полученной суммы на число календарных дней месяца. В среднесписочную

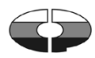


численность работников не включены женщины, находившиеся в отпусках по беременности и родам, лица, находившиеся в отпусках в связи с усыновлением новорожденного ребенка непосредственно из родильного дома, а также в отпусках по уходу за ребенком, работники, обучавшиеся в образовательных организациях и находившиеся в дополнительном отпуске без сохранения заработной платы, а также поступившие в образовательные организации и находившиеся в дополнительном отпуске без сохранения заработной платы для сдачи вступительных экзаменов.

Сальдированный финансовый результат (прибыль минус убыток) - конечный финансовый результат, выявленный на основании бухгалтерского учета всех хозяйственных операций организаций. Представляет собой сумму прибыли (убытка) от продажи товаров, продукции (работ, услуг), основных средств, иного имущества организаций и чистых доходов от прочих операций. Данные по сальдированному финансовому результату приводятся без субъектов малого предпринимательства, в фактически действовавших ценах, структуре и методологии соответствующих лет.

Рентабельность проданных товаров, продукции (работ, услуг) - рассчитывается как соотношение между величиной сальдированного финансового результата (прибыль минус убыток) от продажи товаров, продукции (работ, услуг) и себестоимостью проданных товаров, продукции (работ, услуг) с учетом коммерческих и управленческих расходов. В том случае, если получен отрицательный сальдированный финансовый результат от продажи товаров, продукции (работ, услуг), имеет место убыточность. 


\section{ОБЩЕЭКОНОМИЧЕСКИЕ ПОКАЗАТЕЛИ ОРГАНИЗАЦИЙ ПО ВИДАМ ЭКОНОМИЧЕСКОЙ ДЕЯТЕЛЬНОСТИ В СФЕРЕ ПРОМЫШЛЕННОГО ПРОИЗВОДСТВА}

\section{1. ОСНОВНЫЕ ЭКОНОМИЧЕСКИЕ ПОКАЗАТЕЛИ ДЕЯТЕЛЬНОСТИ ОРГАНИЗАЦИЙ}

\begin{tabular}{|c|c|}
\hline & 2017 \\
\hline \multicolumn{2}{|l|}{$\begin{array}{l}\text { Объем отгруженных товаров собственного про- } \\
\text { изводства, выполненных работ и услуг собствен- } \\
\text { ными силами, млрд. руб.: }\end{array}$} \\
\hline добыча полезных ископаемых ${ }^{1)}$ & 13756 \\
\hline обрабатывающие производства & 37331 \\
\hline $\begin{array}{l}\text { обеспечение электрической энергией, газом и } \\
\text { паром; кондиционирование воздуха }{ }^{3)}\end{array}$ & 5196 \\
\hline $\begin{array}{l}\text { водоснабжение; водоотведение, организация } \\
\text { сбора и утилизации отходов, деятельность по } \\
\text { ликвидации загрязнений }\end{array}$ & 921 \\
\hline $\begin{array}{l}\text { Индекс промышленного производства }{ }^{5)} \\
\text { в процентах к предыдущему году }\end{array}$ & 101,0 \\
\hline $\begin{array}{l}\text { Среднегодовая численность работников } \\
\text { организаций, тыс. человек }\end{array}$ & 9858,8 \\
\hline $\begin{array}{l}\text { Сальдированный финансовый результат } \\
\text { (прибыль минус убыток) организаций, млн. руб. }\end{array}$ & 6077885 \\
\hline $\begin{array}{l}\text { Рентабельность проданных товаров, продукции } \\
\text { (работ, услуг) организаций, процентов }\end{array}$ & 13,8 \\
\hline
\end{tabular}

1) 2016 г. - 11701 млрд. руб.

2) 2016 г. - 34284 млрд. руб.

3) 2016 г. - 4874 млрд. руб.

4) 2016 г. - 824 млрд. руб.

5) Агрегированный индекс производства по видам экономической деятельности «Добыча полезных ископаемых», "Обрабатывающие производства», «Обеспечение электрической энергией, газом и паром; кондиционирование воздуха», «Водоснабжение; водоотведение, организация сбора и утилизации отходов, деятельность по ликвидации загрязнений». 2016 г. - 101,3\%. 
16.2. СТРУКТУРА ОБЪЕМА ОТГРУЖЕННЫХ ТОВАРОВ СОБСТВЕННОГО ПРОИЗВОДСТВА, ВЫПОЛНЕННЫХ РАБОТ И УСЛУГ СОБСТВЕННЫМИ СИЛАМИ ПО ВИДАМ ЭКОНОМИЧЕСКОЙ ДЕЯТЕЛЬНОСТИ

(в процентах)

\begin{tabular}{|c|c|c|}
\hline & 2016 & 2017 \\
\hline $\begin{array}{l}\text { Добыча полезных ископаемых } \\
\text { в том числе: }\end{array}$ & 100 & 100 \\
\hline добыча угля & 7,5 & 8,5 \\
\hline добыча сырой нефти и природного газа & 67,8 & 68,4 \\
\hline добыча металлических руд & 7,6 & 7,2 \\
\hline добыча прочих полезных ископаемых & 5,2 & 4,0 \\
\hline $\begin{array}{l}\text { предоставление услуг в области добычи по- } \\
\text { лезных ископаемых }\end{array}$ & 11,9 & 11,9 \\
\hline $\begin{array}{l}\text { Обрабатывающие производства } \\
\text { в том числе: }\end{array}$ & 100 & 100 \\
\hline производство пищевых продуктов & 15,3 & 14,1 \\
\hline производство напитков & 2,2 & 1,9 \\
\hline производство табачных изделий & 0,9 & 0,5 \\
\hline производство текстильных изделий & 0,5 & 0,5 \\
\hline производство одежды & 0,4 & 0,4 \\
\hline производство кожи и изделий из кожи & 0,2 & 0,2 \\
\hline $\begin{array}{l}\text { обработка древесины и производство изде- } \\
\text { лий из дерева и пробки, кроме мебели, про- } \\
\text { изводство изделий из соломки и материалов } \\
\text { для плетения }\end{array}$ & 1,5 & 1,4 \\
\hline производство бумаги и бумажных изделий & 2,2 & 2,0 \\
\hline $\begin{array}{l}\text { деятельность полиграфическая и копирова- } \\
\text { ние носителей информации }\end{array}$ & 0,6 & 0,6 \\
\hline производство кокса и нефтепродуктов & 20,1 & 22,1 \\
\hline $\begin{array}{l}\text { производство химических веществ и химиче- } \\
\text { ских продуктов }\end{array}$ & 7,4 & 7,1 \\
\hline $\begin{array}{l}\text { производство лекарственных средств и ма- } \\
\text { териалов, применяемых в медицинских це-- } \\
\text { лях }\end{array}$ & 1,1 & 1,1 \\
\hline $\begin{array}{l}\text { производство резиновых и пластмассовых } \\
\text { изделий }\end{array}$ & 2,8 & 2,6 \\
\hline $\begin{array}{l}\text { производство прочей неметаллической ми- } \\
\text { неральной продукции }\end{array}$ & 3,6 & 3,5 \\
\hline производство металлургическое & 13,5 & 13,7 \\
\hline
\end{tabular}


Продолжение табл. 16.2

\begin{tabular}{|c|c|c|}
\hline & 2016 & 2017 \\
\hline $\begin{array}{l}\text { производство готовых металлических изде- } \\
\text { лий, кроме машин и оборудования }\end{array}$ & 6,1 & 6,0 \\
\hline $\begin{array}{l}\text { производство компьютеров, электронных и } \\
\text { оптических изделий }\end{array}$ & 3,5 & 3,3 \\
\hline производство электрического оборудования & 2,4 & 2,3 \\
\hline $\begin{array}{l}\text { производство машин и оборудования, не } \\
\text { включенных в другие группировки }\end{array}$ & 3,0 & 2,9 \\
\hline $\begin{array}{l}\text { производство автотранспортных средств, } \\
\text { прицепов и полуприцепов }\end{array}$ & 4,8 & 5,6 \\
\hline $\begin{array}{l}\text { производство прочих транспортных средств } \\
\text { и оборудования }\end{array}$ & 4,4 & 4,8 \\
\hline производство мебели & 0,6 & 0,6 \\
\hline производство прочих готовых изделий & 0,7 & 0,6 \\
\hline ремонт и монтаж машин и оборудования & 2,2 & 2,2 \\
\hline $\begin{array}{l}\text { Обеспечение электрической энергией, га- } \\
\text { зом и паром; кондиционирование воздуха } \\
\text { в том числе: }\end{array}$ & 100 & 100 \\
\hline $\begin{array}{l}\text { производство, передача и распределение } \\
\text { электроэнергии }\end{array}$ & 65,8 & 66,9 \\
\hline $\begin{array}{l}\text { производство и распределение газообразного } \\
\text { топлива }\end{array}$ & 4,1 & 4,1 \\
\hline $\begin{array}{l}\text { производство, передача и распределение } \\
\text { пара и горячей воды; кондиционирование } \\
\text { воздуха }\end{array}$ & 30,1 & 29,0 \\
\hline $\begin{array}{l}\text { Водоснабжение; водоотведение, органи- } \\
\text { зация сбора и утилизации отходов, дея- } \\
\text { тельность по ликвидации загрязнений }\end{array}$ & 100 & 100 \\
\hline в том числе: & & \\
\hline забор, очистка и распределение воды & 30,6 & 28,8 \\
\hline сбор и обработка сточных вод & 26,1 & 24,6 \\
\hline $\begin{array}{l}\text { сбор, обработка и утилизация отходов; обра- } \\
\text { ботка вторичного сырья }\end{array}$ & 40,0 & 43,7 \\
\hline $\begin{array}{l}\text { предоставление услуг в области ликвидации } \\
\text { последствий загрязнений и прочих услуг, свя- } \\
\text { занных с удалением отходов }\end{array}$ & 3,3 & 2,9 \\
\hline
\end{tabular}




\section{ОСНОВНЫЕ ПОКАЗАТЕЛИ РАБОТЫ ОРГАНИЗАЦИЙ ОТДЕЛЬНЫХ ВИДОВ ЭКОНОМИЧЕСКОЙ ДЕЯТЕЛЬНОСТИ}

\section{3. ОСНОВНЫЕ ПОКАЗАТЕЛИ РАБОТЫ ОРГАНИЗАЦИЙ ПО ВИДУ ЭКОНОМИЧЕСКОЙ ДЕЯТЕЛЬНОСТИ «ДОБЫЧА ПОЛЕЗНЫХ ИСКОПАЕМЫХ»}

\begin{tabular}{|c|c|}
\hline & 2017 \\
\hline $\begin{array}{l}\text { Объем отгруженных товаров собственного производ- } \\
\text { ства, выполненных работ и услуг собственными } \\
\text { силами }{ }^{1)} \text {, млрд. руб. }\end{array}$ & 13756 \\
\hline $\begin{array}{l}\text { Индекс производства }{ }^{2)} \text {, в процентах к предыдущему } \\
\text { году }\end{array}$ & 102,0 \\
\hline $\begin{array}{l}\text { Среднегодовая численность работников организаций, } \\
\text { тыс. человек }\end{array}$ & 989,7 \\
\hline $\begin{array}{l}\text { Сальдированный фринансовый результат (прибыль } \\
\text { минус убыток), млн. руб. }\end{array}$ & 2595632 \\
\hline $\begin{array}{l}\text { Рентабельность проданных товаров, продукции } \\
\text { (работ, услуг), процентов }\end{array}$ & 25,9 \\
\hline
\end{tabular}

1) 2016 г. - 11701 млрд. руб.

2) 2016 г. $-102,7 \%$.

\section{4. ДОБЫЧА И ПЕРЕРАБОТКА ОСНОВНЫХ ВИДОВ ПОЛЕЗНЫХ ИСКОПАЕМЫХ}

\begin{tabular}{l|r|r}
\hline & 2016 & 2017 \\
\hline Уголь каменный и бурый, млн. т & 385 & 410 \\
Торф неагломерированный, млн. т & 1,2 & 0,9 \\
Нефть сырая, включая газовый & 548 & 546 \\
конденсат, млн. т & 640 & 691 \\
Газ природный и попутный, млрд. м & \\
Концентрат железорудный, млн. т & 101 & 95,0 \\
Руды и концентраты золотосодержащие, в & 102,2 & 106,4 \\
процентах к предыдущему году & 235 & 249 \\
Пески природные, млн. м & & \\
Гранулы, крошка и порошок; галька, & 254 & 265 \\
\hline гравий, млн. м & &
\end{tabular}




\section{5. ОСНОВНЫЕ ПОКАЗАТЕЛИ РАБОТЫ ОРГАНИЗАЦИЙ ПО ВИДУ ЭКОНОМИЧЕСКОЙ ДЕЯТЕЛЬНОСТИ «ОБРАБАТЫВАЮЩИЕ ПРОИЗВОДСТВА»}

\begin{tabular}{l|r}
\hline & 2017 \\
\hline $\begin{array}{l}\text { Объем отгруженных товаров собственного производст- } \\
\text { ва, выполненных работ и услуг собственными силами }\end{array}$ & \\
$\begin{array}{l}\text { млрд. руб. } \\
\text { Индекс производства }\end{array}{ }^{2)}$ в процентах к предыдущему & 37331 \\
году & 100,2 \\
$\begin{array}{l}\text { Среднегодовая численность работников организаций, } \\
\text { тыс. человек }\end{array}$ & 6834,2 \\
$\begin{array}{l}\text { Сальдированный финансовый результат (прибыль } \\
\text { минус убыток), млн. руб. }\end{array}$ & 2902753 \\
Рентабельность проданных товаров, продукции (работ, \\
услуг), процентов
\end{tabular}

1) 2016 г. - 34284 млрд. руб.

2) 2016 г. $-100,5 \%$.

\section{6. ОСНОВНЫЕ ПОКАЗАТЕЛИ РАБОТЫ ОРГАНИЗАЦИЙ ПО ВИДУ ЭКОНОМИЧЕСКОЙ ДЕЯТЕЛЬНОСТИ «ПРОИЗВОДСТВО ПИЩЕВЫХ ПРОДУКТОВ»}

\begin{tabular}{l|r}
\hline & 2017 \\
\hline $\begin{array}{l}\text { Объем отгруженных товаров собственного производст- } \\
\text { ва, выполненных работ и услуг собственными силами }\end{array}$ & \\
$\begin{array}{l}\text { млрд. руб. } \\
\text { Индекс производства }{ }^{2)}, \text { в процентах к предыдущему } \\
\text { году }\end{array}$ & 105,6 \\
$\begin{array}{l}\text { Среднегодовая численность работников организаций, } \\
\text { тыс. человек }\end{array}$ & 1001,0 \\
$\begin{array}{l}\text { Сальдированный финансовый результат (прибыль } \\
\text { минус убыток), млн. руб. }\end{array}$ & 223106 \\
Рентабельность проданных товаров, продукции (работ, \\
услуг), процентов
\end{tabular}

1) 2016 г. - 5245 млрд. руб.

2) 2016 г. $-103,1 \%$. 


\section{7. ПРОИзВОДСтВО ОСНОВНЫХ ВИДОВ ПИЩЕВЫХ ПРОДУКТОВ}

Мясо крупного рогатого скота, свинина,
баранина, козлятина, конина и мясо прочих
животных семейства лошадиных, оленина
и мясо прочих животных семейства оленьих
(оленевых) парные, остывшие или охлаж-
денные, тыс.т

Субпродукты пищевые крупного рогатого скота, свиные, бараньи, козьи, лошадей, ослов, мулов, лошаков и прочих животных семейства лошадиных, оленьи и прочих животных семейства оленьих (оленевых) парные, остывшие или охлажденные, в том числе для детского питания, тыс.т

Мясо и субпродукты пищевые домашней птицы, тыс. т

Полуфабрикаты мясные, мясосодержащие, охлажденные, замороженные ${ }^{1)}$, тыс.т

Изделия колбасные вареные, в том числе фаршированные, тыс. т

Изделии колбасные из термически обработанных ингредиентов, тыс.т

Изделия колбасные копченые, тыс.т

Консервы мясные (мясосодержащие), включая консервы для детского питания, млн. условных банок

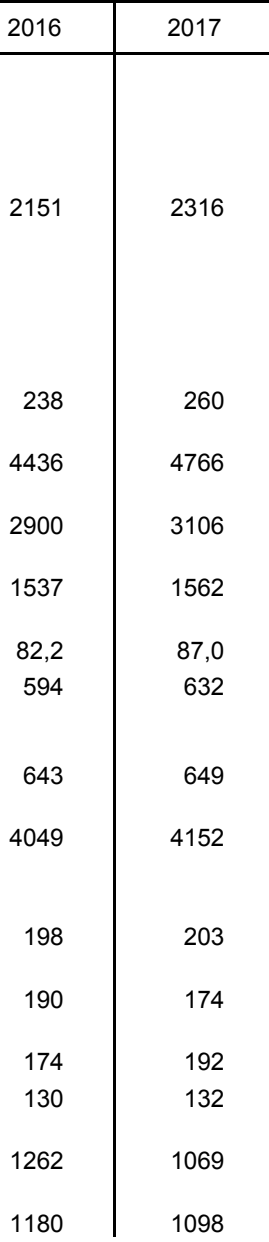

Рыба переработанная и консервированная, ракообразные и моллюски, тыс. т

в том числе:

консервы рыбные натуральные, млн. условных банок

консервы рыбные в томатном coусе, млн. условных банок

консервы рыбные в масле, млн. условных банок

пресервы рыбные, млн. условных банок

Соки из фруктов и овощей,

млн. условных банок

Нектары фруктовые и (или) овощные, млн. условных банок

.


Продолжение табл. 16.7

Овощи (кроме картофеля) и грибы, консер-
вированные без уксуса или уксусной кисло-
ты, прочие (кроме готовых овощных блюд),
млн. условных банок

Овощи (кроме картофеля), фрукты, орехи и прочие съедобные части растений, переработанные или консервированные с уксусом или уксусной кислотой, млн. условных банок Масла растительные и их фракции нерафинированные, тыс. т

Молоко, кроме сырого, тыс. т

Масло сливочное и пасты масляные, тыс. т

Сыры, тыс. т

Продукты молочные сгущенные, млн. условных банок

Мука из зерновых культур, овощных и других растительных культур; смеси из них, млн. т

Крупа и мука грубого помола из пшеницы, тыс. т

\begin{tabular}{|c|c|}
\hline 2016 & 2017 \\
\hline 1064 & 1203 \\
\hline 450 & 340 \\
\hline 5312 & 5773 \\
\hline 5468 & 5336 \\
\hline 250 & 269 \\
\hline 438 & 462 \\
\hline 835 & 856 \\
\hline 9,6 & 9,2 \\
\hline 173 & 192 \\
\hline 946 & 1109 \\
\hline 25,6 & 27,6 \\
\hline 6183 & 5957 \\
\hline 329 & 315 \\
\hline 323 & 333 \\
\hline 1504 & 1512 \\
\hline 1767 & 1828 \\
\hline 5771 & 6689 \\
\hline 254 & 1,9 \\
\hline 1204 & 1250 \\
\hline
\end{tabular}

Крупа, мука грубого помола и гранулы из зерновых культур, не включенные в другие группировки, тыс. т

Комбикорма, млн. т

Изделия хлебобулочные недлительного хранения, тыс. т

Изделия хлебобулочные пониженной влажности, тыс. т

Изделия мучные кондитерские, торты и пирожные недлительного хранения ${ }^{1)}$, тыс. т

Печенье и пряники имбирные и аналогичные изделия; печенье сладкое; вафли и вафельные облатки; торты и пирожные длительного хранения ${ }^{1)}$, тыс. т

Какао, шоколад и изделия кондитерские сахаристые $^{1)}$, тыс. т

Сахар белый свекловичный в твердом состоянии без вкусоароматических или красящих добавок, тыс. т

Сахар белый тростниковый в твердом состоянии без вкусоароматических или красящих добавок, тыс. т

Изделия макаронные и аналогичные мучные изделия, тыс.Т

1) Без продукции организаций общественного питания. 


\section{8. ОСНОВНЫЕ ПОКАЗАТЕЛИ РАБОТЫ ОРГАНИЗАЦИЙ ПО ВИДУ ЭКОНОМИЧЕСКОЙ ДЕЯТЕЛЬНОСТИ «ПРОИЗВОДСТВО НАПИТКОВ»}

\begin{tabular}{l|c}
\hline & 2017 \\
\hline $\begin{array}{l}\text { Объем отгруженных товаров собственного производст- } \\
\text { ва, выполненных работ и услуг собственными силами } \\
\text { млрд. руб. }\end{array}$ & 708 \\
$\begin{array}{l}\text { Индекс производства }{ }^{2)}, \text { в процентах к предыдущему } \\
\text { году }\end{array}$ & 99,0 \\
$\begin{array}{l}\text { Среднегодовая численность работников организаций, } \\
\text { тыс. человек }\end{array}$ & 133,9 \\
$\begin{array}{l}\text { Сальдированный финансовый результат (прибыль } \\
\text { минус убыток), млн. руб. }\end{array}$ & 54775 \\
$\begin{array}{l}\text { Рентабельность проданных товаров, продукции } \\
\text { (работ, услуг), процентов }\end{array}$ & 12,4 \\
\hline
\end{tabular}

1) 2016 г. - 767 млрд. руб.

2) 2016 г. $-101,3 \%$.

\section{9. ПРОИЗВОДСТВО НАПИТКОВ}

\begin{tabular}{|c|c|c|}
\hline & 2016 & 2017 \\
\hline Пиво, кроме отходов пивоварения, млн. дкл & 763 & 744 \\
\hline Воды минеральные природные питьевые и & & \\
\hline воды питьевые, расфрасованные в емкости, & & \\
\hline не содержащие добавки сахара или других & & \\
\hline подслащивающих или вкусоароматических & & \\
\hline веществ, млн. полулитров & 11556 & 11684 \\
\hline Напитки безалкогольные прочие, млн. дкл & 639 & 652 \\
\hline
\end{tabular}


16.10. ОСНОВНЫЕ ПОКАЗАТЕЛИ РАБОТЫ ОРГАНИЗАЦИЙ ПО ВИДУ ЭКОНОМИЧЕСКОЙ ДЕЯТЕЛЬНОСТИ «ПРОИЗВОДСТВО ТАБАЧНЫХ ИЗДЕЛИЙ

\begin{tabular}{l|c}
\hline & 2017 \\
\hline $\begin{array}{l}\text { Объем отгруженных товаров собственного производст- } \\
\text { ва, выполненных работ и услуг собственными силами }\end{array}$ & \\
млрд. руб. \\
$\begin{array}{l}\text { Индекс производства }{ }^{2)}, \text { в процентах к предыдущему } \\
\text { году }\end{array}$ \\
$\begin{array}{l}\text { Среднегодовая численность работников организаций, } \\
\text { тыс. человек }\end{array}$ \\
$\begin{array}{l}\text { Сальдированный финансовый результат (прибыль } \\
\text { минус убыток), млн. руб. }\end{array}$ \\
$\begin{array}{l}\text { Рентабельность проданных товаров, продукции } \\
\text { (работ, услуг), процентов }\end{array}$ \\
\hline
\end{tabular}

1) 2016 г. - 296 млрд. руб.

2) 2016 г. $-97,9 \%$.

16.11. ПРОИЗВОДСТВО ТАБАЧНЫХ ИЗДЕЛИЙ

\begin{tabular}{l|r|r}
\hline & 2016 & 2017 \\
\hline Сигареты, млрд. шт. & 331 & 246 \\
Папиросы из табака или заменителей & & 421 \\
табака, млн. шт.
\end{tabular}

\subsection{2. ОСНОВНЫЕ ПОКАЗАТЕЛИ РАБОТЫ ОРГАНИЗАЦИЙ ПО ВИДУ ЭКОНОМИЧЕСКОЙ ДЕЯТЕЛЬНОСТИ «ПРОИЗВОДСТВО ТЕКСТИЛЬНЫХ ИЗДЕЛИЙ»}

\begin{tabular}{l|c}
\hline & 2017 \\
\hline $\begin{array}{l}\text { Объем отгруженных товаров собственного производст- } \\
\text { ва, выполненных работ и услуг собственными силами }\end{array}$ & 172 \\
млрд. руб. \\
$\begin{array}{l}\text { Индекс производства }{ }^{2)} \text {, в процентах к предыдущему } \\
\text { году }\end{array}$ \\
$\begin{array}{l}\text { Среднегодовая численность работников организаций, } \\
\text { тыс. человек }\end{array}$ \\
$\begin{array}{l}\text { Сальдированный финансовый результат (прибыль } \\
\text { минус убыток), млн. руб. }\end{array}$ \\
$\begin{array}{l}\text { Рентабельность проданных товаров, продукции } \\
\text { (работ, услуг), процентов }\end{array}$ \\
\hline
\end{tabular}

1) 2016 г. - 162 млрд. руб.

2) 2016 г. $-104,6 \%$. 


\subsection{3. ПРОИзводСтвО ОСНОВНЫХ ВИдОВ} ТЕКСТИЛЬНЫХ ИЗДЕЛИЙ

\begin{tabular}{l|r|r}
\hline & 2016 & 2017 \\
\hline Ткани - всего, млн. м & 5405 & 5957 \\
\multicolumn{1}{c|}{ в том числе: } & & \\
хлопчатобумажные & 671 & 704 \\
марля, кроме узких тканей & 497 & 477 \\
шерстяные & 7,8 & 8,7 \\
льняные & 22,8 & 23,1 \\
шелковые, тыс. м² & 157 & 158 \\
$\begin{array}{l}\text { ткани из синтетических и искусственных } \\
\text { волокон и нитей (включая штапельные) } \\
\text { материалы нетканые (кроме ватинов) }\end{array}$ & 330 & 412 \\
\hline
\end{tabular}

\subsection{4. ОСНОВНЫЕ ПОКАЗАТЕЛИ РАБОТЫ ОРГАНИЗАЦИЙ ПО ВИДУ ЭКОНОМИЧЕСКОЙ ДЕЯТЕЛЬНОСТИ «ПРОИЗВОДСТВО ОДЕЖДЫ»}

\begin{tabular}{l|r}
\hline & 2017 \\
\hline $\begin{array}{l}\text { Объем отгруженных товаров собственного производст- } \\
\text { ва, выполненных работ и услуг собственными силами }\end{array}$ & 152 \\
млрд. руб. & \\
$\begin{array}{l}\text { Индекс производства }{ }^{2)} \text {, в процентах к предыдущему } \\
\text { году }\end{array}$ & 103,8 \\
$\begin{array}{l}\text { Среднегодовая численность работников организаций, } \\
\text { тыс. человек }\end{array}$ & 140,0 \\
$\begin{array}{l}\text { Сальдированный финансовый результат (прибыль } \\
\text { минус убыток), млн. руб. }\end{array}$ & 14151 \\
$\begin{array}{l}\text { Рентабельность проданных товаров, продукции } \\
\text { (работ, услуг), процентов }\end{array}$ & 13,3 \\
\hline
\end{tabular}

1) 2016 г. - 146 млрд. руб.

2) 2016 г. $-107,1 \%$. 
16.15. ПРОИЗВОДСТВО ОСНОВНЫХ ВИДОВ ОДЕЖДЫ

\begin{tabular}{l|r|r}
\hline & 2016 & 2017 \\
\hline Изделия чулочно-носочные трикотажные & 215 & 212 \\
или вязаные, млн. пар & 54,1 & 54,4 \\
\multicolumn{1}{c|}{ в том числе для детей } & 117 & 134 \\
Изделия трикотажные или вязаные, млн. шт. & & \\
Швейные изделия из текстильных & & \\
материалов кроме трикотажных или вяза- & & 1,1 \\
ных, млн. шт.: & 1,2 & 2,3 \\
пальто, полупальто & 2,1 & 4,9 \\
куртки & 5,1 & 4,4 \\
костюмы и комплекты & 4,2 & 11,0 \\
платья женские или для девочек & 12,6 & \\
брюки, бриджи и шорты & & \\
\hline
\end{tabular}

16.16. ОСНОВНЫЕ ПОКАЗАТЕЛИ РАБОТЫ ОРГАНИЗАЦИЙ ПО ВИДУ ЭКОНОМИЧЕСКОЙ ДЕЯТЕЛЬНОСТИ «ПРОИЗВОДСТВО КОЖИ И ИЗДЕЛИЙ ИЗ КОЖИ»

\begin{tabular}{l|c}
\hline & 2017 \\
\hline $\begin{array}{l}\text { Объем отгруженных товаров собственного производст- } \\
\text { ва, выполненных работ и услуг собственными силами }\end{array}$ & \\
млрд. руб. & 63,9 \\
$\begin{array}{l}\text { Индекс производства } \\
\text { году }\end{array}$ & \\
$\begin{array}{l}\text { Среднегодовая численность работников организаций, } \\
\text { тыс. человек }\end{array}$ & 104,3 \\
$\begin{array}{l}\text { Сальдированный финансовый результат (прибыль } \\
\text { минус убыток), млн. руб. }\end{array}$ & 41,9 \\
$\begin{array}{l}\text { Рентабельность проданных товаров, продукции } \\
\text { (работ, услуг), процентов }\end{array}$ & 2728 \\
\hline
\end{tabular}

1) 2016 г. - 67,8 млрд. руб.

2) 2016 г. $-104,4 \%$. 


\subsection{7. ПРОИЗВОДСтво ОСНОВНЫХ ВИдОВ кожИ И ИЗДЕЛИЙ ИЗ КОЖИ}

\begin{tabular}{l|r|r}
\hline & 2016 & 2017 \\
\hline $\begin{array}{l}\text { Замша, млн. дм² } \\
\text { Кожа из целых шкур крупного рогатого скота } \\
\text { без волосяного покрова, млн. дм }\end{array}$ & 1246 & 329 \\
$\begin{array}{l}\text { Кожа из нецелых шкур крупного рогатого } \\
\text { скота без волосяного покрова, млн. дм }\end{array}$ & 533 & 380 \\
$\begin{array}{l}\text { Чемоданы, сумки дамские и аналогичные } \\
\text { изделия из натуральной кожи, сочетаний }\end{array}$ & & \\
$\begin{array}{l}\text { кожи, листов пластмассы, текстильных ма- } \\
\text { териалов, вулканизированных волокон или } \\
\text { картона; наборы дорожные, используемые } \\
\text { для личной гигиены, шитья или для чистки } \\
\text { одежды или обуви, млн. руб. }\end{array}$ & & \\
Обувь, млн. пар & 5461 & 5271 \\
\hline
\end{tabular}

16.18. ОСНОВНЫЕ ПОКАЗАТЕЛИ РАБОТЫ ОРГАНИЗАЦИЙ ПО ВИДУ ЭКОНОМИЧЕСКОЙ ДЕЯТЕЛЬНОСТИ «ОБРАБОТКА ДРЕВЕСИНЫ И ПРОИЗВОДСТВО ИЗДЕЛИЙ ИЗ ДЕРЕВА И ПРОБКИ, КРОМЕ МЕБЕЛИ, ПРОИЗВОДСТВО ИЗДЕЛИЙ ИЗ СОЛОМКИ И МАТЕРИАЛОВ ДЛЯ ПЛЕТЕНИЯ»

\begin{tabular}{l|r}
\hline & 2017 \\
\hline $\begin{array}{l}\text { Объем отгруженных товаров собственного производст- } \\
\text { ва, выполненных работ и услуг собственными силами }\end{array}$ & 522 \\
$\begin{array}{l}\text { млрд. руб. } \\
\text { Индекс производства }{ }^{2)}, \text { в процентах к предыдущему }\end{array}$ & 102,2 \\
$\begin{array}{l}\text { году } \\
\text { Среднегодовая численность работников организаций, } \\
\text { тыс. человек }\end{array}$ & 196,5 \\
$\begin{array}{l}\text { Сальдированный финансовый результат (прибыль } \\
\text { минус убыток), млн. руб. }\end{array}$ & 11783 \\
$\begin{array}{l}\text { Рентабельность проданных товаров, продукции } \\
\text { (работ, услуг), процентов }\end{array}$ & 8,4 \\
\hline
\end{tabular}

1) 2016 г. - 500 млрд. руб.

2) 2016 г. $-102,8 \%$. 


\subsection{9. ПРОИЗВОДСТВО ОСНОВНЫХ ВИДОВ ПРОДУКЦИИ ДЕРЕВООБРАБОТКИ}

\begin{tabular}{|c|c|c|}
\hline & 2016 & 2017 \\
\hline $\begin{array}{l}\text { Лесоматериалы, продольно распиленные } \\
\text { или расколотые, разделенные на слои или } \\
\text { лущеные, толщиной более } 6 \text { мм; деревянные } \\
\text { шпалы железнодорожные или трамвайные } \\
\text { непропитанные, млн. м }{ }^{3}\end{array}$ & 23,8 & 25,9 \\
\hline Фанера, тыс. м³ & 3812 & 3729 \\
\hline $\begin{array}{l}\text { Плиты древесностружечные и аналогичные } \\
\text { плиты из древесины или других одревес- } \\
\text { невших материалов, тыс. условных м³ }\end{array}$ & 7394 & 8473 \\
\hline $\begin{array}{l}\text { Плиты древесноволокнистые из древесины } \\
\text { или других одревесневших материалов, } \\
\text { млн. условных м² }\end{array}$ & 555 & 591 \\
\hline
\end{tabular}

16.20. ОСНОВНЫЕ ПОКАЗАТЕЛИ РАБОТЫ ОРГАНИЗАЦИЙ ПО ВИДУ ЭКОНОМИЧЕСКОЙ ДЕЯТЕЛЬНОСТИ «ПРОИЗВОДСТВО БУМАГИ И БУМАЖНЫХ ИЗДЕЛИЙ»

\begin{tabular}{l|c}
\hline & 2017 \\
\hline $\begin{array}{l}\text { Объем отгруженных товаров собственного производст- } \\
\text { ва, выполненных работ и услуг собственными силами }\end{array}$ & \\
млрд. руб. & 748 \\
$\begin{array}{l}\text { Индекс производства }{ }^{2)}, \text { в процентах к предыдущему } \\
\text { году }\end{array}$ & 104,7 \\
$\begin{array}{l}\text { Среднегодовая численность работников организаций, } \\
\text { тыс. человек }\end{array}$ & 117,0 \\
$\begin{array}{l}\text { Сальдированный финансовый результат (прибыль } \\
\text { минус убыток), млн. руб. }\end{array}$ & 84854 \\
$\begin{array}{l}\text { Рентабельность проданных товаров, продукции } \\
\text { (работ, услуг), процентов }\end{array}$ & 20,5 \\
\hline
\end{tabular}

1) 2016 г. - 755 млрд. руб.

2) 2016 г. $-105,1 \%$. 


\subsection{1. ПРОИЗВОДСТВО ОСНОВНЫХ ВИДОВ БУМАГИ И ИЗДЕЛИЙ ИЗ БУМАГИ}

\begin{tabular}{l|r|r}
\hline & 2016 & \multicolumn{1}{|c}{2017} \\
\hline Целлюлоза древесная и целлюлоза & & \\
из прочих волокнистых материалов, тыс. т & 8208 & 8587 \\
Бумага и картон, тыс. т & 8646 & 8569 \\
$\quad$ из них: & & \\
бумага газетная & & \\
$\quad$ тыс. т & 1469 & 1438 \\
$\quad$ млрд. м & 33,7 & 33,1 \\
картон тарный (крафт-лайнер) небеле- & & \\
ный, немелованный & & 1888 \\
$\quad$ тыс. т & 1889 & 11,7 \\
млрд. м ${ }^{2}$ & 11,5 & \\
\hline
\end{tabular}

16.22. ОСНОВНЫЕ ПОКАЗАТЕЛИ РАБОТЫ ОРГАНИЗАЦИЙ ПО ВИДУ ЭКОНОМИЧЕСКОЙ ДЕЯТЕЛЬНОСТИ «ПРОИЗВОДСТВО КОКСА И НЕФТЕПРОДУКТОВ»

\begin{tabular}{l|c}
\hline & 2017 \\
\hline $\begin{array}{l}\text { Объем отгруженных товаров собственного производст- } \\
\text { ва, выполненных работ и услуг собственными силами }\end{array}$ & \\
$\begin{array}{l}\text { млрд. руб. } \\
\text { Индекс производства }{ }^{2)}, \text { в процентах к предыдущему }\end{array}$ & 8241 \\
$\begin{array}{l}\text { году } \\
\text { Среднегодовая численность работников организаций, } \\
\text { тыс. человек }\end{array}$ & 100,6 \\
$\begin{array}{l}\text { Сальдированный финансовый результат (прибыль } \\
\text { минус убыток), млн. руб. }\end{array}$ & 133,8 \\
$\begin{array}{l}\text { Рентабельность проданных товаров, продукции } \\
\text { (работ, услуг), процентов }\end{array}$ & 746009 \\
\hline
\end{tabular}

1) 2016 г. - 6903 млрд. руб.

2) 2016 г. $-98,3 \%$. 


\subsection{3. ПРОИЗВОДСТВО КОКСА И ОСНОВНЫХ ВИДОВ НЕФТЕПРОДУКТОВ}

(млн. тонн)

\begin{tabular}{l|r|r}
\hline & 2016 & 2017 \\
\hline Кокс и полукокс из каменного угля & 29,1 & 28,0 \\
Нефть, поступившая на переработку (пер- & & \\
вичная переработка нефти) & 285 & 284 \\
Бензин автомобильный & 38,6 & 38,0 \\
Топливо дизельное & 75,8 & 76,8 \\
Мазут топочный & 56,6 & 51,3 \\
\hline
\end{tabular}

\subsection{4. ОСНОВНЫЕ ПОКАЗАТЕЛИ РАБОТЫ ОРГАНИЗАЦИЙ} ПО ВИДУ ЭКОНОМИЧЕСКОЙ ДЕЯТЕЛЬНОСТИ «ПРОИЗВОДСТВО ХИМИЧЕСКИХ ВЕЩЕСТВ И ХИМИЧЕСКИХ ПРОДУКТОВ»

\begin{tabular}{l|r}
\hline & 2017 \\
\hline $\begin{array}{l}\text { Объем отгруженных товаров собственного производст- } \\
\text { ва, выполненных работ и услуг собственными силами }\end{array}$ & \\
млрд. руб. & 2646 \\
$\begin{array}{l}\text { Индекс производства }{ }^{2)} \text {, в процентах к предыдущему } \\
\text { году }\end{array}$ & 104,3 \\
$\begin{array}{l}\text { Среднегодовая численность работников организаций, } \\
\text { тыс. человек }\end{array}$ & 349,9 \\
$\begin{array}{l}\text { Сальдированный финансовый результат (прибыль } \\
\text { минус убыток), млн. руб. }\end{array}$ & 307464 \\
$\begin{array}{l}\text { Рентабельность проданных товаров, продукции } \\
\text { (работ, услуг), процентов }\end{array}$ & 19,8 \\
\hline
\end{tabular}

1) 2016 г. - 2536 млрд. руб.

2) 2016 г. $-106,3 \%$. 
16.25. ПРОИЗВОДСТВО ОСНОВНЫХ ВИДОВ ХИМИЧЕСКИХ ВЕЩЕСТВ И ХИМИЧЕСКИХ ПРОДУКТОВ

\begin{tabular}{l|r|r}
\hline & 2016 & 2017 \\
\hline Олеум, кислота серная, млн. т & 11,7 & 12,4 \\
Удобрения минеральные или химические & & \\
(в пересчете на 100\% питательных ве- & & \\
ществ), млн.т & 20,8 & 22,5 \\
Пластмассы в первичных фрормах, тыс. т & 7597 & 7759 \\
Каучуки синтетические в первичных формах, & 1519 & 1572 \\
тыс. т & 2791 & 2860 \\
Этилен, тыс. т & & \\
Материалы лакокрасочные и аналогичные & & \\
для нанесения покрытий, полиграфические & 1327 & 1384 \\
краски и мастики, тыс.т & 183 & \\
Волокна химические, тыс. т & & \\
\hline
\end{tabular}

16.26. ОСНОВНЫЕ ПОКАЗАТЕЛИ РАБОТЫ ОРГАНИЗАЦИЙ ПО ВИДУ ЭКОНОМИЧЕСКОЙ ДЕЯТЕЛЬНОСТИ «ПРОИЗВОДСТВО РЕЗИНОВЫХ И ПЛАСТМАССОВЫХ ИЗДЕЛИЙ»

\begin{tabular}{l|c}
\hline & 2017 \\
\hline $\begin{array}{l}\text { Объем отгруженных товаров собственного производст- } \\
\text { ва, выполненных работ и услуг собственными силами }\end{array}$ & \\
$\begin{array}{l}\text { млрд. руб. } \\
\text { Индекс производства }{ }^{2)}, \text { в процентах к предыдущему } \\
\text { году }\end{array}$ & 104,2 \\
$\begin{array}{l}\text { Среднегодовая численность работников организаций, } \\
\text { тыс. человек }\end{array}$ & 233,9 \\
$\begin{array}{l}\text { Сальдированный финансовый результат (прибыль } \\
\text { минус убыток), млн. руб. }\end{array}$ & 37619 \\
$\begin{array}{l}\text { Рентабельность проданных товаров, продукции } \\
\text { (работ, услуг), процентов }\end{array}$ & 9,1 \\
\hline
\end{tabular}

1) 2016 г. - 942 млрд. руб.

2) 2016 г. $-106,3 \%$. 
16.27. ПРОИЗВОДСТВО ОСНОВНЫХ ВИДОВ РЕЗИНОВЫХ И ПЛАСТМАССОВЫХ ИЗДЕЛИЙ

\begin{tabular}{|c|c|c|}
\hline & 2016 & 2017 \\
\hline $\begin{array}{l}\text { Шины, покрышки и камеры резиновые } \\
\text { новые, млн. шт. } \\
\text { в том числе: } \\
\text { шины и покрышки пневматические } \\
\text { для легковых автомобилей новые } \\
\text { шины и покрышки пневматические } \\
\text { для автобусов, троллейбусов и грузовых } \\
\text { автомобилей новые } \\
\text { шины и покрышки пневматические } \\
\text { для сельскохозяйственных машин; } \\
\text { шины и покрышки пневматические } \\
\text { прочие новые } \\
\text { Трубы, трубки и шланги и их фитинги } \\
\text { пластмассовые, тыс. т } \\
\text { Материалы для покрытий пола, стен или } \\
\text { потолка пластмассовые в рулонах или } \\
\text { в форме плиток, млн. м² }\end{array}$ & $\begin{array}{r}1,7 \\
581\end{array}$ & 1,8 \\
\hline
\end{tabular}

16.28. ОСНОВНЫЕ ПОКАЗАТЕЛИ РАБОТЫ ОРГАНИЗАЦИЙ ПО ВИДУ ЭКОНОМИЧЕСКОЙ ДЕЯТЕЛЬНОСТИ «ПРОИЗВОДСТВО ПРОЧЕЙ НЕМЕТАЛЛИЧЕСКОЙ МИНЕРАЛЬНОЙ ПРОДУКЦИИ»

\begin{tabular}{l|c}
\hline & 2017 \\
\hline $\begin{array}{l}\text { Объем отгруженных товаров собственного производст- } \\
\text { ва, выполненных работ и услуг собственными силами }\end{array}$ & \\
$\begin{array}{l}\text { млрд. руб. } \\
\text { Индекс производства }{ }^{2)}, \text { в процентах к предыдущему } \\
\text { году }\end{array}$ & 1308 \\
$\begin{array}{l}\text { Среднегодовая численность работников организаций, } \\
\text { тыс. человек }\end{array}$ & 102,5 \\
$\begin{array}{l}\text { Сальдированный финансовый результат (прибыль } \\
\text { минус убыток), млн. руб. }\end{array}$ & 418,8 \\
$\begin{array}{l}\text { Рентабельность проданных товаров, продукции } \\
\text { (работ, услуг), процентов }\end{array}$ & 48091 \\
\hline
\end{tabular}

1) 2016 г. - 1241 млрд. руб.

2) 2016 г. $-94,0 \%$. 
16.29. ПРОИЗВОДСТВО ОСНОВНЫХ ВИДОВ ПРОЧЕЙ НЕМЕТАЛЛИЧЕСКОЙ МИНЕРАЛЬНОЙ ПРОДУКЦИИ

\begin{tabular}{|c|c|c|}
\hline & 2016 & 2017 \\
\hline $\begin{array}{l}\text { Плитки керамические глазурованные для } \\
\text { внутренней облицовки стен, млн. м² }\end{array}$ & 71,9 & 75,6 \\
\hline Плитки керамические для полов, млн. м² & 92,3 & 82,8 \\
\hline Кирпич керамический неогнеупорный & & \\
\hline строительный, млрд. условных кирпичей & 5,6 & 5,6 \\
\hline $\begin{array}{l}\text { Кирпич строительный (включая камни) из } \\
\text { цемента, бетона или искусственного камня, } \\
\text { млрд. условных кирпичей }\end{array}$ & 2,7 & 2,9 \\
\hline $\begin{array}{l}\text { Портландцемент, цемент глиноземистый, } \\
\text { цемент шлаковый и аналогичные гидравли- } \\
\text { ческие цементы, млн. т }\end{array}$ & 54,9 & 54,7 \\
\hline $\begin{array}{l}\text { Блоки стеновые силикатные, } \\
\text { млрд. условных кирпичей }\end{array}$ & 5,6 & 5,2 \\
\hline $\begin{array}{l}\text { Изделия аналогичные из цемента, бетона } \\
\text { или искусственного камня, млрд. условных } \\
\text { кирпичей }\end{array}$ & 1,2 & 1,2 \\
\hline $\begin{array}{l}\text { Блоки и прочие изделия сборные строитель- } \\
\text { ные для зданий и сооружений из цемента, } \\
\text { бетона или искусственного камня, млн. м }\end{array}$ & 21,3 & 21,3 \\
\hline $\begin{array}{l}\text { Листы асбестоцементные (шифер), } \\
\text { млн. условных плиток }\end{array}$ & 588 & 547 \\
\hline $\begin{array}{l}\text { Трубы и муфрты асбестоцементные, } \\
\text { тыс. км условных труб }\end{array}$ & 4,1 & 3,5 \\
\hline $\begin{array}{l}\text { Материалы рулонные кровельные } \\
\text { и гидроизоляционные, млн. м² }\end{array}$ & 474 & 457 \\
\hline
\end{tabular}

16.30. ОСНОВНЫЕ ПОКАЗАТЕЛИ РАБОТЫ ОРГАНИЗАЦИЙ ПО ВИДУ ЭКОНОМИЧЕСКОЙ ДЕЯТЕЛЬНОСТИ «ПРОИЗВОДСТВО МЕТАЛЛУРГИЧЕСКОЕ»

\begin{tabular}{l|c}
\hline & 2017 \\
\hline $\begin{array}{l}\text { Объем отгруженных товаров собственного производст- } \\
\text { ва, выполненных работ и услуг собственными силами }\end{array}$ & 5101 \\
млрд. руб. & 96,4 \\
$\begin{array}{l}\text { Индекс производства }{ }^{2)}, \text { в процентах к предыдущему } \\
\text { году }\end{array}$ & 552,3 \\
$\begin{array}{l}\text { Среднегодовая численность работников организаций, } \\
\text { тыс. человек }\end{array}$ & 880099 \\
$\begin{array}{l}\text { Сальдированный финансовый результат (прибыль } \\
\text { минус убыток), млн. руб. }\end{array}$ & 20,7 \\
$\begin{array}{l}\text { Рентабельность проданных товаров, продукции } \\
\text { (работ, услуг), процентов }\end{array}$ &
\end{tabular}

1) 2016 г. -4615 млрд. руб.

2) 2016 r. $-99,0 \%$. 


\subsection{1. ПРОИЗВОДСТВО ОСНОВНЫХ ВИДОВ ПРОДУКЦИИ МЕТАЛЛУРГИЧЕСКОГО ПРОИЗВОДСТВА}

\begin{tabular}{l|r|r}
\hline & 2016 & 2017 \\
\hline $\begin{array}{l}\text { Чугун зеркальный и передельный в чушках, } \\
\text { болванках или в прочих первичных формах, } \\
\text { млн. т }\end{array}$ & 51,9 & 52,2 \\
$\begin{array}{l}\text { Сталь нелегированная в слитках или } \\
\text { в прочих первичных формах и полуфабрика- }\end{array}$ & & \\
ты из нелегированнои стали, млн. т & 54,6 & 54,5 \\
Прокат готовый, млн. т & 60,5 & 60,9 \\
$\begin{array}{l}\text { Трубы, профили пустотелые и их фитинги } \\
\text { стальные, млн. т }\end{array}$ & 10,8 & 11,3 \\
$\begin{array}{l}\text { Алюминий первичный, в процентах } \\
\text { к предыдущему году }\end{array}$ & 92,3 & 94,2 \\
$\begin{array}{l}\text { Свинец необработанный, в процентах } \\
\text { к предыдущему году }\end{array}$ & 98,5 & 97,2 \\
Цинк необработанный, в процентах & 103,8 \\
к предыдущему году & 107,1 & 108,3 \\
$\begin{array}{l}\text { Медь рафинированная необработанная, } \\
\text { в процентах к предыдущему году }\end{array}$ & 100,7 & 80,9 \\
$\begin{array}{l}\text { Никель необработанный, в процентах } \\
\text { к предыдущему году }\end{array}$ & 82,9 &
\end{tabular}

16.32. ОСНОВНЫЕ ПОКАЗАТЕЛИ РАБОТЫ ОРГАНИЗАЦИЙ ПО ВИДУ ЭКОНОМИЧЕСКОЙ ДЕЯТЕЛЬНОСТИ «ПРОИЗВОДСТВО ГОТОВЫХ МЕТАЛЛИЧЕСКИХ ИЗДЕЛИЙ, КРОМЕ МАШИН И ОБОРУДОВАНИЯ»

\begin{tabular}{l|c}
\hline & 2017 \\
\hline $\begin{array}{l}\text { Объем отгруженных товаров собственного производст- } \\
\text { ва, выполненных работ и услуг собственными силами }\end{array}$ & \\
$\begin{array}{l}\text { млрд. руб. } \\
\text { Индекс производства }{ }^{2)}, \text { в процентах к предыдущему }\end{array}$ & 2253 \\
году & 97,3 \\
$\begin{array}{l}\text { Среднегодовая численность работников организаций, } \\
\text { тыс. человек }\end{array}$ & 636,6 \\
$\begin{array}{l}\text { Сальдированный финансовый результат (прибыль } \\
\text { минус убыток), млн. руб. }\end{array}$ & 102349 \\
$\begin{array}{l}\text { Рентабельность проданных товаров, продукции } \\
\text { (работ, услуг), процентов }\end{array}$ & 10,7 \\
\hline
\end{tabular}

1) 2016 г. - 2107 млрд. руб.

2) 2016 г. $-101,3 \%$.

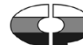


16.33. ПРОИЗВОДСТВО ОСНОВНЫХ ВИДОВ ГОТОВЫХ МЕТАЛЛИЧЕСКИХ ИЗДЕЛИЙ, КРОМЕ МАШИН И ОБОРУДОВАНИЯ

\begin{tabular}{l|c|c}
\hline & 2016 & 2017 \\
\hline $\begin{array}{l}\text { Конструкции и детали конструкций } \\
\text { из черных металлов, млн.т }\end{array}$ & 3,9 & 4,2 \\
$\begin{array}{l}\text { Конструкции и детали конструкций } \\
\text { из алюминия прочие, тыс.т }\end{array}$ & & \\
\hline
\end{tabular}

16.34. ОСНОВНЫЕ ПОКАЗАТЕЛИ РАБОТЫ ОРГАНИЗАЦИЙ ПО ВИДУ ЭКОНОМИЧЕСКОЙ ДЕЯТЕЛЬНОСТИ «ПРОИЗВОДСТВО МАШИН И ОБОРУДОВАНИЯ, НЕ ВКЛЮЧЕННЫХ В ДРУГИЕ ГРУППИРОВКИ»

\begin{tabular}{l|r}
\hline & 2017 \\
\hline $\begin{array}{l}\text { Объем отгруженных товаров собственного производст- } \\
\text { ва, выполненных работ и услуг собственными силами }\end{array}$ & \\
млрд. руб. & 1099 \\
$\begin{array}{l}\text { Индекс производства }{ }^{2)} \text {, в процентах к предыдущему } \\
\text { году }\end{array}$ & 102,5 \\
$\begin{array}{l}\text { Среднегодовая численность работников организаций, } \\
\text { тыс. человек }\end{array}$ & 460,4 \\
$\begin{array}{l}\text { Сальдированный финансовый результат (прибыль } \\
\text { минус убыток) }\end{array}$ & \\
$\begin{array}{l}\text { Рентабельность руб. } \\
\text { (работ, услуг), процентов }\end{array}$ & -24574 \\
\hline
\end{tabular}

1) 2016 г. - 1023 млрд. руб.

2) 2016 г. $-99,3 \%$.

3) Знак (-) означает убыток (убыточность). 
16.35. ПРОИЗВОДСТВО ОСНОВНЫХ ВИДОВ МАШИН И ОБОРУДОВАНИЯ, НЕ ВКЛЮЧЕННЫХ В ДРУГИЕ ГРУППИРОВКИ

\begin{tabular}{|c|c|c|}
\hline & 2016 & 2017 \\
\hline $\begin{array}{l}\text { Турбины на водяном паре и прочие } \\
\text { паровые турбины, млн. кВт }\end{array}$ & 0,8 & 2,0 \\
\hline $\begin{array}{l}\text { Турбины гидравлические и водяные } \\
\text { колеса, млн. кВт }\end{array}$ & 1,2 & 2,0 \\
\hline $\begin{array}{l}\text { Турбины газовые, кроме турбореактив- } \\
\text { ных и турбовинтовых, млн. кВт }\end{array}$ & 1,3 & 0,7 \\
\hline $\begin{array}{l}\text { Насосы центробежные подачи жидко- } \\
\text { стей прочие; насосы прочие, млн. шт. }\end{array}$ & 1,4 & 1,2 \\
\hline $\begin{array}{l}\text { Тракторы для сельского хозяйства, } \\
\text { тыс. шт. }\end{array}$ & 6,4 & 7,2 \\
\hline Комбайны зерноуборочные, тыс. шт. & 6,1 & 7,3 \\
\hline Установки доильные, тыс. шт. & 3,8 & 3,9 \\
\hline $\begin{array}{l}\text { Аппараты контрольно-кассовые, } \\
\text { тыс. шт. }\end{array}$ & 401 & 929 \\
\hline Станки металлорежущие, тыс. шт. & 4,3 & 4,5 \\
\hline Машины кузнечно-прессовые, шт. & 3006 & 2474 \\
\hline $\begin{array}{l}\text { Машины литейные для металлургиче- } \\
\text { ского производства, тыс. т }\end{array}$ & 16,2 & 16,0 \\
\hline $\begin{array}{l}\text { Станы прокатные металлургического } \\
\text { производства, т }\end{array}$ & 966 & 957 \\
\hline $\begin{array}{l}\text { Бульдозеры и бульдозеры } \\
\text { с поворотным отвалом, шт. }\end{array}$ & 495 & 609 \\
\hline Экскаваторы, тыс. шт. & 1,4 & 2,0 \\
\hline Тракторы гусеничные, шт. & 449 & 373 \\
\hline $\begin{array}{l}\text { Машины прядильные; тростильные, } \\
\text { крутильные, намоточные и мотальные } \\
\text { машины, шт. }\end{array}$ & 67 & 70 \\
\hline Станки ткацкие, шт. & 7 & 9 \\
\hline
\end{tabular}


16.36. ОСНОВНЫЕ ПОКАЗАТЕЛИ РАБОТЫ ОРГАНИЗАЦИЙ ПО ВИДУ ЭКОНОМИЧЕСКОЙ ДЕЯТЕЛЬНОСТИ «ПРОИЗВОДСТВО КОМПЬЮТЕРОВ, ЭЛЕКТРОННЫХ И ОПТИЧЕСКИХ ИЗДЕЛИЙ»

\begin{tabular}{l|r}
\hline & 2017 \\
\hline $\begin{array}{l}\text { Объем отгруженных товаров собственного производст- } \\
\text { ва, выполненных работ и услуг собственными силами }\end{array}$ & \\
$\begin{array}{l}\text { млрд. руб. } \\
\text { Индекс производства }{ }^{2)}, \text { в процентах к предыдущему } \\
\text { году }\end{array}$ & 1237 \\
$\begin{array}{l}\text { Среднегодовая численность работников организаций, } \\
\text { тыс. человек }\end{array}$ & 92,7 \\
$\begin{array}{l}\text { Сальдированный финансовый результат (прибыль } \\
\text { минус убыток), млн. руб. }\end{array}$ & 432,5 \\
$\begin{array}{l}\text { Рентабельность проданных товаров, продукции } \\
\text { (работ, услуг), процентов }\end{array}$ & 116936 \\
\hline
\end{tabular}

1) 2016 г. - 1198 млрд. руб.

2) 2016 г. $-100,6 \%$.

16.37. ПРОИзводСтво ОСНОВНЫХ вИдОВ КОМПЬЮТЕРОВ, ЭЛЕКТРОННЫХ И ОПТИЧЕСКИХ ИЗДЕЛИЙ

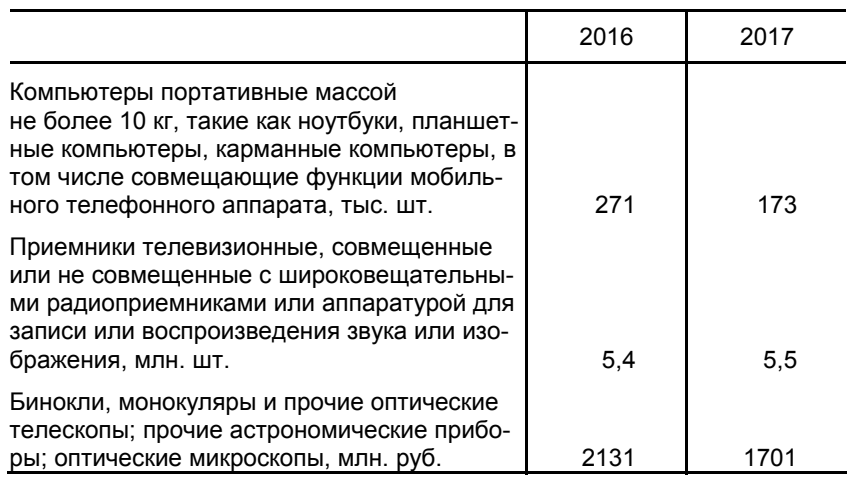


16.38. ОСНОВНЫЕ ПОКАЗАТЕЛИ РАБОТЫ ОРГАНИЗАЦИЙ ПО ВИДУ ЭКОНОМИЧЕСКОЙ ДЕЯТЕЛЬНОСТИ «ПРОИЗВОДСТВО ЭЛЕКТРИЧЕСКОГО ОБОРУДОВАНИЯ»

\begin{tabular}{l|c}
\hline & 2017 \\
\hline $\begin{array}{l}\text { Объем отгруженных товаров собственного производст- } \\
\text { ва, выполненных работ и услуг собственными силами }\end{array}$ & \\
млрд. руб. & 859 \\
$\begin{array}{l}\text { Индекс производства }{ }^{2)}, \text { в процентах к предыдущему } \\
\text { году }\end{array}$ & 102,8 \\
$\begin{array}{l}\text { Среднегодовая численность работников организаций, } \\
\text { тыс. человек }\end{array}$ & 269,7 \\
$\begin{array}{l}\text { Сальдированный финансовый результат (прибыль } \\
\text { минус убыток), млн. руб. }\end{array}$ & 46943 \\
$\begin{array}{l}\text { Рентабельность проданных товаров, продукции } \\
\text { (работ, услуг), процентов }\end{array}$ & 8,3 \\
\hline
\end{tabular}

1) 2016 г. - 836 млрд. руб.

2) 2016 г. $-100,9 \%$.

\subsection{9. ПРОИЗВОДСТВО ОСНОВНЫХ ВИДОВ} ЭЛЕКТРИЧЕСКОГО ОБОРУДОВАНИЯ

\begin{tabular}{|c|c|c|}
\hline & 2016 & 2017 \\
\hline $\begin{array}{l}\text { Электродвигатели мощностью не более } 37,5 \\
\text { Вт; электродвигатели постоянного тока про- } \\
\text { чие; генераторы постоянного тока, млн. шт. }\end{array}$ & 1,1 & 1,0 \\
\hline $\begin{array}{l}\text { Электродвигатели переменного и постоян- } \\
\text { ного тока универсальные мощностью более } \\
37,5 \text { Вт, тыс. шт. }\end{array}$ & 381 & 289 \\
\hline $\begin{array}{l}\text { Электродвигатели переменного тока много- } \\
\text { фазные мощностью от } 750 \text { Вт до } 75 \text { кВт, } \\
\text { тыс. шт. }\end{array}$ & 268 & 219 \\
\hline $\begin{array}{l}\text { Холодильники и морозильники бытовые, } \\
\text { млн. шт. }\end{array}$ & 3,3 & 3,0 \\
\hline Электрочайники, тыс. шт. & 187 & 57,7 \\
\hline Печи микроволновые, тыс. шт. & 328 & 311 \\
\hline $\begin{array}{l}\text { Плиты кухонные электрические, } \\
\text { тыс. шт. }\end{array}$ & 1165 & 1003 \\
\hline
\end{tabular}


16.40. ОСНОВНЫЕ ПОКАЗАТЕЛИ РАБОТЫ ОРГАНИЗАЦИЙ

ПО ВИДУ ЭКОНОМИЧЕСКОЙ ДЕЯТЕЛЬНОСТИ «ПРОИЗВОДСТВО АВТОТРАНСПОРТНЫХ СРЕДСТВ, ПРИЦЕПОВ И ПОЛУПРИЦЕПОВ»

\begin{tabular}{l|c}
\hline & 2017 \\
\hline $\begin{array}{l}\text { Объем отгруженных товаров собственного производст- } \\
\text { ва, выполненных работ и услуг собственными силами }\end{array}$ & \\
млрд. руб. & 2107 \\
$\begin{array}{l}\text { Индекс производства }{ }^{2)}, \text { в процентах к предыдущему } \\
\text { году }\end{array}$ & 112,9 \\
$\begin{array}{l}\text { Среднегодовая численность работников организаций, } \\
\text { тыс. человек }\end{array}$ & 279,9 \\
$\begin{array}{l}\text { Сальдированный финансовый результат (прибыль } \\
\text { минус убыток) }\end{array}$ & -14945 \\
$\begin{array}{l}\text { Рентабельность продануб. } \\
\text { (работ, услуг), процентов }\end{array}$ & 3,2 \\
\hline
\end{tabular}

1) 2016 г. - 1649 млрд. руб.

2) 2016 г. $-100,5 \%$.

3) Знак (-) означает убыток (убыточность).

16.41. ПРОИзВОДСтвО ОСНОВНЫХ ВИДОВ АВТОТРАНСПОРТНЫХ СРЕДСТВ И ОБОРУДОВАНИЯ, ПРИЦЕПОВ И ПОЛУПРИЦЕПОВ

\begin{tabular}{|c|c|c|}
\hline & 2016 & 2017 \\
\hline Автомобили легковые, тыс. шт. & 1120 & 1355 \\
\hline $\begin{array}{l}\text { Автобусы (включая средства автотранс- } \\
\text { портные пассажирские с числом мест для } \\
\text { сидения не менее } 10 \text { прочие), тыс. шт. }\end{array}$ & 42,8 & 40,8 \\
\hline Троллейбусы, шт. & 210 & 259 \\
\hline $\begin{array}{l}\text { Средства автотранспортные грузовые, } \\
\text { тыс. шт. }\end{array}$ & 137 & 162 \\
\hline $\begin{array}{l}\text { Прицепы и полуприцепы, технически } \\
\text { допустимая максимальная масса которых } \\
\text { не более } 0,75 \text { т, тыс. шт. }\end{array}$ & 101 & 84,8 \\
\hline
\end{tabular}


16.42. ОСНОВНЫЕ ПОКАЗАТЕЛИ РАБОТЫ ОРГАНИЗАЦИЙ ПО ВИДУ ЭКОНОМИЧЕСКОЙ ДЕЯТЕЛЬНОСТИ «ПРОИЗВОДСТВО ПРОЧИХ ТРАНСПОРТНЫХ СРЕДСТВ И ОБОРУДОВАНИЯ»

\begin{tabular}{l|r}
\hline & 2017 \\
\hline $\begin{array}{l}\text { Объем отгруженных товаров собственного производст- } \\
\text { ва, выполненных работ и услуг собственными силами }\end{array}$ & \\
млрд. руб. & 1782 \\
$\begin{array}{l}\text { Индекс производства }{ }^{2)}, \text { в процентах к предыдущему } \\
\text { году }\end{array}$ & 100,6 \\
$\begin{array}{l}\text { Среднегодовая численность работников организаций, } \\
\text { тыс. человек }\end{array}$ & 633,6 \\
$\begin{array}{l}\text { Сальдированный финансовый результат (прибыль } \\
\text { минус убыток), млн. руб. }\end{array}$ & 110989 \\
$\begin{array}{l}\text { Рентабельность проданных товаров, продукции } \\
\text { (работ, услуг), процентов }\end{array}$ & 12,9 \\
\hline
\end{tabular}

1) 2016 г. - 1502 млрд. руб.

2) 2016 r. $-104,2 \%$.

16.43. ПРОИЗВОДСТВО ОСНОВНЫХ ВИДОВ ПРОЧИХ ТРАНСПОРТНЫХ СРЕДСТВ И ОБОРУДОВАНИЯ

\begin{tabular}{l|c|c}
\hline & 2016 & 2017 \\
\hline $\begin{array}{l}\text { Тепловозы магистральные, секций } \\
\begin{array}{l}\text { Вагоны грузовые магистральные } \\
\text { широкой колеи, тыс. шт. }\end{array}\end{array}$ & 223 & 197 \\
$\begin{array}{l}\text { Мотоциклы и мотоциклетные коляски, тыс. } \\
\text { шт. }\end{array}$ & 8,1 & 3,9 \\
$\begin{array}{l}\text { Велосипеды двухколесные и прочие, } \\
\text { без двигателя, тыс. шт. }\end{array}$ & 1129 & 1436 \\
\hline
\end{tabular}


16.44. ОСНОВНЫЕ ПОКАЗАТЕЛИ РАБОТЫ ОРГАНИЗАЦИЙ ПО ВИДУ ЭКОНОМИЧЕСКОЙ ДЕЯТЕЛЬНОСТИ «ОБЕСПЕЧЕНИЕ ЭЛЕКТРИЧЕСКОЙ ЭНЕРГИЕЙ, ГАЗОМ И ПАРОМ; КОНДИЦИОНИРОВАНИЕ ВОЗДУХА»

\begin{tabular}{l|r}
\hline & 2017 \\
\hline $\begin{array}{l}\text { Объем отгруженных товаров собственного производст- } \\
\text { ва, выполненных работ и услуг собственными силами }\end{array}$ & \\
млрд. руб. & 5196 \\
$\begin{array}{l}\text { Индекс производства }{ }^{2)} \text {, в процентах к предыдущему } \\
\text { году }\end{array}$ & 100,1 \\
$\begin{array}{l}\text { Среднегодовая численность работников организаций, } \\
\text { тыс. человек }\end{array}$ & 1468,7 \\
$\begin{array}{l}\text { Сальдированный финансовый результат (прибыль } \\
\text { минус убыток), млн. руб. }\end{array}$ & 560093 \\
$\begin{array}{l}\text { Рентабельность проданных товаров, продукции } \\
\text { (работ, услуг), процентов }\end{array}$ & 8,3 \\
\hline
\end{tabular}

1) 2016 г. - 4874 млрд. руб.

2) 2016 г. $-101,7 \%$.

16.45. ПРОИЗВОДСТВО ЭЛЕКТРОЭНЕРГИИ И ТЕПЛОЭНЕРГИИ

\begin{tabular}{l|r|r}
\hline & 2016 & 2017 \\
\hline Электроэнергия, млрд. кВт·ч & 1090 & 1091 \\
в том числе произведенная: & 706 & 700 \\
тепловыми электростанциями & 186 & 187 \\
гидроэлектростанциями & 197 & 203 \\
атомными электростанциями & 1,1 & 1,1 \\
от возобновляемых источников энергии & 1269 & 1258 \\
Пар и горячая вода, млн.Гкал & & \\
\hline
\end{tabular}




\section{7. СЕЛЬСКОЕ, ЛЕСНОЕ ХОЗЯЙСТВО, РЫБОЛОВСТВО И РЫБОВОДСТВО}

В разделе содержится информация о структурных изменениях в сельскохозяйственном производстве, развитии индивидуального сектора на селе, состоянии материально-технической базы сельского хозяйства, продукции растениеводства и животноводства, продовольственных ресурсах и их использовании и др. Данные приводятся в целом по сельскому хозяйству и по категориям сельскохозяйственных производителей. Представлены сведения по лесному хозяйству.

Представлена информация о добыче (производстве) основных видов продукции рыболовства, розничной продаже рыбы и морепродуктов, экспорте и импорте рыбы, рыбопродуктов и морепродуктов, выпуске молоди водных биологических ресурсов.

По категории "сельскохозяйственные организации" показаны данные по хозяйственным товариществам, обществам и партнерствам, производственным кооперативам, унитарным предприятиям, подсобным хозяйствам несельскохозяйственных организаций и учреждений.

К хозяйствам населения относятся личные подсобные и другие индивидуальные хозяйства граждан в сельских и городских поселениях, а также хозяйства граждан, имеющих земельные участки в садоводческих, огороднических и дачных некоммерческих объединениях.

Личные подсобные хозяйства - форма непредпринимательской деятельности по производству и переработке сельскохозяйственной продукции, осуществляемой личным трудом гражданина и членов его семьи в целях удовлетворения личных потребностей на земельном участке, предоставленном или приобретенном для ведения личного подсобного хозяйства. Землепользование хозяйств может состоять из приусадебных и полевых участков.

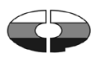


Садоводческое, огородническое или дачное некоммерческое объединение граждан - некоммерческая организация, учрежденная гражданами на добровольных началах для содействия еe членам в решении общих социальнохозяйственных задач ведения садоводства, огородничества и дачного хозяйства.

Крестьянское (фермерское) хозяйство - объединение граждан, связанных родством и (или) свойством, имеющих в общей собственности имущество и совместно осуществляющих производственную и иную хозяйственную деятельность (производство, переработку, хранение, транспортировку и реализацию сельскохозяйственной продукции), основанную на их личном участии.

Индивидуальный предприниматель по сельскохозяйственной деятельности - гражданин (физическое лицо), занимающийся предпринимательской деятельностью без образования юридического лица с момента его государственной регистрации в соответствии с Гражданским кодексом Российской Федерации и заявивший в Свидетельстве о государственной регистрации виды деятельности, отнесенные согласно Общероссийскому классификатору видов экономической деятельности (ОКВЭД) к сельскому хозяйству.

Продукция сельского хозяйства представляет собой сумму данных об объеме продукции растениеводства и животноводства всех сельхозпроизводителей, включая хозяйства индивидуального сектора (хозяйства населения, крестьянские (фермерские) хозяйства и индивидуальные предприниматели), в стоимостной оценке по фактически действовавшим ценам.

Продукция растениеводства включает стоимость сырых продуктов, полученных от урожая отчетного года - зерновых и зернобобовых культур, картофеля, овощей, семян и плодов масличных культур, табака необработанного и махорки, свеклы сахарной, соломы и культур кормовых, сырья растительного, используемого в текстильном производстве, растений, используемых для парфюмерии, фармации и аналогичных целей, семян сахарной свеклы, семян кормовых культур, растений живых, цветов и бутонов цветочных срезанных, семян цветов, фрруктовых деревьев, семян овощей, винограда, фруктов, ягод 
и орехов, культур для производства напитков, пряностей необработанных и изменение стоимости незавершенного производства в растениеводстве от начала к концу года (посадка и выращивание до плодоношения сельскохозяйственных культур и многолетних насаждений).

Продукция животноводства включает стоимость сырых продуктов, полученных в результате выращивания и хозяйственного использования сельскохозяйственных животных и птицы (молока, шерсти, яиц и др.), стоимость выращивания (приплода, прироста, привеса) скота и птицы в отчетном году, стоимость продукции пчеловодства и др.

Для исчисления индекса производства продукции сельского хозяйства используется показатель ее объема в сопоставимых ценах предыдущего года.

Индекс производства продукции сельского хозяйства - относительный показатель, характеризующий изменение объема произведенных продуктов растениеводства и животноводства в сравниваемых периодах.

Пашня - сельскохозяйственное угодье, систематически обрабатываемое и используемое под посевы сельскохозяйственных культур, включая посевы многолетних трав, а также чистые пары.

Посевные площади - часть пашни, занятая под посевы сельскохозяйственных культур.

Валовой сбор сельскохозяйственных культур включает в себя объем собранной продукции как с основных, так и с повторных и междурядных посевов в сельскохозяйственных организациях, крестьянских (фермерских) хозяйствах, у индивидуальных предпринимателей и в хозяйствах населения.

Поголовье скота включает поголовье всех возрастных групп соответствующего вида скота.

Производство скота и птицы на убой - показатель, характеризующий результат использования скота и птицы для забоя на мясо. Общий объем производства скота и птицы на убой отражается в пересчете на убойный вес и включает как проданные скот и птицу, подлежащие забою, так и забитые в сельскохозяйственных организациях, крестьянских (фермер-

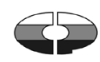


ских) хозяйствах, у индивидуальных предпринимателей и в хозяйствах населения.

Производство молока характеризуется фрактически надоенным сырым коровьим, козьим, овечьим, кобыльим и буйволиным молоком, независимо от того, было ли оно реализовано или потреблено в хозяйстве на выпойку молодняка. Молоко, высосанное молодняком при подсосном его содержании, в продукцию не включается и не учитывается при определении средних удоев.

При расчете среднего годового надоя молока на одну корову в сельскохозяйственных организациях производство молока, полученного от коров молочного стада, делится на их среднее поголовье.

Производство шерсти включает весь объем фрактически настриженной немытой овечьей шерсти, а также тонкий и грубый волос коз и верблюдов. Шерсть, полученная с овчин при промышленной переработке их на кожу, в продукцию не включается.

Производство яиц включает их сбор за год от всех видов сельскохозяйственной птицы, в том числе яйца, использованные на воспроизводство птицы (инкубация и др.).

Информация о продовольственных ресурсах и их использовании формируется на базе данных форм федерального статистического наблюдения, данных обследования домашних хозяйств, таможенной статистики и других источников, характеризующих образование продовольственных ресурсов и направления их использования за календарный год.

Лесной фонд - часть территории страны (субъекта Российской Федерации), занятая лесом, а также не занятая им, но предназначенная для нужд лесного хозяйства, включает: совокупность лесных земель и нелесных земель (занятых находящимися в лесах пашнями, сенокосами, пастбищами, водами, дорогами, просеками, усадьбами, болотами, песками и др.).

Лесные земли - земли, покрытые лесной растительностью (лесом), и земли, не покрытые лесной растительностью, но предназначенные для ее восстановления: несомкнувшиеся лесные культуры; лесные питомники и плантации; естествен- 
ные редины; фронд лесовосстановления (гари, погибшие насаждения, вырубки, прогалины, пустыри).

Земли, покрытые лесной растительностью (лесом):

земли, занятые лесными насаждениями естественного и искусственного происхождения с полнотой 0,4 и выше в возрасте молодняков и с полнотой 0,3 и выше в возрасте, превышающем возраст молодняков;

земли, занятые кустарниками, на которых в силу естественно-географических условий не могут произрастать древесные породы или на которых специально организуются кустарниковые хозяйства (прутяных и высокотаннидных ив, орехоплодных, технических культур);

плантации лесных древесных пород, предназначенные для ускоренного выращивания древостоев с целью получения целевых сортиментов или древесной массы для химической переработки (учитываются как лесные насаждения искусственного происхождения - лесные плантационные культуры).

Лесовосстановление - проведение мероприятий по восстановлению лесов на вырубках, гарях, пустырях, прогалинах и иных бывших под лесом площадях. Лесовосстановление осуществляется путем естественного, искусственного (создание лесных культур) или комбинированного восстановления лесов.

Искусственное лесовосстановление осуществляется путем посадки сеянцев, саженцев, черенков или посева семян лесных растений.

В выпуске молоди водных биологических ресурсов учитывается количество молоди ценных, особо ценных (осетровых, лососевых, сиговых, частиковых, растительноядных и прочих ценных видов рыб) и прочих видов водных биологических ресурсов, выпущенной в водные объекты рыбохозяйственного значения для сохранения численности естественных популяций и биологического разнообразия, а также восстановления водных биоресурсов и среды их обитания при осуществлении градостроительной и иной хозяйственной деятельности.

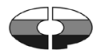




\section{СЕЛЬСКОЕ ХОЗЯЙСТВО}

\section{ОСНОВНЫЕ ПОКАЗАТЕЛИ СЕЛЬСКОГО ХОЗЯЙСТВА}

\section{1. ПРОДУКЦИЯ СЕЛЬСКОГО ХОЗЯЙСТВА ПО КАТЕГОРИЯМ ХОЗЯЙСТВ}

(в фактически действовавших ценах; млрд. рублей; 1992 г. - трлн. руб.)

\begin{tabular}{|c|c|c|c|c|c|c|c|c|c|}
\hline & 1992 & 2000 & 2005 & 2010 & 2013 & 2014 & 2015 & 2016 & 2017 \\
\hline & \multicolumn{9}{|c|}{ Хозяйства всех категорий } \\
\hline Продукция сель- & & & & & & & 51610 & 56057 & 56510 \\
\hline $\begin{array}{l}\text { ского хозяиства } \\
\text { в том числе: }\end{array}$ & 2,1 & 142,4 & 1380,9 & $258 /, 8$ & $368 /, 1$ & 4319,1 & 5164,9 & b5us, & 5654,0 \\
\hline водства & 1,3 & 394,7 & 669,8 & 1191,5 & 1918,8 & 2222,5 & 2791,4 & 3035,8 & 3033,2 \\
\hline $\begin{array}{l}\text { животно- } \\
\text { водства }\end{array}$ & 1,4 & 347,7 & 711,1 & 1396,3 & $\mid 1768,3$ & 2096,6 & 2373,5 & 2469,9 & 2620,8 \\
\hline & \multicolumn{9}{|c|}{ Сельскохозяйственные организации } \\
\hline $\begin{array}{l}\text { Продукция сель- } \\
\text { ского хозяйства }\end{array}$ & 1,8 & 335,6 & 615,6 & 1150,0 & 1756,0 & 2139,0 & 2657,1 & 2890,4 & 2978,0 \\
\hline $\begin{array}{l}\text { в том числе: } \\
\text { растение- }\end{array}$ & 0 & 1800 & 2044 & 4859 & 8406 & 0741 & 13071 & 14728 & 11272 \\
\hline $\begin{array}{l}\text { животно- } \\
\text { водства }\end{array}$ & 0,9 & $\mid 146,6$ & 321,2 & 664,1 & 915,4 & 1164,9 & 1350,0 & 1416,6 & 1540,7 \\
\hline & \multicolumn{9}{|c|}{ Хозяйства населения } \\
\hline $\begin{array}{l}\text { Продукция сель- } \\
\text { ского хозяйства }\end{array}$ & 0,9 & 383,2 & 681,0 & 1250,4 & 1569,8 & 1750,3 & 1932,8 & 1951,1 & 1957,9 \\
\hline $\begin{array}{l}\text { в том числе: } \\
\text { растение- } \\
\text { водства }\end{array}$ & 0,4 & 188,5 & 311,4 & 572.1 & 800.4 & 9179 & 1024.3 & 1025.4 & 1018.7 \\
\hline $\begin{array}{l}\text { животно- } \\
\text { водства }\end{array}$ & 0,5 & $\mid 194,7$ & 369,6 & 678,3 & 769,4 & 832,4 & 908,5 & 925,7 & 939,2 \\
\hline & \multicolumn{9}{|c|}{ Крестьянские (фермерские) хозяйства ${ }^{1)}$} \\
\hline $\begin{array}{l}\text { Продукция сель- } \\
\text { ского хозяйства }\end{array}$ & 0,03 & 23,6 & 84,3 & 187,4 & 361,3 & 429,8 & 575,0 & 664,2 & 718,1 \\
\hline $\begin{array}{l}\text { в том числе: } \\
\text { растение- } \\
\text { водства }\end{array}$ & 0,02 & 17,2 & 64,0 & 133,5 & 277,8 & 330,5 & 460,0 & 536,6 & 577,2 \\
\hline $\begin{array}{l}\text { животно- } \\
\text { водства }\end{array}$ & 0,01 & 6,4 & 20,3 & 53,9 & 83,5 & 99,3 & 115,0 & 127,6 & 140,9 \\
\hline
\end{tabular}

1) Включая индивидуальных предпринимателей. 


\section{2. ПРОДУКЦИЯ СЕЛЬСКОГО ХОЗЯЙСТВА}

ПО КАТЕГОРИЯМ ХОЗЯЙСТВ

(в фактически действовавших ценах; в процентах к итогу)

\begin{tabular}{|c|c|c|c|c|c|c|c|c|c|}
\hline & 1992 & 2000 & 2005 & 2010 & 2013 & 2014 & 2015 & 2016 & 2017 \\
\hline $\begin{array}{l}\text { Хозяйства всех } \\
\text { категорий }\end{array}$ & 100 & 100 & 100 & 100 & 100 & 100 & 100 & 100 & 100 \\
\hline в том числе: & & & & & & & & & \\
\hline $\begin{array}{l}\text { сельскохозяйствен- } \\
\text { ные организации }\end{array}$ & 67,1 & 45,2 & 44,6 & 44,5 & 47,6 & 49,5 & 51,5 & 52,5 & 52,7 \\
\hline $\begin{array}{l}\text { хозяйства населе- } \\
\text { ния }\end{array}$ & 31,8 & 51,6 & 49,3 & 48,3 & 42,6 & 40,5 & 37,4 & 35,4 & 34,6 \\
\hline $\begin{array}{l}\text { крестьянские (фер- } \\
\text { мерские) хозяйства }\end{array}$ & 1,1 & 3,2 & 6,1 & 7,2 & 9,8 & 10,0 & 11,1 & 12,1 & 12,7 \\
\hline
\end{tabular}

17.3. ИНДЕКСЫ ПРОИЗВОДСТВА ПРОДУКЦИИ СЕЛЬСКОГО ХОЗЯЙСТВА ПО КАТЕГОРИЯМ ХОЗЯЙСТВ (в сопоставимых ценах; в процентах к предыдущему году)

\begin{tabular}{l|r|r|r|r}
\hline \multirow{2}{*}{ Годы } & Хозяйства & \multicolumn{3}{|c}{ из них } \\
\cline { 3 - 5 } & всех категорий & $\begin{array}{c}\text { сельскохозяй- } \\
\text { ственные } \\
\text { организации }\end{array}$ & $\begin{array}{c}\text { хозяйства } \\
\text { населения }\end{array}$ & $\begin{array}{c}\text { крестьянские } \\
\text { (фермерские) } \\
\text { хозяйства }{ }^{1)}\end{array}$ \\
\hline 1992 & 90,6 & 82,7 & 108,1 & в 5,7p. \\
1995 & 92,0 & 84,6 & 103,4 & 97,4 \\
2000 & 106,2 & 106,4 & 105,3 & 121,9 \\
2005 & 101,6 & 103,1 & 98,9 & 110,5 \\
2010 & 88,7 & 89,4 & 88,8 & 83,9 \\
2013 & 105,8 & 108,4 & 100,3 & 118,4 \\
2014 & 103,5 & 106,7 & 98,5 & 110,4 \\
2015 & 102,6 & 104,5 & 99,1 & 107,6 \\
2016 & 104,8 & 108,0 & 98,0 & 113,1 \\
2017 & 102,4 & 105,2 & 95,6 & 111,1 \\
\hline
\end{tabular}

1) Включая индивидуальных предпринимателей. 


\section{4. ПРОИзВОДСтво ОСНОВНЫХ ВИДОВ СЕЛЬСКОХОЗЯЙСТВЕННОЙ ПРОДУКЦИИ ПО КАТЕГОРИЯМ ХОЗЯЙСТВ}

(в процентах от общего объема производства)

\begin{tabular}{|c|c|c|c|c|c|c|c|c|}
\hline & 1992 & 2000 & 2010 & 2013 & 2014 & 2015 & 2016 & 2017 \\
\hline \multirow[t]{2}{*}{ Сельскохозяйственные организации } & \multicolumn{8}{|c|}{ Сельскохозяйственные организации } \\
\hline & & & & & & & & \\
\hline доработки) & 97,4 & 90,8 & 77,1 & 74,5 & 73,7 & 72,7 & 71,4 & 70,2 \\
\hline Сахарная свекла & 97,8 & 94,5 & 88,7 & 89,6 & 89,2 & 89,0 & 88,1 & 88,2 \\
\hline Семена подсолнечника ${ }^{1)}$ & 93,0 & 84,3 & 73,0 & 70,5 & 70,1 & 70,3 & 68,7 & 68,0 \\
\hline Картофрель & 21,2 & 7,5 & 10,5 & 10,9 & 12,1 & 13,8 & 13,6 & 14,3 \\
\hline Овощи & 44,5 & 22,9 & 17,1 & 16,3 & 16,5 & 17,9 & 18,9 & 21,2 \\
\hline Плоды и ягоды & 31,0 & 15,7 & 15,0 & 21,2 & 21,5 & 21,6 & 23,7 & 24,8 \\
\hline Скот и птица на убой & & & & & & & & \\
\hline (в убойном весе) & 64,0 & 40,2 & 60,6 & 70,3 & 72,4 & 74,6 & 75,9 & 77,4 \\
\hline Молоко & 68,1 & 47,3 & 44,9 & 46,0 & 46,7 & 47,8 & 49,0 & 50,2 \\
\hline Яйца & 73,9 & 70,8 & 77,1 & 78,1 & 77,8 & 78,5 & 79,2 & 80,0 \\
\hline Шерсть (в физическом & & & & & & & & \\
\hline веce) & 67,0 & 37,8 & | 19,7 & | 18,3 & 17,9 & 17,0 & 16,4 & . \\
\hline & \multicolumn{8}{|c|}{ Хозяйства населения } \\
\hline \multicolumn{9}{|l|}{ Зерно (в весе после } \\
\hline доработки) & 0,5 & 0,8 & 1,0 & 0,9 & 1,0 & 1,0 & 0,9 & 0,7 \\
\hline Сахарная свекла & 0,2 & 0,6 & 0,4 & 0,5 & 0,5 & 0,4 & 0,2 & 0,2 \\
\hline Семена подсолнечника") & 1,2 & 1,2 & 0,6 & 0,4 & 0,5 & 0,4 & 0,4 & 0,5 \\
\hline Картофрель & 78,0 & 91,2 & 84,0 & 82,3 & 80,4 & 77,6 & 77,9 & 77,2 \\
\hline Овощи & 54,7 & 74,7 & 71,5 & 69,4 & 69,9 & 67,0 & 66,5 & 62,9 \\
\hline Плоды и ягоды & 68,7 & 84,1 & 82,8 & 77,3 & 76,7 & 76,3 & 74,4 & 72,3 \\
\hline Скот и птица на убой & & & & & & & & \\
\hline (в убойном весе) & 35,3 & 58,0 & 36,5 & 26,9 & 24,7 & 22,5 & 21,2 & 19,7 \\
\hline Молоко & 31,4 & 50,9 & 50,4 & 48,1 & 47,1 & 45,6 & 43,9 & 42,1 \\
\hline Яйца & 26,0 & 28,8 & 22,1 & 21,2 & 21,4 & 20,6 & 19,8 & 18,9 \\
\hline Шерсть (в физическом & & & & & & & & \\
\hline вece) & 32,2 & 56,8 & 54,4 & | 49,1 & 49,0 & 49,2 & 47,0 & \\
\hline & \multicolumn{8}{|c|}{ Крестьянские (фермерские) хозяйства } \\
\hline \multicolumn{9}{|l|}{ Зерно (в весе после } \\
\hline доработки) & 2,1 & 8,4 & 21,9 & 24,6 & 25,3 & 26,3 & 27,7 & 29,1 \\
\hline Сахарная свекла & 2,0 & 4,9 & 10,9 & 9,9 & 10,3 & 10,6 & 11,7 & 11,6 \\
\hline Семена подсолнечника ${ }^{1)}$ & 5,8 & 14,5 & 26,4 & 29,1 & 29,4 & 29,3 & 30,9 & 31,5 \\
\hline Картофель & 0,8 & 1,3 & 5,5 & 6,8 & 7,5 & 8,6 & 8,5 & 8,5 \\
\hline Овощи & 0,8 & 2,4 & 11,4 & 14,3 & 13,6 & 15,1 & 14,6 & 15,9 \\
\hline Плоды и ягоды & 0,3 & 0,2 & 2,2 & 1,5 & 1,8 & 2,1 & 1,9 & 2,9 \\
\hline \multicolumn{9}{|l|}{ Скот и птица на убой } \\
\hline (в убойном весе) & 0,7 & 1,8 & 2,9 & 2,8 & 2,9 & 2,9 & 2,9 & 2,9 \\
\hline Молоко & 0,5 & 1,8 & 4,7 & 5,9 & 6,2 & 6,6 & 7,1 & 7,7 \\
\hline Яйца & 0,1 & 0,4 & 0,8 & 0,7 & 0,8 & 0,9 & 1,0 & 1,1 \\
\hline \multicolumn{9}{|l|}{ Шерсть (в физическом } \\
\hline Bece) & 0,8 & 5,4 & 25,9 & 32,6 & 33,1 & 33,8 & 36,6 & \\
\hline
\end{tabular}

1) С 2013 г. - в весе после доработки.

2) Включая индивидуальных предпринимателей. 
17.5. ОСНОВНЫЕ ПОКАЗАТЕЛИ ПРОИЗВОДСТВЕННОЙ ДЕЯТЕЛЬНОСТИ СЕЛЬСКОХОЗЯЙСТВЕННЫХ ОРГАНИЗАЦИЙ

\begin{tabular}{|c|c|c|c|c|c|c|c|c|c|}
\hline & 1992 & 2000 & 2005 & 2010 & 2013 & 2014 & 2015 & 2016 & 2017 \\
\hline $\begin{array}{l}\text { осевная площа } \\
\text { лн. га }\end{array}$ & 108,7 & 74,2 & 60,5 & 56,1 & 56,1 & 55,3 & 55,1 & 54,7 & 54,4 \\
\hline в том числе: & & & & & & & & & \\
\hline $\begin{array}{l}\text { зерновых и зернобо- } \\
\text { бовых культур }\end{array}$ & 60,0 & 40,7 & 34,7 & 32,0 & 32,6 & 32,1 & 32,1 & 31,9 & 31,6 \\
\hline технических культур & 5,6 & 5,3 & 5,5 & 7,9 & 8,7 & 8,7 & 9,0 & 9,5 & 9,8 \\
\hline $\begin{array}{l}\text { картофелеля и овоще- } \\
\text { бахчевых культур }\end{array}$ & 1,4 & 0,5 & 0,3 & 0,4 & 0,3 & 0,3 & 0,3 & 0,3 & 0,3 \\
\hline кормовых культур & 41,7 & 27,7 & 20,0 & 15,8 & 14,5 & 14,1 & $\mid 13,7$ & 13,0 & 12,7 \\
\hline $\begin{array}{l}\text { Поголовье скота } \\
\text { (на конец года), } \\
\text { млн. голов: }\end{array}$ & & & & & & & & & \\
\hline $\begin{array}{l}\text { крупного рогатого } \\
\text { скота }\end{array}$ & 40,2 & 16,5 & 11,1 & 9,3 & 8,8 & 8,5 & 8,5 & 8,4 & 8,3 \\
\hline в том числе коров & 13,7 & 6,5 & 4,3 & 3,7 & 3,5 & 3,4 & 3,4 & 3,4 & 3,3 \\
\hline свиней & 23,5 & 8,5 & 7,3 & 10,8 & 14,7 & 15,6 & 17,6 & 18,4 & 19,9 \\
\hline овец и коз & 32,7 & 4,6 & 4,3 & 4,4 & 4,4 & 4,4 & 4,4 & 4,2 & 4,1 \\
\hline $\begin{array}{l}\text { Производство продук- } \\
\text { тов сельского хозяйст- } \\
\text { ва, млн. т: }\end{array}$ & & & & & & & & & \\
\hline & 104,1 & 59,4 & 62,7 & 47,0 & 68,9 & 77,6 & 76,2 & 86,2 & 95,0 \\
\hline сахарной свеклы & 25,0 & 13,3 & 18,8 & $\mid 19,7$ & 35,2 & 29,9 & 34,7 & 45,2 & 45,8 \\
\hline семян подсолнечника ${ }^{1)}$ & 2,9 & 3,3 & 4,7 & 3,9 & 6,9 & 5,9 & 6,5 & 7,6 & 7,1 \\
\hline льноволокна, тыс. т & 76,4 & 48,4 & 52,6 & 30,4 & 32,4 & 31,4 & 34,6 & 31,4 & 27,4 \\
\hline картофеляя & 8,1 & 2,2 & 2,4 & 2,2 & 3,3 & 3,8 & 4,7 & 4,2 & 4,2 \\
\hline овощей & 4,5 & 2,5 & 2,1 & 2,1 & 2,4 & 2,6 & 2,9 & 3,1 & 3,5 \\
\hline $\begin{array}{l}\text { скота и птицы на убой } \\
\text { (в убойном весе) }\end{array}$ & 5,3 & 1,8 & 2,3 & 4,4 & 6,0 & 6,6 & 7,1 & 7,5 & 8,0 \\
\hline молока & 32,2 & 15,3 & 14,0 & 14,3 & 14,0 & 14,4 & 14,7 & 15,1 & 15,7 \\
\hline $\begin{array}{l}\text { яиц, млрд. шт. } \\
\text { шерсти (в физиче- } \\
\text { ском весе), тыс. т }\end{array}$ & 31,7 & 24,2 & 27,3 & 31,3 & 32,3 & 32,6 & 33,4 & 34,5 & 35,9 \\
\hline
\end{tabular}

1) С 2013 г. - в весе после доработки. 
17.6. ПРОИзВодСТВо ОСНОВНЫХ ВИДОВ

СЕЛЬСКОХОЗЯЙСТВЕННОЙ ПРОДУКЦИИ

В ХОЗЯЙСТВАХ НАСЕЛЕНИЯ

(МЛН. ТОНН)

\begin{tabular}{l|r|r|r|r|r|r|r|r|r}
\hline & 1992 & 2000 & 2005 & 2010 & 2013 & 2014 & 2015 & 2016 & 2017 \\
\hline Картофель & 29,9 & 26,9 & 25,0 & 17,8 & 24,8 & 25,3 & 26,1 & 24,2 & 22,8 \\
Овощи & 5,5 & 8,1 & 8,4 & 8,7 & 10,2 & 10,8 & 10,8 & 10,8 & 10,3 \\
Плоды и ягоды & 2,0 & 2,3 & 1,9 & 1,8 & 2,3 & 2,3 & 2,2 & 2,5 & 2,1 \\
Скот и птица & & & & & & & & & \\
на убой (в убойном & & & & & & & & & \\
весе) & 2,9 & 2,5 & 2,6 & 2,6 & 2,3 & 2,2 & 2,2 & 2,1 & 2,1 \\
Молоко & 14,8 & 16,4 & 16,1 & 16,0 & 14,7 & 14,5 & 14,1 & 13,5 & 13,1 \\
Яйца, млрд. шт. & 11,2 & 9,8 & 9,5 & 9,0 & 8,7 & 9,0 & 8,8 & 8,6 & 8,5 \\
Шерсть (в физи- & & & & & & & & & \\
ческом весе), & & & & & & & & & \\
тыс. т & 57 & 23 & 27 & 29 & 27 & 28 & 27 & 26 & 27 \\
\hline
\end{tabular}

17.7. ПРОИЗВОДСТВО ОСНОВНЫХ ВИДОВ

СЕЛЬСКОХОЗЯЙСТВЕННОЙ ПРОДУКЦИИ

КРЕСТЬЯНСКИМИ (фермерсКИмИ) ХОЗЯЙСТВАМИ ${ }^{1)}$

(тыс. Тонн)

\begin{tabular}{l|r|r|r|r|r|r|r|r|r}
\hline & 1992 & 2000 & 2005 & 2010 & 2013 & 2014 & 2015 & 2016 & 2017 \\
\hline $\begin{array}{l}\text { Зерно (в весе } \\
\text { после доработ- }\end{array}$ & & & & & & & & & \\
ки) & 2232 & 5513 & 14272 & 13339 & 22749 & 26600 & 27517 & 33388 & 39425 \\
Сахарная & & & & & & & & & \\
свекла & 512 & 690 & 2232 & 2419 & 3892 & 3454 & 4147 & 6018 & 6032 \\
Семена & & & & & & & & & \\
подсолнечника & 180 & 567 & 1772 & 1413 & 2870 & 2491 & 2717 & 3400 & 3299 \\
Картофель & 307 & 375 & 802 & 1175 & 2052 & 2365 & 2895 & 2654 & 2510 \\
Овощи & 78 & 263 & 781 & 1388 & 2094 & 2101 & 2427 & 2379 & 5296 \\
Скот и птица на & & & & & & & & & \\
убой (в убойном & & & & & & & & & \\
весе) & 56 & 80 & 119 & 210 & 236 & 263 & 279 & 290 & 301 \\
Молоко & 248 & 568 & 981 & 1484 & 1804 & 1918 & 2035 & 2195 & 2391 \\
Яйца, млн. шт. & 24 & 141 & 260 & 303 & 300 & 321 & 369 & 444 & 465 \\
Шерсть (в фи- & & & & & & & & & 21 \\
зическом весе) & 1,4 & 2,2 & 9,6 & 14 & 18 & 19 & 19 & 21 & 21 \\
\hline
\end{tabular}

1) Включая индивидуальных предпринимателей.

2) С 2013 г. - в весе после доработки. 
17.8. ПАРК ОСНОВНЫХ ВИДОВ ТЕХНИКИ

В СЕЛЬСКОХОЗЯЙСТВЕННЫХ ОРГАНИЗАЦИЯ Х)

(на конец года; тыс. штук)

\begin{tabular}{|c|c|c|c|c|c|c|c|c|c|}
\hline & 1992 & 2000 & 2005 & 2010 & 2013 & 2014 & 2015 & 2016 & 2017 \\
\hline Тракторы ${ }^{2)}$ & 1290,7 & 746,7 & 480,3 & 310,3 & 259,7 & 247,3 & 233,6 & 223,4 & 216,8 \\
\hline Плуги & 460,3 & 237,6 & 148,8 & 87,7 & 71,4 & 67,8 & 64,1 & 61,6 & 59,7 \\
\hline Культиваторы & 541,6 & 260,1 & 175,5 & 119,8 & 102,2 & 97,8 & 93,2 & 90,3 & 87,6 \\
\hline Сеялки & 582,8 & 314,9 & 218,9 & 134,0 & 107,5 & 100,7 & 93,6 & 87,8 & 82,8 \\
\hline $\begin{array}{l}\text { Комбайны: } \\
\text { зерноуборочные }\end{array}$ & 370,8 & 198,7 & 129,2 & 80,7 & 67,9 & 64,6 & 61,4 & 59,3 & 57,6 \\
\hline $\begin{array}{l}\text { кукурузоубороч- } \\
\text { ные }\end{array}$ & 10,0 & 4,4 & 2,2 & 1,1 & 0,7 & 0,7 & 0,8 & 0,7 & 0,7 \\
\hline кормоуборочные & 120,1 & 59,6 & 33,4 & 20,0 & 16,1 & 15,2 & 14,0 & 13,3 & 12,7 \\
\hline $\begin{array}{l}\text { картофелеубо- } \\
\text { рочные }\end{array}$ & 30,9 & 10,0 & 4,5 & 2,9 & 2,6 & 2,4 & 2,3 & 2,2 & 2,1 \\
\hline льноуборочные & 8,5 & 3,2 & 1,8 & 0,7 & 0,5 & 0,4 & 0,4 & 0,3 & 0,3 \\
\hline $\begin{array}{l}\text { Свеклоубороч- } \\
\text { ные машины (без } \\
\text { ботвоуборочных) }\end{array}$ & 24,7 & 12,5 & 7,2 & 3,2 & 2,5 & 2,4 & 2,2 & 2,2 & 2,2 \\
\hline Косилки & 208,2 & 98,4 & 63,9 & 41,3 & 35,6 & 33,9 & 32,2 & 31,0 & 30,5 \\
\hline $\begin{array}{l}\text { Пресс- } \\
\text { подборщики }\end{array}$ & 79,5 & 44,0 & 32,4 & 24,1 & 22,7 & 21,9 & 20,9 & 20,4 & 19,9 \\
\hline Жатки валковые & 218,7 & 85,2 & 46,9 & 27,0 & 22,3 & 21,2 & 19,7 & 19,0 & 19,1 \\
\hline $\begin{array}{l}\text { Дождевальные и } \\
\text { поливные маши- } \\
\text { ны и установки }\end{array}$ & 69,5 & 19,2 & 8,6 & 5,4 & 5,3 & 5,7 & 5,9 & 6,0 & 6,2 \\
\hline $\begin{array}{l}\text { Разбрасыватели } \\
\text { твердых мине- } \\
\text { ральных удобре- } \\
\text { ний }\end{array}$ & 111,3 & 34,3 & 19,7 & 16,6 & 15,8 & 15,8 & 15,5 & 15,7 & 15,5 \\
\hline $\begin{array}{l}\text { Машины для } \\
\text { внесения в почву } \\
\text { органических } \\
\text { удобрений: }\end{array}$ & & & & & & & & & \\
\hline твердых & 80,0 & 22,0 & 10,9 & 6,5 & 5,2 & 5,1 & 4,8 & 4,7 & 4,7 \\
\hline жидких & 38,6 & 12,1 & 5,8 & 3,9 & 3,6 & 3,7 & 3,6 & 3,6 & 3,7 \\
\hline $\begin{array}{l}\text { Опрыскиватели } \\
\text { и опыливатели } \\
\text { тракторные }\end{array}$ & 88,6 & 32,5 & 24,6 & 23,2 & 22,7 & 23,1 & 22,4 & 22,8 & 23,1 \\
\hline $\begin{array}{l}\text { Доильные уста- } \\
\text { новки и агрегаты }\end{array}$ & 197,5 & 88,7 & 50,3 & 31,4 & 27,3 & 26,3 & 25,1 & 24,1 & 22,9 \\
\hline
\end{tabular}

1) С 2010 г. - без учета микропредприятий.

2) Без тракторов, на которых смонтированы землеройные, мелиоративные и другие машины. 
17.9. ОБЕСПЕЧЕННОСТЬ СЕЛЬСКОХОЗЯЙСТВЕННЫХ ОРГАНИЗАЦИЙ ТРАКТОРАМИ И КОМБАЙНАМИ ${ }^{1)}$

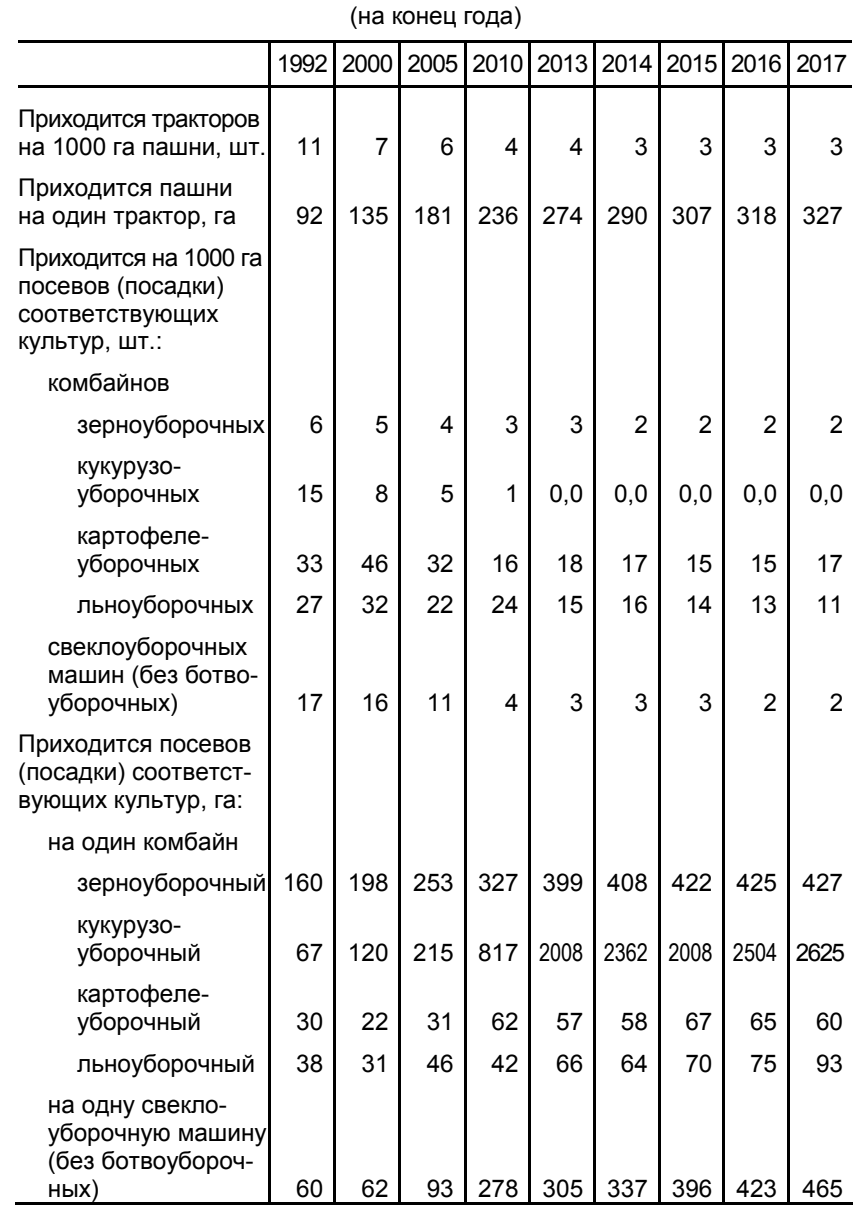

1) С 2010 г. - без учета микропредприятий. 


\subsection{0. ВНЕСЕНИЕ МИНЕРАЛЬНЫХ УДОБРЕНИЙ ПОД ПОСЕВЫ} В СЕЛЬСКОХОЗЯЙСТВЕННЫХ ОРГАНИЗАЦИЯХ ${ }^{1)}$

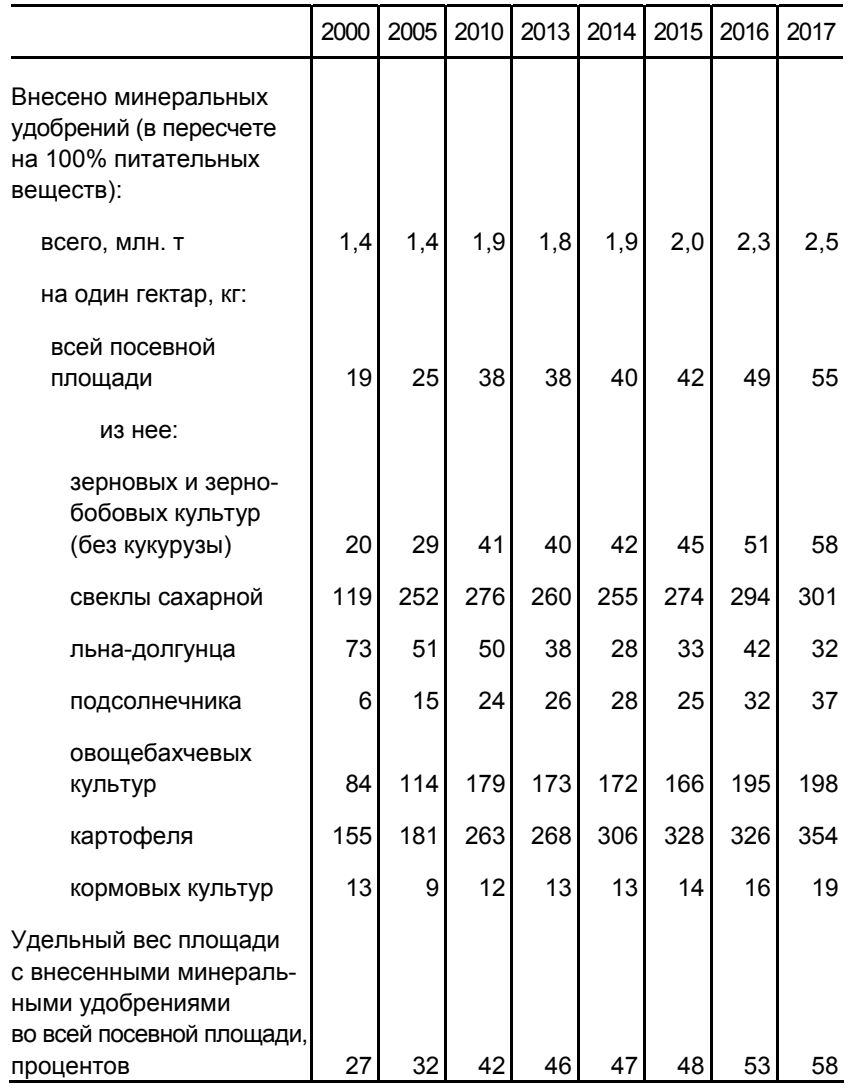

1) С 2010 г. - без учета микропредприятий. 
17.11. ВНЕСЕНИЕ ОРГАНИЧЕСКИХ УДОБРЕНИЙ ПОД ПОСЕВЫ В СЕЛЬСКОХОЗЯЙСТВЕННЫХ ОРГАНИЗАЦИЯ ${ }^{11}$

\begin{tabular}{|c|c|c|c|c|c|c|c|c|}
\hline & 2000 & 2005 & 2010 & 2013 & 2014 & 2015 & 2016 & 2017 \\
\hline $\begin{array}{l}\text { Внесено органических } \\
\text { удобрений: }\end{array}$ & & & & & & & & \\
\hline $\begin{array}{l}\text { всего, млн. т } \\
\text { на один гектар, т: }\end{array}$ & 66,0 & 49,9 & 53,1 & 55,7 & 61,6 & 64,2 & 65,2 & 66,6 \\
\hline $\begin{array}{l}\text { всей посевной } \\
\text { площади }\end{array}$ & 0,9 & 0,9 & 1,1 & 1,1 & 1,3 & 1,3 & 1,4 & 1,5 \\
\hline из нее: & & & & & & & & \\
\hline $\begin{array}{l}\text { зерновых и зерно- } \\
\text { бобовых культур } \\
\text { (без кукурузы) }\end{array}$ & 1,0 & 0,9 & 1,0 & 1,0 & 1,1 & 1,2 & 1,2 & 1,3 \\
\hline сахарной свеклы & 1,8 & 2,3 & 2,2 & 2,2 & 2,0 & 2,2 & 2,5 & 2,2 \\
\hline подсолнечника & 0,1 & 0,2 & 0,5 & 0,6 & 0,7 & 0,9 & 0,9 & 0,9 \\
\hline $\begin{array}{l}\text { овощебахчевых } \\
\text { культур }\end{array}$ & 7 & 5 & 4 & 4 & 3 & 4 & 3 & 3 \\
\hline картофеля & 27 & 16 & 9 & 5 & 5 & 6 & 6 & 6 \\
\hline кормовых культур & 0,7 & 0,7 & 1,0 & 1,3 & 1,4 & 1,5 & 1,6 & 1,7 \\
\hline $\begin{array}{l}\text { Удельный вес площади } \\
\text { с внесенными органиче- } \\
\text { скими удобрениями } \\
\text { во всей посевной площади, } \\
\text { процентов }\end{array}$ & 2,2 & 3,4 & 7,5 & 7,5 & 8,2 & 8,4 & 9,3 & 9,2 \\
\hline
\end{tabular}

1) С 2010 г. - без учета микропредприятий. 
РАСТЕНИЕВОДСТВО

17.12. ПОСЕВНЫЕ ПЛОЩАДИ СЕЛЬСКОХОЗЯЙСТВЕННЫХ КУЛЬТУР

(в хозяйствах всех категорий; тыс. гектаров)

\begin{tabular}{l|r|r|r|r|r|r|r|r}
\hline & 1992 & 2000 & 2005 & 2010 & 2014 & 2015 & 2016 & 2017 \\
\hline Вся посевная & & & & & & & & \\
площадь & 114591 & 84670 & 75837 & 75188 & 78525 & 79319 & 79993 & 80617 \\
Зерновые и & & & & & & & & \\
зернобобовые & & & & & & & & \\
культуры & 61939 & 45585 & 43593 & 43194 & 46220 & 46642 & 47110 & 47673 \\
в том числе: & & & & & & & & \\
озимые зерно- & & & & & & & & \\
вые культуры & 19191 & 11997 & 13189 & 15078 & 14872 & 15410 & 16062 & 16780 \\
из них: & & & & & & & & \\
пшеница & 10799 & 7933 & 10363 & 12699 & 12161 & 13354 & 14021 & 14925 \\
рожь & 7574 & 3530 & 2333 & 1757 & 1874 & 1290 & 1259 & 1180 \\
ячмень & 818 & 534 & 493 & 461 & 600 & 530 & 571 & 515 \\
яровые зерно- & & & & & & & & \\
вые и зернобо- \\
бовые культуры
\end{tabular}


Продолжение табл. 17.12

\begin{tabular}{|c|c|c|c|c|c|c|c|c|}
\hline & 1992 & 2000 & 2005 & 2010 & 2014 & 2015 & 2016 & 2017 \\
\hline $\begin{array}{c}\text { масличные } \\
\text { культуры } \\
\text { из них: }\end{array}$ & 3921 & 5489 & 6680 & 9616 & 11204 & 11501 & 12302 & 12624 \\
\hline подсолнечник & 2889 & 4643 & 5568 & 7153 & 6907 & 7005 & 7598 & 7988 \\
\hline соя & 645 & 421 & 718 & 1206 & 2006 & 2123 & 2228 & 2635 \\
\hline $\begin{array}{l}\text { рапс } \\
\text { Картофель и ово- } \\
\text { щебахчевые куль }\end{array}$ & 154 & 232 & 244 & 856 & 1191 & 1021 & 978 & 1005 \\
\hline $\begin{array}{l}\text { туры } \\
\text { в том числе: }\end{array}$ & 4287 & 3728 & 3019 & 3022 & 2945 & 2993 & 2906 & 2712 \\
\hline $\begin{array}{l}\text { картофель } \\
\text { овощи }\end{array}$ & 3404 & 2834 & 2277 & 2212 & 2112 & 2128 & 2053 & 1905 \\
\hline $\begin{array}{l}\text { (без высадков) } \\
\text { Кормовые }\end{array}$ & 682 & 744 & 641 & 662 & 684 & 694 & 692 & 662 \\
\hline $\begin{array}{l}\text { культуры } \\
\text { в том числе: } \\
\text { многолетние }\end{array}$ & 42474 & 28899 & 21610 & 18071 & 17127 & 16974 & 16378 & 16280 \\
\hline $\begin{array}{l}\text { травы } \\
\text { однолетние }\end{array}$ & 18813 & 18046 & 14557 & 11463 & 10808 & 10713 & 10646 & 10511 \\
\hline травы & 11210 & 5946 & 4930 & 4680 & 4582 & 4540 & 4190 & 4102 \\
\hline $\begin{array}{l}\text { кукуруза на корм } \\
\text { кормовые кор- } \\
\text { неплоды (вклю- } \\
\text { чая сахарную } \\
\text { свеклу на корм }\end{array}$ & 9535 & 3668 & 1570 & 1502 & 1384 & 1381 & 1242 & 1365 \\
\hline $\begin{array}{l}\text { скоту) } \\
\text { Площадь } \\
\text { чистых паров }\end{array}$ & $\begin{array}{r}495 \\
13026\end{array}$ & $\begin{array}{r}151 \\
18042\end{array}$ & $\begin{array}{r}70 \\
14895\end{array}$ & $\begin{array}{r}50 \\
14660\end{array}$ & $\begin{array}{r}50 \\
12416\end{array}$ & $\begin{array}{r}46 \\
11859\end{array}$ & $\begin{array}{r}42 \\
11979\end{array}$ & $\begin{array}{r}37 \\
11819\end{array}$ \\
\hline
\end{tabular}

\subsection{3. ПОСЕВНЫЕ ПЛОЩАДИ СЕЛЬСКОХОЗЯЙСТВЕННЫХ КУЛЬТУР} ПО КАТЕГОРИЯМ ХОЗЯЙСТВ в 2017 г.

(млн. гектаров)

\begin{tabular}{|c|c|c|c|c|c|}
\hline & \multirow{2}{*}{\begin{tabular}{|c|} 
Вся \\
посевная \\
площадь \\
\end{tabular}} & \multicolumn{4}{|c|}{ в том числе } \\
\hline & & \begin{tabular}{|l|} 
зерновые \\
и зерно- \\
бобовые \\
культуры
\end{tabular} & $\begin{array}{c}\text { техни- } \\
\text { ческие } \\
\text { культуры }\end{array}$ & \begin{tabular}{|c|} 
карто- \\
фель и \\
овоще- \\
бахчевые \\
культуры
\end{tabular} & $\begin{array}{l}\text { кормовые } \\
\text { культуры } \\
\end{array}$ \\
\hline $\begin{array}{l}\text { Хозяйства всех категорий } \\
\text { в том числе: } \\
\text { сельскохозяйственные }\end{array}$ & 80,6 & 47,7 & 13,9 & 2,7 & 16,3 \\
\hline организации & 54,4 & 31,6 & 9,8 & 0,3 & 12,7 \\
\hline хозяйства населения & 3,1 & 0,5 & 0,0 & 2,1 & 0,5 \\
\hline $\begin{array}{l}\text { крестьянские (фермерские) } \\
\text { хозяйства }\end{array}$ & 23,1 & 15,6 & 4,1 & 0,3 & 3,1 \\
\hline
\end{tabular}

1) Включая индивидуальных предпринимателей. 


\subsection{4. ВАЛОВОЙ СБОР И УРОЖАЙНОСТЬ ОСНОВНЫХ} СЕЛЬСКОХОЗЯЙСТВЕННЫХ КУЛЬТУР

(в хозяйствах всех категорий)

\begin{tabular}{|c|c|c|c|c|c|c|c|c|c|}
\hline & 1992 & 2000 & 2005 & 2010 & 2013 & 2014 & 2015 & 2016 & 2017 \\
\hline & \multicolumn{9}{|c|}{ Валовой сбор, млн. т } \\
\hline $\begin{array}{l}\text { Зерно (в весе после } \\
\text { доработки) }\end{array}$ & 106,9 & 65,4 & 77,8 & 61,0 & 92,4 & 105,3 & 104,8 & 120,7 & 135,4 \\
\hline Сахарная свекла & 25,5 & 14,1 & 21,3 & 22,3 & 39,3 & 33,5 & 39,0 & 51,4 & 51,9 \\
\hline $\begin{array}{l}\text { Семена масличных } \\
\text { культур }{ }^{1)}\end{array}$ & 3,9 & 4,5 & 7,6 & 7,5 & 13,1 & 12,9 & 13,8 & 16,3 & 16,5 \\
\hline \multicolumn{10}{|l|}{ из них: } \\
\hline подсолнечника & 3,1 & 3,9 & 6,5 & 5,3 & 9,8 & 8,5 & 9,3 & 11,0 & 10,5 \\
\hline con & 0,5 & 0,3 & 0,7 & 1,2 & 1,5 & 2,4 & 2,7 & 3,1 & 3,6 \\
\hline $\begin{array}{l}\text { рапса озимого } \\
\text { и ярового }\end{array}$ & 0,2 & 0,1 & 0,3 & 0,7 & 1,3 & 1,3 & 1,0 & 1,0 & 1,5 \\
\hline Льноволокно, тыс. т & 78 & 51 & 56 & 35 & 39 & 37 & 45 & 41 & 39 \\
\hline Картофель & 38,3 & 29,5 & 28,1 & 21,1 & 30,2 & 31,5 & 33,6 & 31,1 & 29,6 \\
\hline Овощи & 10,0 & 10,8 & 11,3 & 12,1 & 14,7 & 15,5 & 16,1 & 16,3 & 16,4 \\
\hline $\begin{array}{l}\text { Плоды, ягоды и } \\
\text { виноград }\end{array}$ & 3,4 & 3,0 & 2,7 & 2,5 & 3,4 & 3,5 & 3,4 & 3,9 & 3,5 \\
\hline \multicolumn{10}{|c|}{ Урожайность, ц/га убранной площади } \\
\hline $\begin{array}{l}\text { Зерновые и зернобобо- } \\
\text { вые культуры (в весе } \\
\text { после доработки) }\end{array}$ & 18,0 & 15,6 & 18,5 & 18,3 & 22,0 & 24,1 & 23,7 & 26,2 & 29,2 \\
\hline Сахарная свекла & 192 & 188 & 282 & 241 & 442 & 370 & 388 & 470 & 442 \\
\hline Подсолнечник ${ }^{1)}$ & 11,6 & 9,0 & 11,9 & 9,6 & 14,5 & 13,1 & 14,2 & 15,1 & 14,5 \\
\hline $\operatorname{Cog}^{1)}$ & 8,5 & 10,1 & 10,5 & 11,8 & 12,6 & 12,3 & 13,0 & 14,8 & 14,1 \\
\hline Рапс озимый ${ }^{1)}$ & 16,3 & 13,6 & 17,7 & 19,0 & 16,6 & 16,8 & 19,3 & 18,2 & 22,7 \\
\hline Рапс яровой ${ }^{11}$ & 10,5 & 6,8 & 11,0 & 6,8 & 9,9 & 11,2 & 9,8 & 10,2 & 14,5 \\
\hline Лен-долгунец (волокно) & 3,1 & 5,5 & 6,3 & 8,2 & 8,5 & 9,0 & 9,1 & 9,4 & 9,2 \\
\hline Картофель & 114 & 105 & 124 & 100 & 145 & 150 & 159 & 153 & 156 \\
\hline Овощи & 145 & 143 & 170 & 180 & 214 & 218 & 225 & 227 & 236 \\
\hline
\end{tabular}

1) С 2013 г. - в весе после доработки. 
17.15. ВАЛОВОЙ СБОР И УРОЖАЙНОСТЬ ОТДЕЛЬНЫХ ЗЕРНОВЫХ И ЗЕРНОБОБОВЫХ КУЛЬТУР

(в хозяйствах всех категорий; в весе после доработки)

\begin{tabular}{|c|c|c|c|c|c|c|c|c|c|}
\hline & 1992 & 2000 & 2005 & 2010 & 2013 & 2014 & 2015 & 2016 & 2017 \\
\hline & \multicolumn{9}{|c|}{ Валовой сбор, млн. Т } \\
\hline $\begin{array}{l}\text { Пшеница ози } \\
\text { и яровая }\end{array}$ & 46,2 & 34,5 & 47,6 & 41,5 & 52,1 & 59,7 & 61,8 & 73,3 & 85,9 \\
\hline Рожь озимая и яровая & 13,9 & 5,4 & 3,6 & 1,6 & 3,4 & 3,3 & 2,1 & 2,5 & 2,5 \\
\hline Кукуруза на зерно & 2,1 & 1,5 & 3,1 & 3,1 & 11,6 & 11,3 & 13,2 & 15,3 & 13,2 \\
\hline $\begin{array}{l}\text { Ячмень оз } \\
\text { и яровой }\end{array}$ & 27,0 & 14,0 & 15,7 & 8,4 & 15,4 & 20,4 & 17,5 & 18,0 & 20,6 \\
\hline Овес & 11,2 & 6,0 & 4,5 & 3,2 & 4,9 & 5,3 & 4,5 & 4,8 & 5,5 \\
\hline Просо, тыс. т & 1535 & 1124 & 455 & 134 & 419 & 493 & 572 & 630 & 317 \\
\hline Гречиха, тыс. т & 1038 & 997 & 605 & 339 & 834 & 662 & 861 & 1186 & 1524 \\
\hline Рис, тыс. т & 754 & 584 & 571 & 1061 & 935 & 1049 & 1110 & 1081 & 987 \\
\hline \multirow[t]{2}{*}{ Зернобобовые } & 3,1 & 1,2 & 1,6 & 1,4 & 2,0 & 2,2 & 2,4 & $|2,9|$ & 4,3 \\
\hline & \multicolumn{9}{|c|}{ Урожайность, ц/га убранной площади } \\
\hline \multicolumn{10}{|l|}{ Пшеница: } \\
\hline озимая & 26,5 & 22,3 & 28,3 & 24,9 & 29,9 & 35,1 & 32,0 & 37,6 & 41,7 \\
\hline яровая & 13,9 & 12,7 & 13,0 & 12,9 & 14,2 & 14,7 & 15,5 & 15,7 & 18,9 \\
\hline Рожь озимая & 18,5 & 15,8 & 15,7 & 11,9 & 18,9 & 17,7 & 16,7 & 20,3 & 21,7 \\
\hline Кукуруза на зерно & 29,0 & 21,2 & 38,5 & 30,0 & 50,1 & 43,6 & 49,3 & 55,1 & 49,0 \\
\hline \multicolumn{10}{|l|}{ Ячмень: } \\
\hline озимый & 34,7 & 34,1 & 32,4 & 37,4 & 40,3 & 35,9 & 40,0 & 39,5 & 41,9 \\
\hline яровой & 18,3 & 15,5 & 17,3 & 14,8 & 18,1 & 21,8 & 20,0 & 20,8 & 25,2 \\
\hline Овес & 14,4 & 14,7 & 14,4 & 14,4 & 16,4 & 17,1 & 16,0 & 17,3 & 19,6 \\
\hline Просо & 9,1 & 8,2 & 11,2 & 7,8 & 11,8 & 12,3 & 12,9 & 15,4 & 13,4 \\
\hline Гречиха & 6,7 & 6,9 & 7,3 & 5,9 & 9,2 & 9,3 & 9,5 & 10,6 & 10,2 \\
\hline Рис & 30,3 & 34,9 & 42,0 & 52,8 & 49,5 & 53,6 & 55,8 & 53,0 & 53,1 \\
\hline Зернобобовые & 14,2 & 14,2 & 15,4 & 13,9 & 12,1 & 14,6 & 15,9 & 17,5 & 20,1 \\
\hline
\end{tabular}




\subsection{6. ПРОИЗВОДСТВО ЗЕРНА}

ПО ВИДАМ КУЛЬТУР

(в хозяйствах всех категорий; в процентах от общего валового сбора)

2006-2010

(в среднем за год)

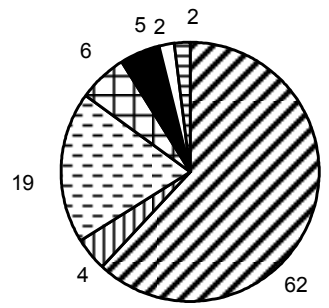

2016

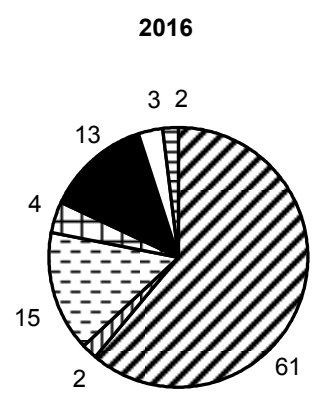

2013

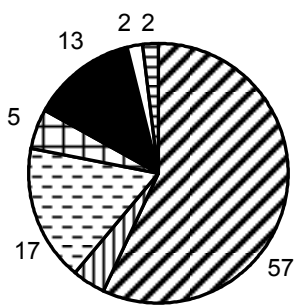

4

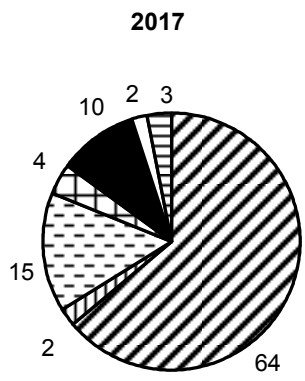

\begin{tabular}{|c|c|}
\hline $\boldsymbol{\nabla}$ Пшеница и тритикале & 口 Рожь \\
\hline Фячмень & 田 Овес \\
\hline Кукуруза на зерно & $\square$ Крупяные \\
\hline 曰Зернобобовые & \\
\hline
\end{tabular}




\section{ЖИВОТНОВОДСТВО}

\subsection{7. ПОГОЛОВЬЕ СКОТА}

(на конец года; в хозяйствах всех категорий; млн. голов)

\begin{tabular}{c|c|c|c|c}
\hline Годы & $\begin{array}{c}\text { Крупный } \\
\text { рогатый скот }\end{array}$ & $\begin{array}{c}\text { в том числе } \\
\text { коровы }\end{array}$ & Свиньи & Овцы и козы \\
\hline 1992 & 52,2 & 20,2 & 31,5 & 51,4 \\
2000 & 27,5 & 12,7 & 15,8 & 15,0 \\
2005 & 21,6 & 9,5 & 13,8 & 18,6 \\
2010 & 20,0 & 8,8 & 17,2 & 21,8 \\
2013 & 19,6 & 8,7 & 19,1 & 24,3 \\
2014 & 19,3 & 8,5 & 19,5 & 24,7 \\
2015 & 19,0 & 8,4 & 21,5 & 24,9 \\
2016 & 18,8 & 8,3 & 22,0 & 24,8 \\
2017 & 18,7 & 8,2 & 23,2 & 24,5 \\
\hline
\end{tabular}

17.18. ПОГОЛОВЬЕ СКОТА ПО КАТЕГОРИЯМ ХОЗЯЙСТВ на конец 2017 г.

(млн. голов)

\begin{tabular}{|c|c|c|c|c|}
\hline & $\begin{array}{c}\text { Крупный } \\
\text { рогатый } \\
\text { скот }\end{array}$ & $\begin{array}{c}\text { в том } \\
\text { числе } \\
\text { коровы }\end{array}$ & Свиньи & $\begin{array}{l}\text { Овцы } \\
\text { и козы }\end{array}$ \\
\hline $\begin{array}{l}\text { Хозяйства всех категорий } \\
\text { в том числе: } \\
\text { сельскохозяйственные }\end{array}$ & 18,7 & 8,2 & 23,2 & 24,5 \\
\hline организации & 8,3 & 3,3 & 19,9 & 4,1 \\
\hline $\begin{array}{l}\text { хозяйства населения } \\
\text { крестьянские (фермерские) }\end{array}$ & 7,9 & 3,7 & 2,9 & 11,4 \\
\hline хозяйства ${ }^{1)}$ & 2,5 & 1,2 & 0,4 & 9,0 \\
\hline
\end{tabular}

1) Включая индивидуальных предпринимателей.

\subsection{9. ПРОИЗВОДСТВО ОСНОВНЫХ ПРОДУКТОВ ЖИВОТНОВОДСТВА}

(в хозяйствах всех категорий)

\begin{tabular}{l|r|r|r|r|r|r|r|r|r}
\hline & 1992 & 2000 & 2005 & 2010 & 2013 & 2014 & 2015 & 2016 & 2017 \\
\hline $\begin{array}{l}\text { Скот и птица на убой } \\
\text { (в убойном весе), }\end{array}$ & & & & & & & & & \\
млн. т & 8,3 & 4,4 & 5,0 & 7,2 & 8,5 & 9,1 & 9,6 & 9,9 & 10,4 \\
Молоко, млн. т & 47,2 & 32,3 & 31,1 & 31,8 & 30,5 & 30,8 & 30,8 & 30,8 & 31,2 \\
Яйца, млрд. шт. & 42,9 & 34,1 & 37,1 & 40,6 & 41,3 & 41,9 & 42,6 & 43,6 & 44,9 \\
Шерсть (в физиче- \\
ском весе), тыс. т
\end{tabular}




\subsection{0. ПРОИЗВОДСТВО СКОТА И ПТИЦЫ НА УБОЙ}

ПО ОТДЕЛЬНЫМ ВИДАМ

(в хозяйствах всех категорий; тыс. тонн)

\begin{tabular}{|c|c|c|c|c|c|}
\hline \multirow[b]{2}{*}{ Годы } & \multirow{2}{*}{$\begin{array}{c}\text { Скот и птица } \\
\text { на убой } \\
\text { (в убойном } \\
\text { весе) } \\
\end{array}$} & \multicolumn{4}{|c|}{ В том числе } \\
\hline & & $\begin{array}{c}\text { крупный } \\
\text { рогатый скОт }\end{array}$ & свиньи & овцы и козы & птица \\
\hline 1992 & 8260 & 3632 & 2784 & 329 & 1428 \\
\hline 2000 & 4446 & 1898 & 1578 & 140 & 768 \\
\hline 2005 & 4990 & 1809 & 1569 & 154 & 1388 \\
\hline 2010 & 7167 & 1727 & 2331 & 185 & 2847 \\
\hline 2013 & 8544 & 1633 & 2816 & 190 & 3831 \\
\hline 2014 & 9070 & 1654 & 2974 & 204 & 4161 \\
\hline 2015 & 9565 & 1649 & 3099 & 204 & 4536 \\
\hline 2016 & 9899 & 1619 & 3368 & 213 & 4621 \\
\hline 2017 & 10384 & 1614 & 3530 & 222 & 4939 \\
\hline
\end{tabular}

17.21. ПРОДУКТИВНОСТЬ СКОТА И ПТИЦЫ

(в сельскохозяйственных организациях; килограммов)

\begin{tabular}{|c|c|c|c|c|c|c|c|c|c|}
\hline & 1992 & 2000 & 2005 & 2010 & 2013 & 2014 & 2015 & 2016 & 2017 \\
\hline $\begin{array}{l}\text { Надой молока } \\
\text { на одну корову }\end{array}$ & 2243 & 2341 & 3280 & 4189 & 4519 & 4841 & 5140 & 5370 & 5660 \\
\hline $\begin{array}{l}\text { Средняя годовая } \\
\text { яйценоскость } \\
\text { кур-несушек"1), шт. }\end{array}$ & 224 & 264 & 301 & 307 & 305 & 308 & 310 & 308 & 311 \\
\hline $\begin{array}{l}\text { Средний годовой } \\
\text { настриг шерсти } \\
\text { с одной овцы } \\
\text { (в фризическом весе) }\end{array}$ & 3,2 & 3,2 & 2,8 & 2,3 & 2,3 & 2,4 & 2,3 & 2,2 & 2,2 \\
\hline $\begin{array}{l}\text { Продукция выращи- } \\
\text { вания (приплод, } \\
\text { прирост, привес) } \\
\text { скота в расчете } \\
\text { на одну голову: }\end{array}$ & & & & & & & & & \\
\hline & 84 & 79 & 94 & 105 & 109 & 116 & 121 & 122 & 126 \\
\hline свиней & 61 & 62 & 107 & 155 & 187 & 199 & 205 & 201 & 206 \\
\hline
\end{tabular}

1) Сельскохозяйственные организации, не относящиеся к субъектам малого предпринимательства. 


\section{ПРОДОВОЛЬСТВЕННЫЕ РЕСУРСЫ И ИХ ИСПОЛЬЗОВАНИЕ}

17.22. РЕСУРСЫ И ИСПОЛЬЗОВАНИЕ МЯСА И МЯСОПРОДУКТОВ (МлН. ТОНн)

\begin{tabular}{l|r|r|r|r|r|r|r|r|r}
\hline & 1992 & 2000 & 2005 & 2010 & 2013 & 2014 & 2015 & 2016 & 2017 \\
\hline Ресурсы & & & & & & & & & \\
Запасы на начало & & & & & & & & & \\
года & 1,0 & 0,6 & 0,6 & 0,8 & 0,8 & 0,9 & 0,8 & 0,8 & 0,8 \\
Производство ${ }^{1)}$ & 8,3 & 4,4 & 5,0 & 7,2 & 8,5 & 9,1 & 9,6 & 9,9 & 10,4 \\
Импорт & 1,4 & 2,1 & 3,1 & 2,8 & 2,5 & 1,9 & 1,3 & 1,2 & 1,1 \\
Итого ресурсов & 10,7 & 7,1 & 8,7 & 10,8 & 11,8 & 11,9 & 11,7 & 11,9 & 12,3 \\
Использование & & & & & & & & & \\
Производственное & & & & & & & & & \\
потребление & 0,3 & 0,1 & 0,05 & 0,04 & 0,1 & 0,1 & 0,1 & 0,04 & 0,04 \\
Потери & 0,1 & 0,01 & 0,02 & 0,02 & 0,02 & 0,02 & 0,02 & 0,01 & 0,01 \\
Экспорт & 0,1 & 0,03 & 0,1 & 0,1 & 0,1 & 0,1 & 0,1 & 0,2 & 0,3 \\
Личное потребление & 8,9 & 6,6 & 7,9 & 9,9 & 10,8 & 10,9 & 10,7 & 10,9 & 11,1 \\
Запасы на конец & & & & & & & & & 0 \\
года & 1,3 & 0,4 & 0,7 & 0,8 & 0,8 & 0,8 & 0,8 & 0,8 & 0,8 \\
\hline
\end{tabular}

1) Скот и птица на убой (в убойном весе).

17.23. РЕСУРСЫ И ИСПОЛЬЗОВАНИЕ МОЛОКА И МОЛОКОПРОДУКТОВ

(млн. тонн)

\begin{tabular}{l|r|r|r|r|r|r|r|r|r}
\hline & 1992 & 2000 & 2005 & 2010 & 2013 & 2014 & 2015 & 2016 & 2017 \\
\hline Ресурсы & & & & & & & & & \\
Запасы на начало & & & & & & & & & \\
года & 1,9 & 1,3 & 1,7 & 1,9 & 2,0 & 2,0 & 2,1 & 1,9 & 1,7 \\
Производство & 47,2 & 32,3 & 30,8 & 31,8 & 30,5 & 30,8 & 30,8 & 30,8 & 31,1 \\
Импорт & 3,2 & 4,7 & 7,1 & 8,2 & 9,5 & 9,1 & 7,9 & 7,5 & 6,6 \\
Итого ресурсов & 52,3 & 38,3 & 39,6 & 41,9 & 42,0 & 41,9 & 40,8 & 40,2 & 39,4 \\
Использование & & & & & & & & & \\
Производственное & & & & & & & & & \\
потребление & 7,8 & 5,2 & 4,1 & 4,3 & 3,8 & 3,5 & 3,3 & 3,2 & 2,9 \\
Потери & 0,04 & 0,03 & 0,02 & 0,03 & 0,03 & 0,03 & 0,03 & 0,03 & 0,03 \\
Экспорт & 0,2 & 0,5 & 0,5 & 0,5 & 0,6 & 0,6 & 0,6 & 0,6 & 0,6 \\
Личное потребление & 41,8 & 31,3 & 33,2 & 35,2 & 35,6 & 35,7 & 34,9 & 34,7 & 34,2 \\
Запасы на конец & & & & & & & & & 1,7 \\
года & 2,5 & 1,2 & 1,8 & 1,9 & 2,0 & 2,1 & 2,0 & 1,7 & 1,7 \\
\hline
\end{tabular}




\section{ЛЕСНОЕ ХОЗЯЙСТВО}

\subsection{4. ЛЕСНЫЕ РЕСУРСЫ ${ }^{1)}$}

(на конец года)

\begin{tabular}{c|c|c|c|c}
\hline Годы & $\begin{array}{c}\text { Общая } \\
\text { площадь земель } \\
\text { лесного фонда и } \\
\text { земель иных } \\
\text { категорий, на } \\
\text { которых располо- } \\
\text { жены леса, млн. га }\end{array}$ & $\begin{array}{c}\text { в том числе } \\
\text { лесные } \\
\text { земли }\end{array}$ & $\begin{array}{c}\text { из них } \\
\text { покрытые лесной } \\
\text { растительностью }\end{array}$ & $\begin{array}{c}\text { Общий запас } \\
\text { древесины, } \\
\text { млрд. м }\end{array}$ \\
\hline 1992 & 1180,9 & 886,5 & 763,5 & 80,7 \\
1997 & 1178,6 & 882,0 & 774,3 & 81,9 \\
2002 & 1179,0 & 883,0 & 776,1 & 82,1 \\
2010 & 1183,3 & 891,8 & 797,1 & 83,4 \\
2013 & 1183,4 & 891,2 & 795,3 & 83,0 \\
2014 & 1184,1 & 891,6 & 795,2 & 82,8 \\
2015 & 1184,1 & 890,9 & 795,0 & 82,8 \\
2016 & 1184,3 & 891,4 & 795,1 & 82,7 \\
\hline
\end{tabular}

1) По данным Рослесхоза. С 2010 г. - ежегодно по данным Государственного лесного реестра; до 2002 г. государственный учет лесного фонда проводился один раз в пять лет.

17.25. ЛЕСОВОССТАНОВЛЕНИЕ ${ }^{1)}$

(тыс. гектаров)

\begin{tabular}{|c|c|c|c|c|c|c|c|c|c|}
\hline & 1992 & 2000 & 2005 & 2010 & 2013 & 2014 & 2015 & 2016 & 2017 \\
\hline $\begin{array}{l}\text { Всего } \\
\text { в том числе: } \\
\text { искусственное } \\
\text { (создание лесных }\end{array}$ & 1402 & 973 & 812 & 812 & 872 & 863 & 803 & 840 & 962 \\
\hline $\begin{array}{l}\text { культур) } \\
\text { содействие есте- } \\
\text { ственному лесо- } \\
\text { восстановлению }\end{array}$ & 447 & 710 & 187 & 633 & 187 & 187 & 182 & 179 & 177 \\
\hline
\end{tabular}

1) С 2013 г. - включая индивидуальных предпринимателей.

17.26. ЛЕСНЫЕ ПОЖАРЫ НА ЗЕМЛЯХ ЛЕСНОГО ФОНДА И ЗЕМЛЯХ ИНЫХ КАТЕГОРИЙ ${ }^{1)}$

\begin{tabular}{|c|c|c|c|c|c|c|}
\hline & 2010 & 2013 & 2014 & 2015 & 2016 & 2017 \\
\hline Число лесных & & & & & & \\
\hline $\begin{array}{l}\text { пожаров, тыс. } \\
\text { Площадь лесных }\end{array}$ & 33,4 & 10,0 & 16,9 & 12,3 & 11,0 & 10,9 \\
\hline $\begin{array}{l}\text { земель, пройденная } \\
\text { пожарами, тыс. га }\end{array}$ & 1962,3 & 1158,0 & 31907 & 2748.9 & 25083 & 32821 \\
\hline Площадь нелесных & 1902,0 & & & & & \\
\hline земель, пройденная & 430.0 & 2421 & 492.0 & 220.8 & 3657 & 1276.7 \\
\hline
\end{tabular}

1) По данным Рослесхоза по итогам за год. 
17.27. ОСНОВНЫЕ ПОКАЗАТЕЛИ РАБОТЫ ОРГАНИЗАЦИЙ ПО ВИДУ ЭКОНОМИЧЕСКОЙ ДЕЯТЕЛЬНОСТИ ЛЕСОЗАГОТОВКИ

\begin{tabular}{|c|c|c|c|c|c|c|c|}
\hline & 2005 & 2010 & 2013 & 2014 & 2015 & 2016 & 2017 \\
\hline Число организаций & & & & & & & \\
\hline$(\text { на конец года })^{1}$, тыс. & 20,8 & 15,6 & 11,4 & 10,6 & 10,2 & 8,9 & 8,0 \\
\hline Среднегодовая числен- & & & & & & & \\
\hline ность работников органи- & & & & & & & \\
\hline заций ${ }^{2)}$, тыс.человек & 248 & 157 & 119 & 107 & 103 & 98 & 64 \\
\hline $\begin{array}{l}\text { Сальдированный финан- } \\
\text { совый результат (прибыль }\end{array}$ & & & & & & & \\
\hline минус убыток)"), млн. руб. & -2800 & -5420 & -8465 & -17652 & -6591 & 5973 & -152 \\
\hline Рентабельность продан- & & & & & & & \\
\hline ных товаров, продукции & & & & & & & \\
\hline$(\text { работ, услуг })^{3)}$, процентов & $-1,7$ & $-0,9$ & $-3,6$ & $-0,8$ & 4,2 & 3,9 & 6,1 \\
\hline
\end{tabular}

1) По данным государственной регистрации.

2) Данные за 2014 г. приведены без учета сведений по Крымскому федеральному округу.

3) 2005-2016 гг. - по данным бухгалтерской отчетности. Знак (-) означает убыток (убыточность).

17.28. ПРОИЗВОДСТВО ПРОДУКЦИИ ЛЕСОЗАГОТОВОК

\begin{tabular}{l|c|c}
\hline & 2016 & 2017 \\
\hline $\begin{array}{l}\text { Лесоматериалы необработанные, млн. } \\
\text { плотных м }\end{array}$ & 136,6 & 134,4 \\
\hline
\end{tabular}




\section{РЫБОЛОВСТВО И РЫБОВОДСТВО}

\subsection{9. ОСНОВНЫЕ ПОКАЗАТЕЛИ РАБОТЫ ОРГАНИЗАЦИЙ ПО ВИДУ ЭКОНОМИЧЕСКОЙ ДЕЯТЕЛЬНОСТИ «РЫБОЛОВСТВО И РЫБОВОДСТВО»}

\begin{tabular}{|c|c|c|c|c|c|c|c|c|}
\hline & 2003 & 2005 & 2010 & 2013 & 2014 & 2015 & 2016 & 2017 \\
\hline $\begin{array}{l}\text { Число организаций } \\
(\text { на конец года) })^{1)} \text {, тыс. } \\
\text { Среднегодовая чис- } \\
\text { ленность работников } \\
\text { организаций }{ }^{2)},\end{array}$ & 5,3 & 7,4 & 9,2 & 8,5 & 8,4 & 8,5 & 8,2 & 7,9 \\
\hline $\begin{array}{l}\text { тыс. человек } \\
\text { Сальдированный фи- } \\
\text { нансовый результат } \\
(\text { прибыль минус убы- } \\
\text { ток) }{ }^{3)}, \text { млн. руб. }\end{array}$ & -7194 & 98,2 & 69,8 & 59,3 & 55,3 & 56,8 & 56,1 & 61,8 \\
\hline $\begin{array}{l}\text { Рентабельность про- } \\
\text { данных товаров, про- } \\
\text { дукции (работ, услуг) })^{3)} \text {, } \\
\text { процентов }\end{array}$ & $-3,3$ & 5,2 & 19,6 & 16,5 & 28,6 & 54,3 & 54,5 & 49,9 \\
\hline
\end{tabular}

1) По данным государственной регистрации.

2) Данные за 2014 г. приведены без учета сведений по Крымскому федеральному округу.

3) 2003-2016 гг. по данным бухгалтерской отчетности. Знак (-) означает убыток (убыточность).

\subsection{0. ДОБЫЧА (ПРОИЗВОДСТВО) ОСНОВНЫХ ВИДОВ ПРОДУКЦИИ РЫБОЛОВСТВА}

(тыс. тонн)

\begin{tabular}{l|c|c}
\hline & 2016 & 2017 \\
\hline $\begin{array}{l}\text { Рыба морская живая, не являющая- } \\
\text { ся продукцией рыбоводства }\end{array}$ & 163 & 144 \\
$\begin{array}{l}\text { Рыба морская свежая или охлаж- } \\
\text { денная, не являющаяся продукцией } \\
\text { рыбоводства }\end{array}$ & 664 & 597 \\
$\begin{array}{l}\text { Ракообразные немороженые, не } \\
\text { являющиеся продукцией рыбовод- }\end{array}$ & & \\
$\begin{array}{l}\text { ства } \\
\text { Растения водные, животные мор- }\end{array}$ & 69,3 & 75,6 \\
ские и их продукты прочие & 3,8 & 3,6 \\
\hline
\end{tabular}

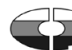




\subsection{1. РОЗНИЧНАЯ ПРОДАЖА РЫБЫ, РАКООБРАЗНЫХ} И МОЛЛЮСКОВ И ПРОДУКТОВ ИЗ НИХ

\begin{tabular}{l|c}
\hline & $2017^{1)}$ \\
\hline $\begin{array}{l}\text { Розничная продажа рыбы, ракообразных и } \\
\text { моллюсков }\end{array}$ \\
$\quad$ млн. руб. \\
$\quad$ в процентах к предыдущему году, \\
$\quad$ в сопоставимых ценах) \\
Розничная продажа консервов из рыбы и \\
морепродуктов \\
$\quad$ млн. руб. \\
$\quad$ в процентах к предыдущему году, \\
$\quad$ (в сопоставимых ценах) \\
Удельный вес рыбы, ракообразных и \\
моллюсков в обороте розничной торговли \\
пищевыми продуктами, включая напитки, и \\
табачные изделия (в фрактически \\
действовавших ценах), процентов \\
\hline 1
\end{tabular}

1) Оперативные данные.

\subsection{2. ЭКСПОРТ И ИМПОРТ РОССИЙСКОЙ ФЕДЕРАЦИИ РЫБЫ, РЫБОПРОДУКТОВ И МОРЕПРОДУКТОВ ${ }^{1)}$}

\begin{tabular}{|c|c|c|c|c|c|c|c|c|c|c|c|c|}
\hline & \multicolumn{2}{|c|}{$2010^{2)}$} & \multicolumn{2}{|c|}{2013} & \multicolumn{2}{|c|}{2014} & \multicolumn{2}{|c|}{2015} & \multicolumn{2}{|c|}{2016} & \multicolumn{2}{|c|}{2017} \\
\hline & $\begin{array}{l}\text { Экс- } \\
\text { порт }\end{array}$ & $\begin{array}{l}\text { Им- } \\
\text { порт }\end{array}$ & $\begin{array}{l}\text { Экс- } \\
\text { порт }\end{array}$ & $\begin{array}{l}\text { Им- } \\
\text { порт }\end{array}$ & $\mid \begin{array}{l}\text { Экс- } \\
\text { порт }\end{array}$ & $\begin{array}{l}\text { Им- } \\
\text { порт }\end{array}$ & $\mid \begin{array}{l}\text { Экс- } \\
\text { порт }\end{array}$ & $\begin{array}{l}\text { Им- } \\
\text { порт }\end{array}$ & $\mid \begin{array}{l}\text { Экс- } \\
\text { порт }\end{array}$ & \begin{tabular}{l|l} 
Им- \\
Порт
\end{tabular} & $\begin{array}{l}\text { Экс- } \\
\text { порт }\end{array}$ & $\begin{array}{l}\text { Им- } \\
\text { порт }\end{array}$ \\
\hline $\begin{array}{l}\text { Рыба и ракооб- } \\
\text { разные, моллюски } \\
\text { и прочие водные } \\
\text { беспозвоночные, } \\
\text { млн. долл. США }\end{array}$ & 2708 & 2033 & 3356 & 2862 & 3619 & 2565 & 3501 & 1356 & 3711 & 1398 & 34348 & 1626 \\
\hline $\begin{array}{c}\text { из них: } \\
\text { рыба свежая } \\
\text { или охлажден- } \\
\text { ная, за исклю- } \\
\text { чением рыбно- } \\
\text { го филе, тыс. т }\end{array}$ & 1,3 & 104 & 1,0 & 142 & 10,5 & 86,3 & 2,7 & 29,7 & 2,9 & 25,8 & 2,7 & 32,1 \\
\hline $\begin{array}{l}\text { рыба мороже- } \\
\text { ная, за исклю- } \\
\text { чением рыбно- } \\
\text { го фриле, тыс. т }\end{array}$ & 1501 & 550 & 1701 & 513 & 1487 & 438 & 1596 & 301 & 1678 & 271 & 1876 & 328 \\
\hline
\end{tabular}


Продолжение Табл. 17.32

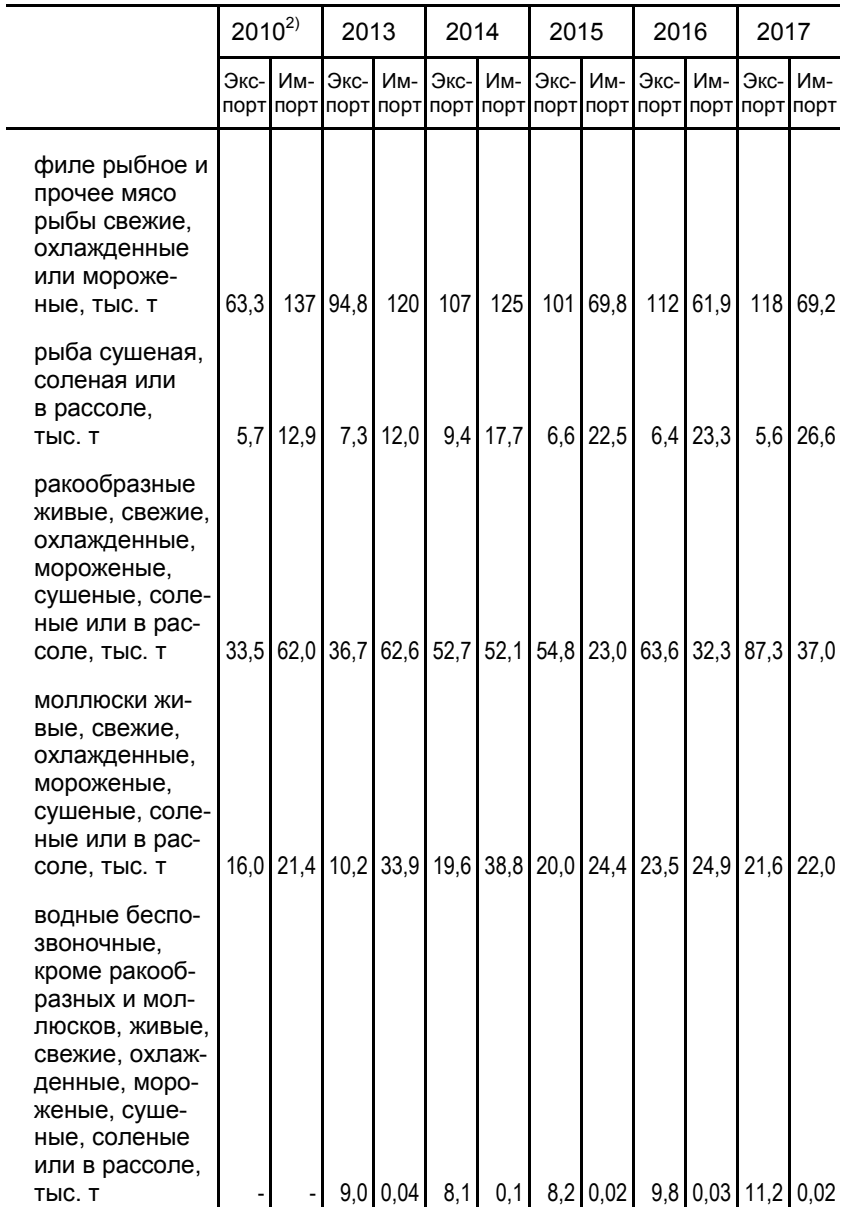


Продолжение Табл. 17.32

\begin{tabular}{|c|c|c|c|c|c|c|c|c|c|c|c|c|}
\hline & \multicolumn{2}{|c|}{$2010^{2)}$} & \multicolumn{2}{|c|}{2013} & \multicolumn{2}{|c|}{2014} & \multicolumn{2}{|c|}{2015} & \multicolumn{2}{|c|}{2016} & \multicolumn{2}{|c|}{2017} \\
\hline & $\mid \begin{array}{l}\text { Экс- } \\
\text { порт }\end{array}$ & $\begin{array}{l}\text { Им- } \\
\text { порт }\end{array}$ & $\begin{array}{l}\text { Экс- } \\
\text { порт }\end{array}$ & $\begin{array}{l}\text { Им- } \\
\text { порт }\end{array}$ & $\begin{array}{l}\text { Экс- } \\
\text { порт }\end{array}$ & $\begin{array}{l}\text { Им- } \\
\text { порт }\end{array}$ & $\begin{array}{l}\text { Экс- } \\
\text { порт }\end{array}$ & $\begin{array}{l}\text { Им- } \\
\text { порт }\end{array}$ & $\mid \begin{array}{l}\text { Экс- } \\
\text { порт }\end{array}$ & $\begin{array}{l}\text { Им- } \\
\text { порт }\end{array}$ & \begin{tabular}{|l} 
Экс- \\
порт
\end{tabular} & $\begin{array}{l}\text { Им- } \\
\text { порт }\end{array}$ \\
\hline $\begin{array}{l}\text { Готовая или кон- } \\
\text { сервированная } \\
\text { рыба; икра осет- } \\
\text { ровых и ее заме- } \\
\text { нители, тыс. т }\end{array}$ & 25,7 & 94,2 & 23,6 & 114 & 20,6 & 119 & 13,6 & 79,4 & 15,7 & 61,2 & 18,3 & 64,7 \\
\hline $\begin{array}{l}\text { Готовые или } \\
\text { консервирован- } \\
\text { ные ракообраз- } \\
\text { ные, моллюски и } \\
\text { прочие водные } \\
\text { беспозвоночные, } \\
\text { тыс. т }\end{array}$ & 1,1 & 11,2 & 1,2 & 16,4 & 0,9 & 15,1 & 0,6 & 10,5 & 0,7 & 13,9 & 0,7 & 19,3 \\
\hline
\end{tabular}

1) По данным ФТС России с учетом взаимной торговли товарами с государствамичленами ЕАЭС; экспорта рыбы, рыбопродуктов, морепродуктов, выловленных (добытых) и проданных вне зоны действия таможенного контроля.

2) Данные приведены без учета взаимной торговли Российской Федерации с Республикой Казахстан за июль-декабрь 2010 г. в связи с отменой таможенного оформления товаров на российско-казахстанской границе с 1 июля 2010 г.

\subsection{3. ВЫПУСК МОЛОДИ ВОДНЫХ БИОЛОГИЧЕСКИХ РЕСУРСОВ В ВОДНЫЕ ОБЪЕКТЫ РЫБОХОЗЯЙСТВЕННОГО ЗНАЧЕНИЯ ${ }^{1)}$}

(млн. штук)

\begin{tabular}{l|r|r|r|r|r|r|r|r}
\hline & 2000 & 2005 & 2010 & 2013 & 2014 & 2015 & 2016 & 2017 \\
\hline $\begin{array}{l}\text { Выпуск молоди } \\
\text { водных биоло- } \\
\text { гических ре- } \\
\text { сурсов }\end{array}$ & & & & & & & & \\
$\quad$ из них: & 6646,1 & 6938,6 & 10056,8 & 9275,6 & 8864,7 & 8974,8 & 8980,6 & 9076,8 \\
осетровых & 82,7 & 59,6 & 51,3 & 55,3 & 59,8 & 58,5 & 61,2 & 59,3 \\
лососевых & 684,7 & 682,5 & 1110,0 & 1016,4 & 1073,0 & 993,4 & 1033,2 & 1039,8 \\
сиговых & 46,1 & 45,4 & 109,2 & 26,8 & 48,7 & 95,7 & 147,9 & 462 \\
растительно- & & & & & & & & \\
ядных & 50,8 & 83,3 & 24,0 & 26,4 & 25,5 & 27,4 & 11,3 & 15,2 \\
частиковых & 5781,9 & 6065,9 & 8757,1 & 8149,3 & 7653,9 & 7798,6 & 7724,2 & 7499,7 \\
\hline
\end{tabular}

1) По данным Росрыболовства. 


\section{8. СТРОИТЕЛЬСТВО}

В разделе представлены данные о деятельности строительных организаций, вводе в действие зданий, производственных мощностей, жилищном и социально-культурном строительстве.

К строительным организациям относятся все общестроительные и специализированные организации, включая ремонтно-строительные организации, тресты (управления) механизации и домостроительные комбинаты, буровые организации, осуществляющие строительство разведочных скважин на нефть и газ, и другие организации, зарегистрированные кодами ОКВЭД2, входящими в раздел $\mathrm{F}$ «Строительство».

Объем работ, выполненных по виду экономической деятельности «Строительство» - это строительные работы, выполненные организациями собственными силами на основании договоров и (или) контрактов, заключаемых с заказчиками, а также (начиная с 2015 года) работы, выполненные хозяйственным способом организациями и населением. В стоимость этих работ включаются работы по строительству новых объектов, по капитальному и текущему ремонту, реконструкции жилых и нежилых зданий и инженерных сооружений.

Стоимостные показатели по строительству приведены в фактически действовавших ценах, индексы физического объема работ, выполненных по виду экономической деятельности «Строительство», рассчитаны в сопоставимых ценах. В качестве сопоставимых цен приняты среднегодовые цены предыдущего года.

К зданиям относится строительная система, состоящая из несущих и ограждающих или совмещенных (несущих и ограждающих) конструкций, которые образуют надземный замкнутый объем, предназначенный для проживания или пребывания людей в зависимости от функционального назначения и для выполнения различного вида производственных процессов.

Общий строительный объем зданий определяется как сумма строительного объема выше отметки плюс минус 0,00 (надземная часть) и ниже этой отметки (подземная часть). Строительный объем надземной и подземной частей здания определяется в пределах ограничивающих поверхностей, проветриваемых подполий под зданиями, проектируемыми для строительства на вечномерзлых грунтах.

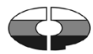


Общая площадь здания определяется как сумма площадей всех этажей здания (включая технические, мансардные, цокольные и подвальные), измеренных в пределах внутренних поверхностей наружных стен, а также площадей балконов и лоджий. Площади помещений определяются по их размерам, измеряемым между отделанными поверхностями стен и перегородок в уровне пола.

Общий строительный объем и площадь жилых зданий определяется в соответствии со СНиП 31-01-2003.

Ввод в действие мощностей - показатель мощности (производительности, вместимости, пропускной способности, площади, протяженности и т.д.), созданной в результате осуществления инвестиций в основной капитал.

Данные о вводе в действие объектов и мощностей производственного и социально-культурного назначения включают ввод за счет строительства и реконструкции.

Прирост производственных мощностей за счет технического перевооружения и проведения других организационнотехнических мероприятий в эти данные не включен.

В данные об общем числе построенных квартир включены квартиры в законченных строительством жилых домах квартирного, гостиничного типа и общежитиях, квартиры в нежилых зданиях, а также в построенных населением индивидуальных жилых домах.

Общая площадь жилых помещений во введенных в эксплуатацию жилых и нежилых зданиях, жилых домах определяется как сумма площадей всех частей жилых помещений, включая площадь помещений вспомогательного использования, предназначенных для удовлетворения гражданами бытовых и иных нужд, связанных с их проживанием в жилом помещении, площадей лоджий, балконов, веранд, террас, подсчитываемых с соответствующими понижающими коэфффициентами, а также жилых и подсобных помещений в построенных населением индивидуальных жилых домах. К помещениям вспомогательного использования относятся кухни, передние, холлы, внутриквартирные коридоры, ванные или душевые, туалеты, кладовые или хозяйственные встроенные шкафы. В домах-интернатах для престарелых и инвалидов, ветеранов, специальных домах для одиноких престарелых, детских домах к подсобным помещениям относятся столовые, буфеты, клубы, читальни, спортивные залы, приемные пункты бытового обслуживания и медицинского обслуживания.

В общую площадь жилых помещений не входит площадь вестибюлей, тамбуров, лестничных клеток, лифтовых холлов, общих коридоров, а также площадь в жилых домах, предназначенная для встроено-пристроенных помещений. 


\section{СТРОИТЕЛЬНАЯ ДЕЯТЕЛЬНОСТЬ}

18.1. ОБЪЕМ РАБОТ, ВЫПОЛНЕННЫХ ПО ВИДУ ЭКОНОМИЧЕСКОЙ ДЕЯТЕЛЬНОСТИ «СТРОИТЕЛЬСТВО»

\begin{tabular}{|c|c|c|c|}
\hline \multirow[t]{2}{*}{ Годы } & \multirow{2}{*}{$\begin{array}{c}\text { Млрд. руб. (1992 г.- } \\
\text { трлн. руб.; в фактически } \\
\text { действовавших ценах) }\end{array}$} & \multicolumn{2}{|c|}{$\begin{array}{c}\text { В процентах } \\
\text { (в сопоставимых ценах) }\end{array}$} \\
\hline & & к предыдущему году & к 1990 \\
\hline 1992 & 1,5 & 64,0 & 63,0 \\
\hline 2000 & 503,8 & 113,5 & 36,1 \\
\hline 2005 & 1754,4 & 113,2 & 57,7 \\
\hline 2010 & 4454,1 & 105,0 & 82,8 \\
\hline 2013 & 6019,5 & 100,1 & 89,3 \\
\hline 2014 & 6125,2 & $97,7^{1)}$ & 87,3 \\
\hline 2015 & 7010,4 & 96,1 & 83,9 \\
\hline 2016 & 7204,2 & 97,8 & 82,1 \\
\hline 2017 & 7545,9 & 98,6 & 80,9 \\
\hline
\end{tabular}

1) В целях обеспечения статистической сопоставимости относительные показатели рассчитаны без учета данных по Республике Крым и г. Севастополю.

18.2. ОБЪЕМ РАБОТ, ВЫПОЛНЕННЫХ ПО ВИДУ ЭКОНОМИЧЕСКОЙ ДЕЯТЕЛЬНОСТИ «СТРОИТЕЛЬСТВО» ОРГАНИЗАЦИЯМИ

РАЗЛИЧНЫХ ФОРМ СОБСТВЕННОСТИ

(в фактически действовавших ценах; млрд. рублей)

\begin{tabular}{l|r|r|r|r|r|r|r|r}
\hline & 2000 & 2005 & 2010 & 2013 & 2014 & 2015 & 2016 & $2017^{1)}$ \\
\hline $\begin{array}{l}\text { Объем выпол- } \\
\text { ненных работ - } \\
\text { всего }\end{array}$ & $\mathbf{5 0 3 , 8}$ & $\mathbf{1 7 5 4 , 4}$ & $\mathbf{4 4 5 4 , 1}$ & $\mathbf{6 0 1 9 , 5}$ & $\mathbf{6 1 2 5 , 2}$ & $\mathbf{7 0 1 0 , 4}$ & $\mathbf{7 2 0 4 , 2}$ & $\mathbf{2 7 0 6 , 5}$ \\
$\begin{array}{l}\text { в том числе } \\
\text { организациями } \\
\text { по формам } \\
\text { собственности: }\end{array}$ & & & & & & & & \\
государственная & 52,9 & 95,6 & 154,2 & 176,9 & 150,3 & 157,6 & 153,9 & 132,9 \\
муниципальная & 4,5 & 13,4 & 16,9 & 22,8 & 17,4 & 17,2 & 18,5 & 16,5 \\
частная & 322,0 & 1428,2 & 3973,8 & 5304,5 & 5500,4 & 6403,2 & 6519,0 & 2070,2 \\
смешанная & & & & & & & & \\
российская & 111,9 & 131,5 & 102,8 & 96,4 & 109,3 & 92,6 & 65,2 & 59,0 \\
прочие & 12,5 & 85,7 & 206,4 & 418,9 & 347,8 & 339,8 & 447,6 & 427,9 \\
\hline 1) Без субъектов малого предпринимательства.
\end{tabular}


18.3. ИНВЕСТИЦИИ В ОСНОВНОЙ КАПИТАЛ ОРГАНИЗАЦИЙ, ОСУЩЕСТВЛЯЮЩИХ ДЕЯТЕЛЬНОСТЬ В СТРОИТЕЛЬСТВЕ (в фактически действовавших ценах)

\begin{tabular}{c|c|c}
\hline Годы & Млрд. руб. & $\begin{array}{c}\text { В процентах от общего } \\
\text { объема инвестций } \\
\text { в основной капитал }\end{array}$ \\
\hline 2002 & 80,1 & 5,6 \\
2005 & 172,7 & 6,0 \\
2009 & 696,2 & 11,5 \\
2010 & 770,1 & 11,6 \\
2013 & 941,1 & 9,3 \\
2014 & 949,2 & 9,1 \\
2015 & 919,8 & 8,8 \\
2016 & 877,0 & 7,8 \\
2017 & 826,4 & 6,9 \\
\hline
\end{tabular}

1) Без субъектов малого предпринимательства и объема инвестиций, не наблюдаемых прямыми статистическими методами.

18.4. ОСНОВНЫЕ ФОНДЫ ОРГАНИЗАЦИЙ, ОСУЩЕСТВЛЯЮЩИХ ДЕЯТЕЛЬНОСТЬ В СТРОИТЕЛЬСТВЕ ${ }^{1)}$

(на конец года; по полной учетной стоимости; в процентах к итогу)

\begin{tabular}{l|c|c|c|c|c|c}
\hline & 2005 & 2010 & 2013 & 2014 & 2015 & 2016 \\
\hline Основные фонды - всего & 100 & 100 & 100 & 100 & 100 & 100 \\
в том числе: & & & & & & \\
здания и сооружения & 36,0 & 36,9 & 36,3 & 37,0 & 40,2 & 39,2 \\
машины и оборудование & 42,1 & 41,9 & 40,9 & 40,5 & 38,6 & 39,2 \\
транспортные средства & 18,4 & 18,6 & 20,2 & 19,8 & 17,9 & 17,5 \\
прочие виды основных & & & & & & \\
фондов & 3,5 & 2,6 & 2,6 & 2,7 & 3,2 & 4,1 \\
\hline 1) По коммерческим организациям (без субъектов малого предпринимательства). \\
С 2013 г. - с учетом переоценки, проведенной коммерческими организациями.
\end{tabular}




\section{5. НАЛИЧИЕ И СОСТОЯНИЕ ОСНОВНЫХ СТРОИТЕЛЬНЫХ МАШИН В СТРОИТЕЛЬНЫХ ОРГАНИЗАЦИЯХ на 1 января 2018 г. ${ }^{1)}$}

\begin{tabular}{l|c|c|c}
\hline & $\begin{array}{c}\text { Bсего, } \\
\text { тыс. шт. }\end{array}$ & \multicolumn{2}{|c}{ Из общего количества машин, } \\
\cline { 3 - 4 } & & $\begin{array}{c}\text { процентов } \\
\text { с истекшим } \\
\text { сроком службы }\end{array}$ & $\begin{array}{c}\text { машины } \\
\text { зарубежного } \\
\text { производства }\end{array}$ \\
\hline Экскаваторы одноковшовые & 10,8 & 32,4 & 74,9 \\
Скреперы & 0,2 & 74,7 & 52,5 \\
Бульдозеры на тракторах & 7,8 & 47,6 & 44,2 \\
Краны башенные & 3,0 & 40,7 & 33,5 \\
Краны на автомобильном & 6,4 & 34,3 & 29,7 \\
ходу & 1,2 & 37,1 & 65,0 \\
Краны на пневмоколесном & 1,9 & 57,0 & 40,4 \\
ходу & 3,6 & 45,8 & 33,0 \\
Краны на гусеничном ходу & & & \\
Автогрейдеры & &
\end{tabular}

1) Без субъектов малого предпринимательства.

18.6. ВВОД В ДЕЙСТВИЕ ЗДАНИЙ

\begin{tabular}{|c|c|c|c|c|c|c|}
\hline & \multicolumn{2}{|c|}{ Число зданий } & \multicolumn{2}{|c|}{$\begin{array}{l}\text { Общий строи- } \\
\text { тельный объем } \\
\text { зданий, млн. м }{ }^{3}\end{array}$} & \multicolumn{2}{|c|}{$\begin{array}{l}\text { Общая площадь } \\
\text { зданий, млн. м² }\end{array}$} \\
\hline & 2016 & 2017 & 2016 & 2017 & 2016 & 2017 \\
\hline $\begin{array}{l}\text { Введено в действие } \\
\text { зданий - всего } \\
\text { в том числе: }\end{array}$ & 278295 & 272615 & 608,5 & 599,4 & 135,8 & 137,3 \\
\hline жилого назначения & 259518 & 253806 & 400,4 & 401,3 & 103,4 & 104,6 \\
\hline $\begin{array}{l}\text { нежилого назначения } \\
\text { из них: }\end{array}$ & 18777 & 18809 & 208,1 & 198,1 & 32,4 & 32,7 \\
\hline промышленные & 2861 & 2684 & 45,5 & 46,3 & 4,6 & 4,8 \\
\hline сельскохозяйственные & 2734 & 2740 & 34,7 & 42,0 & 5,8 & 7,7 \\
\hline коммерческие & 6067 & 6275 & 65,4 & 53,3 & 10,2 & 9,0 \\
\hline административные & 1191 & 1164 & 9,6 & 7,6 & 1,9 & 1,6 \\
\hline учебные & 752 & 639 & 14,8 & 15,6 & 3,3 & 3,3 \\
\hline системы здравоохранения & 672 & 567 & 4,7 & 4,7 & 1,1 & 1,3 \\
\hline другие & 4500 & 4740 & 33,4 & 28,6 & 5,5 & 5,0 \\
\hline
\end{tabular}


18.7. ВВОД В ДЕЙСТВИЕ ОТДЕЛЬНЫХ ПРОИЗВОДСТВЕННЫХ МОЩНОСТЕЙ

\begin{tabular}{|c|c|c|c|c|c|c|c|c|}
\hline & 1992 & 2000 & 2005 & 2010 & 2014 & 2015 & 2016 & 2017 \\
\hline \multicolumn{9}{|l|}{ Мощности по добыче } \\
\hline $\begin{array}{l}\text { угля, млн. т } \\
\text { руды золотосодержа- }\end{array}$ & 7,7 & 5,1 & 6,4 & 8,6 & 5,4 & 4,6 & 4,5 & 14,2 \\
\hline щей, тыс. т & - & & 50,0 & 90,0 & 400,0 & 40,0 & 3120,2 & 10400,0 \\
\hline нефти, млн. т & - & 0,3 & 0,04 & 6,8 & 5,5 & 15,1 & 0,2 & 1,4 \\
\hline газа, млрд. м³ & - & 1,5 & 0,8 & - & 1,2 & 0,9 & 3,7 & - \\
\hline скважины, единиц: & & & & & & & & \\
\hline нефтяные, тыс. & 7,9 & 2,8 & 3,1 & 4,3 & 4,8 & 4,8 & 5,3 & 6,4 \\
\hline $\begin{array}{l}\text { газовые } \\
\text { Мощности по произ- } \\
\text { водству: }\end{array}$ & 104 & 115 & 160 & 174 & 162 & 112 & 121 & 153 \\
\hline $\begin{array}{l}\text { стали, тыс. т } \\
\text { готового проката чер- }\end{array}$ & 380,0 & 3,3 & 1112,7 & 306,0 & 1460,0 & - & 1,5 & 1,4 \\
\hline ных металлов, млн. т & - & - & 1,2 & 0,6 & 1,3 & & & - \\
\hline $\begin{array}{l}\text { стальных труб, тыс. т } \\
\text { машин непрерывного }\end{array}$ & - & - & 88,3 & 635,2 & 60,0 & 350,0 & 0,6 & 129,0 \\
\hline литья заготовок, млн. т & 0,4 & - & 3,4 & 1,7 & 1,4 & - & 0,9 & - \\
\hline $\begin{array}{l}\text { минеральных удобре- } \\
\text { ний (в пересчете на } \\
100 \% \text { питательных }\end{array}$ & & & & & & & & \\
\hline веществ), тыс. т & - & - & 268,1 & 730,0 & & 1381,5 & 2,5 & 548,0 \\
\hline кислоты серной & & & & & & & & \\
\hline в моногидрате, тыс. т & - & - & 623,0 & 705,0 & & - & - & - \\
\hline лаков и красок, тыс. т & - & 8,6 & 16,9 & 3,6 & 39,9 & 21,0 & 30,6 & 35,4 \\
\hline резинотехнических & & & & & & & & \\
\hline изделий формовых и & & & & & & & & \\
\hline неформовых, тыс.т & - & - & 0,3 & - & - & 9,8 & - & 10,0 \\
\hline $\begin{array}{l}\text { пленки полимерной, } \\
\text { тыс. т }\end{array}$ & - & - & 21,6 & 2,8 & 30,5 & 0,2 & 64,1 & - \\
\hline готовых лекарствен- & & & & & & & & \\
\hline $\begin{array}{l}\text { ных средств, млн. шт. } \\
\text { пиломатериалов, }\end{array}$ & - & 240,0 & 201,5 & & 2560,7 & 842,5 & 15,0 & 3542,6 \\
\hline тыс. $\mathbf{M}^{3}$ & 12,0 & 166,7 & 805,5 & 949,6 & 600,4 & 451,8 & 669,5 & 700,1 \\
\hline $\begin{array}{l}\text { бумаги, тыс. т } \\
\text { плит древесностру- }\end{array}$ & & & & 40,0 & & & & \\
\hline жечных, тыс. м & & 110,0 & & 210,0 & 573,0 & & - & 61,4 \\
\hline цемента, млн. т & 0,4 & & 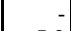 & 1,3 & 1,9 & 2,8 & 0,5 & - \\
\hline $\begin{array}{l}\text { линолеума, млн. м² } \\
\text { стеновых материалов } \\
\text { (без стеновых железо- } \\
\text { бетонных панелей), }\end{array}$ & 3,0 & 1,5 & 5,0 & & & & & - \\
\hline $\begin{array}{r}\text { млн. условных кирпичей } \\
\text { в том числе кирпича }\end{array}$ & 95,0 & 92,4 & 76,6 & 1018,7 & 711,7 & 111,5 & 130,0 & 107,2 \\
\hline строительного & 95,0 & 45,0 & 61,6 & 495,9 & 131,1 & 9,0 & 130,0 & 105,0 \\
\hline $\begin{array}{l}\text { изделий санитарных } \\
\text { керамических } \\
\text { и из полимербетона, } \\
\text { тыс. шт. }\end{array}$ & 400,0 & & & & 250,0 & & & \\
\hline
\end{tabular}


Продолжение табл. 18.7

\begin{tabular}{|c|c|c|c|c|c|c|c|c|}
\hline & 1992 & 2000 & 2005 & 2010 & 2014 & 2015 & 2016 & 2017 \\
\hline конструкций и изделий & & & & & & & & \\
\hline тонных, тыс. ${ }^{3}$ & 359,2 & 120,1 & 51,2 & 358,2 & 89,2 & 136,6 & 64,2 & 92,0 \\
\hline $\begin{array}{l}\text { плитки керамической, } \\
\text { млн. м }\end{array}$ & & 0,3 & 0,1 & 0,3 & 3,6 & 0,0 & t & 3,0 \\
\hline $\begin{array}{l}\text { нерудных материалов, } \\
\text { млн. м }{ }^{3}\end{array}$ & 3,2 & 2,6 & 2,4 & 5,9 & 1,2 & 0,4 & 1,5 & - \\
\hline $\begin{array}{l}\text { теплоизоляционных } \\
\text { материалов, тыс. м³ }\end{array}$ & & 20,0 & 718,8 & 1977,8 & 4158,0 & 415,0 & 1119,6 & - \\
\hline $\begin{array}{l}\text { трикотажных изделий, } \\
\text { млн. шт. }\end{array}$ & 11,7 & 0,3 & 1,5 & 1,4 & & & & - \\
\hline $\begin{array}{l}\text { мяса, т в смену } \\
\text { цельномолочной }\end{array}$ & 50,0 & 56,3 & 61,4 & 176,3 & 387,7 & 1015,8 & 452,1 & 82,4 \\
\hline продукции, т в смену & 364,0 & 570,0 & 270,9 & 409,0 & 415,8 & 201,2 & 323,6 & 466,3 \\
\hline сортов (без плавле- & & & & & & & & \\
\hline $\begin{array}{l}\text { ных), т в смену } \\
\text { сахара-песка, } \\
\text { тыс. ц переработки }\end{array}$ & 2,2 & 9,4 & 17,1 & 28,0 & 2,5 & 55,0 & 3,0 & 4,0 \\
\hline $\begin{array}{l}\text { свеклы в сутки } \\
\text { изделий кондитерских, }\end{array}$ & - & - & 34,1 & 5,5 & 0,5 & 16,5 & 8,0 & 6,5 \\
\hline тыс. т & 41,7 & 12,5 & 28,2 & 107,2 & 257,3 & 81,2 & 47,0 & 83,9 \\
\hline $\begin{array}{l}\text { масла растительного, } \\
\text { тыс.т переработки }\end{array}$ & & & & & & & & \\
\hline маслосемян в сутки & & & & & & & & \\
\hline $\begin{array}{l}\text { методом экстракции } \\
\text { хлебобулочных }\end{array}$ & 0,004 & 2,0 & 4,2 & 1,5 & 3,9 & 2,6 & 2,0 & 3,1 \\
\hline изделий, т в сутки & 410,2 & 167,5 & 121,8 & 200,0 & 96,0 & 144,7 & 114,6 & 40,2 \\
\hline $\begin{array}{l}\text { Построено: } \\
\text { электростанций }\end{array}$ & & & & & & & & \\
\hline $\begin{array}{l}\text { турбинных, млн. кВт } \\
\text { в том числе гидро- }\end{array}$ & 0,2 & 0,4 & 2,2 & 1,9 & 3,5 & 1,7 & 0,9 & 3,8 \\
\hline \begin{tabular}{l}
\multicolumn{1}{c}{ электростанций } \\
трансформаторных \\
понизительных под- \\
станций напряжением \\
35 кВ и выше,
\end{tabular} & - & 0,2 & 0,4 & 0,6 & 1,3 & - & 0,1 & 0,02 \\
\hline млн. кВ·A & 8,6 & 3,3 & 2,8 & 12,2 & 10,8 & 4,7 & 5,4 & 4,4 \\
\hline $\begin{array}{l}\text { котлов паровых на те- } \\
\text { плоэлектроцентралях, }\end{array}$ & & & & & & & & \\
\hline $\begin{array}{l}\text { т в час } \\
\text { фабрик углеобогати- } \\
\text { тельных, млн. т пере- }\end{array}$ & 2250,0 & 1074,8 & 620,3 & 1,0 & 168,4 & 225,9 & 420,0 & - \\
\hline $\begin{array}{l}\text { работки угля } \\
\text { помещений для содер- } \\
\text { жания крупного рога- }\end{array}$ & & 0,6 & 12,9 & 2,0 & 9,3 & 1,5 & 5,7 & - \\
\hline $\begin{array}{l}\text { того скота, тыс. мест } \\
\text { помещений для }\end{array}$ & 484,2 & 102,8 & 27,5 & 111,1 & 104,1 & 102,6 & 120,7 & 275,1 \\
\hline $\begin{array}{l}\text { содержания свиней, } \\
\text { тыс. мест }\end{array}$ & 183,2 & 30,2 & 60,7 & 603,3 & |1322,4 & 877,3 & 775,7 & 1335,2 \\
\hline
\end{tabular}


Продолжение табл. 18.7

\begin{tabular}{|c|c|c|c|c|c|c|c|c|}
\hline & 1992 & 2000 & 2005 & 2010 & 2014 & 2015 & 2016 & 2017 \\
\hline $\begin{array}{l}\text { помещений для } \\
\text { содержания овец, } \\
\text { тыс. мест }\end{array}$ & 331,4 & 9,6 & 6,2 & 6,3 & 11,9 & 9,8 & 14,2 & 19,2 \\
\hline $\begin{array}{l}\text { птицефабрик яичного } \\
\text { направления, } \\
\text { тыс. кур - несушек }\end{array}$ & 201,3 & 36,0 & 1150,0 & 702,7 & 222,4 & 248,0 & 1420,2 & 845,0 \\
\hline $\begin{array}{l}\text { птицефабрик мясного } \\
\text { направления, млн. } \\
\text { голов мясной птицы }\end{array}$ & & & & & & & & \\
\hline $\begin{array}{l}\text { в год } \\
\text { зерносеменохрани- } \\
\text { лищ, тыс. т едино- }\end{array}$ & 1,9 & 0,04 & 8,9 & 122,5 & 11,1 & 11,0 & 35,5 & 121,8 \\
\hline $\begin{array}{l}\text { хранилищ для карто- } \\
\text { феля, овощей и фрук- } \\
\text { тов, тыс. т единовре- }\end{array}$ & & & & & & & & \\
\hline менного хранения & 304,2 & 26,8 & 9,2 & 149,6 & 126,6 & 213,7 & 138,5 & 377,7 \\
\hline $\begin{array}{l}\text { силосных и сенажных } \\
\text { сооружений, тыс. м }\end{array}$ & 1504,3 & 34,0 & 38,4 & 188,2 & 243,0 & 102,5 & 229,6 & 174,8 \\
\hline $\begin{array}{l}\text { комбинатов теплич- } \\
\text { ных, га }\end{array}$ & 7,3 & 2,0 & 144,2 & - & 57,0 & 85,2 & 73,4 & 131,2 \\
\hline $\begin{array}{l}\text { складов механизиро- } \\
\text { ванных для хранения } \\
\text { минеральных удобре- } \\
\text { ний, ядохимикатов и } \\
\text { микробиологических } \\
\text { средств, тыс. т едино- } \\
\text { временного хранения }\end{array}$ & 242,6 & 2,2 & 1,2 & - & 2,0 & & 11,5 & 8,2 \\
\hline $\begin{array}{l}\text { элеваторов, тыс. т } \\
\text { единовременного }\end{array}$ & & & & & & & & \\
\hline $\begin{array}{l}\text { хранения } \\
\text { предприятий мель- } \\
\text { ничных сортового по- } \\
\text { мола, тыс. т перера- }\end{array}$ & 139,2 & 43,1 & 2,4 & 56,0 & 147,7 & 301,0 & 224,5 & 295,8 \\
\hline $\begin{array}{l}\text { ботки зерна в сутки } \\
\text { предприятий комби- } \\
\text { кормовых, т комби- } \\
\text { кормов в сутки }\end{array}$ & 100,0 & 62,0 & 155,0 & 786,8 & 2307,0 & 3102,0 & 2540,0 & 1355,0 \\
\hline $\begin{array}{l}\text { предприятий крупя- } \\
\text { ных, т переработки }\end{array}$ & & & & & & & & \\
\hline зерна в сутки & - & 530,4 & 412,0 & 47,2 & 238,0 & 326,0 & 45,8 & 352,5 \\
\hline $\begin{array}{l}\text { городских АТС, } \\
\text { млн. номеров }\end{array}$ & 0,7 & 1,0 & 2,3 & 1,0 & 0,2 & 0,07 & 0,0 & 0,1 \\
\hline
\end{tabular}


Продолжение табл. 18.7

\begin{tabular}{|c|c|c|c|c|c|c|c|c|}
\hline & 1992 & 2000 & 2005 & 2010 & 2014 & 2015 & 2016 & 2017 \\
\hline $\begin{array}{l}\text { объектов подвижной } \\
\text { радиотелефонной } \\
\text { связи, млн. номеров }\end{array}$ & - & 0,1 & 7,3 & 35,4 & 0,1 & 0,4 & 0,0 & - \\
\hline $\begin{array}{l}\text { радиовещательных } \\
\text { станций, кВт }\end{array}$ & 121,0 & 8,6 & 2,0 & 128,3 & 4,5 & 7,3 & 11,5 & 36,2 \\
\hline $\begin{array}{l}\text { междугородных } \\
\text { кабельных линий } \\
\text { связи, тыс. км }\end{array}$ & 3,1 & 4,4 & 12,2 & 6,9 & 0,5 & 0,1 & 0,0 & - \\
\hline $\begin{array}{l}\text { радиорелейных линий } \\
\text { связи, тыс. км }\end{array}$ & 1,9 & 1,1 & 9,9 & 13,2 & 20,9 & 10,8 & 8,6 & 5,4 \\
\hline $\begin{array}{l}\text { линий электропере- } \\
\text { дачи напряжением } 35 \\
\text { кВ и выше, тыс. км }\end{array}$ & 6,3 & 2,6 & 2,3 & 2,1 & 4,5 & 2,3 & 2,7 & 1,8 \\
\hline $\begin{array}{l}\text { автомобильных дорог } \\
\text { с твердым покрытием, } \\
\text { тыс. км }\end{array}$ & 27,0 & 7,9 & 2,6 & 3,1 & 2,3 & 2,5 & 2,4 & 2,3 \\
\hline $\begin{array}{l}\text { в том числе автомо- } \\
\text { бильных дорог об- } \\
\text { щего пользования }\end{array}$ & 6,4 & 6,6 & 2,0 & 2,2 & 2,0 & 2,3 & 2,2 & 2,1 \\
\hline $\begin{array}{l}\text { новых железнодорож- } \\
\text { ных линий, км }\end{array}$ & 45,1 & 1,7 & 127,8 & 111,1 & 13,0 & 17,8 & 62,5 & 157,1 \\
\hline $\begin{array}{l}\text { вторых путей, км } \\
\text { причалов морских } \\
\text { портов (включая пе- } \\
\text { регрузочные комплек- } \\
\text { сы морских портов): }\end{array}$ & 135,7 & 45,8 & 119,7 & 104,5 & 31,8 & 97,3 & 16,7 & 61,6 \\
\hline тыс. пог. м & 0,2 & 0,2 & 1,1 & 0,9 & 0,4 & - & 0,06 & 0,6 \\
\hline $\begin{array}{l}\text { млн. т груза в год } \\
\text { механизированных } \\
\text { причалов речных } \\
\text { портов: }\end{array}$ & 0,1 & 1,2 & 0,6 & 2,8 & & & & - \\
\hline тыс. пог. м & - & - & 0,2 & 0,4 & 0,09 & 0,1 & - & - \\
\hline $\begin{array}{c}\text { млн. т груза в год } \\
\text { взлетно-посадочных } \\
\text { полос с твердым }\end{array}$ & - & - & 0,5 & 0,2 & 0,1 & 0,1 & & - \\
\hline $\begin{array}{l}\text { покрытием, тыс. м² } \\
\text { газопроводов магист- } \\
\text { ральных и отводов }\end{array}$ & 212,8 & 567,4 & 162,2 & 143,8 & 596,5 & 40,3 & 144,2 & 264,1 \\
\hline от них, тыс. км & 1,4 & 2,0 & 2,2 & 2,0 & 2,0 & 2,5 & 1,0 & 0,8 \\
\hline
\end{tabular}


Продолжение табл. 18.7

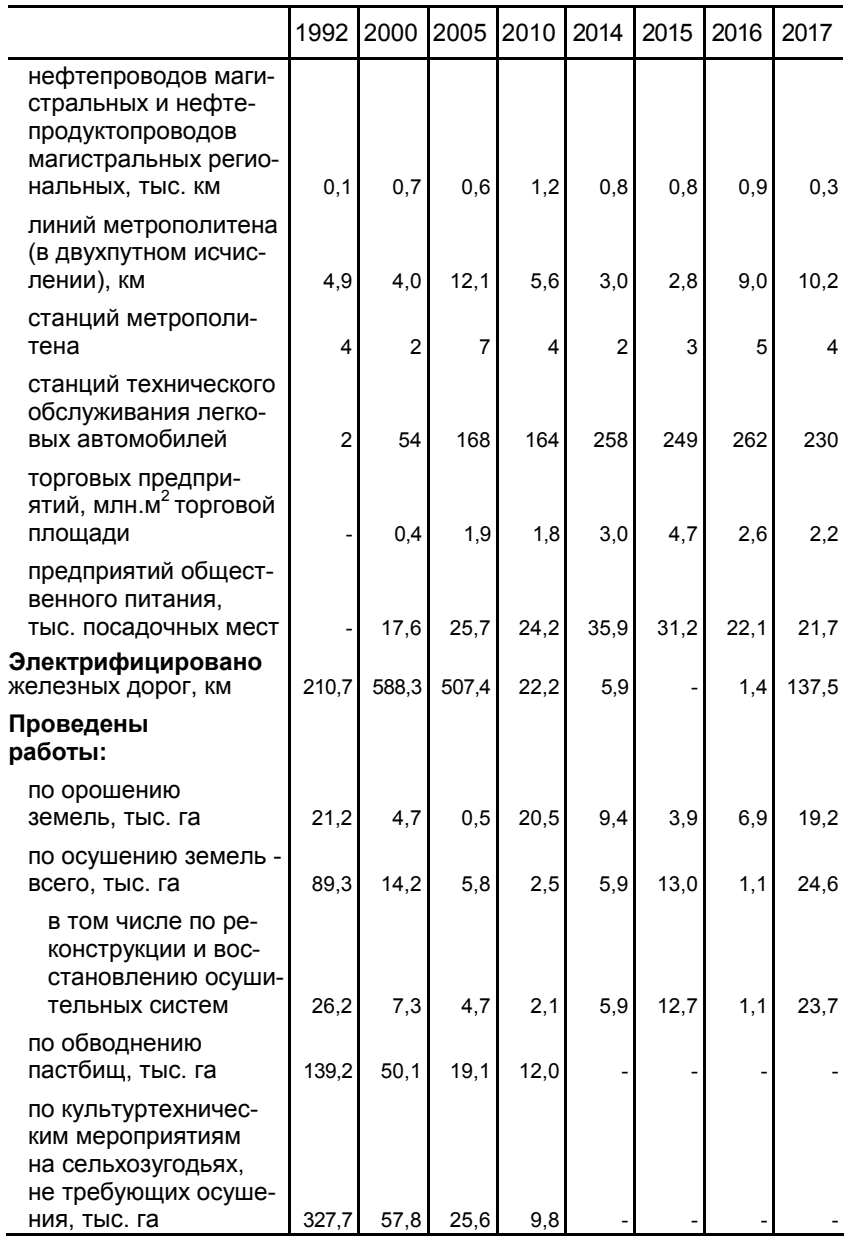




\section{ЖИЛИЩНОЕ И СОЦИАЛЬНО-КУЛЬТУРНОЕ СТРОИТЕЛЬСТВО}

18.8. ВВОД В ДЕЙСТВИЕ ЖИЛЫХ ДОМОВ

(млн. квадратных метров общей площади жилых помещений)

\begin{tabular}{c|c|c|c|c|c}
\hline & $\begin{array}{c}\text { Всего } \\
\text { построено }\end{array}$ & \multicolumn{2}{|c|}{ в том числе } & $\begin{array}{c}\text { Удельный вес в общем } \\
\text { вводе, процентов }\end{array}$ \\
\cline { 3 - 6 } & & $\begin{array}{c}\text { населением } \\
\text { за счет } \\
\text { собственных } \\
\text { и привле- } \\
\text { ченных } \\
\text { средств }\end{array}$ & $\begin{array}{c}\text { жилищо- } \\
\text { строитель- } \\
\text { ными коопе- } \\
\text { ративами }\end{array}$ & $\begin{array}{c}\text { жилых до- } \\
\text { мов насе- } \\
\text { ления }\end{array}$ & $\begin{array}{c}\text { жилых до- } \\
\text { мов жилищ- } \\
\text { но-строи- } \\
\text { тельных ко- } \\
\text { оперативов }\end{array}$ \\
\hline 1992 & 41,5 & 4,9 & 2,1 & 11,8 & 5,0 \\
2000 & 30,3 & 12,6 & 0,7 & 41,6 & 2,4 \\
2005 & 43,6 & 17,5 & 0,6 & 40,2 & 1,4 \\
2010 & 58,4 & 25,5 & 0,3 & 43,7 & 0,6 \\
2013 & 70,5 & 30,7 & 0,5 & 43,5 & 0,7 \\
2014 & 84,2 & 36,2 & 0,4 & 43,0 & 0,4 \\
2015 & 85,3 & 35,2 & 0,6 & 41,2 & 0,7 \\
2016 & 80,2 & 31,8 & 1,0 & 39,6 & 1,2 \\
2017 & 79,2 & 33,0 & 0,8 & 41,6 & 1,0 \\
\hline
\end{tabular}

18.9. ИНДЕКСЫ ВВОДА В ДЕЙСТВИЕ ЖИЛЫХ ДОМОВ $(1990=100)$

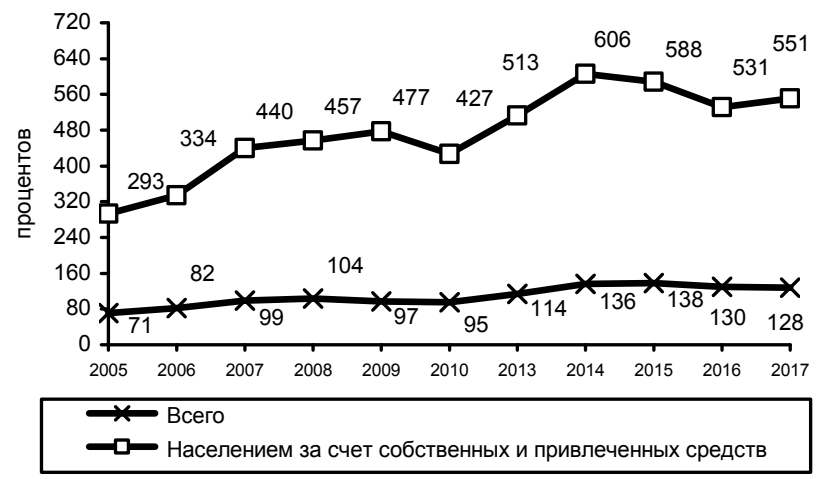


18.10. ВВОД В ДЕЙСТВИЕ ЖИЛЫХ ДОМОВ ОРГАНИЗАЦИЯМИ РАЗЛИЧНЫХ ФОРМ СОБСТВЕННОСТИ И НАСЕЛЕНИЕМ

\begin{tabular}{|c|c|c|c|c|c|c|c|c|}
\hline & 2000 & 2005 & 2010 & 2013 & 2014 & 2015 & 2016 & 2017 \\
\hline & \multicolumn{8}{|c|}{$\begin{array}{c}\text { Млн. квадратных метров общей площади } \\
\text { жилых помещений }\end{array}$} \\
\hline $\begin{array}{l}\text { Введено - всего } \\
\text { В том числе: }\end{array}$ & 30,3 & 43,6 & 58,4 & 70,5 & 84,2 & 85,3 & 80,2 & | 79,2 \\
\hline $\begin{array}{l}\text { организациями всех } \\
\text { форм собственности: } \\
\text { из них: }\end{array}$ & 17,7 & 26,1 & 32,9 & 39,8 & 48,0 & 50,1 & 48,4 & 46,2 \\
\hline $\begin{array}{c}\text { государственной } \\
\text { в том числе: }\end{array}$ & 3,5 & 3,0 & 3,5 & 3,5 & 2,9 & 2,5 & 2,2 & 2,4 \\
\hline $\begin{array}{l}\text { федеральной } \\
\text { собственности } \\
\text { субъектов Россий- } \\
\text { ской Федерации }\end{array}$ & 2,4 & 1,5 & 2,0 & 1,5 & 1,4 & 1,0 & 1,0 & 1,5 \\
\hline муниципальной & 2,8 & 2,8 & 2,0 & 1,5 & 1,7 & 1,9 & 1,7 & 1,9 \\
\hline $\begin{array}{l}\text { смешанной } \\
\text { российской }\end{array}$ & 4,2 & 4,2 & 1,0 & 0,7 & 0,6 & 0,6 & 0,5 & 0,5 \\
\hline \multirow{3}{*}{$\begin{array}{l}\text { частной } \\
\text { населением за счет } \\
\text { собственных и привле- } \\
\text { ченных средств }\end{array}$} & 6,7 & 15,5 & 24,9 & 31,4 & 39,2 & 41,6 & 40,2 & 38,7 \\
\hline & 12,6 & 17,5 & 25,5 & 30,7 & 36,2 & 35,2 & 31,8 & 33,0 \\
\hline & \multicolumn{8}{|c|}{ В процентах к итогу } \\
\hline $\begin{array}{c}\text { Введено - всего } \\
\text { в том числе: }\end{array}$ & 100 & 100 & 100 & 100 & 100 & 100 & 100 & 100 \\
\hline $\begin{array}{l}\text { организациями всех } \\
\text { форм собственности: } \\
\text { из них: }\end{array}$ & 58,4 & 59,8 & 56,3 & 56,5 & 57,0 & 58,8 & 60,4 & 58,4 \\
\hline $\begin{array}{c}\text { государственной } \\
\text { в том числе: }\end{array}$ & 11,6 & 6,9 & 6,0 & 5,0 & 3,4 & 2,9 & 2,7 & 3,0 \\
\hline федеральной & 7,8 & 3,5 & 3,4 & 2,2 & 1,7 & 1,2 & 1,2 & 1,9 \\
\hline $\begin{array}{l}\text { собственности } \\
\text { субъектов Россий- } \\
\text { ской Федерации }\end{array}$ & 3,8 & 3,4 & 2,6 & 2,8 & 1,8 & 1,7 & 1,5 & 1,1 \\
\hline муниципальной & 9,2 & 6,3 & 3,4 & 2,1 & 2,0 & 2,2 & 2,1 & 2,4 \\
\hline $\begin{array}{l}\text { смешанной } \\
\text { российской }\end{array}$ & 13,9 & 9,5 & 1,7 & 1,0 & 0,7 & 0,7 & 0,6 & 0,6 \\
\hline частной & 22,1 & 35,6 & 42,6 & 44,5 & 46,6 & 48,8 & 50,1 & 48,9 \\
\hline $\begin{array}{l}\text { населением за счет } \\
\text { собственных и привле- } \\
\text { ченных средств }\end{array}$ & 41,6 & 40,2 & 43,7 & 43,5 & 43,0 & 41,2 & 39,6 & 41,6 \\
\hline
\end{tabular}




\subsection{1. ВВОД В ДЕЙСТВИЕ ЖИЛЫХ ДОМОВ на 1000 человек населения}

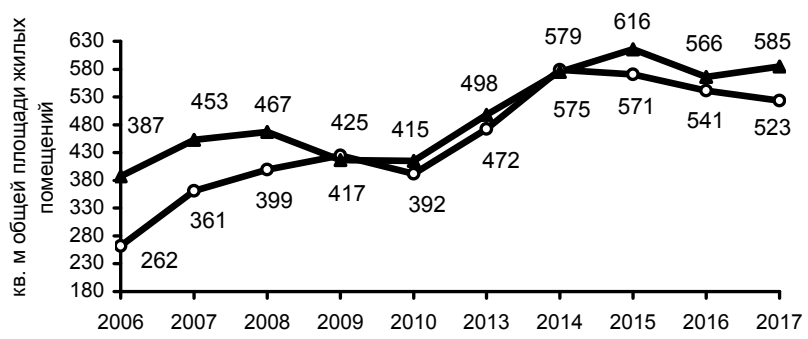

-

В сельской местности

18.12. ВВОД В ДЕЙСТВИЕ ЖИЛЫХ ДОМОВ В ГОРОДАХ И ПОСЕЛКАХ ГОРОДСКОГО ТИПА И СЕЛЬСКОЙ МЕСТНОСТИ

(млн. квадратных метров общей площади жилых помещений)

\begin{tabular}{c|c|c|c|c}
\hline Годы & \multicolumn{2}{|c|}{$\begin{array}{c}\text { В городах и поселках } \\
\text { городского типа }\end{array}$} & \multicolumn{2}{|c}{ В сельской местности } \\
\cline { 2 - 5 } & $\begin{array}{c}\text { всего } \\
\text { построено }\end{array}$ & $\begin{array}{c}\text { в том числе } \\
\text { населением } \\
\text { за счет собст- } \\
\text { венных и } \\
\text { привлеченных } \\
\text { средств }\end{array}$ & $\begin{array}{c}\text { всего } \\
\text { построено }\end{array}$ & $\begin{array}{c}\text { в том числе } \\
\text { населением } \\
\text { за счет собст- } \\
\text { венных и } \\
\text { привлеченных } \\
\text { средств }\end{array}$ \\
\hline 1992 & 31,0 & 1,9 & 10,5 & 3,0 \\
2000 & 23,1 & 6,2 & 7,2 & 6,4 \\
2005 & 34,1 & 8,8 & 9,5 & 8,7 \\
2010 & 43,7 & 12,7 & 14,7 & 12,8 \\
2013 & 53,0 & 15,8 & 17,5 & 14,9 \\
2014 & 62,2 & 18,1 & 22,0 & 18,1 \\
2015 & 62,0 & 16,3 & 23,3 & 18,9 \\
2016 & 58,8 & 14,9 & 21,4 & 16,9 \\
2017 & 57,2 & 15,5 & 22,0 & 17,5 \\
\hline
\end{tabular}


18.13. ОСНОВНЫЕ ХАРАКТЕРИСТИКИ ПОСТРОЕННЫХ КВАРТИР

\begin{tabular}{|c|c|c|c|c|c|c|c|c|c|}
\hline & 1992 & 2000 & 2005 & 2010 & 2013 & 2014 & 2015 & 2016 & 2017 \\
\hline & \multicolumn{9}{|c|}{ Всего } \\
\hline \multicolumn{10}{|l|}{ Число квартир, тыс. } \\
\hline $\begin{array}{l}\text { Их средний размер, } \\
\text { м² общей площади }\end{array}$ & 60,8 & 81.1 & 845 & 81.5 & 75.8 & 749 & 714 & 687 & 696 \\
\hline $\begin{array}{l}\text { Из них по видам } \\
\text { квартир, в процентах }\end{array}$ & & & & & & & & & \\
\hline & & & & & & & & & \\
\hline однокомнатные & 18 & 20 & 28 & 34 & 39 & $\begin{array}{l}41 \\
31\end{array}$ & 43 & 46 & $\begin{array}{l}46 \\
29\end{array}$ \\
\hline $\begin{array}{l}\text { двухкомнатные } \\
\text { трехкомнатные }\end{array}$ & 32 & 29 & 32 & 32 & 31 & $\begin{array}{l}31 \\
19\end{array}$ & $\begin{array}{l}30 \\
18\end{array}$ & $\begin{array}{l}29 \\
17\end{array}$ & 29 \\
\hline $\begin{array}{l}\text { трехкомнатные } \\
\text { четырехкомнатнь }\end{array}$ & & 34 & & & & & & & \\
\hline и более & 10 & 17 & 13 & 11 & 10 & 9 & 9 & 8 & 9 \\
\hline & Жи & лищн & 10-стр & оител & іьны & кос & & & \\
\hline Число квартир, тыс. & 37 & 11 & 9 & 5 & 8 & 7 & 11 & 18 & 13 \\
\hline Их средний размер, & & & & & & & & 554 & 612 \\
\hline м² общей площади & 56,1 & $\begin{array}{l}67,1 \\
\text { Hac }\end{array}$ & 69,3 & 69,1 & 59,0 & 56,3 & 54,9 & 55,4 & 61,3 \\
\hline & & & & влеч & & & & & \\
\hline Число квартир, тыс. & 61 & 106 & $127 \mid$ & 192 & 228 & 268 & 272 & 251 & 244 \\
\hline $\begin{array}{l}\text { Их средний размер, } \\
\text { м общей площади }\end{array}$ & 80,1 & 118,8 & 138,3 & 132,6 & 134,4 & 135,2 & 129,6 & 126,7 & 135,1 \\
\hline
\end{tabular}

18.14. ВВОД В ДЕЙСТВИЕ МОЩНОСТЕЙ И ОБЪЕКТОВ СОЦИАЛЬНО-КУЛЬТУРНОГО НАЗНАЧЕНИЯ

\begin{tabular}{|c|c|c|c|c|c|}
\hline Годы & \begin{tabular}{|c|} 
Общеобра- \\
зователь- \\
ные органи- \\
зации, тыс. \\
ученических \\
мест
\end{tabular} & \begin{tabular}{|c|} 
Дошколь- \\
ные обра- \\
зователь- \\
ные органи- \\
зации, \\
тыс. мест
\end{tabular} & $\begin{array}{c}\text { Больничные } \\
\text { организа- } \\
\text { ции, } \\
\text { тыс. коек }\end{array}$ & \begin{tabular}{|c|} 
Амбулатор- \\
но-поликли- \\
нические \\
организа- \\
ции, тыс. \\
посещений \\
в смену \\
\end{tabular} & \begin{tabular}{|c} 
Учрежде- \\
ния культу- \\
ры клубного \\
типа, \\
тыс. мест \\
\\
\end{tabular} \\
\hline & \multicolumn{5}{|c|}{ В городах и поселках городского типа } \\
\hline $\begin{array}{l}1992 \\
2000 \\
2005 \\
2010 \\
2013 \\
2014 \\
2015 \\
2016 \\
2017\end{array}$ & $\begin{array}{r}303,1 \\
133,8 \\
73,0 \\
67,8 \\
70,0 \\
55,7 \\
66,3 \\
90,3 \\
108,4\end{array}$ & $\begin{array}{r}95,7 \\
6,8 \\
5,0 \\
22,9 \\
90,3 \\
128,9 \\
143,3 \\
63,3 \\
40,8\end{array}$ & \begin{tabular}{|l}
8,2 \\
9,5 \\
7,0 \\
8,7 \\
8,6 \\
2,7 \\
4,3 \\
6,1 \\
3,9
\end{tabular} & \begin{tabular}{|l}
39,6 \\
24,8 \\
20,2 \\
26,8 \\
17,5 \\
18,8 \\
23,7 \\
18,1 \\
20,7
\end{tabular} & $\begin{array}{l}56,3 \\
12,1 \\
12,6 \\
13,4 \\
13,2 \\
17,4 \\
16,0 \\
16,5 \\
21,0\end{array}$ \\
\hline $\begin{array}{l}1992 \\
2000 \\
2005 \\
2010 \\
2013 \\
2014 \\
2015 \\
2016 \\
2017\end{array}$ & $\begin{array}{l}\text { B } \\
96,3 \\
53,5 \\
27,9 \\
20,2 \\
24,2 \\
16,8 \\
24,0 \\
19,5 \\
26,3\end{array}$ & \begin{tabular}{|r} 
ом числе \\
34,6 \\
3,0 \\
0,9 \\
3,5 \\
15,6 \\
26,3 \\
31,5 \\
13,7 \\
12,5
\end{tabular} & $\begin{array}{c}\text { сельской } \\
2,3 \\
1,5 \\
0,9 \\
0,9 \\
0,4 \\
0,9 \\
0,4 \\
0,6 \\
0,1\end{array}$ & \begin{tabular}{|c} 
местності \\
7,8 \\
3,3 \\
2,6 \\
2,6 \\
5,1 \\
8,4 \\
9,6 \\
8,2 \\
7,1
\end{tabular} & $\begin{array}{r}45,4 \\
9,6 \\
5,7 \\
9,0 \\
10,2 \\
12,5 \\
10,5 \\
8,5 \\
16,3\end{array}$ \\
\hline
\end{tabular}


18.15. ВВОД В ДЕЙСТВИЕ МОЩНОСТЕЙ ОБРАЗОВАТЕЛЬНЫХ ОРГАНИЗАЦИЙ ВЫСШЕГО ОБРАЗОВАНИЯ, ПРОФЕССИОНАЛЬНЫХ ОБРАЗОВАТЕЛЬНЫХ ОРГАНИЗАЦИЙ

\begin{tabular}{|c|c|c|c|c|c|c|c|c|c|}
\hline & 1992 & 2000 & 2005 & 2010 & 2013 & 2014 & 2015 & 2016 & 2017 \\
\hline $\begin{array}{l}\text { Образовательные ор- } \\
\text { ганизации высшего } \\
\text { образования, } \\
\text { тыс. м² общей пло- } \\
\text { щади учебно- } \\
\text { лаборатор- } \\
\text { ных зданий } \\
\text { Профессиональные } \\
\text { образовательные } \\
\text { организации, } \\
\text { тыс. м² общей пло- } \\
\text { щади учебно- } \\
\text { лаборатор- } \\
\text { ных зданий1) } \\
\text { Профессиональные } \\
\text { образовательные } \\
\text { организации среднего } \\
\text { профессионального } \\
\text { образования, тыс. м² } \\
\text { общей площади учеб- } \\
\text { но-лабораторных } \\
\text { зданий } \\
\text { Образовательные } \\
\text { организации началь- } \\
\text { ного профессиональ- } \\
\text { ного образования, } \\
\text { тыс. ученических мест }\end{array}$ & 139,3 & 105,6 & 161,3 & 219,7 & 210,1 & 16,1 & 222,0 & 220,2 & 32,3 \\
\hline
\end{tabular}

1) В соответствии с Федеральным законом от 29.12.2012 № 273-Ф3 «Об образовании в Российской Федерации», начиная с 2016 г., в составе показателя «Профессиональные образовательные организации» учитываются данные о вводе в действие образовательных организаций начального и среднего профессионального образования. 
18.16. ВВОД В ДЕЙСТВИЕ ДОМОВ-ИНТЕРНАТОВ ДЛЯ ПРЕСТАРЕЛЫХ, ИНВАЛИДОВ (ВЗросЛЫХ И ДеТеЙ)

\begin{tabular}{c|c||c|c}
\hline Годы & Тыс. мест & Годы & Тыс. мест \\
\hline 1992 & 2,9 & 2013 & 1,7 \\
2000 & 1,6 & 2014 & 0,9 \\
2005 & 1,4 & 2015 & 0,7 \\
2007 & 2,1 & 2016 & 0,7 \\
2010 & 2,0 & 2017 & 1,0 \\
\hline
\end{tabular}

18.17. ВВОД В ДЕЙСТВИЕ ОБЪЕКТОВ, СВЯЗАННЫХ С ОХРАНОЙ МАТЕРИНСТВА И ДЕТСТВА

\begin{tabular}{l|c|c|c|c|c|c|c|c|c}
\hline & 1992 & 2000 & 2005 & 2010 & 2013 & 2014 & 2015 & 2016 & 2017 \\
\hline $\begin{array}{l}\text { Детские больницы, } \\
\text { коек }\end{array}$ & 796 & 1278 & 1060 & 389 & 319 & 85 & 278 & 296 & 1045 \\
Детские поликлиники, & & & & & & & & & \\
посещений в смену & 1825 & 2760 & 3877 & 3245 & 1585 & 2247 & 1284 & 1176 & 2539 \\
Родильные дома, коек & 477 & 572 & 293 & 1262 & 327 & 701 & 867 & 1670 & 1887 \\
Женские консультации, \\
посещений в смену
\end{tabular}

18.18. ВВОД В ДЕЙСТВИЕ САНАТОРИЕВ И ДОМОВ ОТДЫХА

\begin{tabular}{c|c|c}
\hline Годы & Санатории, тыс. коек & Дома отдыха, тыс. мест \\
\hline 1992 & 2,2 & 1,1 \\
2000 & 2,6 & 1,2 \\
2005 & 2,7 & 1,0 \\
2010 & 2,5 & 1,7 \\
2013 & 0,7 & 1,0 \\
2014 & 1,4 & 1,5 \\
2015 & 0,4 & 0,7 \\
2016 & 0,4 & 0,7 \\
2017 & 1,3 & 0,9 \\
\hline
\end{tabular}




\section{9. ТОРГОВЛЯ И УСЛУГИ НАСЕЛЕНИЮ}

Раздел представляет статистику розничной, оптовой торговли и потребительского рынка услуг. Публикуются статистические данные, характеризующие деятельность организаций розничной и оптовой торговли. Состояние розничной и оптовой торговли иллюстрируют данные об обороте торговли, индексах физического объема оборота розничной и оптовой торговли. Приведена также информация о товарной структуре оборота розничной торговли, продаже основных товаров, их качестве. Содержатся статистические данные о деятельности бирж, осуществляющих организованную торговлю товарами.

В разделе представлена информация об объеме платных услуг населению в целом и по отдельным видам услуг. Информация в стоимостном выражении приведена в фрактически действовавших ценах.

Данные в таблицах, содержащих показатели по видам экономической деятельности, приводятся за 2017 год в соответствии с Общероссийским классификатором видов экономической деятельности (ОКВЭД 2) ОК 029-2014, введенным в действие с 1 января 2017 г.

Аналогичные сведения за период до 2016 г. включительно, разработанные в соответствии с ранее действовавшим Общероссийским классификатором видов экономической деятельности (ОКВЭД-2007) ОК 029-2007, опубликованы в кратком статистическом сборнике «Россия в цифрах. 2017», электронная версия которого размещена на официальном Интернет-портале Росстата в разделе «Публикации».

Оборот розничной торговли - выручка от продажи товаров населению для личного потребления или использования в домашнем хозяйстве за наличный расчет или оплаченных по кредитным карточкам, расчетным чекам банков, по перечислениям со счетов вкладчиков, по поручению физического лица без открытия счета, посредством платежных карт (электронных денег).

Стоимость товаров, проданных (отпущенных) отдельным категориям населения со скидкой, или полностью оплаченных органами социальной защиты, включается в оборот розничной торговли в полном объеме. В оборот розничной торговли не включается стоимость товаров, проданных (отпущенных) из

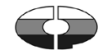


розничной торговой сети юридическим лицам (в том числе организациям социальной сферы, спецпотребителям и т.п.) и индивидуальным предпринимателям, и оборот общественного питания.

Оборот розничной торговли включает данные как по организациям, для которых эта деятельность является основной, так и по организациям других видов деятельности, осуществляющим продажу товаров населению через собственные торговые заведения. Оборот розничной торговли также включает стоимость товаров, проданных населению индивидуальными предпринимателями и фризическими лицами на розничных рынках и ярмарках.

Оборот розничной торговли формируется по данным сплошного федерального статистического наблюдения за организациями, не относящимися к субъектам малого предпринимательств, которое проводится с месячной периодичностью, ежеквартальных выборочных обследований малых предприятий розничной торговли (за исключением микропредприятий) и розничных рынков, а также, ежегодных выборочных обследований индивидуальных предпринимателей и микропредприятий с распространением полученных данных на генеральную совокупность объектов наблюдения.

Оборот розничной торговли приводится в фактических продажных ценах, включающих торговую наценку, налог на добавленную стоимость и аналогичные обязательные платежи.

Оборот оптовой торговли выручка от реализации товаров, приобретенных ранее на стороне в целях перепродажи юридическим лицам и индивидуальным предпринимателям для профессионального использования (переработки или дальнейшей продажи).

Оборот оптовой торговли включает данные как по организациям, для которых эта деятельность является основной, так и по организациям других видов деятельности, осуществляющим оптовую торговлю.

Оборот оптовой торговли формируется по данным сплошного фредерального статистического наблюдения за организациями, не относящимися к субъектам малого предпринимательства, выборочного обследования малых предприятий оптовой торговли (кроме микропредприятий), которые проводятся с месячной периодичностью, а также ежегодных выборочных обследований индивидуальных предпринимателей (начиная с 2007 года) и микропредприятий с распространением полученных данных на генеральную совокупность объектов наблюдения. 
Оборот оптовой торговли приводится в фактических продажных ценах, включающих торговую наценку, налог на добавленную стоимость, акциз, экспортную пошлину, таможенные сборы и аналогичные обязательные платежи. Сумма вознаграждения комиссионеров (поверенных, агентов) отражается по фактической стоимости, включая НДС.

Кроме того, в соответствии с требованиями системы национальных счетов оборот розничной торговли торгующих организаций и оборот оптовой торговли досчитываются на объемы деятельности, не наблюдаемой прямыми статистическими методами.

Динамику оборота розничной торговли и розничной продажи отдельных товаров характеризуют индексы физического объема, которые определяются путем сопоставления величины оборота (продажи) за отчетный и базисный периоды в сопоставимых ценах.

Объем платных услуг населению представляет собой денежный эквивалент объема услуг, оказанных резидентами российской экономики (юридическими лицами и гражданами, занимающимися предпринимательской деятельностью без образования юридического лица, зарегистрированными на территории Российской Федерации) гражданам Российской Федерации, а также гражданам других государств (нерезидентам), потребляющим те или иные услуги на территории Российской Федерации. Этот показатель формируется на основании данных форм федерального статистического наблюдения и оценки ненаблюдаемой деятельности на рынке услуг (по методологии, утвержденной приказом Росстата от 29 сентября 2017 г. № 643). Динамику объема платных услуг характеризует индекс физического объема, исчисленный путем сопоставления его величины за отчетный и базисный периоды в сопоставимых ценах. В целях обеспечения статистической сопоставимости данных индексы физического объема за 2014 г. рассчитаны без учета сведений по Республике Крым и г. Севастополю.

Платные услуги населению включают: бытовые, транспортные, почтовой связи и курьерские, телекоммуникационные, жилищные, коммунальные, услуги гостиниц и аналогичных средств размещения, услуги системы образования, культуры, туристские, услуги физической культуры и спорта, медицинские, санаторнооздоровительные, ветеринарные, услуги правового характера, услуги, предоставляемые гражданам пожилого возраста и инвалидам, и другие.

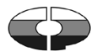


19.1. ЧИСЛО ХОЗЯЙСТВУЮЩИХ СУБЪЕКТОВ ТОРГОВЛИ ПО ВИДАМ ЭКОНОМИЧЕСКОЙ ДЕЯТЕЛЬНОСТИ

(на конец года, тыс.)

\begin{tabular}{|c|c|}
\hline & 2017 \\
\hline $\begin{array}{l}\text { Организации торговли оптовой и розничной; } \\
\text { по ремонту автотранспортных средств } \\
\text { и мотоциклов } \\
\text { в том числе: } \\
\text { торговля оптовая и розничная автотранспорт- } \\
\text { ными средствами и мотоциклами и их ремонт } \\
\text { торговля оптовая, кроме торговли автотранс- } \\
\text { портными средствами и мотоциклами } \\
\text { торговля розничная, кроме торговли автотранс- } \\
\text { портными средствами и мотоциклами } \\
\text { Индивидуальные предприниматели в розничной } \\
\text { торговле, кроме торговли автотранспортными } \\
\text { средствами и мотоциклами }\end{array}$ & $\begin{array}{r}126,6 \\
1011,3 \\
327,2\end{array}$ \\
\hline
\end{tabular}

1) По данным государственной регистрации.

19.2. ОБОРОТ И СРЕДНЕГОДОВАЯ ЧИСЛЕННОСТЬ РАБОТНИКОВ ОРГАНИЗАЦИЙ ТОРГОВЛИ

\begin{tabular}{l|c|c|c|c}
\hline & \multicolumn{2}{|c|}{$\begin{array}{c}\text { Оборот организаций, } \\
\text { млрд. руб. }\end{array}$} & \multicolumn{2}{c}{$\begin{array}{c}\text { Среднегодовая числен- } \\
\text { ность работников, } \\
\text { тыс. человек }\end{array}$} \\
\cline { 2 - 5 } & 2016 & 2017 & 2016 & 2017 \\
\hline $\begin{array}{l}\text { Торговля оптовая и роз- } \\
\text { ничная автотранспортными } \\
\text { средствами и мотоциклами } \\
\text { и их ремонт }\end{array}$ & 4576,0 & 5174,1 & 578,3 & 436,7 \\
$\begin{array}{l}\text { Торговля оптовая, кроме } \\
\text { оптовой торговли авто- } \\
\text { транспортными средствами } \\
\text { и мотоциклами }\end{array}$ & 36445,5 & 38228,0 & 2412,0 & 2474,8 \\
$\begin{array}{l}\text { Торговля розничная, кроме } \\
\text { торговли автотранспорт- } \\
\text { ными средствами и мото- } \\
\text { циклами }\end{array}$ & 13200,7 & 14428,2 & 2719,2 & 2866,4 \\
\hline
\end{tabular}




\section{РОЗНИЧНАЯ ТОРГОВЛЯ}

19.3. ОБОРОТ И ТОВАРНЫЕ ЗАПАСЫ РОЗНИЧНОЙ ТОРГОВЛИ ${ }^{1)}$

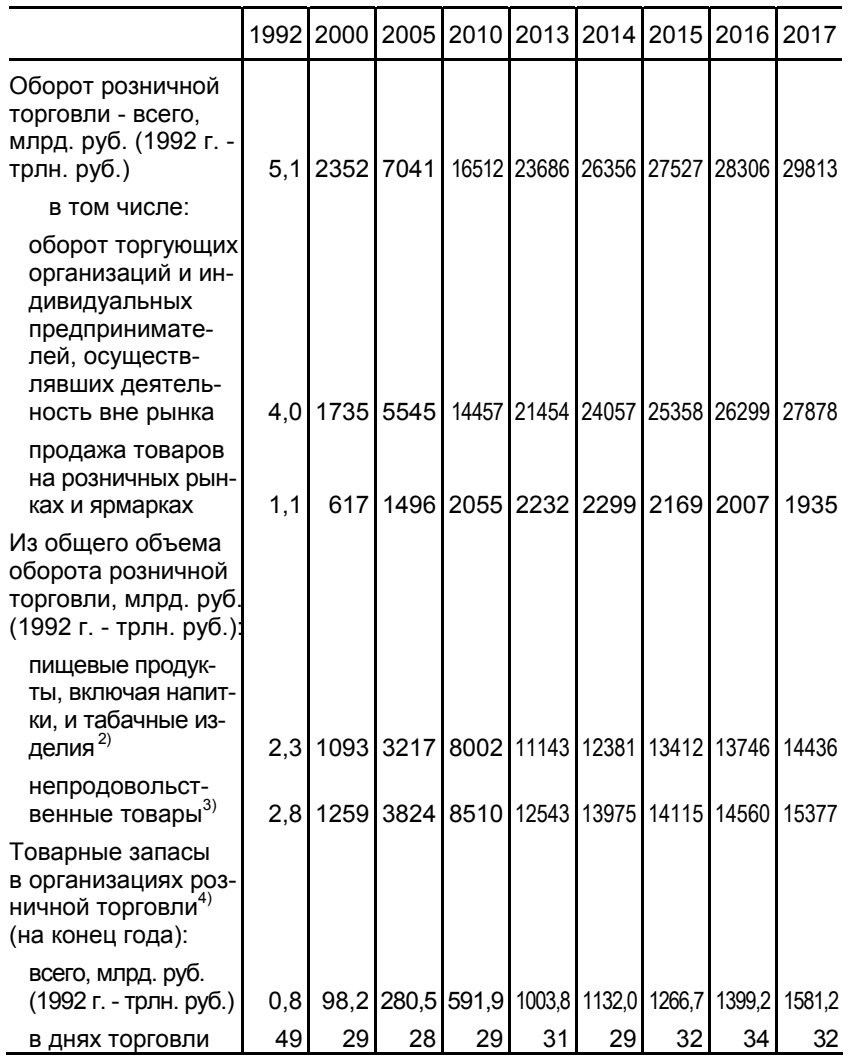

1) Стоимостные показатели приведены в фактически действовавших ценах.

2) До 2010 г. данные приведены по обороту розничной торговли продовольственными товарами.

3) До 2010 г. данные приведены по обороту розничной торговли непродовольственными товарами, включая табачные изделия.

4) За 2005 г. приведены товарные запасы по всем организациям, осуществляющим розничную торговлю.

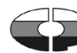




\section{4. ИНДЕКСЫ ФИЗИЧЕСКОГО ОБЪЕМА ОБОРОТА РОЗНИЧНОЙ ТОРГОВЛИ}

(в процентах к предыдущему году)

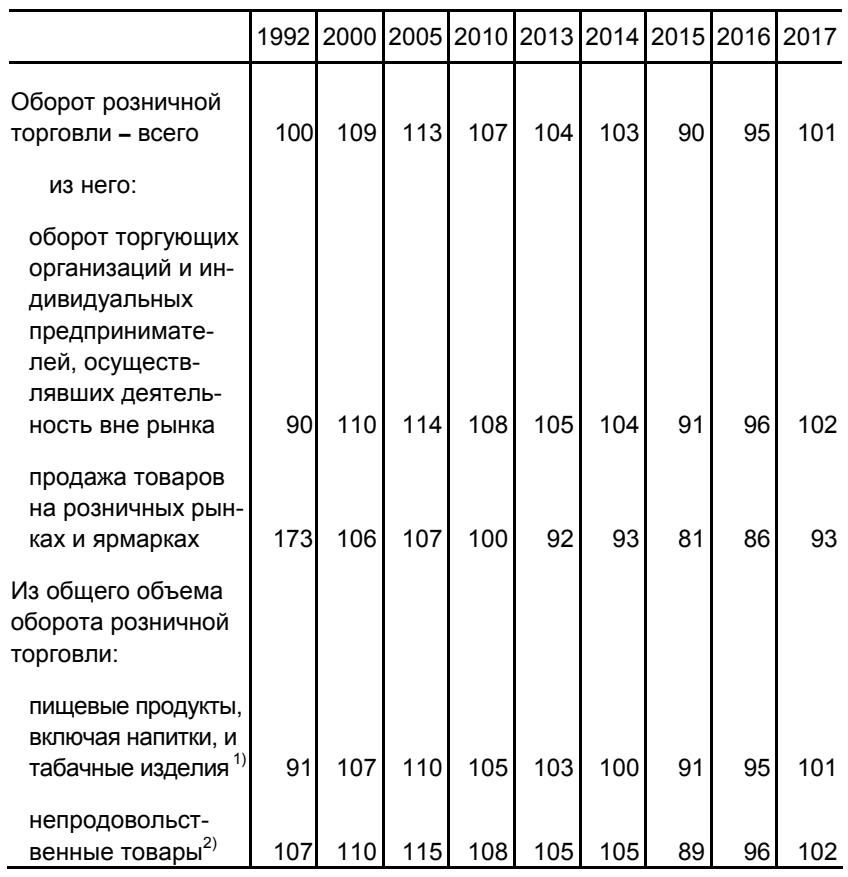

1) До 2010 г. данные приведены по обороту розничной торговли продовольственными товарами.

2) До 2010 г. данные приведены по обороту розничной торговли непродовольственными товарами, включая табачные изделия. 
19.5. РАСПРЕДЕЛЕНИЕ ОБОРОТА РОЗНИЧНОЙ ТОРГОВЛИ ПО ФОРМАМ СОБСТВЕННОСТИ

(в фактически действовавших ценах)

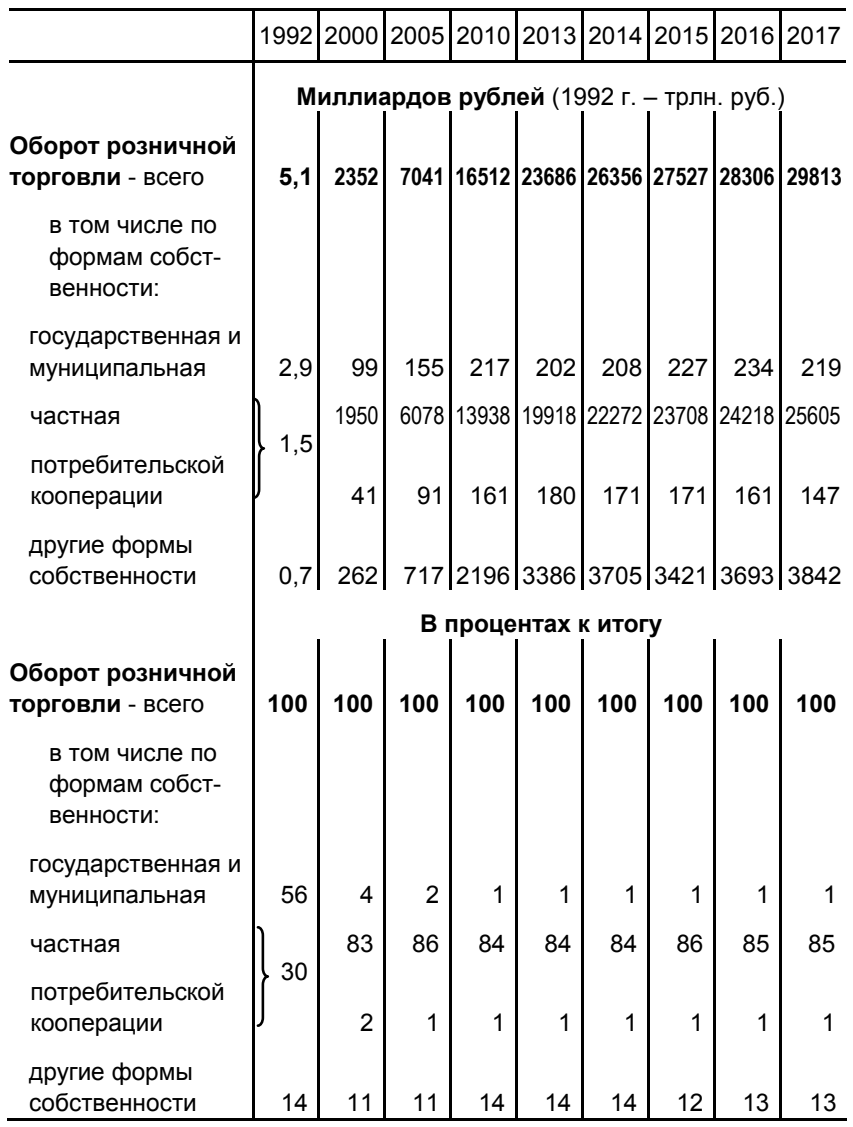


19.6. ОБОРОТ РОЗНИЧНОЙ ТОРГОВЛИ ОТДЕЛЬНЫМИ ТОВАРАМИ (в фактически действовавших ценах; в процентах)

\begin{tabular}{|c|c|c|}
\hline & 2016 & $2017^{1)}$ \\
\hline Все товары & 100 & 100 \\
\hline Мясо животных и домашней птицы & 3,6 & 3,5 \\
\hline Продукты из мяса & 4,0 & 4,0 \\
\hline Консервы из мяса & 0,4 & 0,4 \\
\hline Рыба, ракообразные и моллюски & 2,1 & 2,1 \\
\hline Животные масла & 0,8 & 0,8 \\
\hline Растительные масла & 0,7 & 0,6 \\
\hline Маргариновая продукция & 0,2 & 0,2 \\
\hline $\begin{array}{c}\text { Молочные продукты: } \\
\text { из них }\end{array}$ & 4,4 & 4,5 \\
\hline молоко питьевое & 1,1 & 1,1 \\
\hline сыры жирные & 1,2 & 1,2 \\
\hline Яйцо птицы & 0,7 & 0,6 \\
\hline Caxap & 0,9 & 0,8 \\
\hline Кондитерские изделия & 3,5 & 3,5 \\
\hline Мука & 0,4 & 0,4 \\
\hline Крупа & 0,7 & 0,6 \\
\hline Макаронные изделия & 0,5 & 0,5 \\
\hline Хлеб и хлебобулочные изделия & 2,4 & 2,4 \\
\hline Свежий картофель & 0,4 & 0,5 \\
\hline Свежие овощи & 1,5 & 1,6 \\
\hline Свежие фрукты & 2,0 & 1,9 \\
\hline Чай & 0,6 & 0,6 \\
\hline Алкогольные напитки & 6,8 & 6,7 \\
\hline Табачные изделия & 2,5 & 2,6 \\
\hline Ткани & 0,2 & 0,2 \\
\hline Мужская, женская и детская одежда & 5,6 & 5,4 \\
\hline Изделия из меха & 0,4 & 0,3 \\
\hline Чулочно-носочные изделия & 0,3 & 0,3 \\
\hline
\end{tabular}


Продолжение табл.19.6

\begin{tabular}{|c|c|c|}
\hline & 2016 & $2017^{1)}$ \\
\hline Обувь ${ }^{2)}$ & 2,1 & 2,1 \\
\hline Туалетное и хозяйственное мыло & 0,2 & 0,2 \\
\hline $\begin{array}{l}\text { Косметические и парфюмерные товары, } \\
\text { кроме мыла }\end{array}$ & 2,0 & 2,0 \\
\hline Часы & 0,1 & 0,1 \\
\hline Компьютеры & 0,6 & 0,6 \\
\hline Мобильные телефоны & 0,9 & 1,0 \\
\hline Аудиоаппаратура & 0,1 & 0,1 \\
\hline Телевизоры & 0,6 & 0,6 \\
\hline Игры и игрушки & 0,4 & 0,5 \\
\hline Холодильники и морозильники & 0,4 & 0,4 \\
\hline Стиральные машины & 0,3 & 0,2 \\
\hline Велосипеды ${ }^{3)}$ & 0,1 & 0,1 \\
\hline Мотоциклы & 0,04 & 0,03 \\
\hline Автомобили легковые & 5,0 & 5,5 \\
\hline Бензины автомобильные & 6,5 & 6,3 \\
\hline Мебель & 1,5 & 1,4 \\
\hline Строительные материалы & 1,9 & 2,0 \\
\hline Ювелирные изделия ${ }^{4)}$ & 0,8 & 0,8 \\
\hline Лекарственные средства ${ }^{5)}$ & & 3,4 \\
\hline $\begin{array}{l}\text { Изделия, применения в медицинских целях }{ }^{5} \text {, } \\
\text { ортопедические изделия }\end{array}$ & 4,0 & 0,8 \\
\hline Книги & 0,3 & 0,4 \\
\hline Газеты и журналы & 0,2 & 0,2 \\
\hline
\end{tabular}

1) Оперативные данные.

В 2016 г. данные приведены по товарной позиции:

2) обувь кожаная;

3) велосипеды и мотовелосипеды;

4) ювелирные изделия из драгоценных металлов;

5) фармацевтические медицинские и ортопедические товары. 
19.7. ЧИСЛО РОЗНИЧНЫХ РЫНКОВ И ТОРГОВЫХ МЕСТ НА НИХ (на 1 января)

\begin{tabular}{c|c|c|c}
\hline Годы & Число розничных & \multicolumn{2}{|c}{ Число торговых мест на них } \\
\cline { 3 - 4 } & рынков & всего, тыс. & в среднем на один рынок, мест \\
\hline 2007 & 5892 & 1203 & 204 \\
2010 & 3497 & 971 & 277 \\
2013 & 2162 & 625 & 289 \\
2014 & 1589 & 424 & 267 \\
2015 & 1447 & 394 & 272 \\
2016 & 1308 & 352 & 269 \\
2017 & 1158 & 311 & 269 \\
2018 & 1091 & 282 & 258 \\
\hline
\end{tabular}

19.8. ЧИСЛО ПРОВЕДЕННЫХ РОЗНИЧНЫХ ЯРМАРОК И ТОРГОВЫХ MECT HA HИX

\begin{tabular}{c|c|c|c}
\hline Годы & Число проведенных & \multicolumn{2}{|c}{ Число торговых мест на них } \\
\cline { 3 - 4 } & розничных ярмарок & всего, тыс. & в среднем на одну ярмарку, мест \\
\hline 2013 & 26843 & 1959 & 73 \\
2014 & 28162 & 1792 & 64 \\
2015 & 32225 & 1852 & 58 \\
2016 & 34951 & 1864 & 53 \\
2017 & 36695 & 1873 & 51 \\
\hline
\end{tabular}

\section{9. УДЕЛЬНЫЙ ВЕС ПРОДАЖИ ТОВАРОВ НА РЫНКАХ И ЯРМАРКАХ В ОБОРОТЕ РОЗНИЧНОЙ ТОРГОВЛИ}

(в фактически действовавших ценах)

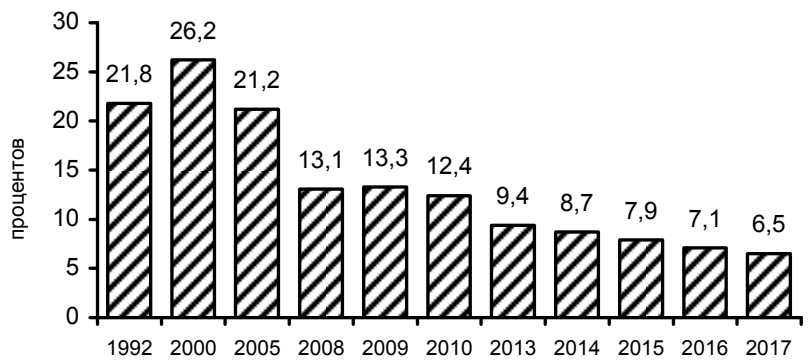


19.10. ИНДЕКСЫ ФИЗИЧЕСКОГО ОБЪЕМА РОЗНИЧНОЙ ПРОДАЖИ ОТДЕЛЬНЫХ ТОВАРОВ

(в процентах к предыдущему году)

Мясо животных и домашней птицы

Продукты из мяса

Консервы из мяса

Рыба, ракообразные и моллюски

Животные масла

Растительные масла

Маргариновая продукция

Молочные продукты

из них:

молоко питьевое

сыры жирные

Яйцо птицы

Caxap

Кондитерские изделия

Мука

Крупа

Макаронные изделия

Хлеб и хлебобулочные изделия

Свежий картофель

Свежие овощи

Свежие фрукты

Чай

Алкогольные напитки

Табачные изделия

Ткани

Мужская, женская и детская одежда

Изделия из меха

300
$2017^{1)}$

102,2

101,1

102,9

98,8

98,4

97,5

101,3

93,1

92,4

95,8

103,3

94,7

102,1

91,9

98,2

100,3

98,8

101,3

99,2

98,9

101,3

105,1

100,4

110,4

96,3

102,9

98,1

103,2

97,5

107,7

97,3

103,4

98,2

100,7

112,3

100,7

103,2

112,6

99,2

104,7

93,2

100,6

94,6

98,3

92,5

98,2

91,8

93,2

91,2

98,1

94,3

97,3 
Продолжение табл. 19.10

\begin{tabular}{l|r|r}
\hline & 2016 & $2017^{1)}$ \\
\hline Чулочно-носочные изделия & 95,3 & 104,0 \\
Обувь ${ }^{2)}$ & 90,0 & 100,2 \\
Туалетное и хозяйственное мыло & 94,3 & 102,1 \\
Косметические и парфюмерные товары, & & \\
кроме мыла & 97,0 & 105,0 \\
Часы & 91,8 & 92,0 \\
Компьютеры & 104,7 & 112,0 \\
Мобильные телефоны & 116,6 & 120,5 \\
Аудиоаппаратура & 101,8 & 103,9 \\
Телевизоры & 101,9 & 107,9 \\
Игры и игрушки & 95,8 & 111,2 \\
Холодильники и морозильники & 100,2 & 99,0 \\
Стиральные машины & 98,1 & 100,9 \\
Велосипеды & \\
Мотоциклы & 98,1 & 103,0 \\
Автомобили легковые & 86,9 & 86,4 \\
Бензины автомобильные & 97,5 & 98,1 \\
Мебель & 97,1 & 111,9 \\
Строительные материалы & 99,2 & 98,0 \\
Ювелирные изделия & & \\
Лекарственные средства5) & 89,7 & 99,7 \\
Изделия, применения в медицинских целях, & 108,7 \\
ортопедические изделия) & \\
Книги & 97,1 & 107,9 \\
Газеты и журналы & 94,4 \\
\hline
\end{tabular}

1) Оперативные данные.

В 2016 г. данные приведены по товарной позиции:

2) обувь кожаная;

3) велосипеды и мотовелосипеды;

4) ювелирные изделия из драгоценных металлов;

5) фармацевтические медицинские и ортопедические товары. 
19.11. ПРОДАЖА ОТДЕЛЬНЫХ ПИЩЕВЫХ ПРОДУКТОВ ${ }^{1)}$

\begin{tabular}{l|r|r|r|r|r|r|r}
\hline & 2000 & 2005 & 2010 & 2013 & 2014 & 2015 & 2016 \\
\hline \begin{tabular}{l} 
Мясо и птица, тыс. т \\
\multicolumn{1}{c|}{ из них: }
\end{tabular} & 2865 & 4871 & 5520 & 6163 & 6465 & 6266 & 6409 \\
$\quad$ мясо птицы, & & & & & & & \\
тыс. т & $\ldots$ & 2480 & 3600 & 4027 & 4308 & 4239 & 4341 \\
Консервы мясные, & & & & & & & \\
млн. условных & 492 & 634 & 657 & 701 & 710 & 545 & 515 \\
банок & & & & & & & \\
Масла животные, & 388 & 476 & 364 & 391 & 377 & 355 & 340 \\
тыс. т & & & & & & & \\
Растительные & 571 & 1013 & 1632 & 1677 & 1794 & 1643 & 1613 \\
масла, тыс. т & 339 & 689 & 808 & 850 & 789 & 762 & 793 \\
Сыры, тыс. т & 2623 & 2984 & 2936 & 3017 & 3083 & 3115 & 3146 \\
Сахар, тыс. т & $\ldots$ & 2888 & 3033 & 3082 & 3159 & 3073 & 3009 \\
Мука, тыс. т & $\ldots$ & 961 & 1284 & 1320 & 1433 & 1330 & 1346 \\
\hline Крупа, тыс. т & & & & \\
\hline
\end{tabular}

1) Оценка Росстата на основе балансового метода.

19.12. ТОВАРНЫЕ РЕСУРСЫ РОЗНИЧНОЙ ТОРГОВЛИ (в фактически действовавших ценах; в процентах к итогу)

\begin{tabular}{l|r|r|r|r|r|r|r|r|r}
\hline & 1992 & 2000 & 2005 & 2010 & 2013 & 2014 & 2015 & 2016 & 2017 \\
\hline $\begin{array}{l}\text { Товарные ресурсы } \\
\text { розничной тор- } \\
\text { говли - всего }\end{array}$ & 100 & 100 & 100 & 100 & 100 & 100 & 100 & 100 & 100 \\
$\begin{array}{l}\text { в том числе } \\
\text { за счет: }\end{array}$ & & & & & & & & & \\
$\begin{array}{l}\text { отечественного } \\
\text { производства } \\
\text { поступлений } \\
\text { по импорту }\end{array}$ & 77 & 60 & 55 & 56 & 56 & 58 & 62 & 62 & 65 \\
\hline
\end{tabular}


19.13. КАЧЕСТВО ТОВАРОВ, ПОСТУПИВШИХ НА ПОТРЕБИТЕЛЬСКИЙ РЫНОК ${ }^{1)}$

(в процентах от количества отобранных образцов (проб) товаров по каждой товарной группе)

\begin{tabular}{|c|c|c|c|c|c|c|}
\hline & \multicolumn{6}{|c|}{$\begin{array}{c}\text { Установлены ненадлежащее качество } \\
\text { и (или) опасность товаров }\end{array}$} \\
\hline & \multicolumn{2}{|c|}{2005} & \multicolumn{2}{|c|}{2016} & \multicolumn{2}{|c|}{2017} \\
\hline & $\begin{array}{c}\text { оте- } \\
\text { чест- } \\
\text { венных }\end{array}$ & $\begin{array}{c}\text { импорт- } \\
\text { ных }\end{array}$ & $\begin{array}{c}\text { оте- } \\
\text { чест- } \\
\text { венных }\end{array}$ & $\begin{array}{c}\text { импорт- } \\
\text { ных }\end{array}$ & \begin{tabular}{|c|}
$\begin{array}{c}\text { оте- } \\
\text { чест- } \\
\text { венных }\end{array}$ \\
\end{tabular} & $\begin{array}{c}\text { импорт- } \\
\text { ных }\end{array}$ \\
\hline Продукты питания & & & & & & \\
\hline Мясо и птица & 14,1 & 9,5 & 3,3 & 2,9 & 3,2 & 1,3 \\
\hline из них мясо птицы & 10,6 & 4,7 & 3,1 & 3,8 & 3,4 & 0,4 \\
\hline Колбасные изделия & 5,7 & 3,6 & 2,1 & 0,7 & 1,5 & 1,8 \\
\hline $\begin{array}{l}\text { Продукция рыбная пищевая } \\
\text { товарная (без рыбных кон- }\end{array}$ & & & & & & \\
\hline $\begin{array}{l}\text { сервов) } \\
\text { Консервы мясные и }\end{array}$ & 3,8 & 44,1 & 1,7 & 1,0 & 3,7 & 5,0 \\
\hline мясорастительные & 8,8 & 3,1 & 1,3 & 5,9 & 0,3 & 0,7 \\
\hline $\begin{array}{l}\text { Консервы и пресервы рыб- } \\
\text { ные }\end{array}$ & 2,9 & 35,3 & 8,3 & 2,4 & 0,5 & 1,8 \\
\hline $\begin{array}{l}\text { Консервы плодовоовощные } \\
\text { и ягодные }\end{array}$ & 26,6 & 8,8 & 0,6 & 4,6 & 0,8 & 6,4 \\
\hline Изделия макаронные & 12,6 & 2,5 & 0,4 & 10,2 & 0,4 & 0,7 \\
\hline Крупа & 17,4 & 53,7 & 0,9 & 3,2 & 1,0 & 2,3 \\
\hline Мука & 7,1 & 6,1 & 0,5 & 0,0 & 1,2 & 0,0 \\
\hline Изделия кондитерские & 6,7 & 14,1 & 2,4 & 1,2 & 2,6 & 4,5 \\
\hline Масло животное & 2,0 & 4,8 & 4,0 & 1,2 & 3,5 & 0,9 \\
\hline Масла растительные & 8,8 & 4,0 & 0,1 & 0,3 & 0,9 & 0,3 \\
\hline Продукция маргариновая & & & & & & \\
\hline и майонезная & 7,8 & 25,3 & 0,3 & 1,8 & 1,7 & 1,0 \\
\hline Цельномолочная продукция & 4,4 & 5,3 & 1,1 & 2,8 & 3,8 & 0,4 \\
\hline Сыры & 1,6 & 5,6 & 1,7 & 0,6 & 2,6 & 0,5 \\
\hline $\begin{array}{l}\text { Алкогольные напитки и } \\
\text { пиво }\end{array}$ & & & & & & \\
\hline $\begin{array}{l}\text { Водка и ликероводочные } \\
\text { изделия }\end{array}$ & 5,7 & 1,4 & 6,1 & 7,5 & 0,5 & 2,4 \\
\hline Вина виноградные & & & & & & \\
\hline и плодовые & 2,1 & 4,6 & 1,0 & 2,8 & 0,4 & 4,5 \\
\hline $\begin{array}{l}\text { Вина шампанские } \\
\text { и игристые }\end{array}$ & 1,1 & 0,6 & 0,3 & 1,5 & 0,1 & 0,2 \\
\hline $\begin{array}{l}\text { Коньяки, коньячные напитки } \\
\text { и спирты коньячные }\end{array}$ & & 60 & 07 & 1 1 & 1 & \\
\hline $\begin{array}{l}\text { и спирты коньячные } \\
\text { Пиво }\end{array}$ & $\begin{array}{l}4,7 \\
8,6\end{array}$ & $\begin{array}{l}6,0 \\
4,1\end{array}$ & $\begin{array}{l}0,1 \\
1,3\end{array}$ & $\begin{array}{l}0,1 \\
1,7\end{array}$ & $\begin{array}{l}0,1 \\
2,5\end{array}$ & $\begin{array}{l}0,2 \\
5,7\end{array}$ \\
\hline $\begin{array}{l}\text { Непродовольственные } \\
\text { товары }\end{array}$ & & & & & & \\
\hline $\begin{array}{l}\text { Изделия парфюмерно- } \\
\text { косметические }\end{array}$ & 30,5 & 19,1 & 0,1 & 9,2 & 7,8 & 1,5 \\
\hline Средства моющие & & & & & & \\
\hline синтетические & 8,3 & 57,1 & 5,8 & 4,8 & 6,1 & 1,3 \\
\hline Изделия швейные & 51,6 & 56,3 & 4,9 & 46,0 & 1,7 & 31,3 \\
\hline
\end{tabular}


Продолжение табл. 19.13

\begin{tabular}{|c|c|c|c|c|c|c|}
\hline & \multicolumn{6}{|c|}{$\begin{array}{c}\text { Установлено ненадлежащее качество } \\
\text { и (или) опасность товаров }\end{array}$} \\
\hline & \multicolumn{2}{|c|}{2005} & \multicolumn{2}{|c|}{2016} & \multicolumn{2}{|c|}{2017} \\
\hline & $\begin{array}{c}\text { оте } \\
\text { чест- } \\
\text { венных } \\
\end{array}$ & $\begin{array}{c}\text { импорт- } \\
\text { ных }\end{array}$ & $\begin{array}{c}\text { оте- } \\
\text { чест- } \\
\text { венных }\end{array}$ & $\begin{array}{c}\text { импорт- } \\
\text { ных }\end{array}$ & $\begin{array}{c}\text { оте- } \\
\text { чест- } \\
\text { венных }\end{array}$ & $\begin{array}{c}\text { импорт- } \\
\text { ных }\end{array}$ \\
\hline Изделия трикотажные & 25,5 & 42,3 & 3,8 & 55,2 & 6,0 & 13,2 \\
\hline Изделия чулочно-носочные & 30,8 & 52,3 & 5,8 & $44, \overline{9}$ & 1,6 & 1,2 \\
\hline Обувь кожаная & 37,4 & 48,5 & 1,8 & 49,3 & 8,2 & 2,9 \\
\hline $\begin{array}{l}\text { Телевизоры } \\
\text { Аппаратура видеозаписи }\end{array}$ & 13,6 & 14,8 & 0,5 & 1,2 & 2,3 & 2,0 \\
\hline и воспроизведения (видео- & & & & & & \\
\hline $\begin{array}{l}\text { магнитофоны) } \\
\text { Видео- и аудиокассеты }\end{array}$ & 56,0 & 24,6 & 0,9 & 12,1 & 5,7 & 0,7 \\
\hline с записью & & & 1,4 & 4,8 & 0,1 & 0,1 \\
\hline Радиоприемные устройства & 13,6 & 29,9 & 3,7 & 13,6 & 1,1 & 14,1 \\
\hline Стиральные машины & 8,3 & 25,5 & 0,1 & 0,3 & 0,7 & 1,1 \\
\hline Холодильники & 10,3 & 13,4 & 0,1 & 0,6 & 1,1 & 0,8 \\
\hline Автомобили легковые & 25,9 & 30,4 & 0,0 & 0,0 & 14,3 & 0,0 \\
\hline Мебель бытовая & 41,0 & 41,1 & 16,8 & 15,1 & 4,9 & 0,3 \\
\hline
\end{tabular}

1) По данным проверок Роспотребнадзора в организациях торговли.

\section{ОПТОВАЯ ТОРГОВЛЯ}

19.14. ОБОРОТ ОПтОВОЙ ТОРГОВлИ

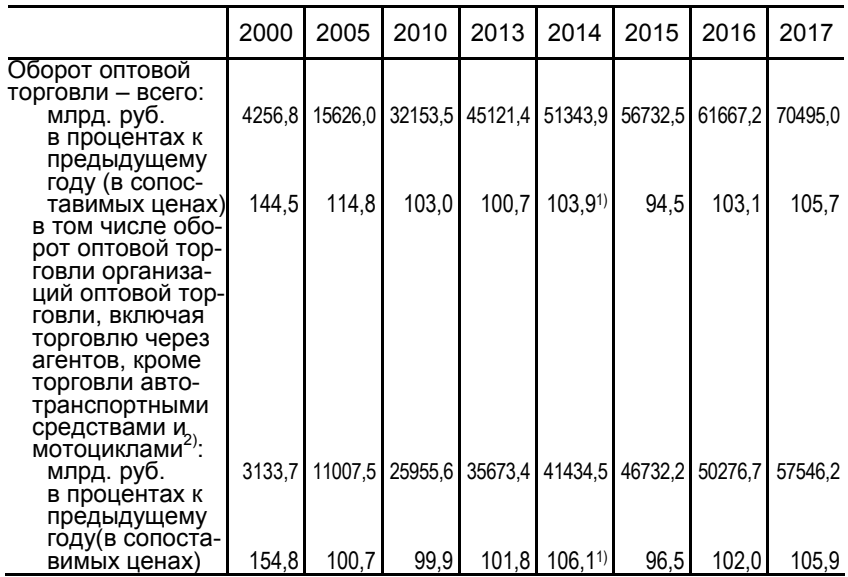

1) В целях обеспечения статистической сопоставимости относительные показатели рассчитаны без учета данных по Республике Крым и г. Севастополю.

2) Данные за 2000 г. приведены по организациям оптовой торговли, включая торговлю автотранспортными средствами и мотоциклами. 
19.15. ОСНОВНЫЕ ПОКАЗАТЕЛИ ДЕЯТЕЛЬНОСТИ БИРЖ1)

\begin{tabular}{|c|c|c|c|c|c|c|c|c|c|}
\hline & 1992 & 2000 & 2005 & 2010 & 2013 & 2014 & 2015 & 2016 & 2017 \\
\hline $\begin{array}{l}\text { Число бирж (на } \\
\text { конец года) }\end{array}$ & 224 & 45 & 31 & 23 & 14 & 5 & 7 & 7 & 7 \\
\hline $\begin{array}{l}\text { Среднесписочная } \\
\text { численность ра- } \\
\text { ботающих (без } \\
\text { совместителей и } \\
\text { работников не- }\end{array}$ & & & & & & & & & \\
\hline $\begin{array}{l}\text { списочного соста- } \\
\text { ва), тыс. человек }\end{array}$ & 7,8 & 0,5 & 0,2 & 0,5 & 0,2 & 0,2 & 1,0 & 1,0 & 1,0 \\
\hline $\begin{array}{l}\text { Численность } \\
\text { совместителей, } \\
\text { человек (1992 г. - }\end{array}$ & & & & & & & & & \\
\hline тыс. человек) & 2,0 & 70 & 55 & 31 & 19 & 27 & 50 & 24 & 29 \\
\hline Число проведен- & & & & & & & & & \\
\hline $\begin{array}{l}\text { ных торгов, тыс. } \\
\text { Число заключен- }\end{array}$ & 19,7 & 2,6 & 1,8 & 3,4 & 2,6 & 1,3 & 1,3 & 1,5 & 11,7 \\
\hline $\begin{array}{l}\text { ных сделок с ре- } \\
\text { альным товаром, } \\
\text { тыс. }\end{array}$ & 147,7 & 9,8 & 22.6 & 73.0 & 62,3 & 904 & 1073 & 1331 & 1604 \\
\hline $\begin{array}{l}\text { Биржевой оборот по } \\
\text { сделкам с реаль- } \\
\text { ным товаром }{ }^{2)}- \\
\text { всего, млн. руб. }\end{array}$ & & & & & & & & & \\
\hline $\begin{array}{c}\text { (1992 г. - млрд. руб.) } \\
\text { в том числе: } \\
\text { продукция про- } \\
\text { изводственно- } \\
\text { технического }\end{array}$ & 335,1 & 4997 & 7404 & 257110 & 450581 & 541873 & 567630 & 637733 & 765429 \\
\hline назначения & 227,0 & 1812 & 1155 & 157831 & 424158 & 539809 & 544578 & 624653 & 759640 \\
\hline $\begin{array}{l}\text { продукция сель- } \\
\text { ского хозяйства }\end{array}$ & & 2929 & 5834 & 4180 & 26268 & 2064 & 23052 & 13080 & 5789 \\
\hline $\begin{array}{l}\text { непродовольст- } \\
\text { венные потре- } \\
\text { бительские то- } \\
\text { вары }\end{array}$ & $(107,94)$ & 86 & 173 & 2104 & 117 & & & & - \\
\hline $\begin{array}{l}\text { прочие виды } \\
\text { товаров }\end{array}$ & 0,2 & 170 & 242 & 92995 & 38 & & & & - \\
\hline
\end{tabular}

На биржевых торгах в 2017 г. преобладала продажа топлива минерального, нефти и продуктов перегонки (99,6\% биржевого оборота).

1) Данные приведены по биржам, осуществлявшим деятельность по проведению биржевых торгов по сделкам с реальными товарами.

2) В фактически действовавших ценах, без оборота по фьючерсным сделкам и сделкам по продаже квот.

3) До 2014 г. - продукция агрокомплекса.

4) Потребительские товары, зерно. 


\section{УСЛУГИ НАСЕЛЕНИЮ}

19.16 ОБЪЕМ ПЛАТНЫХ УСЛУГ НАСЕЛЕНИЮ

\begin{tabular}{c|c|c}
\hline Годы & $\begin{array}{c}\text { Млн. руб. } \\
\text { (1992 г. - млрд. руб.) }\end{array}$ & $\begin{array}{c}\text { В процентах к } \\
\text { предыдущему году } \\
\text { (в сопоставимых ценах) }\end{array}$ \\
\hline 1992 & 515 & 81,6 \\
2000 & 602755 & 104,7 \\
2005 & 2271733 & 106,3 \\
2010 & 4943482 & 101,5 \\
2012 & 6036839 & 103,5 \\
2013 & 6927482 & 102,0 \\
2014 & 7467521 & 101,0 \\
2015 & 8050808 & 98,9 \\
2016 & 8636277 & 100,7 \\
$2017^{1)}$ & 8839021 & 100,2 \\
\hline
\end{tabular}

1) Оперативные данные.

19.17. ИНДЕКСЫ ФИЗИЧЕСКОГО ОБЪЕМА ПЛАТНЫХ УСЛУГ НАСЕЛЕНИЮ

(в сопоставимых ценах; в процентах к предыдущему году)

\begin{tabular}{|c|c|c|c|c|c|c|c|c|}
\hline & 2000 & 2005 & 2010 & 2013 & 2014 & 2015 & 2016 & $2017^{1)}$ \\
\hline $\begin{array}{l}\text { се оказанные услуги } \\
\text { из них: }\end{array}$ & 04,7 & 106,3 & 101,5 & 102,0 & 101,0 & 98,9 & $|100,7|$ & 100,2 \\
\hline бытовые & 103,0 & 105,5 & 102,9 & 105,1 & 101,6 & 101,1 & 100,8 & 100,3 \\
\hline транспортные & 99,6 & 104,2 & 96,1 & 101,5 & 99,7 & 96,5 & 106,1 & 98,5 \\
\hline $\begin{array}{l}\text { почтовой связи, } \\
\text { курьерские }{ }^{2)}\end{array}$ & & & & & 1 & 187 & 077 & 60,7 \\
\hline $\begin{array}{l}\text { телекоммуникацион- } \\
\text { ные }^{2)}\end{array}$ & & & jus, & 103,9 & $\mid 102,1$ & 98,1 & $y, 1$ & 104,1 \\
\hline жилищные & 94,1 & 102,5 & 106,0 & 101,6 & 99,7 & 98,1 & 101,6 & 103,0 \\
\hline коммунальные & 100,9 & 100,7 & 103,5 & 99,7 & 100,7 & 99,6 & 99,5 & 100,9 \\
\hline $\begin{array}{l}\text { гостиниц и аналогич- } \\
\text { ных средств разме- } \\
\text { щенияз }\end{array}$ & & 96,1 & 99,1 & 103,1 & $\mid 103,5$ & $\mid 102,6$ & 109,6 & 108,7 \\
\hline культуры & 105,6 & 99,1 & 99,5 & 101,6 & 98,7 & 99,0 & 104,0 & 97,7 \\
\hline туристские & 97,8 & $|121,6|$ & 120,8 & $\mid 101,0$ & $|94,6|$ & 96,0 & 95,0 & 97,5 \\
\hline
\end{tabular}


Продолжение табл. 19.17

\begin{tabular}{|c|c|c|c|c|c|c|c|c|}
\hline & 2000 & 2005 & 2010 & 2013 & 2014 & 2015 & 2016 & $2017^{1)}$ \\
\hline $\begin{array}{l}\text { физической культуры } \\
\text { и спорта }\end{array}$ & 100,1 & 137,7 & 98,4 & 106,7 & 106,4 & 109,8 & 107,7 & 102,7 \\
\hline медицинские & 110,1 & 106,8 & 102,2 & 103,5 & 104,0 & 100,1 & 99,9 & 102,3 \\
\hline $\begin{array}{l}\text { санаторно- } \\
\text { оздоровительные }\end{array}$ & 99,8 & 105,6 & 94,3 & 99,8 & 104,2 & 107,4 & 97,9 & 98,6 \\
\hline ветеринарные & & 95,5 & 91,5 & 107,2 & 103,2 & 98,9 & 102,1 & 100,8 \\
\hline правового характера & 113,7 & 106,3 & 85,3 & 100,2 & 96,2 & 91,9 & 90,7 & 95,9 \\
\hline $\begin{array}{l}\text { системы образования } \\
\text { предоставляемые гра- } \\
\text { жданам пожилого воз- } \\
\text { раста и инвалидам }{ }^{4}\end{array}$ & 121,7 & 107,7 & 99,1 & 98,9 & 98,0 & 96,8 & 98,0 & 99,5 \\
\hline прочие платные услугия) & $\ldots$ & $\ldots$ & $\ldots$ & $\ldots$ & $\ldots$ & $\ldots$ & $\ldots$ & \\
\hline
\end{tabular}

19.18. РАСПРЕДЕЛЕНИЕ ПЛАТНЫХ УСЛУГ НАСЕЛЕНИЮ ПО ВИДАМ (в процентах к итогу)

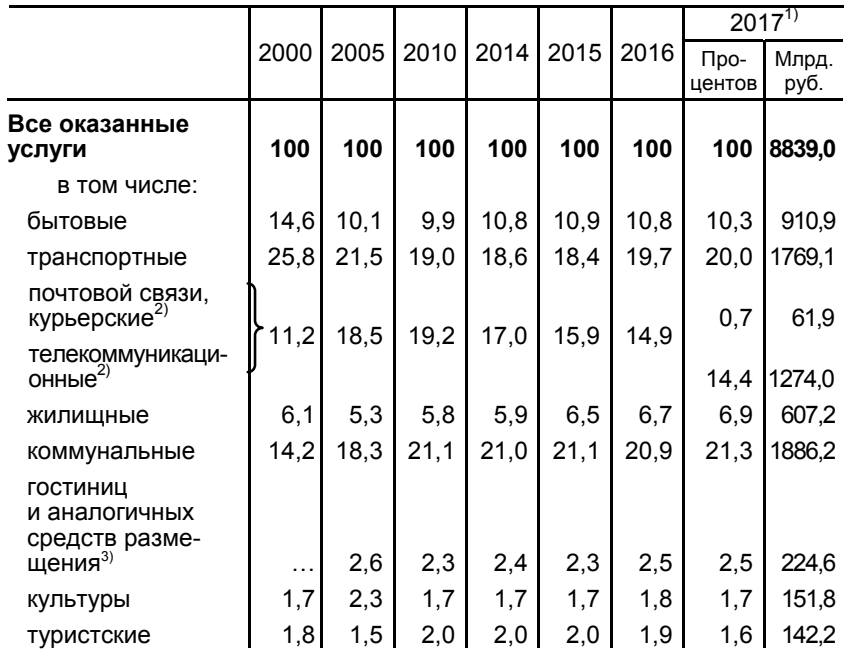


Продолжение табл. 19.18

\begin{tabular}{|c|c|c|c|c|c|c|c|c|}
\hline & \multirow[b]{2}{*}{2000} & \multirow[b]{2}{*}{2005} & \multirow[b]{2}{*}{2010} & \multirow[b]{2}{*}{2014} & \multirow[b]{2}{*}{2015} & \multirow[b]{2}{*}{2016} & \multicolumn{2}{|c|}{$2017^{1)}$} \\
\hline & & & & & & & \begin{tabular}{|c|} 
Про- \\
центов
\end{tabular} & $\begin{array}{l}\text { Млрд. } \\
\text { руб. }\end{array}$ \\
\hline $\begin{array}{l}\text { физической куль- } \\
\text { туры и спорта }\end{array}$ & 0,4 & 0,7 & 0,6 & 0,7 & 0,8 & 0,8 & 0,8 & 72,0 \\
\hline медицинские & 4,6 & 4,8 & 5,1 & 6,4 & 6,6 & 6,6 & 6,7 & 591,5 \\
\hline $\begin{array}{l}\text { санаторно- } \\
\text { оздоровительные }\end{array}$ & 2,8 & 1,6 & 1,2 & 1,2 & 1,4 & 1,4 & 1,4 & 120,7 \\
\hline ветеринарные & $\ldots$ & 0,2 & 0,2 & 0,2 & 0,2 & 0,2 & 0,2 & 17,0 \\
\hline $\begin{array}{l}\text { правового } \\
\text { характера }\end{array}$ & 5,2 & 2,3 & 1,7 & 1,2 & 1,2 & 1,1 & 1,1 & 101,6 \\
\hline $\begin{array}{l}\text { системы } \\
\text { образования }\end{array}$ & 6,9 & 6,7 & 6,6 & 6,5 & 6,7 & 6,6 & 6,7 & 592,9 \\
\hline $\begin{array}{l}\text { предоставляемые } \\
\text { гражданам пожи- } \\
\text { лого возраста и } \\
\text { инвалидам }\end{array}$ & $\ldots$ & $\ldots$ & $\ldots$ & 0,2 & 0,2 & 0,2 & 0,2 & 21,0 \\
\hline $\begin{array}{l}\text { прочие платные } \\
\text { услуги }\end{array}$ & 4,7 & 3,6 & 3,6 & 4,2 & 4,1 & 3,9 & 3,5 & 294,3 \\
\hline
\end{tabular}

1) Оперативные данные.

2) До 2017 г. - услуги связи.

3) В 2000 г. учитывались в составе жилищных услуг.

19.19. ОБЪЕМ БЫТОВЫХ УСЛУГ НАСЕЛЕНИЮ

\begin{tabular}{c|c|c}
\hline Годы & Млн. руб. & $\begin{array}{c}\text { В процентах } \\
\text { к предыдущему году } \\
\text { (в сопоставимых ценах) }\end{array}$ \\
\hline 2000 & 87889 & 103,0 \\
2005 & 228679 & 105,5 \\
2010 & 487178 & 102,9 \\
2013 & 745747 & 105,1 \\
2014 & 806022 & 101,6 \\
2015 & 877938 & 101,1 \\
2016 & 928625 & 100,8 \\
$2017^{1)}$ & 910931 & 100,3 \\
\hline
\end{tabular}

1) Оперативные данные. 
19.20. ИНДЕКСЫ ФИЗИЧЕСКОГО ОБЪЕМА

БЫТОВЫХ УСЛУГ НАСЕЛЕНИЮ

(в сопоставимых ценах; в процентах к предыдущему году)

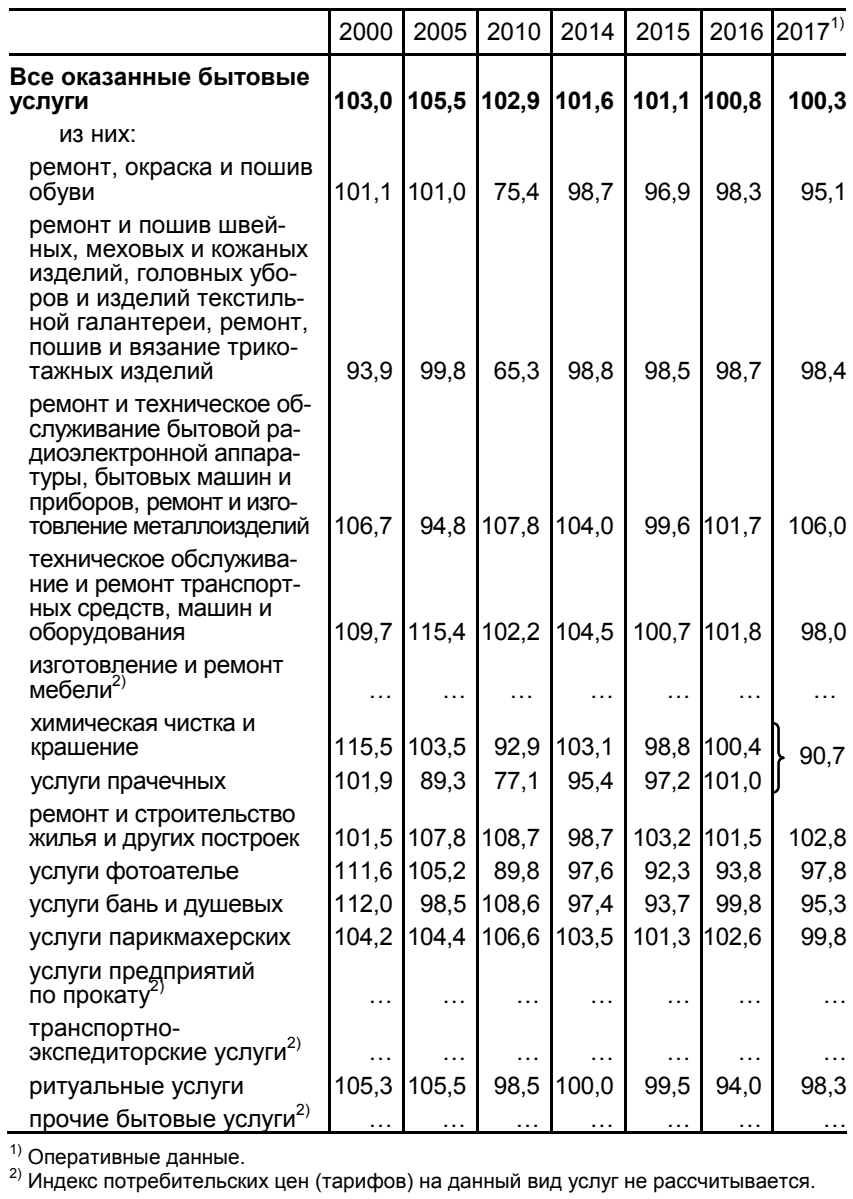


19.21. РАСПРЕДЕЛЕНИЕ БЫТОВЫХ УСЛУГ НАСЕЛЕНИЮ ПО ВИДАМ (в процентах к итогу)

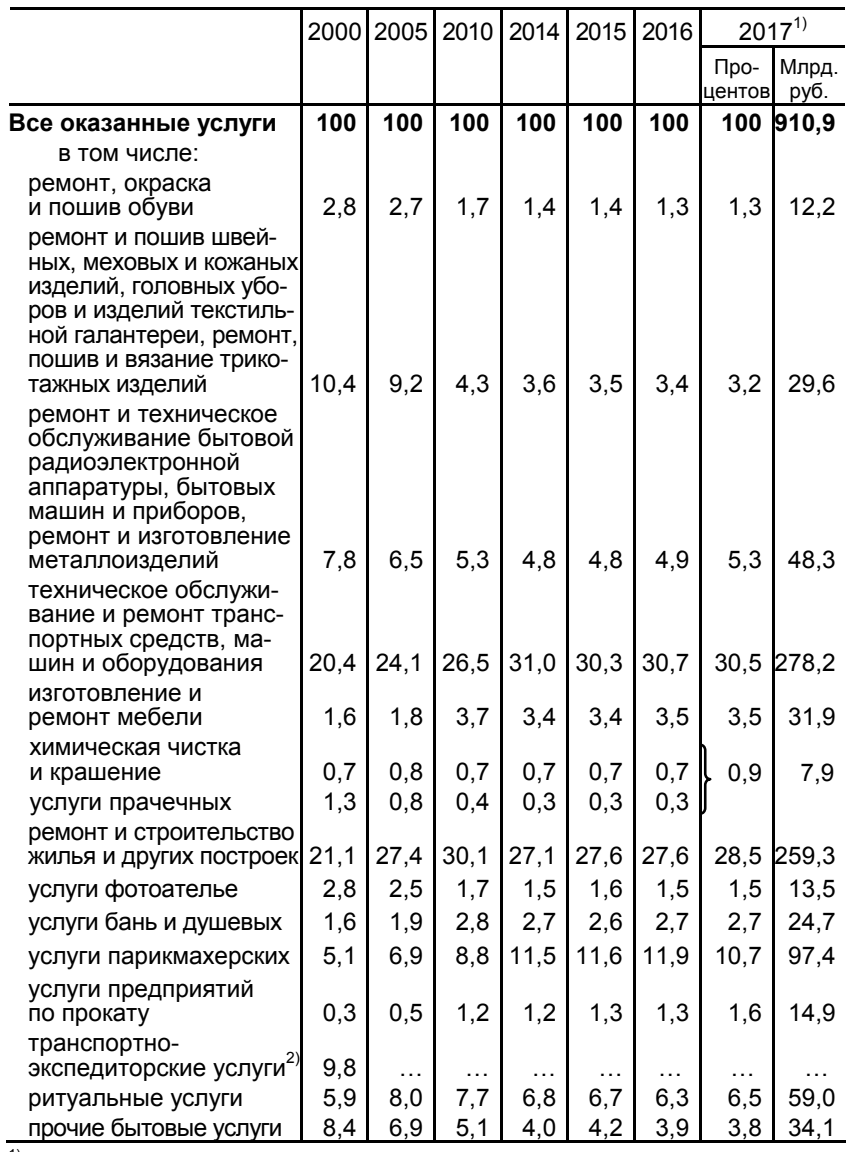

1) Оперативные данные.

2) С 2002 г. учитываются в составе транспортных услуг. 


\section{TPAНСПОРТ}

В разделе представлены данные об объемах перевозок грузов и пассажиров транспортом, о протяженности транспортных путей, аварийности на транспорте.

Информация, содержащаяся в таблицах раздела, сформирована Росстатом по данным, предоставленным Росморречфолотом, Росавиацией, Ространснадзором, МВД России. Данные за 2016 г. уточнены по итогам годовых отчетов.

Транспорт как вид хозяйственной деятельности подразделяется на транспорт общего и необщего пользования.

Транспорт общего пользования - транспорт, удовлетворяющий потребности всех отраслей экономики и населения в перевозках грузов и пассажиров, перемещающий различные виды продукции между производителями и потребителями, осуществляющий общедоступное транспортное обслуживание населения. К перевозкам транспортом общего пользования относятся перевозки на коммерческой основе (за плату) пассажиров (включая граждан, пользующихся правом бесплатного проезда на общественном транспорте) или грузов.

Перевозка, осуществляемая коммерческой организацией, признается перевозкой транспортом общего пользования, если из закона, иных правовых актов вытекает, что эта организация обязана осуществлять перевозки грузов, пассажиров и багажа по обращению любого гражданина или юридического лица.

Договор перевозки транспортом общего пользования является публичным договором.

По всем видам транспорта общего пользования, кроме автомобильного, объем перевезенных грузов показан по моменту отправления. На автомобильном транспорте учет перевезенных грузов осуществляется по моменту прибытия.

Грузооборот транспорта - объем работы транспорта по перевозкам грузов. Единицей измерения является тоннокилометр. Исчисляется суммированием произведений массы перевезенных грузов в тоннах на расстояние перевозки в километрах (милях).

Информация по перевозкам грузов и грузообороту автомобильного транспорта приводится с учетом оценки деятельности субъектов малого предпринимательства.

Перевезено пассажиров - число пассажиров, перевезенных за определенный период времени. Учитывается по видам транспорта и видам сообщения. Единицей наблюдения в статистике перевозок пассажиров является пассажиропоездка. Момент учета отправленных пассажиров определяется на отдельных видах транспорта неодинаково: или по моменту приобретения билета 
(на железнодорожном, автомобильном, городском электрическом транспорте), или по моменту отправления транспортного средства (на водном и воздушном транспорте). Момент прибытия в статистике перевозок пассажиров на практике, за исключением воздушного транспорта, не используется.

Данные по перевозке пассажиров приведены с учетом пассажиров, пользующихся правом бесплатного и льготного проезда.

Пассажирооборот транспорта - объем работы транспорта по перевозкам пассажиров. Единицей измерения является пассажиро-километр. Определяется суммированием произведений числа пассажиров по каждой позиции перевозки на расстояние перевозки; исчисляется раздельно по видам транспорта, сообщения и другим признакам.

Сведения о перевозках пассажиров и пассажирообороте на железнодорожном транспорте приведены с 2000 г. с учетом оценки объемов перевозок пассажиров, пользующихся правом бесплатного проезда в пригородном сообщении, и изменения системы учета объемов перевозок работников железнодорожного транспорта.

Данные по воздушному транспорту приведены по регулярным и нерегулярным авиаперевозчикам.

Регулярные перевозчики на воздушном транспорте организации, осуществляющие коммерческие перевозки пассажиров, грузов и почты, а также авиационные работы по обслуживанию отраслей экономики как на регулярной, так и на нерегулярной основе. К регулярным перевозкам относятся полеты, запланированные и выполняемые в соответствии с опубликованным расписанием за плату, или достаточно частые полеты, которые поддаются определенной систематизации и доступны для общественного пользования, а также дополнительные полеты, вызванные перегрузкой регулярных рейсов.

Нерегулярные перевозчики на воздушном транспорте организации, осуществляющие коммерческие перевозки грузов и пассажиров и авиационные работы по обслуживанию отраслей экономики только на нерегулярной основе (чартерные (заказные) полеты, спецрейсы, туристские маршруты, не отраженные в регулярных перевозках).

Грузооборот и пассажирооборот на воздушном транспорте определены только по перевозкам транспортной авиацией, т.е. без учета перевозок авиацией, применяемой для нужд организаций и населения.

Эксплуатационная длина железнодорожных путей общего пользования - протяженность в километрах железнодорожных линий общего пользования, измеряемая по оси главного пути, а на многопутных линиях - кратчайшего главного пути между осями раздельных пунктов (станций, разъездов, обгонных пунктов), ограничивающих эту линию.

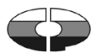


К автомобильным дорогам общего пользования относятся: автомобильные дороги федерального, регионального или межмуниципального, местного значения (включая улицы), предназначенные для движения транспортных средств неограниченного круга лиц.

Магистральный газопровод - технологически неделимый, централизованно управляемый имущественный производственный комплекс, состоящий из взаимосвязанных объектов, являющихся его неотъемлемой технологической частью, предназначенных для транспортировки подготовленной в соответствии с требованиями национальных стандартов безопасности продукции (природного газа) от объектов добычи и/или пунктов приема до пунктов сдачи потребителям и передачи в распределительные газопроводы или иной вид транспорта и/или хранения.

Магистральные нефтепроводы - инженерные сооружения, состоящие из подземных, подводных, наземных и надземных трубопроводов и связанных с ними насосных станций, хранилищ нефти и других технологических объектов, обеспечивающих транспортировку, приемку, сдачу нефти потребителям или перевалку на другой вид транспорта.

Магистральные нефтепродуктопроводы - трубопроводы с избыточным давлением до 10 МПа, с комплексом подземных, надземных и подводных сооружений, предназначенные для транспортировки подготовленных в соответствии с требованиями государственных стандартов, технических условий и других нормативно-технических документов нефтепродуктов от пунктов приемки до пунктов сдачи, технологического хранения или перевалки (передачи) на другой вид транспорта.

Протяженность магистральных трубопроводов представляет собой сумму линейных протяжений всех участков трубопроводов в однониточном исчислении, включая отводы от них.

Внутренние водные пути - естественные или искусственно созданные федеральные пути сообщения, обозначенные навигационными знаками или иным способом, и используемые в целях судоходства.

Протяженность внутренних водных судоходных путей протяженность участков внутренних водных путей, включенных в Перечень внутренних водных путей Российской Федерации, утвержденный распоряжением Правительства Российской Федерации от 21.12.2002 № 1800-р (с изменениями), и содержащихся администрациями бассейнов внутренних водных путей и ФГБУ «Канал имени Москвы».

Внутренние водные пути с гарантированными габаритами судового хода - участки водных путей, на которых устанавливаются наименьшие габариты судового хода: глубина, ширина и радиус округления при проектном уровне воды (расчетном низком уровне воды с заданной обеспеченностью). 


\section{ГРУЗОВЫЕ ПЕРЕВОЗКИ}

\section{1. ПЕРЕВОЗКИ ГРУЗОВ ПО ВИДАМ ТРАНСПОРТА}

(Млн. Тонн)

\begin{tabular}{|c|c|c|c|c|c|c|c|c|c|}
\hline & 1992 & 2000 & 2005 & 2010 & 2013 & 2014 & 2015 & 2016 & 2017 \\
\hline $\begin{array}{l}\text { Транспорт } \\
\text { всего }\end{array}$ & 15737 & 7907 & 9167 & 7749 & 8264 & 8006 & 7898 & 7987 & 7985 \\
\hline $\begin{array}{l}\text { в том } \\
\text { числе } \\
\text { по ви- } \\
\text { дам: }\end{array}$ & & & & & & & & & \\
\hline $\begin{array}{l}\text { железно- } \\
\text { дорожный }\end{array}$ & 1640 & 1047 & 1273 & 1312 & 1381 & 1375 & 1329 & 1325 & $1266^{1)}$ \\
\hline $\begin{array}{l}\text { автомо- } \\
\text { бильный }\end{array}$ & 12750 & 5878 & 6685 & 5236 & 5635 & 5417 & 5357 & 5431 & 5447 \\
\hline $\begin{array}{l}\text { трубопро- } \\
\text { водный }\end{array}$ & 947 & 829 & 1048 & 1061 & 1095 & 1078 & 1071 & 1088 & 1138 \\
\hline морской ${ }^{2)}$ & 91 & 35 & 26 & 37 & 17 & 16 & 19 & $\begin{array}{r}25 \\
25\end{array}$ & $\begin{array}{r}150 \\
25\end{array}$ \\
\hline $\begin{array}{l}\text { внутрен- } \\
\text { ний вод- } \\
\text { ный }\end{array}$ & 308 & 117 & 134 & 102 & 135 & 119 & 121 & 118 & 119 \\
\hline $\begin{array}{l}\text { воздуш- } \\
\text { ный }\end{array}$ & 1,4 & 0,8 & 0,8 & 1,1 & 1,2 & 1,3 & 1,2 & 1,1 & 1,2 \\
\hline
\end{tabular}

20.2. ГРУЗООБОРОТ ПО ВИДАМ ТРАНСПОРТА

(млрд. тонно-километров)

\begin{tabular}{|c|c|c|c|c|c|c|c|c|c|}
\hline & 1992 & 2000 & 2005 & 2010 & 2013 & 2014 & 2015 & 2016 & 2017 \\
\hline $\begin{array}{l}\text { Транспорт - } \\
\text { всего }\end{array}$ & 4913 & 3638 & 4676 & 4751 & 5084 & 5080 & 5108 & 5198 & 5479 \\
\hline $\begin{array}{l}\text { в том } \\
\text { числе } \\
\text { по видам: }\end{array}$ & & & & & & & & & \\
\hline $\begin{array}{l}\text { железнодо- } \\
\text { рожный }\end{array}$ & 1967 & 1373 & 1858 & 2011 & 2196 & 2301 & 2306 & 2344 & 2493 \\
\hline $\begin{array}{l}\text { автомобиль- } \\
\text { ный }\end{array}$ & 257 & 153 & 194 & 199 & 250 & 247 & 247 & 248 & 253 \\
\hline $\begin{array}{l}\text { трубопро- } \\
\text { водный }\end{array}$ & 2146 & 1916 & 2474 & 2382 & 2513 & 2423 & 2444 & 2489 & 2615 \\
\hline морской & 405 & 122 & 60 & 100 & 40 & 32 & 42 & 43 & 46 \\
\hline внутренний & & & & & & & & & \\
\hline водный & 136 & 71 & 87 & 54 & 80 & 72 & 64 & 67 & 67 \\
\hline воздушный & 1,8 & 2,5 & 2,8 & 4,7 & 5,0 & 5,2 & 5,4 & 6,6 & 7,6 \\
\hline
\end{tabular}




\section{ПАССАЖИРСКИЕ ПЕРЕВОЗКИ}

\section{3. ПЕРЕВОЗКИ ПАССАЖИРОВ ПО ВИДАМ ТРАНСПОРТА ОБЩЕГО ПОЛЬЗОВАНИЯ}

(млн. человек)

\begin{tabular}{l|r|r|r|r|r|r|r|r|r}
\hline & 1992 & 2000 & 2005 & 2010 & 2013 & 2014 & 2015 & 2016 & 2017 \\
\hline $\begin{array}{l}\text { Транспорт - } \\
\text { всего }\end{array}$ & 47885 & 44854 & 30128 & 22065 & 19652 & 19558 & 19122 & 18689 & 18479 \\
$\quad$ из него \\
$\begin{array}{l}\text { по видам: } \\
\text { железнодо- } \\
\text { рожный }\end{array}$ & 2372 & 1419 & 1339 & 947 & 1080 & 1076 & 1025 & 1040 & 1121 \\
автобусный & & & & & & & & \\
трамвайный & 807874 & 23001 & 16374 & 13434 & 11587 & 11554 & 11523 & 11296 & 11184 \\
троллейбусный & 8619 & 8721 & 4123 & 2079 & 1629 & 1551 & 1478 & 1397 & 1327 \\
метрополи- & & 4653 & 2206 & 1735 & 1803 & 1616 & 1483 & 1376 \\
тены & 3567 & 4186 & 3574 & 3294 & 3491 & 3437 & 3336 & 3312 & 3298 \\
морской & & & & & & & & \\
внутренний & 9 & 1,1 & 1,3 & 1,5 & 0,5 & 6,9 & 9,6 & 13,0 & 11,7 \\
водный & \\
воздушный & 44 & 28 & 21 & 16 & 13 & 13 & 14 & 13 & 13 \\
\hline
\end{tabular}

Метрополитены эксплуатировались в Екатеринбурге, Казани, Москве, Нижнем Новгороде, Новосибирске, Самаре и СанктПетербурге; трамвайные пути эксплуатировались в 61 городе, в том числе в 3 городах имелись линии скоростного трамвая; троллейбусные линии эксплуатировались в 87 городах.

1) Здесь и в табл. 20.4 с 2000 г. - данные приведены по юридическим лицам и индивидуальным предпринимателям (включая субъекты малого предпринимательства), осуществляющим перевозки пассажиров автобусами.

2) Здесь и в табл. 20.4 с 2015 г. - по данным Росморречфлота.

\section{4. ПАССАЖИРООБОРОТ ПО ВИДАМ ТРАНСПОРТА ОБЩЕГО ПОЛЬЗОВАНИЯ}

(млрд. пассажиро-километров)

\begin{tabular}{|c|c|c|c|c|c|c|c|c|c|}
\hline & 1992 & 2000 & 2005 & 2010 & 2013 & 2014 & 2015 & 2016 & 2017 \\
\hline $\begin{array}{l}\text { Транспорт - } \\
\text { всего }\end{array}$ & 681,2 & 496,2 & 473,3 & 484,0 & 547,2 & 556,2 & 530,0 & 519,8 & 560,6 \\
\hline $\begin{array}{l}\text { из него } \\
\text { по видам: }\end{array}$ & & & & & & & & & \\
\hline & & 16 & 2,2 & 138,9 & 138,5 & 130,0 & 120,6 & 124,6 & 23,1 \\
\hline ก0 & & & 142,3 & 140,6 & 126.0 & & & & \\
\hline
\end{tabular}


Продолжение табл. 20.4

\begin{tabular}{l|r|r|r|r|r|r|r|r|r}
\hline & 1992 & 2000 & 2005 & 2010 & 2013 & 2014 & 2015 & 2016 & 2017 \\
\hline $\begin{array}{l}\text { трамвайный } \\
\text { троллей- }\end{array}$ & 26,0 & 25,1 & 13,5 & 6,7 & 5,3 & 5,0 & 4,8 & 4,6 & 4,3 \\
бусный & 26,2 & 28,1 & 15,0 & 7,1 & 5,7 & 6,4 & 6,0 & 5,5 & 5,2 \\
метрополи- & & & & & & & & & \\
тены & 39,6 & 46,9 & 43,4 & 42,4 & 45,6 & 45,4 & 44,6 & 44,1 & 44,1 \\
морской & 0,5 & 0,1 & 0,09 & 0,06 & 0,04 & 0,07 & 0,06 & 0,09 & 0,08 \\
внутренний & & & & & & & & & $0,0,6$ \\
водный & 1,9 & 1,0 & 0,9 & 0,8 & 0,6 & 0,5 & 0,5 & 0,6 & 0,6 \\
воздушный & 117,7 & 54,0 & 85,8 & 147,1 & 225,2 & 241,4 & 226,8 & 215,6 & 259,4 \\
\hline
\end{tabular}

20.5. ПРОТЯЖЕННОСТЬ ПУТЕЙ СООБЩЕНИЯ

(на конец года; тыс. километров)

\begin{tabular}{|c|c|c|c|c|c|c|c|c|c|}
\hline & 1992 & 2000 & 2005 & 2010 & 2013 & 2014 & 2015 & 2016 & 2017 \\
\hline $\begin{array}{l}\text { Железнодорожные } \\
\text { пути общего } \\
\text { пользования }\end{array}$ & 88 & 86 & 85 & 86 & 86 & 86 & 86 & 86 & 86 \\
\hline $\begin{array}{l}\text { Автомобильные } \\
\text { дороги общего } \\
\text { пользования }\end{array}$ & 466 & 584 & 581 & 825 & 1396 & 1451 & 1481 & 1498 & 1508 \\
\hline $\begin{array}{c}\text { из них: } \\
\text { с твердым } \\
\text { покрытием }\end{array}$ & 419 & 532 & 531 & 665 & 985 & 1024 & 1045 & 1054 & 1064 \\
\hline Трамвайные пути ${ }^{1)}$ & 3,1 & 3,0 & 2,8 & 2,6 & 2,5 & 2,5 & 2,5 & 2,5 & 2,5 \\
\hline $\begin{array}{l}\text { Троллейбусные } \\
\text { линии }\end{array}$ & 4,6 & 4,8 & 4,9 & 4,9 & 4,8 & 5,3 & 5,3 & 5,3 & 5,2 \\
\hline $\begin{array}{l}\text { Пути метрополите- } \\
\text { HOB }^{11}, \text { кM }\end{array}$ & 367 & 405 & 436 & 475 & 512 & 514 & 517 & 532 & 542 \\
\hline $\begin{array}{l}\text { Магистральные } \\
\text { трубопроводы - } \\
\text { всего }\end{array}$ & 207 & 215 & 225 & 233 & 250 & 251 & 252 & 250 & 250 \\
\hline в том числе: & & & & & & & & & \\
\hline газопроводы & 140 & 152 & 160 & 168 & 175 & 177 & 178 & 179 & 180 \\
\hline нефтепроводы & 51 & 48 & 50 & 49 & 55 & 55 & 55 & 54 & 53 \\
\hline $\begin{array}{l}\text { нефттепродукто- } \\
\text { проводыз }\end{array}$ & 15 & 15 & 16 & 16 & 20 & 19 & 19 & 17 & 17 \\
\hline
\end{tabular}


Продолжение табл. 20.5

\begin{tabular}{l|r|r|r|r|r|r|r|r|r}
\hline & 1992 & 2000 & 2005 & 2010 & 2013 & 2014 & 2015 & 2016 & 2017 \\
\hline $\begin{array}{l}\text { Внутренние водные } \\
\text { судоходные пути } \\
\begin{array}{l}\text { в том числе } \\
\text { с гарантирован- } \\
\text { ными габаритами }\end{array}\end{array}$ & 58 & 85 & 102 & 101 & 102 & 102 & 102 & 101 & 101 \\
\hline
\end{tabular}

1) Эксплуатационная длина.

2) С 2013 г. - включая протяженность улиц.

${ }^{3)}$ С 2013 г. - включая протяженность магистральных нефтепродуктопроводов на территории иностранных государств.

\section{АВАРИЙНОСТЬ НА ТРАНСПОРТЕ}

20.6. ЧИСЛО ПРОИСШЕСТВИЙ И ЧИСЛЕННОСТЬ ПОСТРАДАВШИХ В ПРОИСШЕСТВИЯХ С ПОДВИЖНЫМ СОСТАВОМ ${ }^{11}$

\begin{tabular}{|c|c|c|c|c|c|c|c|c|c|}
\hline \multirow{5}{*}{$\begin{array}{l}\text { На транспорте: } \\
\text { железнодорожном } \\
\text { общего пользования }{ }^{2)}\end{array}$} & 1994 & 2000 & 2005 & 2010 & 2013 & 2014 & 2015 & 2016 & 2017 \\
\hline & \multicolumn{9}{|c|}{ Число происшествий } \\
\hline & \multirow{4}{*}{34} & \multirow{4}{*}{7} & \multirow{4}{*}{5} & \multirow{4}{*}{1} & \multirow[b]{3}{*}{17} & \multirow[b]{3}{*}{15} & \multirow{4}{*}{15} & \multirow{4}{*}{12} & \multirow{4}{*}{14} \\
\hline & & & & & & & & & \\
\hline & & & & & & & & & \\
\hline на автомобильных до- & & & & & & & & & \\
\hline $\begin{array}{l}\text { рогах и улицах - всего, } \\
\text { тыс. }\end{array}$ & 175 & 158 & 223 & 199 & 204 & 200 & 184 & 174 & 169 \\
\hline в том числе по вине & & & & & & & & & \\
\hline $\begin{array}{l}\text { водителей транс- } \\
\text { портных средств }\end{array}$ & & & & & & & & & \\
\hline в состоянии алко- & & 213 & 196 & 118 & 136 & 165 & $15 ?$ & 156 & 140 \\
\hline морском ${ }^{3)}$ & 31 & 20 & $\begin{array}{r}19,0 \\
41\end{array}$ & $\begin{array}{r}11,0 \\
25\end{array}$ & 33 & 36 & 49 & $\begin{array}{r}10,0 \\
47\end{array}$ & 49 \\
\hline внутреннем водном & 12 & 2 & 4 & 2 & 5 & 4 & 7 & 6 & 5 \\
\hline воздушном & 59 & 17 & 12 & 24 & 30 & 38 & 41 & 52 & 39 \\
\hline $\begin{array}{l}\text { В происшествиях } \\
\text { на транспорте: }\end{array}$ & & & & іггиб & & елове & & & \\
\hline $\begin{array}{l}\text { железнодорожном } \\
\text { общего пользования }\end{array}$ & 24 & 3 & 1 & - & 2 & 8 & 3 & - & 3 \\
\hline $\begin{array}{l}\text { на автомобильных } \\
\text { дорогах и улицах }{ }^{4)} \text { - }\end{array}$ & & & & & & & & & \\
\hline всего, тыс. & 35,6 & 29,6 & 34,0 & 26,6 & 27,0 & 27,0 & 23,1 & 20,3 & 19,1 \\
\hline $\begin{array}{l}\text { в том числе по вине } \\
\text { водителей транс- } \\
\text { портных средств }\end{array}$ & & & & & & & & & \\
\hline $\begin{array}{l}\text { в состоянии алко- } \\
\text { гольного опьянения }\end{array}$ & $\cdots$ & 4,1 & 3,2 & 2,0 & 2,3 & 3,4 & 3,7 & 4,6 & 4,3 \\
\hline морском ${ }^{3)}$ & 2 & 1 & - & 10 & 1 & 2 & 12 & 9 & 6 \\
\hline внутреннем водном & 23 & 7 & 16 & 3 & 11 & 3 & 5 & 2 & 2 \\
\hline воздушном & 310 & 20 & 56 & 34 & 102 & 59 & 60 & 59 & 50 \\
\hline
\end{tabular}


Продолжение табл. 20.6

\begin{tabular}{l|r|r|r|r|r|r|r|r|r}
\hline & 1994 & 2000 & 2005 & 2010 & 2013 & 2014 & 2015 & 2016 & 2017 \\
\hline & & & & & & \\
В происшествиях \\
на транспорте:
\end{tabular}

1) По данным ОАО «РЖД» (до 2013 г.), МВД России, Росавиации, Ространснадзора.

2) Транспортные происшествия и иные, связанные с нарушением правил безопасности движения и эксплуатации железнодорожного транспорта, события, имевшие место на железнодорожных путях общего пользования; до 2013 г. учитывались происшествия только по вине ОАО "РЖД".

3) С 2014 г. с учетом происшествий с судами смешанного (река-море) плавания.

4) С 2010 г. погибшим в результате ДТП считается лицо, погибшее на месте дТП, либо умершее в течение 30 последующих суток (до 2009 г. - в течение 7 суток). 


\section{1. ИНФОРМАЦИОННЫЕ И КОММУНИКАЦИОННЫЕ ТЕХНОЛОГИИ}

Раздел содержит статистическую информацию об использовании информационных и коммуникационных технологий в организациях практически всех видов экономической деятельности (данные приведены по кругу обследуемых организаций (без субъектов малого предпринимательства), домашних хозяйствах.

Информация о доступности телекоммуникационных услуг приведена по данным Минкомсвязи о деятельности операторов связи ${ }^{1)}$ - юридических лиц или индивидуальных предпринимателей, оказывающих услуги связи на основании соответствующей лицензии.

Под информационными и коммуникационными технологиями (ИКТ) понимаются технологии, использующие средства микроэлектроники для сбора, хранения, обработки, поиска, передачи и представления данных, текстов, образов и звука.

Глобальная информационная сеть охватывает совокупность электронно-вычислительных машин (ЭВМ) и/или их локальных сетей, которые могут быть расположены в любых точках земного шара, связанных между собой каналами дальней связи (коммутируемыми или выделенными), предоставляемыми телефонными компаниями или другими организациями связи. Глобальная информационная сеть обеспечивает пользователям возможность обмениваться информацией, совместно использовать технические и программные средства, информационные ресурсы. Глобальная сеть может быть как общедоступной (Интернет), так и специализированной (корпоративной или ведомственной - Интранет, Экстранет).

Интернет - глобальное (всемирное) множество независимых компьютерных сетей, соединенных между собой для обмена информацией по стандартным открытым протоколам.

Широкополосный доступ к сети Интернет - доступ к сети Интернет со скоростью передачи данных 256 кбит/сек и выше. 
Интранет - распределенная корпоративная вычислительная сеть, базирующаяся на технологиях Интернета и предназначенная для обеспечения доступа сотрудников к корпоративным информационным электронным ресурсам.

Экстранет - расширение Интранета, содержащее выделенные области, к которым разрешен доступ внешним пользователям. Например, частичное предоставление внешним пользователям доступа к корпоративным данным о движении их заказов или о наличии продукции на складе.

Локальная вычислительная сеть соединяет две или более ЭВМ (возможно, разного типа), а также принтеры, сканеры, системы сигнализации (охранной, пожарной) и другое производственное оборудование или периферийные устройства, расположенные в пределах одного или нескольких соседних зданий, и не использует для этого средства связи общего назначения.

Затраты на информационные и коммуникационные технологии представляют собой выраженные в денежной форме фактические расходы организации, связанные с закупкой вычислительной техники и программного обеспечения, оплатой услуг связи, обучением сотрудников разработке и применению ИКТ, оплатой услуг сторонних организаций и специалистов, а также прочие расходы на ИКТ, включая затраты организации на разработку программных средств собственными силами. В составе затрат на ИКТ учитываются текущие и капитальные затраты обследованных организаций (без субъектов малого предпринимательства).

Подвижная связь - совокупность технических средств (радиооборудование, коммутационное оборудование, соединительные линии и сооружения), с помощью которых можно предоставить подвижным абонентам связь между собой и с абонентами телефонной сети общего пользования.

1) Ст. 2 Федерального закона от 07.07.2003 № 126-ФЗ «О связи» (с изменениями).

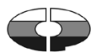


21.1. ИСПОЛЬЗОВАНИЕ ИНФОРМАЦИОННЫХ И КОММУНИКАЦИОННЫХ ТЕХНОЛОГИЙ В ОРГАНИЗАЦИЯХ

(в процентах от общего числа обследованных организаций)

\begin{tabular}{|c|c|c|c|c|c|c|}
\hline & 2005 & 2010 & 2013 & 2014 & 2015 & 2016 \\
\hline \multicolumn{7}{|l|}{$\begin{array}{l}\text { Организации, использо- } \\
\text { вавшие: } \\
\text { персональные }\end{array}$} \\
\hline компьютеры & 91,1 & 93,8 & 94,0 & 93,8 & 92,3 & 92,4 \\
\hline серверы $^{1}{ }^{r}$ & 9,3 & 18,2 & 19,7 & 26,6 & 47,7 & 50,8 \\
\hline $\begin{array}{l}\text { локальные вычисли- } \\
\text { тельные сети }\end{array}$ & 52,4 & 68,4 & 73,4 & 67,2 & 63,5 & 62,3 \\
\hline $\begin{array}{l}\text { электронную почту } \\
\text { глобальные информа- }\end{array}$ & 56,0 & 81,9 & 86,5 & 84,2 & 84,0 & 87,6 \\
\hline $\begin{array}{l}\text { ционные сети } \\
\text { из них сеть: }\end{array}$ & 54,3 & 83,4 & 88,7 & 89,8 & 89,0 & 89,6 \\
\hline $\begin{array}{l}\text { Интернет } \\
\text { в том числе } \\
\text { широкополосный }\end{array}$ & 53,3 & 82,4 & 88,1 & 89,0 & 88,1 & 88,7 \\
\hline доступ & $\cdots$ & 56,7 & 79,4 & 81,2 & 79,5 & 81,8 \\
\hline Интранет & $\ldots$ & 13,1 & 16,7 & 16,8 & 19,2 & 21,6 \\
\hline Экстранет & $\ldots$ & 5,3 & 7,7 & 14,3 & 16,9 & 15,0 \\
\hline $\begin{array}{l}\text { Организации, имевшие } \\
\text { Web-сайты в сети }\end{array}$ & & & & & & \\
\hline Интернет & 14,8 & 28,5 & 41,3 & 40,3 & 42,6 & 45,9 \\
\hline
\end{tabular}

${ }^{1)}$ До 2015 г. - ЭВМ других типов.

21.2. ИСПОЛЬЗОВАНИЕ ИНФОРМАЦИОННЫХ И

КОММУНИКАЦИОННЫХ ТЕХНОЛОГИЙ В ОРГАНИЗАЦИЯХ ПО ВИДАМ ЭКОНОМИЧЕСКОЙ ДЕЯТЕЛЬНОСТИ В 2016 г.

(в процентах от общего числа обследованных организаций соответствующего вида деятельности)

\begin{tabular}{|c|c|c|c|c|c|c|c|}
\hline & \multicolumn{7}{|c|}{ Организации, использовавшие } \\
\hline & $\begin{array}{l}\text { персо- } \\
\text { наль- } \\
\text { ные } \\
\text { компь- } \\
\text { ютеры }\end{array}$ & $\begin{array}{c}\text { серве- } \\
\text { ры }\end{array}$ & \begin{tabular}{|c|} 
локаль- \\
ные \\
вы- \\
числи- \\
тель- \\
ные \\
сети
\end{tabular} & $\begin{array}{l}\text { элек- } \\
\text { трон- } \\
\text { ную } \\
\text { почту }\end{array}$ & \begin{tabular}{|c|} 
гло- \\
баль- \\
ные \\
инфор- \\
ма- \\
цион- \\
ные \\
сети
\end{tabular} & \begin{tabular}{|l|} 
из них \\
сеть \\
Ин- \\
тернет
\end{tabular} & \begin{tabular}{|c} 
в том \\
числе \\
широко- \\
полос- \\
ный дос- \\
туп
\end{tabular} \\
\hline $\begin{array}{l}\text { Всего } \\
\text { Добыча полезных }\end{array}$ & 92,4 & 50,8 & 62,3 & 87,6 & 89,6 & 88,7 & 81,8 \\
\hline $\begin{array}{c}\text { ископаемых } \\
\text { в том числе: } \\
\text { добыча топливно- } \\
\text { энергетических }\end{array}$ & 93,9 & 71,9 & 78,6 & 92,1 & 92,7 & 92,4 & 88,8 \\
\hline $\begin{array}{l}\text { полезных ископаемых } \\
\text { добыча полезных } \\
\text { ископаемых, кроме } \\
\text { топливно- }\end{array}$ & 94,2 & 73,8 & 82,2 & 92,4 & 92,7 & 92,3 & 89,4 \\
\hline энергетических & 93,5 & 68,4 & 71,8 & 91,5 & 92,7 & 92,6 & 87,8 \\
\hline
\end{tabular}


Продолжение табл.21.2

\begin{tabular}{|c|c|c|c|c|c|c|c|}
\hline & \multicolumn{7}{|c|}{ Организации, использовавшие } \\
\hline & \begin{tabular}{|c|} 
персо- \\
наль- \\
ные \\
компь- \\
ютеры
\end{tabular} & $\begin{array}{c}\text { серве- } \\
\text { ры }\end{array}$ & \begin{tabular}{|c|} 
локаль- \\
ные \\
вы- \\
числи- \\
тель- \\
ные \\
сети
\end{tabular} & $\begin{array}{l}\text { элек- } \\
\text { трон- } \\
\text { ную } \\
\text { почту }\end{array}$ & \begin{tabular}{|c|} 
гло- \\
баль- \\
ные \\
инфор- \\
ма- \\
цион- \\
ные \\
сети \\
\end{tabular} & \begin{tabular}{|c|} 
из них \\
сеть \\
Ин- \\
тернет \\
\\
\end{tabular} & $\begin{array}{c}\text { в том } \\
\text { числе } \\
\text { широко- } \\
\text { полос- } \\
\text { ный дос- } \\
\text { туп }\end{array}$ \\
\hline $\begin{array}{l}\text { Обрабатывающие } \\
\text { производства }\end{array}$ & 97,0 & 71,3 & 75,5 & 94,4 & 96,0 & 95,6 & 91,3 \\
\hline $\begin{array}{l}\quad \text { из них: } \\
\text { производство пище- } \\
\text { вых продуктов, } \\
\text { включая напитки, }\end{array}$ & & & & & & & \\
\hline $\begin{array}{l}\text { и табака } \\
\text { текстильное и швей- }\end{array}$ & 97,0 & 79,5 & 80,1 & 94,0 & 96,0 & 95,9 & 91,9 \\
\hline $\begin{array}{l}\text { ное производство } \\
\text { производство кожи, }\end{array}$ & 95,7 & 62,3 & 69,3 & 91,6 & 93,8 & 93,8 & 87,4 \\
\hline $\begin{array}{l}\text { изделий из кожи и } \\
\text { производство обуви } \\
\text { обработка древесины }\end{array}$ & 94,4 & 71,3 & 69,4 & 91,7 & 92,6 & 92,6 & 89,8 \\
\hline $\begin{array}{l}\text { и производство изде- } \\
\text { лий из дерева }\end{array}$ & 93,5 & 69,0 & 70,5 & 91,5 & 92,5 & 92,3 & 86,0 \\
\hline $\begin{array}{l}\text { целлюлозно- } \\
\text { бумажное производ- } \\
\text { ство; издательская и } \\
\text { полиграфическая }\end{array}$ & & & & & & & \\
\hline деятельность & 98,4 & 47,7 & 60,9 & 95,5 & 97,6 & 97,6 & 89,5 \\
\hline $\begin{array}{l}\text { производство кокса и } \\
\text { нефтепродуктов }\end{array}$ & 95,7 & 84,7 & 84,7 & 94,5 & 95,1 & 95,1 & 93,3 \\
\hline химическое произ- & & & & & & & \\
\hline $\begin{array}{l}\text { водство } \\
\text { производство рези- }\end{array}$ & 97,6 & 80,4 & 80,4 & 95,9 & 97,0 & 97,0 & 93,9 \\
\hline $\begin{array}{l}\text { новых и пластмассо- } \\
\text { вых изделий }\end{array}$ & 97,5 & 80,1 & 78,6 & 95,0 & 96,8 & 96,8 & 93,5 \\
\hline $\begin{array}{l}\text { производство прочих } \\
\text { неметаллических }\end{array}$ & & & & & & & \\
\hline $\begin{array}{l}\text { минеральных про- } \\
\text { дуктов }\end{array}$ & 97,7 & 79,1 & 80,1 & 95,0 & 96,6 & 96,5 & 92,5 \\
\hline $\begin{array}{l}\text { металлургическое } \\
\text { производство и про- } \\
\text { изводство готовых }\end{array}$ & & & & & & & \\
\hline металлических & & & & & & & \\
\hline изделий & 96,5 & 80,1 & 79,7 & 94,5 & 96,1 & 96,0 & 93,2 \\
\hline $\begin{array}{l}\text { производство машин } \\
\text { и оборудования }\end{array}$ & 97,3 & 71,1 & 76,3 & 94,1 & 95,0 & 93,9 & 90,3 \\
\hline $\begin{array}{l}\text { производство элек- } \\
\text { трооборудования, } \\
\text { электронного и }\end{array}$ & & & & & & & \\
\hline $\begin{array}{l}\text { оптического } \\
\text { оборудования }\end{array}$ & 97,6 & 81.9 & 84.3 & 960 & 969 & 968 & 948 \\
\hline производство транс- & & & & & & & \\
\hline оборудования & 93,6 & 70,3 & 76,3 & 91,4 & 92,5 & 90,1 & 87,4 \\
\hline & & & & & & & \\
\hline
\end{tabular}


Продолжение табл.21.2

\begin{tabular}{|c|c|c|c|c|c|c|c|}
\hline & \multicolumn{7}{|c|}{ Организации, использовавшие } \\
\hline & $\begin{array}{l}\text { персо- } \\
\text { наль- } \\
\text { ные } \\
\text { компь- } \\
\text { ютеры }\end{array}$ & $\begin{array}{c}\text { серве- } \\
\text { ры }\end{array}$ & \begin{tabular}{|c|} 
локаль- \\
ные \\
вы- \\
числи- \\
тель- \\
ные \\
сети
\end{tabular} & $\begin{array}{l}\text { элек- } \\
\text { трон- } \\
\text { ную } \\
\text { почту }\end{array}$ & \begin{tabular}{|c|} 
гло- \\
баль- \\
ные \\
инфор- \\
ма- \\
цион- \\
ные \\
сети \\
\end{tabular} & \begin{tabular}{|c|} 
из них \\
сеть \\
Ин- \\
тернет \\
\end{tabular} & $\begin{array}{c}\text { в том } \\
\text { числе } \\
\text { широко- } \\
\text { полос- } \\
\text { ный дос- } \\
\text { туп }\end{array}$ \\
\hline $\begin{array}{l}\text { Производство и рас- } \\
\text { пределение электро- } \\
\text { энергии, газа и воды }\end{array}$ & 93,1 & 55,0 & 65,7 & 89,0 & 90,2 & 88,7 & 80,1 \\
\hline $\begin{array}{l}\text { Строительство } \\
\text { Оптовая и розничная } \\
\text { торговля; ремонт } \\
\text { автотранспортных } \\
\text { средств, мотоциклов, } \\
\text { бытовых изделий и } \\
\text { педметов иичного }\end{array}$ & 93,0 & 61,6 & 65,0 & 88,9 & 91,2 & 90,4 & 85,0 \\
\hline пользования & 96,9 & 69,2 & 75,4 & 95,0 & 95,7 & 94,4 & 91,6 \\
\hline Гостиницы и рестораны & 88,5 & 50,4 & 54,9 & 81,9 & 83,8 & 83,3 & 75,3 \\
\hline Транспорт и связь & 88,4 & 56,8 & 69,1 & 84,3 & 86,2 & 80,7 & 76,3 \\
\hline из них связь & 96,6 & 72,4 & 82,3 & 94,2 & 95,3 & 92,9 & 89,9 \\
\hline $\begin{array}{l}\text { Финансовая } \\
\text { деятельность }\end{array}$ & 94,7 & 60,9 & 77,5 & 90,4 & 92,0 & 91,7 & 89,3 \\
\hline $\begin{array}{l}\text { Операции с недвижи- } \\
\text { мым имуществом, } \\
\text { аренда и предостав- } \\
\text { ление услуг }\end{array}$ & 79,8 & 42,6 & 48,3 & 74,9 & 77,2 & 76,5 & 69,9 \\
\hline $\begin{array}{l}\text { из них научные } \\
\text { исследования и } \\
\text { разработки }\end{array}$ & 96,2 & 71,0 & 76,1 & 93,8 & 95,1 & 94,7 & 90,8 \\
\hline $\begin{array}{l}\text { Государственное } \\
\text { управление и обеспе- } \\
\text { чение военной безо- } \\
\text { пасности; социальное }\end{array}$ & & & & & & & \\
\hline страхование & 98,2 & 45,7 & 64,1 & 93,8 & 95,6 & 95,2 & 85,0 \\
\hline $\begin{array}{l}\text { Высшее профессио- } \\
\text { нальное образование }\end{array}$ & 97,4 & 73,8 & 81,6 & 95,4 & 96,7 & 96,7 & 93,9 \\
\hline $\begin{array}{l}\text { Здравоохранение и } \\
\text { предоставление } \\
\text { социальных услуг }\end{array}$ & 97,7 & 59,9 & 78,0 & 94,5 & 96,2 & 96,1 & 89,9 \\
\hline $\begin{array}{l}\text { Деятельность по орга- } \\
\text { низации отдыха и раз- } \\
\text { влечений, культуры и } \\
\text { спорта }\end{array}$ & 90,7 & 23,3 & 36,6 & 78,1 & 82,5 & 82,3 & 71,7 \\
\hline $\begin{array}{l}\text { Другие виды деятель- } \\
\text { ности }\end{array}$ & 95,9 & 38,1 & 58,5 & 91,9 & 93,3 & 93,3 & 82,9 \\
\hline
\end{tabular}




\section{3. ПЕРСОНАЛЬНЫЕ КОМПЬЮТЕРЫ В ОРГАНИЗАЦИЯХ}

\begin{tabular}{|c|c|c|c|c|c|c|}
\hline & 2005 & 2010 & 2013 & 2014 & 2015 & 2016 \\
\hline $\begin{array}{l}\text { पисло персональных } \\
\text { компьютеров в обследо- }\end{array}$ & & & & & & \\
\hline $\begin{array}{l}\text { ванных организациях - } \\
\text { всего, тыс. шт. } \\
\text { из них: }\end{array}$ & 5709,6 & 9288,1 & 11438,0 & 11740,8 & 11992,3 & 12422,1 \\
\hline $\begin{array}{l}\text { в составе локальных } \\
\text { вычислительных сетей }\end{array}$ & 4057,6 & 7480,2 & 9394,5 & $\ldots$ & & \\
\hline $\begin{array}{l}\text { имевшие доступ к гло- } \\
\text { бальным информаци- }\end{array}$ & & & & & & \\
\hline онным сетям & 2032,0 & 4997,1 & 7220,8 & 8157,5 & 8362,0 & 8782,2 \\
\hline $\begin{array}{l}\text { Интернет } \\
\text { Поступило персональ- }\end{array}$ & 1686,1 & 4553,3 & 6764,4 & 7277,6 & 7561,5 & 8117,9 \\
\hline $\begin{array}{l}\text { ных компьютеров } \\
\text { в отчетном году, тыс. шт. } \\
\text { Число персональных }\end{array}$ & 984,2 & 999,9 & 1351,5 & 1177,7 & 952,2 & 986,7 \\
\hline $\begin{array}{l}\text { компьютеров на } 100 \text { ра- } \\
\text { ботников - всего, шт. }\end{array}$ & 23 & 36 & 44 & 47 & 49 & 49 \\
\hline пом к сети Интернет & 7 & 18 & 26 & 29 & 31 & 32 \\
\hline
\end{tabular}

21.4. ОРГАНИЗАЦИИ, ИМЕВШИЕ WЕВ-САЙТ, ПО ВИДАМ ЭКОНОМИЧЕСКОЙ ДЕЯТЕЛЬНОСТИ (в процентах от общего числа обследованных организаций соответствующего вида деятельности)

\begin{tabular}{|c|c|c|c|c|c|c|}
\hline & 2005 & 2010 & 2013 & 2014 & 2015 & 2016 \\
\hline $\begin{array}{l}\text { Всего } \\
\text { Добыча полезных }\end{array}$ & 14,8 & 28,5 & 41,3 & 40,3 & 42,6 & 45,9 \\
\hline & 16,4 & 27,9 & 36,8 & 34,5 & 37,2 & 41,0 \\
\hline $\begin{array}{l}\text { добыча топливно- } \\
\text { энергетических }\end{array}$ & & & & & & \\
\hline $\begin{array}{l}\text { полезных ископаемых } \\
\text { добыча полезных ис- } \\
\text { копаемых кроме топ- }\end{array}$ & 16,6 & 25,4 & 35,1 & 32,9 & 35,2 & 39,9 \\
\hline $\begin{array}{l}\text { копаемых, кроме топ- } \\
\text { ливно-энергетических } \\
\text { обрабатывающие }\end{array}$ & 16,2 & 31,5 & 39,4 & 37,4 & 40,9 & 43,1 \\
\hline $\begin{array}{c}\text { производства } \\
\text { из них: }\end{array}$ & 29,5 & 50,8 & 57,9 & 55,9 & 57,5 & 62,3 \\
\hline $\begin{array}{l}\text { производство пище- } \\
\text { вых продуктов, вклю- } \\
\text { чая напити и табака }\end{array}$ & 222 & 42.7 & 50.3 & 48.7 & 53.4 & 57.2 \\
\hline $\begin{array}{l}\text { текстильное и швей- } \\
\text { ное производство }\end{array}$ & 16,2 & 40,5 & 47,7 & 51,6 & 53,4 & 56,8 \\
\hline $\begin{array}{l}\text { производство кожи, } \\
\text { изделий из кожи }\end{array}$ & & & & & & \\
\hline и производство обуви & 28,7 & 43,4 & 52,6 & 48,2 & 49,0 & 52,8 \\
\hline $\begin{array}{l}\text { и производство } \\
\text { изделий из дерева } \\
\text { целлюлозно-бумажное } \\
\text { производство; изда- }\end{array}$ & 19,2 & 37,5 & 38,3 & 42,5 & 45,1 & 51,8 \\
\hline $\begin{array}{l}\text { тельская и полиграфи- } \\
\text { ческая деятельность }\end{array}$ & 19,4 & 37,1 & 51,9 & 50,1 & 51,0 & 57,8 \\
\hline
\end{tabular}

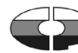


Продолжение табл. 21.4

\begin{tabular}{|c|c|c|c|c|c|c|}
\hline & 2005 & 2010 & 2013 & 2014 & 2015 & 2016 \\
\hline производство коКса & & & & & & \\
\hline и нефтепродуктов & 43,5 & 40,2 & 49,5 & 47,1 & 56,1 & 58,9 \\
\hline $\begin{array}{l}\text { химическое производ- } \\
\text { ство }\end{array}$ & 48,2 & 64,2 & 65.7 & 63.9 & 62.9 & 68.6 \\
\hline производство резино- & 40,2 & 04,2 & & & & \\
\hline $\begin{array}{l}\text { вых и пластмассовых } \\
\text { изделий }\end{array}$ & 44,1 & 62,9 & 66,7 & 61,9 & 62,4 & 65,0 \\
\hline производство прочих & & & & & & \\
\hline $\begin{array}{l}\text { неметаллических ми- } \\
\text { неральных продуктов }\end{array}$ & 32,4 & 58,3 & 62,7 & 60,1 & 62,5 & 68,0 \\
\hline $\begin{array}{l}\text { металлургическое } \\
\text { производство готовых }\end{array}$ & & & & & & \\
\hline $\begin{array}{l}\text { металлических изде- } \\
\text { лий }\end{array}$ & 39,8 & 61,6 & 66,9 & 63,8 & 67,5 & 70,8 \\
\hline $\begin{array}{l}\text { производство машин } \\
\text { и оборудования }\end{array}$ & 35,7 & 60.0 & 65,9 & 60.8 & 60,8 & 63,5 \\
\hline $\begin{array}{l}\text { производство электро- } \\
\text { оборудования, элек- }\end{array}$ & 35,1 & 00,0 & 05,9 & 00,0 & 00,0 & 00,0 \\
\hline $\begin{array}{l}\text { тронного и оптическо- } \\
\text { го оборудования } \\
\text { производство транс- }\end{array}$ & 47,9 & 67,3 & 72,1 & 67,2 & 67,4 & 73,0 \\
\hline $\begin{array}{l}\text { портных средств } \\
\text { и оборудования }\end{array}$ & 433 & 579 & 592 & 568 & 538 & 563 \\
\hline Производство и распре- & & 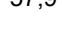 & 3,2 & 00,0 & 30,0 & 00,0 \\
\hline деление электроэнер- & & & & & & \\
\hline $\begin{array}{l}\text { Гии, газа и воды } \\
\text { Строительство }\end{array}$ & $\begin{array}{l}10,2 \\
13,7\end{array}$ & $\begin{array}{l}24,0 \\
31,2\end{array}$ & $\begin{array}{l}35,7 \\
38,7\end{array}$ & $\begin{array}{l}34,2 \\
37,1\end{array}$ & $\begin{array}{l}38,6 \\
40,1\end{array}$ & $\begin{array}{l}41,8 \\
41,0\end{array}$ \\
\hline $\begin{array}{l}\text { Оптовая и розничная } \\
\text { торговля; ремонт авто- } \\
\text { транспортных средств, }\end{array}$ & & & & & & \\
\hline $\begin{array}{l}\text { мотоциклов, бытовых } \\
\text { изделий и предметов }\end{array}$ & & & & & & \\
\hline личного пользования & 14,2 & 35,7 & 43,9 & 48,5 & 53,3 & 53,5 \\
\hline Гостиницы и рестораны & 13,3 & 28,5 & 36,8 & 38,2 & 42,2 & 44,4 \\
\hline $\begin{array}{l}\text { Транспорт и связь } \\
\text { из них связь }\end{array}$ & $\begin{array}{l}16,7 \\
42,9\end{array}$ & $\begin{array}{l}30,8 \\
62,5\end{array}$ & $\begin{array}{l}36,7 \\
67,8\end{array}$ & $\begin{array}{l}35,5 \\
63,6\end{array}$ & $\begin{array}{l}36,9 \\
62,1\end{array}$ & $\begin{array}{l}37,7 \\
60,9\end{array}$ \\
\hline $\begin{array}{l}\text { Финансовая деятель- } \\
\text { ность }\end{array}$ & 38,8 & 54,9 & 62,9 & 60,7 & 61,6 & 64,7 \\
\hline & & & & & & \\
\hline $\begin{array}{l}\text { аренда и предоставле- } \\
\text { ние услуг } \\
\text { из них научные }\end{array}$ & 15,5 & 26,4 & 31,7 & 29,9 & 29,7 & 31,7 \\
\hline $\begin{array}{l}\text { исследования и } \\
\text { разработки }\end{array}$ & 41,8 & 63,7 & 68,8 & 64,5 & 66,8 & 69,3 \\
\hline $\begin{array}{l}\text { Государственное управ- } \\
\text { ление и обеспечение }\end{array}$ & & & & & & \\
\hline $\begin{array}{l}\text { военной безопасности; } \\
\text { социальное страхование } \\
\text { Высшее профессио- }\end{array}$ & 8,2 & 24,6 & 42,4 & 39,3 & 40,9 & 45,2 \\
\hline $\begin{array}{l}\text { нальное образование } \\
\text { Здравоохранение }\end{array}$ & 50,4 & 77,2 & 82,4 & 77,2 & 78,7 & 80,9 \\
\hline и предоставление & & & & & & \\
\hline $\begin{array}{l}\text { социиальных услуг } \\
\text { Деятельность по органи- }\end{array}$ & 7,4 & 18,1 & 50,6 & 52,7 & 59,0 & 64,9 \\
\hline $\begin{array}{l}\text { зации отдыха и развле- } \\
\text { чений, культуры и спорта }\end{array}$ & 11,2 & 14,9 & 26,9 & 27,7 & 32,0 & 37,3 \\
\hline Другие виды деятельности & $4, \overline{9}$ & 8,2 & 16,9 & 16,5 & 17,1 & 18,5 \\
\hline
\end{tabular}


21.5. РАСПРЕДЕЛЕНИЕ ЗАТРАТ ОРГАНИЗАЦИЙ НА ИНФОРМАЦИОННЫЕ И КОММУНИКАЦИОННЫЕ ТЕХНОЛОГИИ ПО ВИДАМ

(млрд. рублей)

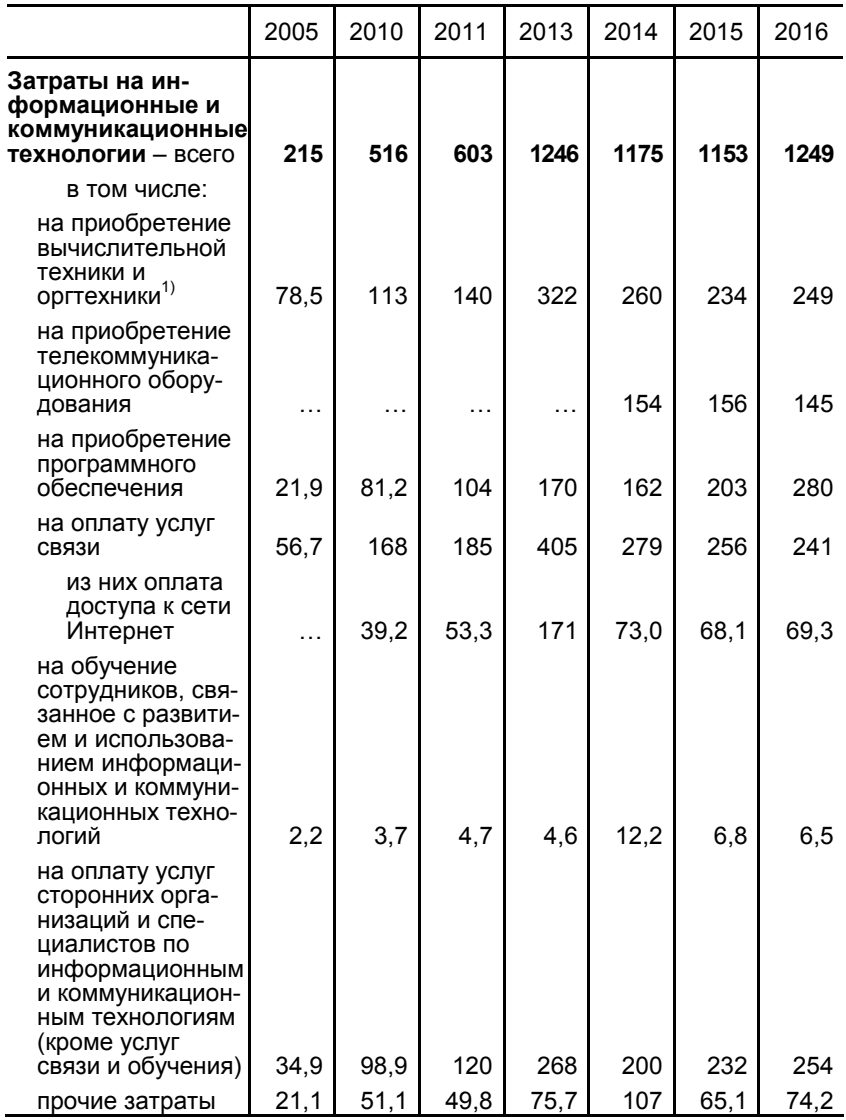

1) До 2014 г. - на приобретение вычислительной техники. 
21.6. РАСПРЕДЕЛЕНИЕ ЗАТРАТ ОРГАНИЗАЦИЙ

НА ИНФОРМАЦИОННЫЕ И КОММУНИКАЦИОННЫЕ ТЕХНОЛОГИИ

ПО ВИДАМ ЭКОНОМИЧЕСКОЙ ДЕЯТЕЛЬНОСТИ в 2016 Г.

(в процентах к итогу соответствующего вида деятельности)

\begin{tabular}{|c|c|c|c|c|c|c|c|c|c|}
\hline & \multirow[b]{2}{*}{\begin{tabular}{|c|} 
За- \\
траты \\
на \\
икT- \\
всего \\
\\
\\
\\
\end{tabular}} & \multicolumn{8}{|c|}{ в том числе } \\
\hline & & \begin{tabular}{|c} 
на \\
при- \\
обре- \\
тение \\
вы- \\
числи- \\
тельь- \\
ной \\
техни- \\
ки \\
и орг- \\
техни- \\
ки
\end{tabular} & \begin{tabular}{|c|} 
на \\
при- \\
обре- \\
тение \\
теле-- \\
ком- \\
муни- \\
каци- \\
онно- \\
го \\
обо- \\
рудо- \\
вания
\end{tabular} & $\begin{array}{c}\text { на } \\
\text { при- } \\
\text { обре- } \\
\text { тение } \\
\text { про- } \\
\text { грам- } \\
\text { много } \\
\text { обес- } \\
\text { пече- } \\
\text { ния }\end{array}$ & $\begin{array}{c}\text { на оп- } \\
\text { лату } \\
\text { услуг } \\
\text { связи } \\
\end{array}$ & \begin{tabular}{|c|} 
из них \\
опла- \\
та \\
дос- \\
тупа к \\
сети \\
Ин- \\
тер- \\
нет
\end{tabular} & $\begin{array}{c}\text { на } \\
\text { обу- } \\
\text { чение } \\
\text { со-- } \\
\text { труд- } \\
\text { ников, } \\
\text { свя- } \\
\text { зан- } \\
\text { ное с } \\
\text { раз- } \\
\text { вити- } \\
\text { ем и } \\
\text { ис- } \\
\text { поль- } \\
\text { зова- } \\
\text { нием } \\
\text { ИкТ }\end{array}$ & \begin{tabular}{|c} 
на оп- \\
лату \\
услуг \\
сто- \\
рон- \\
них \\
орга- \\
низа- \\
ций и \\
спе- \\
циа- \\
лис- \\
тов \\
икт \\
кро- \\
ме ус- \\
луг \\
связи \\
и обу- \\
чения)
\end{tabular} & $\begin{array}{c}\text { про- } \\
\text { чие } \\
\text { затра- } \\
\text { ты }\end{array}$ \\
\hline Всего & 100 & 20,0 & 11,6 & 22,4 & 19,3 & 5,5 & 0,5 & 20,3 & 5,9 \\
\hline $\begin{array}{c}\text { Добыча полезных } \\
\text { ископаемых } \\
\text { в том числе: } \\
\text { добыча топлив- } \\
\text { но-энергети- } \\
\text { ческих полезных }\end{array}$ & 100 & 13,6 & 3,6 & 12,7 & 15,1 & 2,5 & 0,5 & 50,4 & 4,0 \\
\hline $\begin{array}{l}\text { ископаемых } \\
\text { добыча полез- } \\
\text { ных ископае- } \\
\text { мых, кроме топ- } \\
\text { ливно-энерге- } \\
\text { тических }\end{array}$ & 100 & 12,4 & 3,5 & 11,2 & 13,2 & 1,7 & 0,6 & 54,9 & 4,2 \\
\hline $\begin{array}{c}\text { Обрабатывающие } \\
\text { производства } \\
\text { из них: } \\
\text { производство } \\
\text { пищевых про- } \\
\text { дуктов, включая } \\
\text { напитки, и таба- }\end{array}$ & 100 & 17,7 & 6,1 & 20,4 & 18,1 & 6,5 & 0,7 & 32,3 & 4,6 \\
\hline $\begin{array}{l}\text { ка } \\
\text { текстильное и } \\
\text { швейное произ- }\end{array}$ & 100 & 20,6 & 4,2 & 18,6 & 29,6 & 10,4 & 0,2 & 22,9 & 3,9 \\
\hline $\begin{array}{l}\text { водство } \\
\text { производство } \\
\text { кожи, изделий } \\
\text { из кожи и про- } \\
\text { изводство обуви }\end{array}$ & 100 & 29,6 & 3,9 & 14,4 & 30,3 & 10,4 & 0,2 & 19,2 & 2,4 \\
\hline
\end{tabular}


Продолжение табл. 21.6

\begin{tabular}{|c|c|c|c|c|c|c|c|c|c|}
\hline & \multirow[b]{2}{*}{\begin{tabular}{|c|} 
3а- \\
траты \\
на \\
икТ- \\
всего \\
\\
\\
\end{tabular}} & \multicolumn{8}{|c|}{ в том числе } \\
\hline & & \begin{tabular}{|c|} 
на \\
при- \\
обре- \\
тение \\
вы- \\
числи- \\
тель- \\
ной \\
техни- \\
ки \\
и орг- \\
техни- \\
ки
\end{tabular} & \begin{tabular}{|c|} 
на \\
при- \\
обре-- \\
тение \\
теле-- \\
ком- \\
муни- \\
каци- \\
онно- \\
го \\
обо- \\
рудо- \\
вания
\end{tabular} & \begin{tabular}{|c|} 
на \\
при- \\
обре- \\
тение \\
про- \\
грам- \\
много \\
обес- \\
пече- \\
ния
\end{tabular} & \begin{tabular}{|c|} 
на оп- \\
лату \\
услуг \\
связи \\
\\
\\
\\
\end{tabular} & \begin{tabular}{|c|} 
из них \\
опла- \\
та \\
дос- \\
тупа к \\
сети \\
Ин- \\
тер- \\
нет
\end{tabular} & $\begin{array}{c}\text { на } \\
\text { обу- } \\
\text { чение } \\
\text { со- } \\
\text { труд- } \\
\text { ников, } \\
\text { свя- } \\
\text { зан- } \\
\text { ное с } \\
\text { раз- } \\
\text { вити- } \\
\text { ем и } \\
\text { ис- } \\
\text { поль- } \\
\text { зова- } \\
\text { нием } \\
\text { ИкТ }\end{array}$ & \begin{tabular}{|c} 
на оп- \\
лату \\
услуг \\
сто- \\
рон- \\
них \\
орга- \\
низа- \\
ций и \\
спе- \\
циа- \\
лис- \\
тов \\
икТ \\
(кро- \\
ме \\
услуг \\
связи \\
и обу- \\
чения)
\end{tabular} & $\begin{array}{l}\text { про- } \\
\text { чие } \\
\text { затра- } \\
\text { ты }\end{array}$ \\
\hline $\begin{array}{l}\text { обработка дре- } \\
\text { весины и произ- } \\
\text { водство изде- } \\
\text { лий из дерева } \\
\text { целлюлозно- } \\
\text { бумажное про- } \\
\text { изводство; изда- } \\
\text { тельская и поли- } \\
\text { графическая }\end{array}$ & 100 & 16,4 & 3,4 & 12,8 & 25,1 & 8,1 & 0,1 & 39,8 & 2,4 \\
\hline $\begin{array}{l}\text { деятельность } \\
\text { производство } \\
\text { кокса и нефте- } \\
\text { продуктов }\end{array}$ & 100 & 6,3 & 2,7 & 14,6 & 4,2 & 0,4 & 2,4 & 68,3 & 1,5 \\
\hline $\begin{array}{l}\text { химическое про- } \\
\text { изводство } \\
\text { производство } \\
\text { резиновых и } \\
\text { пластмассовых } \\
\text { изделий }\end{array}$ & 100 & 27,7 & 4,6 & 25,4 & 10,3 & 3,6 & 0,6 & 28,5 & 2,9 \\
\hline $\begin{array}{l}\text { производство } \\
\text { прочих неме-- } \\
\text { таллических } \\
\text { минеральных } \\
\text { продуктов }\end{array}$ & 100 & 14,3 & 2,9 & 16,6 & 32,0 & 13,0 & 0,3 & 24,1 & 9,8 \\
\hline $\begin{array}{l}\text { металлургиче- } \\
\text { ское производ- } \\
\text { ство и произ- } \\
\text { водство гото- } \\
\text { вых металличе- } \\
\text { ских изделий }\end{array}$ & 100 & 14,7 & 4,0 & 21,4 & 14,7 & 2,9 & 0,2 & 42,1 & 2,9 \\
\hline
\end{tabular}


Продолжение табл. 21.6

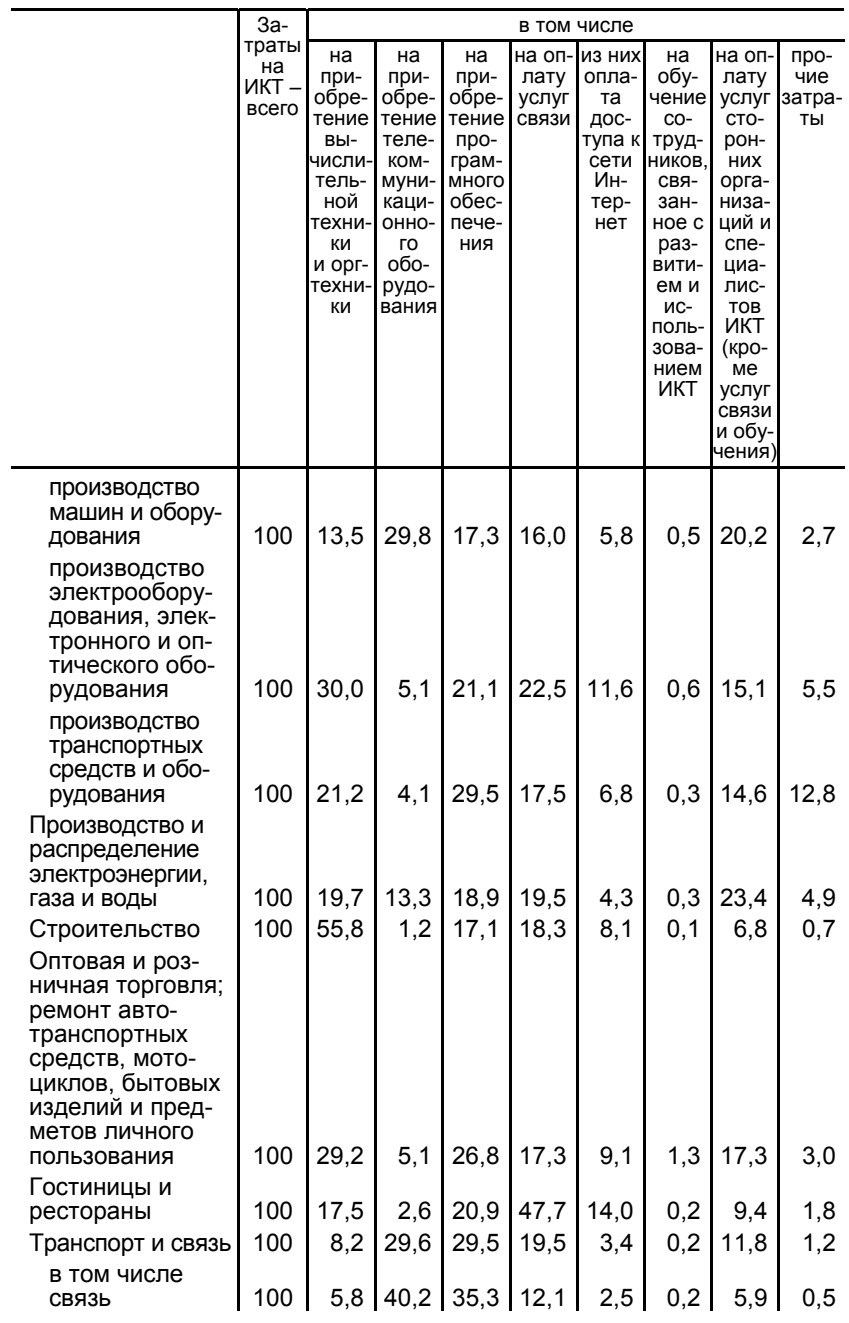


Продолжение табл. 21.6

\begin{tabular}{|c|c|c|c|c|c|c|c|c|c|}
\hline & \multirow{2}{*}{\begin{tabular}{|c|} 
За- \\
траты \\
на \\
ИкТ - \\
всего
\end{tabular}} & \multicolumn{8}{|c|}{ в том числе } \\
\hline & & \begin{tabular}{|c|} 
на \\
при- \\
обре- \\
тение \\
вы- \\
числи- \\
тель- \\
ной \\
техни- \\
ки \\
и орг- \\
техни- \\
ки
\end{tabular} & $\begin{array}{c}\text { на } \\
\text { при- } \\
\text { обре- } \\
\text { тение } \\
\text { теле- } \\
\text { ком- } \\
\text { муни- } \\
\text { каци- } \\
\text { онно- } \\
\text { го } \\
\text { обо- } \\
\text { рудо- } \\
\text { вания }\end{array}$ & $\begin{array}{c}\text { на } \\
\text { при- } \\
\text { обре- } \\
\text { тение } \\
\text { про- } \\
\text { грам- } \\
\text { много } \\
\text { обес- } \\
\text { пече- } \\
\text { ния }\end{array}$ & \begin{tabular}{|c|} 
на оп- \\
лату \\
услуг \\
связи \\
\\
\end{tabular} & \begin{tabular}{|c|} 
из них \\
опла- \\
та \\
дос- \\
тупа к \\
сети \\
Ин- \\
тер- \\
нет
\end{tabular} & \begin{tabular}{|c|} 
на \\
обу- \\
чение \\
со- \\
труд- \\
ников, \\
свя- \\
зан- \\
ное с \\
раз- \\
вити- \\
ем и \\
ис- \\
поль- \\
зова- \\
нием \\
ИкТ \\
\end{tabular} & \begin{tabular}{|c|} 
на оп- \\
лату \\
услуг \\
сто- \\
рон- \\
них \\
орга- \\
низа- \\
ций и \\
спе- \\
циа- \\
лис- \\
тов \\
икТ \\
(кро- \\
ме \\
услуг \\
связи \\
и обу- \\
чения)
\end{tabular} & $\begin{array}{c}\text { про- } \\
\text { чиe } \\
\text { затра- } \\
\text { ты } \\
\\
\end{array}$ \\
\hline $\begin{array}{l}\text { Финансовая } \\
\text { деятельность }\end{array}$ & 100 & 22,9 & 5,0 & 23,7 & 16,1 & 2,9 & 0,6 & 22,5 & 9,2 \\
\hline $\begin{array}{l}\text { Операции с не- } \\
\text { движимым имуще- } \\
\text { ством, аренда и } \\
\text { предоставление }\end{array}$ & 100 & 209 & 98 & 196 & 130 & 52 & $0_{5}$ & 240 & 120 \\
\hline $\begin{array}{l}\text { в том числе на- } \\
\text { учные исследо- } \\
\text { вания и разра- } \\
\text { ботки }\end{array}$ & 100 & 34,5 & 4,9 & 22,1 & 7,7 & 3,0 & 0,8 & 16,4 & 13,4 \\
\hline $\begin{array}{l}\text { Государственное } \\
\text { управление и } \\
\text { обеспечение во- } \\
\text { енной безопасно- } \\
\text { сти; социальное } \\
\text { страхование }\end{array}$ & 100 & 18,8 & 4,8 & 13,1 & 27,6 & 7,5 & 0,2 & 23,2 & 12,2 \\
\hline $\begin{array}{l}\text { Высшее профес- } \\
\text { сиональное обра- } \\
\text { зование }\end{array}$ & 100 & 35,3 & 10,6 & 16,8 & 15,5 & 7,0 & 0,4 & 16,7 & 4,7 \\
\hline $\begin{array}{l}\text { Здравоохранение } \\
\text { и предоставление } \\
\text { социальных услуг }\end{array}$ & 100 & 24,2 & 1,7 & 14,6 & 28,7 & 12,9 & 0,5 & 23,5 & 6,7 \\
\hline $\begin{array}{l}\text { Деятельность по } \\
\text { организации отды- } \\
\text { ха и развлечений, } \\
\text { культуры и спорта }\end{array}$ & 100 & 17,6 & 9,7 & 7,1 & 56,9 & 12,7 & 0,3 & 6,6 & 1,8 \\
\hline $\begin{array}{l}\text { Другие виды } \\
\text { деятельности }\end{array}$ & 100 & 15,5 & 4,0 & 8,7 & 58,1 & 25,7 & 0,1 & 12,0 & 2,0 \\
\hline
\end{tabular}


21.7. ОСНОВНЫЕ ПОКАЗАТЕЛИ РАЗВИТИЯ ФИКСИРОВАННОГО И МОБИЛЬНОГО ДОСТУПА К СЕТИ ИНТЕРНЕТ ${ }^{1)}$

(на конец года)

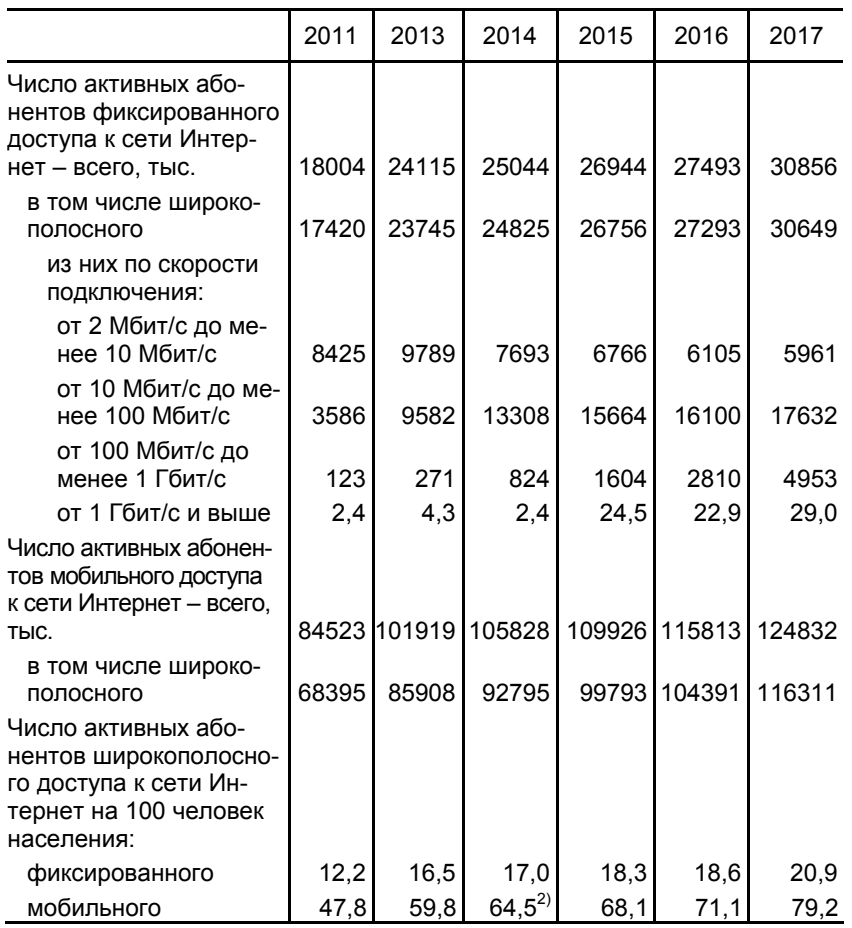

1) По данным Минкомсвязи России.

2) Без учета данных по Крымскому федеральному округу. 


\section{8. ДОМАШНИЕ ХОЗЯЙСТВА, ИМЕЮЩИЕ ДОСТУП К СЕТИ ИНТЕРНЕТ}

(по материалам выборочных обследований населения по вопросам использования ИКТ; в процентах от общего числа домашних хозяйств)

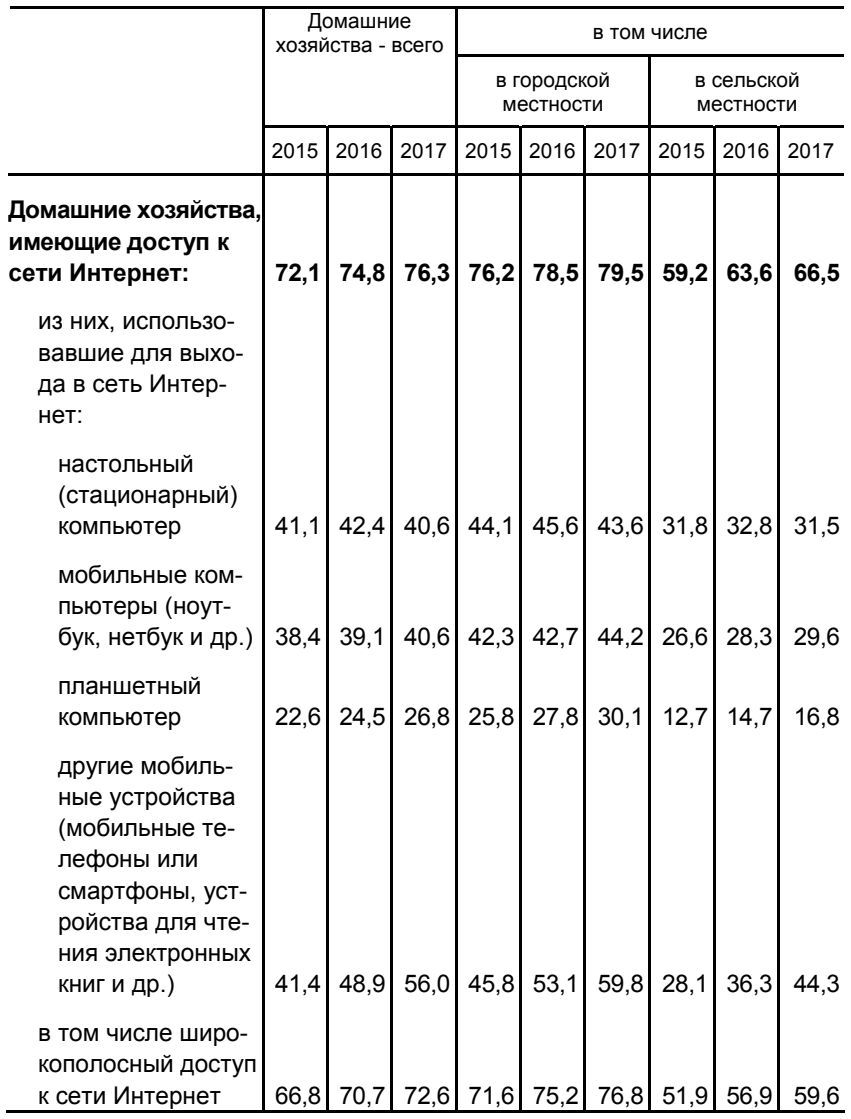

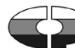


21.9. ИСПОЛЬЗОВАНИЕ НАСЕЛЕНИЕМ СЕТИ ИНТЕРНЕТ

(по материалам выборочных обследований населения по вопросам использования ИКТ; в процентах от общей

численности населения ${ }^{1)}$ )

\begin{tabular}{|c|c|c|c|c|c|c|c|c|c|}
\hline & \multirow{2}{*}{\multicolumn{3}{|c|}{ Все население }} & \multicolumn{6}{|c|}{ в том числе проживающее } \\
\hline & & & & \multicolumn{3}{|c|}{$\begin{array}{l}\text { в городской } \\
\text { местности }\end{array}$} & \multicolumn{3}{|c|}{$\begin{array}{l}\text { в сельской } \\
\text { местности }\end{array}$} \\
\hline & 2015 & 2016 & 2017 & 2015 & 2016 & 2017 & 2015 & 2016 & 2017 \\
\hline $\begin{array}{l}\text { Население, исполь- } \\
\text { зовавшее сеть } \\
\text { Интернет: }\end{array}$ & & & & & & & & & \\
\hline $\begin{array}{l}\text { в течение послед- } \\
\text { них 3-х месяцев }\end{array}$ & 70,1 & 73,1 & 76,0 & 74,1 & 77,1 & 79,2 & 58,1 & 61,1 & 66,3 \\
\hline $\begin{array}{l}\text { от 3-х месяцев до } \\
\text { года }\end{array}$ & 3,3 & 3,3 & 3,8 & 3,2 & 3,0 & 3,7 & 3,7 & 4,4 & 4,4 \\
\hline более года назад & 4,3 & 4,4 & 3,8 & 4,4 & 4,2 & 3,9 & 3,7 & 4,9 & 3,6 \\
\hline $\begin{array}{l}\text { никогда не исполь- } \\
\text { зовали }\end{array}$ & 22,3 & 19,2 & 16,3 & 18,3 & 15,7 & 13,2 & 34,5 & 29,7 & 25,7 \\
\hline $\begin{array}{l}\text { Население, исполь- } \\
\text { зовавшее мобиль- } \\
\text { ные телефо- } \\
\text { ны/смартфоны для } \\
\text { доступа в сеть Ин- } \\
\text { тернет за последние } \\
3 \text { месяца }\end{array}$ & 37,6 & 44,7 & 53,1 & 40,1 & 47,8 & 56,0 & 30,1 & 35,1 & 44,4 \\
\hline $\begin{array}{l}\text { Места использова- } \\
\text { ния населением сети } \\
\text { Интернет за послед- } \\
\text { ние } 3 \text { месяца'): }\end{array}$ & & & & & & & & & \\
\hline дома & 94,7 & 96,0 & 96,3 & 95,7 & 96,8 & 96,9 & 90,8 & 92,8 & 94,1 \\
\hline на работе & 32,7 & 35,4 & 40,5 & 34,7 & 37,5 & 42,8 & 25,4 & 27,3 & 32,0 \\
\hline по месту учебы & 8,6 & 9,0 & 9,6 & 8,4 & 9,0 & 9,7 & 9,1 & 9,0 & 9,2 \\
\hline у друзей, знакомых & 11,7 & 13,9 & 18,5 & 11,8 & 13,9 & 18,5 & 11,3 & 14,1 & 18,6 \\
\hline $\begin{array}{l}\text { в точках общест- } \\
\text { венного доступа } \\
\text { (в гостиницах, } \\
\text { аэропортах, кафе и } \\
\text { т.д.) }\end{array}$ & 10,6 & 12,3 & 19,0 & 12,1 & 14,2 & 21,5 & 4,7 & 5,3 & 9,8 \\
\hline
\end{tabular}

1) В возрасте 15-74 лет, до 2017 г. - в возрасте 15-72 лет.

2) В процентах от общей численности населения, использовавшего сеть Интернет за последние 3 месяца. 


\section{2. НАУКА И ИННОВАЦИИ}

Раздел содержит статистическую информацию о состоянии и развитии научного и инновационного потенциала России.

Данные в таблицах, содержащих показатели по видам экономической деятельности, приводятся за 2017 год в соответствии с Общероссийским классификатором видов экономической деятельности (ОКВЭД 2) ОК 029-2014, введенным в действие с 1 января 2017 г.

Аналогичные сведения за период до 2016 г. включительно, разработанные в соответствии с ранее действовавшим Общероссийским классификатором видов экономической деятельности (ОКВЭД-2007) ОК 029-2007, опубликованы в кратком статистическом сборнике «Россия в цифрах. 2017», электронная версия которого размещена на официальном Интернет-портале Росстата в разделе «Публикации».

Статистические данные охватывают организации, выполнявшие научные исследования и разработки. Указанные организации классифицируются по следующим секторам деятельности: государственный, предпринимательский, высшего образования, некоммерческих организаций.

В состав государственного сектора входят: организации министерств и ведомств, обеспечивающие управление государством и удовлетворение потребностей общества в целом; некоммерческие организации, полностью или в основном финансируемые и контролируемые Правительством Российской Федерации.

Предпринимательский сектор включает: все организации, чья основная деятельность связана с производством продукции или услуг в целях продажи, в том числе находящиеся в собствен-

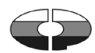


ности государства; частные некоммерческие организации, обслуживающие вышеназванные организации.

В сектор высшего образования входят: образовательные организации высшего образования, независимо от источников финансирования и правового статуса, а также находящиеся под их контролем либо ассоциированные с ними научноисследовательские институты, экспериментальные станции, клиники.

Сектор некоммерческих организаций состоит из частных организаций, не ставящих своей целью получение прибыли (профессиональные общества, общественные организации, фонды и т.д.), и частных индивидуальных организаций.

Персонал, занятый исследованиями и разработками, совокупность лиц, чья творческая деятельность, осуществляемая на систематической основе, направлена на увеличение и поиск новых областей применения знаний, а также занятых оказанием прямых услуг, связанных с выполнением исследований и разработок. В статистике персонал, занятый исследованиями и разработками, учитывается как списочный состав работников организаций (соответствующих подразделений: образовательных организаций высшего образования; организаций промышленности и др.), выполняющих исследования и разработки, по состоянию на конец года.

В составе персонала, занятого исследованиями и разработками, выделяются четыре категории: исследователи, техники, вспомогательный и прочий персонал.

Исследователи - работники, профессионально занимающиеся исследованиями и разработками и непосредственно осуществляющие создание новых знаний, продуктов, методов и систем, а также управление указанными видами деятельности. Исследователи обычно имеют законченное высшее образование. 
Техники - работники, участвующие в исследованиях и разработках и выполняющие технические функции, как правило, под руководством исследователей.

Вспомогательный персонал - работники, выполняющие вспомогательные функции, связанные с проведением исследований и разработок: работники планово-экономических, финансовых подразделений, патентных служб, подразделений научно-технической информации, научно-технических библиотек; рабочие, осуществляющие монтаж, наладку, обслуживание и ремонт научного оборудования и приборов; рабочие опытных (экспериментальных) производств; лаборанты, не имеющие высшего и среднего профессионального образования.

Прочий персонал - работники по хозяйственному обслуживанию, а также выполняющие функции общего характера, связанные с деятельностью организации в целом (работники бухгалтерии, кадровой службы, канцелярии, подразделений материальнотехнического обеспечения и т.п.).

Расходы на гражданскую науку из средств федерального бюджета - средства федерального бюджета, выделенные на фундаментальные и прикладные научные исследования гражданского назначения.

Внутренние затраты на исследования и разработки затраты на исследование и разработки собственными силами организаций, включая текущие и капитальные затраты, в течение отчетного года независимо от источников финансирования.

Гранты - денежные и иные средства, передаваемые безвозмездно и безвозвратно гражданами и юридическими лицами, в том числе иностранными гражданами и иностранными юридическими лицами, а также международными организациями, получившими право на предоставление грантов на территории Российской Федерации в установленном Правительством Российской Федерации порядке, на осуществление конкретных

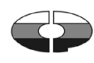


научных, научно-технических программ и проектов, инновационных проектов, проведение конкретных научных исследований на условиях, предусмотренных грантодателями.

Конкурсное финансирование - средства, поступившие на счет организации, занявшей первое место по решению конкурсной комиссии в результате подведения итогов конкурса научных, научно-технических программ, инновационных и других проектов, связанных с выполнением научных исследований и разработок, на основании представленных этой организацией лучших условий реализации конкурсного проекта по сравнению с предложенными другими участниками.

Аспирантура - подготовка кадров высшей квалификации по программам подготовки научно-педагогических кадров в образовательных организациях высшего образования, организациях дополнительного профессионального образования и научных организациях.

К освоению программ подготовки научно-педагогических кадров в аспирантуре допускаются лица, имеющие образование не ниже высшего (специалитет или магистратура) (п.4 ст.69 Федерального закона от 29.12.2012 № 273-Ф3 «Об образовании в Российской Федерации»).

Аспиранты - лица, обучающиеся в аспирантуре по программе подготовки научно-педагогических кадров (п.4 ст.33 Федерального закона от 29.12.2012 № 273-Ф3 «Об образовании в Российской Федерации»).

Подготовка аспирантов осуществляется по направлениям подготовки высшего образования, отраслям наук и специальностям, утвержденным Министерством образования и науки Российской Федерации.

Докторантура - форма подготовки научных кадров.

Докторанты - лица, имеющие ученую степень кандидата наук и направленные в докторантуру для подготовки диссерта- 
ции на соискание ученой степени доктора наук, соответствующие требованиям, указанным в разделе II Положения о докторантуре, утвержденного постановлением Правительства Российской Федерации от 04.04.2014 № 267).

Численность аспирантов и докторантов приводится на конец года, включая граждан из стран СНГ и других зарубежных стран.

Под передовыми производственными технологиями понимаются технологии и технологические процессы (включая необходимое для их реализации оборудование), управляемые с помощью компьютера или основанные на микроэлектронике и используемые при проектировании, производстве или обработке продукции (товаров и услуг).

Новыми технологиями для России считаются технологии, не имеющие отечественных аналогов.

Принципиально новыми признаются технологии, не имеющие отечественных или зарубежных аналогов, разработанные впервые и обладающие качественно новыми характеристиками, отвечающими требованиям современного уровня или превосходящими его.

Стоимостью предмета соглашения является общая стоимость соглашения, приведенная в договоре (контракте).

Под поступлениями (выплатами) средств за год понимаются суммы всех поступлений (выплат) по действующим соглашениям в отчетном году. Поступления (выплаты) денежных средств для целей статистического наблюдения признаются в том отчетном периоде, в котором они имели место независимо от фрактического поступления денежных средств (метод начисления).

Инновационная деятельность - вид деятельности, связанный с трансформацией идей (обычно результатов научных исследований и разработок, либо иных научно-технических достижений) в технологически новые или усовершенствованные про-

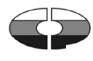


дукты или услуги, внедренные на рынке, в новые или усовершенствованные технологические процессы или способы производства (передачи) услуг, использованные в практической деятельности. Инновационная деятельность предполагает целый комплекс научных, технологических, организационных, финансовых и коммерческих мероприятий, и именно в своей совокупности они приводят к инновациям.

Инновационные товары, работы, услуги включают товары, работы, услуги, новые или подвергавшиеся в течение последних трех лет разной степени технологическим (для организаций сельского хозяйства также биологическим) изменениям.

Технологические инновации - конечный результат инновационной деятельности, получивший воплощение в виде нового либо усовершенствованного продукта или услуги, внедренных на рынке, нового либо усовершенствованного процесса или способа производства (передачи) услуг, используемых в практической деятельности.

Маркетинговые инновации - реализация новых или значительно улучшенных маркетинговых методов, охватывающих существенные изменения в дизайне и упаковке продуктов; использование новых методов продаж и презентации продуктов (услуг), их представления и продвижения на рынки сбыта; формирование новых ценовых стратегий.

Организационные инновации - реализация нового метода в ведении бизнеса, организации рабочих мест или организации внешних связей.

Организации, осуществлявшие технологические инновации - организации, осуществлявшие разработку и внедрение новых или усовершенствованных продуктов, работ, услуг, технологических процессов или способов производства (передачи) услуг и иные виды инновационной деятельности. 
Затраты на технологические инновации - выраженные в денежной форме фактические расходы, связанные с осуществлением различных видов инновационной деятельности, выполняемой в масштабе организации (отрасли, региона, страны). В составе затрат на технологические инновации учитываются текущие и капитальные затраты.

По инновационной деятельности организаций приведены данные по организациям, осуществляющим экономическую деятельность в сфере растениеводства, животноводства, растениеводства в сочетании с животноводством (смешанное сельское хозяйство), предоставление услуг в области растениеводства, декоративного садоводства и животноводства, кроме ветеринарных услуг (начиная с 2016 г.); добычи полезных ископаемых; обрабатывающих производств; производства и распределения электроэнергии, газа и воды (за исключением торговли электроэнергией; торговли газообразным топливом, подаваемым по распределительным сетям); монтажа зданий и сооружений из сборных конструкций, устройства покрытий зданий и сооружений, производства прочих строительных работ (начиная с 2015 г.); связи; деятельности, связанной с использованием вычислительной техники и информационных технологий; научных исследований и разработок; предоставления прочих видов услуг в соответствии с Общероссийским классификатором видов экономической деятельности (ОКВЭД ОК 029-2007 (КДЕС Ред. 1.1.).

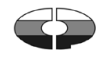


22.1. ЧИСЛО ОРГАНИЗАЦИЙ, ВЫПОЛНЯВШИХ ИССЛЕДОВАНИЯ И РАЗРАБОТКИ

\begin{tabular}{|c|c|c|c|c|c|c|c|c|}
\hline & 1992 & 2000 & 2005 & 2010 & 2013 & 2014 & 2015 & 2016 \\
\hline \multicolumn{9}{|l|}{ Число } \\
\hline $\begin{array}{l}\text { организаций - } \\
\text { всего } \\
\text { в том числе: }\end{array}$ & 4555 & 4099 & 3566 & 3492 & 3605 & 3604 & 4175 & 4032 \\
\hline $\begin{array}{l}\text { научно-иссле- } \\
\text { довательские }\end{array}$ & & & & & & & & \\
\hline организации & 2077 & 2686 & 2115 & 1840 & 1719 & 1689 & 1708 & 1673 \\
\hline конструкторские & & & & & & & & \\
\hline $\begin{array}{l}\text { организации } \\
\text { проектные }\end{array}$ & 865 & 318 & 489 & 362 & 331 & 317 & 322 & 304 \\
\hline и проектно- & & & & & & & & \\
\hline $\begin{array}{l}\text { изыскатель- } \\
\text { ские организа- }\end{array}$ & & & & & & & & \\
\hline ции & 495 & 85 & 61 & 36 & 33 & 32 & 29 & 26 \\
\hline $\begin{array}{l}\text { опытные (экс- } \\
\text { перименталь- }\end{array}$ & & & & & & & & \\
\hline $\begin{array}{l}\text { ные) предпри- } \\
\text { ятия }\end{array}$ & 29 & 33 & 30 & 47 & 53 & 53 & 61 & 62 \\
\hline $\begin{array}{l}\text { образователь- } \\
\text { ные организа- }\end{array}$ & & & & & & & & \\
\hline $\begin{array}{l}\text { ции высшего } \\
\text { образования }\end{array}$ & 446 & 390 & 406 & 517 & 671 & 702 & 1040 & 979 \\
\hline организации & & & & & & & & \\
\hline промышленно- & & & & & & & & \\
\hline $\begin{array}{l}\text { сти, имевшие } \\
\text { научно-иссле- }\end{array}$ & & & & & & & & \\
\hline $\begin{array}{l}\text { довательские, } \\
\text { проектно- }\end{array}$ & & & & & & & & \\
\hline конструк- & & & & & & & & \\
\hline $\begin{array}{l}\text { торские под- } \\
\text { разделения }\end{array}$ & 340 & 284 & 231 & 238 & 266 & 275 & 371 & 363 \\
\hline прочие & 303 & 303 & 234 & 452 & 532 & 536 & 644 & 625 \\
\hline
\end{tabular}

22.2. ЧИСЛЕННОСТЬ ПЕРСОНАЛА, ЗАНЯТОГО ИССЛЕДОВАНИЯМИ И РАЗРАБОТКАМИ

(на конец года; тыс. человек)

\begin{tabular}{|c|c|c|c|c|c|c|c|c|}
\hline & 1992 & 2000 & 2005 & 2010 & 2013 & 2014 & 2015 & 2016 \\
\hline $\begin{array}{l}\text { Численность } \\
\text { персонала - } \\
\text { всего } \\
\text { в том числе: }\end{array}$ & 1532,6 & 887,7 & 813,2 & 736,5 & 727,0 & 732,3 & 738,9 & 722,3 \\
\hline исследователи & 804,0 & 425,9 & 391,1 & 368,9 & 369,0 & 373,9 & 379,4 & 370,4 \\
\hline $\begin{array}{l}\text { техники } \\
\text { вспомогатель- }\end{array}$ & 180,7 & 75,2 & 66,0 & 59,3 & 61,4 & 63,2 & 62,8 & 60,4 \\
\hline $\begin{array}{l}\text { ный персонал } \\
\text { прочий }\end{array}$ & 382,2 & 240,5 & 215,6 & 183,7 & 175,4 & 173,6 & 174,1 & 171,9 \\
\hline персонал & 165,7 & 146,1 & 140,5 & 124,6 & 121,2 & 121,6 & 122,6 & 119,6 \\
\hline
\end{tabular}


22.3. ОСНОВНЫЕ ПОКАЗАТЕЛИ ДЕЯТЕЛЬНОСТИ АСПИРАНТУРЫ

\begin{tabular}{|c|c|c|c|c|c|}
\hline Годы & $\begin{array}{c}\text { Число } \\
\text { организаций, } \\
\text { ведущих } \\
\text { подготовку } \\
\text { аспирантов } \\
\end{array}$ & $\begin{array}{c}\text { Численность } \\
\text { аспирантов } \\
\text { (на конец года), } \\
\text { человек }\end{array}$ & $\begin{array}{c}\text { Прием } \\
\text { в аспиран- } \\
\text { туру, } \\
\text { человек }\end{array}$ & $\begin{array}{c}\text { Выпуск } \\
\text { из аспиран- } \\
\text { туры, } \\
\text { человек }\end{array}$ & $\begin{array}{c}\text { в том числе } \\
\text { с защитой } \\
\text { диссертации }\end{array}$ \\
\hline & \multicolumn{5}{|c|}{ Всего } \\
\hline 1992 & 1296 & 51915 & 13865 & 14857 & 3135 \\
\hline 2000 & 1362 & 117714 & 43100 & 24828 & 7503 \\
\hline 2005 & 1473 & 142899 & 46896 & 33561 & 10650 \\
\hline 2010 & 1568 & 157437 & 54558 & 33763 & 9611 \\
\hline 2013 & 1557 & 132002 & 38971 & 34733 & 8979 \\
\hline 2014 & 1519 & 119868 & 32981 & 28273 & 5189 \\
\hline 2015 & 1446 & 109936 & 31647 & 25826 & 4651 \\
\hline 2016 & 1359 & 98352 & 26421 & 25992 & 3730 \\
\hline \multirow[t]{2}{*}{2017} & 1284 & 93523 & 26081 & 18069 & 2320 \\
\hline & \multicolumn{5}{|c|}{ Научно-исследовательские организации } \\
\hline 1992 & 853 & 15168 & 2627 & 5325 & 922 \\
\hline 2000 & 797 & 17502 & 6075 & 3813 & 873 \\
\hline 2005 & 833 & 19986 & 6577 & 4806 & 1009 \\
\hline 2010 & 809 & 16936 & 5655 & 4335 & 729 \\
\hline 2013 & 818 & 13593 & 4166 & 3943 & 674 \\
\hline 2014 & 805 & 12175 & 3126 & 3331 & 397 \\
\hline 2015 & 771 & 11528 & 3189 & 2728 & 313 \\
\hline 2016 & 733 & 10581 & 2949 & 2954 & 331 \\
\hline \multirow[t]{2}{*}{2017} & 670 & 10231 & 3133 & 2209 & 247 \\
\hline & \multicolumn{5}{|c|}{ Образовательные организации высшего образования } \\
\hline 1992 & 443 & 36747 & 11238 & 9532 & 2213 \\
\hline 2000 & 565 & 100212 & 37025 & 21015 & 6630 \\
\hline 2005 & 640 & 122913 & 40319 & 28755 & 9641 \\
\hline 2010 & 748 & 139908 & 48748 & 29268 & 8854 \\
\hline 2013 & 724 & 117790 & 34643 & 30639 & 8257 \\
\hline 2014 & 698 & 107083 & 29700 & 24836 & 4770 \\
\hline 2015 & 661 & 97847 & 28285 & 22971 & 4318 \\
\hline 2016 & 611 & 87180 & 23281 & 22917 & 3379 \\
\hline 2017 & 599 & 82633 & 22749 & 15753 & 2063 \\
\hline
\end{tabular}


Продолжение табл. 22.3

\begin{tabular}{|c|c|c|c|c|c|}
\hline Годы & $\begin{array}{c}\text { Число } \\
\text { организаций, } \\
\text { ведущих } \\
\text { подготовку } \\
\text { аспирантов } \\
\end{array}$ & $\begin{array}{c}\text { Численность } \\
\text { аспирантов } \\
\text { (на конец года), } \\
\text { человек }\end{array}$ & $\begin{array}{c}\text { Прием } \\
\text { в аспиран- } \\
\text { туру, } \\
\text { человек }\end{array}$ & \begin{tabular}{|c|} 
Выпуск \\
из аспиран- \\
туры, \\
человек
\end{tabular} & $\begin{array}{c}\text { в том числе } \\
\text { с защитой } \\
\text { диссертации }\end{array}$ \\
\hline & \multicolumn{5}{|c|}{$\begin{array}{c}\text { Организации дополнительного } \\
\text { профессионального образования }\end{array}$} \\
\hline 2010 & 11 & 593 & 155 & 160 & 28 \\
\hline 2013 & 15 & 619 & 162 & 151 & 48 \\
\hline 2014 & 16 & 610 & 155 & 106 & 22 \\
\hline 2015 & 14 & 561 & 173 & 127 & 20 \\
\hline 2016 & 15 & 591 & 191 & 121 & 20 \\
\hline 2017 & 15 & 659 & 199 & 107 & 10 \\
\hline
\end{tabular}

22.4. ВЫПУСК АСПИРАНТОВ ПО ОТРАСЛЯМ НАУК в 2017 г. (человек)

\begin{tabular}{l|r|r}
\hline & $\begin{array}{c}\text { Выпуск } \\
\text { из аспирантуры }\end{array}$ & $\begin{array}{c}\text { в том числе } \\
\text { с защитой } \\
\text { дисертации }\end{array}$ \\
\hline Всего & 10612 & 1455 \\
$\quad$ из них & & \\
по отраслям наук: & 907 & 143 \\
химико-математические & 428 & 106 \\
биологические & 763 & 104 \\
технические & 3079 & 466 \\
сельскохозяйственные & 381 & 96 \\
исторические науки & & 28 \\
и археология & 219 & 72 \\
экономические & 1030 & 19 \\
филососские & 162 & 55 \\
филологические & 443 & 24 \\
юридические & 497 & 46 \\
педагогические & 529 & 219 \\
медицинские & 1213 & 12 \\
искусствоведение & 97 & 7 \\
психологические & 169 & 11 \\
социологические & 123 & 4 \\
политология & 130 & 10 \\
культурология & 69 & 29 \\
науки о Земле & 336 & \\
\hline
\end{tabular}




\section{5. ВЫПУСК АСПИРАНТОВ ПО НАПРАВЛЕНИЯМ ПОДГОТОВКИ} B 2017 r.

(человек)

\begin{tabular}{|c|c|c|}
\hline & $\begin{array}{c}\text { Выпуск } \\
\text { из аспирантуры }\end{array}$ & $\begin{array}{l}\text { в том числе } \\
\text { с защитой } \\
\text { диссертации }\end{array}$ \\
\hline $\begin{array}{l}\text { Bcero } \\
\text { в том числе по направле- } \\
\text { ниям подготовки: }\end{array}$ & 7457 & 865 \\
\hline математика и механика & 49 & 11 \\
\hline $\begin{array}{l}\text { компьютерные и информаци- } \\
\text { онные науки }\end{array}$ & 26 & 6 \\
\hline фризика и астрономия & 102 & 33 \\
\hline химия & 57 & 18 \\
\hline науки о Земле & 480 & 37 \\
\hline биологические науки & 128 & 15 \\
\hline архитектура & 53 & 3 \\
\hline $\begin{array}{l}\text { техника и технологии строи- } \\
\text { тельства }\end{array}$ & 26 & 6 \\
\hline $\begin{array}{l}\text { информатика и вычислитель- } \\
\text { ная техника }\end{array}$ & 130 & 22 \\
\hline $\begin{array}{l}\text { инфоормационная безопас- } \\
\text { ность }\end{array}$ & 3 & - \\
\hline $\begin{array}{l}\text { электроника, радиотехника и } \\
\text { системы связи }\end{array}$ & 40 & 8 \\
\hline $\begin{array}{l}\text { фотоника, приборостроение, } \\
\text { оптические и биотехнические }\end{array}$ & & \\
\hline системы и технологии & 9 & 4 \\
\hline электро- и теплоэнергетика & 25 & 5 \\
\hline $\begin{array}{l}\text { ядерная энергетика и техно- } \\
\text { логии }\end{array}$ & 5 & - \\
\hline машиностроение & 29 & 6 \\
\hline $\begin{array}{l}\text { физико-технические науки и } \\
\text { технологии }\end{array}$ & 1 & - \\
\hline оружие и системы вооружения & - & - \\
\hline химические технологии & 9 & 2 \\
\hline $\begin{array}{l}\text { промышленная экология и } \\
\text { биотехнологии }\end{array}$ & 17 & 5 \\
\hline $\begin{array}{l}\text { техносферная безопасность и } \\
\text { природообустройство }\end{array}$ & - & - \\
\hline $\begin{array}{l}\text { прикладная геология, горное } \\
\text { дело, нефтегазовое дело и } \\
\text { геодезия }\end{array}$ & 15 & 6 \\
\hline технологии материалов & 12 & 2 \\
\hline $\begin{array}{l}\text { техника и технологии назем- } \\
\text { ного транспорта }\end{array}$ & 16 & 1 \\
\hline
\end{tabular}


Продолжение табл. 22.5

\begin{tabular}{|c|c|c|}
\hline & $\begin{array}{c}\text { Выпуск } \\
\text { из аспирантуры }\end{array}$ & $\begin{array}{c}\text { в том числе } \\
\text { с защитой } \\
\text { диссертации } \\
\end{array}$ \\
\hline авиационная и ракетно- & 1 & 1 \\
\hline космическая техника & 12 & 1 \\
\hline $\begin{array}{l}\text { аэронавигация и эксплуата- } \\
\text { ция авиационной и ракетно- } \\
\text { космической техники }\end{array}$ & - & - \\
\hline техника и технологии кораб- & & \\
\hline $\begin{array}{l}\text { лестроения и водного транс- } \\
\text { порта }\end{array}$ & 8 & - \\
\hline $\begin{array}{l}\text { управление в технических } \\
\text { системах }\end{array}$ & 18 & 9 \\
\hline $\begin{array}{l}\text { нанотехнологии и наномате- } \\
\text { риалы }\end{array}$ & - & - \\
\hline $\begin{array}{l}\text { технологии легкой промыш- } \\
\text { ленности }\end{array}$ & 32 & 1 \\
\hline фундаментальная медицина & 122 & 26 \\
\hline клиническая медицина & 915 & 139 \\
\hline $\begin{array}{l}\text { науки о здоровье и профилак- } \\
\text { тическая медицина }\end{array}$ & 62 & 4 \\
\hline фрармация & 60 & 10 \\
\hline $\begin{array}{l}\text { сельское, лесное и рыбное } \\
\text { хозяйство }\end{array}$ & 241 & 43 \\
\hline ветеринария и зоотехния & 225 & 47 \\
\hline психологические науки & 220 & 16 \\
\hline экономика и управление & 1333 & 79 \\
\hline $\begin{array}{l}\text { социология и социальная } \\
\text { работа }\end{array}$ & 162 & 15 \\
\hline юриспруденция & 600 & 46 \\
\hline $\begin{array}{l}\text { политические науки и регио- } \\
\text { новедение }\end{array}$ & 178 & 7 \\
\hline $\begin{array}{l}\text { средства массовой информа- } \\
\text { ции и информационно- } \\
\text { библиотечное дело }\end{array}$ & 59 & 8 \\
\hline $\begin{array}{l}\text { образование и педагогиче- } \\
\text { ские науки }\end{array}$ & 497 & 31 \\
\hline $\begin{array}{l}\text { языкознание и литературове- } \\
\text { дение }\end{array}$ & 552 & 88 \\
\hline история и археология & 414 & 58 \\
\hline $\begin{array}{l}\text { философиия, этика и религио- } \\
\text { ведение }\end{array}$ & 237 & 30 \\
\hline теология & - & - \\
\hline фризическая культура и спорт & 88 & 3 \\
\hline искусствознание & 112 & 6 \\
\hline $\begin{array}{l}\text { культуроведение и социо- } \\
\text { культурные проекты }\end{array}$ & 78 & 8 \\
\hline
\end{tabular}


22.6. ОСНОВНЫЕ ПОКАЗАТЕЛИ ДЕЯТЕЛЬНОСТИ ДОКТОРАНТУРЫ

\begin{tabular}{|c|c|c|c|c|c|}
\hline Годы & $\begin{array}{c}\text { Число орга- } \\
\text { низаций, ве- } \\
\text { дущих подго- } \\
\text { товку докто- } \\
\text { рантов }\end{array}$ & $\begin{array}{c}\text { Численность } \\
\text { докторантов } \\
\text { (на конец } \\
\text { года), } \\
\text { человек }\end{array}$ & $\begin{array}{c}\text { Прием в док- } \\
\text { торантуру, } \\
\text { человек }\end{array}$ & $\begin{array}{c}\text { Выпуск } \\
\text { из докторан- } \\
\text { туры, } \\
\text { человек }\end{array}$ & $\begin{array}{c}\text { в том числе } \\
\text { с защитой } \\
\text { диссертации }\end{array}$ \\
\hline & \multicolumn{5}{|c|}{ Всего } \\
\hline 1992 & 338 & 1644 & 540 & 617 & 247 \\
\hline 2000 & 492 & 4213 & 1637 & 1251 & 486 \\
\hline 2005 & 535 & 4282 & 1457 & 1417 & 516 \\
\hline 2010 & 602 & 4418 & 1650 & 1259 & 336 \\
\hline 2013 & 585 & 4572 & 1582 & 1356 & 323 \\
\hline 2014 & 478 & 3204 & 166 & 1359 & 231 \\
\hline 2015 & 437 & 2007 & 419 & 1386 & 181 \\
\hline 2016 & 385 & 921 & 397 & 1346 & 151 \\
\hline \multirow[t]{2}{*}{2017} & 223 & 1059 & 439 & 253 & 65 \\
\hline & \multicolumn{5}{|c|}{ Научно-исследовательские организации } \\
\hline 1992 & 198 & 516 & 125 & 216 & 91 \\
\hline 2000 & 178 & 505 & 192 & 151 & 63 \\
\hline 2005 & 173 & 445 & 147 & 148 & 48 \\
\hline 2010 & 192 & 299 & 100 & 95 & 20 \\
\hline 2013 & 184 & 262 & 110 & 73 & 9 \\
\hline 2014 & 105 & 194 & 23 & 78 & 14 \\
\hline 2015 & 91 & 153 & 46 & 67 & 8 \\
\hline 2016 & 82 & 96 & 29 & 76 & 8 \\
\hline \multirow[t]{2}{*}{2017} & 45 & 97 & 26 & 27 & 9 \\
\hline & \multicolumn{5}{|c|}{ Образовательные организации высшего образования } \\
\hline 1992 & 140 & 1128 & 415 & 401 & 156 \\
\hline 2000 & 314 & 3708 & 1445 & 1100 & 423 \\
\hline 2005 & 362 & 3837 & 1310 & 1269 & 468 \\
\hline 2010 & 407 & 4116 & 1548 & 1162 & 316 \\
\hline 2013 & 398 & 4307 & 1471 & 1281 & 314 \\
\hline 2014 & 372 & 3009 & 143 & 1281 & 217 \\
\hline 2015 & 345 & 1853 & 373 & 1319 & 173 \\
\hline 2016 & 303 & 825 & 368 & 1270 & 143 \\
\hline 2017 & 178 & 962 & 413 & 226 & 56 \\
\hline
\end{tabular}


Продолжение табл. 22.6

\begin{tabular}{|c|c|c|c|c|c|}
\hline Годы & $\begin{array}{c}\text { Число орга- } \\
\text { низаций, ве- } \\
\text { дущих подго- } \\
\text { товку докто- } \\
\text { рантов } \\
\end{array}$ & \begin{tabular}{|c|} 
Численность \\
докторантов \\
(на конец \\
года), \\
человек \\
\end{tabular} & $\begin{array}{c}\text { Прием в док- } \\
\text { торантуру, } \\
\text { человек }\end{array}$ & $\begin{array}{c}\text { Выпуск } \\
\text { из докторан- } \\
\text { туры, } \\
\text { человек }\end{array}$ & $\begin{array}{c}\text { в том числе } \\
\text { с защитой } \\
\text { диссертации }\end{array}$ \\
\hline & \multicolumn{5}{|c|}{$\begin{array}{c}\text { Организации дополнительного } \\
\text { профессионального образования }\end{array}$} \\
\hline 2010 & 3 & 3 & 2 & 2 & - \\
\hline 2013 & 3 & 3 & 1 & 2 & - \\
\hline 2014 & 1 & 1 & - & - & - \\
\hline 2015 & 1 & 1 & - & - & - \\
\hline 2016 & - & - & - & - & - \\
\hline 2017 & - & - & - & - & - \\
\hline
\end{tabular}

1) Статистическое наблюдение ведется с 2009 г.

22.7. ВЫПУСК ДОКТОРАНТОВ ПО ОТРАСЛЯМ НАУК в 2017 г. (человек)

\begin{tabular}{l|c|c}
\hline & $\begin{array}{c}\text { Выпуск } \\
\text { из докторантуры }\end{array}$ & $\begin{array}{c}\text { в том числе } \\
\text { с защитой } \\
\text { диссертации }\end{array}$ \\
\hline Всего & $\mathbf{2 5 3}$ & $\mathbf{6 5}$ \\
$\quad$ из них по отраслям наук: & 14 & 5 \\
физико-математические & 4 & 1 \\
химические & 9 & 3 \\
биологические & 50 & 11 \\
технические & 13 & 4 \\
сельскохозяйственные & 12 & 4 \\
исторические науки и археология & 38 & 5 \\
экономические & 6 & 1 \\
философские & 15 & 4 \\
филологические & 24 & 5 \\
юридические & 17 & 3 \\
педагогические & 16 & 8 \\
медицинские & 7 & 2 \\
искусствоведение & 6 & 2 \\
психологические & 6 & 2 \\
социологические & 8 & - \\
политология & 3 & 2 \\
культурология & 5 & 3 \\
науки о Земле & & \\
\hline
\end{tabular}




\section{8. ФИНАНСИРОВАНИЕ НАУКИ ИЗ СРЕДСТВ} ФЕДЕРАЛЬНОГО БЮДЖЕТА ${ }^{1)}$

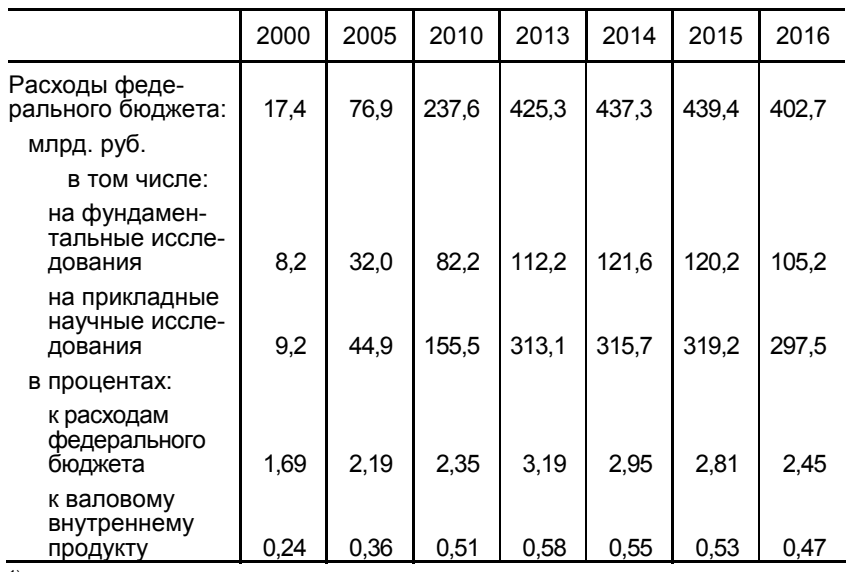

1) 2000 г. - в соответствии с Приложением 2 к Федеральным законам «Об исполнении федерального бюджета»; 2005, 2010-2016 гг. - по данным Федерального казначейства «Отчет об исполнении консолидированного бюджета Российской Федерации и бюджетов государственных внебюджетных фондов» на 1 января следующего за отчетным годом.

22.9. ВНУТРЕННИЕ ЗАТРАТЫ НА ИССЛЕДОВАНИЯ И РАЗРАБОТКИ

\begin{tabular}{l|c|c|c|c|c|c|c|c}
\hline & 1992 & 2000 & 2005 & 2010 & 2013 & 2014 & 2015 & 2016 \\
\hline $\begin{array}{l}\text { Внутренние } \\
\text { затраты на } \\
\begin{array}{l}\text { исследова- } \\
\text { ния и раз- } \\
\text { работки } \\
\text { млрд. руб. }\end{array} \\
\begin{array}{l}\text { в процен- } \\
\text { тах в вало- }\end{array}\end{array}$ & 140,6 & 76,7 & 230,8 & 523,4 & 749,8 & 847,5 & 914,7 & 943,8 \\
$\begin{array}{l}\text { вому внут- } \\
\text { реннему } \\
\text { продукту }\end{array}$ & 0,74 & 1,05 & 1,07 & 1,13 & 1,03 & 1,07 & 1,10 & 1,10 \\
\hline
\end{tabular}


22.10. ВНУТРЕННИЕ ЗАТРАТЫ НА ИССЛЕДОВАНИЯ И РАЗРАБОТКИ ПО ИСТОЧНИКАМ ФИНАНСИРОВАНИЯ

(млрд. рублей)

\begin{tabular}{|c|c|c|c|c|c|c|c|}
\hline & 2000 & 2005 & 2010 & 2013 & 2014 & 2015 & 2016 \\
\hline $\begin{array}{l}\text { Все затраты } \\
\text { в том числе } \\
\text { по источни- } \\
\text { кам финанси- } \\
\text { рования: } \\
\text { средства бюд- } \\
\text { жетов всех уров- }\end{array}$ & 76,7 & 230,8 & 523,4 & 749,8 & 847,5 & 914,7 & 943,8 \\
\hline $\begin{array}{l}\text { ней }^{1)} \\
\text { собственные } \\
\text { средства науч- } \\
\text { ных организа- } \\
\text { ций }\end{array}$ & 41,2 & 140,5 & 360,3 & 493,5 & 569,1 & 617,3 & 622,3 \\
\hline $\begin{array}{l}\text { средства фон- } \\
\text { дов поддержки } \\
\text { научной, науч- } \\
\text { но-технической } \\
\text { и инновацион- } \\
\text { ной деятельно- } \\
\text { сти }\end{array}$ & & $\ldots$ & $\ldots$ & & $\ldots$ & 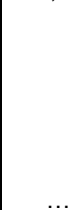 & 9,3 \\
\hline $\begin{array}{l}\text { средства орга- } \\
\text { низаций пред- } \\
\text { приниматель- }\end{array}$ & $\cdots$ & & $\cdots$ & $\cdots$ & $\cdots$ & $\cdots$ & , \\
\hline $\begin{array}{l}\text { ского сектора } \\
\text { средства обра- } \\
\text { зовательных } \\
\text { организаций } \\
\text { высшего обра- }\end{array}$ & 14,3 & 47,8 & 85,9 & 129,1 & 145,8 & 150,9 & 154,9 \\
\hline $\begin{array}{l}\text { зования } \\
\text { средства част- } \\
\text { ных некоммер- } \\
\text { ческих органи- }\end{array}$ & 0,1 & 0,2 & 0,5 & 1,5 & 1,8 & 2,3 & 1,6 \\
\hline $\begin{array}{l}\text { заций } \\
\text { средства } \\
\text { иностранных } \\
\text { источников } \\
\end{array}$ & 0,03 & 17,5 & 18,6 & 22,7 & 21,0 & 24,2 & 25,4 \\
\hline
\end{tabular}




\subsection{1. ВНУТРЕННИЕ ЗАТРАТЫ НА ИССЛЕДОВАНИЯ И РАЗРАБОТКИ ПО СЕКТОРАМ ДЕЯТЕЛЬНОСТИ}

(млрд. рублей)

\begin{tabular}{l|r|r|r|r|r|r|r}
\hline & 2000 & 2005 & 2010 & 2013 & 2014 & 2015 & 2016 \\
\hline $\begin{array}{l}\text { Всего } \\
\text { в том числе } \\
\text { по секторам }\end{array}$ & $\mathbf{7 6 , 7}$ & $\mathbf{2 3 0 , 8}$ & $\mathbf{5 2 3 , 4}$ & $\mathbf{7 4 9 , 8}$ & $\mathbf{8 4 7 , 5}$ & $\mathbf{9 1 4 , 7}$ & $\mathbf{9 4 3 , 8}$ \\
$\begin{array}{l}\text { деятельности: } \\
\text { государственный }\end{array}$ & 18,7 & 60,2 & 162,0 & 227,0 & 258,0 & $\mathbf{2 8 4 , 1}$ & 301,8 \\
$\begin{array}{l}\text { предпринима- } \\
\text { тельский }\end{array}$ & 54,3 & 156,9 & 316,7 & 454,4 & 505,2 & 541,5 & 554,1 \\
$\begin{array}{l}\text { высшего } \\
\text { образования }\end{array}$ & 3,5 & 13,3 & 43,7 & 67,5 & 83,2 & 87,7 & 85,9 \\
некоммерческих \\
организаций
\end{tabular}

22.12. ГРАНТЫ, СУБСИДИИ, КОНКУРСНОЕ ФИНАНСИРОВАНИЕ ИССЛЕДОВАНИЙ И РАЗРАБОТОК В 2016 r.

\begin{tabular}{|c|c|c|c|c|}
\hline & \multirow{2}{*}{$\begin{array}{l}\text { Всего, } \\
\text { млрд. } \\
\text { рублей }\end{array}$} & \multicolumn{2}{|c|}{$\begin{array}{c}\text { в том числе финансируе- } \\
\text { мые за счет средств }\end{array}$} & \multirow[b]{2}{*}{$\begin{array}{c}\text { Удельный } \\
\text { вес грантов, } \\
\text { субсидий, } \\
\text { конкурсного } \\
\text { финансир-- } \\
\text { вания во } \\
\text { внутренних } \\
\text { затратах на } \\
\text { исследов- } \\
\text { ния и разра- } \\
\text { ботки, } \\
\text { процентов }\end{array}$} \\
\hline & & $\begin{array}{c}\text { бюджетов } \\
\text { всех } \\
\text { уровней }\end{array}$ & $\begin{array}{c}\text { из них } \\
\text { федераль- } \\
\text { ного } \\
\text { бюджета }\end{array}$ & \\
\hline $\begin{array}{l}\text { Из внутренних затрат } \\
\text { на исследования и } \\
\text { разработки: } \\
\text { субсидии бюджета на } \\
\text { финансовое обеспечение } \\
\text { выполнения государствен- } \\
\text { ного задания в сфере } \\
\text { научной (научно-исследо- } \\
\text { вательской) деятельности } \\
\text { субсидии бюджета на } \\
\text { выполнение научно-ис- } \\
\text { следовательских и/или } \\
\text { опытно-конструкторских } \\
\text { работ } \\
\text { гранты фондов поддерж- } \\
\text { ки научной, научно-тех- } \\
\text { нической и инноваци- } \\
\text { онной деятельности } \\
\text { другие виды конкурсного } \\
\text { финансирования } \\
\end{array}$ & $\begin{array}{l}22,6 \\
58,7 \\
\end{array}$ & 19,5 & 17,6 & 2,4 \\
\hline
\end{tabular}


22.13. РАЗРАБОТАННЫЕ ПЕРЕДОВЫЕ ПРОИЗВОДСТВЕННЫЕ ТЕХНОЛОГИИ ПО ГРУППАМ

(единиц)

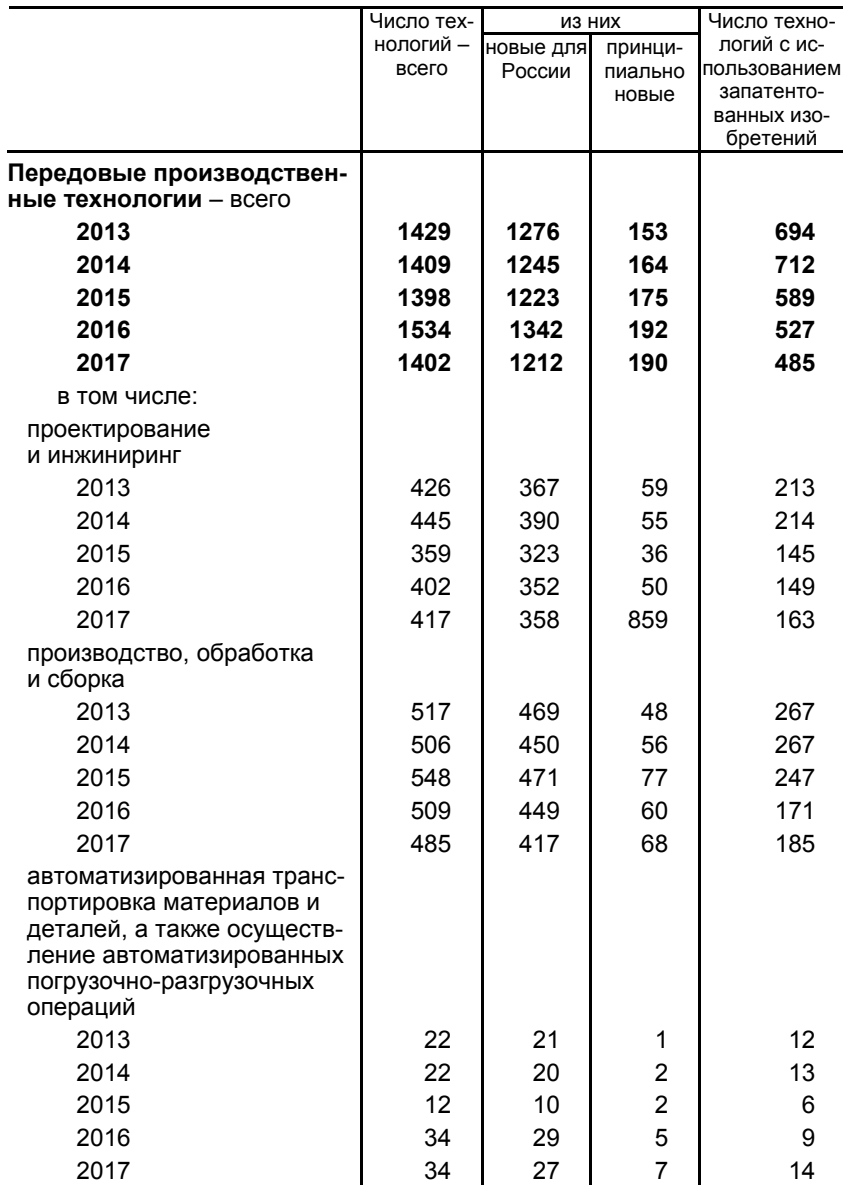


Продолжение табл. 22.13

\begin{tabular}{|c|c|c|c|c|}
\hline & \multirow{2}{*}{$\begin{array}{l}\text { Число тех- } \\
\text { нологий - } \\
\text { всего }\end{array}$} & \multicolumn{2}{|c|}{ из них } & \multirow[b]{2}{*}{\begin{tabular}{|c} 
Число техно- \\
логий с ис- \\
пользованием \\
запатенто- \\
ванных изо- \\
бретений
\end{tabular}} \\
\hline & & $\begin{array}{c}\text { новые для } \\
\text { России }\end{array}$ & $\begin{array}{l}\text { принци- } \\
\text { пиально } \\
\text { новые }\end{array}$ & \\
\hline \multicolumn{5}{|c|}{$\begin{array}{l}\text { аппаратура автоматизиро- } \\
\text { ванного наблюдения и (или) } \\
\text { контроля }\end{array}$} \\
\hline 2013 & 137 & 108 & 29 & 63 \\
\hline 2014 & 110 & 84 & 26 & 56 \\
\hline 2015 & 117 & 82 & 35 & 53 \\
\hline 2016 & 160 & 111 & 49 & 76 \\
\hline 2017 & 134 & 107 & 27 & 44 \\
\hline \multicolumn{5}{|c|}{ связь и управление } \\
\hline 2013 & 206 & 195 & 11 & 83 \\
\hline 2014 & 202 & 187 & 15 & 110 \\
\hline 2015 & 232 & 218 & 14 & 92 \\
\hline 2016 & 285 & 264 & 21 & 81 \\
\hline 2017 & 218 & 194 & 24 & 45 \\
\hline \multicolumn{5}{|c|}{$\begin{array}{l}\text { производственная } \\
\text { информационная система }\end{array}$} \\
\hline 2013 & 68 & 66 & 2 & 32 \\
\hline 2014 & 65 & 59 & 6 & 27 \\
\hline 2015 & 84 & 78 & 6 & 33 \\
\hline 2016 & 83 & 80 & 3 & 29 \\
\hline 2017 & 44 & 44 & - & 11 \\
\hline \multicolumn{5}{|c|}{$\begin{array}{l}\text { интегрированное управле- } \\
\text { ние и контроль }\end{array}$} \\
\hline 2013 & 53 & 50 & 3 & 24 \\
\hline 2014 & 59 & 55 & 4 & 25 \\
\hline 2015 & 46 & 41 & 5 & 13 \\
\hline 2016 & 61 & 57 & 4 & 12 \\
\hline 2017 & 70 & 65 & 5 & 23 \\
\hline
\end{tabular}




\subsection{4. ИСПОЛЬЗУЕМЫЕ ПЕРЕДОВЫЕ ПРОИЗВОДСТВЕННЫЕ} ТЕХНОЛОГИИ ПО ГРУППАМ

(единиц)

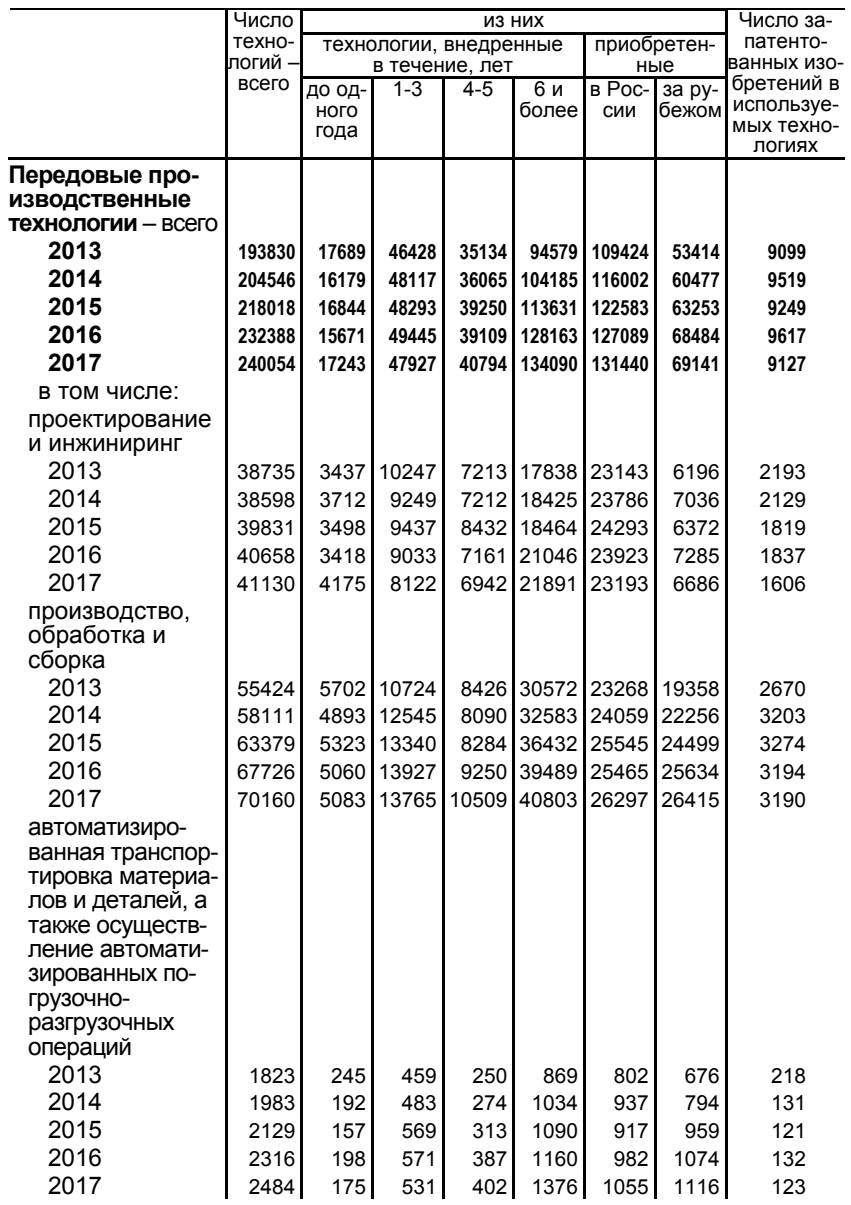


Продолжение табл. 22.14

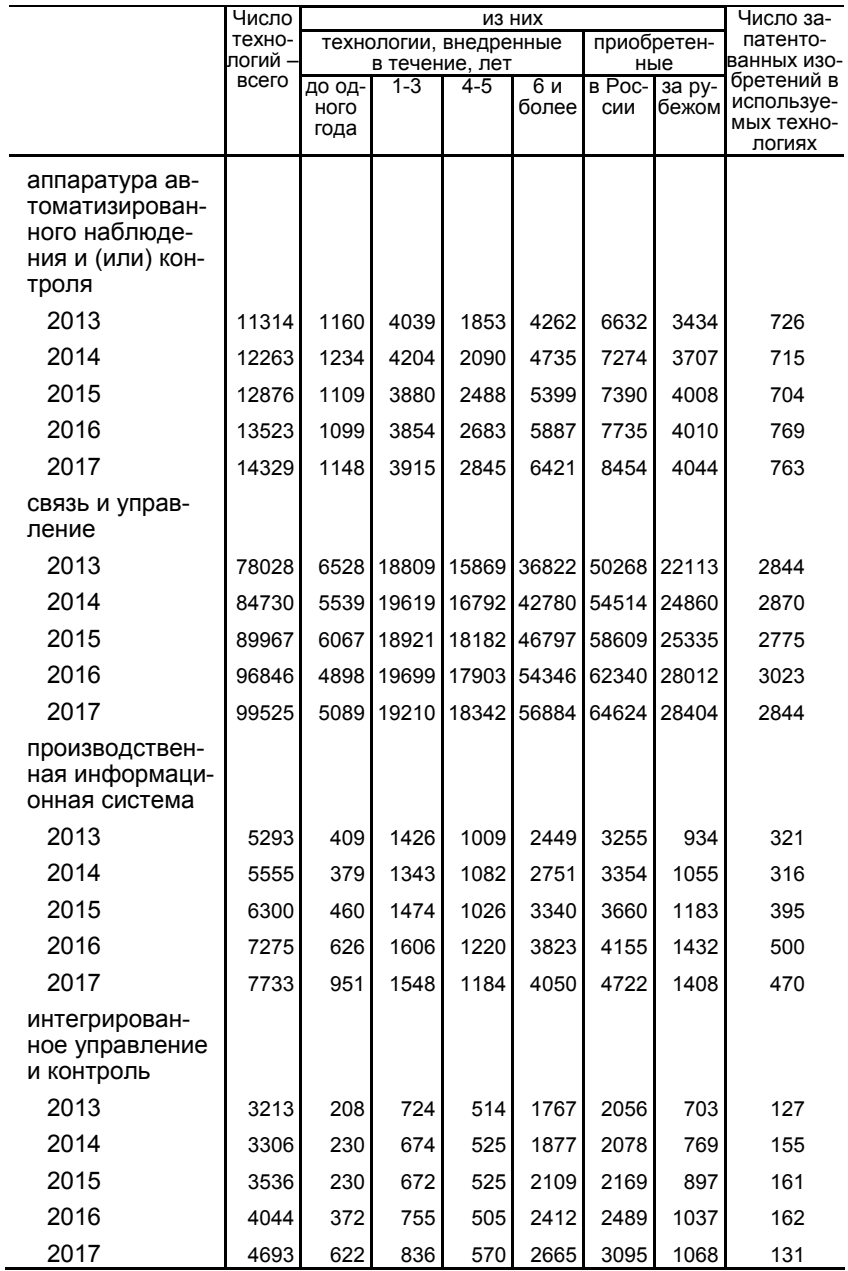




\subsection{5. ТОРГОВЛЯ ТЕХНОЛОГИЯМИ С ЗАРУБЕЖНЫМИ СТРАНАМИ} ПО ОБЪЕКТАМ СДЕЛОК В 2017 г.

\begin{tabular}{|c|c|c|c|c|c|c|}
\hline & \multicolumn{3}{|c|}{ Экспорт } & \multicolumn{3}{|c|}{ Импорт } \\
\hline & $\begin{array}{l}\text { Число } \\
\text { согла- } \\
\text { шений }\end{array}$ & \begin{tabular}{|c|} 
Стои- \\
мость \\
предме- \\
та со- \\
глаше- \\
ния, млн. \\
долл. \\
СшА
\end{tabular} & \begin{tabular}{|c|} 
Поступ- \\
ление \\
средств \\
за год, \\
млн. \\
долл. \\
США
\end{tabular} & $\begin{array}{l}\text { Число } \\
\text { согла- } \\
\text { шений } \\
\\
\end{array}$ & \begin{tabular}{|c} 
Стои- \\
мость \\
предме- \\
та со- \\
глаше- \\
ния, млн. \\
долл. \\
СшА
\end{tabular} & $\begin{array}{c}\text { Выплаты } \\
\text { средств } \\
\text { за год, } \\
\text { млн. } \\
\text { долл. } \\
\text { США }\end{array}$ \\
\hline $\begin{array}{l}\text { Bceго } \\
\text { в том числе } \\
\text { по объектам сделок: }\end{array}$ & 2757 & 26416 & 1181 & 4358 & 17676 & 3305 \\
\hline $\begin{array}{l}\text { патент на изобретение } \\
\text { в том числе патент } \\
\text { на селекционное }\end{array}$ & 5 & 0,1 & 0,1 & 64 & 91,4 & 11,1 \\
\hline $\begin{array}{c}\text { достижение } \\
\text { патентная лицензия }\end{array}$ & - & - & - & 1 & 0,03 & 0,03 \\
\hline на изобретение & 117 & 329 & 94,8 & 165 & 592 & 106 \\
\hline полезная модель & 7 & 5,0 & 3,9 & 9 & 8,0 & 8,4 \\
\hline ноу-хау & 55 & 23,7 & 7,0 & 130 & 259 & 152 \\
\hline товарный знак & 28 & 5,2 & 2,6 & 314 & 960 & 504 \\
\hline промышленный образец & 4 & 20,1 & 20,0 & 40 & 3,5 & 1,4 \\
\hline инжиниринговые услуги & 1036 & 25068 & 720 & 2133 & 14475 & 2133 \\
\hline научные исследования & 840 & 630 & 178 & 339 & 216 & 83,5 \\
\hline прочие & 665 & 334 & 155 & 1164 & 1071 & 306 \\
\hline
\end{tabular}

22.16. ТОРГОВЛЯ ТЕХНОЛОГИЯМИ С ЗАРУБЕЖНЫМИ СТРАНАМИ ПО ОБЛАСТИ НАЗНАЧЕНИЯ ПРЕДМЕТА СОГЛАШЕНИЯ В 2017 г.

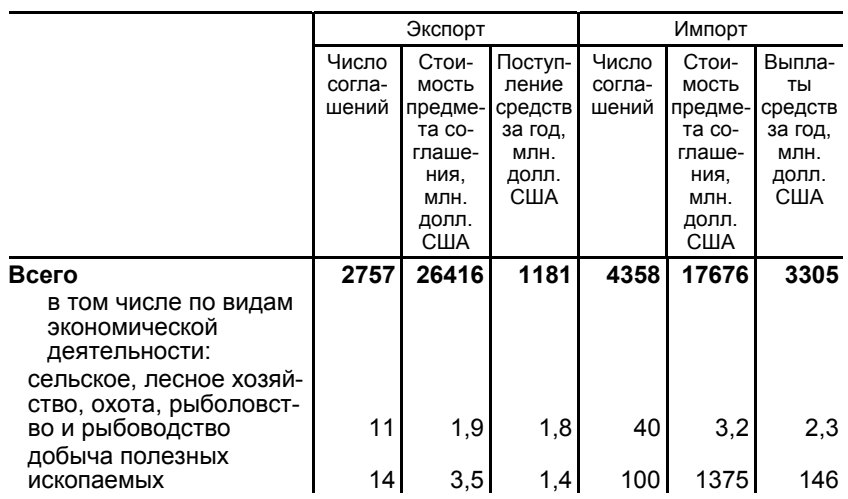


Продолжение табл. 22.16

\begin{tabular}{|c|c|c|c|c|c|c|}
\hline & \multicolumn{3}{|c|}{ Экспорт } & \multicolumn{3}{|c|}{ Импорт } \\
\hline & $\begin{array}{l}\text { Число } \\
\text { согла- } \\
\text { шений }\end{array}$ & \begin{tabular}{|c|} 
Стои- \\
мость \\
предме- \\
та со- \\
глаше- \\
ния, \\
млн. \\
долл. \\
США \\
\end{tabular} & $\begin{array}{c}\text { Поступ- } \\
\text { ление } \\
\text { средств } \\
\text { за год, } \\
\text { млн. } \\
\text { долл. } \\
\text { США }\end{array}$ & $\begin{array}{l}\text { Число } \\
\text { согла- } \\
\text { шений }\end{array}$ & \begin{tabular}{|c|} 
Стои- \\
мость \\
предме- \\
та со- \\
глаше- \\
ния, \\
млн. \\
долл. \\
США \\
\end{tabular} & $\begin{array}{l}\text { Выпла- } \\
\text { ты } \\
\text { средств } \\
\text { за год, } \\
\text { млн. } \\
\text { долл. } \\
\text { США }\end{array}$ \\
\hline $\begin{array}{l}\text { обрабатывающие } \\
\text { производства }\end{array}$ & 439 & 890 & 214 & 2401 & 5597 & 1645 \\
\hline $\begin{array}{l}\text { обеспечение электриче- } \\
\text { ской энергией, газом и } \\
\text { паром; кондициониро- } \\
\text { вание воздуха; водо- } \\
\text { снабжение; водоотведе- } \\
\text { ние, организация сбора } \\
\text { и утилизации отходов, } \\
\text { деятельность по ликви- } \\
\text { дации загрязнений }\end{array}$ & 32 & 1399 & 127 & 20 & 1,6 & 1,1 \\
\hline $\begin{array}{l}\text { строительство } \\
\text { оптовая и розничная } \\
\text { торговля, ремонт авто- } \\
\text { транспортных средств, } \\
\text { мотоциклов, бытовых } \\
\text { изделий и предметов }\end{array}$ & 27 & 22258 & 259 & 45 & 55,0 & 24,1 \\
\hline личного пользования & 56 & 0,6 & 1,4 & 142 & 69,1 & 45,6 \\
\hline транспорт и связь & 60 & 5,5 & 5,2 & 51 & 17,6 & 19,3 \\
\hline $\begin{array}{l}\text { из них деятельность в } \\
\text { области связи на базе } \\
\text { проводных технологий }\end{array}$ & 5 & 0,1 & 0,1 & 9 & 9,1 & 2,0 \\
\hline операции с недвижимым & & & & & & \\
\hline $\begin{array}{l}\text { имуществом, аренда и } \\
\text { предоставление услуг }\end{array}$ & 1897 & 1770 & 484 & 1404 & 9041 & 837 \\
\hline из них: & & & & & & \\
\hline $\begin{array}{l}\text { научные исследования } \\
\text { и разработки } \\
\text { предоставление }\end{array}$ & 858 & 567 & 155 & 341 & 467 & 145 \\
\hline прочих видов услуг & 509 & 844,9 & 149 & 675 & 9809 & 1096 \\
\hline $\begin{array}{l}\text { образование } \\
\text { предоставление комму- }\end{array}$ & 117 & 1,5 & 1,2 & 58 & 1,6 & 0,8 \\
\hline $\begin{array}{l}\text { нальных, социальных } \\
\text { и персональных услуг }\end{array}$ & 31 & 71,7 & 71,6 & 44 & 1406 & 474 \\
\hline $\begin{array}{l}\text { из них деятельность } \\
\text { по организации отды- } \\
\text { ха и развлечений, } \\
\text { культуры и спорта }\end{array}$ & 28 & 71,7 & 71,6 & 40 & 1405 & 474 \\
\hline $\begin{array}{l}\text { Прочие виды экономиче- } \\
\text { ской деятельности }\end{array}$ & 73 & 13,9 & 13,9 & 53 & 109 & 110 \\
\hline
\end{tabular}


22.17. ПОСТУПЛЕНИЕ ПАТЕНТНЫХ ЗАЯВОК И ВЫДАЧА ПАТЕНТОВ В РОССИИ ${ }^{1)}$

(единиц)

\begin{tabular}{|c|c|c|c|c|c|c|c|c|}
\hline & 2000 & 2005 & 2010 & 2013 & 2014 & 2015 & 2016 & 2017 \\
\hline \multicolumn{9}{|l|}{$\begin{array}{l}\text { Подано патентных } \\
\text { заявок: }\end{array}$} \\
\hline $\begin{array}{l}\text { на изобретения - } \\
\text { всего }\end{array}$ & 28688 & 32254 & 42500 & 44914 & 40308 & 45517 & 41587 & 36454 \\
\hline $\begin{array}{l}\text { из них российски- } \\
\text { ми заявителями }\end{array}$ & 23377 & 23644 & 28722 & 28765 & 24072 & 29269 & 26795 & 22777 \\
\hline $\begin{array}{l}\text { на полезные моде- } \\
\text { ли - всего }\end{array}$ & 4631 & 9473 & 12262 & 14358 & 13952 & 11906 & 11112 & 10643 \\
\hline $\begin{array}{l}\text { из них российски- } \\
\text { ми заявителями }\end{array}$ & 4549 & 9082 & 11757 & 13589 & 13000 & 11403 & 10643 & 10152 \\
\hline $\begin{array}{l}\text { на промышленные } \\
\text { образцы - всего }\end{array}$ & 2290 & 3917 & 3997 & 4994 & 5184 & 4929 & 5464 & 6487 \\
\hline $\begin{array}{l}\text { из них российски- } \\
\text { ми заявителями }\end{array}$ & 1918 & 2516 & 1981 & 1902 & 2200 & 2015 & 2391 & 3263 \\
\hline Выдано патентов: & & & & & & & & \\
\hline $\begin{array}{l}\text { на изобретения - } \\
\text { всего }\end{array}$ & 17592 & 23390 & 30322 & 31638 & 33950 & 34706 & 33536 & 34254 \\
\hline $\begin{array}{l}\text { из них российским } \\
\text { заявителям }\end{array}$ & 14444 & $\mid 19447$ & 21627 & 21378 & 23065 & 22560 & 21020 & 21037 \\
\hline $\begin{array}{l}\text { на полезные моде- } \\
\text { ли - всего }\end{array}$ & 4098 & 7242 & 10581 & 12653 & 13080 & 9008 & 8875 & 8774 \\
\hline $\begin{array}{l}\text { из них российским } \\
\text { заявителям }\end{array}$ & 4044 & 6958 & 10187 & 12154 & 12267 & 8390 & 8474 & 8376 \\
\hline $\begin{array}{l}\text { на промышленные } \\
\text { образцы - всего }\end{array}$ & 1626 & 2469 & 3566 & 3461 & 3742 & 5459 & 4455 & 5339 \\
\hline $\begin{array}{l}\text { из них российским } \\
\text { заявителям }\end{array}$ & 1228 & 1630 & 1741 & 1278 & 1394 & 2031 & 1780 & 2194 \\
\hline $\begin{array}{l}\text { Число действующих } \\
\text { патентов - всего }\end{array}$ & $\ldots$ & 164099 & 259698 & 272641 & 292048 & 305119 & 314615 & 326624 \\
\hline в том числе: & & & & & & & & \\
\hline на изобретения & $\ldots$ & 123089 & 181904 & 194248 & 208320 & 218974 & 230870 & 244321 \\
\hline на полезные модели & $\ldots$ & 28364 & 54848 & 54420 & 58238 & 57448 & 53263 & 50078 \\
\hline $\begin{array}{l}\text { на промышленные } \\
\text { образцы }\end{array}$ & $\ldots$ & 12646 & 22946 & 23973 & 25490 & 28697 & 30482 & 32225 \\
\hline
\end{tabular}


22.18. ИННОВАЦИОННАЯ АКТИВНОСТЬ ОРГАНИЗАЦИЙ

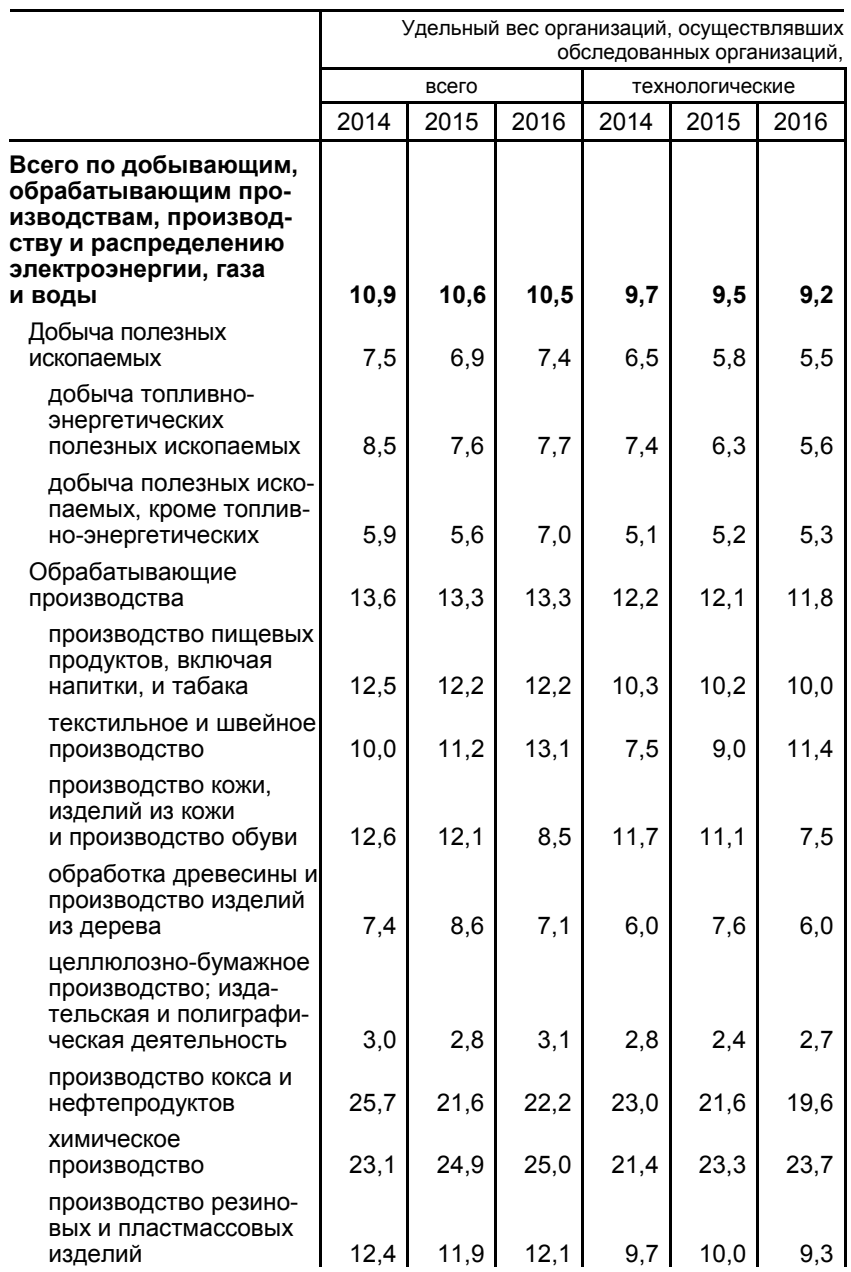




\section{ПО ВИДАМ ЭКОНОМИЧЕСКОЙ ДЕЯТЕЛЬНОСТИ}

\begin{tabular}{|c|c|c|c|c|c|c|}
\hline \multicolumn{6}{|c|}{$\begin{array}{l}\text { инновации отдельных типов, в общем числе } \\
\text { процентов }\end{array}$} & \\
\hline \multicolumn{3}{|c|}{ маркетинговые } & \multicolumn{3}{|c|}{ организационные } & \\
\hline 2014 & 2015 & 2016 & 2014 & 2015 & 2016 & \\
\hline 2,0 & 2,0 & 1,9 & 3,0 & 2,9 & 2,8 & $\begin{array}{l}\text { Всего по добывающим, } \\
\text { обрабатывающим про- } \\
\text { изводствам, производ- } \\
\text { ству и распределению } \\
\text { электроэнергии, газа } \\
\text { и воды }\end{array}$ \\
\hline & & & & & & Добыча полезных \\
\hline 0,5 & 0,5 & 0,5 & 2,3 & 2,6 & 2,8 & ископаемых \\
\hline 0,5 & 0,6 & 0,4 & 2,6 & 2,7 & 3,3 & $\begin{array}{l}\text { добыча топливно- } \\
\text { энергетических } \\
\text { полезных ископаемых }\end{array}$ \\
\hline 0,5 & 0,5 & 0,6 & 2,0 & 2,3 & 2,1 & $\begin{array}{l}\text { добыча полезных иско- } \\
\text { паемых, кроме топлив- } \\
\text { но-энергетических }\end{array}$ \\
\hline 2,8 & 2,9 & 2,8 & 3,6 & 3,6 & 3,4 & $\begin{array}{l}\text { Обрабатывающие } \\
\text { производства }\end{array}$ \\
\hline 4,3 & 4,1 & 4,0 & 2,4 & 2,2 & 2,0 & $\begin{array}{l}\text { производство пищевых } \\
\text { продуктов, включая } \\
\text { напитки, и табака }\end{array}$ \\
\hline 3,1 & 4,0 & 4,3 & 3,5 & 3,3 & 2,8 & $\begin{array}{l}\text { текстильное и швейное } \\
\text { производство }\end{array}$ \\
\hline 1,8 & 2,0 & 0,9 & 1,8 & 2,0 & 1,9 & $\begin{array}{l}\text { производство кожи, } \\
\text { изделий из кожи } \\
\text { и производство обуви }\end{array}$ \\
\hline 1,2 & 1,5 & 1,3 & 3,0 & 3,3 & 2,3 & $\begin{array}{l}\text { обработка древесины и } \\
\text { производство изделий } \\
\text { из дерева }\end{array}$ \\
\hline 0,5 & 0,5 & 0,5 & 0,5 & 0,7 & 0,5 & $\begin{array}{l}\text { целлюлозно-бумажное } \\
\text { производство; изда- } \\
\text { тельская и полиграфи- } \\
\text { ческая деятельность }\end{array}$ \\
\hline 1,8 & 2,2 & 3,3 & 9,7 & 8,6 & 8,5 & $\begin{array}{l}\text { производство кокса и } \\
\text { нефтепродуктов }\end{array}$ \\
\hline 5,8 & 4,7 & 5,1 & 5,4 & 6,1 & 5,7 & $\begin{array}{l}\text { химическое } \\
\text { производство }\end{array}$ \\
\hline 3,0 & 3,3 & 3,5 & 3,5 & 3,2 & 4,5 & $\begin{array}{l}\text { производство резино- } \\
\text { вых и пластмассовых } \\
\text { изделий }\end{array}$ \\
\hline
\end{tabular}




\begin{tabular}{|c|c|c|c|c|c|c|}
\hline & \multicolumn{6}{|c|}{$\begin{array}{r}\text { Удельный вес организаций, осуществлявших } \\
\text { обследованных организаций, }\end{array}$} \\
\hline & \multicolumn{3}{|c|}{ всего } & \multicolumn{3}{|c|}{ технологические } \\
\hline & 2014 & 2015 & 2016 & 2014 & 2015 & 2016 \\
\hline $\begin{array}{l}\text { производство прочих } \\
\text { неметаллических ми- } \\
\text { неральных продуктов }\end{array}$ & 9,3 & 9,3 & 9,7 & 7,9 & 7,9 & 8,0 \\
\hline $\begin{array}{l}\text { металлургическое про- } \\
\text { изводство и производ- } \\
\text { ство готовых металли- } \\
\text { ческих изделий }\end{array}$ & 14,7 & 14,1 & 13,4 & 13,0 & 12,8 & 11,7 \\
\hline $\begin{array}{l}\text { производство машин и } \\
\text { оборудования }\end{array}$ & 15,9 & 13,9 & 14,3 & 14,6 & 12,9 & 12,6 \\
\hline $\begin{array}{l}\text { производство электро- } \\
\text { оборудования, элек- } \\
\text { тронного и оптического } \\
\text { оборудования }\end{array}$ & 28,3 & 27,4 & 25,9 & 27,0 & 26,5 & 24,8 \\
\hline $\begin{array}{l}\text { производство транс- } \\
\text { портных средств и } \\
\text { оборудования }\end{array}$ & 21,2 & 18,2 & 19,0 & 19,4 & 16,9 & 17,3 \\
\hline $\begin{array}{l}\text { прочие производства, } \\
\text { не включенные } \\
\text { в другие группировки } \\
\text { обрабатывающих } \\
\text { производств }\end{array}$ & 15,8 & 17,7 & 16,6 & 14,7 & 16,5 & 14,7 \\
\hline $\begin{array}{l}\text { Производство и распре- } \\
\text { деление электроэнергии, } \\
\text { газа и воды }\end{array}$ & 5,1 & 4,9 & 4,8 & 4,5 & 4,3 & 4,1 \\
\hline $\begin{array}{l}\text { Всего по монтажу зданий } \\
\text { и сооружений из сборных } \\
\text { конструкций, устройству } \\
\text { покрытий зданий и со- } \\
\text { оружений, производству } \\
\text { прочих строительных ра- } \\
\text { бот }{ }^{1)}\end{array}$ & & 2,0 & 1,5 & & 2,0 & 1,1 \\
\hline $\begin{array}{l}\text { монтаж зданий и соору- } \\
\text { жений из сборных конст- } \\
\text { рукций }\end{array}$ & & 3,4 & - & & 3,4 & - \\
\hline $\begin{array}{l}\text { устройство покрытий } \\
\text { зданий и сооружений }\end{array}$ & & - & - & & - & - \\
\hline $\begin{array}{l}\text { производство прочих } \\
\text { строительных работ }\end{array}$ & & 1,5 & 2,2 & & 1,5 & 1,6 \\
\hline $\begin{array}{l}\text { из них производство } \\
\text { бетонных и железобе- } \\
\text { тонных работ }\end{array}$ & & - & - & & - & - \\
\hline
\end{tabular}


Продолжение табл. 22.18

инновации отдельных типов, в общем числе процентов

\begin{tabular}{|c|c|c|c|c|c|c|}
\hline \multicolumn{3}{|c|}{ маркетинговые } & \multicolumn{3}{|c|}{ организационные } & \\
\hline 2014 & 2015 & 2016 & 2014 & 2015 & 2016 & \\
\hline 1,6 & 2,0 & 2,5 & 2,1 & 4,1 & 4,1 & $\begin{array}{l}\text { производство прочих } \\
\text { неметаллических ми- } \\
\text { неральных продуктов } \\
\text { металлургическое про- } \\
\text { изводство и производ- } \\
\text { ство готовых металли- } \\
\text { ческих изделий }\end{array}$ \\
\hline 2,8 & 2,7 & 2,7 & 4,6 & 3,7 & 3,7 & $\begin{array}{l}\text { производство машин и } \\
\text { оборудования }\end{array}$ \\
\hline 5,1 & 5,7 & 4,8 & 7,8 & 7,6 & 6,8 & $\begin{array}{l}\text { производство электро- } \\
\text { оборудования, элек- } \\
\text { тронного и оптического } \\
\text { оборудования }\end{array}$ \\
\hline 1,7 & 1,6 & 1,5 & 6,4 & 5,9 & 5,6 & $\begin{array}{l}\text { производство транс- } \\
\text { портных средств и обо } \\
\text { рудования }\end{array}$ \\
\hline 3,7 & 3,8 & 3,8 & 6,4 & 6,4 & 7,0 & $\begin{array}{l}\text { прочие производства, } \\
\text { не включенные } \\
\text { в другие группировки } \\
\text { обрабатывающих } \\
\text { производств }\end{array}$ \\
\hline 0,3 & 0,3 & 0,4 & 1,5 & 1,5 & 1,5 & $\begin{array}{l}\text { Производство и рас- } \\
\text { пределение электро- } \\
\text { энергии, газа и воды }\end{array}$ \\
\hline & - & 0,4 & & - & 1,1 & $\begin{array}{l}\text { Всего по монтажу зданий } \\
\text { и сооружений из сборных } \\
\text { конструкций, устройству } \\
\text { покрытий зданий и со- } \\
\text { оружений, производству } \\
\text { прочих строительных ра- } \\
\text { бот 1) }\end{array}$ \\
\hline & - & 0,5 & & - & 1,6 & $\begin{array}{l}\text { монтаж зданий и соору- } \\
\text { жений из сборных конст- } \\
\text { рукций } \\
\text { устройство покрытий } \\
\text { зданий и сооружений } \\
\text { производство прочих } \\
\text { строительных работ }\end{array}$ \\
\hline & & & & - & & $\begin{array}{l}\text { из них производство } \\
\text { бетонных и железобе- } \\
\text { тонных работ }\end{array}$ \\
\hline
\end{tabular}




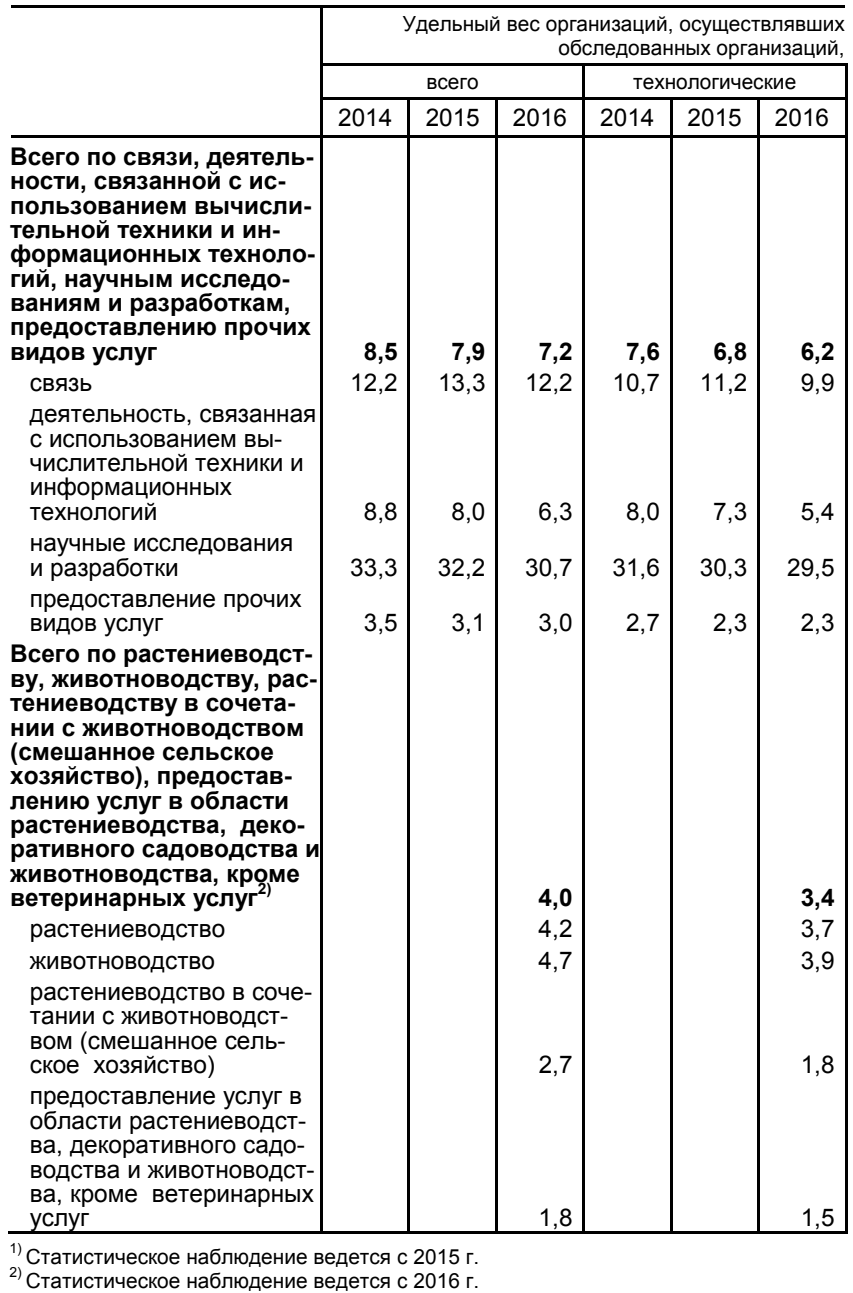


Продолжение табл. 22.18

инновации отдельных типов, в общем числе процентов

\begin{tabular}{|c|c|c|c|c|c|c|}
\hline \multicolumn{3}{|c|}{ маркетинговые } & \multicolumn{3}{|c|}{ организационные } & \\
\hline 2014 & 2015 & 2016 & 2014 & 2015 & 2016 & \\
\hline 1,3 & 1,5 & 1,2 & 2,7 & 2,5 & 2,3 & $\begin{array}{l}\text { Всего по связи, деятель- } \\
\text { ности, связанной с ис- } \\
\text { пользованием вычисли- } \\
\text { тельной техники и ин- } \\
\text { формационных техноло- } \\
\text { гий, научным исследо- } \\
\text { ваниям и разработкам, } \\
\text { предоставлению прочих } \\
\text { видов услуг }\end{array}$ \\
\hline 3,3 & 5,5 & 3,5 & 4,5 & 5,3 & 4,6 & $\begin{array}{l}\text { связь } \\
\text { деятельность, связанная } \\
\text { с использованием вы- } \\
\text { числительной техники и } \\
\text { информационных } \\
\text { технологий }\end{array}$ \\
\hline 4,1 & 4,3 & 4,4 & 8,7 & 7,5 & $\begin{array}{r}8,2 \\
1,1\end{array}$ & $\begin{array}{l}\text { научные исследования } \\
\text { и разработки } \\
\text { предоставление прочих } \\
\text { видов услуг }\end{array}$ \\
\hline & & $\begin{array}{l}\mathbf{0 , 4} \\
0,2 \\
0,7\end{array}$ & & & $\begin{array}{l}0,9 \\
0,8 \\
1,1\end{array}$ & $\begin{array}{l}\text { Всего по растениеводст- } \\
\text { ву, животноводству, рас- } \\
\text { тениеводству в сочета- } \\
\text { нии с животноводством } \\
\text { (смешанное сельское } \\
\text { хозяйство), предостав- } \\
\text { лению услуг в области } \\
\text { растениеводства, деко- } \\
\text { ративного садоводства и } \\
\text { животноводства, кроме } \\
\text { ветеринарных услуг }{ }^{2} \text { ) } \\
\text { растениеводство } \\
\text { животноводство } \\
\text { растениеводство в соче- } \\
\text { тании с животноводст- } \\
\text { вом (смешанное сель- } \\
\text { ское хозяйство) } \\
\text { предоставление услуг в } \\
\text { области растениеводст- } \\
\text { ва, декоративного садо- } \\
\text { водства и животноводст- } \\
\text { ва, кроме ветеринарных } \\
\text { услуг } \\
\end{array}$ \\
\hline
\end{tabular}


22.19. ЗАТРАТЫ НА ТЕХНОЛОГИЧЕСКИЕ ИННОВАЦИИ ОРГАНИЗАЦИЙ ПО ВИДАМ ЭКОНОМИЧЕСКОЙ ДЕЯТЕЛЬНОСТИ

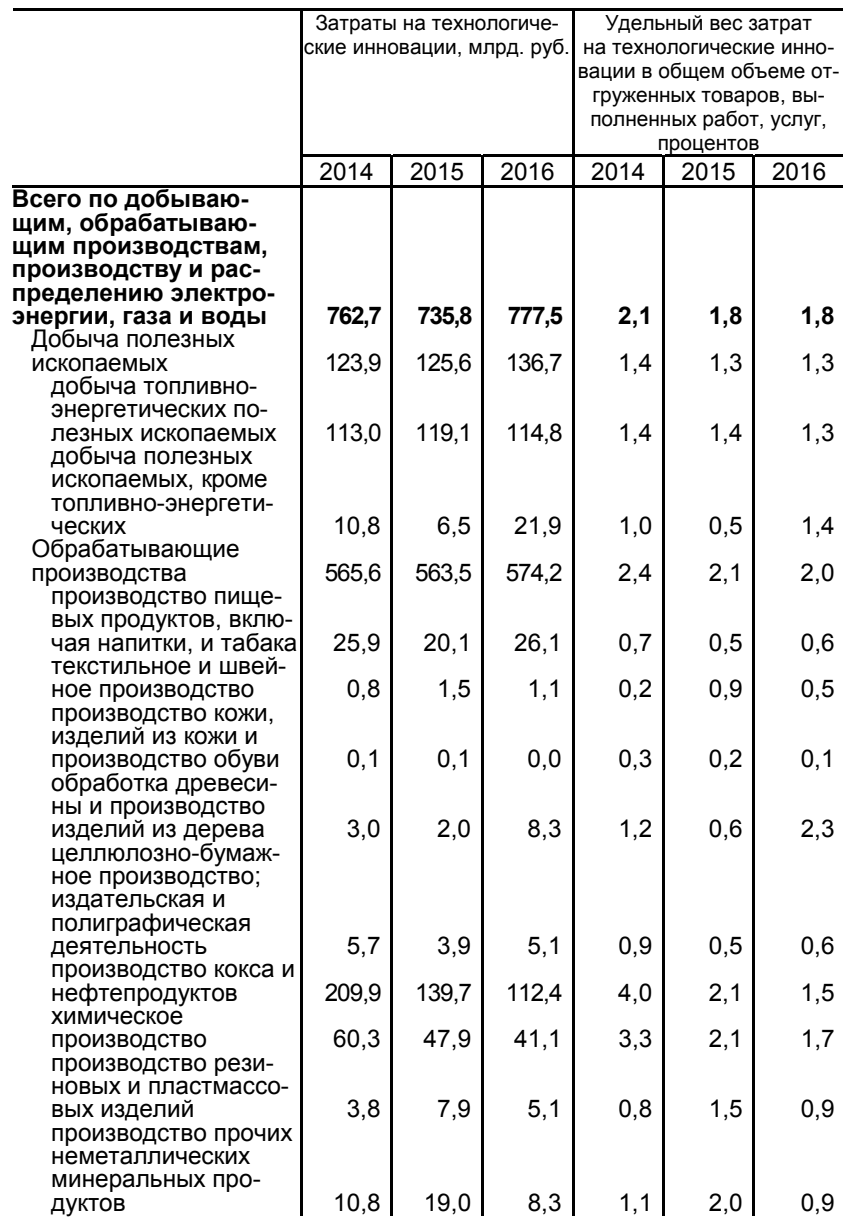


Продолжение табл. 22.19

\begin{tabular}{|c|c|c|c|c|c|c|}
\hline & \multicolumn{3}{|c|}{$\begin{array}{l}\text { Затраты на технологиче- } \\
\text { ские инновации, млрд. руб. }\end{array}$} & \multicolumn{3}{|c|}{$\begin{array}{c}\text { Удельный вес затрат } \\
\text { на технологические инно- } \\
\text { вации в общем объеме от- } \\
\text { груженных товаров, вы- } \\
\text { полненных работ, услуг, } \\
\text { процентов }\end{array}$} \\
\hline & 2014 & 2015 & 2016 & 2014 & 2015 & 2016 \\
\hline $\begin{array}{l}\text { металлургическое } \\
\text { производство и } \\
\text { производство гото- } \\
\text { вых металлических } \\
\text { изделий }\end{array}$ & 52,3 & 60,0 & 63,0 & 1,3 & 1,3 & 1,4 \\
\hline $\begin{array}{l}\text { производство машин } \\
\text { и оборудования } \\
\text { производство элек- } \\
\text { трооборудования, } \\
\text { электронного } \\
\text { и оптического } \\
\text { оборудования }\end{array}$ & 19,2 & 18,0 & 138,0 & 1,8 & 1,7 & 1,6 \\
\hline $\begin{array}{l}\text { производство транс- } \\
\text { портных средств и } \\
\text { оборудования }\end{array}$ & 77,9 & 105,5 & 81,3 & 2,8 & 3,9 & 2,7 \\
\hline $\begin{array}{l}\text { прочие производства, } \\
\text { не включенные } \\
\text { в другие группировки } \\
\text { обрабатывающих } \\
\text { производств }\end{array}$ & 39,0 & 66,5 & 65,6 & 3,3 & 5,3 & 4,3 \\
\hline $\begin{array}{l}\text { Производство и рас- } \\
\text { пределение электро- } \\
\text { энергии, газа и воды }\end{array}$ & 73,3 & 46,7 & 66,7 & 1,8 & 1,2 & 1,5 \\
\hline $\begin{array}{l}\text { Всего по монтажу зда- } \\
\text { ний и сооружений из } \\
\text { сборных конструкций, } \\
\text { устройству покрытий } \\
\text { зданий и сооружений, } \\
\text { производству прочих } \\
\text { строительных работ }{ }^{1)}\end{array}$ & & 0,01 & 0,0 & & 0,00 & 0,01 \\
\hline $\begin{array}{l}\text { монтаж зданий и со- } \\
\text { оружений из сборных } \\
\text { конструкций }\end{array}$ & & 0,01 & - & & 0,04 & - \\
\hline $\begin{array}{l}\text { устройство покрытий } \\
\text { зданий и сооружений }\end{array}$ & & - & - & & - & - \\
\hline $\begin{array}{l}\text { производство прочих } \\
\text { строительных работ }\end{array}$ & & 0,00 & 0,00 & & 0,00 & 0,01 \\
\hline $\begin{array}{l}\text { из них производство } \\
\text { бетонных и железо- } \\
\text { бетонных работ }\end{array}$ & & - & - & & - & - \\
\hline
\end{tabular}


Продолжение табл. 22.19

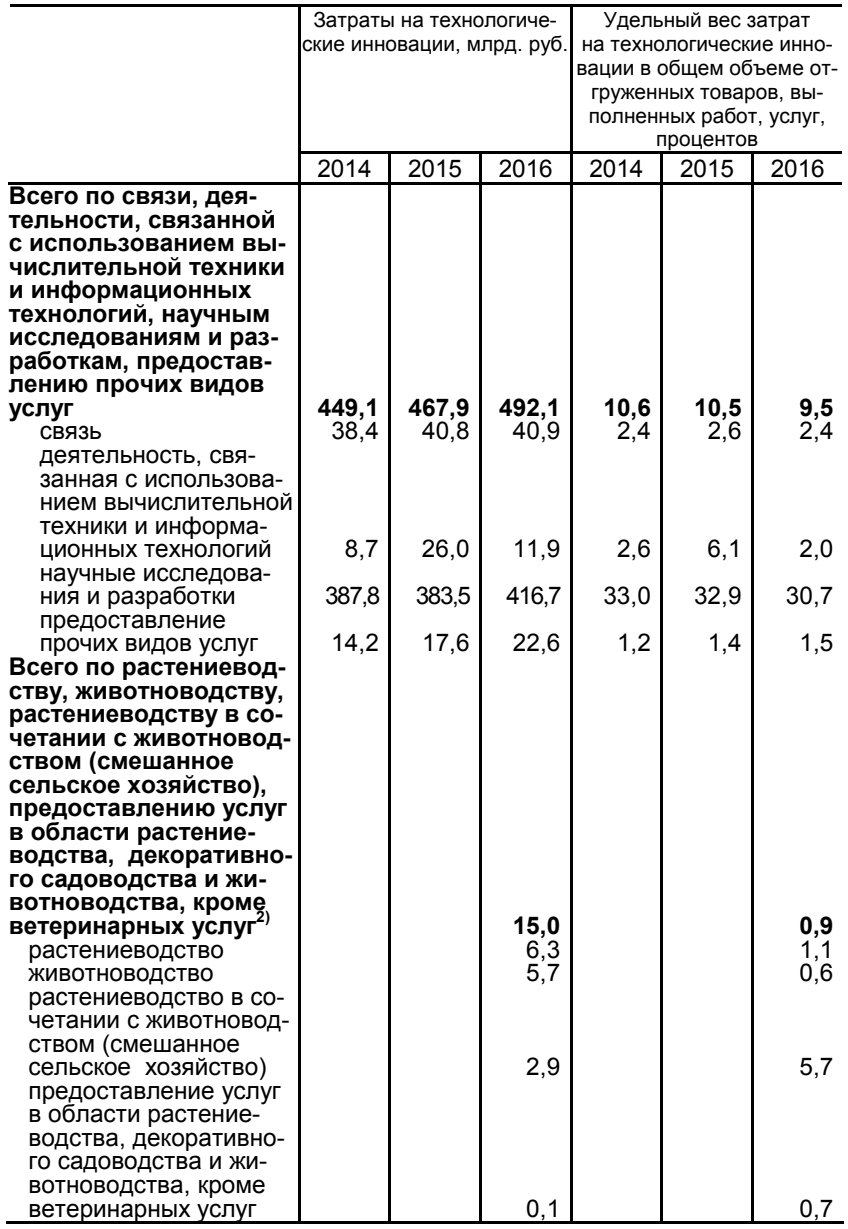

1) Статистическое наблюдение ведется с 2015 г.

${ }^{2)}$ Статистическое наблюдение ведется с 2016 г. 
22.20. ОБЪЕМ ИННОВАЦИОННЫХ ТОВАРОВ, РАБОТ, УСЛУГ ОРГАНИЗАЦИЙ ПО ВИДАМ ЭКОНОМИЧЕСКОЙ ДЕЯТЕЛЬНОСТИ

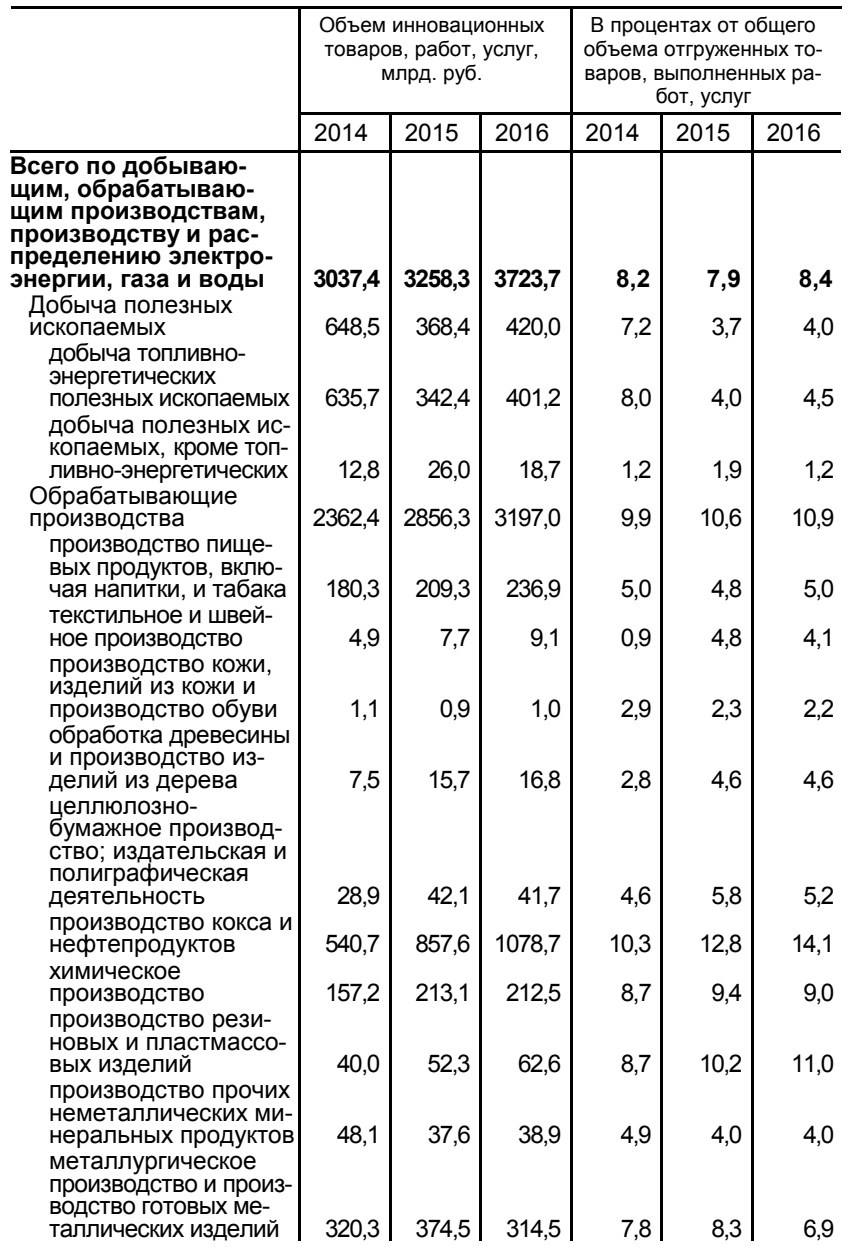


Продолжение табл. 22.20

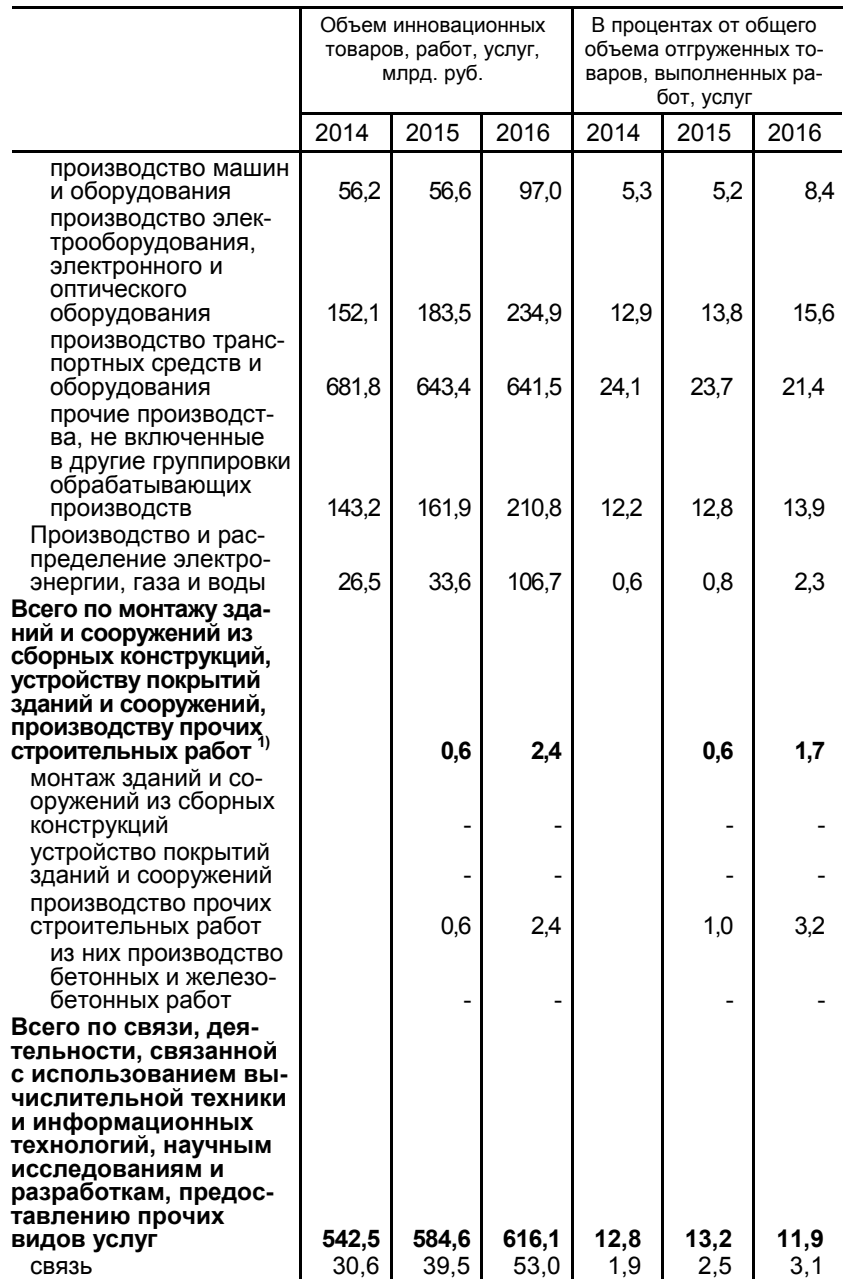


Продолжение табл. 22.20

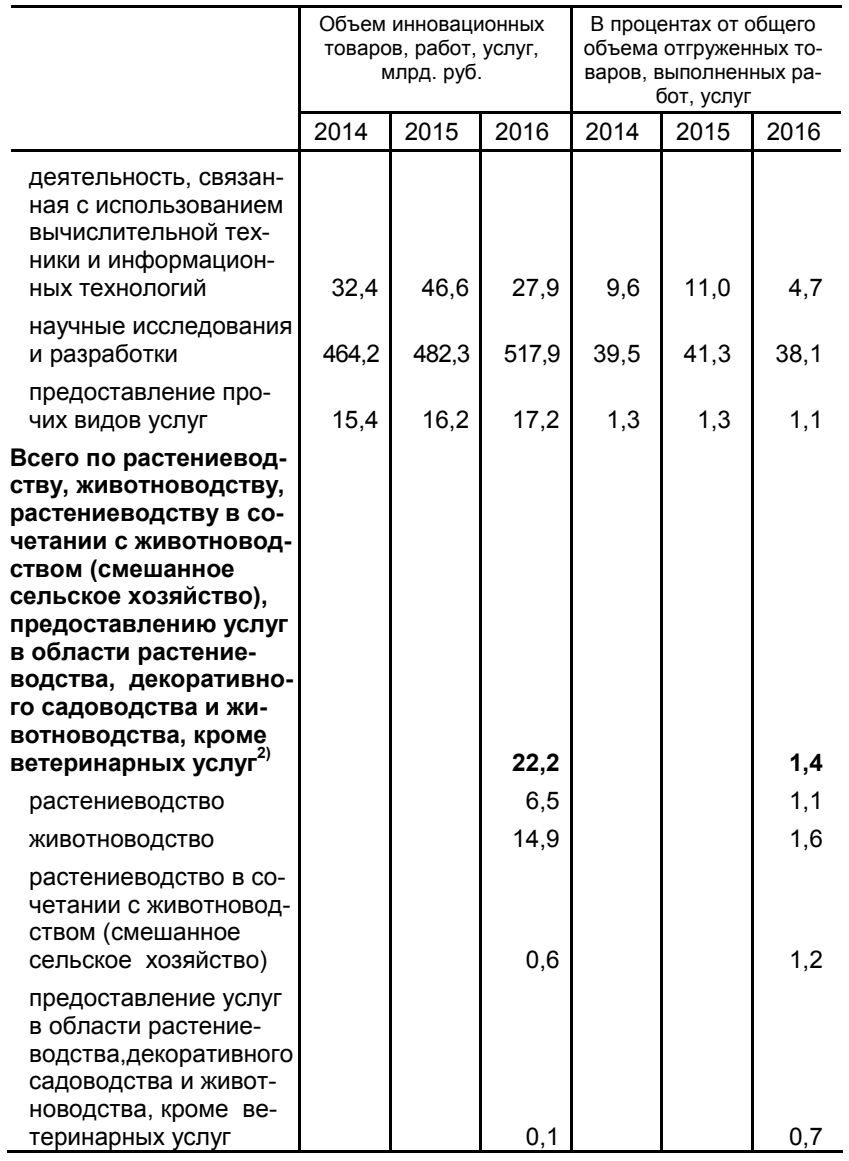

1) Статистическое наблюдение ведется с 2015 г.

${ }^{2)}$ Статистическое наблюдение ведется с 2016 г. 


\section{3. ФИНАНСЫ}

Раздел представляет статистику государственных финансов, денежно-кредитной системы, данные о финансовой деятельности организаций.

Данные в таблицах, содержащих показатели по видам экономической деятельности, приводятся за 2017 год в соответствии с Общероссийским классификатором видов экономической деятельности (ОКВЭД 2) ОК 029-2014, введенным в действие с 1 января 2017 г.

Аналогичные сведения за период до 2016 г. включительно, разработанные в соответствии с ранее действовавшим Общероссийским классификатором видов экономической деятельности (ОКВЭД-2007) ОК 029-2007, опубликованы в кратком статистическом сборнике «Россия в цифрах. 2017», электронная версия которого размещена на официальном Интернет-портале Росстата в разделе «Публикации».

Статистика государственных финансов ведет учет доходов и расходов сектора государственного управления.

Информационная база статистики государственных фринансов сформирована на основе данных, разрабатываемых Федеральным казначейством.

Для составления проектов и исполнения бюджетов всех уровней, начиная с 1995 г., используется бюджетная классификация Российской Федерации.

Бюджетная классификация Российской Федерации является группировкой доходов, расходов и источников финансирования дефицитов бюджетов бюджетной системы Российской Федерации, используемой для составления и исполнения бюджетов, а также группировкой доходов, расходов и источников финансирования дефрицитов бюджетов и (или) операций сектора государственного управления, используемой для ведения бюджетного (бухгалтерского) учета, составления бюджетной (бухгалтерской) и иной финансовой отчетности, обеспечивающей сопоставимость показателей бюджетов бюджетной системы Российской Федерации.

Текущий финансовый год - год, в котором осуществляется исполнение бюджета, составление и рассмотрение проекта бюджета на очередной финансовый год (очередной финансовый год и плановый период). Финансовый год соответствует календарному году и длится с 1 января по 31 декабря.

Бюджетная система Российской Федерации - основанная на экономических отношениях и государственном устройст-

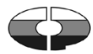


ве Российской Федерации, регулируемая законодательством Российской Федерации совокупность федерального бюджета, бюджетов субъектов Российской Федерации, местных бюджетов и бюджетов государственных внебюджетных фондов.

Федеральный бюджет предназначен для исполнения расходных обязательств Российской Федерации.

Бюджет субъекта Российской Федерации (региональный бюджет) предназначен для исполнения расходных обязательств субъекта Российской Федерации. Бюджет субъекта Российской Федерации и свод бюджетов муниципальных образований, входящих в состав субъекта Российской Федерации (без учета межбюджетных трансфертов между этими бюджетами), образуют консолидированный бюджет субъекта Российской Федерации.

Бюджет муниципального образования (местный бюджет) предназначен для исполнения расходных обязательств муниципального образования.

Консолидированный бюджет Российской Федерации образуют федеральный бюджет и свод консолидированных бюджетов субъектов Российской Федерации (без учета межбюджетных трансфертов между этими бюджетами).

Бюджеты государственных внебюджетных фондов включают бюджеты государственных внебюджетных фондов Российской Федерации и бюджеты территориальных государственных внебюджетных фондов.

Бюджетами государственных внебюджетных фондов Российской Федерации являются: бюджет Пенсионного фонда Российской Федерации, бюджет Фонда социального страхования Российской Федерации, бюджет Федерального фонда обязательного медицинского страхования. Бюджетами территориальных государственных внебюджетных фондов являются бюджеты территориальных фондов обязательного медицинского страхования.

Доходы бюджета - поступающие в бюджет денежные средства, за исключением средств, являющихся в соответствии с Бюджетным кодексом Российской Федерации источниками финансирования дефицита бюджета.

К доходам бюджетов относятся налоговые доходы, неналоговые доходы и безвозмездные поступления.

К налоговым доходам относятся доходы от предусмотренных законодательством Российской Федерации о налогах и сборах федеральных налогов и сборов, в том числе от налогов, предусмотренных специальными налоговыми режимами, региональных налогов, местных налогов и сборов, а также пеней и штрафов по ним.

К неналоговым доходам относятся: доходы от использования имущества, находящегося в государственной или муни- 
ципальной собственности, за исключением имущества бюджетных и автономных учреждений, а также имущества государственных и муниципальных унитарных предприятий, в том числе казенных, земельных участков и иных объектов недвижимого имущества, находящихся в федеральной собственности, используемых единым институтом развития в жилищной сфере (в соответствии с Федеральным законом от 24.07.2008 г. № 161-Ф3 «О содействии развитию жилищного строительства»); доходы от продажи имущества (кроме акций и иных форм участия в капитале, государственных запасов драгоценных металлов и драгоценных камней), находящегося в государственной или муниципальной собственности, за исключением движимого имущества бюджетных и автономных учреждений, а также имущества государственных и муниципальных унитарных предприятий, в том числе казенных, земельных участков и иных объектов недвижимого имущества, находящихся в федеральной собственности, используемых единым институтом развития в жилищной сфере (в соответствии с Федеральным законом от 23.07. 2008 г. № 161-Ф3 «О содействии развитию жилищного строительства»); доходы от платных услуг, оказываемых казенными учреждениями; средства, полученные в результате применения мер гражданско-правовой, административной и уголовной ответственности, в том числе штрафы, конфискации, компенсации, а также средства, полученные в возмещение вреда, причиненного Российской Федерации, субъектам Российской Федерации, муниципальным образованиям, и иные суммы принудительного изъятия; средства самообложения граждан; иные неналоговые доходы.

Расходы бюджета - выплачиваемые из бюджета денежные средства, за исключением средств, являющихся в соответствии с Бюджетным кодексом Российской Федерации источниками финансирования дефицита бюджета.

Дефицит бюджета - превышение расходов бюджета над его доходами.

Профицит бюджета - превышение доходов бюджета над его расходами.

Статистика денежно-кредитной системы разрабатывается на основании данных Банка России, Сбербанка России и данных федеральных статистических наблюдений.

Денежная масса (денежный агрегат М2) - это сумма наличных денег в обращении и остатков средств нефинансовых и финансовых (кроме кредитных) организаций - резидентов Российской Федерации и физических лиц - резидентов Российской Федерации на расчетных, текущих и иных счетах до востребования (в том числе счетах для расчетов с использованием банковских карт), срочных депозитов и иных привлеченных на срок

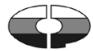


средств, открытых в банковской системе Российской Федерации в рублях, а также начисленные проценты по ним.

Переводные депозиты включают остатки средств нефинансовых и финансовых (кроме кредитных) организаций - резидентов Российской Федерации и физических лиц - резидентов Российской Федерации на расчетных, текущих и иных счетах до востребования (в том числе счетах для расчетов с использованием банковских карт), открытых в банковской системе Российской Федерации в рублях, а также начисленные проценты по ним.

Другие депозиты включают остатки средств нефинансовых и финансовых (кроме кредитных) организаций и физических лиц на срочных депозитах и иных привлеченных на срок средств в валюте Российской Федерации, а также начисленные проценты по ним.

Внешний долг Российской Федерации по состоянию на отчетную дату представляет собой непогашенную сумму текущих безусловных обязательств резидентов Российской Федерации перед нерезидентами, которая требует погашения основного долга и/или процентов в будущем.

Органы государственного управления. Данная категория включает внешнюю задолженность федеральных органов управления, возникшую как в период с 1992 г., - новый российский долг, так и задолженность, сформировавшуюся до 1992 г. и принятую на себя Россией после распада СССР, - долг бывшего СССР, а также задолженность органов управления субъектов Российской Федерации перед нерезидентами по привлеченным кредитам и выпущенным долговым ценным бумагам.

Новый российский долг охватывает средства, привлеченные от МБРР, ЕБРР, других международных организаций и правительств иностранных государств, задолженность перед нерезидентами по всем суверенным еврооблигациям, размещенным Правительством Российской Федерации, а также долг перед Лондонским клубом кредиторов. В состав прочей задолженности включается внешняя задолженность по текущим операциям.

Долг бывшего СССР включает заимствования у бывших социалистических стран и прочих стран - официальных кредиторов, а также остаток обязательств по товарным кредитам и процентам на просроченную задолженность, входящим в прочую задолженность.

Долг субъектов Российской Федерации - задолженность перед нерезидентами по кредитам, привлеченным субъектами Российской Федерации, и по выпущенным ими долговым ценным бумагам, номинированным в российских рублях.

Центральный банк. Данная категория охватывает внешние долговые обязательства Банка России. 
Банки. Данные включают обязательства кредитных организаций и Внешэкономбанка (в части его коммерческой деятельности) перед нерезидентами.

Прочие секторы. Данная категория содержит сведения о привлеченных внешних ресурсах с выделением обязательств других фринансовых организаций (не банков) и обязательств нефинансовых организаций, домашних хозяйств и некоммерческих организаций, обслуживающих домашние хозяйства (НКОДХ).

Вклады (депозиты), кредиты и прочие привлеченные кредитными организациями средства в рублях и иностранной валюте - денежные средства юридических и фризических лиц, индивидуальных предпринимателей, включая средства нерезидентов Российской Федерации, без учета начисленных процентов. Данные подразделяются на:

депозиты и прочие привлеченные средства юридических лиц - депозиты и прочие привлеченные средства (до востребования и срочные) органов государственного управления и внебюджетных фондов всех уровней, финансовых (кроме кредитных) и нефинансовых организаций всех форм собственности (включая депозитные сертификаты), а также неисполненные обязательства по договорам на привлечение средств по депозитам и прочим привлеченным средствам;

вклады (депозиты) фризических лиц - депозиты и прочие привлеченные кредитными организациями средства фризических лиц (включая сберегательные сертификаты), неисполненные обязательства по договорам на привлечение средств по депозитам и прочим привлеченным средствам, а также средства на прочих счетах фризических лиц. В расчет данного показателя не включаются средства индивидуальных предпринимателей, избирательных фондов физических лиц, переводы из Российской Федерации и в Российскую Федерацию;

средства на счетах индивидуальных предпринимателей - денежные средства на счетах индивидуальных предпринимателей, осуществляющих свою деятельность без образования юридического лица;

депозиты, кредиты и прочие привлеченные средства кредитных организаций включают вклады (депозиты), кредиты и прочие привлеченные средства кредитных организаций и банков-нерезидентов.

Кредиты, депозиты и прочие размещенные средства, предоставленные организациям (кроме органов государственной власти, местного самоуправления, государственных и внебюджетных фондов), физическим лицам и кредитным организациям, в рублях и иностранной валюте, задолженность клиентов (резидентов и нерезидентов), включая просроченную задолженность, перед кредитными организация-

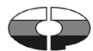


ми по всем предоставленным им средствам указанных видов. В общую величину задолженности, кроме соответствующих сумм, выделенных в том числе из общего итога (физическим лицам, организациям, кредитным организациям), включаются также кредиты иностранным государствам и задолженность (включая просроченную) по операциям с драгоценными металлами (кроме операций с кредитными организациями).

Страховщики - страховые организации и общества взаимного страхования, созданные в соответствии с законодательством Российской Федерации для осуществления деятельности по страхованию, перестрахованию, взаимному страхованию и получившие лицензии на осуществление соответствующего вида страховой деятельности в соответствии с Законом от 27.11.1992 г. № 4015-1 «Об организации страхового дела в Российской Федерации».

Страховые премии (взносы) - плата за страхование, которую страхователь (выгодоприобретатель) обязан уплатить страховщику в порядке и в сроки, которые установлены договором страхования.

Выплаты по договорам страхования - денежная сумма, которая определена в порядке, установленном федеральным законом и (или) договором страхования, и выплачивается страховщиком страхователю, застрахованному лицу, выгодоприобретателю при наступлении страхового случая.

Обязательное медицинское страхование (ОМС) - вид обязательного социального страхования, представляющий собой систему создаваемых государством правовых, экономических и организационных мер, направленных на обеспечение при наступлении страхового случая гарантий бесплатного оказания медицинской помощи за счет средств обязательного медицинского страхования. В соответствии с Федеральным законом от 29.11.2010 г. № 326-Ф3 «Об обязательном медицинском страховании в Российской Федерации» страховые медицинские организации с 01.01.2012 г. осуществляют свою деятельность в сфере обязательного медицинского страхования на основании договора о финансовом обеспечении ОМС, заключенного с территориальным фондом ОМС.

Официальный курс доллара США по отношению к российскому рублю рассчитывается и устанавливается Банком России каждый рабочий день на основе котировок межбанковского внутреннего валютного рынка по операциям "доллар США - рубль".

Официальный курс евро по отношению к российскому рублю рассчитывается и устанавливается Банком России на основе официального курса доллара США по отношению к рублю и котировок межбанковского международного валютного рынка по операциям “доллар США - евро”. 
Статистика финансов организаций содержит показатели, отражающие финансовое положение организаций. Сбор данных осуществляется на основе форм федерального статистического наблюдения и бухгалтерской отчетности.

Сальдированный финансовый результат (прибыль минус убыток) - конечный финансовый результат, выявленный на основании бухгалтерского учета всех хозяйственных операций организаций. Представляет собой сумму прибыли (убытка) от продажи товаров, продукции (работ, услуг), основных средств, иного имущества организаций и чистых доходов от прочих операций. Данные по сальдированному финансовому результату приводятся без субъектов малого предпринимательства, в фактически действовавших ценах, структуре и методологии соответствующих лет.

Рентабельность организаций характеризует эфрфективность их деятельности.

Рентабельность проданных товаров, продукции (работ, услуг) рассчитывается как соотношение между величиной сальдированного финансового результата (прибыль минус убыток) от продажи товаров, продукции (работ, услуг) и себестоимостью проданных товаров, продукции (работ, услуг) с учетом коммерческих и управленческих расходов. В том случае, если получен отрицательный сальдированный финансовый результат от продажи товаров, продукции (работ, услуг), имеет место убыточность.

Рентабельность активов рассчитывается как соотношение сальдированного финансового результата (прибыль минус убыток) до налогообложения и стоимости активов организаций. В том случае, если получен отрицательный сальдированный финансовый результат, имеет место убыточность.

Суммарная задолженность по обязательствам организаций включает кредиторскую задолженность, задолженность по кредитам банков и займам.

Кредиторская задолженность - задолженность по расчетам с поставщиками и подрядчиками за поступившие материальные ценности, выполненные работы и оказанные услуги, в том числе задолженность, обеспеченная векселями выданными; задолженность по расчетам с дочерними и зависимыми обществами по всем видам операций; с рабочими и служащими по оплате труда, представляющая собой начисленные, но не выплаченные суммы оплаты труда; задолженность по отчислениям на государственное социальное страхование, пенсионное обеспечение и медицинское страхование работников организации, задолженность по всем видам платежей в бюджет и внебюджетные фонды; задолженность организации по платежам по обязательному и добровольному страхованию имущества и работников организации и другим видам страхования, в кото-

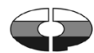


рых организация является страхователем; авансы полученные, включающие сумму полученных авансов от сторонних организаций по предстоящим расчетам по заключенным договорам, а также штрафы, пени и неустойки, признанные организацией или по которым получены решения суда (арбитражного суда) или другого органа, имеющего в соответствии с законодательством Российской Федерации право на принятие решения об их взыскании и отнесенные на финансовые результаты организации.

Дебиторская задолженность - задолженность по расчетам с покупателями и заказчиками за товары, работы и услуги, в том числе задолженность, обеспеченная векселями полученными; задолженность по расчетам с дочерними и зависимыми обществами; сумма уплаченных другим организациям авансов по предстоящим расчетам в соответствии с заключенными договорами; задолженность по расчетам с прочими дебиторами, включающая в себя задолженность финансовых и налоговых органов (в том числе по переплате по налогам, сборам и прочим платежам в бюджет); задолженность работников организации по предоставленным им ссудам и займам за счет средств этой организации или кредита (ссуды на индивидуальное и кооперативное жилищное строительство, приобретение и благоустройство садовых участков, беспроцентные ссуды молодым семьям на улучшение жилищных условий или обзаведение домашним хозяйством и др.); задолженность подотчетных лиц; поставщиков по недостачам товарно-материальных ценностей, обнаруженным при приемке; задолженность по государственным заказам, федеральным программам за поставленные товары, работы и услуги, а также штрафы, пени и неустойки, признанные должником или по которым получены решения суда (арбитражного суда) или другого органа, имеющего в соответствии с законодательством Российской Федерации право на принятие решения об их взыскании, отнесенные на финансовые результаты организации.

Просроченная задолженность - задолженность, не погашенная в сроки, установленные договором.

Просроченная задолженность по заработной плате работникам организаций - фактически начисленные суммы заработной платы, но не выплаченные в срок, установленный коллективным договором или договором на расчетно-кассовое обслуживание, заключенным с банком. В сумму просроченной задолженности включаются переходящие остатки задолженности, не погашенные на отчетную дату, и не включается задолженность на внутримесячные даты (аванс). 


\section{ГОСУДАРСТВЕННЫЕ ФИНАНСЫ}

\section{1. КОНСОЛИДИРОВАННЫЙ БЮДЖЕТ \\ РОССИЙСКОЙ ФЕДЕРАЦИИ И БЮДЖЕТОВ ГОСУДАРСТВЕННЫХ ВНЕБЮДЖЕТНЫХ ФОНДОВ в 2017 г. ${ }^{1)}$}

\begin{tabular}{|c|c|c|}
\hline & Млрд. руб. & $\begin{array}{c}\text { В процентах } \\
\text { к ВВП }\end{array}$ \\
\hline Доходы - всего & 31046,7 & 33,7 \\
\hline налог на прибыль организаций & 3290,1 & 3,6 \\
\hline налог на доходы физических лиц & 3252,3 & 3,5 \\
\hline страховые взносы на обязательное & & \\
\hline $\begin{array}{l}\text { социальное страхование } \\
\text { налог на добавленную стоимость: }\end{array}$ & 6784,0 & 7,4 \\
\hline $\begin{array}{l}\text { на товары (работы, услуги), реализуемые } \\
\text { на территории Российской федерации }\end{array}$ & 3070,2 & 3,3 \\
\hline $\begin{array}{l}\text { на товары, ввозимые на территорию } \\
\text { Российской Федерации }\end{array}$ & 2067,4 & 2,2 \\
\hline акцизы по подакцизным товарам (продукции): & & \\
\hline $\begin{array}{l}\text { Федерации } \\
\text { ввозимым на территорию Российской }\end{array}$ & 1521,3 & 1,7 \\
\hline $\begin{array}{l}\text { ввозимым на территорию Российской } \\
\text { Федерации }\end{array}$ & 78,2 & 0,1 \\
\hline налоги на совокупный доход & 446,9 & 0,5 \\
\hline $\begin{array}{l}\text { налоги на имущество } \\
\text { налоги, сборы и регулярные платежи }\end{array}$ & 1250,5 & 1,4 \\
\hline $\begin{array}{l}\text { налоги, сборы и регулярные платежи } \\
\text { за пользование природными ресурсами }\end{array}$ & 4162,9 & 4,5 \\
\hline $\begin{array}{l}\text { доходы от внешнеэкономической деятельности } \\
\text { доходы от использования имущества, нахо- }\end{array}$ & 2602,8 & 2,8 \\
\hline дящегося в государственной и муниципальной & & \\
\hline собственности & 963,8 & 1,0 \\
\hline $\begin{array}{l}\text { платежи при пользовании природными } \\
\text { ресурсами }\end{array}$ & & \\
\hline $\begin{array}{l}\text { ресурсами } \\
\text { безвозмездные поступления }\end{array}$ & $\begin{array}{r}369,5 \\
98,8\end{array}$ & $\begin{array}{l}0,4 \\
0,1\end{array}$ \\
\hline $\begin{array}{l}\text { Расходы - всего } \\
\text { из них на: }\end{array}$ & 32395,7 & 35,2 \\
\hline общегосударственные вопросы & 1952,6 & 2,1 \\
\hline $\begin{array}{l}\text { национальную оборону } \\
\text { национальную безопасность и правоохрани- }\end{array}$ & 2854,2 & 3,1 \\
\hline тельную деятельность & 2034,1 & 2,2 \\
\hline $\begin{array}{l}\text { национальную экономику } \\
\text { из нее на: }\end{array}$ & 4332,0 & 4,7 \\
\hline топливно-энергетический комплекс & 74,7 & 0,1 \\
\hline сельское хозяйство и рыболовство & 343,8 & 0,4 \\
\hline транспорт & 825,8 & 0,9 \\
\hline дорожное хозяйство (дорожные фонды) & 1488,4 & 1,6 \\
\hline $\begin{array}{l}\text { связь и инорорматику } \\
\text { прикладные научные исследования }\end{array}$ & & \\
\hline в области национальной экономики & 210,4 & 0,2 \\
\hline $\begin{array}{l}\text { другие вопросы в области национальной } \\
\text { экономики }\end{array}$ & 1036.6 & 11 \\
\hline жилищно-коммунальное хозяйство & 1209,9 & \\
\hline социально-культурные мероприятия & 19054,9 & 20,7 \\
\hline $\begin{array}{l}\text { обслуживание государственного и } \\
\text { муниципального долга }\end{array}$ & & 0,9 \\
\hline Дефицит & 1349,1 & 1,5 \\
\hline
\end{tabular}

1) По данным Федерального казначейства. 
23.2. ОТНОШЕНИЕ ПРОФИЦИТА (ДЕФИЦИТА)

КОНСОЛИДИРОВАННОГО БЮДЖЕТА РОССИЙСКОЙ ФЕДЕРАЦИИ И БЮДЖЕТОВ ГОСУДАРСТВЕННЫХ ВНЕБЮДЖЕТНЫХ ФОНДОВ К ВАЛОВОМУ ВНУТРЕННЕМУ ПРОДУКТУ ${ }^{1)}$

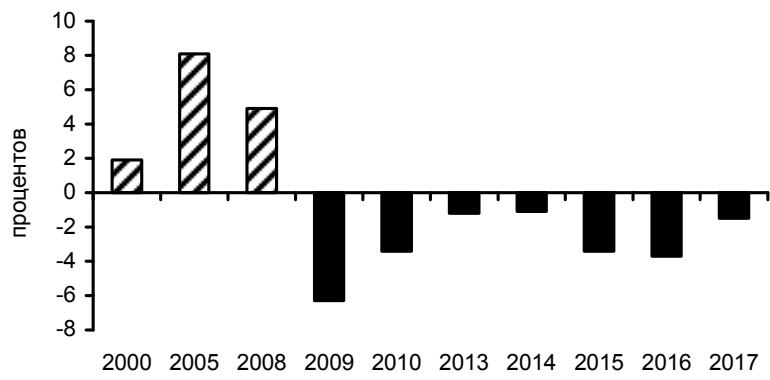

1) За 2000 г. расчет осуществлен без учета бюджетов государственных внебюджетных фондов.

23.3. РАСХОДЫ КОНСОЛИДИРОВАННОГО БЮДЖЕТА РОССИЙСКОЙ ФЕДЕРАЦИИ И БЮДЖЕТОВ ГОСУДАРСТВЕННЫХ

ВНЕБЮДЖЕТНЫХ ФОНДОВ НА СОЦИАЛЬНО-КУЛЬТУРНЫЕ МЕРОПРИЯТИЯ в 2017 г. ${ }^{1)}$

\begin{tabular}{l|r|r}
\hline & Млрд. руб. & $\begin{array}{c}\text { В процентах } \\
\text { к итогу }\end{array}$ \\
\hline Расходы - всего & 19054,9 & 100 \\
\multicolumn{1}{|c|}{ в том числе на: } & 3264,2 & 17,1 \\
образование & 492,9 & 2,6 \\
культуру, кинематографию & 2820,9 & 14,8 \\
здравоохранение & 12022,5 & 63,1 \\
социальную политику & 327,0 & 1,7 \\
физическую культуру и спорт & 127,3 & 0,7 \\
средства массовой информации &
\end{tabular}

1) По данным Федерального казначейства. 


\section{4. ИСПОЛНЕНИЕ РАСХОДНОЙ ЧАСТИ} ФЕДЕРАЛЬНОГО БЮДЖЕТА РОССИЙСКОЙ ФЕДЕРАЦИИ в 2017 г. ${ }^{1)}$

\begin{tabular}{|c|c|c|c|}
\hline & \multirow{2}{*}{\begin{tabular}{|c} 
Утверж- \\
дено свод- \\
ной бюд- \\
жетной \\
росписью \\
(с учетом \\
внесенных \\
изменений), \\
млрд. руб.
\end{tabular}} & \multicolumn{2}{|c|}{$\begin{array}{l}\text { Фактическое } \\
\text { исполнение }\end{array}$} \\
\hline & & млрд. руб. & $\begin{array}{c}\text { в процентах } \\
\text { к утверж- } \\
\text { денному } \\
\text { бюджету }\end{array}$ \\
\hline $\begin{array}{l}\text { Расходы } \\
\text { из них на: }\end{array}$ & 17016,9 & 16420,3 & 96,5 \\
\hline общегосударственные вопросы & 1248,3 & 1162,4 & 93,1 \\
\hline национальную оборону & 3059,6 & 2852,3 & 93,2 \\
\hline $\begin{array}{l}\text { национальную безопасность и } \\
\text { правоохранительную деятельность }\end{array}$ & 1960,8 & 1918,0 & 97,8 \\
\hline $\begin{array}{l}\text { национальную экономику } \\
\text { из нее на: }\end{array}$ & 2580,2 & 2460,1 & 95,3 \\
\hline $\begin{array}{l}\text { топливно-энергетический } \\
\text { комплекс }\end{array}$ & 30,8 & 28,5 & 92,6 \\
\hline сельское хозяйство и рыболовство & 226,7 & 214,1 & 94,4 \\
\hline транспорт & 301,2 & 283,4 & 94,1 \\
\hline $\begin{array}{l}\text { на дорожное хозяйство (дорожные } \\
\text { фонды) }\end{array}$ & 704,9 & 684,6 & 97,1 \\
\hline связь и информатику & 38,9 & 35,0 & 89,9 \\
\hline $\begin{array}{l}\text { на прикладные научные исследова- } \\
\text { ния в области национальной эконо- } \\
\text { мики }\end{array}$ & 226,0 & 209,5 & 92,7 \\
\hline $\begin{array}{l}\text { другие вопросы в области нацио- } \\
\text { нальной экономики }\end{array}$ & 849,9 & 825,5 & 97,1 \\
\hline социально-культурные мероприятия & 6390,5 & 6315,8 & 98,8 \\
\hline $\begin{array}{l}\text { обслуживание государственного и } \\
\text { муниципального долга }\end{array}$ & 730,3 & 709,2 & 97,1 \\
\hline $\begin{array}{l}\text { межбюджетные трансферты общего } \\
\text { характера бюджетам бюджетной сис- } \\
\text { темы Российской Федерации }\end{array}$ & 829,3 & 790,7 & 95,3 \\
\hline
\end{tabular}

1) По данным Федерального казначейства. 


\section{5. ОСНОВНЫЕ ПОКАЗАТЕЛИ РЫНКА ГОСУДАРСТВЕННЫХ КРАТКОСРОЧНЫХ ОБЛИГАЦИЙ (ГКО) И ОБЛИГАЦИЙ ФЕДЕРАЛЬНОГО ЗАЙМА (ОФЗ) ${ }^{1)}$}

(млрд. рублей)

\begin{tabular}{|c|c|c|c|c|c|c|c|c|}
\hline & 2000 & 2005 & 2010 & 2013 & 2014 & 2015 & 2016 & 2017 \\
\hline $\begin{array}{l}\text { Объем государствен- } \\
\text { ного внутреннего } \\
\text { долга по ГКО и ОФЗ } \\
\text { (на конец года) }\end{array}$ & 185,1 & 721,6 & 2054,2 & 3634,8 & 4593,2 & 4990,5 & 5611,4 & 6719,1 \\
\hline $\begin{array}{l}\text { Объем размещения } \\
\text { и доразмещения } \\
\text { по номиналу }\end{array}$ & 20,5 & 169,1 & 715,6 & 764,8 & 159,9 & 668,1 & 121,3 & 126,3 \\
\hline $\begin{array}{l}\text { Объем выручки, полу- } \\
\text { ченной в результате } \\
\text { размещения и дораз- } \\
\text { мещения ГКО-ОФЗ }\end{array}$ & 20,3 & 171,6 & 728,5 & 770,2 & 147,9 & 708,7 & 1089,6 & 1704,9 \\
\hline $\begin{array}{l}\text { Объем погашения / } \\
\text { купонной выплаты }\end{array}$ & 93,3 & 118,1 & 244,3 & 634,9 & 560,0 & 810,1 & 890,4 & 1109,9 \\
\hline $\begin{array}{l}\text { Перечислено средств } \\
\text { в бюджет }\end{array}$ & $-73,0$ & 53,5 & 484,2 & 135,3 & $-412,0$ & $-101,3$ & 199,2 & 595,0 \\
\hline
\end{tabular}

1) По данным Банка России.

2) Знак (-) означает изъятие средств из бюджета на погашение выпусков ценных бумаг и выплату купонных доходов.

\section{ДЕНЕЖНО-КРЕДИТНАЯ СИСТЕМА}

\section{6. ДЕНЕЖНАЯ МАССА ${ }^{1)}$}

(на начало года; млрд. рублей)

\begin{tabular}{|c|c|c|c|c|c|c|c|c|}
\hline & 2001 & 2006 & 2013 & 2014 & 2015 & 2016 & 2017 & 2018 \\
\hline $\begin{array}{l}\text { Денежная масса M2 } \\
\text { (национальное }\end{array}$ & & & & & & & & \\
\hline $\begin{array}{l}\text { определение) } \\
\text { в том числе: }\end{array}$ & 1150,6 & 6032,1 & 27164,6 & 31155,6 & 31615,7 & 35179,7 & 38418,0 & 42442,1 \\
\hline $\begin{array}{l}\text { наличные деньги } \\
\text { в обращении вне } \\
\text { банковской систе- }\end{array}$ & & & & & & & & \\
\hline $\begin{array}{l}\text { мы М0 } \\
\text { безналичные }\end{array}$ & 418,9 & 2009,2 & 6430,1 & 6985,6 & 7171,5 & 7239,1 & 7714,8 & 8446,0 \\
\hline $\begin{array}{c}\text { средства } \\
\text { в том числе: } \\
\text { переводные }\end{array}$ & 731,7 & 4022,9 & 20734,6 & 24170,0 & 24444,2 & 27940,6 & 30703,2 & 33996,1 \\
\hline депозиты & $\ldots$ & $\ldots$ & 7264,0 & 8526,3 & 8170,0 & 9276,4 & 9927,6 & 11062,7 \\
\hline другие депозиты & $\ldots$ & $\ldots$ & 13470,6 & 15643,7 & 16274,3 & 18664,1 & 20775,6 & 22933,3 \\
\hline
\end{tabular}

1) По данным Банка России. 


\section{7. ВНЕШНИЙ ДОЛГ РОССИЙСКОЙ ФЕДЕРАЦИИ ${ }^{1)}$}

(на начало года; млрд. долларов США)

\begin{tabular}{|c|c|c|c|c|c|c|c|}
\hline & 2001 & 2006 & 2014 & 2015 & 2016 & 2017 & 2018 \\
\hline Bcero & 160,2 & 257,2 & 728,9 & 599,9 & 518,5 & 511,7 & 518,9 \\
\hline $\begin{array}{l}\text { Краткосрочные } \\
\text { долговые обя- } \\
\text { зательства }\end{array}$ & $\ldots$ & 39,5 & 90,1 & 63,0 & 48,6 & 51,0 & 56,3 \\
\hline $\begin{array}{l}\text { Долгосрочные } \\
\text { долговые обя- } \\
\text { зательства }\end{array}$ & $\ldots$ & 217,7 & 638,8 & 536,9 & 469,9 & 460,7 & 462,5 \\
\hline Органы государст- & & & & & & & \\
\hline венного управления & 126,6 & 71,1 & 61,7 & 41,6 & 30,5 & 39,1 & 55,8 \\
\hline $\begin{array}{l}\text { Краткосрочные } \\
\text { обязательства }\end{array}$ & $\ldots$ & 2,7 & 0,3 & 0,4 & 0,3 & 0,3 & 0,3 \\
\hline $\begin{array}{l}\text { Долгосрочные } \\
\text { обязательства }\end{array}$ & $\ldots$ & 68,4 & 61,4 & 41,2 & 30,2 & 38,8 & 55,5 \\
\hline $\begin{array}{l}\text { Из долга органов } \\
\text { государственного } \\
\text { управления: }\end{array}$ & & & & & & & \\
\hline $\begin{array}{l}\text { новый россий- } \\
\text { ский долг }\end{array}$ & 58,5 & 35,7 & 58,9 & 39,3 & 28,7 & 37,9 & 54,8 \\
\hline $\begin{array}{l}\text { долг бывшего } \\
\text { СССР }\end{array}$ & 66,9 & 34,3 & 2,0 & 1,8 & 1,2 & 1,0 & 0,8 \\
\hline $\begin{array}{l}\text { долг субъектов } \\
\text { Российской }\end{array}$ & & & & & & & \\
\hline Федерации & 1,2 & 1,2 & 0,8 & 0,6 & 0,6 & 0,2 & 0,2 \\
\hline Центральный банк²) & 3,2 & 11,0 & 16,0 & 10,6 & 11,7 & 12,1 & 14,5 \\
\hline $\begin{array}{l}\text { Краткосрочные } \\
\text { обязательства }\end{array}$ & $\ldots$ & 11,0 & 7,2 & 2,4 & 3,9 & 4,4 & 6,4 \\
\hline $\begin{array}{l}\text { Долгосрочные } \\
\text { обязательства }\end{array}$ & $\ldots$ & & 8,7 & 8,2 & 7,9 & 7,6 & 8,1 \\
\hline Банки & 9,0 & 50,1 & 214,4 & 171,5 & 131,7 & 119,4 & 103,4 \\
\hline $\begin{array}{l}\text { Краткосрочные } \\
\text { обязательства }\end{array}$ & $\ldots$ & 20,2 & 56,7 & 39,9 & 25,3 & 26,7 & 30,6 \\
\hline $\begin{array}{l}\text { Долгосрочные } \\
\text { обязательства }\end{array}$ & $\ldots$ & 29,9 & 157,6 & 131,6 & 106,5 & 92,7 & 72,8 \\
\hline Прочие секторы & 21,5 & 125,0 & 436,8 & 376,2 & 344,5 & 341,1 & 345,2 \\
\hline $\begin{array}{l}\text { Краткосрочные } \\
\text { обязательства }\end{array}$ & $\ldots$ & 5,6 & 20,9 & 18,3 & 13,2 & 13,5 & 14,2 \\
\hline $\begin{array}{l}\text { Долгосрочные } \\
\text { обязательства }\end{array}$ & $\ldots$ & 119,5 & 415,8 & 357,9 & 331,3 & 327,6 & 331,0 \\
\hline
\end{tabular}

1) По данным Банка России, 2018 г. - оперативные данные.

2) 2001, 2006 гг. - включая задолженность Минфина России перед МВФ. 
23.8. КРЕДИТНЫЕ ОРГАНИЗАЦИИ ${ }^{1)}$

(на начало года)

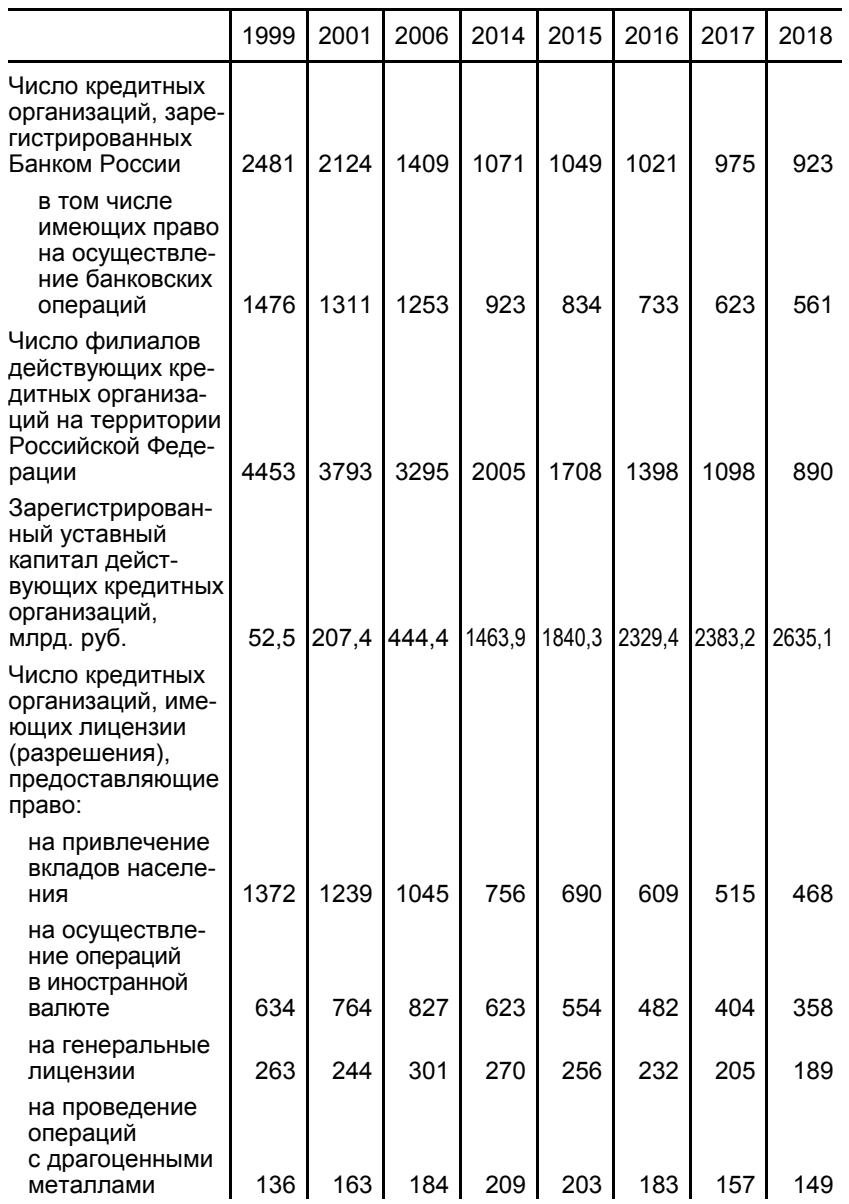


Продолжение табл. 23.8

\begin{tabular}{|c|c|c|c|c|c|c|c|c|}
\hline & 1999 & 2001 & 2006 & 2014 & 2015 & 2016 & 2017 & 2018 \\
\hline $\begin{array}{l}\text { Число кредитных } \\
\text { организаций с ино- } \\
\text { странным участи- } \\
\text { ем в уставном ка- } \\
\text { питале, имеющих } \\
\text { право на осущест- } \\
\text { вление банковских }\end{array}$ & & & & & & & & \\
\hline $\begin{array}{c}\text { операций } \\
\text { из них: } \\
\text { со 100\%-ным } \\
\text { иностранным }\end{array}$ & 142 & 130 & 136 & 251 & 225 & 199 & 174 & 160 \\
\hline $\begin{array}{l}\text { участием } \\
\text { с иностранным } \\
\text { участием }\end{array}$ & 18 & 22 & 41 & 76 & 75 & 68 & 67 & 65 \\
\hline $\begin{array}{l}\text { участием } \\
\text { от } 50 \text { до } 100 \%\end{array}$ & 12 & 11 & 11 & 46 & 38 & 38 & 25 & 19 \\
\hline
\end{tabular}

1) По данным Банка России.

23.9. ГРУППИРОВКА ДЕЙСТВУЮЩИХ КРЕДИТНЫХ ОРГАНИЗАЦИЙ ПО ВЕЛИЧИНЕ ЗАРЕГИСТРИРОВАННОГО УСТАВНОГО КАПИТАЛА

(на начало года)

\begin{tabular}{|c|c|c|c|c|c|c|c|c|}
\hline & 1999 & 2001 & 2006 & 2014 & 2015 & 2016 & 2017 & 2018 \\
\hline $\begin{array}{l}\text { Число дейст- } \\
\text { вующих кредит- } \\
\text { ных организа- } \\
\text { ций - всего } \\
\text { в том числе } \\
\text { по величине } \\
\text { уставного капи- } \\
\text { тала, млн. руб.: }\end{array}$ & 1476 & 1311 & 1253 & 923 & 834 & 733 & 623 & 561 \\
\hline до 3 & 352 & 174 & 56 & 15 & 10 & 13 & 10 & 9 \\
\hline от 3 до 10 & 464 & 282 & 106 & 15 & 13 & 12 & 10 & 9 \\
\hline от 10 до 30 & 349 & 313 & 205 & 45 & 38 & 38 & 37 & 31 \\
\hline от 30 до 60 & 189 & 254 & 212 & 36 & 30 & 28 & 26 & 23 \\
\hline от 60 до 150 & 72 & 127 & 227 & 143 & 112 & 88 & 67 & 68 \\
\hline от 150 до 300 & 21 & 68 & 204 & 251 & 212 & 171 & 137 & 113 \\
\hline от 300 до $500^{2)}$ & 29 & 93 & 243 & 116 & 118 & 104 & 90 & 78 \\
\hline $\begin{array}{l}\text { от } 500 \text { млн. } \\
\text { до } 1 \text { млрд. }\end{array}$ & $\ldots$ & $\ldots$ & $\ldots$ & 116 & 111 & 97 & 77 & 78 \\
\hline $\begin{array}{l}\text { от } 1 \text { млрд. } \\
\text { до } 10 \text { млрд. } \\
10 \text { млрд. и }\end{array}$ & . & $\ldots$ & $\ldots$ & 161 & 163 & 153 & 136 & 117 \\
\hline выше & & $\ldots$ & $\ldots$ & 25 & 27 & 29 & 33 & 35 \\
\hline
\end{tabular}

1) По данным Банка России

2) 1999, 2001, 2006 гг. - от 300 млн. и выше. 


\subsection{0. ВКЛАДЫ (ДЕПОЗИТЫ) ФИЗИЧЕСКИХ ЛИЦ В СБЕРБАНКЕ РОССИИ ${ }^{1)}$}

\begin{tabular}{|c|c|c|c|c|c|c|c|c|}
\hline \multicolumn{9}{|c|}{ (на начало года) } \\
\hline & 1999 & 2001 & 2006 & 2014 & 2015 & 2016 & 2017 & 2018 \\
\hline $\begin{array}{c}\text { Всего, млрд. руб. } \\
\text { в том числе: }\end{array}$ & 153,3 & 347,1 & 1500,1 & 7915,9 & 8347,3 & 10673,5 & 11372,2 & 12069,5 \\
\hline на рублевых счетах & 126,8 & 266,0 & 1225,3 & 7082,4 & 6872,5 & 8126,3 & 9071,2 & 9841,2 \\
\hline на валютных счетах & 26,5 & 81,1 & 274,8 & 833,5 & 1474,8 & 2547,1 & 2301,1 & 2228,3 \\
\hline Средний размер вкла- & & & & & & & & \\
\hline $\begin{array}{r}\text { дов (депозитов), руо.: } \\
\text { на рублевых счетах }\end{array}$ & 559 & 1142 & 4628 & 16383 & 14855 & 16313 & 18081 & 19471 \\
\hline на валютных счетах & & 45794 & 78190 & 196129 & 308163 & 422428 & 366922 & 337833 \\
\hline $\begin{array}{l}\text { Объем вкладов } \\
\text { (депозитов) на душу } \\
\text { населения, руб.: }\end{array}$ & & & & & & & & \\
\hline на рублевых счетах & 867,0 & 1846 & 8554 & 47039 & 44044 & 51750 & 61791 & 67003 \\
\hline на валютных счетах & & 559 & 1918 & 6392 & 10915 & 18172 & 15674 & 15171 \\
\hline
\end{tabular}

23.11. ВКЛАДЫ (ДЕПОЗИТЫ), КРЕДИТЫ И ПРОЧИЕ ПРИВЛЕЧЕННЫЕ КРЕДИТНЫМИ ОРГАНИЗАЦИЯМИ СРЕДСТВА ${ }^{1)}$ (на начало года; млрд. рублей)

\begin{tabular}{|c|c|c|c|c|c|}
\hline & \multirow{2}{*}{$\begin{array}{c}\text { Общий } \\
\text { объем при- } \\
\text { влеченных } \\
\text { средств }\end{array}$} & \multicolumn{4}{|c|}{ в том числе } \\
\hline & & \begin{tabular}{|c|} 
депозиты \\
и прочие \\
привлечен- \\
ные сред- \\
ства юри- \\
дических \\
лиц
\end{tabular} & $\begin{array}{c}\text { вклады } \\
\text { (депозиты) } \\
\text { и прочие } \\
\text { привлечен- } \\
\text { ные сред- } \\
\text { ства фризи- } \\
\text { ческих лиц }\end{array}$ & $\begin{array}{c}\text { средства на } \\
\text { счетах } \\
\text { индивиду- } \\
\text { альных } \\
\text { предпри- } \\
\text { нимателей }\end{array}$ & $\begin{array}{c}\text { депозиты, } \\
\text { кредиты } \\
\text { и прочие } \\
\text { привлечен- } \\
\text { ные сред- } \\
\text { ства кре- } \\
\text { дитных ор-- } \\
\text { ганизаций }\end{array}$ \\
\hline 1999 & & & & & \\
\hline $\begin{array}{l}\text { Всего } \\
\text { в том числе: }\end{array}$ & 465,1 & 68,2 & 200,1 & 1,5 & 195,3 \\
\hline $\begin{array}{l}\text { в рублях } \\
\text { в иностранной }\end{array}$ & 161,4 & 8,9 & 140,0 & 1,3 & 11,1 \\
\hline $\begin{array}{c}\text { валюте } \\
2001\end{array}$ & 303,7 & 59,3 & 60,1 & 0,2 & 184,2 \\
\hline Всего & 883,4 & 251,3 & 445,8 & 7,5 & 178,7 \\
\hline в рублях & 430,2 & 81,2 & 297,8 & 6,9 & 44,2 \\
\hline в иностранной & & & & & \\
\hline $\begin{array}{c}\text { валюте } \\
2006\end{array}$ & 453,2 & 170,1 & 148,0 & 0,6 & 134,6 \\
\hline $\begin{array}{l}\text { Всего } \\
\text { в том числе: }\end{array}$ & 5152,3 & 1271,1 & 2761,2 & 33,5 & 1086,4 \\
\hline $\begin{array}{l}\text { в рублях } \\
\text { в иностранной }\end{array}$ & 3001,9 & 636,2 & 2088,7 & 32,7 & 244,3 \\
\hline валюте & 2150,3 & 634,9 & 672,5 & 0,8 & 842,1 \\
\hline
\end{tabular}


Продолжение табл. 23.11

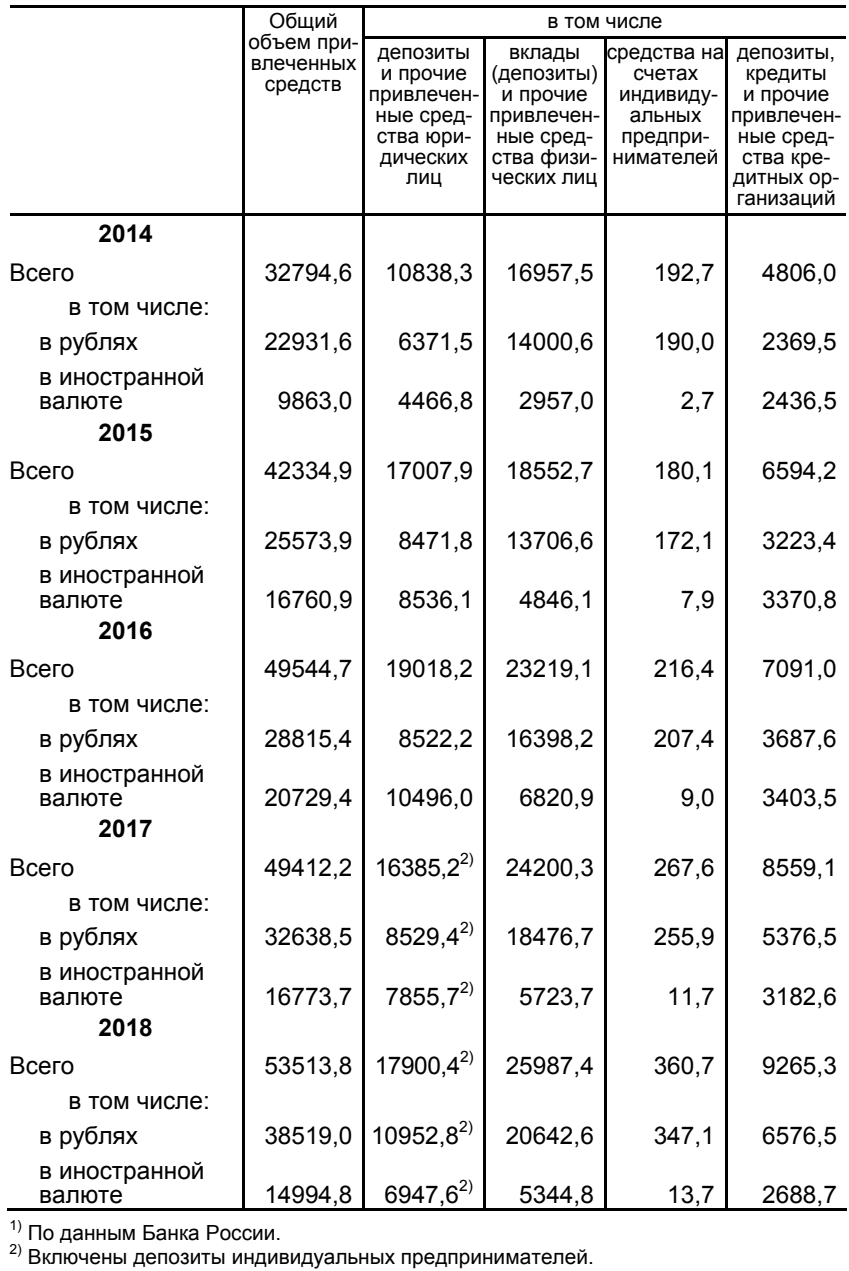


23.12. КРЕДИТЫ, ДЕПОЗИТЫ И ПРОЧИЕ РАЗМЕЩЕННЫЕ СРЕДСТВА, ПРЕДОСТАВЛЕННЫЕ ОРГАНИЗАЦИЯМ, КРЕДИТНЫМ ОРГАНИЗАЦИЯМ И ФИЗИЧЕСКИМ ЛИЦАМ ${ }^{1)}$

(на начало года; млрд. рублей)

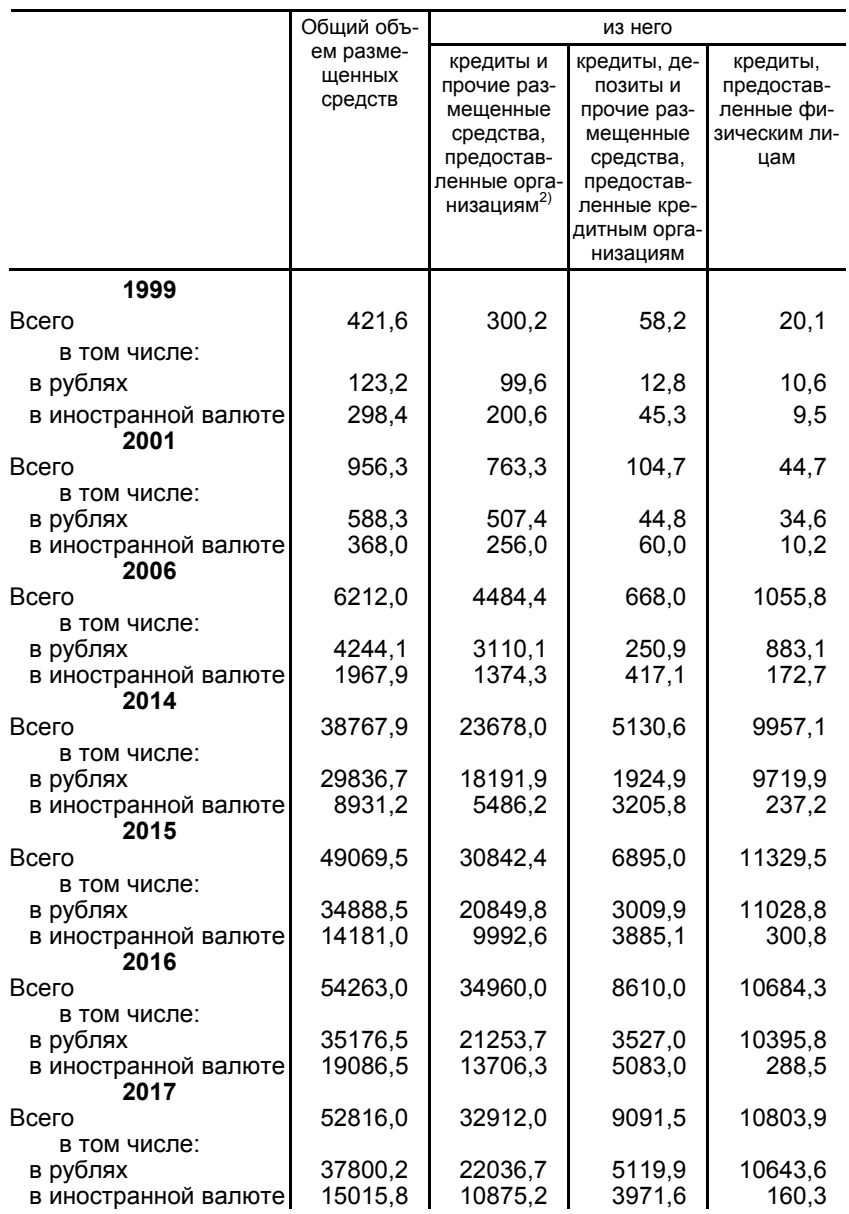


Продолжение табл. 23.12

\begin{tabular}{|c|c|c|c|c|}
\hline & \multirow{2}{*}{$\begin{array}{c}\text { Общий объ- } \\
\text { ем разме- } \\
\text { щенных } \\
\text { средств }\end{array}$} & \multicolumn{3}{|c|}{ из него } \\
\hline & & $\begin{array}{c}\text { кредиты и } \\
\text { прочие раз- } \\
\text { мещенные } \\
\text { средства, } \\
\text { предостав- } \\
\text { ленные орга- } \\
\text { низациям }^{2)}\end{array}$ & \begin{tabular}{|c} 
кредиты, де- \\
позиты и \\
прочие раз- \\
мещенные \\
средства, \\
предостав- \\
ленные кре- \\
дитным орга- \\
низациям
\end{tabular} & $\begin{array}{c}\text { кредиты, } \\
\text { предостав- } \\
\text { ленные фи- } \\
\text { зическим ли- } \\
\text { цам }\end{array}$ \\
\hline \multicolumn{5}{|l|}{2018} \\
\hline Всего & 55809,6 & 33819,9 & 9804,6 & 12173,7 \\
\hline \multicolumn{5}{|l|}{ в том числе: } \\
\hline в рублях & 42928,7 & 24380,8 & 6482,5 & 12065,5 \\
\hline в иностранной валюте & 12880,8 & 9439,1 & 3322,1 & 108,2 \\
\hline
\end{tabular}

1) По данным Банка России.

2) Включая индивидуальных предпринимателей.

23.13. ОСНОВНЫЕ ПОКАЗАТЕЛИ ДЕЯТЕЛЬНОСТИ СТРАХОВЩИКОВ

\begin{tabular}{|c|c|c|c|c|c|c|c|}
\hline & 2000 & 2005 & 2010 & 2013 & $2014^{1)}$ & 2015 & 2016 \\
\hline Число учтенных & & & & & & & \\
\hline $\begin{array}{l}\text { страховщиков } \\
\text { из них об- } \\
\text { ществ взаим- } \\
\text { ного страхова- } \\
\text { ния }\end{array}$ & 1166 & 983 & 600 & 409 & 395 & 360 & 297 \\
\hline $\begin{array}{l}\text { Число филиалов } \\
\text { страховщиков }^{2)}\end{array}$ & 4507 & 5038 & 4567 & 5180 & 4803 & 4863 & 3973 \\
\hline $\begin{array}{l}\text { Уставный капи- } \\
\text { тал страховых } \\
\text { организаций }\end{array}$ & & & & & & & \\
\hline $\begin{array}{l}\text { млрд. руб. } \\
\text { Страховые пре- } \\
\text { мии (взносы) - }\end{array}$ & 16,0 & 142,0 & 155,2 & 224,1 & 217,0 & 204,3 & 228,3 \\
\hline $\begin{array}{l}\text { всего, млрд. руб. } \\
\text { из них по дого- } \\
\text { ворам добро- } \\
\text { вольного стра- } \\
\text { хования }\end{array}$ & 170,1 & 506,2 & 1036,7 & 901,1 & 983,4 & 1033,5 & 1190,6 \\
\hline $\begin{array}{l}\text { из них по до- } \\
\text { говорам, за- } \\
\text { ключенным } \\
\text { с физически- } \\
\text { ми лицами }\end{array}$ & 83,4 & 99,0 & 187,7 & 364,4 & 407,5 & 395,1 & 492,1 \\
\hline
\end{tabular}


Продолжение табл. 23.13

\begin{tabular}{|c|c|c|c|c|c|c|c|}
\hline & 2000 & 2005 & 2010 & 2013 & $2014^{1)}$ & 2015 & 2016 \\
\hline $\begin{array}{l}\text { Выплаты по до- } \\
\text { говорам страхо- } \\
\text { вания - всего, } \\
\text { млрд. руб. } \\
\text { из них по дого- } \\
\text { ворам добро-- } \\
\text { вольного стра- }\end{array}$ & 138,6 & 308,5 & 774,8 & 419,9 & 473,5 & 514,0 & 514,1 \\
\hline $\begin{array}{l}\text { хования } \\
\text { из них } \\
\text { по догово- } \\
\text { рам, заклю- } \\
\text { ченным } \\
\text { с физически- } \\
\text { ми лицами }\end{array}$ & 109,6 & 142,9 & 235,0 & 324,4 & 363,5 & 371,3 & 325,3 \\
\hline $\begin{array}{l}\text { Число заклю- } \\
\text { ченных догово- } \\
\text { ров страхова- }\end{array}$ & & & & & & & \\
\hline $\begin{array}{l}\text { ния - всего, млн. } \\
\text { из них догово- } \\
\text { ры доброволь- } \\
\text { ного страхова- } \\
\text { ния }\end{array}$ & 88,8 & 103,3 & 128,1 & 139,1 & 115,0 & 104,7 & 133,2 \\
\hline
\end{tabular}

1) Без учета данных по Крымскому федеральному округу.

${ }^{2)}$ На конец года.

\subsection{4. ОСНОВНЫЕ ПОКАЗАТЕЛИ РАБОТЫ СТРАХОВЫХ МЕДИЦИНСКИХ ОРГАНИЗАЦИЙ В ЧАСТИ ОБЯЗАТЕЛЬНОГО МЕДИЦИНСКОГО СТРАХОВАНИЯ (ОМС)} (млн. рублей)

\begin{tabular}{|c|c|c|c|}
\hline & $2014^{1)}$ & 2015 & 2016 \\
\hline $\begin{array}{l}\text { Поступило средств - всего } \\
\text { в том числе: } \\
\text { средства, поступившие от территориальных } \\
\text { фондов на финансовое обеспечение обяза- } \\
\text { тельного медицинско страхования в соот- } \\
\text { ветствии с договором о финансовом обес- } \\
\text { печении обязательного медицинского стра- } \\
\text { хования } \\
\text { средства, поступившие из медицинских ор- } \\
\text { ганизаций в результате применения к ним } \\
\text { санкций за нарушения, выявленные при } \\
\text { проведении контроля объемов, сроков, } \\
\text { качества и условий предоставления меди- } \\
\text { цинской помощи } \\
\text { средства, поступившие от юридических или } \\
\text { физических лиц, причинивших вред здоро- } \\
\text { вью застрахованных лиц } \\
\text { прочие поступления целевых средств }\end{array}$ & $\begin{array}{r}14,0 \\
3280,8\end{array}$ & $\begin{array}{r}17,2 \\
1804,2\end{array}$ & $\begin{array}{r}23,6 \\
3804,9\end{array}$ \\
\hline
\end{tabular}


Продолжение табл. 23.14

\begin{tabular}{l|r|r|r}
\hline & $2014^{1)}$ & 2015 & 2016 \\
\hline $\begin{array}{l}\text { Использовано средств - всего } \\
\text { в том числе: }\end{array}$ & 1305540,0 & 1459754,6 & 1490684,8 \\
на оплату медицинской помощи, оказанной & & & \\
застрахованным лицам медицинскими орга- & & & \\
низациями, в соответствии с договорами на & & & \\
оказание и оплату медицинской помощи по & & & \\
обязательному медицинскому страхованию & 1300988,5 & 1454960,2 & 1486017,1 \\
направлено в доход страховой медицинской & & & \\
организации & & \\
прочее использование целевых средств & 353,1 & 4425,0 & 3015,3 \\
\hline
\end{tabular}

1) Без учета данных по Крымскому федеральному округу.

\subsection{5. ОФИЦИАЛЬНЫЕ КУРСЫ ИНОСТРАННЫХ ВАЛЮТ ПО ОТНОШЕНИЮ К РОССИЙСКОМУ РУБЛЮ}

(на конец года; рублей за единицу национальной валюты)

\begin{tabular}{|c|c|c|c|c|c|c|c|}
\hline Страны & $\begin{array}{c}\text { Наимено- } \\
\text { вание } \\
\text { иностран- } \\
\text { ной валюты }\end{array}$ & 2005 & 2010 & 2014 & 2015 & 2016 & 2017 \\
\hline Австралия & $\begin{array}{l}\text { австра- } \\
\text { лийский } \\
\text { доллар }\end{array}$ & 21,13 & 31,01 & 45,91 & 53,12 & 43,81 & 44,96 \\
\hline Австрия & евро & 34,19 & 40,33 & 68,34 & 79,70 & 63,81 & 68,87 \\
\hline $\begin{array}{l}\text { Азербай- } \\
\text { джан }\end{array}$ & $\begin{array}{l}\text { азербайд- } \\
\text { жанский } \\
\text { манат }\end{array}$ & $31,35^{2}$ & 38,11 & 71,84 & 46,74 & 33,67 & 33,82 \\
\hline Армения & $\begin{array}{l}\text { армянский } \\
\text { драм }\end{array}$ & $64,19^{2,33)}$ & $84,13^{3)}$ & $12,10^{4)}$ & $15,05^{4)}$ & $12,52^{4)}$ & $11,90^{4)}$ \\
\hline Беларусь & $\begin{array}{l}\text { белорус- } \\
\text { ский рубль }\end{array}$ & $13,36^{3)}$ & $10,16^{3)}$ & $38,80^{5)}$ & $38,95^{5)}$ & 30,95 & 29,10 \\
\hline Бельгия & евро & 34,19 & 40,33 & 68,34 & 79,70 & 63,81 & 68,87 \\
\hline Германия & евро & 34,19 & 40,33 & 68,34 & 79,70 & 63,81 & 68,87 \\
\hline Греция & евро & 34,19 & 40,33 & 68,34 & 79,70 & 63,81 & 68,87 \\
\hline Дания & $\begin{array}{l}\text { датская } \\
\text { крона }\end{array}$ & $45,81^{6)}$ & $54,10^{6}$ & $92,02^{6)}$ & 10,68 & $85,81^{6)}$ & $92,54^{6)}$ \\
\hline Ирландия & евро & 34,19 & 40,33 & 68,34 & 79,70 & 63,81 & 68,87 \\
\hline Испания & евро & 34,19 & 40,33 & 68,34 & 79,70 & 63,81 & 68,87 \\
\hline Италия & евро & 34,19 & 40,33 & 68,34 & 79,70 & 63,81 & 68,87 \\
\hline Казахстан ${ }^{4)}$ & тенге & 21,53 & 20,68 & 30,83 & 21,52 & 18,16 & 17,32 \\
\hline Канада & $\begin{array}{l}\text { канадский } \\
\text { доллар }\end{array}$ & 24,73 & 30,49 & 48,40 & 52,57 & 44,97 & 45,93 \\
\hline Киргизия ${ }^{4)}$ & сом & $69,71^{2)}$ & 64,84 & 95,52 & 94,84 & 87,40 & 83,48 \\
\hline
\end{tabular}


Продолжение табл. 23.15

\begin{tabular}{|c|c|c|c|c|c|c|c|}
\hline Страны & $\begin{array}{c}\text { Наимено- } \\
\text { вание } \\
\text { иностран- } \\
\text { ной валюты }\end{array}$ & 2005 & 2010 & 2014 & 2015 & 2016 & 2017 \\
\hline $\begin{array}{l}\text { Нидерлан- } \\
\text { ды }\end{array}$ & евро & 34,19 & 40,33 & 68,34 & 79,70 & 63,81 & 68,87 \\
\hline Норвегия ${ }^{6)}$ & $\begin{array}{l}\text { норвежская } \\
\text { крона }\end{array}$ & 42,60 & 51,61 & 75,79 & 83,38 & 70,28 & 70,07 \\
\hline $\begin{array}{l}\text { Португа- } \\
\text { лия }\end{array}$ & евро & 34,19 & 40,33 & 68,34 & 79,70 & 63,81 & 68,87 \\
\hline $\begin{array}{l}\text { Республика } \\
\text { Молдова }\end{array}$ & $\begin{array}{l}\text { молдав- } \\
\text { ский лей }\end{array}$ & $22,42^{2)}$ & 25,07 & 36,03 & 37,06 & 30,53 & 33,65 \\
\hline $\begin{array}{l}\text { Соединен- } \\
\text { ное Коро- } \\
\text { левство } \\
\text { (Велико- } \\
\text { британия) }\end{array}$ & $\begin{array}{l}\text { фунт стер- } \\
\text { лингов }\end{array}$ & 49,72 & 47,26 & 87,42 & 107,98 & 74,56 & 77,67 \\
\hline США & $\begin{array}{l}\text { доллар } \\
\text { США }\end{array}$ & 28,78 & 30,48 & 56,26 & 72,88 & 60,66 & 57,60 \\
\hline $\begin{array}{l}\text { Таджики- } \\
\text { стан }\end{array}$ & сомони & $89,99^{2 / 60}$ & $69,22^{6)}$ & 10,76 & 10,99 & $76,83^{6)}$ & $65,26^{6)}$ \\
\hline Туркмения & $\begin{array}{l}\text { туркмен- } \\
\text { ский манат }\end{array}$ & $55,92^{2 / 5)}$ & $10,70^{7)}$ & $19,74^{7)}$ & $21,44^{7)}$ & $17,36^{7)}$ & $16,48^{7)}$ \\
\hline Турция & $\begin{array}{l}\text { турецкая } \\
\text { лира }\end{array}$ & $21,31^{8)}$ & 19,60 & 24,27 & 25,08 & 17,20 & 15,24 \\
\hline Узбекистан ${ }^{3)}$ & $\begin{array}{l}\text { узбекский } \\
\text { сум }\end{array}$ & $24,40^{2)}$ & 18,58 & 23,22 & 26,45 & 18,93 & $70,94^{5)}$ \\
\hline Украина ${ }^{6)}$ & гривна & 56,72 & 38,28 & 35,56 & 30,46 & 22,38 & 20,50 \\
\hline Франция & евро & 34,19 & 40,33 & 68,34 & 79,70 & 63,81 & 68,87 \\
\hline Швеция ${ }^{6)}$ & $\begin{array}{l}\text { шведская } \\
\text { крона }\end{array}$ & 36,28 & 44,81 & 72,02 & 87,26 & 66,67 & 69,99 \\
\hline Япония ${ }^{4)}$ & иена & 24,53 & 37,38 & 47,06 & 60,51 & 51,83 & 51,15 \\
\hline \multicolumn{8}{|c|}{$\begin{array}{l}\text { 1) По данным Банка России. } \\
\text { 2) На } 1 \text { января } 2006 \text { г. } \\
\text { 3) За } 1000 \text { единиц валюты. } \\
\text { 4) За } 100 \text { единиц валюты. } \\
\text { 5) За } 10000 \text { единиц валюты. } \\
\text { 6) За } 10 \text { единиц валюты. } \\
\text { 7) Новый туркменский манат. } 1 \text { новый туркменский манат = } 5000 \text { туркменских манатов. } \\
\text { 8) Новая турецкая лира. } 1 \text { новая турецкая лира составляла } 1000 \text { 000 прежних турец- } \\
\text { ких лир. С } 1 \text { января } 2009 \text { г. новая турецкая лира вновь преобразована в турецкую } \\
\text { лиру в соотношении 1:1. }\end{array}$} \\
\hline
\end{tabular}




\title{
23.16. ДИНАМИКА ОФИЦИАЛЬНЫХ КУРСОВ ИНОСТРАННЫХ ВАЛЮТ ПО ОТНОШЕНИЮ К РОССИЙСКОМУ РУБЛЮ ${ }^{1)}$
}

\author{
(на конец года)
}

\begin{tabular}{c|c|c|c|r}
\hline \multirow{2}{*}{ Годы } & \multicolumn{2}{|c|}{ Доллар США } & \multicolumn{2}{c}{ Евро } \\
\cline { 2 - 5 } & $\begin{array}{c}\text { руб./ } \\
\text { долл. } \\
\text { США }\end{array}$ & $\begin{array}{c}\text { в процентах } \\
\text { к предыду- } \\
\text { щему году }\end{array}$ & $\begin{array}{c}\text { руб./ } \\
\text { евро }\end{array}$ & $\begin{array}{c}\text { в процентах } \\
\text { к предыду- } \\
\text { щему году }\end{array}$ \\
\hline 1992 & 415 & & - & - \\
2000 & 28,16 & 104,3 & 26,14 & 96,0 \\
2005 & 28,78 & 103,7 & 34,19 & 90,4 \\
2010 & 30,48 & 100,8 & 40,33 & 93,0 \\
2013 & 32,73 & 107,8 & 44,97 & 111,8 \\
2014 & 56,26 & 171,9 & 68,34 & 152,0 \\
2015 & 72,88 & 129,5 & 79,70 & 116,6 \\
2016 & 60,66 & 83,2 & 63,81 & 80,1 \\
2017 & 57,60 & 95,0 & 68,87 & 107,9 \\
\hline
\end{tabular}

1) По данным Банка России. С 2000 г. - с учетом изменения нарицательной стоимости российских денежных знаков (уменьшение в 1000 раз) с 1 января 1998 г.

\section{ФИНАНСОВАЯ ДЕЯТЕЛЬНОСТЬ ОРГАНИЗАЦИЙ}

\subsection{7. САЛЬДИРОВАННЫЙ ФИНАНСОВЫЙ РЕЗУЛЬТАТ (ПРИБЫЛЬ МИНУС УБЫТОК) ДЕЯТЕЛЬНОСТИ ОРГАНИЗАЦИЙ ПО ВИДАМ ЭКОНОМИЧЕСКОЙ ДЕЯТЕЛЬНОСТИ в 2017 г.}

(в фактически действовавших ценах)

\begin{tabular}{|c|c|}
\hline & Млн. руб. \\
\hline $\begin{array}{l}\text { Сальдированный финансовый результат (прибыль } \\
\text { минус убыток) - всего }\end{array}$ & 10320527 \\
\hline в том числе по видам экономической деятельности: & \\
\hline $\begin{array}{l}\text { сельское, лесное хозяйство, охота, рыболовство } \\
\text { и рыбоводство }\end{array}$ & 270106 \\
\hline в том числе: & \\
\hline растениеводство и животноводство, охота & \\
\hline $\begin{array}{l}\text { и предоставление соответствующих услуг в этих } \\
\text { областях }\end{array}$ & 187057 \\
\hline лесоводство и лесозаготовки & -345 \\
\hline рыболовство и рыбоводство & 83394 \\
\hline добыча полезных ископаемых & 2595632 \\
\hline из нее: & \\
\hline добыча угля & 292329 \\
\hline добыча сырой нефти и природного газа & 1649992 \\
\hline добыча металлических руд & 316888 \\
\hline добыча прочих полезных ископаемых & 107508 \\
\hline
\end{tabular}


Продолжение табл. 23.17.

\begin{tabular}{|c|c|}
\hline & Млн. руб. \\
\hline обрабатывающие производства & 2902753 \\
\hline из них: & \\
\hline производство пищевых продуктов & 223106 \\
\hline производство напитков & 54775 \\
\hline производство табачных изделий & 30094 \\
\hline производство текстильных изделий & 7222 \\
\hline производство одежды & 14151 \\
\hline производство кожи и изделий из кожи & 2728 \\
\hline $\begin{array}{l}\text { обработка древесины и производство изделий } \\
\text { из дерева и пробки, кроме мебели, производство } \\
\text { изделий из соломки и материалов для плетения }\end{array}$ & 11783 \\
\hline производство бумаги и бумажных изделий & 84854 \\
\hline $\begin{array}{l}\text { деятельность полиграфическая и копирование } \\
\text { носителей информации }\end{array}$ & 10297 \\
\hline производство кокса и нефтепродуктов & 746009 \\
\hline из них: & \\
\hline производство кокса & 21390 \\
\hline производство нефтепродуктов & 724639 \\
\hline $\begin{array}{l}\text { производство химических веществ и химических } \\
\text { продуктов }\end{array}$ & 307464 \\
\hline $\begin{array}{l}\text { производство лекарственных средств и материалов, } \\
\text { применяемых в медицинских целях }\end{array}$ & 64062 \\
\hline производство резиновых и пластмассовых изделий & 37619 \\
\hline производство металлургическое & 880099 \\
\hline $\begin{array}{l}\text { производство готовых металлических изделий, кроме } \\
\text { машин и оборудования }\end{array}$ & 102349 \\
\hline $\begin{array}{l}\text { производство компьютеров, электронных и оптических } \\
\text { изделий }\end{array}$ & 116936 \\
\hline производство электрического оборудования & 46943 \\
\hline $\begin{array}{l}\text { производство машин и оборудования, не включенных } \\
\text { в другие группировки }\end{array}$ & -24574 \\
\hline $\begin{array}{l}\text { производство автотранспортных средств, прицепов } \\
\text { и полуприцепов }\end{array}$ & -14945 \\
\hline $\begin{array}{l}\text { производство прочих транспортных средств } \\
\text { и оборудования }\end{array}$ & 110989 \\
\hline производство мебели & 4608 \\
\hline производство прочих готовых изделий & -1516 \\
\hline
\end{tabular}


Продолжение табл. 23.17.

\begin{tabular}{l}
\hline \\
\hline обеспечение электрической энергией, газом и паром; \\
кондиционирование воздуха \\
в том числе: \\
производство, передача и распределение электроэнергии \\
производство и распределение газообразного топлива \\
производство, передача и распределение пара и горя- \\
чей воды; кондиционирование воздуха \\
водоснабжение; водоотведение, организация сбора \\
и утилации отходов, деятельность по ликвидации \\
загрязнений \\
строительство \\
из него: \\
строительство зданий \\
строительство инженерных сооружений \\
торговля оптовая и розничная; ремонт автотранспортных \\
средств и мотоциклов \\
в том числе: \\
торговля оптовая и розничная автотранспортными \\
средствами и мотоциклами и их ремонт \\
торговля оптовая, кроме оптовой торговли автотранс- \\
портными средствами и мотоциклами \\
торговля розничная, кроме торговли автотранспортными \\
средствами и мотоциклами
\end{tabular}

Млн. руб.

560093

554948

17601

$-12456$

19407

135639

62635

31699

1811722

64808

1365115

381799

транспортировка и хранение

910754

в том числе:

деятельность сухопутного и трубопроводного транспорта

417858

в том числе:

деятельность железнодорожного транспорта: междугородные и международные пассажирские перевозки

71543

деятельность железнодорожного транспорта:

грузовые перевозки

47240

деятельность прочего сухопутного пассажирского транспорта

$-6162$

деятельность автомобильного грузового транспорта и услуги по перевозкам

12072

деятельность трубопроводного транспорта

293165 
Продолжение табл. 23.17.

\begin{tabular}{|c|c|}
\hline & Млн. руб. \\
\hline деятельность водного транспорта & 12400 \\
\hline деятельность воздушного и космического транспорта & 73742 \\
\hline $\begin{array}{l}\text { складское хозяйство и вспомогательная транспортная } \\
\text { деятельность }\end{array}$ & 403629 \\
\hline деятельность почтовой связи и курьерская деятельность & 3125 \\
\hline $\begin{array}{l}\text { деятельность гостиниц и предприятий общественного } \\
\text { питания }\end{array}$ & 21835 \\
\hline в том числе: & \\
\hline $\begin{array}{l}\text { деятельность по предоставлению мест для временного } \\
\text { проживания }\end{array}$ & -182 \\
\hline $\begin{array}{l}\text { деятельность по предоставлению продуктов питания } \\
\text { и напитков }\end{array}$ & 22017 \\
\hline $\begin{array}{l}\text { деятельность в области информации и связи } \\
\text { из нее: }\end{array}$ & 384663 \\
\hline деятельность издательская & 14459 \\
\hline деятельность в сфере телекоммуникаций & 250759 \\
\hline деятельность в области информационных технологий & 24377 \\
\hline деятельность финансовая и страховая & 172565 \\
\hline деятельность по операциям с недвижимым имуществом & 124443 \\
\hline деятельность профессиональная, научная и техническая & 323038 \\
\hline из нее научные исследования и разработки & 179782 \\
\hline $\begin{array}{l}\text { деятельность административная и сопутствующие } \\
\text { дополнительные услуги }\end{array}$ & 38220 \\
\hline $\begin{array}{l}\text { из нее деятельность туристических агентств и прочих } \\
\text { организаций, предоставляющих услуги в сфере туризма }\end{array}$ & 1513 \\
\hline $\begin{array}{l}\text { государственное управление и обеспечение военной } \\
\text { безопасности; социальное обеспечение }\end{array}$ & 18700 \\
\hline образование & 3962 \\
\hline $\begin{array}{l}\text { деятельность в области здравоохранения и социальных } \\
\text { услуг }\end{array}$ & 21386 \\
\hline из нее деятельность в области здравоохранения & 20893 \\
\hline $\begin{array}{l}\text { деятельность в области культуры, спорта, организации } \\
\text { досуга и развлечений }\end{array}$ & 480 \\
\hline из нее: & \\
\hline $\begin{array}{l}\text { деятельность библиотек, архивов, музеев и прочих } \\
\text { объектов культуры }\end{array}$ & 33 \\
\hline деятельность в области спорта, отдыха и развлечений & -4791 \\
\hline предоставление прочих видов услуг & 5129 \\
\hline
\end{tabular}


23.18. УДЕЛЬНЫЙ ВЕС УБЫТОЧНЫХ ОРГАНИЗАЦИЙ И СУММА УБЫТКА ПО ВИДАМ ЭКОНОМИЧЕСКОЙ ДЕЯТЕЛЬНОСТИ В 2017 Г.

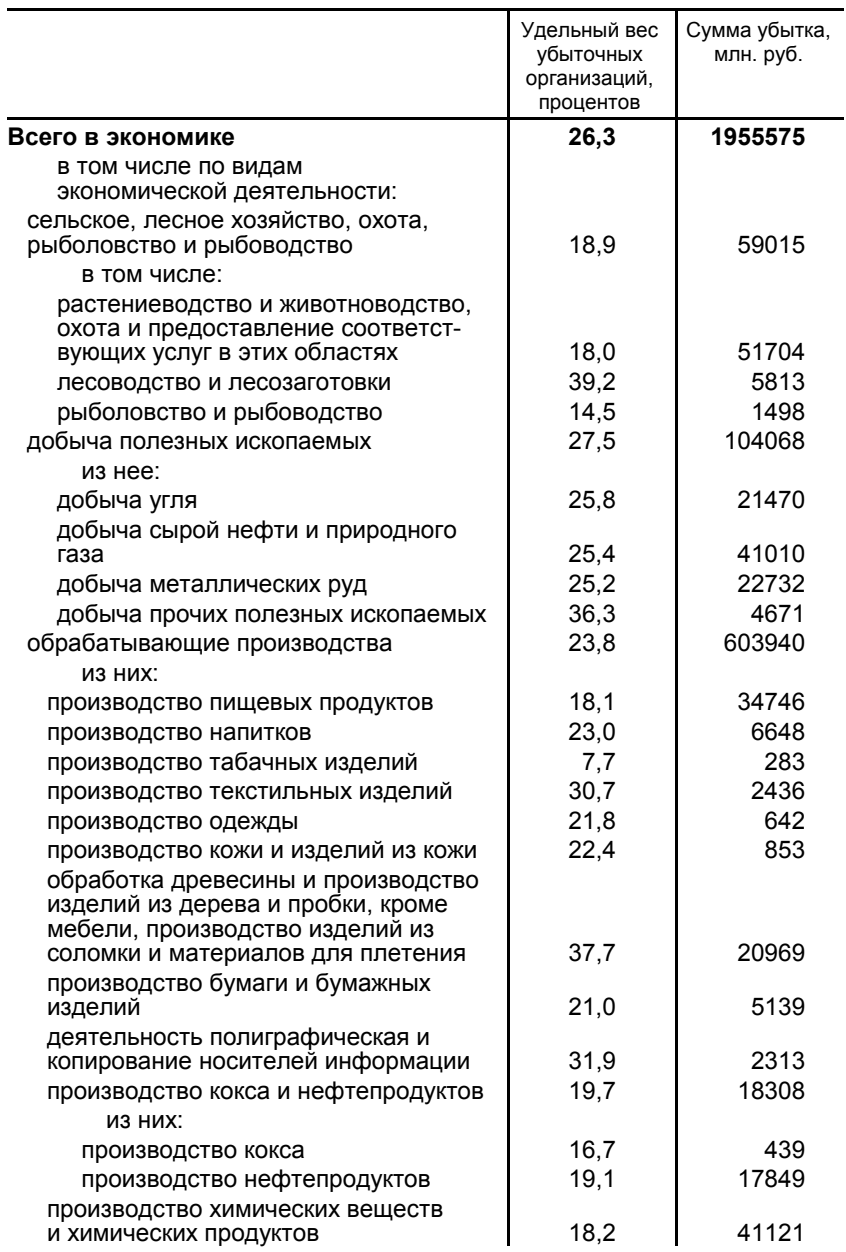

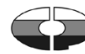


Продолжение табл. 23.18

\begin{tabular}{|c|c|c|}
\hline & $\begin{array}{l}\text { Удельный вес } \\
\text { убыточных } \\
\text { организаций, } \\
\text { процентов }\end{array}$ & $\begin{array}{l}\text { Сумма убытка, } \\
\text { млн. руб. }\end{array}$ \\
\hline $\begin{array}{l}\text { производство лекарственных средств } \\
\text { и материалов, применяемых в меди- } \\
\text { цинских целях }\end{array}$ & 16,4 & 5526 \\
\hline $\begin{array}{l}\text { производство резиновых и пластмассо- } \\
\text { вых изделий }\end{array}$ & 17,4 & 6552 \\
\hline производство металлургическое & 29,9 & 97997 \\
\hline $\begin{array}{l}\text { производство готовых металлических } \\
\text { изделий, кроме машин и оборудования }\end{array}$ & 23,4 & 29307 \\
\hline $\begin{array}{l}\text { производство компьютеров, электрон- } \\
\text { ных и оптических изделий }\end{array}$ & 16,9 & 10802 \\
\hline $\begin{array}{l}\text { производство электрического оборудо- } \\
\text { вания }\end{array}$ & 18,5 & 9314 \\
\hline $\begin{array}{l}\text { производство машин и оборудования, } \\
\text { не включенных в другие группировки }\end{array}$ & 23,6 & 113205 \\
\hline $\begin{array}{l}\text { производство автотранспортных } \\
\text { средств, прицепов и полуприцепов }\end{array}$ & 28,3 & 99386 \\
\hline $\begin{array}{l}\text { производство прочих транспортных } \\
\text { средств и оборудования }\end{array}$ & 28,3 & 43200 \\
\hline производство мебели & 16,3 & 788 \\
\hline производство прочих готовых изделий & 20,8 & 6687 \\
\hline $\begin{array}{l}\text { обеспечение электрической энергией, } \\
\text { газом и паром; кондиционирование }\end{array}$ & & \\
\hline воздуха & 45,1 & 117051 \\
\hline в том числе: & & \\
\hline $\begin{array}{l}\text { производство, передача и распределе- } \\
\text { ние электроэнергии }\end{array}$ & 24,2 & 49585 \\
\hline $\begin{array}{l}\text { производство и распределение газооб- } \\
\text { разного топлива }\end{array}$ & 16,1 & 21019 \\
\hline $\begin{array}{l}\text { производство, передача и распределе- } \\
\text { ние пара и горячей воды; кондициони- } \\
\text { рование воздуха }\end{array}$ & 56,1 & 46447 \\
\hline $\begin{array}{l}\text { водоснабжение; водоотведение, } \\
\text { организация сбора и утилизации отходов, } \\
\text { деятельность по ликвидации загрязнений }\end{array}$ & 43,8 & 15877 \\
\hline строительство & 24,9 & 135970 \\
\hline из него: & & \\
\hline строительство зданий & 24,0 & 52027 \\
\hline строительство инженерных сооружений| & 26,9 & 64524 \\
\hline
\end{tabular}


Продолжение табл. 23.18

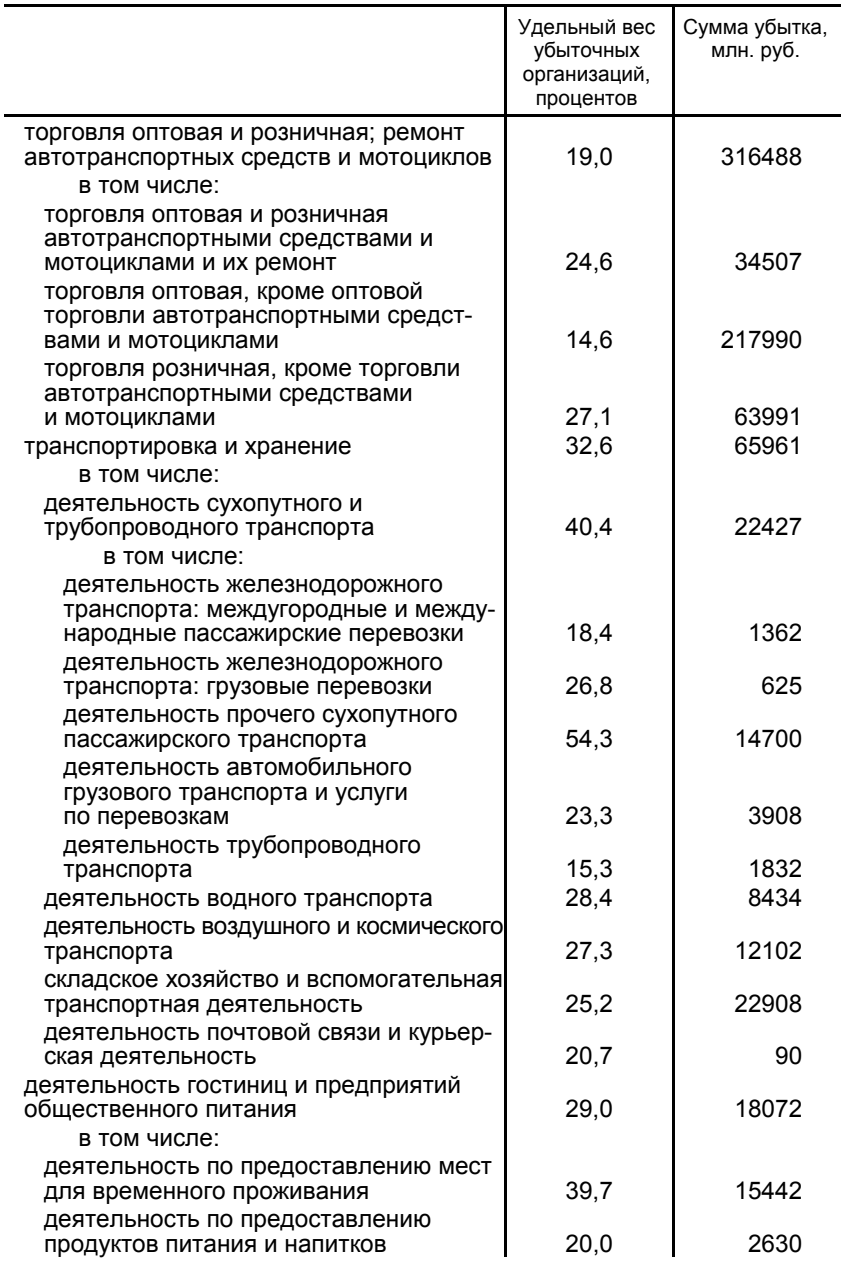

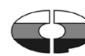


Продолжение табл. 23.18

\begin{tabular}{|c|c|c|}
\hline & $\begin{array}{l}\text { Удельный вес } \\
\text { убыточных } \\
\text { организаций, } \\
\text { процентов }\end{array}$ & $\begin{array}{l}\text { Сумма убытка, } \\
\text { млн. руб. }\end{array}$ \\
\hline $\begin{array}{l}\text { деятельность в области информации } \\
\text { и связи }\end{array}$ & 22,2 & 40435 \\
\hline из нее: & & \\
\hline деятельность издательская & 24,7 & 1813 \\
\hline $\begin{array}{l}\text { деятельность в сфрере телекоммуни- } \\
\text { каций }\end{array}$ & 21,0 & 12238 \\
\hline $\begin{array}{l}\text { деятельность в области информацион- } \\
\text { ных технологий }\end{array}$ & 18,9 & 1446 \\
\hline деятельность финансовая и страховая & 25,9 & 174951 \\
\hline $\begin{array}{l}\text { деятельность по операциям с недвижи- } \\
\text { мым имуществом }\end{array}$ & 31,8 & 74259 \\
\hline $\begin{array}{l}\text { деятельность профессиональная, } \\
\text { научная и техническая }\end{array}$ & 27,2 & 190177 \\
\hline $\begin{array}{l}\text { из нее научные исследования } \\
\text { и разработки }\end{array}$ & 20,1 & 14839 \\
\hline $\begin{array}{l}\text { деятельность административная и } \\
\text { сопутствующие дополнительные услуги }\end{array}$ & 18,8 & 18020 \\
\hline $\begin{array}{l}\text { из нее деятельность туристических } \\
\text { агентств и прочих организаций, предос- } \\
\text { тавляющих услуги в сфере туризма }\end{array}$ & 26,2 & 364 \\
\hline $\begin{array}{l}\text { государственное управление и обеспече- } \\
\text { ние военной безопасности; социальное } \\
\text { обеспечение }\end{array}$ & 25,9 & 251 \\
\hline образование & 23,0 & 2013 \\
\hline $\begin{array}{l}\text { деятельность в области здравоохране- } \\
\text { ния и социальных услуг }\end{array}$ & 21,7 & 6792 \\
\hline $\begin{array}{l}\text { из нее деятельность в области здраво- } \\
\text { охранения }\end{array}$ & 21,7 & 6772 \\
\hline $\begin{array}{l}\text { деятельность в области культуры, спор- } \\
\text { та, организации досуга и развлечений }\end{array}$ & 30,9 & 11075 \\
\hline из нее: & & \\
\hline $\begin{array}{l}\text { деятельность библиотек, архивов, } \\
\text { музеев и прочих объектов культуры }\end{array}$ & 40,9 & 79 \\
\hline $\begin{array}{l}\text { деятельность в области спорта, отдыха } \\
\text { и развлечений }\end{array}$ & 31,8 & 9905 \\
\hline предоставление прочих видов услуг & 28,0 & 1160 \\
\hline
\end{tabular}


23.19. УДЕЛЬНЫЙ ВЕС ПРИБЫЛЬНЫХ ОРГАНИЗАЦИЙ И СУММА ПРИБЫЛИ ПО ВИДАМ ЭКОНОМИЧЕСКОЙ ДЕЯТЕЛЬНОСТИ В 2017 Г.

\begin{tabular}{|c|c|c|}
\hline & \begin{tabular}{|} 
Удельный вес \\
прибыльных ор- \\
ганизаций, \\
процентов
\end{tabular} & $\begin{array}{l}\text { Сумма } \\
\text { прибыли, } \\
\text { млн. руб. }\end{array}$ \\
\hline $\begin{array}{l}\text { Всего в экономике } \\
\text { в том числе по видам } \\
\text { экономической деятельности: }\end{array}$ & 73,7 & 12276102 \\
\hline $\begin{array}{l}\text { сельское, лесное хозяйство, охота, } \\
\text { рыболовство и рыбоводство } \\
\text { в том числе: } \\
\text { растениеводство и животноводство, } \\
\text { охота и предоставление }\end{array}$ & 81,1 & 329121 \\
\hline соответствующих услуг в этих областях & 82,0 & 238761 \\
\hline лесоводство и лесозаготовки & 60,8 & 5468 \\
\hline рыболовство и рыбоводство & 85,5 & 84892 \\
\hline $\begin{array}{l}\text { добыча полезных ископаемых } \\
\text { из нее: }\end{array}$ & 72,5 & 2699700 \\
\hline добыча угля & 74,2 & 313799 \\
\hline добыча сырой нефти и природного газа & 74,6 & 1691002 \\
\hline добыча металлических руд & 74,8 & 339620 \\
\hline добыча прочих полезных ископаемых & 63,7 & 112179 \\
\hline $\begin{array}{l}\text { обрабатывающие производства } \\
\text { из них: }\end{array}$ & 76,2 & 3506693 \\
\hline производство пищевых продуктов & 81,9 & 257852 \\
\hline производство напитков & 77,0 & 61423 \\
\hline производство табачных изделий & 92,3 & 30377 \\
\hline производство текстильных изделий & 69,3 & 9658 \\
\hline производство одежды & 78,2 & 14793 \\
\hline $\begin{array}{l}\text { производство кожи и изделий из кожи } \\
\text { обработка древесины и производство } \\
\text { изделий из дерева и пробки, кроме } \\
\text { мебели, производство изделий из }\end{array}$ & 77,6 & 3581 \\
\hline $\begin{array}{l}\text { соломки и материалов для плетения } \\
\text { производство бумаги и бумажных }\end{array}$ & 62,3 & \\
\hline изделий & 79,0 & 89993 \\
\hline $\begin{array}{l}\text { деятельность полиграфическая и } \\
\text { копирование носителей информации }\end{array}$ & 68,1 & 12610 \\
\hline $\begin{array}{l}\text { производство кокса и нефтепродуктов } \\
\text { из них: }\end{array}$ & 80,3 & 764317 \\
\hline производство кокса & 83,3 & 21829 \\
\hline производство нефтепродуктов & 80,9 & 742488 \\
\hline $\begin{array}{l}\text { производство химических веществ } \\
\text { и химических продуктов }\end{array}$ & 81,8 & 348585 \\
\hline
\end{tabular}


Продолжение табл. 23.19

\begin{tabular}{|c|c|c|}
\hline & \begin{tabular}{|} 
Удельный вес \\
прибыльных ор- \\
ганизаций, \\
процентов
\end{tabular} & $\begin{array}{l}\text { Сумма } \\
\text { прибыли, } \\
\text { млн. руб. }\end{array}$ \\
\hline $\begin{array}{l}\text { производство лекарственных средств } \\
\text { и материалов, применяемых в меди- } \\
\text { цинских целях }\end{array}$ & 83,6 & 69588 \\
\hline $\begin{array}{l}\text { производство резиновых и пластмассо- } \\
\text { вых изделий }\end{array}$ & 82,6 & 44171 \\
\hline производство металлургическое & 70,1 & 978096 \\
\hline $\begin{array}{l}\text { производство готовых металлических } \\
\text { изделий, кроме машин и оборудования }\end{array}$ & 76,6 & 131656 \\
\hline $\begin{array}{l}\text { производство компьютеров, электрон- } \\
\text { ных и оптических изделий }\end{array}$ & 83,1 & 127738 \\
\hline $\begin{array}{l}\text { производство электрического оборудо- } \\
\text { вания }\end{array}$ & 81,5 & 56257 \\
\hline $\begin{array}{l}\text { производство машин и оборудования, } \\
\text { не включенных в другие группировки }\end{array}$ & 76,4 & 88631 \\
\hline $\begin{array}{l}\text { производство автотранспортных } \\
\text { средств, прицепов и полуприцепов }\end{array}$ & 71,7 & 84441 \\
\hline $\begin{array}{l}\text { производство прочих транспортных } \\
\text { средств и оборудования }\end{array}$ & 71,7 & 154189 \\
\hline производство мебели & 83,7 & 5396 \\
\hline производство прочих готовых изделий & 79,2 & 5171 \\
\hline $\begin{array}{l}\text { обеспечение электрической энергией, } \\
\text { газом и паром; кондиционирование } \\
\text { воздуха }\end{array}$ & 54,9 & 677144 \\
\hline $\begin{array}{l}\text { в том числе: } \\
\text { производство, передача и распределе- } \\
\text { ние электроэнергии }\end{array}$ & 75,8 & 604533 \\
\hline $\begin{array}{l}\text { производство и распределение газооб- } \\
\text { разного топлива }\end{array}$ & 83,9 & 38620 \\
\hline $\begin{array}{l}\text { производство, передача и распределе- } \\
\text { ние пара и горячей воды; кондициони- } \\
\text { рование воздуха }\end{array}$ & 43,9 & 33991 \\
\hline $\begin{array}{l}\text { водоснабжение; водоотведение, } \\
\text { организация сбора и утилизации отходов, } \\
\text { деятельность по ликвидации загрязнений }\end{array}$ & 56,2 & 35284 \\
\hline строительство & 75,1 & 271609 \\
\hline из него: & & \\
\hline строительство зданий & 76,0 & 114662 \\
\hline строительство инженерных сооружений| & 73,1 & 96223 \\
\hline
\end{tabular}


Продолжение табл. 23.19

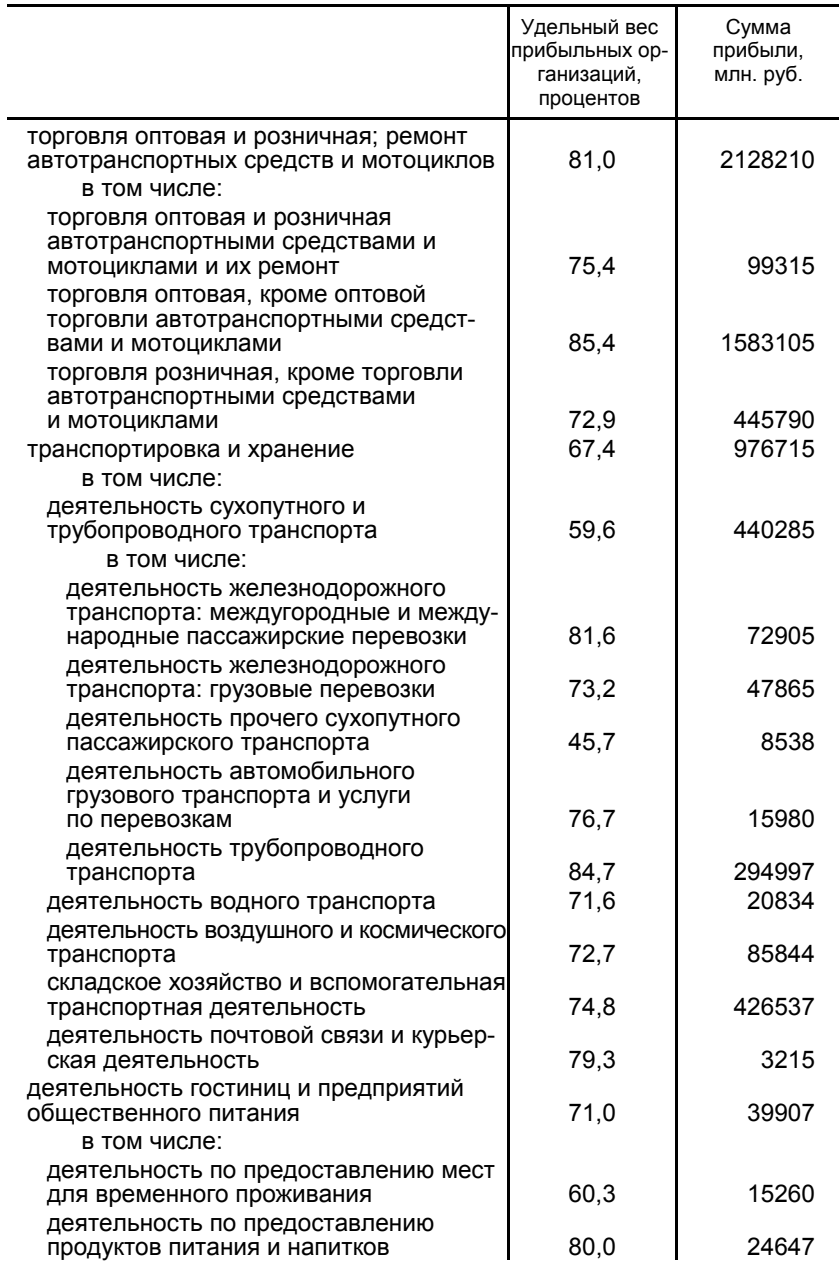

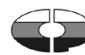


Продолжение табл. 23.19

\begin{tabular}{|c|c|c|}
\hline & \begin{tabular}{|} 
Удельный вес \\
прибыльных ор- \\
ганизаций, \\
процентов
\end{tabular} & $\begin{array}{l}\text { Сумма } \\
\text { прибыли, } \\
\text { млн. руб. }\end{array}$ \\
\hline $\begin{array}{l}\text { деятельность в области информации } \\
\text { и связи }\end{array}$ & 77,8 & 425098 \\
\hline из нее: & & \\
\hline деятельность издательская & 75,3 & 16272 \\
\hline $\begin{array}{l}\text { деятельность в сорере телекоммуника- } \\
\text { ций }\end{array}$ & 79,0 & 262997 \\
\hline $\begin{array}{l}\text { деятельность в области информацион- } \\
\text { ных технологий }\end{array}$ & 81,1 & 25823 \\
\hline деятельность финансовая и страховая & 74,1 & 347516 \\
\hline $\begin{array}{l}\text { деятельность по операциям с недвижи- } \\
\text { мым имуществом }\end{array}$ & 68,2 & 198702 \\
\hline $\begin{array}{l}\text { деятельность профессиональная, } \\
\text { научная и техническая }\end{array}$ & 72,8 & 513215 \\
\hline $\begin{array}{l}\text { из нее научные исследования и разра- } \\
\text { ботки }\end{array}$ & 79,9 & 194621 \\
\hline $\begin{array}{l}\text { деятельность административная и } \\
\text { сопутствующие дополнительные услуги }\end{array}$ & 81,2 & 56240 \\
\hline $\begin{array}{l}\text { из нее деятельность туристических } \\
\text { агентств и прочих организаций, предос- } \\
\text { тавляющих услуги в сфере туризма }\end{array}$ & 73,8 & 1877 \\
\hline $\begin{array}{l}\text { государственное управление и обеспече- } \\
\text { ние военной безопасности; социальное } \\
\text { обеспечение }\end{array}$ & 74,1 & 18951 \\
\hline образование & 77,0 & 5975 \\
\hline $\begin{array}{l}\text { деятельность в области здравоохране- } \\
\text { ния и социальных услуг }\end{array}$ & 78,3 & 28178 \\
\hline $\begin{array}{l}\text { из нее деятельность в области здраво- } \\
\text { охранения }\end{array}$ & 78,3 & 27665 \\
\hline $\begin{array}{l}\text { деятельность в области культуры, спор- } \\
\text { та, организации досуга и развлечений }\end{array}$ & 69,1 & 11555 \\
\hline из нее: & & \\
\hline $\begin{array}{l}\text { деятельность библиотек, архивов, } \\
\text { музеев и прочих объектов культуры }\end{array}$ & 59,1 & 112 \\
\hline $\begin{array}{l}\text { деятельность в области спорта, отдыха } \\
\text { и развлечений }\end{array}$ & 68,2 & 5114 \\
\hline предоставление прочих видов услуг & 72,0 & 6289 \\
\hline
\end{tabular}




\subsection{0. ЗАТРАТЫ НА ПРОИЗВОДСТВО И ПРОДАЖУ ПРОДУКЦИИ (ТОВАРОВ, РАБОТ, УСЛУГ) ПО ВИДАМ ЭКОНОМИЧЕСКОЙ ДЕЯТЕЛЬНОСТИ в 2016 г. ${ }^{1)}$}

(млн. руб.)

\begin{tabular}{|c|c|c|c|c|c|c|}
\hline & \multirow[t]{2}{*}{ Всего } & \multicolumn{5}{|c|}{ в том числе } \\
\hline & & $\begin{array}{c}\text { матери- } \\
\text { альные } \\
\text { затраты }\end{array}$ & $\begin{array}{c}\text { затраты } \\
\text { на оплату } \\
\text { труда }\end{array}$ & $\begin{array}{c}\text { страхо- } \\
\text { вые } \\
\text { взносы в } \\
\text { Пенсион- } \\
\text { ный } \\
\text { фонд, } \\
\text { ФСС, } \\
\text { ФФОМС }\end{array}$ & \begin{tabular}{|} 
аморти- \\
зация \\
основных \\
средств \\
\end{tabular} & $\begin{array}{l}\text { прочие } \\
\text { затраты }\end{array}$ \\
\hline $\begin{array}{l}\text { Сельское хозяйство, } \\
\text { охота и лесное }\end{array}$ & & & & & & \\
\hline $\begin{array}{l}\text { хозяйство } \\
\text { Рыболовство, }\end{array}$ & 2148474,8 & 1464424,6 & 285187,8 & 84915,4 & 174653,2 & 139293,9 \\
\hline $\begin{array}{l}\text { рыбоводство } \\
\text { Добыча полезных }\end{array}$ & 162765,1 & 79106,7 & 33281,6 & 9016,2 & 7772,0 & 33588,7 \\
\hline $\begin{array}{l}\text { ископаемых } \\
\text { Обрабатывающие }\end{array}$ & 9098355,4 & 3108046,6 & 840550,0 & 220777,5 & 1253158,8 & 3675822,5 \\
\hline $\begin{array}{l}\text { производства } \\
\text { Производство и рас- } \\
\text { пределение элек- } \\
\text { троэнергии, газа }\end{array}$ & 27890549,4 & 20720886,2 & 2552326,8 & 720310,0 & 1092617,5 & 2804408,9 \\
\hline и воды & 5871508,1 & 3740947,3 & 778240,8 & 218256,9 & 542464,1 & 591599,0 \\
\hline $\begin{array}{l}\text { Строительство } \\
\text { Оптовая и розничная } \\
\text { торговля; ремонт ав- } \\
\text { тотранспортных } \\
\text { средств, мотоциклов, } \\
\text { бытовых изделий и } \\
\text { предметов личного }\end{array}$ & 3045852,1 & 1710270,6 & 549963,1 & 144588,6 & 84506,3 & 556523,6 \\
\hline $\begin{array}{l}\text { пользования } \\
\text { Гостиницы и ресто- }\end{array}$ & 9158839,5 & 4150640,2 & 1263191,2 & 321893,7 & 848748,6 & 2574365,8 \\
\hline раны & 425279,8 & 184524,6 & 94120,3 & 26337,3 & 17089,5 & 103208,1 \\
\hline Транспорт и связь & 9256562,7 & 3633898,6 & 1613182,7 & 437024,6 & 823887,9 & 2748568,9 \\
\hline $\begin{array}{l}\text { из них связь } \\
\text { Операции с недви- } \\
\text { жимым имуществом, } \\
\text { аренда и предос- }\end{array}$ & 1547379,8 & 356017,4 & 303354,7 & 78795,8 & 230422,6 & 578789,2 \\
\hline $\begin{array}{l}\text { тавление услуг } \\
\text { Государственное } \\
\text { управление и обес- } \\
\text { печение военной } \\
\text { безопасности; соци- }\end{array}$ & 5410434,7 & 1787948,9 & 1424523,3 & 335037,2 & 292686,4 & 1570238,8 \\
\hline альное страхование & 23333,4 & 1956,1 & 8588,5 & 2192,8 & 5691,3 & 4904,7 \\
\hline $\begin{array}{l}\text { Образование } \\
\text { Здравоохранение } \\
\text { и предоставление }\end{array}$ & 88795,5 & 13323,1 & 39037,6 & 9658,8 & 1137,2 & 25638,8 \\
\hline $\begin{array}{l}\text { социальных услуг } \\
\text { Предоставление } \\
\text { прочих коммуналь- }\end{array}$ & 280459,1 & 81955,6 & 102812,5 & 28350,8 & 13983,8 & 53356,4 \\
\hline $\begin{array}{l}\text { ных, социальных и } \\
\text { персональных услуг }\end{array}$ & 620131,0 & 146622,7 & 172912,9 & 39547,6 & 27032,0 & 234015,8 \\
\hline
\end{tabular}

1) Без субъектов малого предпринимательства. 


\subsection{1. СТРУКТУРА ЗАТРАТ НА ПРОИЗВОДСТВО И ПРОДАЖУ ПРОДУКЦИИ (ТОВАРОВ, РАБОТ, УСЛУГ) ПО ВИДАМ ЭКОНОМИЧЕСКОЙ ДЕЯТЕЛЬНОСТИ В 2016 г.)}

(в процентах к итогу)

\begin{tabular}{|c|c|c|c|c|c|c|}
\hline & \multirow[t]{2}{*}{ Всего } & \multicolumn{5}{|c|}{ в том числе } \\
\hline & & $\begin{array}{l}\text { матери- } \\
\text { альные } \\
\text { затраты }\end{array}$ & $\begin{array}{c}\text { затраты } \\
\text { на оплату } \\
\text { труда }\end{array}$ & \begin{tabular}{|l} 
страхо- \\
вые \\
взносы в \\
Пенсион- \\
ный \\
фонд, \\
ФСС, \\
ФФОМС
\end{tabular} & \begin{tabular}{|c} 
аморти- \\
зация \\
основных \\
средств \\
\end{tabular} & $\begin{array}{c}\text { прочие } \\
\text { затраты }\end{array}$ \\
\hline $\begin{array}{l}\text { Сельское хозяйство, } \\
\text { охота и лесное }\end{array}$ & & & & & & \\
\hline $\begin{array}{l}\text { хозяйство } \\
\text { Рыболовство }\end{array}$ & 100 & 68,2 & 13,3 & 4,0 & 8,1 & 6,5 \\
\hline $\begin{array}{l}\text { рыбоводство } \\
\text { Добыча полезных }\end{array}$ & 100 & 48,6 & 20,4 & 5,5 & 4,8 & 20,6 \\
\hline $\begin{array}{l}\text { ископаемых } \\
\text { Обрабатывающие }\end{array}$ & 100 & 34,2 & 9,2 & 2,4 & 13,8 & 40,4 \\
\hline $\begin{array}{l}\text { производства } \\
\text { Производство и рас- } \\
\text { пределение элек- } \\
\text { троэнергии, газа и }\end{array}$ & 100 & 74,3 & 9,2 & 2,6 & 3,9 & 10,1 \\
\hline $\begin{array}{l}\text { воды } \\
\text { Строительство } \\
\text { Оптовая и розничная } \\
\text { торговля; ремонт ав- } \\
\text { тотранспортных } \\
\text { средств, мотоциклов, } \\
\text { бытовых изделий и } \\
\text { предметов личного }\end{array}$ & $\begin{array}{l}100 \\
100\end{array}$ & $\begin{array}{l}63,7 \\
56,2\end{array}$ & $\begin{array}{l}13,3 \\
18,1\end{array}$ & $\begin{array}{l}3,7 \\
4,7\end{array}$ & $\begin{array}{l}9,2 \\
2,8\end{array}$ & $\begin{array}{l}10,1 \\
18,3\end{array}$ \\
\hline $\begin{array}{l}\text { пользования } \\
\text { Гостиницы и ресто- }\end{array}$ & 100 & 45,3 & 13,8 & 3,5 & 9,3 & 28,1 \\
\hline $\begin{array}{l}\text { раны } \\
\text { Транспорт и связь } \\
\text { из них связь }\end{array}$ & $\begin{array}{l}100 \\
100 \\
100\end{array}$ & $\begin{array}{l}43,4 \\
39,3 \\
23,0\end{array}$ & $\begin{array}{l}22,1 \\
17,4 \\
19,6\end{array}$ & $\begin{array}{l}6,2 \\
4,7 \\
5,1\end{array}$ & $\begin{array}{r}4,0 \\
8,9 \\
14,9\end{array}$ & $\begin{array}{l}24,3 \\
29,7 \\
37,4\end{array}$ \\
\hline $\begin{array}{l}\text { Операции с недви- } \\
\text { жимым имуществом, } \\
\text { аренда и предос- }\end{array}$ & & & & & & \\
\hline $\begin{array}{l}\text { тавление услуг } \\
\text { Государственное } \\
\text { управление и обес- } \\
\text { печение военной }\end{array}$ & 100 & 33,0 & 26,3 & 6,2 & 5,4 & 29,0 \\
\hline $\begin{array}{l}\text { безопасности; соци- } \\
\text { альное страхование } \\
\text { Образование } \\
\text { Здравоохранение }\end{array}$ & $\begin{array}{l}100 \\
100\end{array}$ & $\begin{array}{r}8,4 \\
15,0\end{array}$ & $\begin{array}{l}36,8 \\
44,0\end{array}$ & $\begin{array}{r}9,4 \\
10,9\end{array}$ & $\begin{array}{r}24,4 \\
1,3\end{array}$ & $\begin{array}{l}21,0 \\
28,9\end{array}$ \\
\hline $\begin{array}{l}\text { и предоставление } \\
\text { социальных услуг } \\
\text { Предоставление } \\
\text { прочих коммуналь- }\end{array}$ & 100 & 29,2 & 36,7 & 10,1 & 5,0 & 19,0 \\
\hline $\begin{array}{l}\text { ных, социальных и } \\
\text { персональных услуг }\end{array}$ & 100 & 23,6 & 27,9 & 6,4 & 4,4 & 37,7 \\
\hline
\end{tabular}

1) Без субъектов малого предпринимательства. 
23.22. РЕНТАБЕЛЬНОСТЬ ПРОДАННЫХ ТОВАРОВ, ПРОДУКЦИИ (РАБОТ, УСЛУГ) И АКТИВОВ ОРГАНИЗАЦИЙ ПО ВИДАМ ЭКОНОМИЧЕСКОЙ ДЕЯТЕЛЬНОСТИ В 2017 г. ${ }^{1)}$

(в процентах)

\begin{tabular}{|c|c|c|}
\hline & $\begin{array}{c}\text { Рентабельность } \\
\text { проданных } \\
\text { товаров, про- } \\
\text { дукции (работ, } \\
\text { услуг) }\end{array}$ & $\begin{array}{c}\text { Рентабельность } \\
\text { активов }\end{array}$ \\
\hline $\begin{array}{l}\text { Всего в экономике } \\
\text { в том числе по видам } \\
\text { экономической деятельности: }\end{array}$ & 7,5 & 5,3 \\
\hline $\begin{array}{l}\text { сельское, лесное хозяйство, охота, } \\
\text { рыболовство и рыбоводство }\end{array}$ & 17,3 & 6,4 \\
\hline $\begin{array}{l}\text { в том числе: } \\
\text { растениеводство и животноводство, } \\
\text { охота и предоставление соответст- } \\
\text { вующих услуг в этих областях }\end{array}$ & 14,5 & 5,0 \\
\hline лесоводство и лесозаготовки & 5,4 & $-0,3$ \\
\hline рыболовство и рыбоводство & 49,9 & 22,7 \\
\hline $\begin{array}{l}\text { добыча полезных ископаемых } \\
\text { из нее: }\end{array}$ & 25,9 & 11,0 \\
\hline добыча угля & 30,6 & 16,5 \\
\hline $\begin{array}{l}\text { добыча сырой нефти и природного } \\
\text { газа }\end{array}$ & 25,2 & 11,1 \\
\hline добыча металлических руд & 50,3 & 15,6 \\
\hline добыча прочих полезных ископаемых & 42,8 & 8,2 \\
\hline $\begin{array}{l}\text { обрабатывающие производства } \\
\text { из них: }\end{array}$ & 11,5 & 5,5 \\
\hline производство пищевых продуктов & 8,4 & 7,0 \\
\hline производство напитков & 12,4 & 5,9 \\
\hline производство табачных изделий & 24,6 & 10,3 \\
\hline производство текстильных изделий & 8,7 & 4,0 \\
\hline производство одежды & 13,3 & 12,7 \\
\hline $\begin{array}{l}\text { производство кожи и изделий из кожи } \\
\text { обработка древесины и производство } \\
\text { изделий из дерева и пробки, кроме } \\
\text { мебели, производство изделий }\end{array}$ & 10,9 & 4,7 \\
\hline из соломки и материалов для плетения & 8,4 & 2,1 \\
\hline $\begin{array}{l}\text { производство бумаги и бумажных } \\
\text { изделий }\end{array}$ & 20,5 & 13,2 \\
\hline $\begin{array}{l}\text { деятельность полиграфическая и } \\
\text { копирование носителей информации }\end{array}$ & 8,7 & 6,5 \\
\hline $\begin{array}{l}\text { производство кокса и нефтепродуктов } \\
\text { из них: }\end{array}$ & 8,3 & 3,9 \\
\hline производство кокса & 14,5 & 22,6 \\
\hline производство нефтепродуктов & 8,2 & 3,8 \\
\hline
\end{tabular}

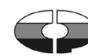


Продолжение табл. 23.22

\begin{tabular}{|c|c|c|}
\hline & $\begin{array}{c}\text { Рентабельность } \\
\text { проданных } \\
\text { товаров, про- } \\
\text { дукции (работ, } \\
\text { услуг) }\end{array}$ & $\begin{array}{c}\text { Рентабельность } \\
\text { активов }\end{array}$ \\
\hline $\begin{array}{l}\text { производство химических веществ } \\
\text { и химических продуктов }\end{array}$ & 19,8 & 8,6 \\
\hline $\begin{array}{l}\text { производство лекарственных средств } \\
\text { и материалов, применяемых } \\
\text { в медицинских целях }\end{array}$ & 28,9 & 10,5 \\
\hline $\begin{array}{l}\text { производство резиновых и пластмассо- } \\
\text { вых изделий }\end{array}$ & 9,1 & 7,0 \\
\hline производство металлургическое & 20,7 & 12,5 \\
\hline $\begin{array}{l}\text { производство готовых металлических } \\
\text { изделий, кроме машин и оборудования }\end{array}$ & 10,7 & 4,2 \\
\hline $\begin{array}{l}\text { производство компьютеров, } \\
\text { и оптических изделий }\end{array}$ & 16,3 & 7,1 \\
\hline $\begin{array}{l}\text { производство электрического оборудо- } \\
\text { вания }\end{array}$ & 8,3 & 6,9 \\
\hline $\begin{array}{l}\text { производство машин и оборудования, } \\
\text { не включенных в другие группировки }\end{array}$ & 7,8 & $-1,7$ \\
\hline $\begin{array}{l}\text { производство автотранспортных } \\
\text { средств, прицепов и полуприцепов }\end{array}$ & 3,2 & $-1,0$ \\
\hline $\begin{array}{l}\text { производство прочих транспортных } \\
\text { средств и оборудования }\end{array}$ & 12,9 & 1,9 \\
\hline производство мебели & 7,5 & 5,2 \\
\hline производство прочих готовых изделий & 6,4 & $-0,9$ \\
\hline $\begin{array}{l}\text { обеспечение электрической энергией, } \\
\text { газом и паром; кондиционирование } \\
\text { воздуха }\end{array}$ & 83 & 4.1 \\
\hline $\begin{array}{l}\text { в том числе: } \\
\text { производство, передача и } \\
\text { распределение электроэнергии }\end{array}$ & 11,7 & 4,8 \\
\hline $\begin{array}{l}\text { производство и распределение газооб- } \\
\text { разного топлива }\end{array}$ & 2,8 & 2,1 \\
\hline $\begin{array}{l}\text { производство, передача и } \\
\text { распределение пара и горячей воды; } \\
\text { кондиционирование воздуха }\end{array}$ & $-3,9$ & $-0,9$ \\
\hline $\begin{array}{l}\text { водоснабжение; водоотведение, } \\
\text { организация сбора и утилизации отходов, } \\
\text { деятельность по ликвидации загрязнений }\end{array}$ & 3,6 & 1,3 \\
\hline строительство & 7,2 & 1,8 \\
\hline из него: & & \\
\hline строительство зданий & 8,2 & 1,5 \\
\hline строительство инженерных сооружений| & 6,1 & 1,4 \\
\hline
\end{tabular}


Продолжение табл. 23.22

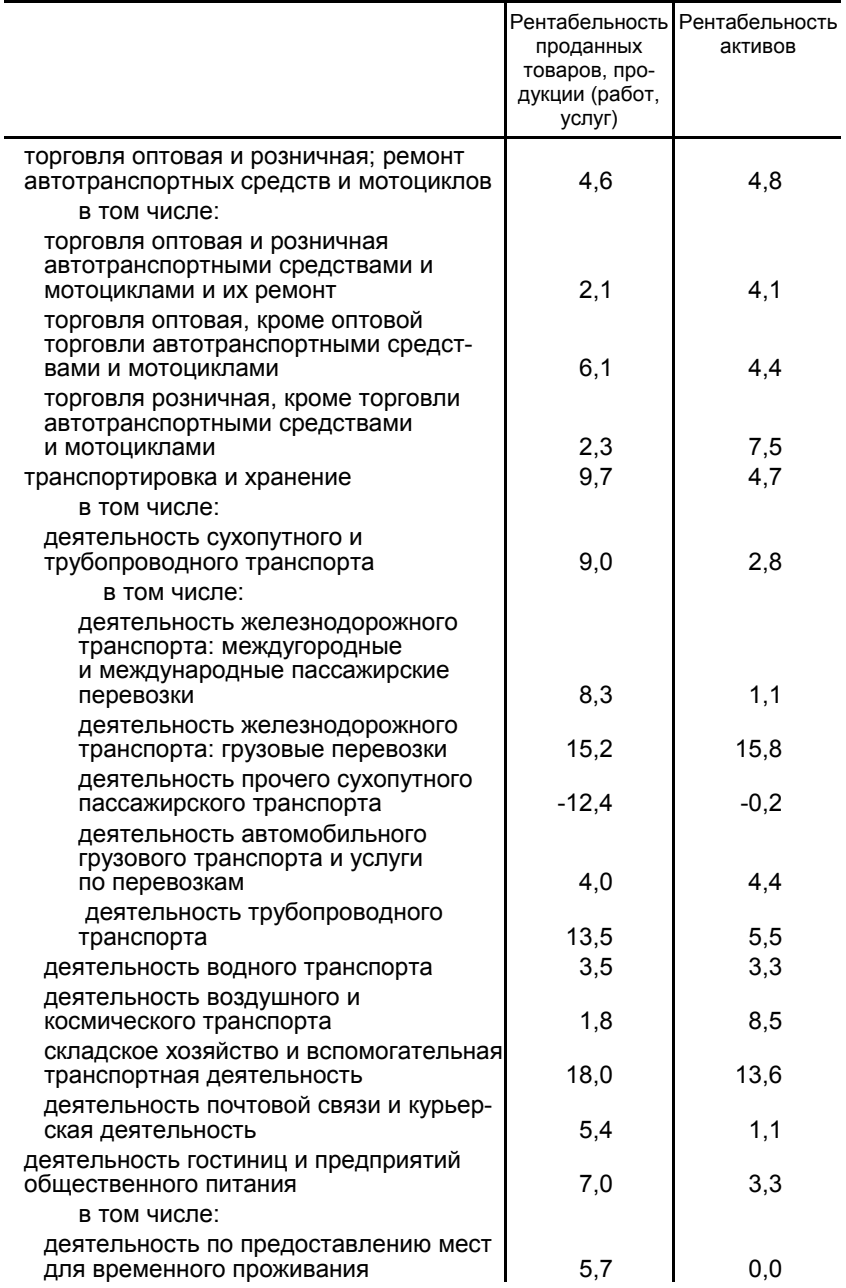


Продолжение табл. 23.22

\begin{tabular}{|c|c|c|}
\hline & $\mid \begin{array}{c}\text { Рентабельность } \\
\text { проданных } \\
\text { товаров, про- } \\
\text { дукции (работ, } \\
\text { услуг) }\end{array}$ & $\begin{array}{c}\text { Рентабельность } \\
\text { активов }\end{array}$ \\
\hline $\begin{array}{l}\text { деятельность по предоставлению } \\
\text { продуктов питания и напитков }\end{array}$ & 7,3 & 8,6 \\
\hline $\begin{array}{l}\text { деятельность в области информации } \\
\text { и связи }\end{array}$ & 14,2 & 9,1 \\
\hline из нее: & & \\
\hline деятельность издательская & 18,6 & 17,0 \\
\hline $\begin{array}{l}\text { деятельность в сферере } \\
\text { телекоммуникаций }\end{array}$ & 18,4 & 8,2 \\
\hline $\begin{array}{l}\text { деятельность в области } \\
\text { информационных технологий }\end{array}$ & 11,7 & 13,3 \\
\hline деятельность финансовая и страховая & 0,4 & 2,1 \\
\hline $\begin{array}{l}\text { деятельность по операциям с } \\
\text { недвижимым имуществом }\end{array}$ & 15,5 & 2,2 \\
\hline $\begin{array}{l}\text { деятельность профессиональная, } \\
\text { научная и техническая }\end{array}$ & 12,3 & 2,7 \\
\hline $\begin{array}{l}\text { из нее научные исследования и разра- } \\
\text { ботки }\end{array}$ & 15,9 & 3,9 \\
\hline $\begin{array}{l}\text { деятельность административная и } \\
\text { сопутствующие дополнительные услуги }\end{array}$ & 12,3 & 3,9 \\
\hline $\begin{array}{l}\text { из нее деятельность туристических } \\
\text { агентств и прочих организаций, предос- } \\
\text { тавляющих услуги в сфере туризма }\end{array}$ & 7,2 & 10,2 \\
\hline $\begin{array}{l}\text { государственное управление и } \\
\text { обеспечение военной безопасности; } \\
\text { социальное обеспечение }\end{array}$ & 1,6 & 1,4 \\
\hline образование & 5,0 & 3,0 \\
\hline $\begin{array}{l}\text { деятельность в области здравоохране- } \\
\text { ния и социальных услуг }\end{array}$ & 10,4 & 6,3 \\
\hline $\begin{array}{l}\text { из нее деятельность в области } \\
\text { здравоохранения }\end{array}$ & 10,3 & 6,3 \\
\hline $\begin{array}{l}\text { деятельность в области культуры, спор- } \\
\text { та, организации досуга и развлечений }\end{array}$ & 1,2 & 0,2 \\
\hline из нее: & & \\
\hline $\begin{array}{l}\text { деятельность библиотек, архивов, } \\
\text { музеев и прочих объектов культуры }\end{array}$ & 0,8 & 0,5 \\
\hline $\begin{array}{l}\text { деятельность в области спорта, отдыха } \\
\text { и развлечений }\end{array}$ & $-8,4$ & $-2,7$ \\
\hline предоставление прочих видов услуг & 4,8 & 3,0 \\
\hline
\end{tabular}

1) Знак (-) означает убыток (убыточность). 
23.23. ЗАДОЛЖЕННОСТЬ ОРГАНИЗАЦИЙ

(на конец года)

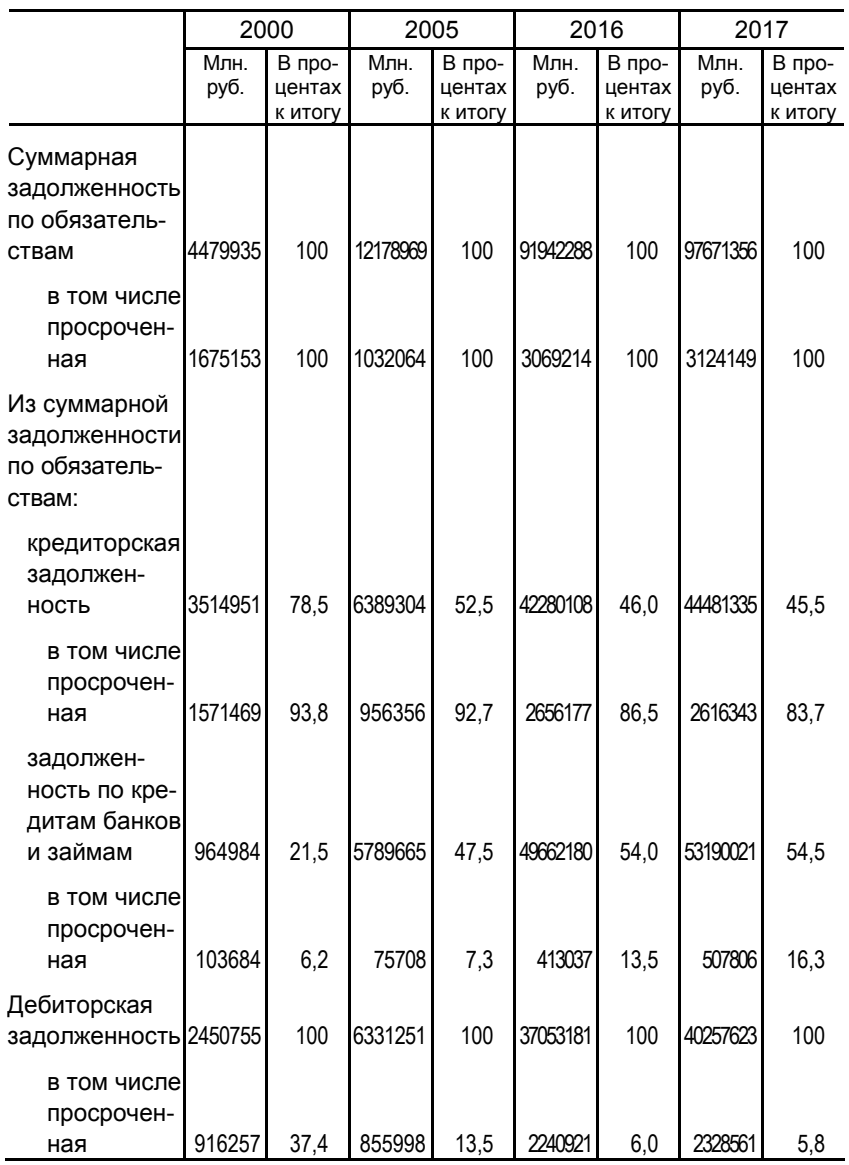


23.24. КРЕДИТОРСКАЯ И ДЕБИТОРСКАЯ ЗАДОЛЖЕННОСТЬ ОРГАНИЗАЦИЙ ПО ВИДАМ ЭКОНОМИЧЕСКОЙ ДЕЯТЕЛЬНОСТИ в 2017 г.

(на конец года)

\begin{tabular}{|c|c|c|c|c|c|c|}
\hline & \multirow{2}{*}{$\begin{array}{c}\text { Креди- } \\
\text { торская } \\
\text { задол- } \\
\text { жен- } \\
\text { ность, } \\
\text { млн.руб. }\end{array}$} & \multicolumn{2}{|c|}{$\begin{array}{c}\text { в том числе } \\
\text { просроченная }\end{array}$} & \multirow{2}{*}{\begin{tabular}{|c|} 
Деби- \\
торская \\
задол- \\
жен- \\
ность, \\
млн.руб. \\
\end{tabular}} & \multicolumn{2}{|c|}{$\begin{array}{c}\text { в том числе } \\
\text { просроченная }\end{array}$} \\
\hline & & млн.руб. & \begin{tabular}{|c|} 
в про- \\
центах от \\
креди- \\
торской \\
задол- \\
женности \\
\end{tabular} & & млн.руб. & $\begin{array}{c}\text { в про- } \\
\text { центах о } \\
\text { дебитор } \\
\text { ской за- } \\
\text { должен- } \\
\text { ности }\end{array}$ \\
\hline $\begin{array}{l}\text { Всего в экономике } \\
\text { в том числе по } \\
\text { видам экономи- } \\
\text { ческой деятель- } \\
\text { ности: } \\
\text { сельское, лесное } \\
\text { хозяйство, охота, } \\
\text { рыболовство и }\end{array}$ & 44481335 & 2616343 & 5,9 & 40257623 & 2328561 & 5,8 \\
\hline $\begin{array}{c}\text { рыбоводство } \\
\text { в том числе: } \\
\text { растениеводство } \\
\text { и животноводст- } \\
\text { во, охота и пре- } \\
\text { доставление } \\
\text { соответствующих } \\
\text { услуг в этих }\end{array}$ & 594744 & 17816 & 3,0 & 689996 & 15472 & 2,2 \\
\hline $\begin{array}{l}\text { областях } \\
\text { лесоводство и } \\
\text { лесозаготовки }\end{array}$ & 518748 & 16293 & 3,1 & 571415 & 12610 & 2,2 \\
\hline $\begin{array}{l}\text { рыболовство и } \\
\text { рыбоводство }\end{array}$ & 47190 & 332 & 0,7 & 98939 & 2404 & 2,4 \\
\hline $\begin{array}{l}\text { добыча полезных } \\
\text { ископаемых }\end{array}$ & 2881170 & 142791 & 5,0 & 4501030 & 285935 & 6,4 \\
\hline из нее: & & & & & & \\
\hline $\begin{array}{l}\text { добыча угля } \\
\text { добыча сырой } \\
\text { нефти и природ- }\end{array}$ & 302479 & 59840 & 19,8 & 424197 & 65867 & 15,5 \\
\hline & 1636894 & 47502 & 2,9 & 2657681 & 165694 & 6,2 \\
\hline $\begin{array}{l}\text { добыча металли- } \\
\text { ческих руд }\end{array}$ & 164641 & 10031 & 6,1 & 224202 & 14372 & 6,4 \\
\hline $\begin{array}{l}\text { добыча прочих } \\
\text { полезных иско- } \\
\text { паемых }\end{array}$ & 112089 & 6286 & 5,6 & 118040 & 8188 & 6,9 \\
\hline
\end{tabular}


Продолжение табл. 23.24

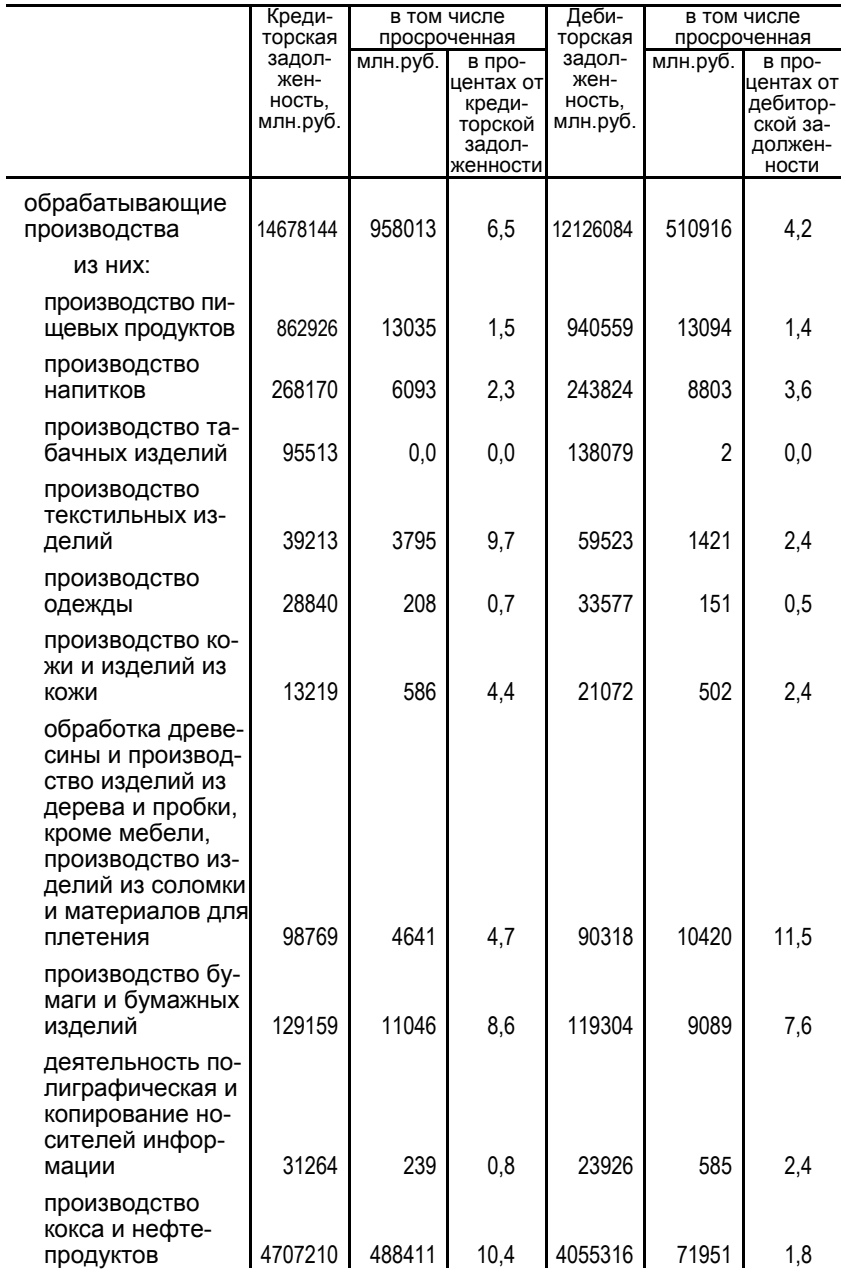


Продолжение табл. 23.24

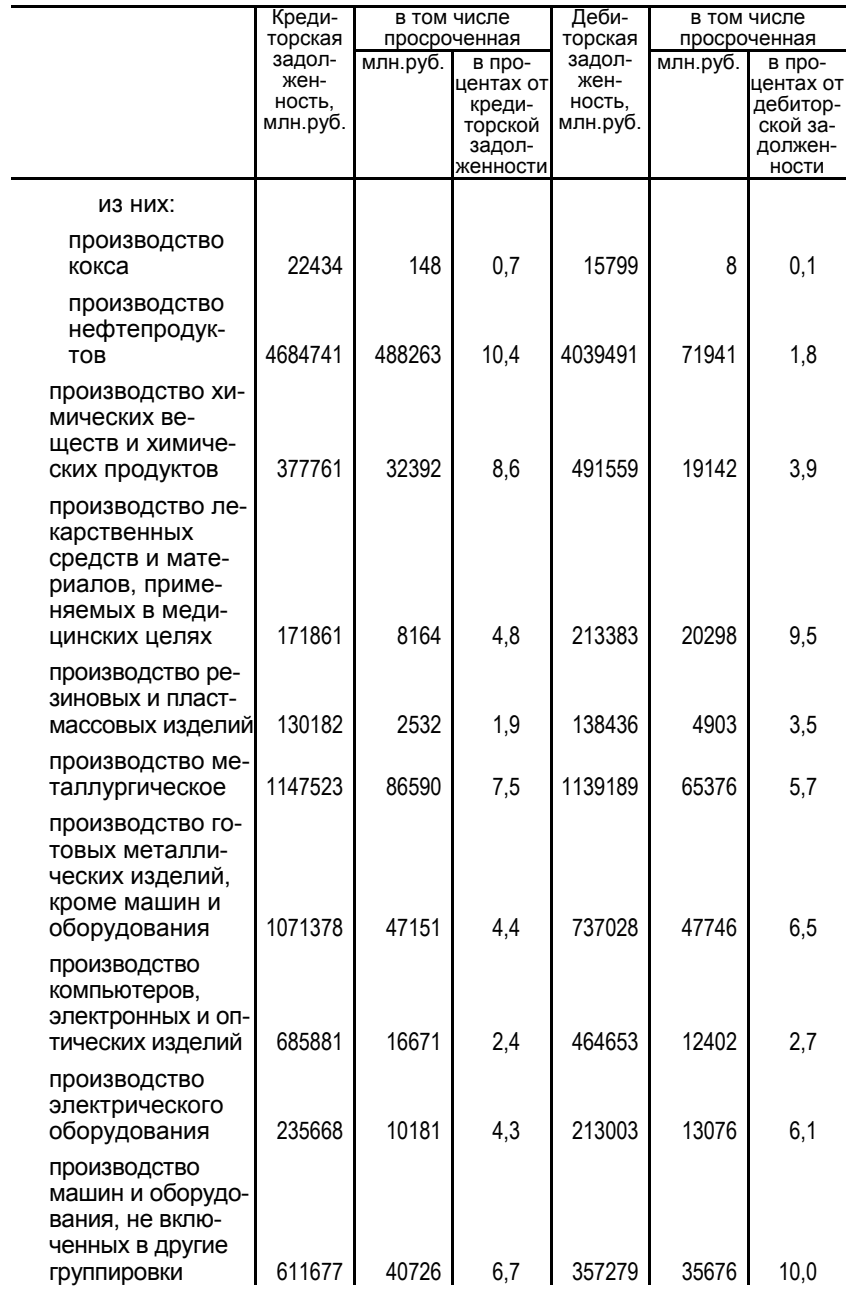


Продолжение табл. 23.24

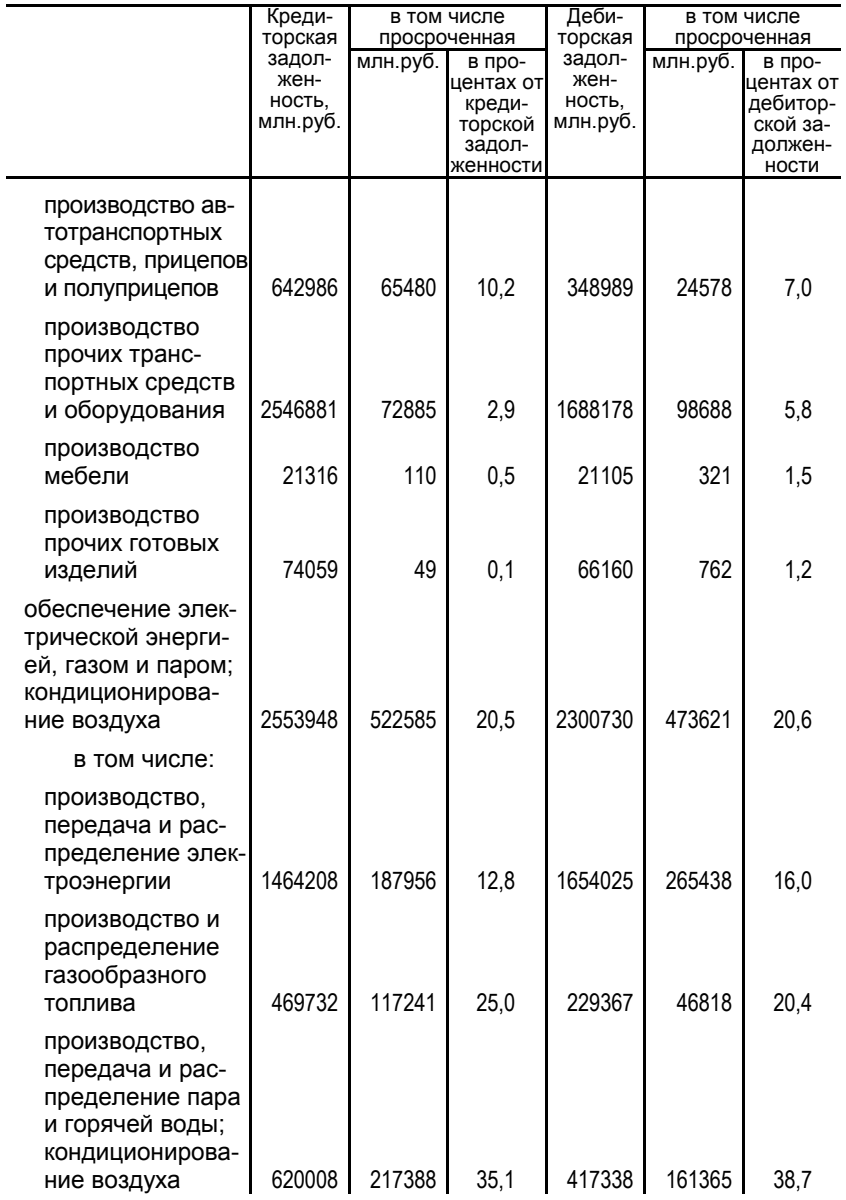


Продолжение табл. 23.24

\begin{tabular}{|c|c|c|c|c|c|c|}
\hline & \multirow{2}{*}{$\begin{array}{c}\text { Креди- } \\
\text { торская } \\
\text { задол- } \\
\text { жен- } \\
\text { ность, } \\
\text { млн.руб. }\end{array}$} & \multicolumn{2}{|c|}{$\begin{array}{c}\text { в том числе } \\
\text { просроченная }\end{array}$} & \multirow{2}{*}{\begin{tabular}{|c|} 
Деби- \\
торская \\
задол- \\
жен- \\
ность, \\
млн.руб. \\
\end{tabular}} & \multicolumn{2}{|c|}{$\begin{array}{c}\text { в том числе } \\
\text { просроченная }\end{array}$} \\
\hline & & млн.руб. & \begin{tabular}{|c|} 
в про- \\
центах от \\
креди-- \\
торской \\
задол- \\
женности \\
\end{tabular} & & млн.руб. & \begin{tabular}{|c} 
в про- \\
центах от \\
дебитор- \\
ской за- \\
должен- \\
ности \\
\end{tabular} \\
\hline $\begin{array}{l}\text { водоснабжение; } \\
\text { водоотведение, ор- } \\
\text { ганизация сбора и } \\
\text { утилизации отхо- } \\
\text { дов, деятельность } \\
\text { по ликвидации за- } \\
\text { грязнений }\end{array}$ & 224859 & 35578 & 15,8 & 197297 & 51525 & 26,1 \\
\hline $\begin{array}{c}\text { строительство } \\
\text { из него: } \\
\text { строительство } \\
\text { зданий }\end{array}$ & 4327986 & 127049 & 2,9 & 3108864 & 124257 & 4,0 \\
\hline $\begin{array}{l}\text { строительство } \\
\text { инженерных со- } \\
\text { оружений }\end{array}$ & 1339534 & 41841 & 3,1 & 897615 & 33435 & 3,7 \\
\hline $\begin{array}{l}\text { торговля оптовая и } \\
\text { розничная; ремонт } \\
\text { автотранспортных } \\
\text { средств и мотоцик- } \\
\text { лов }\end{array}$ & 9486621 & 513239 & 5,4 & 8906780 & 522535 & 5,9 \\
\hline $\begin{array}{l}\quad \text { в том числе: } \\
\text { торговля оптовая } \\
\text { и розничная ав- } \\
\text { тотранспортными } \\
\text { средствами и мо- } \\
\text { тоциклами и их } \\
\text { ремонт }\end{array}$ & 618881 & 8797 & 1,4 & 405581 & 17453 & 4,3 \\
\hline $\begin{array}{l}\text { торговля опто- } \\
\text { вая, кроме опто- } \\
\text { вой торговли ав- } \\
\text { тотранспортными } \\
\text { средствами и мо- } \\
\text { тоциклами }\end{array}$ & 6905444 & 497209 & 7,2 & 7576327 & 499327 & 6,6 \\
\hline $\begin{array}{l}\text { торговля рознич- } \\
\text { ная, кроме тор- } \\
\text { говли автотранс- } \\
\text { портными сред- } \\
\text { ствами и мото- } \\
\text { циклами }\end{array}$ & 1962296 & 7233 & 0,4 & 924872 & 5755 & 0,6 \\
\hline РОССИЯ & & 2018 & & & & 415 \\
\hline
\end{tabular}


Продолжение табл. 23.24

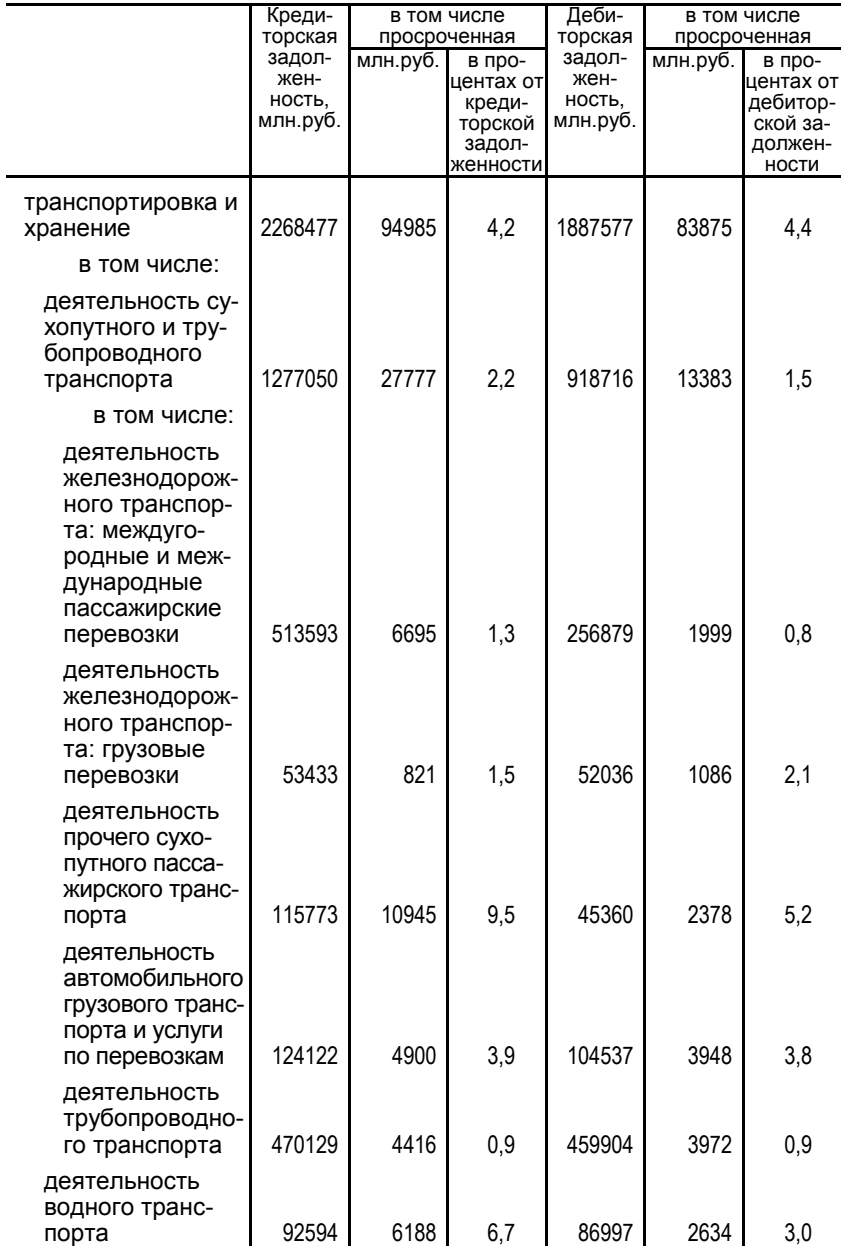


Продолжение табл. 23.24

\begin{tabular}{|c|c|c|c|c|c|c|}
\hline & \multirow{2}{*}{\begin{tabular}{|c|} 
Креди- \\
торская \\
задол- \\
жен- \\
ность, \\
млн.руб.
\end{tabular}} & \multicolumn{2}{|c|}{$\begin{array}{c}\text { в том числе } \\
\text { просроченная }\end{array}$} & \multirow{2}{*}{$\begin{array}{c}\text { Деби- } \\
\text { торская } \\
\text { задол- } \\
\text { жен- } \\
\text { ность, } \\
\text { млн.руб. }\end{array}$} & \multicolumn{2}{|c|}{$\begin{array}{c}\text { в том числе } \\
\text { просроченная }\end{array}$} \\
\hline & & млн.руб. & \begin{tabular}{|c|} 
в про- \\
центах от \\
креди- \\
торской \\
задол- \\
женности \\
\end{tabular} & & млн.руб. & \begin{tabular}{|c} 
в про- \\
центах от \\
дебитор- \\
ской за- \\
должен- \\
ности \\
\end{tabular} \\
\hline $\begin{array}{l}\text { деятельность } \\
\text { воздушного и } \\
\text { космического } \\
\text { транспорта }\end{array}$ & 252009 & 15808 & 6,3 & 264145 & 18896 & 7,2 \\
\hline $\begin{array}{l}\text { складское хозяй- } \\
\text { ство и вспомога- } \\
\text { тельная транс- } \\
\text { портная деятель- } \\
\text { ность }\end{array}$ & 617208 & 45212 & 7,3 & 588443 & 48578 & 8,3 \\
\hline $\begin{array}{l}\text { деятельность } \\
\text { почтовой связи и } \\
\text { курьерская дея- } \\
\text { тельность }\end{array}$ & 29616 & 0,2 & 0,0 & 29276 & 384 & 1,3 \\
\hline $\begin{array}{l}\text { деятельность гос- } \\
\text { тиниц и предпри- } \\
\text { ятий общественного }\end{array}$ & & & & & & \\
\hline $\begin{array}{l}\text { питания } \\
\text { в том числе: }\end{array}$ & 160906 & 1625 & 1,0 & 112280 & 1575 & 1,4 \\
\hline $\begin{array}{l}\text { деятельность по } \\
\text { предоставлению } \\
\text { мест для вре- } \\
\text { менного прожи- } \\
\text { вания }\end{array}$ & 63329 & 456 & 0,7 & 49748 & 713 & 1,4 \\
\hline $\begin{array}{l}\text { деятельность по } \\
\text { предоставлению } \\
\text { продуктов пита- } \\
\text { ния и напитков }\end{array}$ & 97577 & 1169 & 1,2 & 62532 & 862 & 1,4 \\
\hline $\begin{array}{l}\text { деятельность в об- } \\
\text { ласти информации }\end{array}$ & & & & & & \\
\hline $\begin{array}{l}\text { и связи } \\
\text { из нее: }\end{array}$ & 741557 & 16138 & 2,2 & 723756 & 26637 & 3,7 \\
\hline $\begin{array}{l}\text { деятельность из- } \\
\text { дательская }\end{array}$ & 24664 & 95 & 0,4 & 27761 & 467 & 1,7 \\
\hline $\begin{array}{l}\text { деятельность в } \\
\text { сфрере телеком- } \\
\text { муникаций }\end{array}$ & 405542 & 5852 & 1,4 & 329390 & 16007 & 4,9 \\
\hline
\end{tabular}


Продолжение табл. 23.24

\begin{tabular}{|c|c|c|c|c|c|c|}
\hline & \multirow{2}{*}{$\begin{array}{c}\text { Креди- } \\
\text { торская } \\
\text { задол- } \\
\text { жен- } \\
\text { ность, } \\
\text { млн.руб. }\end{array}$} & \multicolumn{2}{|c|}{$\begin{array}{c}\text { в том числе } \\
\text { просроченная }\end{array}$} & \multirow{2}{*}{$\begin{array}{c}\text { Деби- } \\
\text { торская } \\
\text { задол- } \\
\text { жен- } \\
\text { ность, } \\
\text { млн.руб. }\end{array}$} & \multicolumn{2}{|c|}{$\begin{array}{c}\text { в том числе } \\
\text { просроченная }\end{array}$} \\
\hline & & \begin{tabular}{|l|} 
млн.руб. \\
\end{tabular} & \begin{tabular}{|c|} 
в про- \\
центах от \\
креди- \\
торской \\
задол- \\
женности \\
\end{tabular} & & \begin{tabular}{|l|} 
млн.руб. \\
\end{tabular} & $\begin{array}{c}\text { в про- } \\
\text { центах от } \\
\text { дебитор- } \\
\text { ской за- } \\
\text { должен- } \\
\text { ности }\end{array}$ \\
\hline $\begin{array}{l}\text { деятельность } \\
\text { в области ин- } \\
\text { формационных } \\
\text { технологий }\end{array}$ & 77776 & 269 & 0,3 & 67544 & 898 & 1,3 \\
\hline $\begin{array}{l}\text { деятельность } \\
\text { финансовая и стра- } \\
\text { ховая }\end{array}$ & 811244 & 3329 & 0.4 & 1345214 & 63294 & 4,7 \\
\hline $\begin{array}{l}\text { деятельность по } \\
\text { операциям с не- } \\
\text { движимым имуще- } \\
\text { ством }\end{array}$ & 1177974 & 45513 & 3,9 & 932343 & 38361 & 4,1 \\
\hline $\begin{array}{l}\text { деятельность про- } \\
\text { фессиональная, на- } \\
\text { учная и техническая }\end{array}$ & 4023281 & 78448 & 1,9 & 2995800 & 103454 & 3,5 \\
\hline $\begin{array}{l}\text { из нее научные } \\
\text { исследования и } \\
\text { разработки }\end{array}$ & 2447129 & 34557 & 1,4 & 1503650 & 27320 & 1,8 \\
\hline $\begin{array}{l}\text { деятельность ад- } \\
\text { министративная и } \\
\text { сопутствующие до- } \\
\text { полнительные ус- } \\
\text { луги }\end{array}$ & 340853 & 37415 & 11,0 & 238584 & 14566 & 6,1 \\
\hline $\begin{array}{l}\text { из нее деятель- } \\
\text { ность туристиче- } \\
\text { ских агентств и } \\
\text { прочих организа- } \\
\text { ций, предостав- } \\
\text { ляющих услуги } \\
\text { в сфере туризма }\end{array}$ & 9107 & - & - & 6784 & 17 & 0,2 \\
\hline $\begin{array}{l}\text { государственное } \\
\text { управление и обес- } \\
\text { печение военной } \\
\text { безопасности; со- } \\
\text { циальное обеспе- } \\
\text { чение }\end{array}$ & 35636 & 19316 & 54,2 & 51259 & 8641 & 16,9 \\
\hline образование & 25786 & 714 & 2,8 & 15471 & 312 & 2,0 \\
\hline
\end{tabular}


Продолжение табл. 23.24

\begin{tabular}{|c|c|c|c|c|c|c|}
\hline & \multirow{2}{*}{$\begin{array}{c}\text { Креди- } \\
\text { торская } \\
\text { задол- } \\
\text { жен- } \\
\text { ность, } \\
\text { млн.руб. }\end{array}$} & \multicolumn{2}{|c|}{$\begin{array}{c}\text { в том числе } \\
\text { просроченная }\end{array}$} & \multirow{2}{*}{\begin{tabular}{|c|} 
Деби- \\
торская \\
задол- \\
жен- \\
ность, \\
млн.руб. \\
\end{tabular}} & \multicolumn{2}{|c|}{$\begin{array}{c}\text { в том числе } \\
\text { просроченная }\end{array}$} \\
\hline & & млн.руб. & \begin{tabular}{|c|} 
в про- \\
центах от \\
креди- \\
торской \\
задол- \\
женности \\
\end{tabular} & & млн.руб. & $\begin{array}{c}\text { в про- } \\
\text { центах от } \\
\text { дебитор- } \\
\text { ской за- } \\
\text { должен- } \\
\text { ности } \\
\end{array}$ \\
\hline $\begin{array}{l}\text { деятельность в об- } \\
\text { ласти здравоохра- } \\
\text { нения и социаль- }\end{array}$ & 49401 & 895 & 18 & 36022 & 973 & 26 \\
\hline $\begin{array}{l}\text { из нее деятель- } \\
\text { ность в области } \\
\text { здравоохранения }\end{array}$ & 48289 & 895 & 1,9 & 36014 & 971 & 2,7 \\
\hline $\begin{array}{l}\text { деятельность в об- } \\
\text { ласти культуры, } \\
\text { спорта, организа- } \\
\text { ции досуга и раз- } \\
\text { влечений }\end{array}$ & 53251 & 443 & 0,8 & 35334 & 1385 & 3,9 \\
\hline $\begin{array}{l}\quad \text { из нее: } \\
\text { деятельность } \\
\text { библиотек, архи- } \\
\text { вов, музеев и } \\
\text { прочих объектов } \\
\text { культуры }\end{array}$ & 752 & 50 & 6,6 & 582 & 80 & 13,7 \\
\hline $\begin{array}{l}\text { деятельность в } \\
\text { области спорта, } \\
\text { отдыха и развле- } \\
\text { чений }\end{array}$ & 39674 & 325 & 0,8 & 25041 & 1093 & 4,4 \\
\hline $\begin{array}{l}\text { предоставление } \\
\text { прочих видов услуг }\end{array}$ & 45497 & 451 & 1,0 & 52302 & 1227 & 2,3 \\
\hline
\end{tabular}


23.25. ЗАДОЛЖЕННОСТЬ ОРГАНИЗАЦИЙ ПО ПЛАТЕЖАМ

В БЮДЖЕТ И ГОСУДАРСТВЕННЫЕ ВНЕБЮДЖЕТНЫЕ ФОНДЫ ПО ВИДАМ ЭКОНОМИЧЕСКОЙ ДЕЯТЕЛЬНОСТИ В 2017 г.

(на конец года)

\begin{tabular}{|c|c|c|c|c|c|c|}
\hline & \multirow{2}{*}{\begin{tabular}{|c|} 
Задол- \\
жен- \\
ность по \\
плате- \\
жам в \\
бюджет, \\
млн.руб.
\end{tabular}} & \multicolumn{2}{|c|}{$\begin{array}{c}\text { В том числе } \\
\text { просроченная }\end{array}$} & \multirow{2}{*}{\begin{tabular}{|c|} 
Задол- \\
женность \\
государ- \\
ствен- \\
ным вне-- \\
бюджет- \\
ным \\
фондам, \\
млн.руб.
\end{tabular}} & \multicolumn{2}{|c|}{$\begin{array}{c}\text { в том числе } \\
\text { просроченная }\end{array}$} \\
\hline & & млн.руб. & \begin{tabular}{|c|} 
в про- \\
центах от \\
задол- \\
женности \\
по пла- \\
тежам \\
в бюджет
\end{tabular} & & млн.руб. & \begin{tabular}{|c} 
в процен- \\
тах от \\
задол- \\
женности \\
государ- \\
ственным \\
внебюд- \\
жетным \\
фондам \\
\end{tabular} \\
\hline $\begin{array}{c}\text { Всего в экономике } \\
\text { в том числе по } \\
\text { видам экономи- } \\
\text { ческой деятель- } \\
\text { ности: } \\
\text { сельское, лесное } \\
\text { хозяйство, охота, } \\
\text { рыболовство и ры- }\end{array}$ & 2181545 & 63254 & 2,9 & 344511 & 50710 & 14,7 \\
\hline $\begin{array}{c}\text { боводство } \\
\text { в том числе: } \\
\text { растениеводство } \\
\text { и животноводство, } \\
\text { охота и предос- } \\
\text { тавление соот- } \\
\text { ветствующих ус- } \\
\text { луг в этих облас- }\end{array}$ & 15544 & 932 & 6,0 & 11301 & 1358 & 12,0 \\
\hline $\begin{array}{l}\text { тях } \\
\text { лесоводство и } \\
\text { лесозаготовки }\end{array}$ & 13149 & 839 & 6,4 & 10114 & 1300 & $\begin{array}{l}12,8 \\
11,3\end{array}$ \\
\hline $\begin{array}{l}\text { рыболовство и } \\
\text { рыбоводство }\end{array}$ & 1212 & 5 & 0,4 & 679 & 0,5 & 0,1 \\
\hline $\begin{array}{l}\text { добыча полезных } \\
\text { ископаемых }\end{array}$ & 689372 & 5714 & 0,8 & 30922 & 3932 & 12,7 \\
\hline из нее: & & & & & & \\
\hline $\begin{array}{l}\text { добыча угля } \\
\text { добыча сырой } \\
\text { нефти и природ- }\end{array}$ & 21210 & 2926 & 13,8 & 9362 & 2999 & 32,0 \\
\hline ного газа & 611798 & 1236 & 0,2 & 7864 & 316 & 4,0 \\
\hline $\begin{array}{l}\text { добыча металли- } \\
\text { ческих руд } \\
\text { добыча прочих }\end{array}$ & 19373 & 993 & 5,1 & 5359 & 249 & 4,7 \\
\hline $\begin{array}{l}\text { полезных иско- } \\
\text { паемых }\end{array}$ & 11262 & 217 & 1,9 & 2656 & 213 & 8,0 \\
\hline $\begin{array}{l}\text { обрабатывающие } \\
\text { производства }\end{array}$ & 644472 & 16187 & 2,5 & 89703 & 14062 & 15,7 \\
\hline
\end{tabular}


Продолжение табл. 23.25

\begin{tabular}{|c|c|c|c|c|c|c|}
\hline & \multirow{2}{*}{\begin{tabular}{|c|} 
Задол- \\
жен- \\
ность по \\
плате- \\
жам в \\
бюджет, \\
млн.руб.
\end{tabular}} & \multicolumn{2}{|c|}{\begin{tabular}{|c|} 
в том числе \\
просроченная \\
\end{tabular}} & \multirow[b]{2}{*}{\begin{tabular}{|c|} 
Задол- \\
женность \\
государ- \\
ствен- \\
ным вне-- \\
бюджет- \\
ным \\
фондам, \\
млн.руб.
\end{tabular}} & \multicolumn{2}{|c|}{$\begin{array}{c}\text { в том числе } \\
\text { просроченная }\end{array}$} \\
\hline & & млн.руб. & \begin{tabular}{|c|} 
в про- \\
центах от \\
задол-- \\
женности \\
по пла- \\
тежам \\
в бюджет
\end{tabular} & & млн.руб. & \begin{tabular}{|c} 
в процен- \\
тах от \\
задол- \\
женности \\
государ- \\
ственным \\
внебюд- \\
жетным \\
фондам \\
\end{tabular} \\
\hline из них: & & & & & & \\
\hline производство пи- & 38808 & 696 & 1,8 & 7679 & 360 & 4,7 \\
\hline $\begin{array}{l}\text { производство } \\
\text { напитков }\end{array}$ & 55465 & 200 & 0,4 & 1364 & 6 & 0,4 \\
\hline $\begin{array}{l}\text { производство та- } \\
\text { бачных изделий }\end{array}$ & 54416 & - & - & 24 & - & - \\
\hline $\begin{array}{l}\text { производство } \\
\text { текстильных из- } \\
\text { делий }\end{array}$ & 2324 & 377 & 16,2 & 1470 & 528 & 35,9 \\
\hline производство & & & & & & \\
\hline $\begin{array}{l}\text { одежды } \\
\text { производство ко- } \\
\text { жи и изделий из }\end{array}$ & 1562 & 32 & 2,0 & 446 & 29 & 6,6 \\
\hline $\begin{array}{l}\text { кожи } \\
\text { обработка древе- } \\
\text { сины и производ- } \\
\text { ство изделий из } \\
\text { дерева и пробки, } \\
\text { кроме мебели, } \\
\text { производство из- } \\
\text { делий из соломки } \\
\text { и материалов для }\end{array}$ & 622 & 17 & 2,8 & 241 & 14 & 5,7 \\
\hline $\begin{array}{l}\text { и материалов для } \\
\text { плетения } \\
\text { производство бу- } \\
\text { маги и бумажных }\end{array}$ & 3444 & 216 & 6,3 & 1558 & 189 & 12,1 \\
\hline изделий & 6950 & 169 & 2,4 & 1499 & 207 & 13,8 \\
\hline $\begin{array}{l}\text { деятельность по- } \\
\text { лиграфрическая и } \\
\text { копирование носи- } \\
\text { телей информа- }\end{array}$ & & & & & & \\
\hline ции & 1812 & 26 & 1,4 & 352 & 21 & 6,0 \\
\hline $\begin{array}{l}\text { производство } \\
\text { кокса и нефте- } \\
\text { продуктов }\end{array}$ & 187436 & 1137 & 0,6 & 2301 & 179 & 7,8 \\
\hline \begin{tabular}{l}
\multicolumn{1}{c}{ из них: } \\
производство \\
кокса
\end{tabular} & 776 & 8 & 1,0 & 216 & 11 & 5,2 \\
\hline
\end{tabular}


Продолжение табл. 23.25

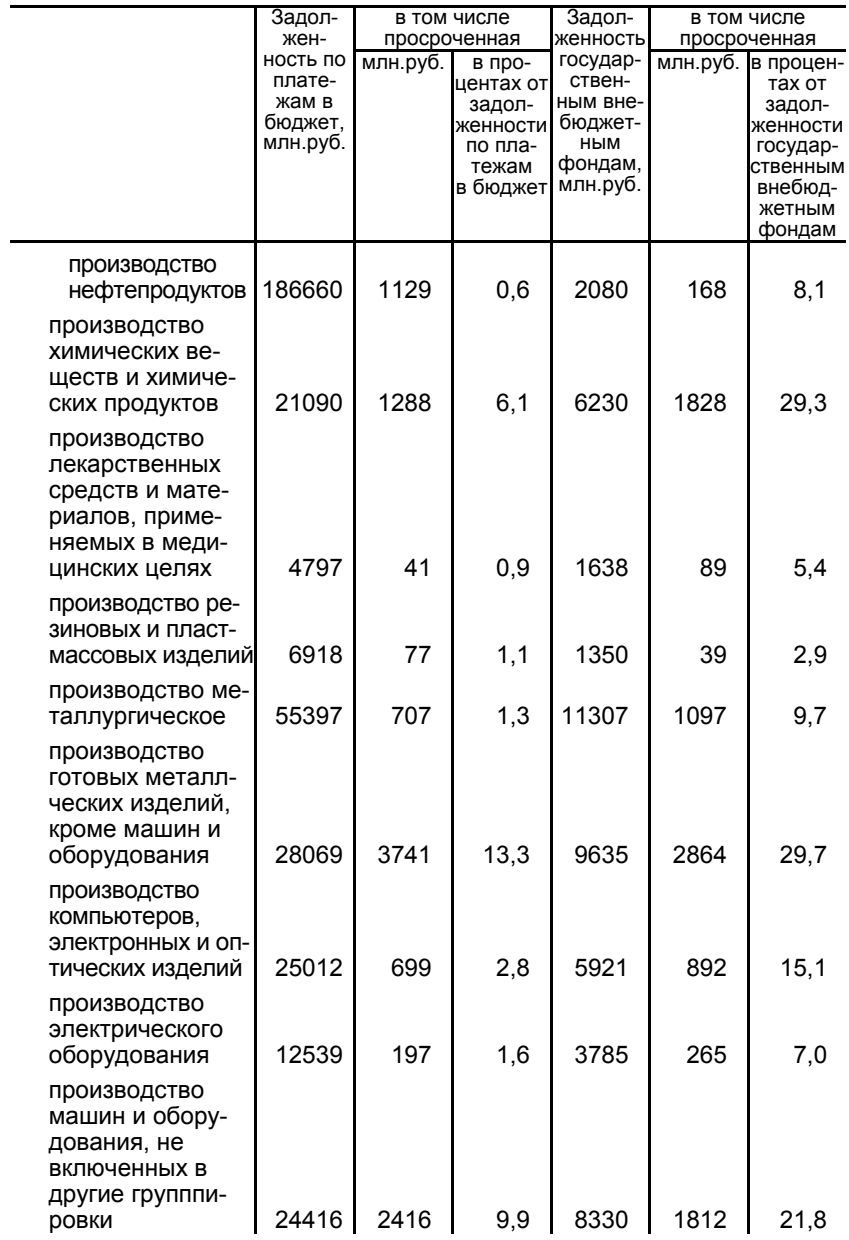


Продолжение табл. 23.25

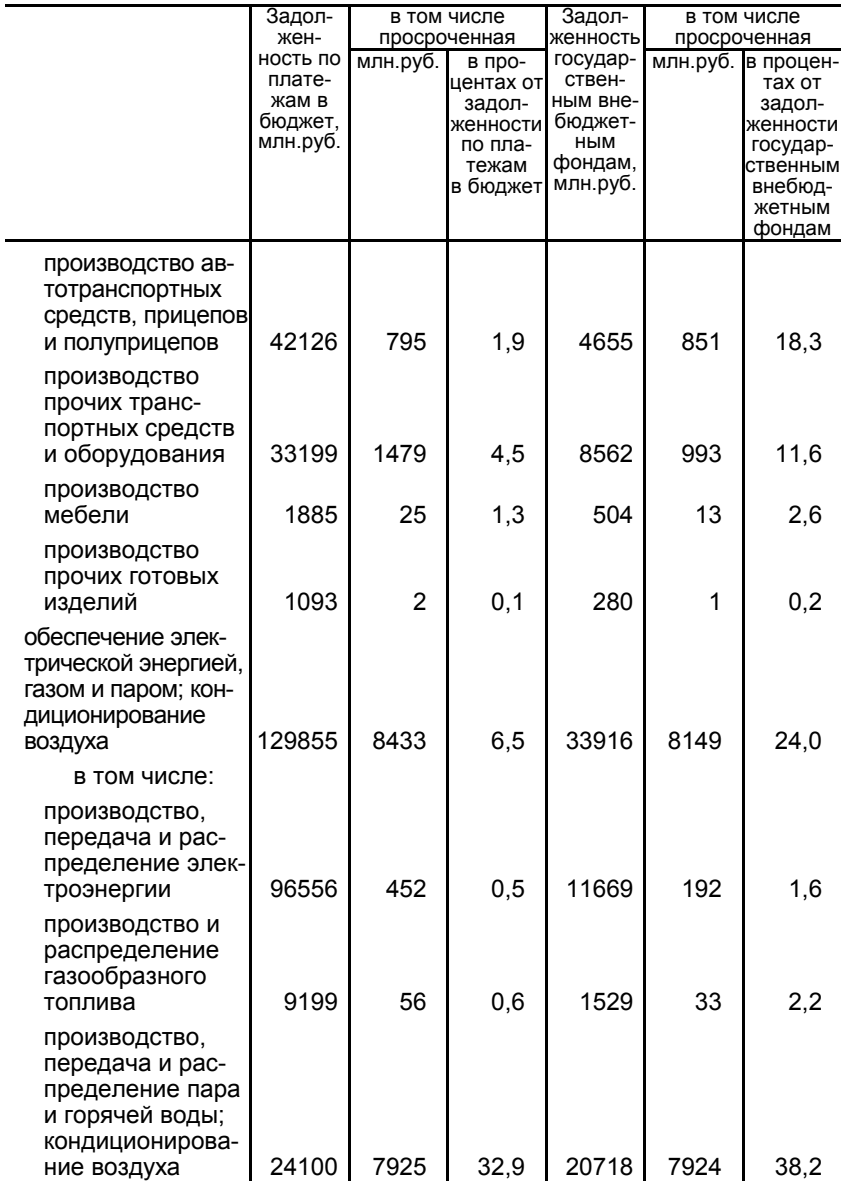


Продолжение табл. 23.25

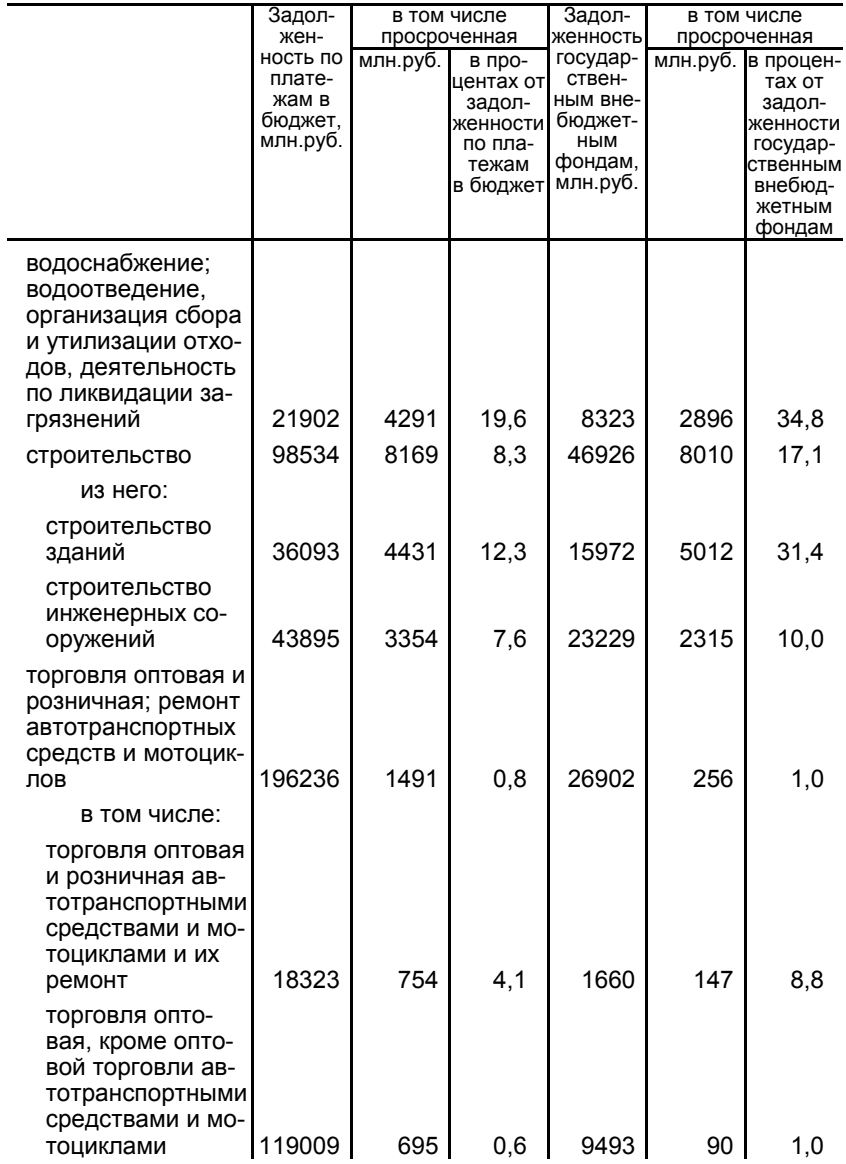


Продолжение табл. 23.25

\begin{tabular}{|c|c|c|c|c|c|c|}
\hline & \multirow{2}{*}{\begin{tabular}{|c|} 
Задол- \\
жен- \\
ность по \\
плате- \\
жам в \\
бюджет, \\
млн.руб.
\end{tabular}} & \multicolumn{2}{|c|}{\begin{tabular}{|c|} 
в том числе \\
просроченная \\
\end{tabular}} & \multirow[b]{2}{*}{\begin{tabular}{|c|} 
Задол- \\
женность \\
государ- \\
ствен- \\
ным вне-- \\
бюджет- \\
ным \\
фондам, \\
млн.руб.
\end{tabular}} & \multicolumn{2}{|c|}{\begin{tabular}{|c|} 
в том числе \\
просроченная \\
\end{tabular}} \\
\hline & & млн.руб. & \begin{tabular}{|c|} 
в про- \\
центах от \\
задол- \\
женности \\
по пла- \\
тежам \\
в бюджет
\end{tabular} & & млн.руб. & \begin{tabular}{|c} 
в процен- \\
тах от \\
задол- \\
женности \\
государ- \\
ственным \\
внебюд- \\
жетным \\
фондам \\
\end{tabular} \\
\hline $\begin{array}{l}\text { торговля рознич- } \\
\text { ная, кроме тор- } \\
\text { говли автотранс- } \\
\text { портными сред- } \\
\text { ствами и мото- } \\
\text { циклами }\end{array}$ & 58904 & 42 & 0,1 & 15749 & 19 & 0,1 \\
\hline $\begin{array}{l}\text { транспортировка и } \\
\text { хранение }\end{array}$ & 106806 & 7816 & 7,3 & 40226 & 4764 & 11,8 \\
\hline \begin{tabular}{l}
\multicolumn{1}{c}{ в том числе: } \\
деятельность су- \\
хопутного и тру- \\
бопроводного \\
транспорта
\end{tabular} & 64367 & 1924 & 3,0 & 26413 & 3392 & 128 \\
\hline $\begin{array}{l}\text { в том числе: } \\
\text { деятельность } \\
\text { железнодорож- } \\
\text { ного транспорта } \\
\text { междугородные } \\
\text { и международ- } \\
\text { ные пассажир- } \\
\text { ские перевозки }\end{array}$ & 15277 & - & - & 10314 & 2 & 12,0 \\
\hline $\begin{array}{l}\text { деятельность } \\
\text { железнодорож- } \\
\text { ного транспор- } \\
\text { та: грузовые } \\
\text { перевозки }\end{array}$ & 4135 & 4 & 0,1 & 482 & - & - \\
\hline $\begin{array}{l}\text { деятельность } \\
\text { прочего сухо- } \\
\text { путного пасса- } \\
\text { жирского транс- } \\
\text { порта }\end{array}$ & 7357 & 1691 & 23,0 & 10987 & 3290 & 29,9 \\
\hline $\begin{array}{l}\text { деятельность } \\
\text { автомобильного } \\
\text { грузового транс- } \\
\text { порта и услуги } \\
\text { по перевозкам }\end{array}$ & 8109 & 229 & 2,8 & 2266 & 102 & 4,5 \\
\hline РОССИЯ ь & & 2018 & & & & 425 \\
\hline
\end{tabular}


Продолжение табл. 23.25

\begin{tabular}{|c|c|c|c|c|c|c|}
\hline & \multirow{2}{*}{\begin{tabular}{|c|} 
Задол- \\
жен- \\
ность по \\
плате- \\
жам в \\
бюджет, \\
млн.руб.
\end{tabular}} & \multicolumn{2}{|c|}{$\begin{array}{c}\text { в том числе } \\
\text { просроченная }\end{array}$} & \multirow{2}{*}{\begin{tabular}{|c|} 
Задол- \\
женность \\
государ- \\
ствен- \\
ным вне- \\
бюджет- \\
ным \\
фондам, \\
млн.руб.
\end{tabular}} & \multicolumn{2}{|c|}{$\begin{array}{c}\text { в том числе } \\
\text { просроченная }\end{array}$} \\
\hline & & млн.руб. & \begin{tabular}{|c} 
в про- \\
центах от \\
задол- \\
женности \\
по пла- \\
тежам \\
в бюджет
\end{tabular} & & млн.руб. & \begin{tabular}{|c} 
в процен- \\
тах от \\
задол- \\
женности \\
государ- \\
ственным \\
внебюд- \\
жетным \\
фондам \\
\end{tabular} \\
\hline $\begin{array}{l}\text { деятельность } \\
\text { трубопроводно- } \\
\text { го транспорта }\end{array}$ & 29489 & - & - & 2364 & - & - \\
\hline $\begin{array}{l}\text { деятельность } \\
\text { водного транс- } \\
\text { порта }\end{array}$ & 9159 & 4348 & 47,5 & 1069 & 210 & 19,6 \\
\hline $\begin{array}{l}\text { деятельность } \\
\text { воздушного и } \\
\text { космического } \\
\text { транспорта }\end{array}$ & 4982 & 178 & 3,6 & 3673 & 178 & 4,8 \\
\hline $\begin{array}{l}\text { складское хозяй- } \\
\text { ство и вспомога- } \\
\text { тельная транс- } \\
\text { портная деятель- } \\
\text { ность }\end{array}$ & 25673 & 1366 & 5,3 & 7022 & 984 & 14,0 \\
\hline $\begin{array}{l}\text { деятельность поч- } \\
\text { товой связи и } \\
\text { курьерская дея- } \\
\text { тельность }\end{array}$ & 2625 & - & - & 2049 & - & - \\
\hline $\begin{array}{l}\text { деятельность гос- } \\
\text { тиниц и предпри- } \\
\text { ятий общественно- } \\
\text { го питания }\end{array}$ & 11063 & 60 & 0,5 & 2230 & 22 & 1,0 \\
\hline $\begin{array}{l}\quad \text { в том числе: } \\
\text { деятельность по } \\
\text { предоставлению } \\
\text { мест для вре- } \\
\text { менного прожи- } \\
\text { вания }\end{array}$ & 4043 & 26 & 0,6 & 618 & 17 & 2,9 \\
\hline $\begin{array}{l}\text { деятельность по } \\
\text { предоставлению } \\
\text { продуктов пита- } \\
\text { ния и напитков }\end{array}$ & 7020 & 34 & 0,5 & 1612 & 5 & 0,3 \\
\hline $\begin{array}{l}\text { деятельность в об- } \\
\text { ласти информации } \\
\text { и связи }\end{array}$ & 74297 & 202 & 0,3 & 9059 & 68 & 0,7 \\
\hline 26 & & & ССИЯ & ЦИФІ & 2018 & \\
\hline
\end{tabular}


Продолжение табл. 23.25

\begin{tabular}{|c|c|c|c|c|c|c|}
\hline & \multirow{2}{*}{\begin{tabular}{|c|} 
Задол- \\
жен- \\
ность по \\
плате- \\
жам в \\
бюджет, \\
млн.руб.
\end{tabular}} & \multicolumn{2}{|c|}{$\begin{array}{c}\text { в том числе } \\
\text { просроченная }\end{array}$} & \multirow[b]{2}{*}{\begin{tabular}{|c|} 
Задол- \\
женность \\
государ- \\
ствен- \\
ным вне- \\
бюджет- \\
ным \\
фондам, \\
млн.руб.
\end{tabular}} & \multicolumn{2}{|c|}{$\begin{array}{c}\text { в том числе } \\
\text { просроченная }\end{array}$} \\
\hline & & млн.руб. & \begin{tabular}{|c|} 
в про- \\
центах от \\
задол- \\
женности \\
по пла- \\
тежам \\
в бюджет
\end{tabular} & & млн.руб. & $\begin{array}{c}\text { в процен- } \\
\text { тах от } \\
\text { задол- } \\
\text { женности } \\
\text { государ- } \\
\text { ственным } \\
\text { внебюд- } \\
\text { жетным } \\
\text { фондам } \\
\end{array}$ \\
\hline из нее: & & & & & & \\
\hline $\begin{array}{l}\text { деятельность из- } \\
\text { дательская }\end{array}$ & 1843 & 83 & 4,5 & 372 & 5 & 1,4 \\
\hline $\begin{array}{l}\text { деятельность в } \\
\text { сфере телеком- } \\
\text { муникаций }\end{array}$ & 45762 & 25 & 0,1 & 4810 & 14 & 0,3 \\
\hline $\begin{array}{l}\text { деятельность в } \\
\text { области инфор- } \\
\text { мационных тех- } \\
\text { нологий }\end{array}$ & 5394 & 1 & 0,0 & 941 & 0,4 & 0,0 \\
\hline $\begin{array}{l}\text { деятельность фи- } \\
\text { нансовая и страхо- } \\
\text { вая }\end{array}$ & 16399 & 204 & 1,2 & 917 & 9 & 1,0 \\
\hline $\begin{array}{l}\text { деятельность по } \\
\text { операциям с не- } \\
\text { движимым имуще- } \\
\text { ством }\end{array}$ & 43482 & 5890 & 13,5 & 9664 & 2705 & 28,0 \\
\hline $\begin{array}{l}\text { деятельность про- } \\
\text { фессиональная, } \\
\text { научная и техниче- } \\
\text { ская }\end{array}$ & 100181 & 2137 & 2,1 & 21205 & 1710 & 8,1 \\
\hline $\begin{array}{l}\text { из нее научные } \\
\text { исследования и } \\
\text { разработки }\end{array}$ & 37739 & 930 & 2,5 & 9867 & 744 & 7,5 \\
\hline $\begin{array}{l}\text { деятельность } \\
\text { административная } \\
\text { и сопутствующие } \\
\text { дополнительные } \\
\text { услуги }\end{array}$ & 20655 & 1267 & 6,1 & 4500 & 278 & 6,2 \\
\hline $\begin{array}{l}\text { из нее деятель- } \\
\text { ность туристиче- } \\
\text { ских агентств и } \\
\text { прочих организа- } \\
\text { ций, предостав- } \\
\text { ляющих услуги в } \\
\text { сфере туризма }\end{array}$ & 272 & - & - & 83 & - & - \\
\hline
\end{tabular}


Продолжение табл. 23.25

\begin{tabular}{|c|c|c|c|c|c|c|}
\hline & \multirow{2}{*}{\begin{tabular}{|c|} 
Задол- \\
жен- \\
ность по \\
плате-- \\
жам в \\
бюджет, \\
млн.руб.
\end{tabular}} & \multicolumn{2}{|c|}{$\begin{array}{c}\text { в том числе } \\
\text { просроченная }\end{array}$} & \multirow[b]{2}{*}{\begin{tabular}{|c|} 
Задол- \\
женность \\
государ- \\
ствен- \\
ным вне- \\
бюджет- \\
ным \\
фондам, \\
млн.руб.
\end{tabular}} & \multicolumn{2}{|c|}{$\begin{array}{c}\text { в том числе } \\
\text { просроченная }\end{array}$} \\
\hline & & млн.руб. & \begin{tabular}{|c|} 
в про- \\
центах от \\
задол- \\
женности \\
по пла- \\
тежам \\
в бюджет
\end{tabular} & & млн.руб. & \begin{tabular}{|c} 
в процен- \\
тах от \\
задол- \\
женности \\
государ- \\
ственным \\
внебюд- \\
жетным \\
фондам \\
\end{tabular} \\
\hline $\begin{array}{l}\text { государственное } \\
\text { управление и обес- } \\
\text { печение военной } \\
\text { безопасности; со- } \\
\text { циальное обеспе- } \\
\text { чение }\end{array}$ & 3013 & 0,0 & 0,0 & 3203 & 2099 & 65,5 \\
\hline $\begin{array}{l}\text { образование } \\
\text { деятельность в об- } \\
\text { ласти здравоохра- } \\
\text { нения и социальных }\end{array}$ & 1156 & 199 & 17,2 & 898 & 169 & 18,8 \\
\hline $\begin{array}{l}\text { услуг } \\
\text { из нее деятель- } \\
\text { ность в области } \\
\text { здравоохранения }\end{array}$ & 2587 & 101 & 3,9 & 2240 & 116 & 5,2 \\
\hline $\begin{array}{l}\text { деятельность в об- } \\
\text { ласти культуры, } \\
\text { спорта, организа- } \\
\text { ции досуга и раз- } \\
\text { влечений }\end{array}$ & 3911 & 95 & 2,4 & 1199 & 50 & 4,2 \\
\hline \begin{tabular}{l}
\multicolumn{1}{c}{ из нее: } \\
деятельность \\
библиотек, архи- \\
вов, музеев и про- \\
чих объектов \\
культуры
\end{tabular} & 33 & - & - & 24 & - & - \\
\hline $\begin{array}{l}\text { деятельность в } \\
\text { области спорта, } \\
\text { отдыха и развле- } \\
\text { чений }\end{array}$ & 3579 & 95 & 2,6 & 1011 & 50 & 4,9 \\
\hline $\begin{array}{l}\text { предоставление } \\
\text { прочих видов услуг }\end{array}$ & 2080 & 66 & 3,2 & 1177 & 57 & 4,8 \\
\hline
\end{tabular}




\subsection{6. ЗАДОЛЖЕННОСТЬ ПОКУПАТЕЛЕЙ И ПОСТАВЩИКАМ ОРГАНИЗАЦИЙ ПО ВИДАМ ЭКОНОМИЧЕСКОЙ ДЕЯТЕЛЬНОСТИ в 2017 r.}

(на конец года)

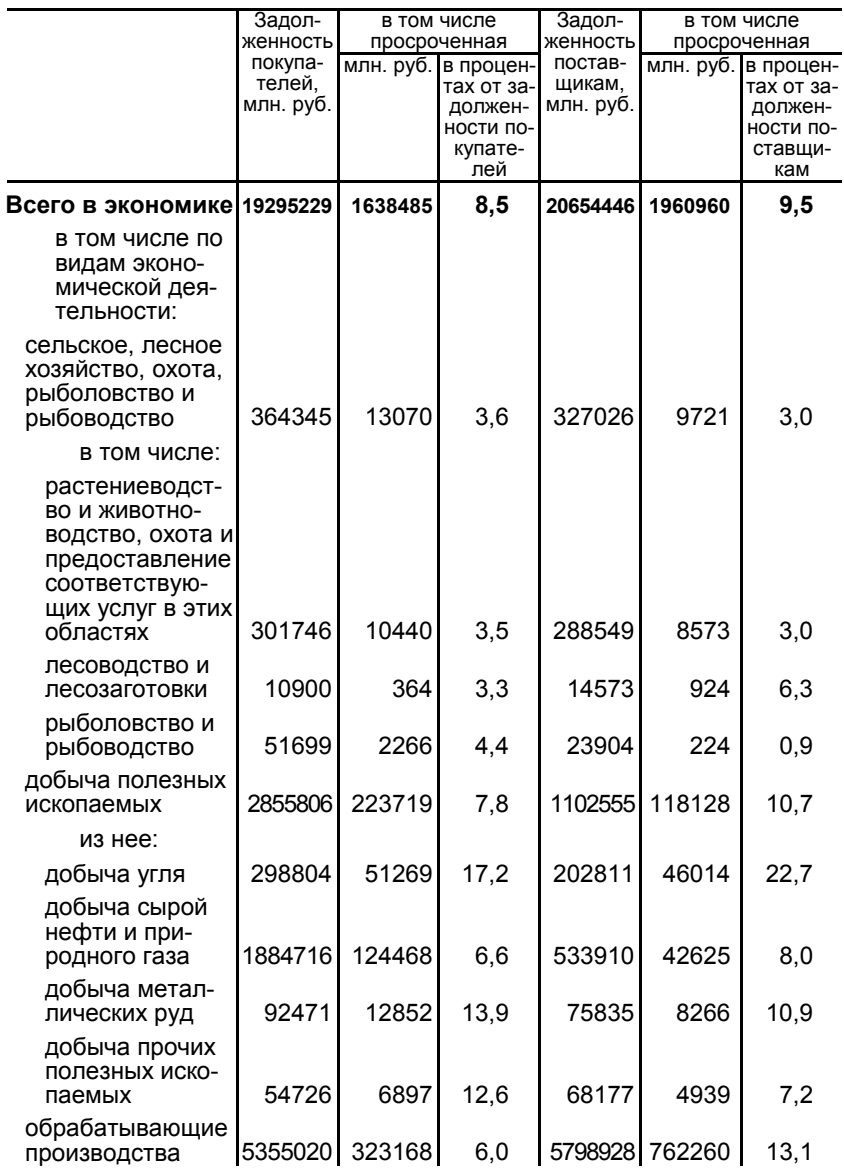


Продолжение табл. 23.26

\begin{tabular}{|c|c|c|c|c|c|c|}
\hline & \multirow{2}{*}{$\begin{array}{c}\text { Задол- } \\
\text { жен- } \\
\text { ность } \\
\text { покупа- } \\
\text { телей, } \\
\text { млн. руб. }\end{array}$} & \multicolumn{2}{|c|}{\begin{tabular}{|c|} 
в том числе \\
просроченная \\
\end{tabular}} & \multirow{2}{*}{\begin{tabular}{|c|} 
Задол- \\
жен- \\
ность по- \\
ставщи- \\
кам, \\
млн. руб. \\
\end{tabular}} & \multicolumn{2}{|c|}{$\begin{array}{c}\text { в том числе } \\
\text { просроченная } \\
\end{array}$} \\
\hline & & млн. руб. & \begin{tabular}{|c|} 
в про- \\
центах от \\
задол- \\
женности \\
покупате- \\
лей \\
\end{tabular} & & млн. руб. & $\begin{array}{c}\text { в про- } \\
\text { центах от } \\
\text { задол- } \\
\text { женности } \\
\text { постав- } \\
\text { щикам } \\
\end{array}$ \\
\hline из них: & & & & & & \\
\hline $\begin{array}{l}\text { производство } \\
\text { пищевых продук- } \\
\text { тов }\end{array}$ & 588472 & 9079 & 1,5 & 591444 & 8962 & 1,5 \\
\hline $\begin{array}{l}\text { производство } \\
\text { напитков }\end{array}$ & 188400 & 8730 & 4,6 & 165960 & 5868 & 3,5 \\
\hline $\begin{array}{l}\text { производство та- } \\
\text { бачных изделий }\end{array}$ & 130744 & $\ldots$ & 0,0 & 39088 & $\ldots$ & 0,0 \\
\hline $\begin{array}{l}\text { производство } \\
\text { текстильных }\end{array}$ & & & & & & \\
\hline изделий & 20574 & 1320 & 6,4 & 23981 & 2850 & 11,9 \\
\hline $\begin{array}{l}\text { производство } \\
\text { одежды }\end{array}$ & 27280 & 113 & 0,4 & 21591 & 146 & 0,7 \\
\hline $\begin{array}{l}\text { производство } \\
\text { кожи и изделий }\end{array}$ & & & & & & \\
\hline $\begin{array}{l}\text { из кожи } \\
\text { обработка древе- } \\
\text { сины и производ- } \\
\text { ство изделий из } \\
\text { дерева и пробки, } \\
\text { кроме мебели, } \\
\text { производство из- } \\
\text { делий из соломки }\end{array}$ & 12020 & 336 & 2,8 & 9583 & 251 & 2,6 \\
\hline $\begin{array}{l}\text { и материалов для } \\
\text { плетения }\end{array}$ & 49639 & 9348 & 18,8 & 55030 & 3531 & 6,4 \\
\hline $\begin{array}{l}\text { производство бу- } \\
\text { маги и бумажных }\end{array}$ & & & & & & \\
\hline изделий & 86003 & 6659 & 7,7 & 85280 & 8690 & 10,2 \\
\hline $\begin{array}{l}\text { деятельность по- } \\
\text { лиграфическая и } \\
\text { копирование но- } \\
\text { сителей инфор- }\end{array}$ & & & & & & \\
\hline $\begin{array}{l}\text { мации } \\
\text { производство }\end{array}$ & 17605 & 533 & 3,0 & 18908 & 176 & 0,9 \\
\hline $\begin{array}{l}\text { кокса и нефте- } \\
\text { продуктов }\end{array}$ & 1090935 & 41144 & 3,8 & 1785246 & 447663 & 25,1 \\
\hline $\begin{array}{c}\text { из них: } \\
\text { производство }\end{array}$ & & & & & & \\
\hline кокса & 8708 & $\cdots$ & 0,1 & 19705 & 126 & 0,6 \\
\hline $\begin{array}{l}\text { производство } \\
\text { нефттепродук- } \\
\text { тов }\end{array}$ & $|1082217|$ & 41137 & 3,8 & 1765523 & 447537 & 25,3 \\
\hline
\end{tabular}


Продолжение табл. 23.26

\begin{tabular}{|c|c|c|c|c|c|c|}
\hline & \multirow{2}{*}{\begin{tabular}{|c|} 
Задол- \\
женность \\
покупа- \\
телей, \\
млн. руб.
\end{tabular}} & \multicolumn{2}{|c|}{\begin{tabular}{|c|} 
в том числе \\
просроченная
\end{tabular}} & \multirow{2}{*}{$\begin{array}{c}\text { Задол- } \\
\text { жен- } \\
\text { ность по- } \\
\text { ставщи- } \\
\text { кам, } \\
\text { млн. руб. } \\
\end{array}$} & \multicolumn{2}{|c|}{$\begin{array}{c}\text { в том числе } \\
\text { просроченная }\end{array}$} \\
\hline & & млн. руб. & \begin{tabular}{|c|} 
в про- \\
центах от \\
задол- \\
женности \\
покупате-- \\
лей
\end{tabular} & & млн. руб. & \begin{tabular}{|c} 
в про- \\
центах от \\
задол- \\
женности \\
постав- \\
щикам
\end{tabular} \\
\hline $\begin{array}{l}\text { производство хи- } \\
\text { мических ве- } \\
\text { ществ и химиче- } \\
\text { ских продуктов }\end{array}$ & 287097 & 13589 & 4,7 & 270442 & 27169 & 10,0 \\
\hline $\begin{array}{l}\text { производство ле- } \\
\text { карственных } \\
\text { средств и мате- } \\
\text { риалов, приме- } \\
\text { няемых в меди- } \\
\text { цинских целях }\end{array}$ & 172287 & 19140 & 11,1 & 137146 & 8023 & 5,8 \\
\hline $\begin{array}{l}\text { производство ре- } \\
\text { зиновых и пласт- } \\
\text { массовых изделий }\end{array}$ & 106550 & 4121 & 3,9 & 89948 & 2079 & 2,3 \\
\hline $\begin{array}{l}\text { производство ме- } \\
\text { таллургическое }\end{array}$ & 608035 & 44751 & 7,4 & 597717 & 75524 & 12,6 \\
\hline $\begin{array}{l}\text { производство го- } \\
\text { товых металли- } \\
\text { ческих изделий, } \\
\text { кроме машин и } \\
\text { оборудования }\end{array}$ & 307621 & 26064 & 8,5 & 272458 & 21181 & 7,8 \\
\hline $\begin{array}{l}\text { производство } \\
\text { компьютеров, } \\
\text { электронных и оп- } \\
\text { тических изделий }\end{array}$ & 236372 & 9570 & 4,0 & 162626 & 4054 & 2,5 \\
\hline $\begin{array}{l}\text { производство } \\
\text { электрического } \\
\text { оборудования }\end{array}$ & 161272 & 10928 & 6,8 & 133080 & 6369 & 4,8 \\
\hline $\begin{array}{l}\text { производство } \\
\text { машин и оборудо- } \\
\text { вания, не вклю- } \\
\text { ченных в другие } \\
\text { группировки }\end{array}$ & 224632 & 22293 & 9,9 & 218893 & 16849 & 7,7 \\
\hline $\begin{array}{l}\text { производство ав- } \\
\text { тотранспортных } \\
\text { средств, прицепов } \\
\text { и полуприцепов }\end{array}$ & 240163 & 13827 & 5,8 & 405617 & 50945 & 12,6 \\
\hline $\begin{array}{l}\text { производство } \\
\text { прочих транс- } \\
\text { портных средств } \\
\text { и оборудования }\end{array}$ & 426185 & 47680 & 11,2 & 343189 & 41451 & 12,1 \\
\hline
\end{tabular}


Продолжение табл. 23.26

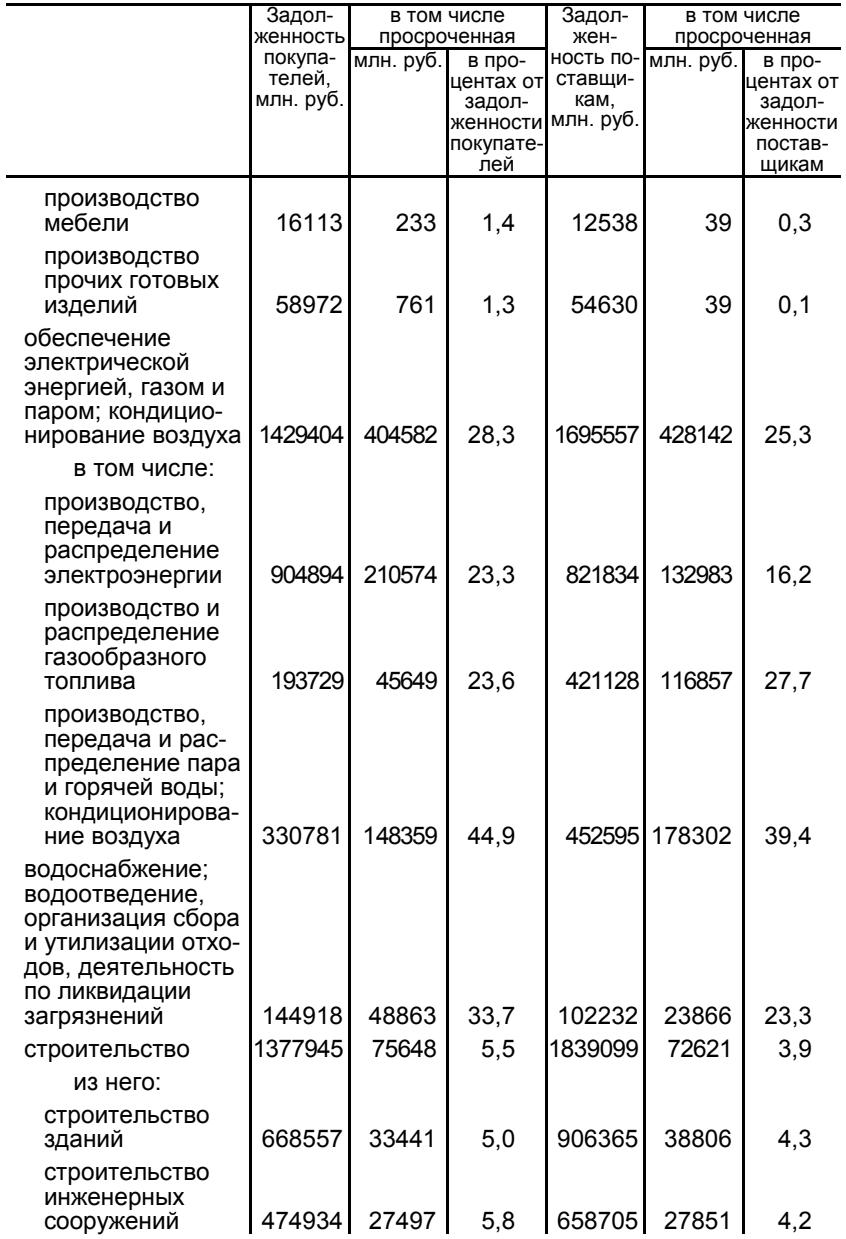


Продолжение табл. 23.26

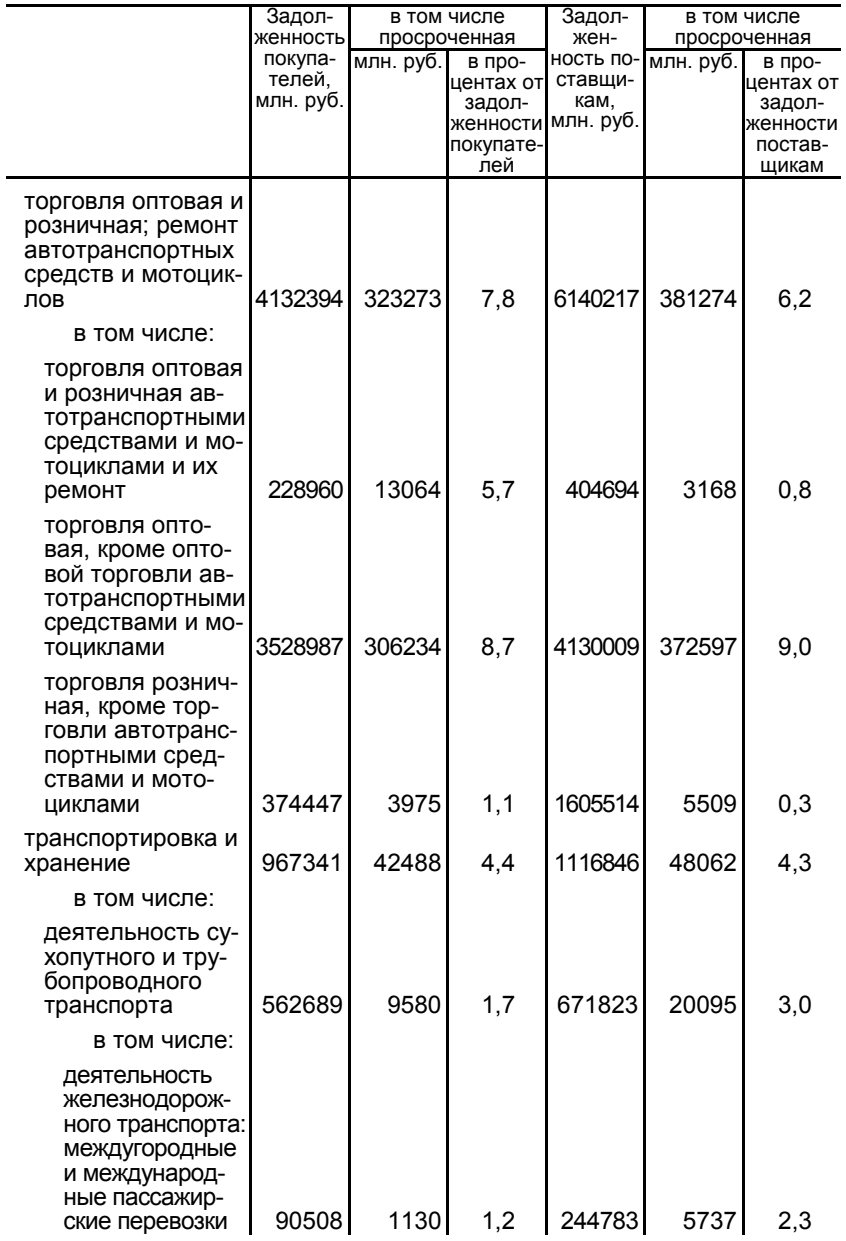


Продолжение табл. 23.26

\begin{tabular}{|c|c|c|c|c|c|c|}
\hline & \multirow{2}{*}{\begin{tabular}{|c} 
Задол- \\
женность \\
покупа- \\
телей, \\
млн. руб.
\end{tabular}} & \multicolumn{2}{|c|}{$\begin{array}{c}\text { в том числе } \\
\text { просроченная }\end{array}$} & \multirow{2}{*}{\begin{tabular}{|c|} 
Задол- \\
жен- \\
ность по- \\
ставщи- \\
кам, \\
млн. руб.
\end{tabular}} & \multicolumn{2}{|c|}{$\begin{array}{c}\text { в том числе } \\
\text { просроченная } \\
\end{array}$} \\
\hline & & млн. руб. & \begin{tabular}{|c|} 
в про- \\
центах от \\
задол- \\
женности \\
покупате- \\
лей \\
\end{tabular} & & млн. руб. & \begin{tabular}{|c} 
в про- \\
центах от \\
задол- \\
женности \\
постав- \\
щикам \\
\end{tabular} \\
\hline $\begin{array}{l}\text { деятельность } \\
\text { железнодорож- } \\
\text { ного транспорта: } \\
\text { грузовые пере- } \\
\text { возки }\end{array}$ & 22635 & 1011 & 4,5 & 15424 & 782 & 5,1 \\
\hline $\begin{array}{l}\text { деятельность } \\
\text { прочего сухопут- } \\
\text { ного пассажир- } \\
\text { ского транспорта }\end{array}$ & 25493 & 2076 & 8,1 & 60808 & 5247 & 8,6 \\
\hline $\begin{array}{l}\text { деятельность } \\
\text { автомобильного } \\
\text { грузового транс- } \\
\text { порта и услуги } \\
\text { по перевозкам }\end{array}$ & 77204 & 3543 & 4,6 & 71495 & 4462 & 6,2 \\
\hline $\begin{array}{l}\text { деятельность } \\
\text { трубопроводного } \\
\text { транспорта }\end{array}$ & 346849 & 1820 & 0,5 & 279313 & 3867 & 1,4 \\
\hline $\begin{array}{l}\text { деятельность вод- } \\
\text { ного транспорта }\end{array}$ & 34672 & 2187 & 6,3 & 54605 & 1438 & 2,6 \\
\hline $\begin{array}{l}\text { деятельность } \\
\text { воздушного и } \\
\text { космического } \\
\text { транспорта }\end{array}$ & 108162 & 8322 & 7,7 & 111308 & 12154 & 10,9 \\
\hline $\begin{array}{l}\text { складское хозяй- } \\
\text { ство и вспомога- } \\
\text { тельная транс- } \\
\text { портная деятель- } \\
\text { ность }\end{array}$ & 250458 & 22048 & 8,8 & 267823 & 14375 & 5,4 \\
\hline $\begin{array}{l}\text { деятельность } \\
\text { почтовой связи и } \\
\text { курьерская дея- } \\
\text { тельность }\end{array}$ & 11360 & 351 & 3,1 & 11287 & $\ldots$ & 0,0 \\
\hline $\begin{array}{l}\text { деятельность гос- } \\
\text { тиниц и предпри- } \\
\text { ятий общественно- } \\
\text { го питания }\end{array}$ & 42610 & 798 & 1,9 & 95575 & 927 & 1,0 \\
\hline $\begin{array}{l}\quad \text { в том числе: } \\
\text { деятельность по } \\
\text { предоставлению } \\
\text { мест для вре-- } \\
\text { менного прожи- } \\
\text { вания }\end{array}$ & 9090 & 508 & 5,6 & 23631 & 224 & 1,0 \\
\hline
\end{tabular}


Продолжение табл. 23.26

\begin{tabular}{|c|c|c|c|c|c|c|}
\hline & \multirow{2}{*}{\begin{tabular}{|c|} 
Задол- \\
женность \\
покупа- \\
телей, \\
млн. руб.
\end{tabular}} & \multicolumn{2}{|c|}{\begin{tabular}{|c|} 
в том числе \\
просроченная \\
\end{tabular}} & \multirow{2}{*}{\begin{tabular}{|c|} 
Задол- \\
жен- \\
ность по- \\
ставщи- \\
кам, \\
млн. руб. \\
\end{tabular}} & \multicolumn{2}{|c|}{\begin{tabular}{|c|} 
в том числе \\
просроченная \\
\end{tabular}} \\
\hline & & млн. руб. & \begin{tabular}{|c|} 
в про- \\
центах от \\
задол- \\
женности \\
покупате- \\
лей \\
\end{tabular} & & млн. руб. & \begin{tabular}{|c} 
в про- \\
центах от \\
задол- \\
женности \\
постав- \\
щикам \\
\end{tabular} \\
\hline $\begin{array}{l}\text { деятельность по } \\
\text { предоставлению } \\
\text { продуктов пита- } \\
\text { ния и напитков }\end{array}$ & 33520 & 290 & 0,9 & 71944 & 703 & 1,0 \\
\hline $\begin{array}{l}\text { деятельность в об- } \\
\text { ласти информации }\end{array}$ & & & & & & \\
\hline $\begin{array}{l}\text { и связи } \\
\text { из нее: }\end{array}$ & 394665 & 16714 & 4,2 & 377143 & 9992 & 2,6 \\
\hline $\begin{array}{l}\text { деятельность из- } \\
\text { дательская }\end{array}$ & 20335 & 368 & 1,8 & 9838 & 7 & 0,1 \\
\hline $\begin{array}{l}\text { деятельность в } \\
\text { сорере телеком- } \\
\text { муникаций }\end{array}$ & 170094 & 10986 & 6,5 & 210731 & 5140 & 2,4 \\
\hline $\begin{array}{l}\text { деятельность в } \\
\text { области инфор- } \\
\text { мационных тех- } \\
\text { нологий }\end{array}$ & 31370 & 768 & 2,4 & 31642 & 267 & 0,8 \\
\hline $\begin{array}{l}\text { деятельность фи- } \\
\text { нансовая и страхо- } \\
\text { вая }\end{array}$ & 547109 & 46526 & 8,5 & 248231 & 3068 & 1,2 \\
\hline $\begin{array}{l}\text { деятельность по } \\
\text { операциям с не- } \\
\text { движимым имуще- } \\
\text { ством }\end{array}$ & 322673 & 34864 & 10,8 & 445038 & 34866 & 7,8 \\
\hline $\begin{array}{l}\text { деятельность про- } \\
\text { фессиональная, } \\
\text { научная и техниче- } \\
\text { ская }\end{array}$ & 1165061 & 58654 & 5,0 & 1130796 & 38891 & 3,4 \\
\hline $\begin{array}{l}\text { из нее научные } \\
\text { исследования и } \\
\text { разработки }\end{array}$ & 386930 & 21774 & 5,6 & 404015 & 19014 & 4,7 \\
\hline $\begin{array}{l}\text { деятельность ад- } \\
\text { министративная и } \\
\text { сопутствующие до- } \\
\text { полнительные ус- } \\
\text { луги }\end{array}$ & 120037 & 14060| & 11,7 & 134605 & 10649 & 7,9 \\
\hline
\end{tabular}


Продолжение табл. 23.26

\begin{tabular}{|c|c|c|c|c|c|c|}
\hline & \multirow{2}{*}{\begin{tabular}{|c} 
Задол- \\
женность \\
покупа- \\
телей, \\
млн. руб.
\end{tabular}} & \multicolumn{2}{|c|}{$\begin{array}{c}\text { в том числе } \\
\text { просроченная }\end{array}$} & \multirow{2}{*}{\begin{tabular}{|c|} 
Задол- \\
жен- \\
ность по- \\
ставщи- \\
кам, \\
млн. руб.
\end{tabular}} & \multicolumn{2}{|c|}{$\begin{array}{c}\text { в том числе } \\
\text { просроченная } \\
\end{array}$} \\
\hline & & млн. руб. & \begin{tabular}{|c|} 
в про- \\
центах от \\
задол- \\
женности \\
покупате- \\
лей \\
\end{tabular} & & млн. руб. & $\begin{array}{c}\text { в про- } \\
\text { центах от } \\
\text { задол- } \\
\text { женности } \\
\text { постав- } \\
\text { щикам } \\
\end{array}$ \\
\hline $\begin{array}{l}\text { из нее деятель- } \\
\text { ность туристиче- } \\
\text { ских агентств и } \\
\text { прочих организа- } \\
\text { ций, предостав- } \\
\text { ляющих услуги } \\
\text { в сфере туризма }\end{array}$ & 4079 & 11 & 0,3 & 4415 & - & - \\
\hline $\begin{array}{l}\text { государственное } \\
\text { управление и обес- } \\
\text { печение военной } \\
\text { безопасности; со- } \\
\text { циальное обеспе- } \\
\text { чение }\end{array}$ & 24213 & 8624 & 35,6 & 25578 & 17208 & 67,3 \\
\hline образование & 6835 & 241 & 3,5 & 11244 & 192 & 1,7 \\
\hline $\begin{array}{l}\text { деятельность в об- } \\
\text { ласти здравоохра- } \\
\text { нения и социаль- } \\
\text { ных услуг }\end{array}$ & 17321 & 701 & 4,0 & 24140 & 589 & 2,4 \\
\hline $\begin{array}{l}\text { из нее деятель- } \\
\text { ность в области } \\
\text { здравоохранения }\end{array}$ & 17133 & 698 & 4,1 & 24048 & 589 & 2,5 \\
\hline $\begin{array}{l}\text { деятельность } \\
\text { в области культу- } \\
\text { ры, спорта, органи- } \\
\text { зации досуга и раз- } \\
\text { влечений }\end{array}$ & 8126 & 1364 & 16,8 & 20039 & 252 & 1,3 \\
\hline $\begin{array}{l}\quad \text { из нее: } \\
\text { деятельность } \\
\text { библиотек, архи- } \\
\text { вов, музеев и } \\
\text { прочих объектов } \\
\text { культуры }\end{array}$ & 394 & $\ldots$ & 20,3 & 560 & & 8,9 \\
\hline $\begin{array}{l}\text { деятельность } \\
\text { в области спорта, } \\
\text { отдыха и развле- } \\
\text { чений }\end{array}$ & 6438 & 1072 & 16,6 & 10753 & 136 & 1,3 \\
\hline $\begin{array}{l}\text { предоставление } \\
\text { прочих видов услуг }\end{array}$ & 19406 & 1128 & 5,8 & 19597 & 252 & 1,3 \\
\hline
\end{tabular}




\subsection{7. ЗАДОЛЖЕННОСТЬ ОРГАНИЗАЦИЙ ПО ПОЛУЧЕННЫМ КРЕДИТАМ БАНКОВ И ПРЕДОСТАВЛЕННЫМ ЗАЙМАМ ПО ВИДАМ ЭКОНОМИЧЕСКОЙ ДЕЯТЕЛЬНОСТИ В 2017 r.}

(на конец года)

\begin{tabular}{|c|c|c|c|c|c|}
\hline & \multicolumn{2}{|c|}{ Млн. руб. } & \multicolumn{2}{|c|}{ В процентах к итогу } & \multirow[b]{2}{*}{\begin{tabular}{|c} 
Удельный \\
вес про- \\
сроченной \\
задолжен- \\
ности в \\
общей за- \\
должен- \\
ности по \\
кредитам \\
банков и \\
займам, \\
процентов
\end{tabular}} \\
\hline & всего & $\begin{array}{c}\text { в том } \\
\text { числе } \\
\text { просро- } \\
\text { ченная } \\
\text { задолжен- } \\
\text { ность }\end{array}$ & всего & \begin{tabular}{|c|} 
просро- \\
ченная \\
задолжен- \\
ность \\
\\
\end{tabular} & \\
\hline $\begin{array}{l}\text { Всего в экономике } \\
\text { в том числе по ви- } \\
\text { дам экономической } \\
\text { деятельности: }\end{array}$ & 53190021 & 507806 & 100 & 100 & 1,0 \\
\hline $\begin{array}{l}\text { сельское, лесное хо- } \\
\text { зяйство, охота, рыбо- } \\
\text { ловство и рыбоводство }\end{array}$ & 1611055 & 15805 & 30 & 31 & 10 \\
\hline $\begin{array}{l}\quad \text { в том числе: } \\
\text { растениеводство и } \\
\text { животноводство, } \\
\text { охота и предостав- } \\
\text { ление соответст- } \\
\text { вующих услуг в этих }\end{array}$ & 1413579 & 14648 & 27 & 29 & 10 \\
\hline лесоводство & 79901 & 1057 & 0,1 & 0,2 & 1,3 \\
\hline $\begin{array}{l}\text { рыболовство } \\
\text { и рыбоводство }\end{array}$ & 117575 & 100 & 0,2 & 0,0 & 0,1 \\
\hline $\begin{array}{l}\text { добыча полезных } \\
\text { ископаемых }\end{array}$ & 5927154 & 97382 & 11,2 & 19,2 & 1,6 \\
\hline из нее: & & & & & \\
\hline добыча угля & 886742 & 71835 & 1,7 & 14,1 & 8,1 \\
\hline $\begin{array}{l}\text { добыча сырой нефти } \\
\text { и природного газа }\end{array}$ & 2185347 & 24025 & 4,1 & 4,7 & 1,1 \\
\hline $\begin{array}{l}\text { добыча металличе- } \\
\text { ских руд }\end{array}$ & 718180 & 105 & 1,4 & 0,0 & 0,0 \\
\hline $\begin{array}{l}\text { добыча прочих по- } \\
\text { лезных ископаемых }\end{array}$ & 334657 & 1418 & 0,6 & 0,3 & 0,4 \\
\hline $\begin{array}{l}\text { обрабатывающие } \\
\text { производства }\end{array}$ & 19248874 & 153166 & 36,2 & 30,2 & 0,8 \\
\hline
\end{tabular}


Продолжение табл. 23.27

\begin{tabular}{|c|c|c|c|c|c|}
\hline & \multicolumn{2}{|c|}{ Млн. руб. } & \multicolumn{2}{|c|}{ В процентах к итогу } & \multirow[b]{2}{*}{\begin{tabular}{|} 
Удельный \\
вес про- \\
сроченной \\
задолжен- \\
ности в \\
общей за- \\
должен- \\
ности по \\
кредитам \\
банков и \\
займам, \\
процентов
\end{tabular}} \\
\hline & всего & $\begin{array}{c}\text { в том } \\
\text { числе } \\
\text { просро- } \\
\text { ченная } \\
\text { задолжен- } \\
\text { ность }\end{array}$ & всего & $\begin{array}{c}\text { просро- } \\
\text { ченная } \\
\text { задолжен- } \\
\text { ность }\end{array}$ & \\
\hline из них: & & & & & \\
\hline $\begin{array}{l}\text { производство пище- } \\
\text { вых продуктов }\end{array}$ & 1200041 & 17024 & 2,3 & 3,4 & 1,4 \\
\hline $\begin{array}{l}\text { производство } \\
\text { напитков }\end{array}$ & 201408 & 764 & 0,4 & 0,2 & 0,4 \\
\hline $\begin{array}{l}\text { производство табач- } \\
\text { ных изделий }\end{array}$ & 81499 & - & 0,2 & - & - \\
\hline $\begin{array}{l}\text { производство тек- } \\
\text { стильных изделий }\end{array}$ & 66746 & 66 & 0,1 & 0,0 & 0,1 \\
\hline производство одежды & 40800 & - & 0,1 & - & - \\
\hline $\begin{array}{l}\text { производство кожи и } \\
\text { изделий из кожи }\end{array}$ & 24314 & 2623 & 0,0 & 0,5 & 10,8 \\
\hline $\begin{array}{l}\text { обработка древесины } \\
\text { и производство изде-- } \\
\text { лий из дерева и проб- } \\
\text { ки, кроме мебели, } \\
\text { производство изде- } \\
\text { лий из соломки и ма- } \\
\text { териалов для плете- }\end{array}$ & & & & & \\
\hline ния & 303126 & 2962 & 0,6 & 0,6 & 1,0 \\
\hline $\begin{array}{l}\text { производство бумаги } \\
\text { и бумажных изделий }\end{array}$ & 263032 & 223 & 0,5 & 0,0 & 0,1 \\
\hline $\begin{array}{l}\text { деятельность поли- } \\
\text { графическая и копи- } \\
\text { рование носителей }\end{array}$ & & & & & \\
\hline информации & 19727 & 651 & 0,0 & 0,1 & 3,3 \\
\hline $\begin{array}{l}\text { производство кокса и } \\
\text { нефтепродуктов }\end{array}$ & 8802457 & 5004 & 16,5 & 1,0 & 0,1 \\
\hline из них: & & & & & \\
\hline производство кокса & 47057 & - & 0,1 & - & - \\
\hline $\begin{array}{l}\text { производство неф- } \\
\text { тепродуктов }\end{array}$ & 8755175 & 5004 & 16,4 & 1,0 & 0,1 \\
\hline $\begin{array}{l}\text { производство хими- } \\
\text { ческих веществ и хи- } \\
\text { мических продуктов }\end{array}$ & 1520119 & 6235 & 2,9 & 1,2 & 0,4 \\
\hline
\end{tabular}


Продолжение табл. 23.27

\begin{tabular}{|c|c|c|c|c|c|}
\hline & \multicolumn{2}{|c|}{ Млн. руб. } & \multicolumn{2}{|c|}{ В процентах к итогу } & \multirow[b]{2}{*}{\begin{tabular}{|} 
Удельный \\
вес про- \\
сроченной \\
задолжен- \\
ности в \\
общей за- \\
должен- \\
ности по \\
кредитам \\
банков и \\
займам, \\
процентов
\end{tabular}} \\
\hline & всего & $\begin{array}{c}\text { в том } \\
\text { числе } \\
\text { просро- } \\
\text { ченная } \\
\text { задолжен- } \\
\text { ность }\end{array}$ & всего & $\begin{array}{c}\text { просро- } \\
\text { ченная } \\
\text { задолжен- } \\
\text { ность }\end{array}$ & \\
\hline $\begin{array}{l}\text { производство лекар- } \\
\text { ственных средств и } \\
\text { материалов, приме- } \\
\text { няемых в медицин- } \\
\text { ских целях }\end{array}$ & 92438 & 713 & 0,2 & 0,1 & 0,8 \\
\hline $\begin{array}{l}\text { производство резино- } \\
\text { вых и пластмассовых } \\
\text { изделий }\end{array}$ & 145361 & 252 & 0,3 & 0,0 & 0,2 \\
\hline $\begin{array}{l}\text { производство метал- } \\
\text { лургическое }\end{array}$ & 2644382 & 23042 & 5,0 & 4,5 & 0,9 \\
\hline $\begin{array}{l}\text { производство готовых } \\
\text { металлических изде- } \\
\text { лий, кроме машин и } \\
\text { оборудования }\end{array}$ & 430621 & 7518 & 0,8 & 1,5 & 1,7 \\
\hline $\begin{array}{l}\text { производство компь- } \\
\text { ютеров, электронных } \\
\text { и оптических изделий }\end{array}$ & 222277 & 3438 & 0,4 & 0,7 & 1,5 \\
\hline $\begin{array}{l}\text { производство элек- } \\
\text { трического оборудо- } \\
\text { вания }\end{array}$ & 151102 & 3066 & 0,3 & 0,6 & 2,0 \\
\hline $\begin{array}{l}\text { производство машин } \\
\text { и оборудования, не } \\
\text { включенных в другие } \\
\text { группировки }\end{array}$ & 454540 & 21600 & 0,9 & 4,3 & 4,8 \\
\hline $\begin{array}{l}\text { производство авто- } \\
\text { транспортных } \\
\text { средств, прицепов и } \\
\text { полуприцепов }\end{array}$ & 538177 & 10735 & 1,0 & 2,1 & 2,0 \\
\hline $\begin{array}{l}\text { производство прочих } \\
\text { транспортных } \\
\text { средств и оборудова- } \\
\text { ния }\end{array}$ & 1254828 & 24359 & 2,4 & 4,8 & 1,9 \\
\hline производство мебели & 24840 & 1465 & 0,0 & 0,3 & 5,9 \\
\hline $\begin{array}{l}\text { производство прочих } \\
\text { готовых изделий }\end{array}$ & 46531 & 78 & 0,1 & 0,0 & 0,2 \\
\hline
\end{tabular}


Продолжение табл. 23.27

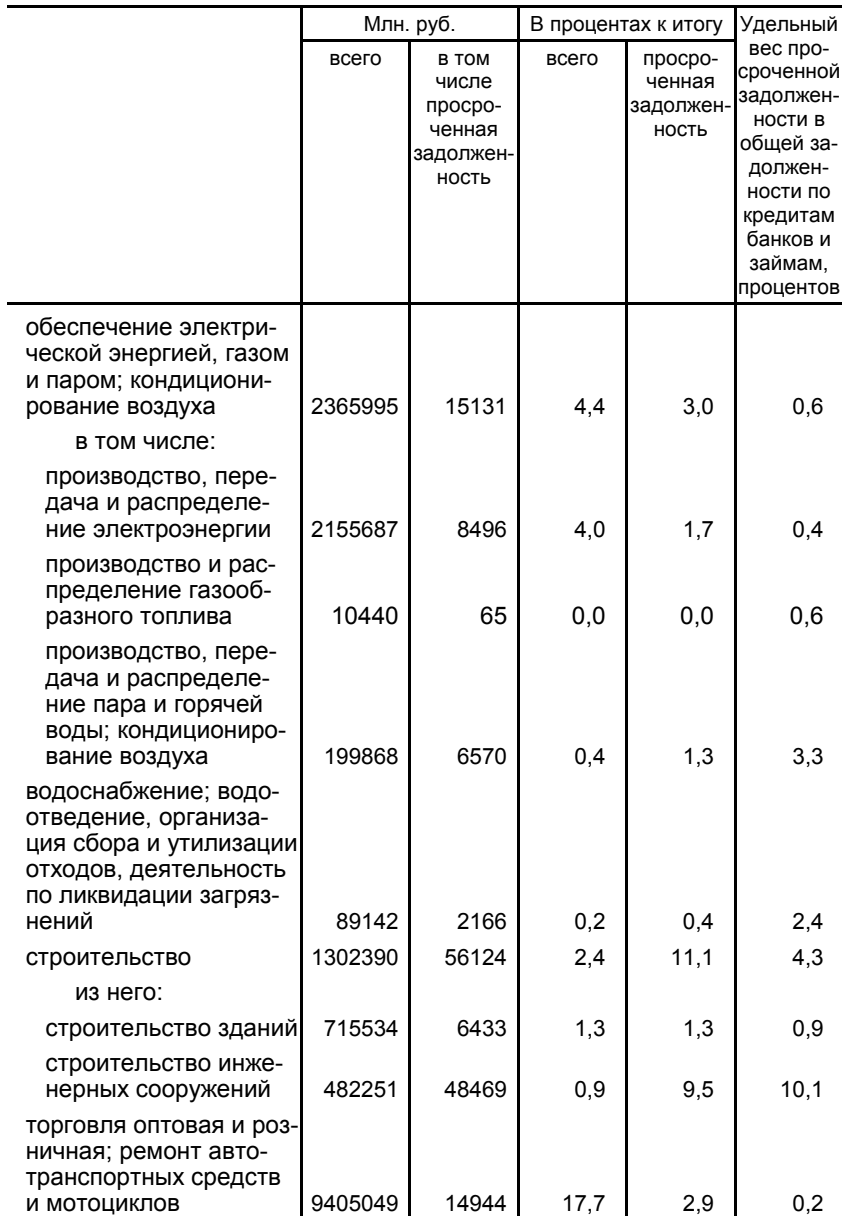


Продолжение табл. 23.27

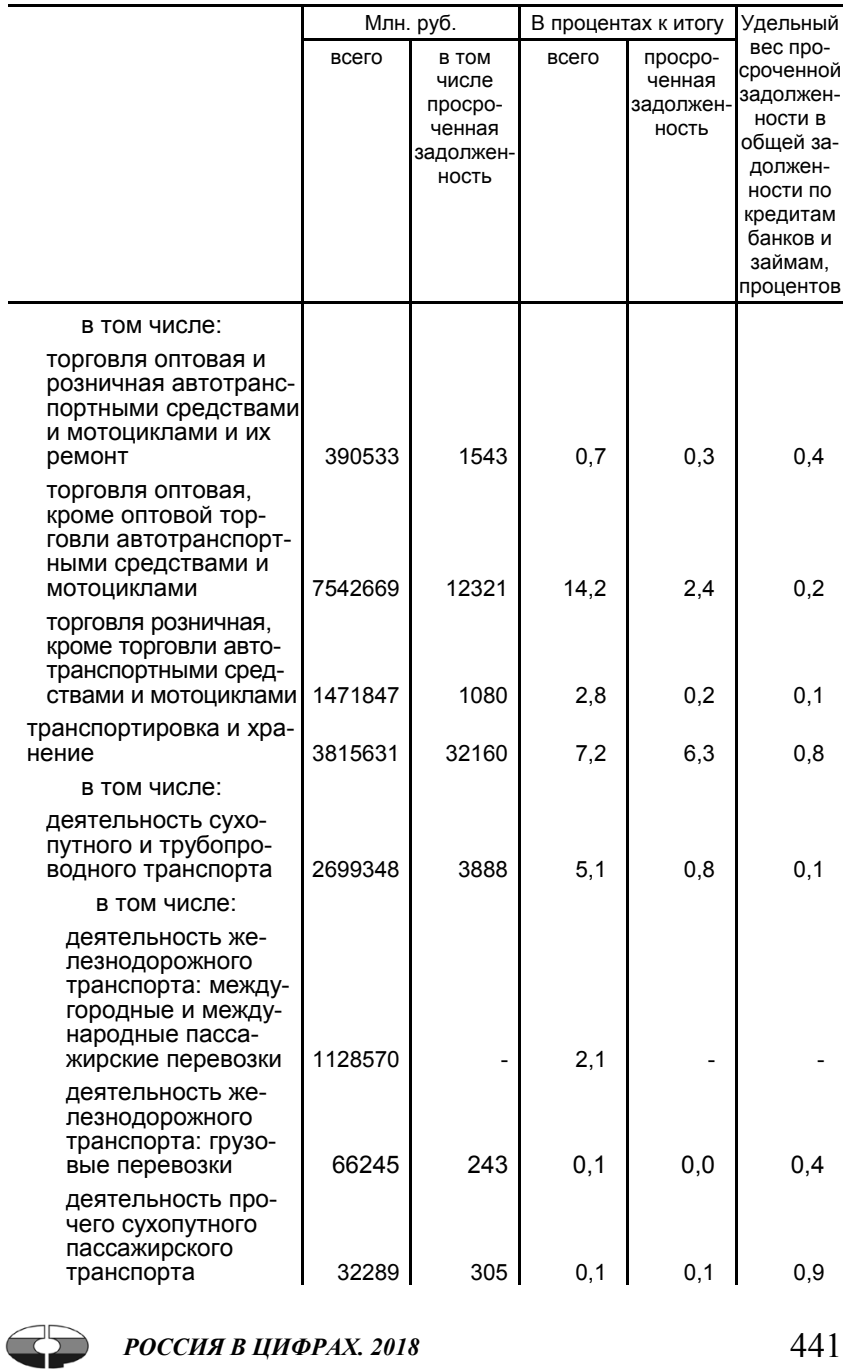


Продолжение табл. 23.27

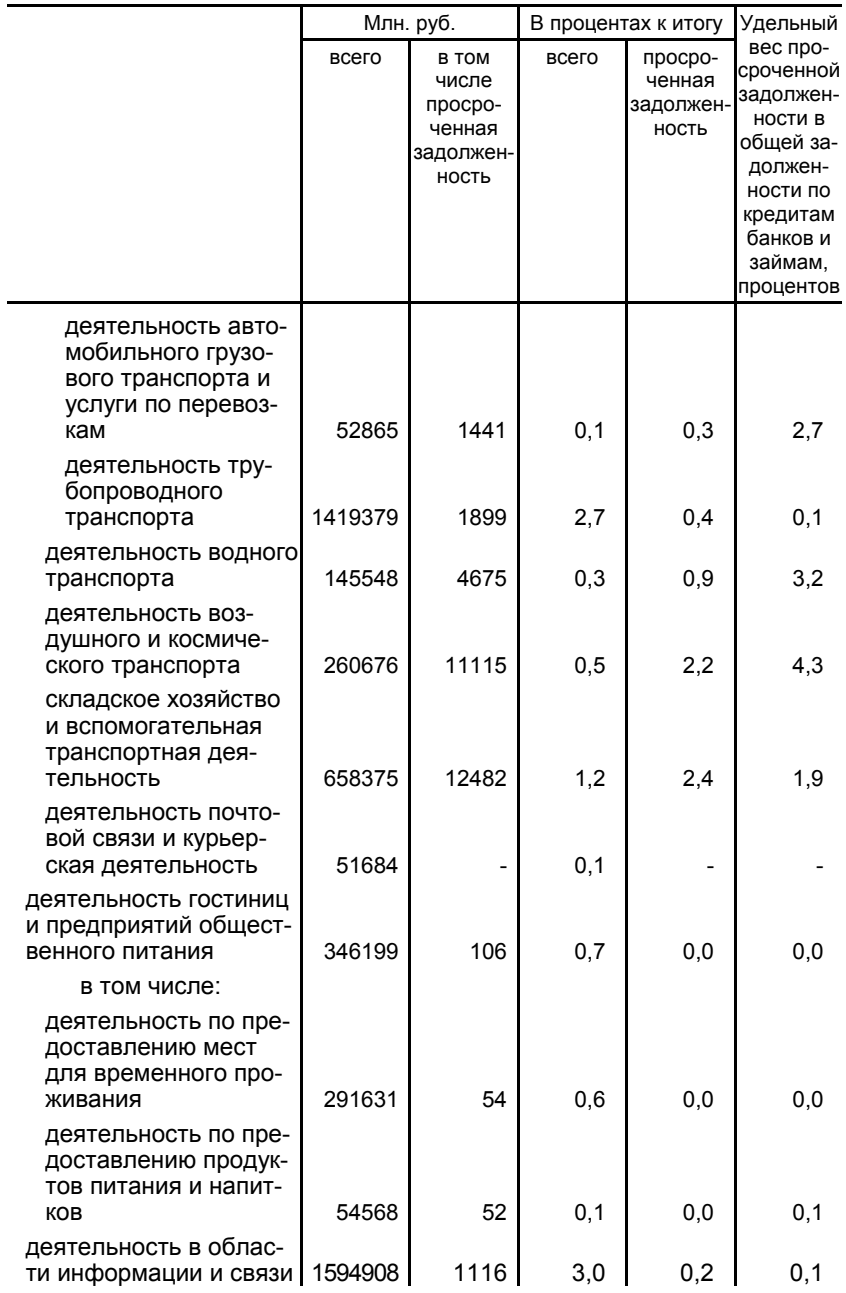


Продолжение табл. 23.27

\begin{tabular}{|c|c|c|c|c|c|}
\hline & \multicolumn{2}{|c|}{ Млн. руб. } & \multicolumn{2}{|c|}{ В процентах к итогу } & \multirow[b]{2}{*}{\begin{tabular}{|c} 
Удельный \\
вес про- \\
сроченной \\
задолжен- \\
ности в \\
общей за- \\
должен- \\
ности по \\
кредитам \\
банков и \\
займам, \\
процентов
\end{tabular}} \\
\hline & всего & $\begin{array}{c}\text { в том } \\
\text { числе } \\
\text { просро- } \\
\text { ченная } \\
\text { задолжен- } \\
\text { ность }\end{array}$ & всего & $\begin{array}{c}\text { просро- } \\
\text { ченная } \\
\text { задолжен- } \\
\text { ность }\end{array}$ & \\
\hline из нее: & & & & & \\
\hline $\begin{array}{l}\text { деятельность изда- } \\
\text { тельская }\end{array}$ & 14961 & 3 & 0,0 & 0,0 & 0,0 \\
\hline $\begin{array}{l}\text { деятельность в сфре- } \\
\text { ре телекоммуникаций }\end{array}$ & 1418830 & 280 & 2,7 & 0,1 & 0,0 \\
\hline $\begin{array}{l}\text { деятельность в об- } \\
\text { ласти информацион- } \\
\text { ных технологий }\end{array}$ & 16630 & - & 0,0 & - & - \\
\hline $\begin{array}{l}\text { деятельность финан- } \\
\text { совая и страховая }\end{array}$ & 3241169 & 3407 & 6,1 & 0,7 & 0,1 \\
\hline $\begin{array}{l}\text { деятельность по опе- } \\
\text { рациям с недвижимым } \\
\text { имуществом }\end{array}$ & 2203824 & 6050 & 4,1 & 1,2 & 0,3 \\
\hline $\begin{array}{l}\text { деятельность профес- } \\
\text { сиональная, научная и } \\
\text { техническая }\end{array}$ & 1604136 & 103363 & 3,0 & 20,4 & 6,4 \\
\hline $\begin{array}{l}\text { из нее научные ис- } \\
\text { следования и разра- } \\
\text { ботки }\end{array}$ & 309831 & 322 & 0,6 & 0,1 & 0,1 \\
\hline $\begin{array}{l}\text { деятельность админи- } \\
\text { стративная и сопутст- } \\
\text { вующие дополнитель- } \\
\text { ные услуги }\end{array}$ & 249657 & 6164 & 0.5 & 12 & 25 \\
\hline $\begin{array}{l}\text { из нее деятельность } \\
\text { туристических } \\
\text { агентств и прочих } \\
\text { организаций, предос- } \\
\text { тавляющих услуги } \\
\text { в сфрере туризма }\end{array}$ & 503 & - & 0,0 & - & - \\
\hline $\begin{array}{l}\text { государственное управ- } \\
\text { ление и обеспечение } \\
\text { военной безопасности; } \\
\text { социальное обеспече- } \\
\text { ние }\end{array}$ & 17307 & 134 & 0,0 & 0,0 & 0,8 \\
\hline
\end{tabular}


Продолжение табл. 23.27

\begin{tabular}{|c|c|c|c|c|c|}
\hline & \multicolumn{2}{|c|}{ Млн. руб. } & \multicolumn{2}{|c|}{ В процентах к итогу } & \multirow[b]{2}{*}{\begin{tabular}{|c} 
Удельный \\
вес про- \\
сроченной \\
задолжен- \\
ности в \\
общей за- \\
должен- \\
ности по \\
кредитам \\
банков и \\
займам, \\
процентов
\end{tabular}} \\
\hline & всего & $\begin{array}{c}\text { в том } \\
\text { числе } \\
\text { просро- } \\
\text { ченная } \\
\text { задолжен- } \\
\text { ность }\end{array}$ & всего & $\begin{array}{c}\text { просро- } \\
\text { ченная } \\
\text { задолжен- } \\
\text { ность }\end{array}$ & \\
\hline образование & 3703 & 36 & 0,0 & 0,0 & 1,0 \\
\hline $\begin{array}{l}\text { деятельность в облас- } \\
\text { ти здравоохранения и }\end{array}$ & & & & & \\
\hline социальных услуг & 61673 & 301 & 0,1 & 0,1 & 0,5 \\
\hline $\begin{array}{c}\text { из нее: } \\
\text { деятельность в об- } \\
\text { ласти здравоохране- }\end{array}$ & & & & & \\
\hline ния & 61386 & 301 & 0,1 & 0,0 & 0,5 \\
\hline $\begin{array}{l}\text { деятельность в облас- } \\
\text { ти культуры, спорта, } \\
\text { организации досуга и } \\
\text { развлечений }\end{array}$ & 64968 & 188 & 0,1 & 0,0 & 0,3 \\
\hline из нее: & & & & & \\
\hline $\begin{array}{l}\text { деятельность биб- } \\
\text { лиотек, архивов, } \\
\text { музеев и прочих } \\
\text { объектов культуры }\end{array}$ & 1145 & - & 0,0 & - & - \\
\hline $\begin{array}{l}\text { деятельность в об- } \\
\text { ласти спорта, отдыха }\end{array}$ & & & & & \\
\hline и развлечений & 48817 & 180 & 0,1 & 0,0 & 0,4 \\
\hline предоставление прочих & & & & & \\
\hline видов услуг & 37187 & 63 & 0,1 & 0,0 & 0,2 \\
\hline
\end{tabular}


23.28. РАСПРЕДЕЛЕНИЕ ОРГАНИЗАЦИЙ, ИМЕВШИХ ПРОСРОЧЕННУЮ ЗАДОЛЖЕННОСТЬ ПОКУПАТЕЛЕЙ И ПОСТАВЩИКАМ, ПО ВИДАМ ЭКОНОМИЧЕСКОЙ ДЕЯТЕЛЬНОСТИ в 2017 r.

\begin{tabular}{|c|c|c|c|c|}
\hline & \multicolumn{2}{|c|}{$\begin{array}{l}\text { Число организаций, } \\
\text { имевших просрочен- } \\
\text { ную задолженность }\end{array}$} & \multicolumn{2}{|c|}{$\begin{array}{c}\text { Удельный вес органи- } \\
\text { заций, имевших про- } \\
\text { сроченную задолжен- } \\
\text { ность, в общем } \\
\text { числе организаций, } \\
\text { процентов } \\
\end{array}$} \\
\hline & $\begin{array}{c}\text { покупа- } \\
\text { телей }\end{array}$ & $\begin{array}{l}\text { постав- } \\
\text { щикам }\end{array}$ & $\begin{array}{c}\text { покупа- } \\
\text { телей } \\
\end{array}$ & $\begin{array}{l}\text { постав- } \\
\text { щикам }\end{array}$ \\
\hline $\begin{array}{l}\text { Всего в экономике } \\
\text { в том числе по видам эконо- } \\
\text { мической деятельности: } \\
\text { сельское, лесное хозяйство, } \\
\text { охота, рыболовство и рыбовод- }\end{array}$ & 12346 & 6677 & 26,2 & 14,1 \\
\hline $\begin{array}{l}\text { ство } \\
\text { в том числе: } \\
\text { растениеводство и животно- } \\
\text { водство, охота и предостав- } \\
\text { ление соответствующих услуг }\end{array}$ & 691 & 408 & 18,2 & 10,8 \\
\hline в этих областях & 621 & 369 & 18,1 & 10,7 \\
\hline лесоводство и лесозаготовки & 43 & 28 & 22,8 & 14,8 \\
\hline рыболовство и рыбоводство & 27 & 11 & 17,0 & 6,9 \\
\hline $\begin{array}{l}\text { добыча полезных ископаемых } \\
\text { из нее: }\end{array}$ & 359 & 267 & 33,5 & 24,9 \\
\hline $\begin{array}{l}\text { добыча угля } \\
\text { добыча сырой нефти и при- }\end{array}$ & 71 & 69 & 47,0 & 45,7 \\
\hline $\begin{array}{l}\text { родного газа } \\
\text { добыча металлических руд }\end{array}$ & $\begin{array}{l}62 \\
54\end{array}$ & $\begin{array}{l}51 \\
37\end{array}$ & $\begin{array}{l}34,3 \\
267\end{array}$ & $\begin{array}{l}28,2 \\
18,3\end{array}$ \\
\hline $\begin{array}{l}\text { добыча металлических руд } \\
\text { добыча прочих полезных ис- } \\
\text { копаемых }\end{array}$ & 91 & 59 & 26,1 & 18,3 \\
\hline $\begin{array}{l}\text { обрабатывающие производства } \\
\text { из них: } \\
\text { производство пищевых }\end{array}$ & 2672 & 1557 & 25,9 & 15,1 \\
\hline продуктов & 371 & 169 & 18,8 & 8,5 \\
\hline $\begin{array}{l}\text { производство напитков } \\
\text { производство табачных }\end{array}$ & 64 & 30 & 22,3 & 10,5 \\
\hline $\begin{array}{l}\text { изделий } \\
\text { производство текстильных }\end{array}$ & $\ldots$ & $\ldots$ & $\ldots$ & $\cdots$ \\
\hline изделий & 49 & 35 & 27,4 & 19,6 \\
\hline $\begin{array}{l}\text { производство одежды } \\
\text { производство кожи и изделий }\end{array}$ & 19 & 9 & 12,2 & 5,8 \\
\hline $\begin{array}{l}\text { из кожи } \\
\text { обработка древесины и про- } \\
\text { изводство изделий из дерева } \\
\text { и пробки, кроме мебели, про- } \\
\text { изводство изделий из соломки }\end{array}$ & 20 & 13 & 26,3 & 17,1 \\
\hline и материалов для плетения & 76 & 45 & 26,8 & 15,8 \\
\hline
\end{tabular}


Продолжение табл. 23.28

\begin{tabular}{|c|c|c|c|c|}
\hline & \multicolumn{2}{|c|}{$\begin{array}{c}\text { Число организаций, } \\
\text { имевших просрочен- } \\
\text { ную задолженность }\end{array}$} & \multicolumn{2}{|c|}{$\begin{array}{c}\text { Удельный вес органи } \\
\text { заций, имевших про- } \\
\text { сроченную задолжен } \\
\text { ность, в общем } \\
\text { числе организаций, } \\
\text { процентов }\end{array}$} \\
\hline & $\begin{array}{c}\text { покупа- } \\
\text { телей }\end{array}$ & $\begin{array}{l}\text { постав- } \\
\text { щикам }\end{array}$ & $\begin{array}{c}\text { покупа- } \\
\text { телей }\end{array}$ & $\begin{array}{l}\text { постав- } \\
\text { щикам }\end{array}$ \\
\hline $\begin{array}{l}\text { производство бумаги и } \\
\text { бумажных изделий }\end{array}$ & 53 & 25 & 29,3 & 13,8 \\
\hline $\begin{array}{l}\text { деятельность полиграфиче- } \\
\text { ская и копирование носителей } \\
\text { информации }\end{array}$ & 46 & 15 & 21,9 & 71 \\
\hline $\begin{array}{l}\text { инсрормации } \\
\text { производство кокса и нефте- } \\
\text { продуктов }\end{array}$ & 52 & 43 & 44,4 & 36,8 \\
\hline из них: & & & & \\
\hline $\begin{array}{l}\text { производство кокса } \\
\text { производство несртепро- }\end{array}$ & $\ldots$ & 3 & $\ldots$ & 50,0 \\
\hline дуктов & 50 & 40 & 45,5 & 36,4 \\
\hline $\begin{array}{l}\text { производство химических ве- } \\
\text { ществ и химических продуктов }\end{array}$ & 150 & 85 & 31,4 & 17,8 \\
\hline $\begin{array}{l}\text { производство лекарственных } \\
\text { средств и материалов, приме- } \\
\text { няемых в медицинских целях }\end{array}$ & 40 & 19 & 26,3 & 12,5 \\
\hline $\begin{array}{l}\text { производство резиновых и } \\
\text { пластмассовых изделий }\end{array}$ & 117 & 51 & 23,7 & 10,3 \\
\hline производство металлургическое & 135 & 102 & 37,0 & 27,9 \\
\hline $\begin{array}{l}\text { производство готовых метал- } \\
\text { лических изделий, кроме ма- } \\
\text { шин и оборудования }\end{array}$ & 260 & 159 & 28,7 & 17,5 \\
\hline $\begin{array}{l}\text { производство компьютеров, } \\
\text { электронных и оптических из- } \\
\text { делий }\end{array}$ & 159 & 106 & 24,5 & 16,3 \\
\hline $\begin{array}{l}\text { производство электрического } \\
\text { оборудования }\end{array}$ & 128 & 78 & 26,6 & 16,2 \\
\hline $\begin{array}{l}\text { производство машин и обору- } \\
\text { дования, не включенных } \\
\text { в другие группировки }\end{array}$ & 192 & 122 & 25,8 & 16,4 \\
\hline $\begin{array}{l}\text { производство автотранспорт- } \\
\text { ных средств, прицепов и по- } \\
\text { луприцепов }\end{array}$ & 93 & 69 & 25,3 & 18,8 \\
\hline $\begin{array}{l}\text { производство прочих транс- } \\
\text { портных средств и оборудова- } \\
\text { ния }\end{array}$ & 98 & 74 & 35,1 & 26,5 \\
\hline производство мебели & 22 & 11 & 13,8 & 6,9 \\
\hline $\begin{array}{l}\text { производство прочих готовых } \\
\text { изделий }\end{array}$ & 26 & 11 & 20,8 & 8,8 \\
\hline
\end{tabular}


Продолжение табл. 23.28

\begin{tabular}{|c|c|c|c|c|}
\hline & \multicolumn{2}{|c|}{\begin{tabular}{|} 
Число организаций, \\
имевших просрочен- \\
ную задолженность
\end{tabular}} & \multicolumn{2}{|c|}{$\begin{array}{c}\text { Удельный вес органи- } \\
\text { заций, имевших про- } \\
\text { сроченную задолжен- } \\
\text { ность, в общем } \\
\text { числе организаций, } \\
\text { процентов } \\
\end{array}$} \\
\hline & $\begin{array}{c}\text { покупа- } \\
\text { телей }\end{array}$ & $\begin{array}{l}\text { постав- } \\
\text { щикам }\end{array}$ & $\begin{array}{c}\text { покупа- } \\
\text { телей }\end{array}$ & $\begin{array}{l}\text { постав- } \\
\text { щикам } \\
\end{array}$ \\
\hline обеспечение электрической & & & & \\
\hline $\begin{array}{l}\text { энергией, газом и паром; конди- } \\
\text { ционирование воздуха }\end{array}$ & 1797 & 1287 & 60,8 & 43,6 \\
\hline в том числе: & & & & \\
\hline $\begin{array}{l}\text { производство, передача и рас- } \\
\text { пределение электроэнергии }\end{array}$ & 342 & 208 & 45,9 & 27,9 \\
\hline $\begin{array}{l}\text { производство и распределе- } \\
\text { ние газообразного топлива }\end{array}$ & 95 & 39 & 43,6 & 17,9 \\
\hline $\begin{array}{l}\text { производство, передача и } \\
\text { распределение пара и горя- } \\
\text { чей воды; кондиционирование } \\
\text { воздуха }\end{array}$ & 1360 & 1040 & 68,3 & 52,2 \\
\hline $\begin{array}{l}\text { водоснабжение; водоотведе- } \\
\text { ние, организация сбора и ути- } \\
\text { лизации отходов, деятельность }\end{array}$ & & & & \\
\hline по ликвидации загрязнений & 1041 & 662 & 53,1 & 33,8 \\
\hline строительство & 773 & 441 & 23,8 & 13,6 \\
\hline из него: & & & & \\
\hline строительство зданий & 279 & 169 & 20,1 & 12,2 \\
\hline $\begin{array}{l}\text { строительство инженерных } \\
\text { сооружений }\end{array}$ & 262 & 161 & 25,0 & 15,4 \\
\hline $\begin{array}{l}\text { торговля оптовая и розничная; } \\
\text { ремонт автотранспортных } \\
\text { средств и мотоциклов }\end{array}$ & 1265 & 346 & 17,5 & 4,8 \\
\hline $\begin{array}{l}\text { в том числе: } \\
\text { торговля оптовая и розничная } \\
\text { автотранспортными средст- } \\
\text { вами и мотоциклами и их } \\
\text { ремонт }\end{array}$ & 127 & 32 & 15,5 & 3,9 \\
\hline $\begin{array}{l}\text { торговля оптовая, кроме опто- } \\
\text { вой торговли автотранспорт- } \\
\text { ными средствами и мотоцик- } \\
\text { лами }\end{array}$ & 948 & 216 & 21,0 & 4.8 \\
\hline $\begin{array}{l}\text { торговля розничная, кроме } \\
\text { торговли автотранспортными } \\
\text { средствами и мотоциклами }\end{array}$ & 190 & 98 & 10,0 & 5,2 \\
\hline $\begin{array}{l}\text { транспортировка и хранение } \\
\text { в том числе: }\end{array}$ & 857 & 478 & 27,3 & 15,2 \\
\hline $\begin{array}{l}\text { деятельность сухопутного и } \\
\text { трубопроводного транспорта }\end{array}$ & 444 & 303 & 29,7 & 20,3 \\
\hline
\end{tabular}


Продолжение табл. 23.28

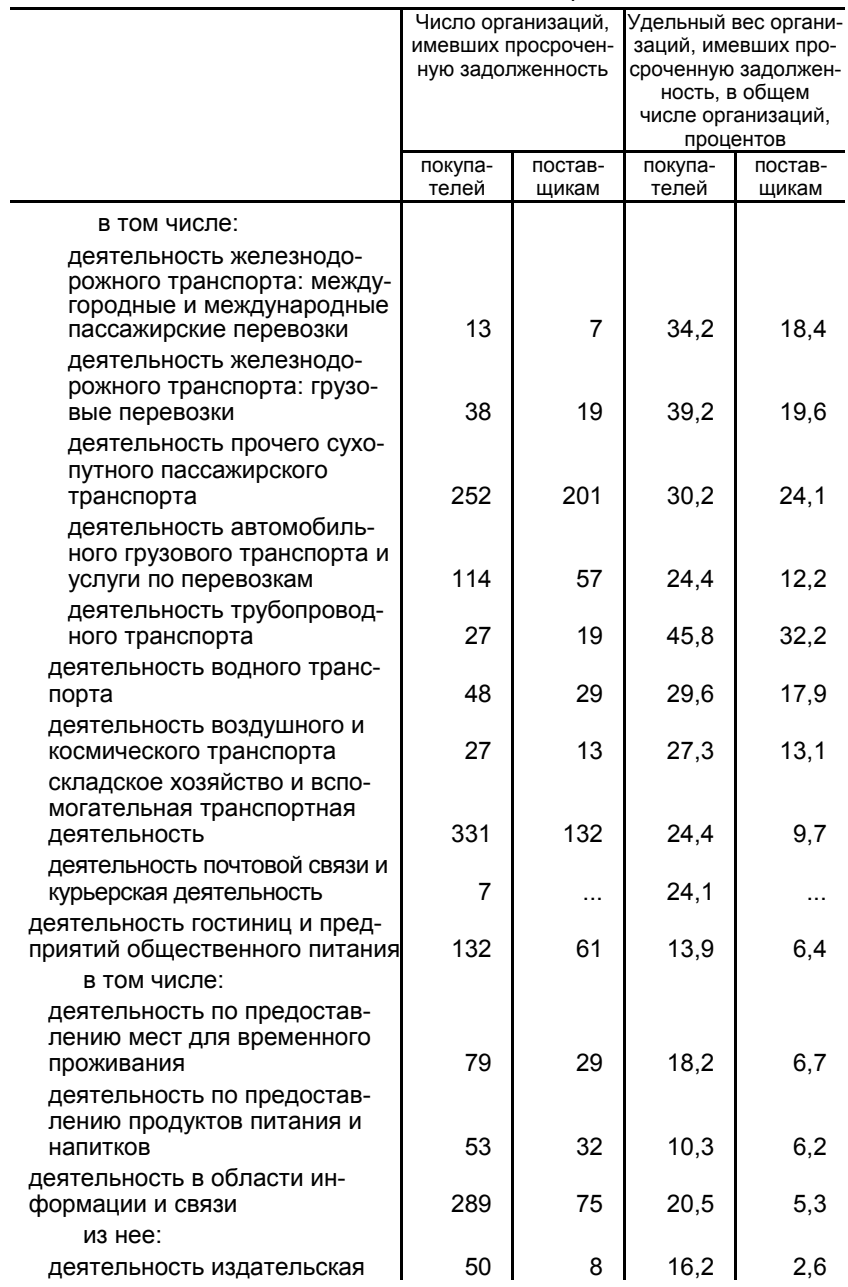


Продолжение табл. 23.28

\begin{tabular}{|c|c|c|c|c|}
\hline & \multicolumn{2}{|c|}{$\begin{array}{l}\text { Число организаций, } \\
\text { имевших просрочен- } \\
\text { ную задолженность }\end{array}$} & \multicolumn{2}{|c|}{$\begin{array}{c}\text { Удельный вес органи } \\
\text { заций, имевших про- } \\
\text { сроченную задолжен- } \\
\text { ность, в общем } \\
\text { числе организаций, } \\
\text { процентов }\end{array}$} \\
\hline & $\begin{array}{c}\text { покупа- } \\
\text { телей }\end{array}$ & $\begin{array}{l}\text { постав- } \\
\text { щикам }\end{array}$ & \begin{tabular}{|c|} 
покупа- \\
телей
\end{tabular} & $\begin{array}{l}\text { постав- } \\
\text { щикам }\end{array}$ \\
\hline $\begin{array}{l}\text { деятельность в сфере теле- } \\
\text { коммуникаций }\end{array}$ & 77 & 27 & 29,4 & 10,3 \\
\hline $\begin{array}{l}\text { деятельность в области ин- } \\
\text { формационных технологий }\end{array}$ & 41 & 7 & 18,9 & 3,2 \\
\hline $\begin{array}{l}\text { деятельность финансовая и } \\
\text { страховая }\end{array}$ & 91 & 19 & 28,4 & 5,9 \\
\hline $\begin{array}{l}\text { деятельность по операциям } \\
\text { с недвижимым имуществом }\end{array}$ & 912 & 459 & 33,9 & 17,0 \\
\hline $\begin{array}{l}\text { деятельность профессиональная, } \\
\text { научная и техническая }\end{array}$ & 706 & 303 & 25,6 & 11,0 \\
\hline $\begin{array}{l}\text { из нее научные исследования } \\
\text { и разработки }\end{array}$ & 221 & 113 & 28,1 & 14,4 \\
\hline $\begin{array}{l}\text { деятельность административ- } \\
\text { ная и сопутствующие дополни- } \\
\text { тельные услуги }\end{array}$ & 215 & 60 & 21,4 & 6,0 \\
\hline $\begin{array}{l}\text { из нее деятельность туристи- } \\
\text { ческих агентств и прочих ор- } \\
\text { ганизаций, предоставляющих } \\
\text { услуги в сфере туризма }\end{array}$ & 6 & - & 14,3 & - \\
\hline $\begin{array}{l}\text { государственное управление и } \\
\text { обеспечение военной безопас- } \\
\text { ности; социальное обеспечение }\end{array}$ & 16 & 9 & 29,6 & 16,7 \\
\hline образование & 195 & 97 & 9,9 & 4,9 \\
\hline $\begin{array}{l}\text { деятельность в области здраво- } \\
\text { охранения и социальных услуг }\end{array}$ & 127 & 48 & 12,6 & 4,8 \\
\hline $\begin{array}{l}\text { из нее деятельность в облас- } \\
\text { ти здравоохранения }\end{array}$ & 126 & 48 & 13,0 & 5,0 \\
\hline $\begin{array}{l}\text { деятельность в области культу- } \\
\text { ры, спорта, организации досуга } \\
\text { и развлечений }\end{array}$ & 62 & 21 & 15,7 & 5,3 \\
\hline $\begin{array}{l}\text { из нее: } \\
\text { деятельность библиотек, ар- } \\
\text { хивов, музеев и прочих объек- } \\
\text { тов культуры }\end{array}$ & $\ldots$ & $\ldots$ & $\ldots$ & $\ldots$ \\
\hline $\begin{array}{l}\text { деятельность в области спор- } \\
\text { та, отдыха и развлечений }\end{array}$ & 51 & 18 & 16,6 & 5,8 \\
\hline $\begin{array}{l}\text { предоставление прочих видов } \\
\text { услуг }\end{array}$ & 146 & 79 & 15,0 & 8,1 \\
\hline
\end{tabular}


23.29. ПРОСРОЧЕННАЯ ЗАДОЛЖЕННОСТЬ

ПО ЗАРАБОТНОЙ ПЛАТЕ РАБОТНИКАМ ОРГАНИЗАЦИЙ ПО ВИДАМ ЭКОНОМИЧЕСКОЙ ДЕЯТЕЛЬНОСТИ ${ }^{1}$

(на начало года, млн. рублей)

\begin{tabular}{|c|c|c|}
\hline & 2017 & 2018 \\
\hline Всего & 3232 & 2487 \\
\hline в том числе: & & \\
\hline сельское хозяйство, охота и предоставление & & \\
\hline услуг в этих областях, лесозаготовки & 194 & 158 \\
\hline рыболовство и рыбоводство & 1,4 & 1,0 \\
\hline добыча полезных ископаемых & 158 & 72 \\
\hline из нее: & & \\
\hline добыча угля & - & \\
\hline добыча сырой нефти и природного газа & & 7 \\
\hline добыча металлических руд & 63 & 14 \\
\hline обрабатывающие производства & 1792 & 1511 \\
\hline из них: & & \\
\hline производство пищевых продуктов & 134 & 172 \\
\hline производство напитков & 8 & \\
\hline производство табачных изделий & - & \\
\hline производство текстильных изделий & 0,9 & 1,1 \\
\hline производство одежды & - & - \\
\hline производство кожи и изделий из кожи & 7 & - \\
\hline обработка древесины и производство изделий & & \\
\hline из дерева и пробки, кроме мебели, производ- & & \\
\hline ство изделий из соломки и материалов для & & \\
\hline плетения & 21 & 29 \\
\hline производство бумаги и бумажных изделий & 6 & \\
\hline деятельность полиграфическая и копирование & & \\
\hline носителей информации & 17 & 16 \\
\hline производство кокса и нефтепродуктов & 59 & 43 \\
\hline $\begin{array}{l}\text { производство химических веществ и химиче- } \\
\text { ских продуктов }\end{array}$ & - & 5 \\
\hline производство лекарственных средств и мате- & & \\
\hline риалов, применяемых в медицинских целях & - & 22 \\
\hline производство резиновых и пластмассовых & & \\
\hline изделий & 4 & \\
\hline производство прочей неметаллической & & \\
\hline минеральной продукции & 94 & 54 \\
\hline производство металлургическое & 67 & 27 \\
\hline $\begin{array}{l}\text { производство готовых металлических изделий, } \\
\text { кроме машин и оборудования }\end{array}$ & 767 & 639 \\
\hline $\begin{array}{l}\text { производство компьютеров, электронных и } \\
\text { оптических изделий }\end{array}$ & 82 & 106 \\
\hline производство электрического оборудования & 66 & 40 \\
\hline производство машин и оборудования, & & \\
\hline не включенных в другие группировки & 258 & 212 \\
\hline $\begin{array}{l}\text { производство автотранспортных средств, } \\
\text { прицепов и полуприцепов }\end{array}$ & 59 & 45 \\
\hline
\end{tabular}


Продолжение табл. 23.29

\begin{tabular}{l|r|r}
\hline & 2017 & 2018 \\
\hline $\begin{array}{l}\text { производство прочих транспортных средств и } \\
\text { оборудования }\end{array}$ & 42 & 76 \\
производство мебели & - & 3 \\
$\quad$ производство прочих готовых изделий & 3 & 1,5 \\
ремонт и монтаж машин и оборудования & 96 & 18 \\
обеспечение электрической энергией, газом & & \\
и паром; кондиционирование воздуха & 39 & 27 \\
водоснабжение; водоотведение, организация & & \\
сбора и утилизации отходов, деятельность & 31 & 13 \\
по ликвидации загрязнений & 693 & 435 \\
строительство & 197 & 159 \\
транспорт & 16 & 17 \\
управление недвижимым имуществом & 23 & 34 \\
за вознаграждение или на договорной основе \\
науные исследования и разработки
\end{tabular}

\subsection{0. ПЛАТЕЖНО-РАСЧЕТНЫЕ ОТНОШЕНИЯ ОРГАНИЗАЦИЙ РОССИИ С ОРГАНИЗАЦИЯМИ СТРАН СНГ В 2017 Г.}

(на конец года; по прямым хозяйственным договорам; млн. рублей)

\begin{tabular}{|c|c|c|c|c|c|c|}
\hline & \multicolumn{4}{|c|}{ Задолженность } & \multirow{2}{*}{\multicolumn{2}{|c|}{$\begin{array}{c}\text { Превышение } \\
\text { задолженности орга- } \\
\text { низаций стран СНГ } \\
\text { над задолженностью } \\
\text { организаций России } \\
\end{array}$}} \\
\hline & \multicolumn{2}{|c|}{\begin{tabular}{|c|} 
организаций стран \\
СНГ организациям \\
России (покупателей)
\end{tabular}} & \multicolumn{2}{|c|}{$\begin{array}{l}\text { организаций России } \\
\text { организациям стран } \\
\text { СНГ (поставщикам) }\end{array}$} & & \\
\hline & всего & \begin{tabular}{|c|} 
в том чис- \\
ле просро- \\
ченная
\end{tabular} & всего & $\begin{array}{l}\text { В том чис- } \\
\text { ле просро- } \\
\text { ченная }\end{array}$ & всего & $\begin{array}{l}\text { В том чис- } \\
\text { ле просро- } \\
\text { ченная }\end{array}$ \\
\hline $\begin{array}{l}\text { Всего } \\
\text { в том числе } \\
\text { с организа- } \\
\text { циями: }\end{array}$ & 188993 & 6958 & 105558 & 4208 & 83435 & 2750 \\
\hline $\begin{array}{l}\text { Азербайджана } \\
\text { Армении } \\
\text { Беларуси } \\
\text { Казахстана } \\
\text { Киргизии }\end{array}$ & $\begin{array}{r}3056 \\
7478 \\
71753 \\
53428 \\
4563\end{array}$ & $\begin{array}{r}181 \\
95 \\
658 \\
1278 \\
24\end{array}$ & $\begin{array}{r}1125 \\
1954 \\
35514 \\
10360 \\
212\end{array}$ & $\begin{array}{r}2 \\
8 \\
298 \\
102 \\
1\end{array}$ & $\begin{array}{r}1931 \\
5524 \\
36239 \\
43068 \\
4351\end{array}$ & $\begin{array}{r}179 \\
87 \\
360 \\
1176 \\
23\end{array}$ \\
\hline $\begin{array}{l}\text { Молдова } \\
\text { Таджикистана } \\
\text { Туркмении } \\
\text { Узбекистана } \\
\text { Украины }\end{array}$ & $\begin{array}{r}3364 \\
3977 \\
3434 \\
8527 \\
29413\end{array}$ & $\begin{array}{r}100 \\
85 \\
260 \\
360 \\
3917\end{array}$ & $\begin{array}{r}886 \\
144 \\
75 \\
8413 \\
46875\end{array}$ & $\begin{array}{r}108 \\
0,3 \\
0,3 \\
32 \\
3657\end{array}$ & $\begin{array}{r}2478 \\
3833 \\
3359 \\
114 \\
-17462\end{array}$ & $\begin{array}{r}-8 \\
85 \\
260 \\
328 \\
260\end{array}$ \\
\hline
\end{tabular}




\section{4. ЦЕНЫ И ТАРИФЫ}

Раздел представляет статистические данные об уровне и индексах цен (тарифов) на товары и услуги на потребительском рынке, на продукцию отраслей производства.

Данные в таблицах, содержащих показатели по видам экономической деятельности, приводятся за 2013-2017 гг. в соответствии с Общероссийским классификатором видов экономической деятельности (ОКВЭД 2) ОК 029-2014, введенным в действие с 1 января 2017 г.

В разделе данные за 2014 г. приведены без учета сведений по Крымскому фредеральному округу.

Система индексов цен, рассчитываемых органами государственной статистики, включает в себя индексы цен и тарифов на товары и услуги на потребительском рынке, цен производителей промышленных товаров, сельскохозяйственной продукции, на приобретенные промышленными организациями отдельные виды товаров, сводный индекс цен на продукцию (затраты, услуги) инвестиционного назначения, тарифов на грузовые перевозки. Эти индексы рассчитываются по данным регистрации цен и тарифов на товары (услуги)-представители по выборочному кругу организаций всех типов и форм собственности.

Индекс потребительских цен характеризует изменение во времени общего уровня цен на товары и услуги, приобретаемые населением для непроизводственного потребления. Он измеряет отношение стоимости фриксированного перечня товаров и услуг в ценах текущего периода к его стоимости в ценах базисного периода.

Расчет осуществляется ежемесячно на базе статистических данных, полученных в результате наблюдения за уровнем цен на товары и услуги в организациях розничной торговли и сферы услуг, на вещевых, смешанных и продовольственных рынках, как в стационарных торговых заведениях, так и при передвижной торговле (палатки, киоски и т.д.), а также на основе данных о потребительских расходах домашних хозяйств.

Индекс потребительских цен является одним из важнейших показателей, характеризующих инфрляционные процессы в потребительском секторе экономики.

Индексы цен на первичном и вторичном рынках жилья рассчитываются на основе зарегистрированных цен на вновь построенные квартиры и на квартиры функционирующего жилого фонда, находящиеся в собственности, если они являются объектами совершения рыночных сделок.

Наблюдение ведется по выборочному кругу организаций, осуществляющих операции с недвижимостью в территориаль-

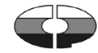


ных центрах и отдельных городах субъектов Российской Федерации. При регистрации цен на квартиры учитываются их количественные и качественные характеристики. Средние цены по Российской Федерации рассчитываются из средних цен, сложившихся в ее субъектах. В качестве весов используются данные о количестве проданной общей площади квартир отдельно на первичном и вторичном рынках жилья, накопленном за предыдущий год.

Индекс цен производителей промышленных товаров рассчитывается на основании регистрации цен на товары (услуги)-представители более чем в 10 тыс. базовых организаций. Расчет средних цен и индексов цен производится более чем по 1100 товарам (услугам)-представителям. Цены производителей представляют собой фактически сложившиеся на момент регистрации цены указанных организаций на произведенные и отгруженные товары (оказанные услуги), предназначенные для реализации на внутреннем рынке (без косвенных товарных налогов - налога на добавленную стоимость, акциза и т.п.). Рассчитанные по товарам (услугам)-представителям индексы цен производителей последовательно агрегируются в индексы цен соответствующих видов, групп, классов, разделов экономической деятельности. В качестве весов используются данные об объеме отгрузки продукции (услуг) в стоимостном выражении за базисный период.

Индексы цен на приобретенные промышленными организациями отдельные виды товаров рассчитываются на основании регистрации цен на товары-представители по установленной номенклатуре. Средняя цена приобретения включает, помимо цены производства, налог на добавленную стоимость, акциз, транспортные, сбытовые, посреднические и другие расходы. Построение индексов цен приобретения осуществляется по сопоставимому кругу видов товаров в отчетном и базисном периодах и предусматривает систему взвешивания на основе данных о количестве приобретенной продукции за предыдущий год.

Индекс цен производителей сельскохозяйственной продукции исчисляется на основании регистрации в отобранных для наблюдения сельскохозяйственных организациях цен на основные виды товаров-представителей, реализуемых заготовительным, перерабатывающим организациям, на рынке, через собственную торговую сеть, населению непосредственно с транспортных средств, на ярмарках, биржах, аукционах, организациям, коммерческим структурам и т.п.

Цены производителей сельскохозяйственной продукции приводятся с учетом надбавок и скидок за качество реализованной продукции, без расходов на транспортировку, экспедирование, погрузку и разгрузку продукции, а также без налога на добавленную стоимость.

Сводный индекс цен на продукцию (затраты, услуги) инвестиционного назначения рассчитывается как агрегиро- 
ванный показатель из индексов цен производителей на строительную продукцию, приобретения машин и оборудования инвестиционного назначения и на прочую продукцию (затраты, услуги) инвестиционного назначения, взвешенных по доле этих элементов в общем объеме инвестиций в основной капитал.

Индекс цен производителей на строительную продукцию формируется из индексов цен на строительно-монтажные работы и на прочие затраты, включенные в сводный сметный расчет строительства, взвешенных по доле этих элементов в общем объеме инвестиций в жилища, здания и сооружения. Расчет индекса цен на строительно-монтажные работы проводится на основе данных формы отчетности о ценах на материалы, детали и конструкции, приобретенные базовыми подрядными организациями, а также на базе технологических моделей, разработанных по видам экономической деятельности с учетом территориальных особенностей строительства.

Индекс цен приобретения машин и оборудования инвестиционного назначения исчисляется по данным об изменении цен производителей этого оборудования, а также транспортных расходов, ставки налога на добавленную стоимость и других расходов.

Индекс цен на прочую продукцию (затраты, услуги) инвестиционного назначения определяется из индексов цен на основные составляющие этих работ (проектно-изыскательские работы, затраты на разведочное бурение, затраты на формирование рабочего, продуктивного и племенного стада и другие затраты).

Индекс тарифов на грузовые перевозки позволяет определить изменение тарифов на грузовые перевозки за текущий период без учета изменения за этот период структуры перевезенных грузов по разнообразным признакам: виду груза, размеру отправки, скорости доставки, расстоянию перевозки, территории перевозки, типу подвижного состава, степени использования его грузоподъемности и др.

Сводный индекс тарифов на грузовые перевозки рассчитывается как агрегированный показатель из индексов тарифов на перевозку грузов разными видами транспорта (железнодорожным, автомобильным, трубопроводным, морским, внутренним водным, воздушным). По каждому виду транспорта регистрируются тарифы на услуги-представители. За услугу-представитель принимается перевозка одной тонны массового груза определенным видом транспорта на фиксированное расстояние. Обследование тарифов осуществляется в выборочной совокупности транспортных организаций. В качестве весов используются доходы соответствующего вида транспорта от перевозок грузов за базисный период.

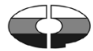


24.1. ИНДЕКСЫ ЦЕН В СЕКТОРАХ ЭКОНОМИКИ

(декабрь к декабрю предыдущего года; в процентах)

\begin{tabular}{|c|c|c|c|c|c|c|c|c|}
\hline & 2000 & 2005 & 2010 & 2013 & 2014 & 2015 & 2016 & 2017 \\
\hline Индекс потребитель- & & & & & & & & \\
\hline $\begin{array}{l}\text { ских цен } \\
\text { из них: }\end{array}$ & 120,2 & 110,9 & 108,8 & 106,5 & 111,4 & 112,9 & 105,4 & 102,5 \\
\hline $\begin{array}{l}\text { продовольственные } \\
\text { товары }\end{array}$ & 117,9 & 109,6 & 112,9 & 107,3 & 115,4 & 114,0 & 104,6 & 101,1 \\
\hline непродовольствен- & & & & & & & & \\
\hline $\begin{array}{l}\text { ные товары } \\
\text { услуги }\end{array}$ & $\begin{array}{l}118,5 \\
133,7\end{array}$ & $\begin{array}{l}106,4 \\
121,0\end{array}$ & $\begin{array}{l}105,0 \\
108,1\end{array}$ & \begin{tabular}{|l}
104,5 \\
108,0
\end{tabular} & $\begin{array}{l}108,1 \\
110,5\end{array}$ & $\begin{array}{l}113,7 \\
110,2\end{array}$ & $\begin{array}{l}106,5 \\
104,9\end{array}$ & $\begin{array}{l}102,8 \\
104,4\end{array}$ \\
\hline $\begin{array}{l}\text { Индекс цен произво- } \\
\text { дителей промышлен- } \\
\text { ных товаров }\end{array}$ & 100 & & & 103,5 & 106.3 & 112,1 & 107.5 & 108,4 \\
\hline $\begin{array}{l}\text { Индекс цен производи- } \\
\text { телей сельскохозяйст- }\end{array}$ & & & & & & & & \\
\hline $\begin{array}{l}\text { венной продукции } \\
\text { Сводныи индекс цен } \\
\text { на продукцию (затра- } \\
\text { ты, услуги) инвестици- }\end{array}$ & 122,2 & 103,0 & 123,6 & 102,7 & 114,1 & 108,5 & 101,8 & 92,2 \\
\hline $\begin{array}{l}\text { онного назначения } \\
\text { из него индекс цен } \\
\text { производителей } \\
\text { на строительную }\end{array}$ & 135,9 & 112,1 & 109,1 & 104,9 & 107,2 & 110,3 & 103,2 & 103,1 \\
\hline $\begin{array}{c}\text { продукцию } \\
\text { Индекс тарифов на }\end{array}$ & 140,5 & 115,8 & 109,6 & 104,3 & 104,6 & 104,1 & 106,6 & 104,9 \\
\hline $\begin{array}{l}\text { VНдекс тарифово на } \\
\text { грузовые перевозки }\end{array}$ & 151,5 & 116,6 & 133,1 & 108,0 & 100,9 & $111,5^{2}$ & 105,6 & 109,0 \\
\hline
\end{tabular}

\section{УРОВЕНЬ И ДИНАМИКА ЦЕН НА ПОТРЕБИТЕЛЬСКОМ РЫНКЕ}

\section{2. ИНДЕКСЫ ПОТРЕБИТЕЛЬСКИХ ЦЕН (ТАРИФОВ) \\ НА ТОВАРЫ И УСЛУГИ}

(к предыдущему месяцу; в процентах)

\begin{tabular}{l|c|c|c|c}
\hline & Bсе товары & \multicolumn{3}{|c}{ из них } \\
\cline { 3 - 5 } & и услуги & $\begin{array}{c}\text { продоволь- } \\
\text { ственные } \\
\text { товары }\end{array}$ & $\begin{array}{c}\text { непродо- } \\
\text { вольствен- } \\
\text { ные товары }\end{array}$ & услуги \\
\hline 2000 & 102,3 & 102,2 & 102,2 & 103,4 \\
Фнварь & 101,0 & 100,5 & 101,3 & 103,0 \\
Марраль & 100,6 & 100,1 & 101,4 & 101,5 \\
Апрель & 100,9 & 100,3 & 101,5 & 102,1 \\
Май & 101,8 & 102,2 & 101,1 & 101,3 \\
Июнь & 102,6 & 103,3 & 100,8 & 103,0 \\
Июль & 101,8 & 101,8 & 100,8 & 103,8 \\
Август & 101,0 & 100,3 & 101,4 & 103,0 \\
Сентябрь & 101,3 & 100,6 & 102,1 & 102,8 \\
Октябрь & 102,1 & 102,1 & 101,9 & 102,4 \\
Ноябрь & 101,5 & 101,5 & 101,5 & 101,6 \\
Декабрь & 101,6 & 101,9 & 101,2 & 101,6
\end{tabular}


Продолжение табл. 24.2

\begin{tabular}{|c|c|c|c|c|}
\hline & \multirow{2}{*}{$\begin{array}{c}\text { Все товары } \\
\text { и услуги }\end{array}$} & \multicolumn{3}{|c|}{ из них } \\
\hline & & \begin{tabular}{|l} 
продоволь- \\
ственные \\
товары $1{ }^{1}$ \\
\end{tabular} & $\begin{array}{c}\text { непродо- } \\
\text { вольствен- } \\
\text { ные товары }\end{array}$ & услуги \\
\hline 2005 & & & & \\
\hline Январь & 102,6 & 101,4 & 100,4 & 108,8 \\
\hline Февраль & 101,2 & 101,4 & 100,4 & 102,2 \\
\hline Март & 101,3 & 102,1 & 100,4 & 101,2 \\
\hline Апрель & 101,1 & 101,7 & 100,5 & 100,8 \\
\hline Май & 100,8 & 101,1 & 100,4 & 100,8 \\
\hline Июнь & 100,6 & 100,7 & 100,3 & 100,9 \\
\hline Июль & 100,5 & 100,3 & 100,4 & 100,9 \\
\hline Август & 99,9 & 99,0 & 100,5 & 100,8 \\
\hline Сентябрь & 100,3 & 99,3 & 101,1 & 100,9 \\
\hline Октябрь & 100,6 & 100,4 & 100,7 & 100,7 \\
\hline Ноябрь & 100,7 & 100,9 & 100,6 & 100,6 \\
\hline $\begin{array}{r}\text { Декабрь } \\
2010\end{array}$ & 100,8 & 101,1 & 100,5 & 100,8 \\
\hline Январь & 101,6 & 101,4 & 100,2 & 103,9 \\
\hline Февраль & 100,9 & 101,3 & 100,3 & 101,0 \\
\hline Март & 100,6 & 101,0 & 100,4 & 100,4 \\
\hline Апрель & 100,3 & 100,3 & 100,3 & 100,2 \\
\hline Май & 100,5 & 100,7 & 100,4 & 100,4 \\
\hline Июнь & 100,4 & 100,5 & 100,2 & 100,4 \\
\hline Июль & 100,4 & 100,3 & 100,3 & 100,6 \\
\hline Август & 100,6 & 100,9 & 100,4 & 100,3 \\
\hline Сентябрь & 100,8 & 101,6 & 100,6 & 100,0 \\
\hline Октябрь & 100,5 & 100,7 & 100,6 & 100,0 \\
\hline Ноябрь & 100,8 & 101,4 & 100,7 & 100,2 \\
\hline $\begin{array}{r}\text { Декабрь } \\
2013\end{array}$ & 101,1 & 102,1 & 100,5 & 100,4 \\
\hline Январь & 101,0 & 101,8 & 100,4 & 100,6 \\
\hline Февраль & 100,6 & 100,8 & 100,4 & 100,4 \\
\hline Март & 100,3 & 100,4 & 100,4 & 100,2 \\
\hline Апрель & 100,5 & 100,7 & 100,4 & 100,5 \\
\hline Май & 100,7 & 101,0 & 100,3 & 100,8 \\
\hline Июнь & 100,4 & 100,5 & 100,2 & 100,6 \\
\hline Июль & 100,8 & 100,0 & 100,1 & 103,1 \\
\hline Август & 100,1 & 99,3 & 100,5 & 100,9 \\
\hline Сентябрь & 100,2 & 100,0 & 100,5 & 100,1 \\
\hline Октябрь & 100,6 & 101,1 & 100,5 & 99,9 \\
\hline Ноябрь & 100,6 & 100,9 & 100,4 & 100,2 \\
\hline Декабрь & 100,5 & 100,8 & 100,2 & 100,6 \\
\hline
\end{tabular}


Продолжение табл. 24.2

\begin{tabular}{|c|c|c|c|c|}
\hline & \multirow{2}{*}{$\begin{array}{c}\text { Все товары } \\
\text { и услуги }\end{array}$} & \multicolumn{3}{|c|}{ из них } \\
\hline & & \begin{tabular}{|c|} 
продоволь- \\
ственные \\
товары 1 1) \\
\end{tabular} & \begin{tabular}{|c|} 
непродо- \\
вольствен- \\
ные товары \\
\end{tabular} & услуги \\
\hline \multicolumn{5}{|l|}{2014} \\
\hline Январь & 100,6 & 101,0 & 100,3 & 100,5 \\
\hline Февраль & 100,7 & 101,2 & 100,4 & 100,4 \\
\hline Март & 101,0 & 101,8 & 100,7 & 100,5 \\
\hline Апрель & 100,9 & 101,3 & 100,6 & 100,7 \\
\hline Май & 100,9 & 101,5 & 100,5 & 100,8 \\
\hline Июнь & 100,6 & 100,7 & 100,4 & 100,9 \\
\hline Июль & 100,5 & 99,9 & 100,4 & 101,4 \\
\hline Август & 100,2 & 99,7 & 100,5 & 100,7 \\
\hline Сентябрь & 100,7 & 101,0 & 100,6 & 100,3 \\
\hline Октябрь & 100,8 & 101,2 & 100,6 & 100,6 \\
\hline Ноябрь & 101,3 & 102,0 & 100,6 & 101,2 \\
\hline Декабрь & 102,6 & 103,3 & 102,3 & 102,2 \\
\hline \multicolumn{5}{|l|}{2015} \\
\hline Январь & 103,9 & 105,7 & 103,2 & 102,2 \\
\hline Февраль & 102,2 & 103,3 & 102,1 & 100,8 \\
\hline Март & 101,2 & 101,6 & 101,4 & 100,3 \\
\hline Апрель & 100,5 & 100,3 & 100,9 & 100,0 \\
\hline Май & 100,4 & 100,1 & 100,5 & 100,5 \\
\hline Июнь & 100,2 & 99,6 & 100,3 & 101,0 \\
\hline Июль & 100,8 & 99,7 & 100,5 & 103,0 \\
\hline Август & 100,4 & 99,3 & 100,8 & 101,3 \\
\hline Сентябрь & 100,6 & 100,4 & 101,1 & 100,0 \\
\hline Октябрь & 100,7 & 101,0 & 101,0 & 99,9 \\
\hline Ноябрь & 100,8 & 101,2 & 100,7 & 100,2 \\
\hline Декабрь & 100,8 & 101,2 & 100,4 & 100,7 \\
\hline \multicolumn{5}{|l|}{2016} \\
\hline Январь & 101,0 & 101,2 & 100,7 & 101,0 \\
\hline Февраль & 100,6 & 100,7 & 100,8 & 100,3 \\
\hline Март & 100,5 & 100,4 & 100,8 & 100,1 \\
\hline Апрель & 100,4 & 100,4 & 100,6 & 100,3 \\
\hline Май & 100,4 & 100,4 & 100,4 & 100,5 \\
\hline Июнь & 100,4 & 100,1 & 100,5 & 100,6 \\
\hline Июль & 100,5 & 100,0 & 100,4 & 101,7 \\
\hline Август & 100,0 & 99,4 & 100,4 & 100,3 \\
\hline Сентябрь & 100,2 & 99,9 & 100,6 & 100,1 \\
\hline Октябрь & 100,4 & 100,8 & 100,5 & 99,7 \\
\hline Ноябрь & 100,4 & 100,7 & 100,4 & 100,0 \\
\hline Декабрь & 100,4 & 100,6 & 100,3 & 100,3 \\
\hline
\end{tabular}


Продолжение табл. 24.2

\begin{tabular}{l|r|r|r|r}
\hline & \multirow{2}{*}{$\begin{array}{c}\text { Все товары } \\
\text { и услуги }\end{array}$} & \multicolumn{3}{|c}{ из них } \\
\cline { 3 - 5 } & & $\begin{array}{c}\text { продоволь- } \\
\text { ственные } \\
\text { товары }\end{array}$ & $\begin{array}{r}\text { непродо- } \\
\text { вольствен- } \\
\text { ные товары }\end{array}$ & услуги \\
Январь & 100,6 & 100,9 & 100,5 & 100,5 \\
Февраль & 100,2 & 100,2 & 100,2 & 100,3 \\
Март & 100,1 & 100,1 & 100,2 & 100,0 \\
Апрель & 100,3 & 100,6 & 100,2 & 100,2 \\
Май & 100,4 & 100,6 & 100,2 & 100,4 \\
Июнь & 100,6 & 101,0 & 100,1 & 100,7 \\
Июль & 100,1 & 99,0 & 100,1 & 101,6 \\
Август & 99,5 & 98,2 & 100,1 & 100,4 \\
Сентябрь & 99,9 & 99,3 & 100,3 & 100,1 \\
Октбрь & 100,2 & 100,4 & 100,3 & 99,8 \\
Ноябрь & 100,2 & 100,2 & 100,3 & 100,1 \\
Декабрь & 100,4 & 100,6 & 100,3 & 100,3 \\
\hline
\end{tabular}

${ }^{1)}$ Включая алкогольные напитки. 


\section{3. БАЗОВЫЙ ИНДЕКС ПОТРЕБИТЕЛЬСКИХ ЦЕН И} ИНДЕКС ПОТРЕБИТЕЛЬСКИХ ЦЕН В 2017 Г.

(на конец месяца; в процентах к декабрю 2016 г.)
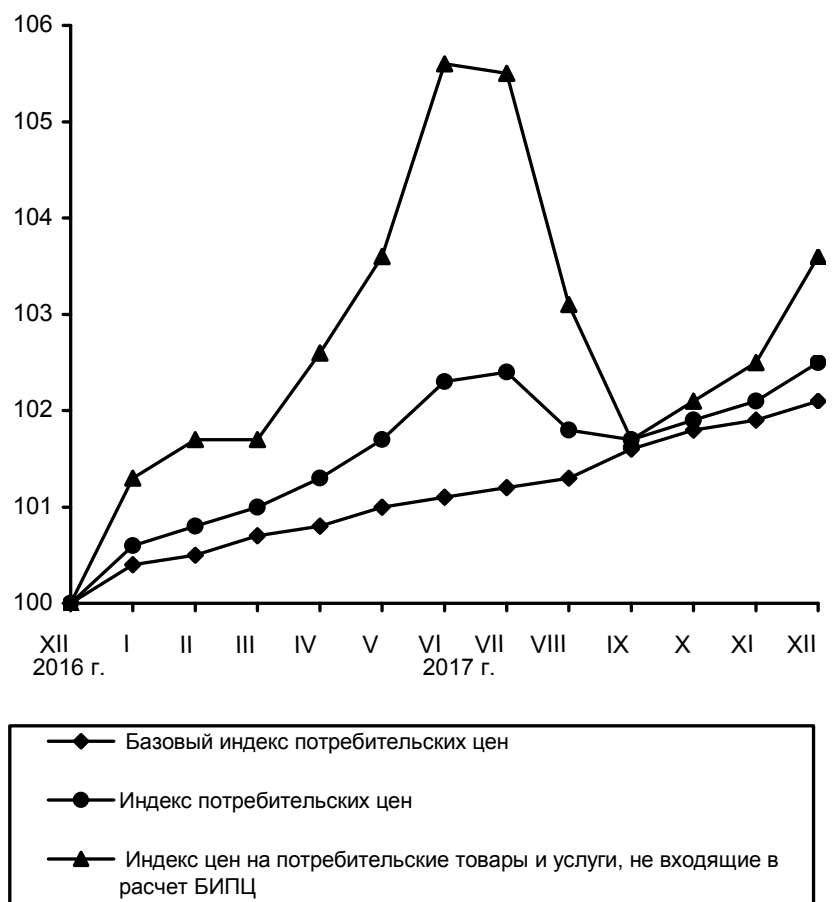

—— Индекс цен на потребительские товары и услуги, не входящие в расчет БИПЦ 
24.4. ИНДЕКСЫ ПОТРЕБИТЕЛЬСКИХ ЦЕН НА ОТДЕЛЬНЫЕ ГРУППЫ ПРОДОВОЛЬСТВЕННЫХ ТОВАРОВ (декабрь к декабрю предыдущего года; в процентах; 1992 г. - в разах)

\begin{tabular}{|c|c|c|c|c|c|c|c|c|c|}
\hline & 1992 & 2000 & 2005 & 2010 & 2013 & 2014 & 2015 & 2016 & 2017 \\
\hline $\begin{array}{l}\text { Продовольственные } \\
\text { товары }\end{array}$ & 26,3 & 117,9 & 109,6 & 112,9 & 107,3 & 115,4 & 114,0 & 104,6 & 101,1 \\
\hline Мясо и птица & 19,3 & 128,3 & 118,6 & 105,3 & 97,0 & 120,1 & 104,3 & 101,6 & 97,7 \\
\hline $\begin{array}{l}\text { Колбасные изделия } \\
\text { и продукты из мяса }\end{array}$ & & & & & & & & & \\
\hline и птицы & 24,5 & 123,8 & 110,1 & 105,5 & 104,4 & 118,0 & 110,9 & 103,9 & 102,4 \\
\hline Консервы мясные & 17,5 & 108,7 & 114,4 & 105,3 & 105,0 & 118,4 & 122,9 & 104,2 & 102,3 \\
\hline Рыбопродукты & 32,1 & 128,4 & 113,1 & 104,6 & 107,0 & 118,0 & 122,9 & 108,6 & 103,3 \\
\hline Масло сливочное & 42,8 & 104,1 & 108,2 & 123,3 & 118,6 & 114,5 & 110,6 & 120,5 & 109,6 \\
\hline Масло подсолнечное & 35,7 & 90,7 & 102,1 & 127,6 & 97,0 & 105,0 & 137,2 & 103,4 & 91,4 \\
\hline $\begin{array}{l}\text { Молоко и молочная } \\
\text { продукция }\end{array}$ & 49,4 & 121,1 & 110,5 & 116,7 & 113,1 & 114,4 & 111,5 & 109,5 & 105,2 \\
\hline Сыр & 35,8 & 113,6 & 112,0 & 119,9 & 118,0 & 118,2 & 108,7 & 109,9 & 103,7 \\
\hline Яйца & 19,5 & 111,7 & 86,1 & 113,2 & 128,8 & 104,6 & 109,8 & 99,3 & 85,8 \\
\hline Сахар-песок & 55,3 & 170,7 & 99,9 & 122,5 & 102,6 & 140,0 & 112,9 & 94,0 & 76,3 \\
\hline Изделия кондитерские & 38,0 & 109,9 & 106,4 & 106,6 & 105,9 & 110,9 & 124,2 & 106,9 & 101,0 \\
\hline $\begin{array}{l}\text { Хлеб и хлебобулоч- } \\
\text { ные изделия }\end{array}$ & 44,3 & 116,5 & 103,0 & 107,6 & 108,0 & 107,5 & 113,2 & 105,9 & 102,7 \\
\hline Крупа и бобовые & 39,7 & 83,6 & 100,2 & 158,8 & 103,2 & 134,6 & 115,5 & 106,4 & 87,0 \\
\hline Изделия макаронные & 35,9 & 108,4 & 101,9 & 104,7 & 104,7 & 108,4 & 119,5 & 104,5 & 99,3 \\
\hline Напитки алкогольные & 24,7 & 125,0 & 107,6 & 108,3 & 114,6 & 113,7 & 110,7 & 106,4 & 102,9 \\
\hline
\end{tabular}


24.5. ИНДЕКСЫ ПОТРЕБИТЕЛЬСКИХ ЦЕН

НА ОТДЕЛЬНЫЕ ГРУППЫ НЕПРОДОВОЛЬСТВЕННЫХ ТОВАРОВ

(декабрь к декабрю предыдущего года; в процентах; 1992 г. - в разах)

\begin{tabular}{|c|c|c|c|c|c|c|c|c|c|}
\hline & 1992 & 2000 & 2005 & 2010 & 2013 & 2014 & 2015 & 2016 & 2017 \\
\hline $\begin{array}{l}\text { Непродовольствен- } \\
\text { ные товары }\end{array}$ & 26,7 & 118,5 & 106,4 & 105,0 & 104,5 & 108,1 & 113,7 & 106,5 & 102,8 \\
\hline $\begin{array}{l}\text { Ткани хлопчатобу- } \\
\text { мажные }\end{array}$ & 14,9 & 119,0 & 104,3 & 112,9 & 107,4 & 109,0 & 122,9 & 108,4 & 103,9 \\
\hline Ткани шерстяные & 6,6 & 125,1 & 105,9 & 104,2 & 105,3 & 108,1 & 123,7 & 107,4 & 104,5 \\
\hline Ткани шелковые & 10,2 & 119,8 & 105,2 & 103,4 & 104,8 & 107,3 & 119,1 & 107,6 & 103,6 \\
\hline Одежда & 11,3 & 122,9 & 107,5 & 107,1 & 104,7 & 106,2 & 112,6 & 107,2 & 103,0 \\
\hline Верхний трикотаж & 8,0 & 123,0 & 108,3 & 107,2 & 104,3 & 105,5 & 111,2 & 106,7 & 103,0 \\
\hline Бельевой трикотаж & 9,6 & 122,2 & 109,4 & 109,0 & 104,8 & 107,9 & 117,2 & 109,2 & 103,9 \\
\hline $\begin{array}{l}\text { Изделия чулочно- } \\
\text { носочные }\end{array}$ & 15,0 & 115,1 & 107,0 & 105,5 & 103,9 & 106,8 & 114,2 & 107,3 & 102,0 \\
\hline $\begin{array}{l}\text { Обувь кожаная, } \\
\text { текстильная и }\end{array}$ & & & & & & & & & \\
\hline комбинированная & 17,7 & 124,7 & 106,3 & 106,1 & 104,5 & 105,7 & 115,1 & 109,2 & 104,0 \\
\hline $\begin{array}{l}\text { Средства моющие и } \\
\text { чистящие }\end{array}$ & 32,3 & 102,0 & 106,4 & 104,0 & 104,6 & 109,2 & 122,4 & 106,3 & 100,6 \\
\hline $\begin{array}{l}\text { Товары парфюмер- } \\
\text { но-косметические }\end{array}$ & 14,9 & 111,5 & 106,3 & 104,5 & 104,9 & 108,3 & 121,8 & 109,4 & 103,0 \\
\hline Галантерея & 26,3 & 120,8 & 106,3 & 106,3 & 105,2 & 107,3 & 116,6 & 108,8 & 103,7 \\
\hline Изделия табачные & 36,8 & 103,6 & 105,3 & 119,5 & 129,3 & 127,1 & 126,6 & 117,8 & 108,6 \\
\hline Телерадиотовары & 19,7 & 109,2 & 99,2 & 98,2 & 99,8 & 115,8 & 109,8 & 100,2 & 97,7 \\
\hline $\begin{array}{l}\text { Электротовары и } \\
\text { другие бытовые } \\
\text { приборы }\end{array}$ & 34,6 & 112,6 & 103,0 & 101,2 & 102,1 & 117,9 & 116,8 & 105,7 & 99,4 \\
\hline $\begin{array}{l}\text { Строительные } \\
\text { материалы }\end{array}$ & 29,6 & 126,4 & 109,1 & 104,6 & 102,5 & 104,8 & 110,4 & 105,8 & 103,1 \\
\hline Мебель & 24,9 & 114,4 & 108,0 & 103,9 & 103,6 & 106,4 & 109,6 & 103,3 & 101,9 \\
\hline Часы & 13,9 & 120,7 & 106,6 & 106,1 & 104,8 & 109,4 & 115,1 & 107,3 & 103,1 \\
\hline Изделия ювелирные & 14,9 & 112,0 & 107,0 & 116,9 & 103,1 & 105,3 & 122,9 & 109,0 & 99,8 \\
\hline $\begin{array}{l}\text { Бензин } \\
\text { автомобильный }\end{array}$ & 79,2 & 125,7 & 115,8 & 106,5 & 105,7 & 108,9 & 104,8 & 103,8 & 107,3 \\
\hline
\end{tabular}




\section{6. ИНДЕКСЫ ПОТРЕБИТЕЛЬСКИХ ЦЕН (ТАРИФОВ)} НА ОТДЕЛЬНЫЕ ГРУППЫ УСЛУГ (декабрь к декабрю предыдущего года; в процентах)

\begin{tabular}{|c|c|c|c|c|c|c|c|c|}
\hline & 2000 & 2005 & 2010 & 2013 & 2014 & 2015 & 2016 & 2017 \\
\hline Услуги & 133,7 & 121,0 & 108,1 & 108,0 & 110,5 & 110,2 & 104,9 & 104,4 \\
\hline Бытовые услуги & 121,8 & 115,3 & 106,0 & 107,6 & 106,1 & 107,9 & 105,1 & 102,9 \\
\hline $\begin{array}{l}\text { Услуги пассажир- } \\
\text { ского транспорта }\end{array}$ & 134,8 & 115,8 & 108,7 & 108,9 & 107,3 & 110,7 & 106,6 & 106,8 \\
\hline Услуги связи & 130,7 & 109,1 & 102,2 & 102,2 & 101,3 & 102,9 & 103,7 & 104,7 \\
\hline $\begin{array}{l}\text { Жилищно- } \\
\text { коммунальные } \\
\text { услуги }\end{array}$ & 142,6 & 132,7 & 113,0 & 109,8 & 109,4 & 110,1 & 105,4 & 104,6 \\
\hline жилищные & 138,6 & 136,1 & 107,9 & 105,4 & 119,0 & 112,1 & 105,5 & 104,8 \\
\hline коммунальные & 144,7 & 131,5 & 115,3 & 111,2 & 105,3 & 109,1 & 105,3 & 104,6 \\
\hline $\begin{array}{l}\text { Услуги дошкольно- } \\
\text { го воспитания }\end{array}$ & 116,7 & 132,1 & 107,7 & 109,9 & 115,6 & 116,8 & 109,3 & 105,2 \\
\hline $\begin{array}{l}\text { Услуги организаций } \\
\text { культуры }\end{array}$ & 140,2 & 117,7 & 108,6 & 110,5 & 109,9 & 107,2 & 105,8 & 104,5 \\
\hline $\begin{array}{l}\text { Экскурсионные } \\
\text { услуги }\end{array}$ & 126,0 & 115,5 & 104,8 & 115,0 & 113,4 & 107,1 & 107,6 & 102,3 \\
\hline $\begin{array}{l}\text { Санаторно- } \\
\text { оздоровительные } \\
\text { услуги }\end{array}$ & 134,7 & 111,2 & 105,4 & 105,7 & 107,6 & 114,4 & 107,3 & 102,4 \\
\hline $\begin{array}{l}\text { Медицинские } \\
\text { услуги }\end{array}$ & 122,9 & 118,7 & 108,4 & 109,0 & 109,2 & 111,1 & 107,8 & 105,0 \\
\hline $\begin{array}{l}\text { Услуги физической } \\
\text { культуры и спорта }\end{array}$ & 131,9 & 118,6 & 107,2 & 106,0 & 105,1 & 104,8 & 104,7 & 103,9 \\
\hline $\begin{array}{l}\text { Услуги правового } \\
\text { характера }\end{array}$ & 103,8 & 100,1 & 112,0 & 107,8 & 110,5 & 116,0 & 111,4 & 104,3 \\
\hline
\end{tabular}


24.7. СРЕДНИЕ ПОТРЕБИТЕЛЬСКИЕ ЦЕНЫ НА ОТДЕЛЬНЫЕ ВИДЫ ПРОДОВОЛЬСТВЕННЫХ ТОВАРОВ (на конец года; рублей за килограмм; 1992 г. - тыс. руб.)

\begin{tabular}{|c|c|c|c|c|c|c|c|c|c|}
\hline & 1992 & 2000 & 2005 & 2010 & 2013 & 2014 & 2015 & 2016 & 2017 \\
\hline $\begin{array}{l}\text { Говядина (кроме } \\
\text { бескостного мяса) }\end{array}$ & 0,22 & 52,72 & 115,77 & 197,64 & 244,55 & 272,28 & 314,94 & 315,02 & 320,34 \\
\hline $\begin{array}{l}\text { Свинина (кроме } \\
\text { бескостного мяса) }\end{array}$ & 0,26 & 58,45 & 131,64 & 198,35 & 214,18 & 272,36 & 271,08 & 264,32 & 255,87 \\
\hline $\begin{array}{l}\text { Куры охлажден- } \\
\text { ные и мороже- } \\
\text { Hые }^{1)}\end{array}$ & 0,19 & 48,80 & 81,35 & 105,14 & 107,03 & 136,14 & 133,73 & 138,49 & 126,29 \\
\hline Колбаса вареная ${ }^{2)}$ & 0,27 & 77,97 & 142,85 & 235,96 & 302,94 & 310,54 & 344,81 & 351,27 & 360,88 \\
\hline $\begin{array}{l}\text { Говядина, свини- } \\
\text { на тушеная кон- } \\
\text { сервированная, } \\
\text { за условную бан- } \\
\text { ку весом } 350 \text { г }\end{array}$ & 0,16 & 19,52 & 37,01 & 63,79 & 79,33 & 94,42 & 117,04 & 121,37 & 125,21 \\
\hline $\begin{array}{l}\text { Рыба мороженая } \\
\text { неразделанная }\end{array}$ & 0,13 & 29,54 & 55,76 & 79,22 & 90,79 & 110,65 & 138,16 & 147,68 & 153,03 \\
\hline $\begin{array}{l}\text { Рыба соленая, } \\
\text { маринованная, } \\
\text { копченая }\end{array}$ & 0,27 & 61,22 & 130,65 & 215,55 & 252,52 & 292,21 & 352,58 & 382,54 & 388,83 \\
\hline $\begin{array}{l}\text { Консервы рыб- } \\
\text { ные натуральные } \\
\text { и с добавлением } \\
\text { масла, за услов- } \\
\text { ную банку весом }\end{array}$ & & & & & & & & & \\
\hline 350 г & 0,12 & 21,15 & 30,79 & 51,46 & 60,50 & 70,12 & 91,94 & 103,94 & 109,09 \\
\hline Масло сливочное & 0,41 & 69,12 & 102,42 & 239,55 & 308,92 & 357,54 & 397,75 & 477,13 & 528,83 \\
\hline $\begin{array}{l}\text { Масло подсол- } \\
\text { нечное }\end{array}$ & 0,19 & 23,20 & 40,06 & 72,60 & 75,47 & 78,09 & 107,62 & 110,10 & 100,16 \\
\hline $\begin{array}{l}\text { Молоко питьевое } \\
\text { цельное пасте- } \\
\text { ризованное } 2,5- \\
3,2 \% \text { жирности, } \\
\text { за л } 6 \text { ж) }\end{array}$ & 0,02 & 9,70 & 17,35 & 31,99 & 38,64 & 43,81 & 47,61 & 51,44 & 53,45 \\
\hline $\begin{array}{l}\text { Сыры сычужные } \\
\text { твердые и мягкие }\end{array}$ & 0,42 & 85,17 & 138,72 & 263,20 & 326,89 & 388,81 & 418,61 & 461,71 & 478,88 \\
\hline $\begin{array}{l}\text { Яйца куриные, } \\
\text { за } 10 \text { шт. }\end{array}$ & 0,09 & 16,57 & 24,50 & 38,56 & 56,01 & 58,76 & 65,02 & 64,17 & 54,63 \\
\hline Сахар-песок & 0,14 & 15,62 & 19,69 & 40,62 & 32,32 & 44,97 & 52,14 & 48,78 & 36,75 \\
\hline $\begin{array}{l}\text { Чай черный, } \\
\text { байховый }\end{array}$ & 1,14 & 144,19 & 193,61 & 348,21 & 422,62 & 496,40 & 685,73 & 759,21 & 765,93 \\
\hline Мука пшеничная & 0,05 & 8,08 & 11,91 & $\mid 21,45$ & 26,83 & 29,46 & 32,78 & 33,27 & 32,11 \\
\hline
\end{tabular}


Продолжение табл. 24.7

\begin{tabular}{|c|c|c|c|c|c|c|c|c|c|}
\hline & 1992 & 2000 & 2005 & 2010 & 2013 & 2014 & 2015 & 2016 & 2017 \\
\hline $\begin{array}{l}\text { Хлеб и булоч- } \\
\text { ные изделия из } \\
\text { пшеничной муки }\end{array}$ & & & & & & & & & \\
\hline высшего сорта & 0,04 & 12,19 & 22,24 & 42,60 & 55,11 & 58,75 & 64,80 & 67,61 & 68,92 \\
\hline Рис шлифованный & 0,09 & 13,03 & 21,36 & 42,14 & 43,51 & 53,03 & 67,87 & 63,98 & 62,83 \\
\hline $\begin{array}{l}\text { Изделия мака- } \\
\text { ронные из пше- } \\
\text { ничной муки }\end{array}$ & & & & & & & & & \\
\hline высшего сорта & 0,07 & 17,52 & 25,68 & 47,77 & 50,67 & 55,18 & 66,01 & 68,41 & 67,61 \\
\hline Картофель & 0,03 & 5,19 & 9,72 & 28,94 & 23,18 & 26,66 & 19,91 & 20,25 & 22,25 \\
\hline $\begin{array}{l}\text { Капуста белоко- } \\
\text { чанная свежая }\end{array}$ & 0,03 & 4,75 & 10,21 & 28,22 & 17,30 & 25,55 & 22,68 & 17,96 & 16,14 \\
\hline Лук репчатый & 0,03 & 6,11 & 12,77 & 27,41 & 21,36 & 26,47 & 24,64 & 21,28 & 21,22 \\
\hline Яблоки & 0,11 & 22,02 & 36,87 & 62,37 & 63,26 & 76,70 & 87,43 & 81,92 & 88,57 \\
\hline $\begin{array}{l}\text { Водка крепостью } \\
40 \% \text { об. спирта и }\end{array}$ & & & & & & & & & \\
\hline $\begin{array}{l}\text { выше }{ }^{7)} \text {, за л } \\
\text { Коньяк ординар- } \\
\text { ный отечествен- } \\
\text { ый }\end{array}$ & 0,50 & 84,05 & 148,89 & 230,22 & 406,51 & 547,02 & 559,21 & 583,00 & 600,59 \\
\hline $\begin{array}{l}\text { Вино игристое } \\
\text { отечественное }{ }^{9} \text {, }\end{array}$ & & & & & & & $\mid$ & 1021,04 & 1000,04 \\
\hline за л & 1,16 & 93,38 & 124,39 & 183,93 & 235,28 & 253,64 & 283,72 & 306,22 & 320,63 \\
\hline $\begin{array}{l}\text { Пиво отечест- } \\
\text { венное, за л }\end{array}$ & 0,06 & 20,06 & 31,00 & 56,14 & 77,18 & 87,37 & 98,36 & 105,68 & 110,22 \\
\hline
\end{tabular}

Регистрировались цены на следующие продовольственные товары:

1) в 1992 г. - мясо птицы;

2) в 2000 - 2013 гг. - колбаса вареная высшего сорта;

3) в 1992 г. - рыба мороженая (кроме деликатесной);

4) в 1992 г. - масло животное;

5) в 1992 г. - масло растительное;

6) в 2005 г. - молоко цельное пастеризованное, стерилизованное 2,5-3,2\% жирности;

7) в 1992 г. - водка; в 2000 - 2013 гг. - водка крепостью 40\% об. спирта и выше обыкновенного качества;

8) в 1992 г. - коньяк;

9) в 1992 г . - шампанское. 
24.8. СООТНОШЕНИЕ ПОТРЕБИТЕЛЬСКИХ ЦЕН НА ОСНОВНЫЕ ВИДЫ ПРОДОВОЛЬСТВЕННЫХ ТОВАРОВ С ЦЕНОЙ НА ГОВЯДИНУ')

(на конец года; в процентах)

\begin{tabular}{|c|c|c|c|c|c|c|c|c|c|}
\hline & 1992 & 2000 & 2005 & 2010 & 2013 & 2014 & 2015 & 2016 & 2017 \\
\hline $\begin{array}{l}\text { Говядина (кроме } \\
\text { бескостного мяса) }\end{array}$ & 100 & 100 & 100 & 100 & 100 & 100 & 100 & 100 & 100 \\
\hline $\begin{array}{l}\text { Рыба мороженая } \\
\text { неразделанная }\end{array}$ & 59 & 56 & 48 & 40 & 37 & 41 & 44 & 47 & 48 \\
\hline Масло сливочное & 186 & 131 & 88 & 121 & 126 & 131 & 126 & 151 & 165 \\
\hline $\begin{array}{l}\text { Масло подсолнечное } \\
\text { Молоко питьевое } \\
\text { цельное пастеризо- } \\
\text { ванное } 2,5-3,2 \%\end{array}$ & 86 & 44 & 35 & 37 & 31 & 29 & 34 & 35 & 31 \\
\hline жирности & 10 & 18 & 15 & 16 & 16 & 16 & 15 & 16 & 17 \\
\hline Яйца куриные & 39 & 31 & 21 & 20 & 23 & 22 & 21 & 20 & 17 \\
\hline Сахар-песок & 61 & 30 & 17 & 21 & 13 & 17 & 17 & 15 & 11 \\
\hline $\begin{array}{l}\text { Хлеб и булочные } \\
\text { изделия из пшенич- } \\
\text { ной муки высшего } \\
\text { сорта }\end{array}$ & 20 & 23 & 19 & 22 & 23 & 22 & 21 & 21 & 22 \\
\hline $\begin{array}{l}\text { Рис шлифованный } \\
\text { Изделия макаронные } \\
\text { из пшеничной муки }\end{array}$ & 39 & 25 & 18 & 21 & 18 & 19 & 22 & 20 & 20 \\
\hline высшего сорта & 34 & 33 & 22 & 24 & 21 & 20 & 21 & 22 & 21 \\
\hline Картофель & 16 & 10 & 8 & 15 & 9 & 10 & 6 & 6 & 7 \\
\hline $\begin{array}{l}\text { Капуста белокочанная } \\
\text { свежая }\end{array}$ & 12 & 9 & 9 & 14 & 7 & 9 & 7 & 6 & 5 \\
\hline Лук репчатый & 16 & 12 & 11 & 14 & 9 & 10 & 8 & 7 & 7 \\
\hline Яблоки & 48 & 42 & 32 & 32 & 26 & 28 & 28 & 26 & 28 \\
\hline $\begin{array}{l}\text { Водка крепостью } 40 \% \\
\text { об. спирта и выше }\end{array}$ & 226 & 159 & 129 & 116 & 166 & 201 & 178 & 185 & 187 \\
\hline
\end{tabular}

1) Цены за килограмм, литр, 10 штук. 


\section{9. СРЕДНИЕ ПОТРЕБИТЕЛЬСКИЕ ЦЕНЫ НА ОТДЕЛЬНЫЕ ВИДЫ НЕПРОДОВОЛЬСТВЕННЫХ ТОВАРОВ}

(на конец года; рублей за штуку; 1992 г. - тыс. руб.)

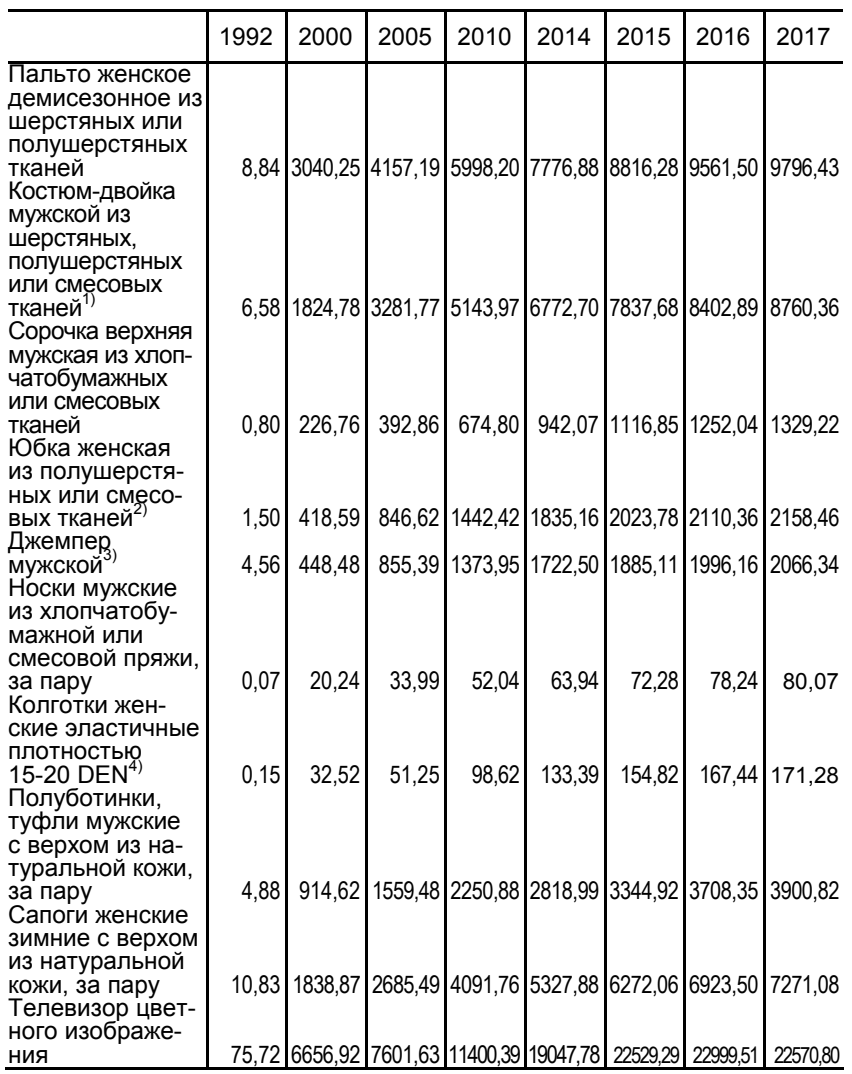

Регистрировались цены на следующие непродовольственные товары:

1) в 1992, 2000, 2005 гг. - костюм-двойка мужской из шерстяных или полушерстяных тканей;

2) в 2000 г. - юбка женская из шерстяных или полушерстяных тканей;

3) в 1992 г. - джемпер, свитер, жакет для взрослых;

4) в 1992 г. - колготки женские. 


\subsection{0. СРЕДНИЕ ПОТРЕБИТЕЛЬСКИЕ ЦЕНЫ (ТАРИФЫ) НА ОТДЕЛЬНЫЕ ВИДЫ УСЛУГ}

(на конец года; рублей за один вид услуг)

\begin{tabular}{|c|c|c|c|c|c|c|c|}
\hline & 2000 & 2005 & 2010 & 2014 & 2015 & 2016 & 2017 \\
\hline $\begin{array}{l}\text { Проезд в городском } \\
\text { муниципальном авто- } \\
\text { бусе, за поездку }\end{array}$ & 2,62 & 6,58 & 12,90 & 17,50 & 19,76 & 21,03 & 24,87 \\
\hline $\begin{array}{l}\text { Проезд в купейном ва- } \\
\text { гоне скорого нефир- } \\
\text { менного поезда даль- } \\
\text { него следования, в }\end{array}$ & & & & & & & \\
\hline расчете на 100 км пути & 29,00 & 117,91 & 240,08 & 275,30 & 313,62 & 300,73 & 309,25 \\
\hline $\begin{array}{l}\text { Абонентская плата за } \\
\text { неограниченный объ- } \\
\text { ем местных }\end{array}$ & & & & & & & \\
\hline $\begin{array}{l}\text { телефонных соедине- } \\
\text { ний, за месяц }\end{array}$ & 52,63 & 189,15 & 348,76 & 422,98 & 430,75 & 434,85 & 446,64 \\
\hline $\begin{array}{l}\text { Плата за жилье } \\
\text { в домах государствен- } \\
\text { ного и муниципального }\end{array}$ & & & & & & & \\
\hline 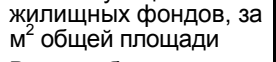 & 1,30 & 7,50 & 14,28 & 21,98 & 24,84 & 25,92 & 28,87 \\
\hline $\begin{array}{l}\text { Водоснабжение } \\
\text { холодное и водоотве- } \\
\text { дение, за месяц } \\
\text { с человека }\end{array}$ & 15,86 & 94,11 & 212,98 & & $\ldots$ & $\ldots$ & \\
\hline $\begin{array}{l}\text { Водоснабжение } \\
\text { холодное, за м }\end{array}$ & & $\cdots$ & $\ldots$ & 21,42 & 23,64 & 25,04 & 26,64 \\
\hline Водоотведение, за м³ & $\ldots$ & $\ldots$ & $\ldots$ & 17,01 & 18,90 & 20,24 & 21,80 \\
\hline $\begin{array}{l}\text { Отопление, за м² об- } \\
\text { щей площади }\end{array}$ & 1,61 & 9,77 & 21,03 & & & & \\
\hline Отопление, за Гкал & $\ldots$ & $\ldots$ & $\ldots$ & 1490,71 & 1649,18 & 1735,87 & 1771,19 \\
\hline $\begin{array}{l}\text { Газ сетевой, за месяц } \\
\text { с человека }\end{array}$ & 5,66 & 18,08 & 43,81 & 63,89 & 67,56 & 68,24 & 73,04 \\
\hline Газ сетевой, за м³ & $\ldots$ & $\ldots$ & $\ldots$ & 5,16 & 5,51 & 5,65 & 5,91 \\
\hline $\begin{array}{l}\text { Электроэнергия } \\
\text { в квартирах без элек- } \\
\text { троплит, за минималь- } \\
\text { ный объем потребле- } \\
\text { ния }^{1)} \text {, в расчете за } 100\end{array}$ & & & & & & & \\
\hline КВт.ч & 39,16 & 110,62 & 232,03 & 314,95 & 333,42 & 359,02 & 371,44 \\
\hline $\begin{array}{l}\text { Посещение детского } \\
\text { ясли-сада, за день }\end{array}$ & 9,19 & 26,53 & 54,86 & 76,55 & 85,19 & 93,12 & 97,94 \\
\hline
\end{tabular}

1) В 2005, 2010 гг. - электроэнергия в квартирах без электроплит. 


\section{УРОВЕНЬ И ДИНАМИКА ЦЕН НА РЫНКЕ ЖИЛЬЯ}

\subsection{1. ИНДЕКСЫ ЦЕН НА ПЕРВИЧНОМ И ВТОРИЧНОМ РЫНКАХ ЖИЛЬЯ}

(на конец года; в процентах к концу предыдущего периода)

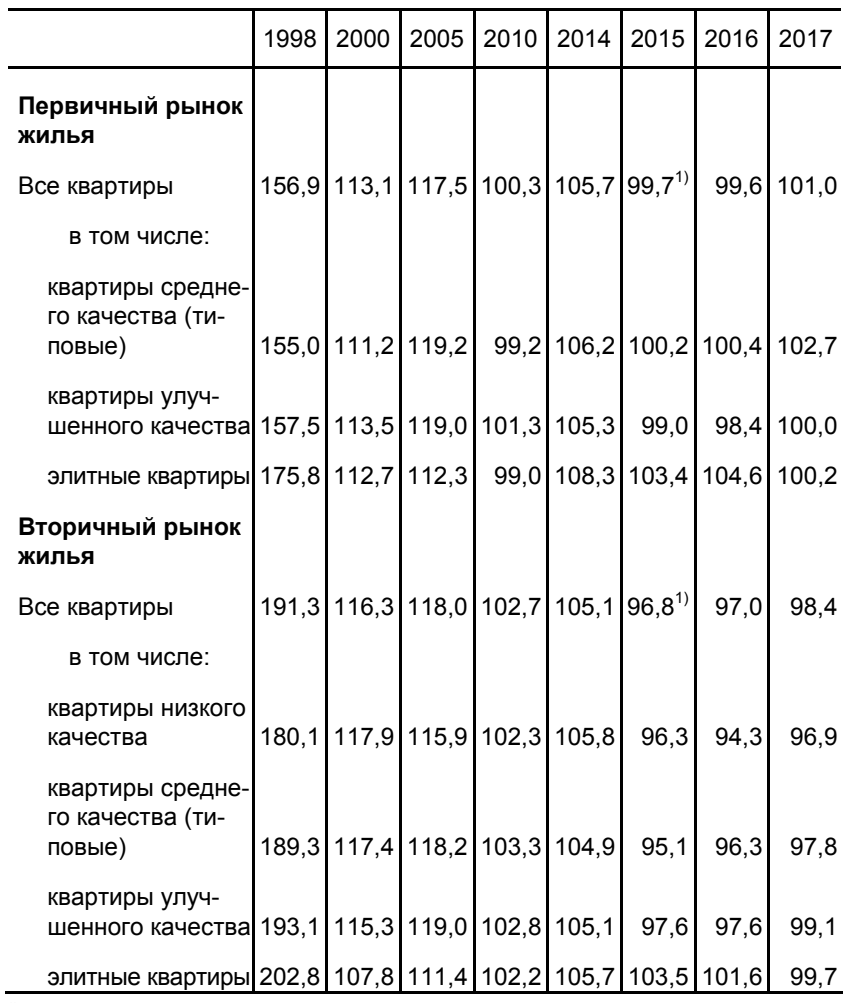

\footnotetext{
${ }^{1)}$ Без учета данных по Крымскому федеральному округу.
} 


\subsection{2. СРЕДНИЕ ЦЕНЫ НА ПЕРВИЧНОМ И ВТОРИЧНОМ РЫНКАХ ЖИЛЬЯ ${ }^{1)}$}

(на конец года; рублей за один квадратный метр общей площади)

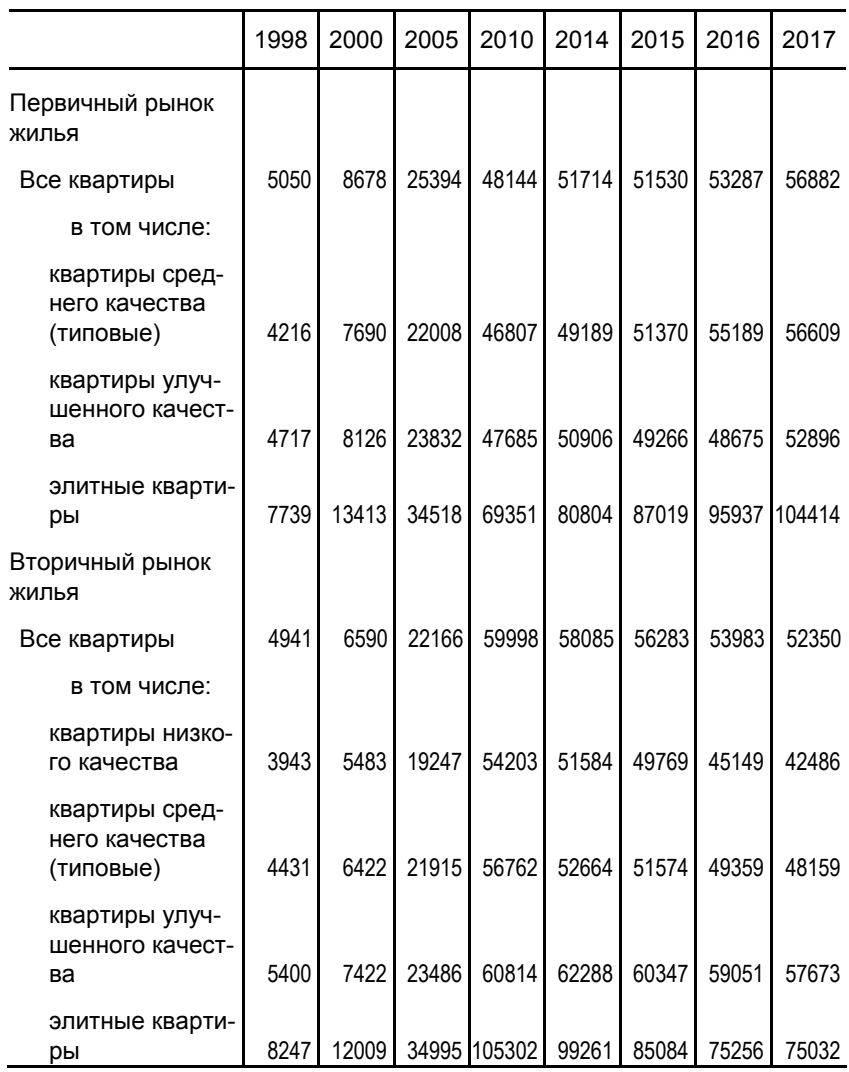

1) Изменение средних цен на рынке жилья может отличаться от индексов цен, так как средние цены рассчитываются как средневзвешенные значения по тому виду квартир, реализация которых осуществлялась в отчетном периоде. 


\section{УРОВЕНЬ И ДИНАМИКА ЦЕН ПРОИЗВОДИТЕЛЕЙ}

\subsection{3. ИНДЕКСЫ ЦЕН ПРОИЗВОДИТЕЛЕЙ \\ ПО ВИДАМ ЭКОНОМИЧЕСКОЙ ДЕЯТЕЛЬНОСТИ}

(декабрь к декабрю предыдущего года; в процентах)

\begin{tabular}{l}
\hline \\
Производство промышленных \\
товаров \\
Добыча полезных ископаемых \\
добыча угля \\
добыча сырой нести и при- \\
родного газа \\
добыча металлических руд \\
добыча прочих полезных \\
ископаемых \\
Обрабатывающие \\
производства \\
производство пищевых \\
продуктов \\
производство напитков \\
производство табачных из- \\
делий \\
производство текстильных \\
изделий \\
производство одежды \\
производство кожи и изде- \\
лий из кожи \\
обработка древесины и \\
производство изделий из \\
дерева и пробки, кроме ме- \\
бели, производство изде- \\
лий из соломки и материа- \\
лов для плетения \\
производство бумаги и бу- \\
мажных изделий \\
деятельность полиграфи- \\
ческая и копирование носи- \\
телей информации \\
производство кокса и нефр- \\
тепродуктов \\
производство химических \\
веществ и химических про- \\
дуктов
\end{tabular}

\begin{tabular}{|c|c|c|c|c|}
\hline 103,5 & 106,3 & 112,1 & 107,5 & 108,4 \\
\hline 107,7 & 97,6 & 111,0 & 108,5 & 123,9 \\
\hline 95,6 & 105,0 & 114,0 & 152,1 & 99,7 \\
\hline 107,9 & 95,4 & 110,9 & 106,7 & 136,4 \\
\hline 92,4 & 115,6 & 112,9 & 111,7 & 107,9 \\
\hline 106,3 & 109,4 & 116,3 & 100,6 & 97,1 \\
\hline 101,3 & 109,2 & 113,2 & 107,6 & 104,2 \\
\hline 100,7 & 116,3 & 115,0 & 103,9 & 95,3 \\
\hline 107,1 & 111,2 & 109,1 & 104,7 & 100,9 \\
\hline 110,3 & 107,5 & 138,7 & 99,3 & 83,5 \\
\hline 103,2 & 112,6 & 111,7 & 104,4 & 100,6 \\
\hline & 104,3 & 113,0 & 103,5 & 101,2 \\
\hline 100,5 & 108,8 & 119,6 & 114,1 & 100,8 \\
\hline
\end{tabular}


Продолжение табл. 24.13

\begin{tabular}{|c|c|c|c|c|c|}
\hline & 2013 & 2014 & 2015 & 2016 & 2017 \\
\hline $\begin{array}{l}\text { производство лекарствен- } \\
\text { ных средств и материалов, } \\
\text { применяемых в медицин- } \\
\text { ских целях }\end{array}$ & 102,9 & 106,3 & 117,9 & 103,7 & 99,8 \\
\hline $\begin{array}{l}\text { производство резиновых и } \\
\text { пластмассовых изделий }\end{array}$ & 101,7 & 107,8 & 116,5 & 104,5 & 98,9 \\
\hline $\begin{array}{l}\text { производство прочей неме- } \\
\text { таллической минеральной } \\
\text { продукции }\end{array}$ & 100,5 & 102,4 & 104,3 & 105,8 & 104,5 \\
\hline $\begin{array}{l}\text { производство металлурги- } \\
\text { ческое }\end{array}$ & 95,4 & 119,8 & 114,0 & 119,5 & 105,4 \\
\hline $\begin{array}{l}\text { производство готовых ме- } \\
\text { таллических изделий, кро- } \\
\text { ме машин и оборудования }\end{array}$ & 100,4 & 103,8 & 109,2 & 108,1 & 104,2 \\
\hline $\begin{array}{l}\text { производство компьютеров, } \\
\text { электронных и оптических } \\
\text { изделий }\end{array}$ & 104,1 & 107,1 & 112,7 & 103,5 & 102,3 \\
\hline $\begin{array}{l}\text { производство электриче- } \\
\text { ского оборудования }\end{array}$ & 99,4 & 113,8 & 114,5 & 104,0 & 102,5 \\
\hline $\begin{array}{l}\text { производство машин и обо- } \\
\text { рудования, не включенных } \\
\text { в другие группировки }\end{array}$ & 101,9 & 105,6 & 124,2 & 109,4 & 104,0 \\
\hline $\begin{array}{l}\text { производство автотранс- } \\
\text { портных средств, прицепов } \\
\text { и полуприцепов }\end{array}$ & 103,1 & 107,5 & 116,0 & 106,6 & 103,7 \\
\hline $\begin{array}{l}\text { производство прочих транс- } \\
\text { портных средств и обору- } \\
\text { дования }\end{array}$ & 97,9 & 104,9 & 119,6 & 118,4 & 93,5 \\
\hline производство мебели & 103,9 & 101,5 & 117,8 & 101,6 & 102,8 \\
\hline $\begin{array}{l}\text { производство прочих гото- } \\
\text { вых изделий }\end{array}$ & 92,6 & 113,4 & 110,5 & 111,2 & 97,2 \\
\hline $\begin{array}{l}\text { ремонт и монтаж машин и } \\
\text { оборудования }\end{array}$ & 104,6 & 114,3 & 107,3 & 110,2 & 108,6 \\
\hline $\begin{array}{l}\text { Обеспечение электрической } \\
\text { энергией, газом и паром; кон- } \\
\text { диционирование воздуха }\end{array}$ & 109,4 & 104,7 & 108,0 & 104,7 & 106,0 \\
\hline $\begin{array}{l}\text { Водоснабжение; водоотведе- } \\
\text { ние, организация сбора и ути- } \\
\text { лизации отходов, деятельность } \\
\text { по ликвидации загрязнений }\end{array}$ & & & & 109,1 & 110,1 \\
\hline
\end{tabular}




\subsection{4. ИНДЕКСЫ ЦЕН ПРОИЗВОДИТЕЛЕЙ И ПРИОБРЕТЕНИЯ ПРОМЫШЛЕННЫМИ ОРГАНИЗАЦИЯМИ ОСНОВНЫХ ВИДОВ ТОПЛИВНО-ЭНЕРГЕТИЧЕСКИХ РЕСУРСОВ}

(на конец года; в процентах к концу предыдущего года)

\begin{tabular}{l|r|r|r|r|r|r|r|r}
\hline & 2000 & 2005 & 2010 & 2013 & 2014 & 2015 & 2016 & 2017 \\
\hline Индексы цен & & & & & & & & \\
Уголь коксующийся & & & & & & & & \\
произодителей & 149,8 & 119,6 & 152,8 & 84,2 & 98,0 & 132,9 & 179,7 & 103,4 \\
приобретения & 207,8 & 98,3 & 154,2 & 89,1 & 100,6 & 127,6 & 155,2 & 110,9 \\
Уголь, за исключе- \\
нием антрацита, уг-
\end{tabular}

1) Электроэнергия собственного производства.

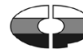


24.15. СРЕДНИЕ ЦЕНЫ ПРИОБРЕТЕНИЯ И ПРОИЗВОДИТЕЛЕЙ ОСНОВНЫХ ВИДОВ ТОПЛИВНО-ЭНЕРГЕТИЧЕСКИХ РЕСУРСОВ И ИХ СООТНОШЕНИЕ

(на конец года; рублей за тонну)

\begin{tabular}{|c|c|c|c|c|c|c|c|c|}
\hline & 2000 & 2005 & 2010 & 2013 & 2014 & 2015 & 2016 & 2017 \\
\hline \multicolumn{9}{|l|}{ Средние цены } \\
\hline Уголь коксующийся & & & & & & & & \\
\hline производителей & 290 & 787 & 1555 & 1590 & 1440 & 2029 & 3809 & 410 \\
\hline приобретения & 928 & 2402 & 5920 & 4045 & 4225 & 5524 & 8524 & 9552 \\
\hline $\begin{array}{l}\text { соотношение цен, } \\
\text { в разах }\end{array}$ & 3,2 & 3,1 & 3,8 & 2,5 & 2,9 & 2,7 & 2,2 & 2 \\
\hline $\begin{array}{l}\text { Уголь, за исключени- } \\
\text { ем антрацита, угля } \\
\text { коксующегося и угля } \\
\text { бурого }\end{array}$ & & & & & & & & \\
\hline производителей & 253 & 453 & 822 & 1283 & 1391 & 1268 & 1497 & 155 \\
\hline приобретения & 390 & 792 & 1308 & 1512 & 1591 & 1658 & 1679 & 1723 \\
\hline $\begin{array}{l}\text { соотношение цен, } \\
\text { в разах }\end{array}$ & 1,5 & 1,7 & 1,6 & 1,2 & 1,1 & 1,3 & 1,1 & 1, \\
\hline $\begin{array}{l}\text { Уголь бурый рядовой } \\
\text { (лигнит) }\end{array}$ & & & & & & & & \\
\hline производителей & 109 & 278 & 405 & 603 & 638 & 637 & 673 & 680 \\
\hline приобретения & 256 & 529 & 895 & 1015 & 1019 & 1114 & 1181 & 1227 \\
\hline $\begin{array}{l}\text { соотношение цен, } \\
\text { в разах }\end{array}$ & 2,3 & 1,9 & 2,2 & 1,7 & 1,6 & 1,7 & 1,8 & 1, \\
\hline Нефть сырая & & & & & & & & \\
\hline производителей & 1546 & 4812 & 7566 & 11328 & 10064 & 11417 & 12607 & 17416 \\
\hline приобретения & 4152 & 6569 & 11045 & 14414 & 9832 & 12325 & 18180 & 2269 \\
\hline $\begin{array}{l}\text { соотношение цен, } \\
\text { в разах }\end{array}$ & 2,7 & 1,4 & 1,5 & 1,3 & 1,0 & 1,1 & 1,4 & 1, \\
\hline $\begin{array}{l}\text { Газ горючий природ- } \\
\text { ный (газ естествен- } \\
\text { ный), за } 1000 \text { м³ }\end{array}$ & & & & & & & & \\
\hline производителей & 86,7 & 330 & 626 & 1301 & 1639 & 1785 & 1434 & 197 \\
\hline приобретения & 468 & 1436 & 3081 & 4638 & 4666 & 5205 & 5055 & 5137 \\
\hline $\begin{array}{l}\text { соотношение цен, } \\
\text { в разах }\end{array}$ & 5,3 & 4,4 & 4,9 & 3,6 & 2,8 & 2,9 & 3,5 & \\
\hline
\end{tabular}


Продолжение табл. 24.15

\begin{tabular}{|c|c|c|c|c|c|c|c|c|}
\hline & 2000 & 2005 & 2010 & 2013 & 2014 & 2015 & 2016 & 2017 \\
\hline $\begin{array}{l}\text { Бензин автомо- } \\
\text { бильный }\end{array}$ & & & & & & & & \\
\hline производителей & 5612 & 9159 & 16699 & 20108 & 20946 & 21995 & 23066 & 26495 \\
\hline приобретения & 8688 & 16984 & 24814 & 35539 & 38496 & 40470 & 43170 & 46131 \\
\hline $\begin{array}{l}\text { соотношение цен, } \\
\text { в разах }\end{array}$ & 1,5 & 1,9 & 1,5 & 1,8 & 1,8 & 1,8 & 1,9 & 1,7 \\
\hline Топливо дизельное & & & & & & & & \\
\hline производителей & 5209 & 12000 & 16340 & 22847 & 23587 & 25463 & 25557 & 29677 \\
\hline приобретения & 7528 & 16830 & 24157 & 36275 & 36622 & 40015 & 39721 & 46998 \\
\hline $\begin{array}{l}\text { соотношение цен, } \\
\text { в разах }\end{array}$ & 1,4 & 1,4 & 1,5 & 1,6 & 1,6 & 1,6 & 1,6 & 1,6 \\
\hline Мазут топочный & & & & & & & & \\
\hline производителей & 2244 & 4108 & 7805 & 7717 & 7242 & 4957 & 7870 & 9566 \\
\hline приобретения & 2966 & 5242 & 12058 & 12357 & 11462 & 70099 & 12431 & 16997 \\
\hline $\begin{array}{l}\text { соотношение цен, } \\
\text { в разах }\end{array}$ & 1,3 & 1,3 & 1,5 & 1,6 & 1,6 & 1,4 & 1,6 & 1,8 \\
\hline $\begin{array}{l}\text { Электроэнергия, } \\
\text { за } 1000 \text { кВт.ч }\end{array}$ & & & & & & & & \\
\hline 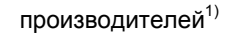 & 191 & 451 & 665 & 910 & 1009 & 989 & 1013 & 1015 \\
\hline приобретения & 410 & 914 & 1539 & 2149 & 2103 & 2189 & 2253 & 2579 \\
\hline $\begin{array}{l}\text { соотношение цен, } \\
\text { в разах }\end{array}$ & 2,1 & 2,0 & 2,3 & 2,4 & 2,1 & 2,2 & 2,2 & 2,5 \\
\hline $\begin{array}{l}\text { Пар и горячая вода, } \\
\text { за Гкал }\end{array}$ & & & & & & & & \\
\hline производителей & 150 & 361 & 686 & 945 & 1007 & 1093 & 1143 & 1241 \\
\hline приобретения & 195 & 411 & 757 & 964 & 997 & 1081 & 1197 & 1266 \\
\hline $\begin{array}{l}\text { соотношение цен, } \\
\text { в разах }\end{array}$ & 1,3 & 1,1 & 1,1 & 1,0 & 1,0 & 1,0 & 1,0 & 1,0 \\
\hline
\end{tabular}

1) Электроэнергия собственного производства. 
24.16. ИНДЕКСЫ ЦЕН ПРОИЗВОДИТЕЛЕЙ

СЕЛЬСКОХОЗЯЙСТВЕННОЙ ПРОДУКЦИИ

(декабрь к декабрю предыдущего года; в процентах)

\begin{tabular}{|c|c|c|c|c|c|c|c|}
\hline & 2000 & 2005 & 2010 & 2014 & 2015 & 2016 & 2017 \\
\hline Сельское хозяйство & 122,2 & 103,0 & 123,6 & 114,1 & 108,5 & 101,8 & 92,2 \\
\hline Растениеводство & 124,7 & 93,9 & 138,3 & 107,6 & 124,7 & 97,1 & 89,1 \\
\hline $\begin{array}{l}\text { Зерновые и } \\
\text { зернобобовые }\end{array}$ & & & & & & & \\
\hline культуры & 133,2 & 85,9 & 131,4 & 104,3 & 120,3 & 98,9 & 88,6 \\
\hline пшеница & 127,7 & 80,2 & 127,8 & 106,3 & 117,6 & 97,4 & 88,4 \\
\hline кукуруза & 129,1 & 88,5 & 143,7 & 103,6 & 126,6 & 103,4 & 83,7 \\
\hline ячмень & 150,9 & 101,9 & 143,8 & 96,2 & 123,6 & 100,0 & 90,6 \\
\hline рожь & 157,9 & 92,2 & 132,7 & 96,2 & 108,3 & 109,3 & 94,1 \\
\hline овес & 141,4 & 100,3 & 120,5 & 95,4 & 107,8 & 108,7 & 98,7 \\
\hline просо & 139,5 & 93,6 & 118,3 & 105,3 & 112,5 & 93,6 & 95,7 \\
\hline гречиха & 106,1 & 92,9 & 259,1 & 136,3 & 149,0 & 118,9 & 53,6 \\
\hline $\begin{array}{l}\text { культуры } \\
\text { зернобобовые }\end{array}$ & 142,1 & 92,4 & 124,4 & 102,1 & 129,4 & 112,8 & 89,5 \\
\hline $\begin{array}{l}\text { Семена } \\
\text { подсолнечника }\end{array}$ & 97,4 & 88,3 & 171,1 & 117,7 & 152,6 & 97,1 & 82,5 \\
\hline Овощи & 119,4 & 128,0 & 147,8 & 99,4 & 109,0 & 94,2 & 107,1 \\
\hline $\begin{array}{l}\text { капуста всех } \\
\text { сортов }\end{array}$ & 110,7 & 137,6 & 212,2 & 130,1 & 107,8 & 78,2 & 94,9 \\
\hline огурцы & 130,6 & 122,5 & 121,5 & 90,5 & 107,4 & 93,3 & 108,9 \\
\hline $\begin{array}{l}\text { томаты } \\
\text { (помидоры) }\end{array}$ & 126,7 & 137,0 & 153,4 & 110,2 & 116,0 & 101,3 & 105,5 \\
\hline морковь столовая & 94,0 & 128,2 & 167,4 & 110,4 & 103,2 & 99,1 & 98,7 \\
\hline лук репчатый & 94,8 & 108,0 & 176,3 & 130,4 & 104,3 & 84,0 & 107,4 \\
\hline свекла столовая & 93,6 & 126,1 & 175,5 & 103,5 & 102,4 & 93,3 & 102,4 \\
\hline Культуры бахчевые & 113,2 & 97,5 & 109,3 & 123,4 & 90,2 & 114,2 & 137,0 \\
\hline Картофель & 99,1 & 116,7 & 201,4 & 116,0 & 83,9 & 95,3 & 110,0 \\
\hline $\begin{array}{l}\text { Корнеплоды свеклы } \\
\text { сахарной }\end{array}$ & 123,9 & 107,3 & 121,1 & 117,0 & 138,1 & 90,9 & 79,8 \\
\hline $\begin{array}{l}\text { Волокно льна- } \\
\text { долгунца }\end{array}$ & 174,8 & 97,9 & 106,3 & 92,3 & 156,2 & 94,5 & 97,1 \\
\hline Виноград & 149,7 & 98,8 & 114,3 & 102,5 & 134,3 & 105,8 & 119,9 \\
\hline Семечковые плоды & 79,4 & 112,5 & 136,7 & 120,9 & 133,2 & 85,7 & 109,9 \\
\hline Косточковые плоды & 123,1 & 94,5 & 134,7 & 116,3 & 114,7 & 98,7 & 112,2 \\
\hline $\begin{array}{l}\text { Ягоды и плоды } \\
\text { растений вида } \\
\text { Vaccinium }\end{array}$ & 126,3 & 118,6 & 111,9 & 98,2 & 111,8 & 111,9 & 105,5 \\
\hline
\end{tabular}


Продолжение табл. 24.16

\begin{tabular}{l|r|r|r|r|r|r|r}
\hline & 2000 & 2005 & 2010 & 2014 & 2015 & 2016 & 2017 \\
\hline $\begin{array}{l}\text { Животноводство } \\
\text { Скот и птица (в жи- }\end{array}$ & 120,7 & 109,0 & 114,9 & 117,5 & 102,4 & 104,5 & 94,1 \\
$\begin{array}{l}\text { вом весе) } \\
\text { крупный рогатый }\end{array}$ & 126,6 & 115,2 & 103,8 & 125,2 & 100,1 & 103,3 & 93,5 \\
$\quad$ скот & 120,8 & 124,4 & 107,9 & 110,8 & 116,1 & 102,5 & 101,3 \\
овцы и козы & 123,4 & 124,4 & 109,5 & 101,9 & 106,6 & 103,4 & 102,8 \\
$\quad$ свиньи & 132,3 & 109,3 & 102,7 & 126,3 & 94,6 & 100,2 & 98,8 \\
птица сельско- \\
хозяйственная
\end{tabular}

\subsection{7. СРЕДНИЕ ЦЕНЫ ПРОИЗВОДИТЕЛЕЙ СЕЛЬСКОХОЗЯЙСТВЕННОЙ ПРОДУКЦИИ}

(в среднем за год; рублей за тонну)

\begin{tabular}{l|r|r|r|r|r|r|r}
\hline & 2000 & 2005 & 2010 & 2014 & 2015 & 2016 & 2017 \\
\hline Зерновые и зерно- & & & & & & & \\
бобовые культуры & 2113 & 2519 & 4017 & 6616 & 8684 & 8923 & 7451 \\
пшеница & 2179 & 2508 & 3867 & 6849 & 8768 & 8837 & 7304 \\
кукуруза & 2616 & 2388 & 4681 & 5799 & 7853 & 8348 & 7030 \\
ячмень & 1822 & 2560 & 3395 & 5516 & 7344 & 7741 & 6782 \\
рожь & 1992 & 2346 & 3411 & 4691 & 5247 & 6149 & 5622 \\
овес & 1637 & 2488 & 3596 & 4965 & 5493 & 6400 & 6520 \\
просо & 1523 & 1860 & 3832 & 5609 & 7365 & 6439 & 5102 \\
гречиха & 4509 & 4581 & 8153 & 8370 & 20137 & 25870 & 15665 \\
культуры зерно- & & & & & & & \\
бобовые & 3365 & 3216 & 5581 & 8458 & 13069 & 16704 & 12275 \\
Семена подсол- & & & & & & & \\
нечника & 2882 & 5672 & 10605 & 11534 & 20284 & 21886 & 17033 \\
Овощи & 6764 & 15788 & 26546 & 36306 & 45490 & 45234 & 47020 \\
капуста всех & 2598 & 5404 & 11029 & 10123 & 15179 & 12217 & 9629 \\
сортов & 12436 & 26972 & 58163 & 62025 & 67896 & 75293 & 75986 \\
огурцы &
\end{tabular}


Продолжение табл. 24.17

\begin{tabular}{|c|c|c|c|c|c|c|c|}
\hline & 2000 & 2005 & 2010 & 2014 & 2015 & 2016 & 2017 \\
\hline $\begin{array}{l}\text { томаты (помидо- } \\
\text { ры) }\end{array}$ & 12595 & 25902 & 52599 & 57961 & 63168 & 62304 & 70969 \\
\hline морковь столовая & 3857 & 6887 & 11309 & 11481 & 14470 & 12344 & 11033 \\
\hline лук репчатый & 3878 & 4873 & 9719 & 10595 & 13982 & 9706 & 9741 \\
\hline свекла столовая & 3513 & 5975 & 8298 & 10403 & 13284 & 10672 & 9250 \\
\hline Культуры бахчевые & 901 & 1168 & 2331 & 8481 & 5844 & 5260 & 6384 \\
\hline Картофрель & 3710 & 5234 & 9501 & 12898 & 13197 & 10248 & 11607 \\
\hline $\begin{array}{l}\text { Корнеплоды свек- } \\
\text { лы сахарной }\end{array}$ & 509 & 965 & 1636 & 1877 & 3072 & 2919 & 2237 \\
\hline $\begin{array}{l}\text { Волокно льна- } \\
\text { долгунца }\end{array}$ & 7018 & 7537 & 13807 & 22824 & 28116 & 22661 & 18215 \\
\hline Виноград & 4232 & 9043 & 15365 & 16780 & 22023 & 24733 & 29946 \\
\hline Семечковые плоды & 5181 & 8418 & 18004 & 22679 & 31309 & 36284 & 32069 \\
\hline $\begin{array}{l}\text { Косточковые } \\
\text { плоды }\end{array}$ & 4487 & 10521 & 25596 & 31561 & 57150 & 58261 & 59227 \\
\hline $\begin{array}{l}\text { Ягоды и плоды } \\
\text { растений вида } \\
\text { Vaccinium }\end{array}$ & 12622 & 22379 & 57469 & 75096 & 117431 & 123353 & 125124 \\
\hline $\begin{array}{l}\text { Скот и птица } \\
\text { (в живом весе) }\end{array}$ & 18437 & 41304 & 56720 & 75256 & 85165 & 82672 & 82580 \\
\hline $\begin{array}{l}\text { крупный рогатый } \\
\text { скот }\end{array}$ & 14142 & 34003 & 55951 & 74405 & 93328 & 96562 & 97558 \\
\hline овцы и козы & 12009 & 29199 & 45174 & 70978 & 79685 & 85818 & 89396 \\
\hline $\begin{array}{l}\text { свиньи } \\
\text { птица сельскохо- } \\
\text { зяйственная }\end{array}$ & 20152 & 50420 & 69748 & 94081 & 103030 & 93976 & 96502 \\
\hline $\begin{array}{l}\text { живая } \\
\text { Молоко сырое } \\
\text { крупного рогатого }\end{array}$ & 20481 & 40813 & 52966 & 63654 & 71275 & 72345 & 68057 \\
\hline $\begin{array}{l}\text { скота } \\
\text { Шерсть стриженая } \\
\text { немытая овец и } \\
\text { коз, включая стри- } \\
\text { женую шерсть, } \\
\text { промытую руном }\end{array}$ & 3633 & 6680 & 12370 & 19614 & 20648 & 21814 & 24487 \\
\hline $\begin{array}{l}\text { Яйца куриные в } \\
\text { скорлупе свежие, } \\
\text { за } 1000 \text { шт. }\end{array}$ & 978 & 1712 & 2341 & 3407 & 4171 & 4184 & 3565 \\
\hline
\end{tabular}




\subsection{8. ИНДЕКСЫ ЦЕН НА ПРОДУКЦИЮ (ЗАТРАТЫ, УСЛУГИ)} ИНВЕСТИЦИОННОГО НАЗНАЧЕНИЯ

(декабрь к декабрю предыдущего года; в процентах)

\begin{tabular}{l|l|l|l|l|l|l|l|l|l}
\hline & 2000 & 2005 & 2009 & 2010 & 2013 & 2014 & 2015 & 2016 & 2017 \\
\hline $\begin{array}{l}\text { Сводный индекс } \\
\text { цен на продукцию } \\
\text { (затраты, услуги) } \\
\text { инвестиционного } \\
\text { назначения }\end{array}$ & 135,9 & 112,1 & 100,1 & 109,1 & 104,9 & 107,2 & 110,3 & 103,2 & 103,1 \\
$\quad \begin{array}{l}\text { из него: } \\
\text { индекс цен произ- } \\
\text { водителей на } \\
\text { строительную } \\
\text { продукцию } \\
\begin{array}{l}\text { индекс цен приоб- } \\
\text { ретения машин и } \\
\text { оборудования ин- } \\
\text { вестиционного на- } \\
\text { значения }\end{array}\end{array}$ & 140,5 & 115,8 & 97,6 & 109,6 & 104,3 & 104,6 & 104,1 & 106,6 & 104,9 \\
\hline
\end{tabular}

24.19. ИНДЕКСЫ ТАРИФОВ НА ГРУЗОВЫЕ ПЕРЕВОЗКИ ОСНОВНЫМИ ВИДАМИ ТРАНСПОРТА

(декабрь к декабрю предыдущего года; в процентах; 1992 г. - в разах)

\begin{tabular}{l|r|r|r|r|r|r|r|r|r}
\hline & 1992 & 2000 & 2005 & 2010 & 2013 & 2014 & $2015^{1)}$ & 2016 & 2017 \\
\hline $\begin{array}{l}\text { Грузовой } \\
\text { транспорт } \\
\quad \text { из него: }\end{array}$ & $\mathbf{3 5 , 6}$ & $\mathbf{1 5 1 , 5}$ & $\mathbf{1 1 6 , 6}$ & $\mathbf{1 3 3 , 1}$ & $\mathbf{1 0 8 , 0}$ & $\mathbf{1 0 0 , 9}$ & $\mathbf{1 1 1 , 5}$ & $\mathbf{1 0 5 , 6}$ & $\mathbf{1 0 9 , 0}$ \\
$\begin{array}{l}\text { железнодорож- } \\
\text { ный }\end{array}$ & & & & & & & & \\
автомобильный & 37,4 & 169,3 & 113,3 & 109,4 & 105,4 & 102,3 & 112,9 & 108,7 & 104,0 \\
трубопроводный & 28,0 & 136,6 & 114,3 & 103,7 & 104,2 & 107,2 & 106,4 & 100,6 & 102,8 \\
морской & 56,5 & 109,3 & 109,4 & 98,9 & 103,3 & 144,1 & 114,4 & 90,1 & 103,4 \\
внутренний & & & & & & & & & \\
водный & 55,6 & 119,2 & 111,0 & 106,7 & 107,5 & 140,0 & 113,5 & 97,8 & 108,3 \\
воздушный & 34,0 & 112,9 & 114,1 & 104,2 & 103,1 & 105,7 & 107,6 & 120,7 & 115,3 \\
\hline
\end{tabular}

${ }^{1)}$ Без учета сведений по Крымскому федеральному округу. 


\section{5. ВНЕШНЕЭКОНОМИЧЕСКАЯ ДЕЯТЕЛЬНОСТЬ}

Раздел содержит данные по статистике внешней торговли (по методологии Платежного баланса) и информацию по статистике внешней торговли (по данным ФТС России), сведения о ценах внешней торговли.

Информация по внешней торговле товарами по методологии Платежного баланса включает:

данные ФТС России, полученные на основе грузовых таможенных деклараций, заполняемых участниками внешнеторговой деятельности, с учетом данных о взаимной торговле с государствами-членами Евразийского экономического союза (ЕАЭС) (Республикой Беларусь, Республикой Казахстан, Республикой Армения, Киргизской Республикой), полученные на основе статистической формы учета перемещения товаров;

данные Росстата по товарам, не пересекающим таможенную границу России (рыба и морепродукты, выловленные (добытые) и проданные вне зоны действия таможенного контроля, топливо и товары, приобретенные российскими (иностранными) транспортными средствами в иностранных (российских) портах), полученные на основе федерального статистического наблюдения;

досчеты Банка России к данным статистики внешней торговли, которые производятся в соответствии с методологическими положениями платежного баланса и включают оценку стоимости товаров, ввезенных (вывезенных) фризическими лицами в пределах установленной беспошлинной квоты и в упрощенном (льготном) порядке, и другие элементы досчетов.

Платежный баланс - это статистический отчет, в котором отражаются все экономические операции между резидентами и нерезидентами, произошедшие в течение отчетного периода. Более подробно с информацией по Платежному балансу можно ознакомится на официальном сайте Банка России по адресу: http://www.cbr.ru \ Статистика \ Макроэкономическая финансовая статистика \Платежный баланс и иные статистические материалы, разработанные по методологии шестого из- 
дания «Руководства по платежному балансу и международной инвестиционной позиции» МВФ (РПБ6).

Экспорт товаров - вывоз товаров с территории Российской Федерации без обязательства об обратном ввозе. Экспорт включает вывоз из страны товаров отечественного производства, а также реэкспорт товаров. К товарам отечественного производства относятся также товары иностранного происхождения, ввезенные в страну и подвергшиеся существенной переработке, изменяющей основные качественные или технические характеристики товаров. К реэкспортным товарам относятся товары, ранее ввезенные на территорию Российской Федерации, а затем вывезенные с этой территории без уплаты таможенных пошлин, налогов и без применения к товарам запретов и ограничений экономического характера.

Учет экспорта товаров производится по ценам франкограницы страны-экспортера (ФОБ), т.е. в цену товара включаются расходы по его доставке до сухопутной границы или до порта отгрузки страны-экспортера.

Импорт товаров - ввоз товаров на территорию Российской Федерации без обязательства об обратном вывозе. В импорт включаются ввезенные товары, предназначенные для потребления в экономике страны, и товары, ввозимые на территорию государства в соответствии с режимом реимпорта. К реимпортным товарам относятся товары, вывезенные с территории Российской Федерации, а затем ввезенные на эту территорию без уплаты таможенных пошлин, налогов и без применения к товарам запретов и ограничений экономического характера.

Учет импорта товаров производится по ценам франкограница страны-импортера (СИФ), т.е в цену товара включаются расходы по страхованию и транспортировке товара до границы страны-импортера.

Удельный вес потребительских, промежуточных и инвестиционных товаров в общем объеме импорта представляет собой отношение стоимости потребительских, промежуточных и инвестиционных товаров к общей стоимости импорта.

Потребительские товары - товары, непосредственно удовлетворяющие потребности человека и предназначенные для семейного и личного потребления.

Промежуточные товары - товары, используемые не для конечного потребления, а для дальнейшего производства товаров и услуг.

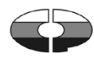


Инвестиционные товары - товары, служащие целям замены, обновления, качественного улучшения основных средств.

Таможенная статистика внешней торговли и статистика взаимной торговли со странами ЕАЭС формируется по всем товарам (в том числе ценностям, за исключением валютных ценностей, находящихся в обращении), ввоз и вывоз которых увеличивает или уменьшает материальные ресурсы страны, и не включает данные по товарам, не пересекающим таможенную границу России (рыба и морепродукты, выловленные (добытые) и проданные вне зоны действия таможенного контроля, топливо и товары, приобретенные российскими (иностранными) транспортными средствами в иностранных (российских) портах), а также данные по ввозу (вывозу) товаров, физическими лицами в пределах установленных беспошлинных квот или перемещаемым через таможенную границу в упрощенном порядке.

Данные ФТС России по товарам сформированы без учета взаимной торговли с Республикой Казахстан с июля по декабрь 2010 г. в связи с отменой таможенного оформления товаров на российско-казахстанской границе с 1 июля 2010 года.

Внешнеторговый оборот по данным ФТС России приведен по состоянию на 6 апреля 2018 года. варов.

Внешнеторговый оборот - сумма экспорта и импорта то-

Сальдо торгового баланса - разница между экспортом и импортом товаров. Положительное сальдо - экспорт превышает импорт, отрицательное сальдо (ставится знак "минус") - импорт превышает экспорт.

Средние фактические экспортные (импортные) цены представляют собой отношение общей стоимости экспортируемого (импортируемого) товара к его количеству.

Информация, содержащаяся в табл. 25.1 представлена по данным Банка России; в табл. 25.2, 25.3, 25.4, 25.7, 25.8, 25.10, 25.11, 25.13, 25.14, 25.15, 25.17, 25.18, 25.20, 25.21, 25.23, 25.24 - по данным ФТС России с учетом взаимной торговли с государствами-членами ЕАЭС: 2000, 2005 гг. с Республикой Беларусь, 2010-2014 гг. с Республикой Беларусь и Республикой Казахстан, 2015 г. с Республикой Армения (с 1 января 2015 г.) и Киргизской Республикой (с 12 августа 2015 г.), Республикой Беларусь, Республикой Казахстан; в табл. 25.5, 25.9, 25.12, 25.16, 25.19, 25.22, 25.25 - по данным ФТС России. 


\section{ВНЕШНЯЯ ТОРГОВЛЯ ТОВАРАМИ}

\section{1. ВНЕШНЯЯ ТОРГОВЛЯ РОССИЙСКОЙ ФЕДЕРАЦИИ ${ }^{1)}$ \\ (по методологии платежного баланса; \\ в фактически действовавших ценах)}

\begin{tabular}{l|r|r|r|r|r|r|r|r}
\hline & 2000 & 2005 & 2010 & 2013 & 2014 & 2015 & 2016 & 2017 \\
\hline & \multicolumn{5}{|c|}{ Миллиардов долларов США } \\
Внешнеторговый & & & & & \\
оборот & 141,4 & 363,9 & $\mathbf{6 3 8 , 4}$ & $\mathbf{8 6 3 , 1}$ & $\mathbf{8 0 4 , 7}$ & $\mathbf{5 3 4 , 4}$ & $\mathbf{4 7 3 , 4}$ & $\mathbf{5 9 1 , 0}$ \\
Экспорт & 99,2 & 240,0 & 392,7 & 521,8 & 496,8 & 341,4 & 281,9 & 353,0 \\
Импорт & 42,1 & 123,8 & 245,7 & 341,3 & 307,9 & 193,0 & 191,6 & 238,0 \\
Сальдо торгового & & & & & & & & \\
баланса & 57,1 & 116,2 & 147,0 & 180,6 & 188,9 & 148,4 & 90,3 & 115,0 \\
$\quad$ в том числе: & & & & & & & \\
со странами даль- \\
него зарубежья
\end{tabular}

1) По данным Банка России. 
25.2. ЭКСПОРТ И ИМПОРТ РОССИЙСКОЙ ФЕДЕРАЦИИ ${ }^{1)}$

(в фрактически действовавших ценах)

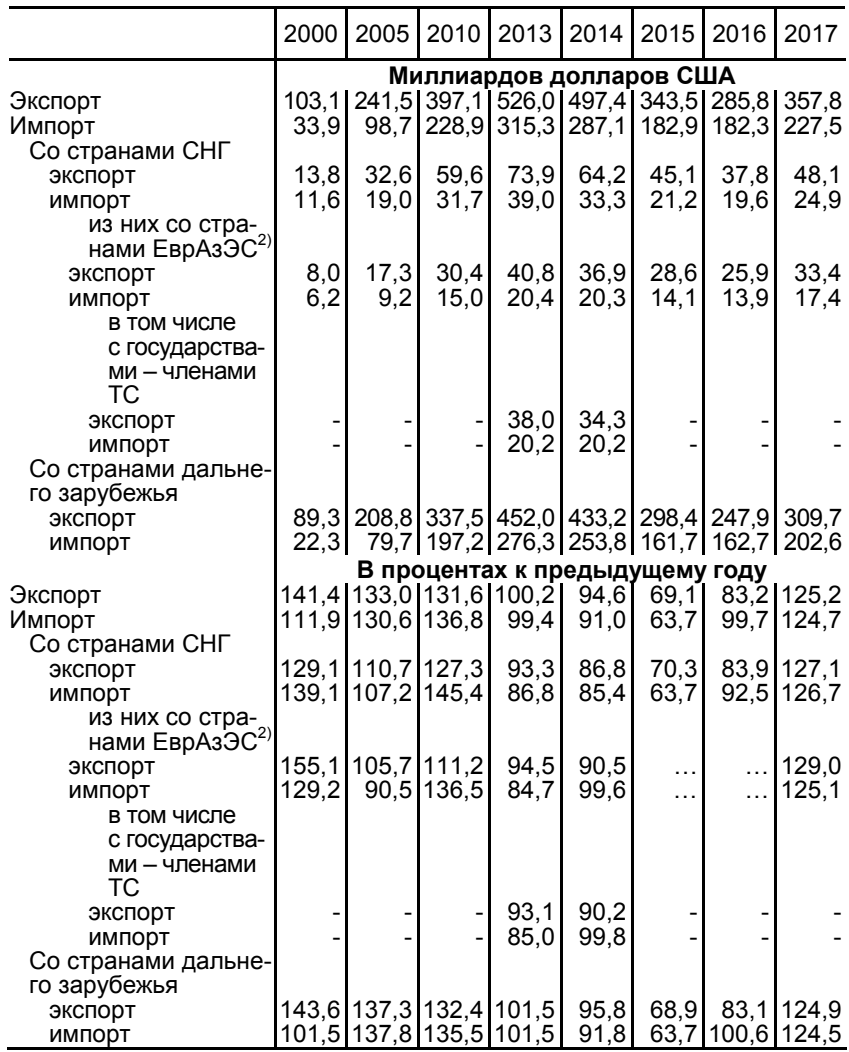

1) Здесь и далее по данным ФТС России с учетом взаимной торговли товарами с государствами-членами ЕАЭС.

2) К странам Евразийского экономического сообщества (ЕврАзЭС) относятся: Республика Беларусь, Республика Казахстан, Киргизская Республика, Российская Федерация, Республика Таджикистан. С 2015 г. - Евразийский экономический союз (ЕАЭС) включает Республику Беларусь, Республику Казахстан, Республику Армения и Киргизскую Республику (начиная с 12 августа 2015 г.).

К государствам - членам Таможенного союза (ТС) относятся: Республика Беларусь, Республика Казахстан, Российская Федерация. 


\section{3. ТОВАРНАЯ СТРУКТУРА ЭКСПОРТА И ИМПОРТА РОССИЙСКОЙ ФЕДЕРАЦИИ}

(в процентах)

\section{Экспорт}

2016

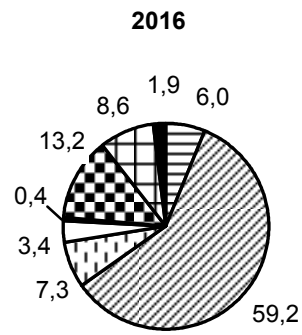

2017

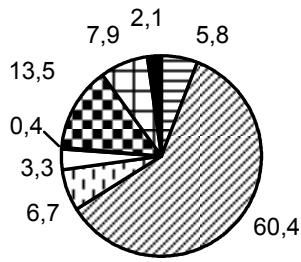

Импорт

2016

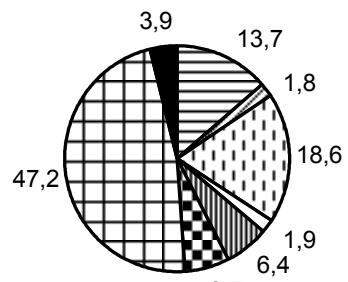

6,5
2017

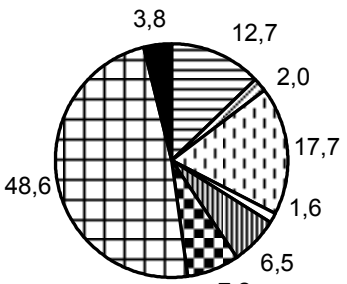

7,2

Продовольственные товары и сельскохозяйственное сырье (кроме текстильного)

В Минеральные продукты

๑ Продукция химической промышленности, каучук

Древесина и целлюлозно-бумажные изделия

Текстиль, текстильные изделия и обувь (включая кожевенное сырье, пушнину и изделия из них)

Металлы, драгоценные камни и изделия из них

Машины, оборудование и транспортные средства

Прочие товары 


\section{4. ВНЕШНЯЯ ТОРГОВЛЯ РОССИЙСКОЙ ФЕДЕРАЦИИ СО СТРАНАМИ СНГ}

(в фактически действовавших ценах; млн. долларов США)

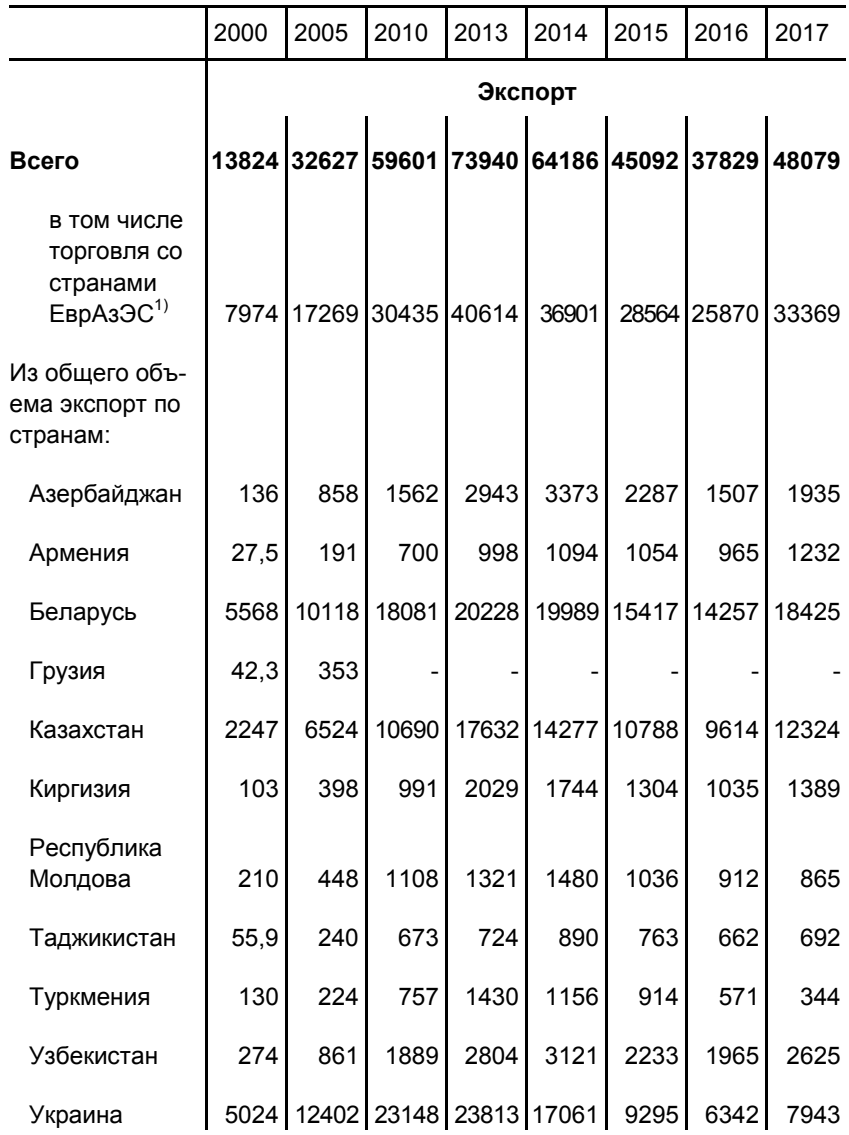


Продолжение табл. 25.4

\begin{tabular}{|c|c|c|c|c|c|c|c|c|}
\hline & 2000 & 2005 & 2010 & 2013 & 2014 & 2015 & 2016 & 2017 \\
\hline & \multicolumn{8}{|c|}{ Импорт } \\
\hline Bcero & 11604 & 18995 & 31728 & 38988 & 33287 & 21210 & 19622 & 24856 \\
\hline $\begin{array}{l}\text { в том числе } \\
\text { торговля со }\end{array}$ & & & & & & & & \\
\hline $\begin{array}{l}\text { странами } \\
\text { ЕврАзЭС }\end{array}$ & 6236 & 9181 & 15009 & 19994 & 20306 & 14106 & 13916 & 17406 \\
\hline Из общего объ- & & & & & & & & \\
\hline ема импорт по & & & & & & & & \\
\hline странам: & & & & & & & & \\
\hline Азербайджан & 135 & 206 & 386 & 636 & 636 & 518 & 446 & 692 \\
\hline Армения & 44,0 & 101 & 159 & 352 & 314 & 214 & 389 & 515 \\
\hline Беларусь & 3710 & 5716 & 9954 & 13959 & 12750 & 9011 & 9714 & 11768 \\
\hline Грузия & 76,6 & 158 & - & - & - & - & - & - \\
\hline Казахстан & 2200 & 3225 & 4449 & 5887 & 7445 & 4807 & 3637 & 4917 \\
\hline Киргизия & 88,6 & 146 & 393 & 110 & 73,9 & 73,1 & 177 & 206 \\
\hline Республика & & & & & & & & \\
\hline Молдова & 325 & 548 & 421 & 417 & 315 & 186 & 249 & 353 \\
\hline Таджикистан & 237 & 95,0 & 214 & 37,9 & 37,3 & 52,2 & 26,4 & 25,2 \\
\hline Туркмения & 473 & 77,2 & 148 & 139 & 90,9 & 73,5 & 331 & 84,4 \\
\hline Узбекистан & 663 & 904 & 1557 & 1257 & 875 & 602 & 762 & 1026 \\
\hline Украина & 3651 & 7819 & 14047 & 15791 & 10750 & 5673 & 3892 & 4912 \\
\hline
\end{tabular}

В 2017 г. в общем объеме экспорта России на долю Беларуси приходилось 5,1\%, Казахстана - 3,4, Украины - 2,2\%.

В импорте преобладали поставки из Беларуси - 5,2\% от всего объема российского импорта, Казахстана - 2,2, Украины - 2,2\%.

1) С 2015 г. - Евразийский экономический союз (ЕАЭС); включает Республику Беларусь, Республику Казахстан, Республику Армения и Киргизскую Республику (начиная с 12 августа 2015 г.). 


\section{5. ВНЕШНЯЯ ТОРГОВЛЯ РОССИЙСКОЙ ФЕДЕРАЦИИ СО СТРАНАМИ ДАЛЬНЕГО ЗАРУБЕЖЬЯ}

(в фактически действовавших ценах; млн. долларов США)

\begin{tabular}{|c|c|c|c|c|c|c|c|c|}
\hline & 2000 & 2005 & 2010 & 2013 & 2014 & 2015 & 2016 & 2017 \\
\hline & \multicolumn{8}{|c|}{ Экспорт } \\
\hline $\begin{array}{l}\text { Всего } \\
\text { в том числе } \\
\text { по странам: }\end{array}$ & 89269 & 208846 & 337467 & 452036 & 433173 & 298420 & 247944 & 309687 \\
\hline $\begin{array}{c}\text { Страны БРИКС } \\
\text { из них: }\end{array}$ & & & & & & & & \\
\hline Бразилия & 259 & 606 & 1798 & 1985 & 2366 & 1924 & 1785 & 2033 \\
\hline Индия & 1082 & 2314 & 6392 & 6983 & 6343 & 5575 & 5312 & 6456 \\
\hline Китай & 5248 & 13048 & 20326 & 35625 & 37492 & 28601 & 28018 & 38922 \\
\hline $\begin{array}{l}\text { Южно- } \\
\text { Африканская } \\
\text { Республика }\end{array}$ & $\ldots$ & 25,2 & 45,8 & 286 & 285 & 271 & 196 & 204 \\
\hline \multicolumn{9}{|l|}{ Страны ЕС } \\
\hline Австрия & 758 & 2353 & 1022 & 1280 & 767 & 1163 & 1052 & 1883 \\
\hline Бельгия & 757 & 2464 & 4927 & 7726 & 9226 & 6366 & 5744 & 6800 \\
\hline Болгария & 585 & 1900 & 3416 & 2217 & 1462 & 1887 & 2311 & 2900 \\
\hline Венгрия & 2406 & 5004 & 5355 & 6352 & 5181 & 3030 & 2650 & 3286 \\
\hline Германия & 9232 & 19736 & 25662 & 37027 & 37132 & 25351 & 21257 & 25747 \\
\hline Греция & 1273 & 1930 & 2852 & 6245 & 3672 & 2523 & 2667 & 3430 \\
\hline Дания & 424 & 725 & 1564 & 1480 & 2902 & 1943 & 14000 & 2948 \\
\hline Ирландия & 288 & 771 & 161 & 329 & 332 & 273 & 317 & 392 \\
\hline Испания & 1068 & 2823 & 4048 & 6027 & 4579 & 2683 & 1952 & 2214 \\
\hline Италия & 7254 & 19053 & 27476 & 39314 & 35225 & 22294 & 11973 & 13839 \\
\hline Кипр & 1722 & 5095 & 1641 & 1923 & 610 & 244 & 283 & 306 \\
\hline Нидерланды & 4349 & 24614 & 53974 & 70126 & 68040 & 40848 & 29261 & 35611 \\
\hline Польша & 4452 & 8623 & 14936 & 19582 & 15941 & 9668 & 9140 & 11578 \\
\hline Румыния & 921 & 3041 & 2025 & 1616 & 1461 & 1679 & 1846 & 2268 \\
\hline Словакия & 2122 & 3190 & 4576 & 5860 & 5196 & 3577 & 2497 & 3253 \\
\hline $\begin{array}{l}\text { Соединенное } \\
\text { Королевство } \\
\text { (Великобритания) }\end{array}$ & 4670 & 8280 & 11309 & 16449 & 11474 & 7475 & 6944 & 8688 \\
\hline Финляндия & 3104 & 7651 & 12170 & 13308 & 11380 & 7092 & 6539 & 8642 \\
\hline Франция & 1903 & 6111 & 12420 & 9203 & 7578 & 5712 & 4778 & 5829 \\
\hline Чехия & 1745 & 3817 & 5500 & 5983 & 5162 & 3260 & 2692 & 3964 \\
\hline Швеция & 1733 & 2320 & 3589 & 4476 & 4794 & 2438 & 2221 & 1934 \\
\hline
\end{tabular}


Продолжение табл. 25.5

\begin{tabular}{|c|c|c|c|c|c|c|c|c|}
\hline & 2000 & 2005 & 2010 & 2013 & 2014 & 2015 & 2016 & 2017 \\
\hline \multicolumn{9}{|l|}{ Другие страны } \\
\hline из них: & & & & & & & & \\
\hline Австралия & 5,6 & 36,0 & 53,3 & 72,0 & 127 & 103 & 64,5 & 121 \\
\hline Алжир & 120 & 206 & 1310 & 1585 & 875 & 1992 & 3966 & 4621 \\
\hline Аргентина & 36,5 & 71,7 & 210 & 400 & 222 & 122 & 163 & 211 \\
\hline Афрганистан & 11,2 & 104 & 549 & 631 & 953 & 150 & 184 & 205 \\
\hline Вьетнам & 168 & 739 & 1334 & 1374 & 1452 & 1842 & 1372 & 1903 \\
\hline Гонконг & 136 & 350 & 831 & 3026 & 1246 & 777 & 698 & 702 \\
\hline Грузия & - & & 211 & 536 & 518 & 531 & 590 & 700 \\
\hline Египет & 449 & 1049 & 1920 & 2503 & 4939 & 3676 & 3784 & 6217 \\
\hline Израиль & 1045 & 1538 & 1763 & 2085 & 2291 & 1540 & 1466 & 1669 \\
\hline $\begin{array}{l}\text { Исламская } \\
\text { Республика } \\
\text { Иран }\end{array}$ & 633 & 1922 & 3380 & 1169 & 1286 & 1017 & 1882 & 1315 \\
\hline Канада & 88,9 & 200 & 1081 & 471 & 697 & 544 & 419 & 644 \\
\hline $\begin{array}{l}\text { Корейская } \\
\text { Народно- } \\
\text { Демократиче- } \\
\text { ская Респуб- }\end{array}$ & & & & & & & & \\
\hline лика & 38,4 & 228 & 82,1 & 103 & 82,2 & 78,3 & 68,0 & 74,2 \\
\hline Куба & 80,7 & 125 & 222 & 158 & 101 & 87,3 & 214 & 277 \\
\hline Марокко & 61,1 & 396 & 558 & 860 & 933 & 548 & 725 & 895 \\
\hline Мексика & 114 & 208 & 289 & 855 & 1374 & 998 & 1059 & 1516 \\
\hline Монголия & 182 & 443 & 937 & 1572 & 1461 & 1117 & 896 & 1327 \\
\hline Нигерия & 82,2 & 156 & 110 & 268 & 352 & 285 & 380 & 386 \\
\hline Новая Зеландия & 0,9 & 11,7 & 78,5 & 332 & 423 & 403 & 77,7 & 82,9 \\
\hline Норвегия & 127 & 683 & 755 & 808 & 935 & 755 & 737 & 776 \\
\hline
\end{tabular}


Продолжение табл. 25.5

\begin{tabular}{|c|c|c|c|c|c|c|c|c|}
\hline & 2000 & 2005 & 2010 & 2013 & 2014 & 2015 & 2016 & 2017 \\
\hline $\begin{array}{l}\text { Объединенные } \\
\text { Арабские } \\
\text { Эмираты }\end{array}$ & 178 & 691 & 983 & 2093 & 1738 & 1081 & 971 & 1459 \\
\hline Пакистан & 62,7 & 231 & 122 & 197 & 147 & 97,0 & 133 & 261 \\
\hline Панама & 140 & 290 & 67,8 & 58,4 & 49,5 & 48,8 & 12,3 & 18,2 \\
\hline $\begin{array}{l}\text { Республика } \\
\text { Корея }\end{array}$ & 972 & 2359 & 10439 & 14867 & 18278 & 13482 & 10006 & 12345 \\
\hline Сингапур & 477 & 309 & 2008 & 1886 & 5550 & 2491 & 1797 & 3290 \\
\hline $\begin{array}{l}\text { Сирийская } \\
\text { Арабская } \\
\text { Республика }\end{array}$ & 95,5 & 440 & 1116 & 360 & 587 & 307 & 182 & 280 \\
\hline США & 4644 & 6323 & 12320 & 11135 & 10583 & 9432 & 9269 & 10700 \\
\hline Таиланд & 80,2 & 547 & 1536 & 1273 & 1750 & 561 & 615 & 514 \\
\hline Тайвань (Китай) & 404 & 1438 & 1797 & 4443 & 3907 & 2622 & 2697 & 3371 \\
\hline Турция & 3098 & 10841 & 20317 & 25476 & 24937 & 19287 & 13582 & 18221 \\
\hline Швейцария & 3857 & 10774 & 8716 & 8792 & 3667 & 2611 & 3017 & 3852 \\
\hline Япония & \multicolumn{8}{|c|}{ Импорт } \\
\hline $\begin{array}{l}\text { Всего } \\
\text { в том числе } \\
\text { по странам: } \\
\text { Страны БРИКС } \\
\text { из них: }\end{array}$ & 22276 & 79712 & 197184 & 276310 & 253776 & 161693 & 162725 & 202608 \\
\hline Бразилия & 388 & 2346 & 4067 & 3359 & 3969 & 2915 & 2524 & 3198 \\
\hline Индия & 557 & 784 & 2143 & 3041 & 3172 & 2258 & 2398 & 2902 \\
\hline $\begin{array}{l}\text { Китай } \\
\text { Южно- } \\
\text { Африканская } \\
\text { Республика }\end{array}$ & 949 & 7265 & 38964 & 51634 & 53773 & 34948 & 38105 & 48042 \\
\hline $\begin{array}{c}\text { Страны EC } \\
\text { из них: }\end{array}$ & & & & & & & & \\
\hline Австрия & 419 & 1211 & 2463 & 3846 & 3438 & 2013 & 1837 & 2177 \\
\hline Бельгия & 481 & 1476 & 3265 & 4034 & 3576 & 2093 & 2269 & 2921 \\
\hline Болгария & 116 & 241 & 540 & 702 & 655 & 486 & 481 & 549 \\
\hline Венгрия & 404 & 1100 & 3141 & 3007 & 2740 & 1715 & 1659 & 2088 \\
\hline Германия & 3898 & 13272 & 26699 & |37917 & 32975 & |20441 & 19453 & 24228 \\
\hline
\end{tabular}


Продолжение табл. 25.5

\begin{tabular}{|c|c|c|c|c|c|c|c|c|}
\hline & 2000 & 2005 & 2010 & 2013 & 2014 & 2015 & 2016 & 2017 \\
\hline Греция & 125 & 188 & 423 & 611 & 496 & 229 & 213 & 240 \\
\hline Дания & 346 & 921 & 1703 & 2178 & 1605 & 875 & 831 & 926 \\
\hline Ирландия & 106 & 290 & 998 & 1372 & 1302 & 831 & 897 & 1118 \\
\hline Испания & 313 & 1227 & 3042 & 4915 & 4343 & 2824 & 2474 & 3126 \\
\hline Италия & 1212 & 4416 & 10043 & 14554 & 12729 & 8320 & 7840 & 10101 \\
\hline Кипр & 35,5 & 47,5 & 27,0 & 42,7 & 48,6 & 59,2 & 12,7 & 8,1 \\
\hline Нидерланды & 740 & 1941 & 4442 & 5837 & 5294 & 3096 & 3021 & 3893 \\
\hline Польша & 716 & 2747 & 5826 & 8326 & 7081 & 4097 & 3959 & 4908 \\
\hline Румыния & 79,4 & 255 & 1345 & 2047 & 2210 & 1311 & 1232 & 1618 \\
\hline Словакия & 105 & 503 & 2492 & 3534 & 2864 & 1760 & 1666 & 2007 \\
\hline $\begin{array}{l}\text { Соединенное } \\
\text { Королевство } \\
\text { (Великобрита- } \\
\text { ния) }\end{array}$ & 861 & 2776 & 4576 & 8106 & 7809 & 3722 & 3433 & 4048 \\
\hline Финляндия & 958 & 3100 & 4584 & 5396 & 4571 & 2671 & 2482 & 3696 \\
\hline Франция & 1187 & 3673 & 10043 & 13012 & 10630 & 5919 & 8490 & 9630 \\
\hline Чехия & 367 & 989 & 2918 & 5318 & 4898 & 2846 & 2767 & 3422 \\
\hline Швеция & 465 & 1861 & 2854 & 3917 & 3239 & 1853 & 1669 & 2110 \\
\hline $\begin{array}{c}\text { Другие страны } \\
\text { из них: }\end{array}$ & & & & & & & & \\
\hline Австралия & 172 & 244 & 769 & 815 & 673 & 582 & 468 & 510 \\
\hline Алжир & 7,0 & 2,0 & 27,4 & 4,8 & 10,2 & 5,5 & 8,2 & 9,1 \\
\hline Аргентина & 86,1 & 621 & 914 & 1100 & 1116 & 825 & 685 & 679 \\
\hline Афрганистан & 5,4 & 3,9 & 22,0 & 14,3 & 12,9 & 9,1 & 6,3 & 2,9 \\
\hline Вьетнам & 36,8 & 174 & 1111 & 2597 & 2295 & 2053 & 2466 & 3324 \\
\hline Гонконг & 3,3 & 18,6 & 61,8 & 172 & 204 & 193 & 168 & 223 \\
\hline Грузия & - & - & 38,0 & 150 & 269 & 163 & 203 & 385 \\
\hline Египет & 4,9 & 77,4 & 271 & 442 & 540 & 414 & 374 & 505 \\
\hline Израиль & 109 & 332 & 825 & 1493 & 1142 & 806 & 720 & 825 \\
\hline $\begin{array}{l}\text { Исламская } \\
\text { Республика } \\
\text { Иран }\end{array}$ & 53,6 & 125 & 272 & 433 & 354 & 268 & 303 & 392 \\
\hline Канада & 193 & 517 & 1485 & 1796 & 1496 & 838 & 720 & 986 \\
\hline
\end{tabular}


Продолжение табл. 25.5

\begin{tabular}{l|r|r|r|r|r|r|r|r}
\hline & 2000 & 2005 & 2010 & 2013 & 2014 & 2015 & 2016 & 2017 \\
\hline Корейская & & & & & & & & \\
Народно- & & & & & & & & \\
Демократиче- & 7,7 & 6,9 & 16,4 & 9,3 & 10,0 & 6,0 & 8,9 & 3,7 \\
ская Республика & 304 & 61,4 & 54,3 & 27,6 & 61,4 & 48,4 & 34,5 & 13,6 \\
Куба & 59,2 & 144 & 374 & 566 & 608 & 467 & 567 & 566 \\
Марокко & 42,2 & 86,8 & 480 & 1048 & 783 & 589 & 644 & 952 \\
Мексика & 40,4 & 22,4 & 79,1 & 40,9 & 40,4 & 44,1 & 35,9 & 41,2 \\
Монголия & 2,3 & 1,9 & 4,1 & 31,2 & 16,5 & 22,7 & 14,6 & 45,0 \\
Нигерия & 26,6 & 63,7 & 151 & 238 & 241 & 111 & 150 & 217 \\
Новая Зеландия & 154 & 750 & 1416 & 1754 & 1151 & 627 & 666 & 646 \\
Норвегия & & & & & & & & \\
Объединенные & 23,0 & 90,1 & 35,9 & 423 & 264 & 164 & 273 & 171 \\
Арабские & 6,2 & 47,1 & 240 & 350 & 311 & 298 & 272 & 280 \\
Эмираты & 46,3 & 3,6 & 2,6 & 960 & 6,6 & 11,2 & 1,9 & 6,4 \\
Пакистан & & & & & & & & \\
Панама & 359 & 4005 & 7287 & 10305 & 9030 & 4560 & 5113 & 6933 \\
Республика & 43,5 & 317 & 332 & 553 & 604 & 517 & 496 & 1158 \\
Корея & 11,2 & 26,0 & 42,5 & 16,2 & 7,1 & 5,3 & 11,0 & 2,9 \\
Сингапур & 2694 & 4563 & 11097 & 16502 & 18496 & 11454 & 10703 & 12499 \\
Сирия & 89,8 & 452 & 1370 & 2084 & 2231 & 1491 & 1147 & 1717 \\
СшА & 88,8 & 492 & 1533 & 1915 & 1672 & 1315 & 1614 & 1925 \\
Таиланд & 349 & 1732 & 4867 & 7273 & 6644 & 4059 & 2161 & 3383 \\
Тайвань (Китай) & 271 & 875 & 2415 & 2984 & 3260 & 1974 & 1942 & 2198 \\
Турция & 572 & 5834 & 10260 & 13561 & 10908 & 6813 & 6681 & 7761 \\
швейцария & & & & & & & & \\
Япония & & & & & \\
\hline
\end{tabular}

В 2017 г. в общем объеме экспорта России на страны дальнего зарубежья наибольшие объемы пришлись на долю Китая - 10,9\%, Нидерландов - 10,0, Германии - 7,2, Турции - 5,1, Италии - 3,9, Республики Корея - 3,5, Польши - 3,2, США - 3,0, Японии - 2,9, Соединенного Королевства (Великобритании) - 2,4, Финляндии - 2,4, Бельгии - 1,9 и Индии - 1,8\%.

В импорте преобладали поставки из Китая - 21,1\%, Германии 10,7, США - 5,5, Италии - 4,4, Франции - 4,2, Японии - 3,4, Республики Корея - 3,0, Польши - 2,2, Соединенного Королевства (Великобритании) - 1,8, Нидерландов - 1,7, Финляндии - 1,6, Чехии - 1,5 и Турции $1,5 \%$. 


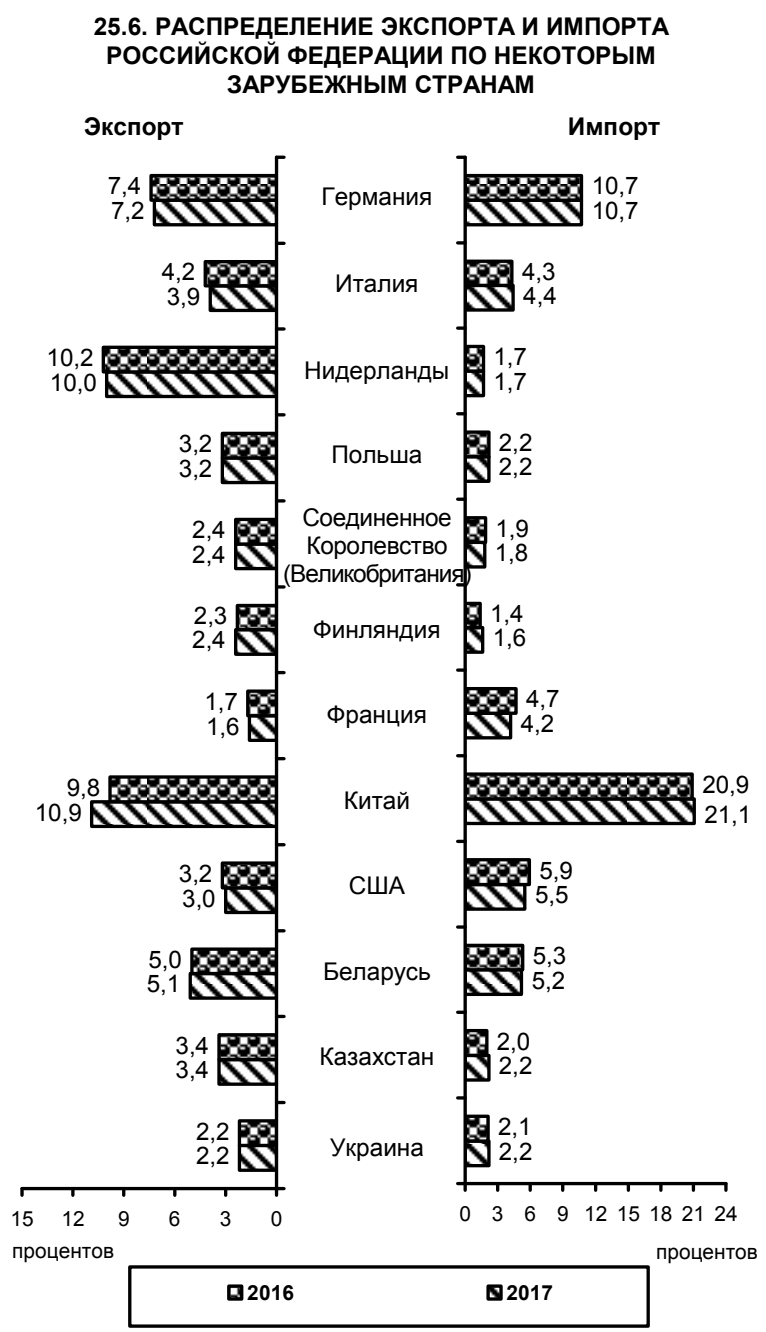




\section{7. ТОВАРНАЯ СТРУКТУРА ЭКСПОРТА РОССИЙСКОЙ ФЕДЕРАЦИИ}

(в фактически действовавших ценах)

\begin{tabular}{|c|c|c|c|c|c|c|c|c|}
\hline & 2000 & 2005 & 2010 & 2013 & 2014 & 2015 & 2016 & 2017 \\
\hline \multirow{5}{*}{$\begin{array}{l}\text { Экспорт - всего } \\
\text { в том числе: } \\
\text { продовольственные } \\
\text { товары и сельско- } \\
\text { хозяиственное сырье } \\
\text { (кроме текстильного) }\end{array}$} & \multicolumn{8}{|c|}{ Миллиардов долларов США } \\
\hline & 103 & 241 & 397 & 526 & 497 & 344 & 286 & 358 \\
\hline & & & & & & & & \\
\hline & & & & & & & & \\
\hline & 1,6 & 4,5 & 8,8 & 16,3 & 19,0 & 16,2 & 17,1 & 20,7 \\
\hline $\begin{array}{l}\text { минеральные } \\
\text { продукты }\end{array}$ & 555 & 156 & 272 & 376 & 350 & 219 & 169 & 216 \\
\hline продукция химичес- & נט, & 100 & 212 & 310 & 300 & 210 & 100 & 210 \\
\hline $\begin{array}{l}\text { кой промышленнос- } \\
\text { ти, каучук }\end{array}$ & 7,4 & 14,4 & 24,5 & 30,8 & 29,2 & 25,4 & 20,8 & 23,9 \\
\hline $\begin{array}{l}\text { кожевенное сырье, } \\
\text { пушнина и изделия }\end{array}$ & & & & & & & & \\
\hline $\begin{array}{l}\text { из них } \\
\text { древесина и цел- }\end{array}$ & 0,3 & 0,3 & 0,3 & 0,6 & 0,4 & 0,3 & 0,3 & 0,3 \\
\hline $\begin{array}{l}\text { древесина и цел- } \\
\text { люлозно-бумажные }\end{array}$ & & & & & & & & \\
\hline изделия & 4,5 & 8,3 & 9,6 & 11,0 & 11,6 & 9,8 & 9,8 & 11,8 \\
\hline $\begin{array}{l}\text { текстиль, текстиль- } \\
\text { ные изделия и обувь }\end{array}$ & 0,8 & 1,0 & 0,8 & 0,9 & 1,1 & 0,9 & 0,9 & 1,1 \\
\hline металлы, драгоцен- & & & & & & & & \\
\hline $\begin{array}{l}\text { ные камни и изделия } \\
\text { из них }\end{array}$ & 22,4 & 40,6 & 50,3 & 55,1 & 52,3 & 40,8 & 37,7 & 48,3 \\
\hline $\begin{array}{l}\text { машины, оборудова- } \\
\text { ние и транспортные }\end{array}$ & & & & & & & & \\
\hline средства & 9,1 & 13,5 & 21,3 & 28,8 & 26,5 & 25,4 & 24,5 & 28,1 \\
\hline прочие & 1,6 & 2,5 & & 6,6 & | 7,0 & 5,5 & 5,5 & 7,3 \\
\hline кспорт - всего & 100 & 100 & $\begin{array}{l}\text { B пр } \\
100\end{array}$ & оцент & $\begin{aligned} \operatorname{rax} k y \\
100\end{aligned}$ & 100 & 100 & 100 \\
\hline $\begin{array}{l}\text { в том числе: } \\
\text { продовольственные }\end{array}$ & & & & & & & & \\
\hline товары и сельско- & & & & & & & & \\
\hline $\begin{array}{l}\text { хозяйственное сырье } \\
\text { (кроме текстильного) }\end{array}$ & 1,6 & 1,9 & 2,2 & 3,1 & 3,8 & 4,7 & 6,0 & 5,8 \\
\hline $\begin{array}{l}\text { минеральные } \\
\text { продукты }\end{array}$ & 53,8 & 64,8 & 68,5 & 71,5 & 70,4 & 63,8 & 59,2 & 60,4 \\
\hline продукция химичес- & & & & & & & & \\
\hline $\begin{array}{l}\text { кой промышленнос- } \\
\text { ти, каучук }\end{array}$ & 7,2 & 6,0 & 6,2 & 5,9 & 5,9 & 7,4 & 7,3 & 6,7 \\
\hline $\begin{array}{l}\text { кожевенное сырье, } \\
\text { пушнина и изделия }\end{array}$ & & & & & & & & \\
\hline $\begin{array}{l}\text { из них } \\
\text { древесина и цел- }\end{array}$ & 0,3 & 0,1 & 0,1 & 0,1 & 0,1 & 0,1 & 0,1 & 0,1 \\
\hline $\begin{array}{l}\text { древесина и цел- } \\
\text { Люлозно-бумажные }\end{array}$ & & & & & & & & \\
\hline изделия & 4,3 & 3,4 & 2,4 & 2,1 & 2,3 & 2,9 & 3,4 & 3,3 \\
\hline $\begin{array}{l}\text { текстиль, текстиль- } \\
\text { ные изделия и обувь }\end{array}$ & 0,8 & 0,4 & 0,2 & 0,2 & 0,2 & 0,3 & 0,3 & 0,3 \\
\hline & & & & & & & & \\
\hline из них & 21,7 & 16,8 & 12,7 & 10,5 & 10,5 & 11,9 & 13,2 & 13,5 \\
\hline $\begin{array}{l}\text { машины, оборудова- } \\
\text { ние и транспортные }\end{array}$ & & & & & & & & \\
\hline средства & 8,8 & 5,6 & 5,4 & 5,5 & 5,3 & 7,4 & 8,6 & 7,9 \\
\hline прочие & 1,5 & 1,0 & & 1,3 & 1,4 & 1,5 & 1,9 & 2,1 \\
\hline
\end{tabular}




\section{8. ТОВАРНАЯ СТРУКТУРА ЭКСПОРТА} РОССИЙСКОЙ ФЕДЕРАЦИИ В СТРАНЫ СНГ (в фактически действовавших ценах)

\begin{tabular}{|c|c|c|c|c|c|c|c|c|}
\hline & 2000 & 2005 & 2010 & 2013 & 2014 & 2015 & 2016 & 2017 \\
\hline & \multicolumn{8}{|c|}{ Миллиардов долларов США } \\
\hline $\begin{array}{l}\text { Экспорт - всего } \\
\text { в том числе: } \\
\text { продовольственные } \\
\text { товары и сельскохо- } \\
\text { зяйственное сырье } \\
\text { (кроме текстильного) }\end{array}$ & 13,8 & 32,6 & 59,6 & 73,9 & 64,2 & 45,1 & 37,8 & 48,1 \\
\hline минеральные продукты & 6,8 & 15,0 & 30,2 & 35,5 & 28,9 & 18,4 & 12,9 & 16,8 \\
\hline $\begin{array}{l}\text { продукция химической } \\
\text { промышленности, каучук }\end{array}$ & 1,4 & 2,9 & 4,8 & 7,7 & 7,2 & 6,1 & 5,8 & 7,1 \\
\hline $\begin{array}{l}\text { кожевенное сырье, пуш- } \\
\text { нина и изделия из них }\end{array}$ & 0,0 & 0,1 & 0,1 & 0,1 & 0,1 & 0,1 & 0,1 & 0,1 \\
\hline $\begin{array}{l}\text { древесина и целлюлоз- } \\
\text { но-бумажные изделия }\end{array}$ & 0,4 & 1,2 & 1,8 & 2,6 & 2,6 & 1,7 & 1,7 & 2,1 \\
\hline $\begin{array}{l}\text { текстиль, текстильные } \\
\text { изделия и обувь }\end{array}$ & 0,3 & 0,5 & 0,5 & 0,7 & 0,8 & 0,6 & 0,7 & 0,8 \\
\hline $\begin{array}{l}\text { металлы, драгоценные } \\
\text { камни и изделия из них }\end{array}$ & 1,4 & 4,1 & 5,7 & 8,2 & 6,9 & 5,1 & 4,6 & 6,0 \\
\hline $\begin{array}{l}\text { машины, оборудование } \\
\text { и транспортные средства }\end{array}$ & 2,4 & 5,9 & 6,9 & 12,2 & 10,5 & 7,4 & 6,5 & 8,3 \\
\hline \multirow[t]{2}{*}{ прочие } & 0,4 & 0,7 & & 2,0 & 2,0 & 1,4 & 1,3 & 1,8 \\
\hline & \multicolumn{8}{|c|}{ В процентах к итогу } \\
\hline $\begin{array}{l}\text { Экспорт - всего } \\
\text { в том числе: } \\
\text { продовольственные } \\
\text { товары и сельскохо- } \\
\text { зяйственное сырье } \\
\text { (кроме текстильного) }\end{array}$ & 100 & 100 & 100 & 100 & 100 & 100 & 100 & 100 \\
\hline минеральные продукты & 49,1 & 46,0 & 50,7 & 48,0 & 45,1 & 40,8 & 34,2 & 35,1 \\
\hline $\begin{array}{l}\text { продукция химической } \\
\text { промышленности, каучук }\end{array}$ & 10,2 & 9,0 & 8,1 & 10,5 & 11,2 & 13,5 & 15,4 & 14,9 \\
\hline $\begin{array}{l}\text { кожевенное сырье, пуш- } \\
\text { нина и изделия из них }\end{array}$ & 0,3 & 0,2 & 0,1 & 0,1 & 0,1 & 0,1 & 0,2 & 0,1 \\
\hline $\begin{array}{l}\text { древесина и целлюлоз- } \\
\text { но-бумажные изделия }\end{array}$ & 3,0 & 3,6 & 3,0 & 3,6 & 4,0 & 3,8 & 4,4 & 4,3 \\
\hline $\begin{array}{l}\text { текстиль, текстильные } \\
\text { изделия и обувь }\end{array}$ & 2,0 & 1,6 & 0,9 & 0,9 & 1,3 & 1,4 & 1,8 & 1,7 \\
\hline $\begin{array}{l}\text { металлы, драгоценные } \\
\text { камни и изделия из них }\end{array}$ & 10,4 & 12,6 & 9,6 & 11,1 & 10,8 & 11,3 & 12,3 & 12,6 \\
\hline $\begin{array}{l}\text { машины, оборудование } \\
\text { и транспортные средства }\end{array}$ & 17,0 & 18,2 & 11,6 & 16,5 & 16,4 & 16,4 & 17,1 & 17,3 \\
\hline прочие & 2,7 & 2,1 & & 2,7 & 3,0 & 3,2 & 3,6 & 3,9 \\
\hline
\end{tabular}


25.9. ТОВАРНАЯ СТРУКТУРА ЭКСПОРТА РОССИЙСКОЙ ФЕДЕРАЦИИ В СТРАНЫ ДАЛЬНЕГО ЗАРУБЕЖЬЯ (в фактически действовавших ценах)

\begin{tabular}{|c|c|c|c|c|c|c|c|c|}
\hline & 2000 & 2005 & 2010 & 2013 & 2014 & 2015 & 2016 & 2017 \\
\hline \multirow{4}{*}{$\begin{array}{l}\text { Экспорт - всего } \\
\text { в том числе: } \\
\text { продовольственные } \\
\text { товары и сельскохо- } \\
\text { зяйственное сырье } \\
\text { (кроме текстильного) }\end{array}$} & \multicolumn{8}{|c|}{ Миллиардов долларов США } \\
\hline & 89,3 & 209 & 337 & 452 & 433 & 298 & 248 & 310 \\
\hline & & & & & & & & \\
\hline & 0,9 & 2,3 & 6,0 & 11,3 & 13,8 & 12,0 & 12,9 & 15,9 \\
\hline \multirow{2}{*}{$\begin{array}{l}\text { продукты } \\
\text { продукция химиче- }\end{array}$} & 48,7 & 141 & 242 & 340 & 321 & 201 & 156 & 199 \\
\hline & & & & & & & & \\
\hline \multirow{2}{*}{$\begin{array}{l}\text { скои промышленно- } \\
\text { сти, каучук } \\
\text { кожевенное сырье, } \\
\text { пушнина и изделия }\end{array}$} & 6,0 & 11,4 & 19,7 & 23,1 & 22,1 & 19,3 & 15,0 & 16,8 \\
\hline & & & & & & & & \\
\hline 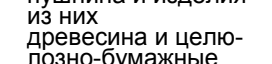 & 0,2 & 0,3 & 0,2 & 0,5 & 0,3 & 0,3 & 0,2 & 0,2 \\
\hline \multirow{2}{*}{$\begin{array}{l}\text { изделия } \\
\text { текстиль, текстиль- }\end{array}$} & 41 & 72 & 78 & 8.3 & 90 & 81 & 81 & 98 \\
\hline & & & & & & & 0,1 & , \\
\hline $\begin{array}{l}\text { ные изделия и обувь } \\
\text { металлы, драгоцен- }\end{array}$ & 0,5 & 0,4 & 0,2 & 0,3 & 0,3 & 0,2 & 0,2 & 0,3 \\
\hline \multirow{2}{*}{$\begin{array}{l}\text { ные камни и изделия } \\
\text { из них }\end{array}$} & & & & & & & & \\
\hline & 21,0 & 36,5 & 44,6 & 46,9 & 45,3 & 35,7 & 33,1 & 42,3 \\
\hline $\begin{array}{l}\text { машины, оборудова- } \\
\text { ние и транспортные }\end{array}$ & & & & & & 180 & 180 & \\
\hline $\begin{array}{l}\text { средства } \\
\text { прочие }\end{array}$ & 1,2 & 1,8 & $\begin{array}{r}14,0 \\
2,8\end{array}$ & 4,7 & 5,0 & 4,1 & 4,2 & 5,4 \\
\hline & \multicolumn{8}{|c|}{ В процентах к итогу } \\
\hline \multirow{3}{*}{$\begin{array}{l}\text { Экспорт - всего } \\
\text { в том числе: } \\
\text { продовольственные } \\
\text { товары и сельскохо- } \\
\text { зяйственное сырье } \\
\text { (кроме текстильного) }\end{array}$} & 100 & 100 & 100 & 100 & 100 & 100 & 100 & 100 \\
\hline & & & & & & & & \\
\hline & 1,0 & 1,1 & 1,8 & 2,5 & 3,2 & 4,0 & 5,2 & 5,1 \\
\hline $\begin{array}{l}\text { минеральные } \\
\text { продукты }\end{array}$ & 545 & 677 & 716 & 753 & 742 & 673 & 630 & 643 \\
\hline $\begin{array}{l}\text { продукция химиче- } \\
\text { скои промышленно- }\end{array}$ & $\checkmark 4, \widetilde{J}$ & $0 T, r$ & T, & 15,0 & 14,2 & 01,0 & 03,0 & 04,0 \\
\hline $\begin{array}{l}\text { ской промышленно- } \\
\text { сти, каучук }\end{array}$ & 6,7 & 5,5 & 5,8 & 5,1 & 5,1 & 6,5 & 6,0 & 5,4 \\
\hline $\begin{array}{l}\text { сти, каучук } \\
\text { кожевенное сырье, }\end{array}$ & & & & & & & & \\
\hline \multirow{2}{*}{$\begin{array}{l}\text { из них } \\
\text { древесина и целлю- } \\
\text { лозно-бумажные }\end{array}$} & 0,3 & 0,1 & 0,1 & 0,1 & 0,1 & 0,1 & 0,1 & 0,1 \\
\hline & & & & & & & & \\
\hline \multirow{2}{*}{$\begin{array}{l}\text { изделия } \\
\text { текстиль, текстиль- }\end{array}$} & 4,5 & 3,4 & 2,3 & 1,8 & 2,1 & 2,7 & 3,3 & 3,2 \\
\hline & 0,6 & 0,2 & 0,1 & 0.1 & 0.1 & 01 & 01 & 01 \\
\hline \multirow{2}{*}{$\begin{array}{l}\text { ные изделия и обувь } \\
\text { металлы, драгоцен- } \\
\text { ные камни и изделия } \\
\text { из них }\end{array}$} & & & & & & & & \\
\hline & 23,5 & 17,5 & 13,2 & 10,4 & 10,5 & 12,0 & 13,3 & 13,7 \\
\hline $\begin{array}{l}\text { машины, оборудова- } \\
\text { ние и транспортные }\end{array}$ & & & & & & & & \\
\hline средства & 7,5 & 3,6 & 4,3 & 3,7 & 3,7 & 6,0 & 7,3 & 6,4 \\
\hline прочие & 1,4 & 0,9 & 0,8 & 1,0 & 1,2 & 1,3 & 1,7 & 1,8 \\
\hline
\end{tabular}


25.10. ТОВАРНАЯ СТРУКТУРА ИМПОРТА РОССИЙСКОЙ ФЕДЕРАЦИИ

(в фактически действовавших ценах)

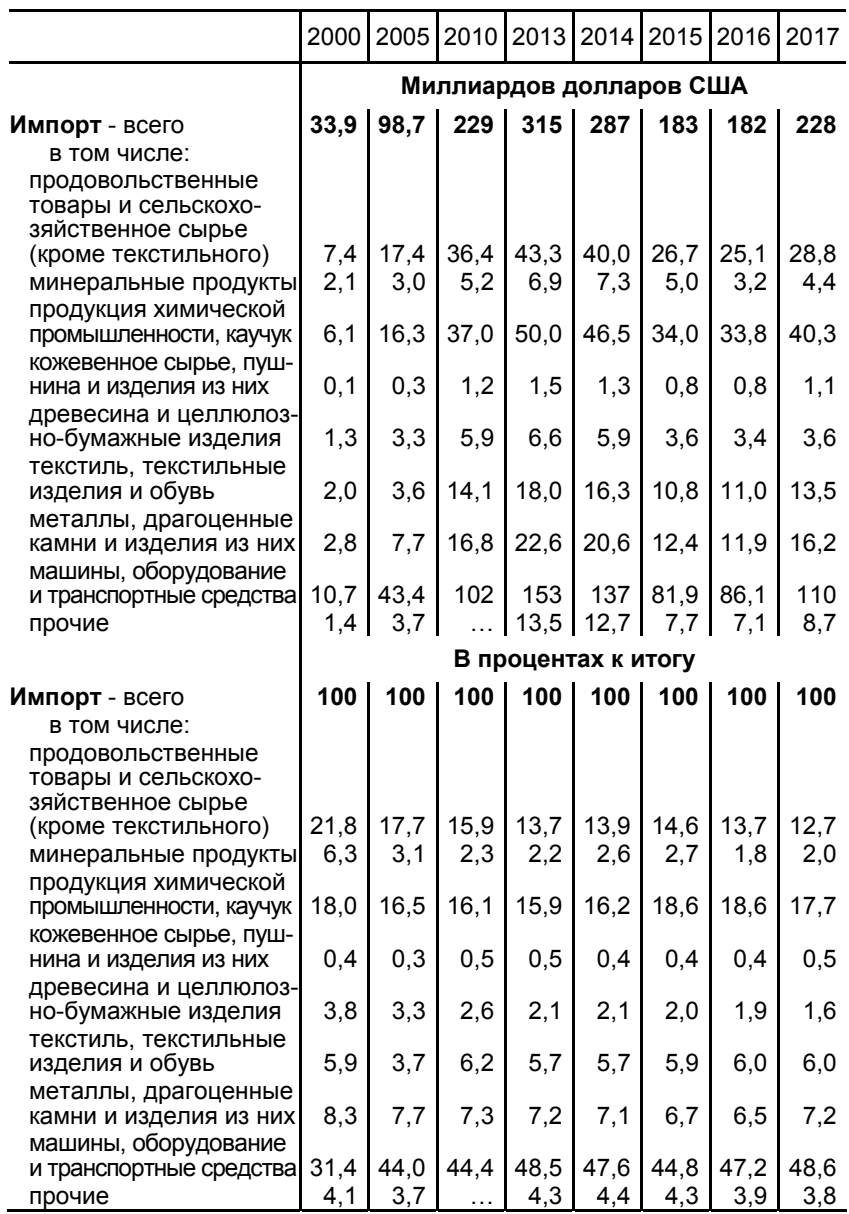


25.11. ТОВАРНАЯ СТРУКТУРА ИМПОРТА РОССИЙСКОЙ ФЕДЕРАЦИИ ИЗ СТРАН СНГ

(в фрактически действовавших ценах)

\begin{tabular}{|c|c|c|c|c|c|c|c|c|}
\hline & 2000 & 2005 & 2010 & 2013 & 2014 & 2015 & 2016 & 2017 \\
\hline & \multicolumn{8}{|c|}{ Миллиардов долларов США } \\
\hline $\begin{array}{l}\text { Импорт - всего } \\
\text { в том числе: } \\
\text { продовольственные } \\
\text { товары и сельскохо- } \\
\text { зяйственное сырье } \\
\text { (кроме текстильного) }\end{array}$ & 11,6 & 19,0 & 31,7 & 39,0 & 33,3 & |21,2 & 19,6 & 24,9 \\
\hline $\begin{array}{l}\text { минеральные продукты } \\
\text { продукция химической }\end{array}$ & 1,7 & 2,3 & 3,3 & 4,5 & 5,2 & 3,5 & 2,0 & 2,7 \\
\hline промышленности, каучук & 1,5 & 2,0 & 2,8 & 4,1 & 3,8 & 3,1 & 2,8 & 3,3 \\
\hline $\begin{array}{l}\text { кожевенное сырье, пуш- } \\
\text { нина и изделия из них }\end{array}$ & 0,0 & 0,0 & 0,0 & 0,0 & 0,0 & 0,0 & 0,0 & 0,1 \\
\hline $\begin{array}{l}\text { древесина и целлюлоз- } \\
\text { но-бумажные изделия }\end{array}$ & 0,3 & 0,6 & 1,0 & 1,5 & 1,1 & 0,7 & 0,6 & 0,6 \\
\hline $\begin{array}{l}\text { текстиль, текстильные } \\
\text { изделия и обувь }\end{array}$ & 1,1 & 1,0 & 1,8 & 2,0 & 1,7 & 1,2 & 1,5 & 1,7 \\
\hline $\begin{array}{l}\text { металлы, драгоценные } \\
\text { камни и изделия из них }\end{array}$ & 1,7 & 3,4 & 4,5 & 6,3 & 5,4 & 2,9 & 2,9 & 4,3 \\
\hline $\begin{array}{l}\text { машины, оборудование } \\
\text { и транспортные средства }\end{array}$ & 2,6 & 5,0 & 9,1 & 12,5 & 8,5 & 4,3 & 4,5 & 5,4 \\
\hline \multirow[t]{2}{*}{ прочие } & 0,6 & 0,8 & $\ldots$ & 1,8 & 1,7 & 1,1 & 0,7 & 0,9 \\
\hline & \multicolumn{8}{|c|}{ В процентах к итогу } \\
\hline $\begin{array}{l}\text { Импорт - всего } \\
\text { в том числе: } \\
\text { продовольственные } \\
\text { товары и сельскохо- } \\
\text { зяйственное сырье }\end{array}$ & 100 & 100 & 100 & 100 & 100 & 100 & 100 & 100 \\
\hline минеральные продукты & 15,1 & 12,1 & 10,4 & 11,5 & 15,6 & 16,3 & 9,9 & 11,1 \\
\hline промышленности, каучук & 12,6 & 10,7 & 8,9 & 10,5 & 11,6 & 14,8 & 14,2 & 13,5 \\
\hline $\begin{array}{l}\text { кожевенное сырье, пуш- } \\
\text { нина и изделия из них }\end{array}$ & 0,4 & 0,2 & 0,1 & 0,1 & 0,1 & 0,1 & 0,2 & 0,2 \\
\hline $\begin{array}{l}\text { древесина и целлюлоз- } \\
\text { но-бумажные изделия }\end{array}$ & 2,5 & 3,0 & 3,2 & 3,8 & 3,3 & 3,3 & 3,1 & 2,4 \\
\hline $\begin{array}{l}\text { текстиль, текстильные } \\
\text { изделия и обувь }\end{array}$ & 9,8 & 5,4 & 5,7 & 5,2 & 5,0 & 5,6 & 7,8 & 7,1 \\
\hline $\begin{array}{l}\text { металлы, драгоценные } \\
\text { камни и изделия из них }\end{array}$ & 14,8 & 17,7 & 14,1 & 16,0 & 16,0 & 13,8 & 14,5 & 17,6 \\
\hline $\begin{array}{l}\text { машины, оборудование } \\
\text { и транспортные средства }\end{array}$ & 22,1 & 26,4 & 28,7 & 32,0 & 25,7 & 20,3 & 23,0 & 22,0 \\
\hline прочие & 4,8 & 4,1 & & 4,6 & 5,1 & 4,9 & 3,7 & 3,7 \\
\hline
\end{tabular}


25.12. ТОВАРНАЯ СТРУКТУРА ИМПОРТА

РОССИЙСКОЙ ФЕДЕРАЦИИ ИЗ СТРАН ДАЛЬНЕГО ЗАРУБЕЖЬЯ

(в фактически действовавших ценах)

\begin{tabular}{|c|c|c|c|c|c|c|c|c|}
\hline & 2000 & 2005 & 2010 & 2013 & 2014 & 2015 & 2016 & 2017 \\
\hline & \multicolumn{8}{|c|}{ Миллиардов долларов США } \\
\hline $\begin{array}{l}\text { Импорт - всего } \\
\text { в том числе: } \\
\text { продовольственные } \\
\text { товары и сельскохо- } \\
\text { зяйственное сырье } \\
\text { (кроме текстильного) }\end{array}$ & 22,3 & 79,7 & 197 & 276 & 254 & 162 & 163 & 203 \\
\hline $\begin{array}{l}\text { минеральные продукты } \\
\text { продукция химической }\end{array}$ & 0,4 & 0,8 & 1,9 & 2,4 & 2,2 & 1,5 & 1,3 & 1,7 \\
\hline промышленности, каучук & 4,6 & 14,2 & 34,2 & 45,9 & 42,6 & 30,8 & 31,0 & 37,0 \\
\hline $\begin{array}{l}\text { кожевенное сырье, пуш- } \\
\text { нина и изделия из них }\end{array}$ & 0,1 & 0,2 & 1,2 & 1,5 & 1,3 & 0,8 & 0,8 & 1,1 \\
\hline $\begin{array}{l}\text { древесина и целлюлоз- } \\
\text { но-бумажные изделия } \\
\text { текстиль, текстильные }\end{array}$ & 1,0 & 2,7 & 4,9 & 5,1 & 4,8 & 2,9 & 2,8 & 3,0 \\
\hline $\begin{array}{l}\text { текстиль, текстильные } \\
\text { изделия и обувь }\end{array}$ & 0,9 & 2,6 & 12,3 & 16,0 & 14,6 & 9,7 & 9,5 & 11,8 \\
\hline $\begin{array}{l}\text { металлы, драгоценные } \\
\text { камни и изделия из них }\end{array}$ & 1,1 & 4,3 & 12,3 & 16,4 & 15,2 & 9,4 & 9,0 & 11,9 \\
\hline $\begin{array}{l}\text { машины, оборудование } \\
\text { и транспортные средства }\end{array}$ & 8,1 & 38,4 & 92,6 & 140 & 128 & 77,6 & 81,6 & 105 \\
\hline \multirow[t]{2}{*}{ прочие } & 0,8 & 2,9 & 7,5 & 11,7 & 10,9 & 6,7 & 6,4 & 7,8 \\
\hline & \multicolumn{8}{|c|}{ В процентах к итогу } \\
\hline $\begin{array}{l}\text { Импорт - всего } \\
\text { в том числе: } \\
\text { продовольственные } \\
\text { товары и сельскохо- } \\
\text { зяйственное сырье }\end{array}$ & 100 & 100 & 100 & 100 & 100 & 100 & 100 & 100 \\
\hline (кроме текстильного) & 23,8 & 17,0 & 15,3 & 13,4 & 13,4 & 13,7 & 12,6 & 11,5 \\
\hline минеральные продукты & 1,7 & 0,9 & 1,0 & 0,9 & 0,8 & 0,9 & 0,8 & 0,8 \\
\hline $\begin{array}{l}\text { продукция химической } \\
\text { промышленности, каучук }\end{array}$ & 20,7 & 17,9 & 17,3 & 16,6 & 16,8 & 19,1 & 19,1 & 18,3 \\
\hline кожевенное сырье, пуш- & & & & & & & & \\
\hline нина и изделия из них & 0,3 & 0,3 & 0,6 & 0,5 & 0,5 & 0,5 & 0,5 & 0,5 \\
\hline $\begin{array}{l}\text { древесина и целлюлоз- } \\
\text { но-бумажные изделия }\end{array}$ & 4,5 & 3,4 & 2,5 & 1,9 & 1,9 & 1,8 & 1,7 & 1,5 \\
\hline $\begin{array}{l}\text { текстиль, текстильные } \\
\text { изделия и обувь }\end{array}$ & 3,9 & 3,3 & 6,3 & 5,8 & 5,8 & 6,0 & 5,8 & 5,8 \\
\hline металлы, драгоценные & & & & & & & & \\
\hline камни и изделия из них & 5,0 & 5,4 & 6,2 & 6,0 & 6,0 & 5,8 & 5,6 & 5,9 \\
\hline машины, оборудование & & & & & & & & \\
\hline $\begin{array}{l}\text { и транспортные средства } \\
\text { прочие }\end{array}$ & $\begin{array}{r}36,3 \\
3,8\end{array}$ & $\begin{array}{r}48,2 \\
3,6\end{array}$ & $\begin{array}{r}47,0 \\
3,8\end{array}$ & $\begin{array}{r}50,8 \\
4,2\end{array}$ & $\begin{array}{r}50,5 \\
4,3\end{array}$ & $\begin{array}{r}48,0 \\
4,2\end{array}$ & $\begin{array}{r}50,1 \\
3,9\end{array}$ & $\begin{array}{r}51,8 \\
3,9\end{array}$ \\
\hline
\end{tabular}

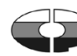


25.13. УДЕЛЬНЫЙ ВЕС ПОТРЕБИТЕЛЬСКИХ, ПРОМЕЖУТОЧНЫХ И ИНВЕСТИЦИОННЫХ ТОВАРОВ В ОБЩЕМ ОБЪЕМЕ ИМПОРТА РОССИЙСКОЙ ФЕДЕРАЦИИ ${ }^{1)}$

(в процентах)

\begin{tabular}{c|c|c|c}
\hline Годы & $\begin{array}{c}\text { Потребительские } \\
\text { товары }\end{array}$ & $\begin{array}{c}\text { Промежуточные } \\
\text { товары }\end{array}$ & $\begin{array}{c}\text { Инвестиционные } \\
\text { товары }\end{array}$ \\
\hline 2010 & 40,4 & 40,1 & 19,5 \\
2013 & 37,7 & 38,0 & 24,3 \\
2014 & 37,8 & 37,7 & 24,5 \\
2015 & 39,9 & 36,6 & 23,5 \\
2016 & 35,6 & 37,9 & 26,5 \\
2017 & 33,6 & 28,9 & 27,5 \\
\hline
\end{tabular}

1) Группировки (потребительские, промежуточные, инвестиционные) сформированы на основе: Гармонизированной Системы (ГС), Международной стандартной торговой классификации (МСТК) и Международной классификации товаров по широким экономическим категориям (МКТШЭК).

\subsection{4. ЭКСПОРТ ВАЖНЕЙШИХ ТОВАРОВ РОССИЙСКОЙ ФЕДЕРАЦИИ}

\begin{tabular}{|c|c|c|c|c|c|c|c|c|}
\hline & 2000 & 2005 & 2010 & 2013 & 2014 & 2015 & 2016 & 201 \\
\hline кспо口т - & & & & & & & & \\
\hline ежая и & 103093 & 241473 & 397068 & 525976 & 497359 & 343512 & 285772 & 3577 \\
\hline ная ${ }^{1)}$, тыс. т & 1060 & 1265 & 1566 & 1797 & 1601 & 1699 & 1793 & 198 \\
\hline меслин, & 594 & 10348 & 11848 & 13796 & 22082 & 21230 & 25328 & \\
\hline концентраты & & & & & & & & \\
\hline & 19,2 & 18,2 & 22,3 & 25,7 & 23,0 & 21,3 & 18,5 & \\
\hline & 44,1 & 79,8 & 116 & 139 & 153 & 153 & 166 & \\
\hline т природный, & 145 & 253 & 247 & 237 & 223 & 245 & 255 & \\
\hline иродный, & 62,7 & 97,1 & 133 & 152 & 165 & 172 & 156 & \\
\hline & 194 & 207 & 174 & 196 & 174 & 186 & 199 & \\
\hline $\begin{array}{l}\text { роэнергия, } \\
\text { Вт.ч } \\
\text { ения мине- } \\
\text { ые азотные, } \\
\text { : }\end{array}$ & 15132 & 22568 & 19091 & 18382 & 14671 & 18244 & 17694 & 170 \\
\hline изическом весе & 9323 & 10181 & 10931 & 11815 & 12150 & 11590 & 12774 & \\
\hline $\begin{array}{l}\text { веществ } \\
\text { Удобрения мине- } \\
\text { ральные калийные, } \\
\text { Тыс. т: }\end{array}$ & 3546 & 3860 & 4204 & 4496 & 4623 & 4423 & 4955 & 50 \\
\hline $\begin{array}{l}\text { в физическом весе } \\
\text { в пересчете на } \\
100 \% \text { питатель- }\end{array}$ & 4697 & 8775 & 9223 & 6321 & 10460 & 11185 & 9486 & 110 \\
\hline & & & & & & & & \\
\hline
\end{tabular}


Продолжение табл. 25.14

\begin{tabular}{l|r|r|r|r|r|r|r|r}
\hline & 2000 & 2005 & 2010 & 2013 & 2014 & 2015 & 2016 & 2017 \\
\hline $\begin{array}{l}\text { Удобрения мине- } \\
\text { ральные смешан- } \\
\text { ные, тыс. т }\end{array}$ & 6312 & 7373 & 8040 & 9151 & 8276 & 8862 & 9242 & 10482 \\
Лесоматериалы \\
необработанные,
\end{tabular}

${ }^{1)}$ Включая рыбу свежую и мороженую выловленную (добытую) и проданную вне зоны действия таможенного контроля.

25.15. ЭКСПОРТ ВАЖНЕЙШИХ ТОВАРОВ РОССИЙСКОЙ ФЕДЕРАЦИИ В СТРАНЫ СНГ

\begin{tabular}{|c|c|c|c|c|c|c|c|c|}
\hline & 2000 & 2005 & 2010 & 2013 & 2014 & 2015 & 2016 & 2017 \\
\hline $\begin{array}{l}\text { кспорт - всего, } \\
\text { лн. долл. США }\end{array}$ & 13824 & 32627 & 59601 & 73940 & 64186 & 45092 & 37829 & 4807 \\
\hline $\begin{array}{l}\text { Рыба свежая и мо- } \\
\text { роженая }{ }^{1}, \text { тыс. т }\end{array}$ & 76,1 & 118 & 28,6 & 52,9 & 61,9 & 58,4 & 64,9 & 67 \\
\hline $\begin{array}{l}\text { Пшеница и меслин, } \\
\text { тыс. т }\end{array}$ & 461 & 1445 & 374 & 811 & 1150 & 1521 & 1385 & 152 \\
\hline $\begin{array}{l}\text { Руды и концентраты } \\
\text { железные, млн. т }\end{array}$ & 10,1 & 2,6 & 3,1 & 3,8 & 3,1 & 3,0 & 1,6 & \\
\hline $\begin{array}{l}\text { Уголь каменный, } \\
\text { млн. т }\end{array}$ & 6,1 & 8,3 & 13,1 & 11,3 & 10,5 & 10,2 & 10,7 & 10 \\
\hline $\begin{array}{l}\text { Нефть сырая, } \\
\text { включая газовый } \\
\text { конденсат природ- } \\
\text { ный, млн.т }\end{array}$ & 17,0 & 38,0 & 22,9 & 28,7 & 24,1 & 22,9 & 18,6 & 18 \\
\hline $\begin{array}{l}\text { Нефтепродукты, } \\
\text { млн. т }\end{array}$ & 3,5 & 3,9 & 5,7 & 10,3 & 9,5 & 8,3 & 8,1 & 11 \\
\hline $\begin{array}{l}\text { Газ природный, } \\
\text { млрд. м }\end{array}$ & 60,1 & 47,5 & 66,9 & 58,4 & 48,0 & 40,7 & 34,0 & 34 \\
\hline
\end{tabular}


Продолжение табл. 25.15

\begin{tabular}{l|r|r|r|r|r|r|r|r}
\hline & 2000 & 2005 & 2010 & 2013 & 2014 & 2015 & 2016 & 2017 \\
\hline $\begin{array}{l}\text { Электроэнергия, } \\
\text { млн. кВт.ч }\end{array}$ & 9095 & 9211 & 581 & 5492 & 3422 & 6972 & 4569 & 3602 \\
$\begin{array}{l}\text { Удобрения мине- } \\
\text { ральные азотные, } \\
\text { тыс. т: }\end{array}$ & & & & & & & & \\
$\begin{array}{l}\text { в физическом } \\
\text { весе }\end{array}$ & 408 & 410 & 1033 & 1234 & 1070 & 1162 & 1329 & 1629 \\
$\begin{array}{l}\text { в пересчете на } \\
\text { 100\% питатель- } \\
\text { ных веществ }\end{array}$ & 143 & 136 & 400 & 440 & 366 & 395 & 464 & 592 \\
Удобрения мине- \\
ральные калийные, \\
тыс. т:
\end{tabular}

1) Включая рыбу свежую и мороженую выловленную (добытую) и проданную вне зоны действия таможенного контроля. 
25.16. ЭКСПОРТ ВАЖНЕЙШИХ ТОВАРОВ

РОССИЙСКОЙ ФЕДЕРАЦИИ В СТРАНЫ ДАЛЬНЕГО ЗАРУБЕЖЬЯ

\begin{tabular}{|c|c|c|c|c|c|c|c|c|}
\hline & 2000 & 2005 & 2010 & 2013 & 2014 & 2015 & 2016 & 2017 \\
\hline $\begin{array}{l}\text { Экспорт - всего, } \\
\text { млн. долл. США }\end{array}$ & 89269 & 208846 & 337467 & 452036 & 433173 & 298420 & 247944 & 309687 \\
\hline $\begin{array}{l}\text { Рыба свежая и мо- } \\
\text { роженая }{ }^{1} \text {, тыс. т }\end{array}$ & 984 & 1147 & 1537 & 1744 & 1539 & 1641 & 1728 & 1928 \\
\hline $\begin{array}{l}\text { Пшеница и меслин, } \\
\text { тыс. т }\end{array}$ & 133 & 8903 & 11474 & 12985 & 20932 & 19709 & 23943 & 31501 \\
\hline $\begin{array}{l}\text { Руды и концентраты } \\
\text { железные, млн. т }\end{array}$ & 9,1 & 15,6 & 19,2 & 21,9 & 19,9 & 18,3 & 16,9 & 18,5 \\
\hline $\begin{array}{l}\text { Уголь каменный, } \\
\text { млн. т }\end{array}$ & 38,0 & 71,5 & 103 & 128 & 143 & 143 & 155 & 235 \\
\hline $\begin{array}{l}\text { Нефть сырая, вклю- } \\
\text { чая газовый кон- } \\
\text { денсат природный, } \\
\text { млн. т }\end{array}$ & 128 & 215 & 224 & 208 & 199 & 222 & 236 & 171 \\
\hline $\begin{array}{l}\text { Нефтепродукты, } \\
\text { млн. т }\end{array}$ & 59,2 & 93,2 & 127 & 142 & 156 & 164 & 148 & 137 \\
\hline $\begin{array}{l}\text { Газ природный, } \\
\text { млрд. м }\end{array}$ & 134 & 160 & 107 & 138 & 126 & 145 & 165 & 176 \\
\hline $\begin{array}{l}\text { Электроэнергия, } \\
\text { млн. кВт.ч }\end{array}$ & 6037 & 13357 & 18510 & 12890 & 11249 & 11272 & 13125 & 13405 \\
\hline $\begin{array}{l}\text { Удобрения мине- } \\
\text { ральные азотные, } \\
\text { тыс. т: }\end{array}$ & & & & & & & & \\
\hline $\begin{array}{l}\text { в фризическом весе } \\
\text { в пересчете } \\
\text { на } 100 \% \text { питатель- }\end{array}$ & 8915 & 9771 & 9898 & 10581 & 11080 & 10428 & 11445 & 11197 \\
\hline $\begin{array}{l}\text { ных веществ } \\
\text { Удобрения мине- } \\
\text { ральные калийные, } \\
\text { тыс. т: }\end{array}$ & 3403 & 3724 & 3804 & 4056 & 4257 & 4028 & 4491 & 4490 \\
\hline $\begin{array}{l}\text { в физическом весе } \\
\text { в пересчете на } \\
100 \% \text { питательных }\end{array}$ & 4686 & 8710 & 9190 & 6296 & 10355 & 11109 & 9441 & 10991 \\
\hline веществ & 2837 & 5246 & 5542 & 3873 & 6289 & 6741 & 5745 & 6674 \\
\hline $\begin{array}{l}\text { Удобрения мине- } \\
\text { ральные смешан- } \\
\text { ные, тыс. т }\end{array}$ & 6283 & 7002 & 7200 & 8039 & 7259 & 7647 & 7644 & 8075 \\
\hline $\begin{array}{l}\text { Лесоматериалы } \\
\text { необработанные, } \\
\text { млн. м }\end{array}$ & 30,7 & 47,4 & 20,9 & 18,5 & 20,3 & 18,8 & 19,6 & 18,9 \\
\hline 502 & \multicolumn{8}{|c|}{ РОССИЯ В ЦИФРАХ. 2018} \\
\hline
\end{tabular}


Продолжение табл. 25.16

\begin{tabular}{l|r|r|r|r|r|r|r|r}
\hline & 2000 & 2005 & 2010 & 2013 & 2014 & 2015 & 2016 & 2017 \\
\hline $\begin{array}{l}\text { Черные металлы, } \\
\text { млн. долл. США }\end{array}$ & 6084 & 16481 & 17325 & 16074 & 16948 & 12791 & 11923 & 15517 \\
Чугун передельный, & & & & & & & & \\
тыс. т & 3550 & 4914 & 3827 & 3931 & 4217 & 5239 & 5018 & 4703 \\
Медь, тыс. т & 646 & 308 & 455 & 212 & 285 & 557 & 501 & 582 \\
Никель необрабо- & & & & & & & & \\
танный, тыс. т & 197 & 261 & 240 & 238 & 238 & 226 & 186 & 136 \\
$\begin{array}{l}\text { Алюминий необра- } \\
\text { ботанный, тыс. т }\end{array}$ & 3192 & 3670 & 3269 & 3242 & 2774 & 3326 & 3271 & 3131 \\
$\begin{array}{l}\text { Автомобили легко- } \\
\text { вые, тыс. шт. }\end{array}$ & 67,8 & 36,4 & 8,4 & 6,2 & 4,4 & 11,3 & 23,4 & 32,8 \\
Автомобили грузо- \\
вые, тыс. шт.
\end{tabular}

1) Включая рыбу свежую и мороженую выловленную (добытую) и проданную вне зоны действия таможенного контроля.

\subsection{7. ИМПОРТ ВАЖНЕЙШИХ ТОВАРОВ}

В РОССИЙСКУЮ ФЕДЕРАЦИЮ

\begin{tabular}{|c|c|c|c|c|c|c|c|c|}
\hline & 2000 & 2005 & 2010 & 2013 & 2014 & 2015 & 2016 & 2017 \\
\hline $\begin{array}{l}\text { Импорт - всего, } \\
\text { млн. долл. США }\end{array}$ & 33880 & 98707 & 228912 & 315298 & 287063 & 182902 & 182347 & 227464 \\
\hline $\begin{array}{l}\text { Мясо свежее и мо- } \\
\text { роженое (без мяса }\end{array}$ & & & & & & & & \\
\hline птицы), тыс. т & 517 & 1340 & 1614 & 1288 & 1012 & 747 & 628 & 643 \\
\hline $\begin{array}{l}\text { Мясо птицы свежее } \\
\text { и мороженое, тыс. т }\end{array}$ & 694 & 1329 & 688 & 527 & 455 & 255 & 225 & 228 \\
\hline $\begin{array}{l}\text { Рыба свежая и моро- } \\
\text { женая, тыс. т }\end{array}$ & 327 & 787 & 792 & 775 & 650 & 401 & 358 & 429 \\
\hline $\begin{array}{l}\text { Масло сливочное и } \\
\text { прочие молочные }\end{array}$ & & & & & & & & \\
\hline жиры, тыс. т & 70,8 & 133 & 134 & 144 & 150 & 95,9 & 105 & 98,8 \\
\hline $\begin{array}{l}\text { Цитрусовые плоды, } \\
\text { свежие или сушеные, }\end{array}$ & & & & & & & & \\
\hline тыс. т & 473 & 953 & 1491 & 1705 & 1653 & 1552 & 1528 & 1565 \\
\hline Koфpe, тыс. T & 20,6 & 39,7 & 102 & 144 & 155 & 157 & 172 & 190 \\
\hline Злаки, тыс. т & 4677 & 1449 & 444 & 1512 & 932 & 765 & 1049 & 740 \\
\hline $\begin{array}{l}\text { Масло подсолнеч- } \\
\text { ное, сафлоровое или }\end{array}$ & & & & & & & & \\
\hline $\begin{array}{l}\text { хлопковое и их } \\
\text { фракции, тыс. т }\end{array}$ & 150 & 131 & 114 & 18,1 & 8,8 & 3,4 & 5,9 & 25,7 \\
\hline
\end{tabular}


Продолжение табл. 25.17

\begin{tabular}{|c|c|c|c|c|c|c|c|c|}
\hline & 2000 & 2005 & 2010 & 2013 & 2014 & 2015 & 2016 & 2017 \\
\hline $\begin{array}{l}\text { Готовые или консер- } \\
\text { вированные продук- } \\
\text { ты из мяса, тыс. т }\end{array}$ & 26,1 & 42,1 & 41,3 & 38,3 & 61,9 & 19,1 & 20,6 & 17,7 \\
\hline Сахар-сырец, тыс. т & 4547 & 2893 & 2086 & 530 & 666 & 507 & 259 & 14,4 \\
\hline Сахар белый, тыс. т & 467 & 625 & 285 & 80,0 & 289 & 445 & 270 & 246 \\
\hline $\begin{array}{l}\text { Алкогольные и без- } \\
\text { алкогольные напит- } \\
\text { ки, млн. долл. США }\end{array}$ & 422 & 1528 & 2265 & 3407 & 3068 & 1792 & 1828 & 2493 \\
\hline $\begin{array}{l}\text { Руды и концентраты } \\
\text { алюминиевые, тыс. т }\end{array}$ & 300 & 121 & 29,6 & 74,3 & 87,7 & 102 & 110 & 18,1 \\
\hline $\begin{array}{l}\text { Лекарственные сред- } \\
\text { ства, млн. долл. США }\end{array}$ & 1150 & 3865 & 9346 & 11805 & 10211 & 6876 & 7066 & 8581 \\
\hline $\begin{array}{l}\text { Одежда трикотажная } \\
\text { и текстильная, } \\
\text { млн. долл. США }\end{array}$ & 228 & 966 & 5906 & 8191 & 7748 & 5103 & 5271 & 6575 \\
\hline $\begin{array}{l}\text { Обувь кожаная, } \\
\text { млн. пар }\end{array}$ & 7,2 & 15,4 & 103 & 85,7 & 70,1 & 48,6 & 39,1 & 51,6 \\
\hline $\begin{array}{l}\text { Черные металлы, } \\
\text { млн. долл. США }\end{array}$ & 890 & 2769 & 5364 & 5892 & 5699 & 3301 & 3048 & 4826 \\
\hline $\begin{array}{l}\text { Трубы из черных } \\
\text { металлов, тыс. т }\end{array}$ & 1064 & 1029 & 1466 & 852 & 675 & 407 & 499 & 719 \\
\hline $\begin{array}{l}\text { Машины, оборудо- } \\
\text { вание и транспорт- } \\
\text { ные средства, } \\
\text { млн. долл. США }\end{array}$ & 10649 & 43436 & 101739 & 152579 & 136232 & 81730 & 86080 & 110281 \\
\hline $\begin{array}{l}\text { комбинированные } \\
\text { холодильники- } \\
\text { морозильники, } \\
\text { тыс. шт. }\end{array}$ & & 1778 & 1625 & 1294 & 1342 & 918 & 963 & 1055 \\
\hline $\begin{array}{l}\text { вычислительные } \\
\text { машины и их блоки, }\end{array}$ & & & & & & & & \\
\hline $\begin{array}{l}\text { млн. долл. США } \\
\text { телефонные аппа- } \\
\text { раты для сотовых } \\
\text { сетей связи или } \\
\text { других беспровод- } \\
\text { ных сетей связи, } \\
\text { тыс. шт. }\end{array}$ & 207 & 1356 & 47955 & 53985 & 51167 & 47519 & 45416 & 46871 \\
\hline $\begin{array}{l}\text { автомобили легко- } \\
\text { вые, тыс. шт. }\end{array}$ & 71,7 & 774 & 710 & 894 & 704 & 350 & 267 & 268 \\
\hline $\begin{array}{l}\text { автомобили грузо- } \\
\text { вые, тыс. шт. }\end{array}$ & 19,2 & 50,1 & 59,0 & 89,1 & 61,5 & 22,2 & 20,3 & 31,8 \\
\hline
\end{tabular}


25.18. ИМПОРТ ВАЖНЕЙШИХ ТОВАРОВ

В РОССИЙСКУЮ ФЕДЕРАЦИЮ ИЗ СТРАН СНГ

\begin{tabular}{|c|c|c|c|c|c|c|c|c|}
\hline & 2000 & 2005 & 2010 & 2013 & 2014 & 2015 & 2016 & 2017 \\
\hline $\begin{array}{l}\text { Импорт - всего, } \\
\text { млн. долл. США }\end{array}$ & 11604 & 18995 & 31728 & 38988 & 33287 & 21210 & 19662 & 24856 \\
\hline $\begin{array}{l}\text { Мясо свежее и мо- } \\
\text { роженое (без мяса }\end{array}$ & & & & & & & & \\
\hline птицы), тыс. т & 178 & 137 & 180 & 118 & 129 & 178 & 147 & 136 \\
\hline Мясо птицы свежее & & & & & & & & \\
\hline и мороженое, тыс. т & 16,7 & 10,5 & 38,3 & 123 & 106 & 126 & 117 & 129 \\
\hline $\begin{array}{l}\text { Рыба свежая и моро- } \\
\text { женая, тыс. т }\end{array}$ & 22,8 & 23,8 & 7,5 & 12,0 & 10,7 & 9,2 & 12,4 & 16,3 \\
\hline $\begin{array}{l}\text { Масло сливочное } \\
\text { и прочие молочные }\end{array}$ & & & & & & & & \\
\hline жиры, тыс. т & 49,0 & 71,4 & 55,9 & 46,6 & 65,6 & 76,2 & 81,0 & 74,1 \\
\hline $\begin{array}{l}\text { Цитрусовые плоды, } \\
\text { свежие или сушеные, } \\
\text { тыс. т }\end{array}$ & 34,3 & 50,7 & 10,5 & 11,3 & 12,2 & 35,1 & 21,7 & 17,0 \\
\hline Koфpe, тыс. т & 0,3 & 0,4 & 0,5 & 1,5 & 0,6 & 0,6 & 0,7 & 1,2 \\
\hline Злаки, тыс. т & 2807 & 826 & 111 & 968 & 505 & 498 & 774 & 384 \\
\hline $\begin{array}{l}\text { Масло подсолнечное, } \\
\text { сафлоровое или } \\
\text { хлопковое и их фррак- }\end{array}$ & & & & & & & & \\
\hline ции, тыс. т & 94,6 & 116 & 114 & 16,9 & 8,0 & 3,1 & 5,4 & 24,7 \\
\hline $\begin{array}{l}\text { Готовые или консер- } \\
\text { вированные продукты }\end{array}$ & & & & & & & & \\
\hline из мяса, тыс. т & 15,5 & 20,1 & 12,8 & 13,0 & 41,5 & 10,7 & 15,1 & 12,2 \\
\hline Сахар-сырец, тыс. т & 0,0 & 0,0 & 0,02 & 0,3 & 0,1 & 5,1 & 29,2 & 8,0 \\
\hline Сахар белый, тыс. т & 197 & 551 & 219 & 26,2 & 235 & 387 & 224 & 205 \\
\hline $\begin{array}{l}\text { Алкогольные и без- } \\
\text { алкогольные напит- } \\
\text { ки, млн. долл. США }\end{array}$ & 251 & 777 & 496 & 550 & 369 & 233 & 266 & 364 \\
\hline $\begin{array}{l}\text { Руды и концентраты } \\
\text { алюминиевые, тыс. т }\end{array}$ & 8,1 & 1,5 & 1,4 & 5,2 & 3,7 & 2,4 & 1,5 & 1,6 \\
\hline $\begin{array}{l}\text { Лекарственные сред- } \\
\text { ства, млн. долл. } \\
\text { США }\end{array}$ & 59,2 & 47,9 & 106 & 146 & 152 & 125 & 130 & 185 \\
\hline $\begin{array}{l}\text { Одежда трикотажная } \\
\text { и текстильная, } \\
\text { млн. долл. США }\end{array}$ & 123 & 207 & 730 & 825 & 637 & 385 & 513 & 635 \\
\hline $\begin{array}{l}\text { Обувь кожаная, } \\
\text { млн. пар }\end{array}$ & 4,4 & 4,0 & 5,8 & 6,2 & 6,0 & 4,2 & 4,6 & 7,0 \\
\hline $\begin{array}{l}\text { Черные металлы, } \\
\text { млн. долл. США }\end{array}$ & 749 & 2055 & 2705 & 2932 & 2844 & 1390 & 1347 & 2250 \\
\hline $\begin{array}{l}\text { Трубы из черных } \\
\text { металлов, тыс. т }\end{array}$ & 794 & 687 & 731 & 434 & 372 & 206 & 309 & 391 \\
\hline
\end{tabular}


Продолжение табл. 25.18

\begin{tabular}{|c|c|c|c|c|c|c|c|c|}
\hline & 2000 & 2005 & 2010 & 2013 & 2014 & 2015 & 2016 & 2017 \\
\hline $\begin{array}{l}\text { Машины, оборудова- } \\
\text { ние и транспортные } \\
\text { средства, млн. долл. } \\
\text { США }\end{array}$ & 2565 & 5006 & 9121 & 12305 & 8236 & 4111 & 4523 & 5390 \\
\hline $\begin{array}{l}\text { комбинированные } \\
\text { холодильники-моро- } \\
\text { зильники, тыс. шт. }\end{array}$ & ... & 856 & 604 & 409 & 534 & 509 & 555 & 457 \\
\hline $\begin{array}{l}\text { вычислительные } \\
\text { машины и их блоки, } \\
\text { млн. долл. США }\end{array}$ & 5,6 & 5,9 & 7,7 & 132 & 435 & 56,0 & 11,9 & 17,6 \\
\hline $\begin{array}{l}\text { телефонные аппа- } \\
\text { ратыдля сотовых } \\
\text { сетей связи или } \\
\text { других беспровод- } \\
\text { ных сетей связи, } \\
\text { тыс. шт. }\end{array}$ & $\ldots$ & & 0,4 & 432 & 639 & 747 & 494 & 77,9 \\
\hline $\begin{array}{l}\text { автомобили легко- } \\
\text { вые, тыс. шт. }\end{array}$ & 14,2 & 55,3 & 128 & 76,0 & 32,6 & 13,2 & 14,4 & 17,5 \\
\hline $\begin{array}{l}\text { автомобили грузо- } \\
\text { вые, тыс. шт. }\end{array}$ & 11,5 & 9,6 & 6,3 & 4,0 & 2,6 & 2,1 & 3,7 & 4,6 \\
\hline
\end{tabular}

25.19. ИМПОРТ ВАЖНЕЙШИХ ТОВАРОВ

В РОССИЙСКУЮ ФЕДЕРАЦИЮ ИЗ СТРАН ДАЛЬНЕГО ЗАРУБЕЖЬЯ

\begin{tabular}{l|r|r|r|r|r|r|r|r}
\hline & 2000 & 2005 & 2010 & 2013 & 2014 & 2015 & 2016 & 2017 \\
\hline $\begin{array}{l}\text { Импорт - всего, } \\
\text { млн. долл. США }\end{array}$ & 22276 & 79712 & 197184 & 276310 & 253776 & 161693 & 162725 & 202608 \\
$\begin{array}{l}\text { Мясо свежее и мо- } \\
\text { роженое (без мяса } \\
\text { птицы), тыс. т }\end{array}$ & 339 & 1203 & 1434 & 1170 & 886 & 569 & 481 & 507 \\
$\begin{array}{l}\text { Мясо птицы свежее } \\
\text { и мороженое, тыс. т }\end{array}$ & 677 & 1318 & 650 & 404 & 349 & 129 & 108 & 98,6 \\
$\begin{array}{l}\text { Рыба свежая и моро- } \\
\text { женая, тыс. т }\end{array}$ & 304 & 763 & 784 & 763 & 639 & 392 & 346 & 413 \\
$\begin{array}{l}\text { Масло сливочное и } \\
\text { прочие молочные }\end{array}$ & & & & & & & & \\
жиры, тыс. т & 21,8 & 61,4 & 78,5 & 97,7 & 84,8 & 19,7 & 23,8 & 24,7 \\
Цитрусовые плоды, \\
свежие или сушеные,
\end{tabular}


Продолжение табл. 25.19

\begin{tabular}{|c|c|c|c|c|c|c|c|c|}
\hline & 2000 & 2005 & 2010 & 2013 & 2014 & 2015 & 2016 & 2017 \\
\hline $\begin{array}{l}\text { Масло подсолнечное, } \\
\text { сафрлоровое или }\end{array}$ & & & & & & & & \\
\hline $\begin{array}{l}\text { хлопковое и их фррак- } \\
\text { ции, тыс. т }\end{array}$ & 55,8 & 15,3 & 1,0 & 1,2 & 0,8 & 0,3 & 0,5 & 1,0 \\
\hline $\begin{array}{l}\text { Готовые или консер- } \\
\text { вированные продук- }\end{array}$ & & & & & & & & \\
\hline ты из мяса, тыс. т & 10,6 & 22,0 & 28,5 & 25,3 & 20,4 & 8,4 & 5,5 & 5,5 \\
\hline Сахар-сырец, тыс. т & 4547 & 2893 & 2086 & 530 & 666 & 502 & 230 & 6,4 \\
\hline Сахар белый, тыс. т & 270 & 74,1 & 66,3 & 53,8 & 54,0 & 58,1 & 46,0 & 41,1 \\
\hline $\begin{array}{l}\text { Алкогольные и без- } \\
\text { алкогольные напит- }\end{array}$ & & & & & & & & \\
\hline ки, млн. долл. США & 171 & 751 & 1768 & 2857 & 2699 & 1559 & 1562 & 2129 \\
\hline $\begin{array}{l}\text { Руды и концентраты } \\
\text { алюминиевые, тыс. т }\end{array}$ & 292 & 120 & 28,2 & 69,1 & 84,0 & 100 & 108 & 16,5 \\
\hline $\begin{array}{l}\text { Лекарственные } \\
\text { средства, }\end{array}$ & & & & & & & & \\
\hline млн. долл. США & 1091 & 3817 & 9240 & 11659 & 10059 & 6751 & 6936 & 8396 \\
\hline $\begin{array}{l}\text { Одежда трикотажная } \\
\text { и текстильная, }\end{array}$ & & & & & & & & \\
\hline млн. долл. США & 106 & 759 & 5176 & 7366 & 7111 & 4718 & 4758 & 5940 \\
\hline $\begin{array}{l}\text { Обувь кожаная, } \\
\text { млн. пар }\end{array}$ & 2,8 & 11,4 & 97,2 & 79,5 & 64,1 & 44,4 & 34,4 & 44,6 \\
\hline $\begin{array}{l}\text { Черные металлы, } \\
\text { млн. долл. США }\end{array}$ & 141 & 714 & 2659 & 2960 & 2855 & 1911 & 1701 & 2576 \\
\hline $\begin{array}{l}\text { Трубы из черных } \\
\text { металлов, тыс. т }\end{array}$ & 270 & 342 & 735 & 418 & 303 & 201 & 190 & 328 \\
\hline $\begin{array}{l}\text { Машины, оборудо- } \\
\text { вание и транспорт- } \\
\text { ные средства, }\end{array}$ & & & & & & & & \\
\hline $\begin{array}{l}\text { млн. долл. США } \\
\text { комбинированные } \\
\text { холодильники моро- }\end{array}$ & 8085 & 38430 & 92618 & 140274 & 127996 & 77619 & 81557 & 104891 \\
\hline зильники, тыс. шт. & $\ldots$ & 922 & 1021 & 885 & 808 & 409 & 408 & 598 \\
\hline $\begin{array}{l}\text { вычислительные } \\
\text { машины и их блоки, } \\
\text { млн. долл. США }\end{array}$ & 201 & 1350 & 4811 & 4733 & 4647 & 3979 & 3812 & 5079 \\
\hline $\begin{array}{l}\text { телефонные аппа- } \\
\text { раты для сотовых } \\
\text { сетей связи или } \\
\text { других беспровод- } \\
\text { ных сетей связи, }\end{array}$ & & & & & & 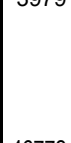 & 3012 & 5015 \\
\hline $\begin{array}{l}\text { тыс. шт. } \\
\text { автомобили легко- }\end{array}$ & & $\ldots$ & 47955 & 53553 & 50528 & 46772 & 44922 & 46793 \\
\hline $\begin{array}{l}\text { вые, тыс. шт. } \\
\text { автомобили грузо- }\end{array}$ & 57,5 & 719 & 582 & 818 & 671 & 337 & 253 & 250 \\
\hline вые, тыс. шт. & 7,7 & 40,5 & 52,7 & 85,1 & 58,9 & 20,1 & 16,6 & 27,2 \\
\hline
\end{tabular}




\section{ЦЕНЫ ВНЕШНЕЙ ТОРГОВЛИ}

25.20. СРЕДНИЕ ЭКСПОРТНЫЕ ЦЕНЫ НА ОСНОВНЫЕ ТОВАРЫ (долларов США за тонну)

\begin{tabular}{l|r|r|r|r|r|r|r|r}
\hline & 2000 & 2005 & 2010 & 2013 & 2014 & 2015 & 2016 & 2017 \\
\hline Рыба свежая и & 1081 & 1197 & 1513 & 1629 & 1843 & 1682 & 1638 & 1587 \\
мороженая & 117 & 110 & 175 & 252 & 245 & 186 & 166 & 175 \\
Пшеница и меслин & & & & & & & & \\
Руды и концентраты & 15,8 & 47,7 & 83,4 & 93,0 & 84,8 & 47,7 & 43,3 & 75,4 \\
железные & 26,3 & 47,2 & 79,4 & 85,1 & 76,0 & 62,1 & 53,6 & 74,6 \\
Уголь каменный & & & & & & & \\
Нефть сырая, вклю- & & & & & & & & \\
чая газовый конден- \\
сат природный,
\end{tabular}

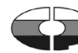


25.21. СРЕДНИЕ ЭКСПОРТНЫЕ ЦЕНЫ НА ОСНОВНЫЕ ТОВАРЫ В ТОРГОВЛЕ СО СТРАНАМИ СНГ (долларов США за тонну)

\begin{tabular}{|c|c|c|c|c|c|c|c|c|}
\hline & 2000 & 2005 & 2010 & 2013 & 2014 & 2015 & 2016 & 2017 \\
\hline $\begin{array}{l}\text { Рыба свежая } \\
\text { и мороженая } \\
\text { Пшеница }\end{array}$ & 658 & 834 & 1338 & 1385 & 1371 & 1058 & 1176 & 1263 \\
\hline $\begin{array}{l}\text { и меслин } \\
\text { Руды и концен- }\end{array}$ & 126 & 114 & 192 & 258 & 230 & 192 & 171 & 166 \\
\hline траты железные & 14,0 & 38,2 & 57,6 & 72,5 & 70,1 & 38,4 & 37,1 & 104 \\
\hline $\begin{array}{l}\text { Уголь каменный } \\
\text { Нефть сырая, } \\
\text { включая газовый } \\
\text { конденсат при- }\end{array}$ & 31,3 & 65,5 & 87,9 & 95,7 & 92,9 & 73,2 & 65,2 & 93,7 \\
\hline $\begin{array}{l}\text { родный, млн. т } \\
\text { Нестепродукты }\end{array}$ & $\begin{array}{l}140 \\
218\end{array}$ & $\begin{array}{l}253 \\
366\end{array}$ & $\begin{array}{l}430 \\
573\end{array}$ & $\begin{array}{l}391 \\
717\end{array}$ & $\begin{array}{l}344 \\
691\end{array}$ & $\begin{array}{l}246 \\
490\end{array}$ & $\begin{array}{l}219 \\
369\end{array}$ & $\begin{array}{l}292 \\
421\end{array}$ \\
\hline $\begin{array}{l}\text { Электроэнергия, } \\
\text { за } 1 \text { млн. кВт.ч } \\
\text { Удобрения мине- } \\
\text { ральные азотные: } \\
\text { в физическом }\end{array}$ & 13970 & 21930 & 44890 & 58101 & 54053 & 41722 & 41163 & 44904 \\
\hline $\begin{array}{l}\text { весе } \\
\text { в пересчете } \\
\text { на } 100 \% \\
\text { питательных }\end{array}$ & 59,9 & 125 & 209 & 309 & 256 & 226 & 181 & 190 \\
\hline $\begin{array}{l}\text { веществ } \\
\text { Удобрения }\end{array}$ & 171 & 376 & 538 & 867 & 748 & 666 & 519 & 523 \\
\hline $\begin{array}{l}\text { минеральные } \\
\text { калийные: } \\
\text { в физическом }\end{array}$ & & & & & & & & \\
\hline $\begin{array}{l}\text { весе } \\
\text { в пересчете } \\
\text { на 100\% пита- } \\
\text { тельных }\end{array}$ & 127 & 119 & 400 & 444 & 298 & 288 & 278 & 236 \\
\hline $\begin{array}{l}\text { веществ } \\
\text { Удобрения ми- } \\
\text { неральные }\end{array}$ & 329 & 223 & 741 & 780 & 507 & 484 & 480 & 431 \\
\hline $\begin{array}{l}\text { смешанные } \\
\text { Лесоматериалы } \\
\text { необработанные, }\end{array}$ & 220 & 201 & 363 & 442 & 382 & 359 & 293 & 260 \\
\hline $\begin{array}{l}\text { За м } \\
\text { Чугун пере- }\end{array}$ & 37,5 & 53,6 & 72,6 & 72,0 & 64,7 & 42,9 & 41,5 & 49,4 \\
\hline $\begin{array}{l}\text { дельный } \\
\text { Медь }\end{array}$ & $\begin{array}{r}158 \\
2004\end{array}$ & $\begin{array}{r}273 \\
2432\end{array}$ & $\begin{array}{r}467 \\
5800\end{array}$ & $\begin{array}{r}492 \\
6128\end{array}$ & $\begin{array}{r}448 \\
4922\end{array}$ & $\begin{array}{r}314 \\
3692\end{array}$ & $\begin{array}{r}250 \\
3247\end{array}$ & $\begin{array}{r}414 \\
4128\end{array}$ \\
\hline $\begin{array}{l}\text { Никель необра- } \\
\text { ботанный } \\
\text { Алюминий }\end{array}$ & 13297 & 15242 & 30776 & 28930 & 26417 & 20073 & 14040 & 13110 \\
\hline $\begin{array}{l}\text { необработанный } \\
\text { Автомобили }\end{array}$ & 1757 & 1768 & 2113 & 2188 & 2014 & 1957 & 1680 & 1944 \\
\hline $\begin{array}{l}\text { легковые, за шт. } \\
\text { Автомобили }\end{array}$ & 3289 & 4901 & 6188 & 10939 & 11469 & 9995 & 12192 & 13794 \\
\hline грузовые, за шт. & 10202 & 9150 & 15965 & 17916 & 18635 & 15674 & 17707 & 18207 \\
\hline
\end{tabular}


25.22. СРЕДНИЕ ЭКСПОРТНЫЕ ЦЕНЫ НА ОСНОВНЫЕ ТОВАРЫ В ТОРГОВЛЕ СО СТРАНАМИ ДАЛЬНЕГО ЗАРУБЕЖЬЯ (долларов США за тонну)

\begin{tabular}{|c|c|c|c|c|c|c|c|c|}
\hline & 2000 & 2005 & 2010 & 2013 & 2014 & 2015 & 2016 & 2017 \\
\hline $\begin{array}{l}\text { Рыба свежая } \\
\text { и мороженая }\end{array}$ & 1114 & 1234 & 1517 & 1636 & 1861 & 1704 & 1656 & 1598 \\
\hline Пшеница и меслин & 84,2 & 109 & 174 & 252 & 246 & 186 & 166 & 176 \\
\hline $\begin{array}{l}\text { Руды и концентраты } \\
\text { железные }\end{array}$ & 17,7 & 49,3 & 87,5 & 96,5 & 87,1 & 49,2 & 43,9 & 71,5 \\
\hline Уголь каменный & 25,5 & 45,0 & 78,3 & 84,1 & 74,8 & 61,3 & 52,8 & 73,5 \\
\hline $\begin{array}{l}\text { Нефть сырая, включая } \\
\text { газовый конденсат } \\
\text { природный, млн. т }\end{array}$ & 180 & 344 & 557 & 781 & 730 & 379 & 295 & 37,5 \\
\hline Нефтепродукты & 172 & 348 & 527 & 722 & 701 & 388 & 291 & 390 \\
\hline $\begin{array}{l}\text { Электроэнергия, } \\
\text { за } 1 \text { млн. кВт.ч }\end{array}$ & 16886 & 33157 & 54229 & 52209 & 49115 & 40201 & 35966 & 35681 \\
\hline $\begin{array}{l}\text { Удобрения минераль- } \\
\text { ные азотные: }\end{array}$ & & & & & & & & \\
\hline $\begin{array}{l}\text { в фризическом весе } \\
\text { в пересчете на } \\
\text { 100\% питательных }\end{array}$ & 57,9 & 140 & 198 & 281 & 268 & 231 & 169 & 181 \\
\hline $\begin{array}{l}\text { веществ } \\
\text { Удобрения минераль- } \\
\text { ные калийные: }\end{array}$ & 152 & 367 & 516 & 734 & 698 & 598 & 430 & 456 \\
\hline $\begin{array}{l}\text { в физическом весе } \\
\text { в пересчете на } \\
\text { 100\% питательных }\end{array}$ & 86,6 & 136 & 283 & 346 & 258 & 264 & 195 & 193 \\
\hline веществ & 143 & 225 & 469 & 562 & 424 & 436 & 321 & 317 \\
\hline $\begin{array}{l}\text { Удобрения минераль- } \\
\text { ные смешанные }\end{array}$ & 102 & 173 & 340 & 383 & 365 & 364 & 280 & 263 \\
\hline $\begin{array}{l}\text { Лесоматериалы } \\
\text { необработанные, за м }\end{array}$ & 43,4 & 59,7 & 87,3 & 86,6 & 85,5 & 70,0 & 68,0 & 76,3 \\
\hline Чугун передельный & 80,7 & 263 & 363 & 387 & 386 & 258 & 228 & 336 \\
\hline Медь & 1675 & 3456 & 7225 & 7342 & 6668 & 5487 & 4733 & 6207 \\
\hline Никель необработанный & 8627 & 13560 & 21773 & 15196 & 16309 & 11373 & 9158 & 10137 \\
\hline $\begin{array}{l}\text { Алюминий необрабо- } \\
\text { танный }\end{array}$ & 1296 & 1313 & 1813 & 1829 & 1819 & 1737 & 1397 & 1697 \\
\hline $\begin{array}{l}\text { Автомобили легковые, } \\
\text { за шт. }\end{array}$ & 3080 & 4604 & 7776 & 8168 & 13964 & 22108 & 23679 & 18551 \\
\hline $\begin{array}{l}\text { Автомобили грузовые, } \\
\text { за шт. }\end{array}$ & 13816 & 14913 & 42628 & 45995 & 36700 & 41845 & 34308 & 37240 \\
\hline
\end{tabular}




\subsection{3. СРЕДНИЕ ИМПОРТНЫЕ ЦЕНЫ НА ОСНОВНЫЕ ТОВАРЫ}

(долларов США за тонну)

\begin{tabular}{|c|c|c|c|c|c|c|c|c|}
\hline & 2000 & 2005 & 2010 & 2013 & 2014 & 2015 & 2016 & 2017 \\
\hline $\begin{array}{l}\text { Мясо свежее и моро- } \\
\text { женое (без мяса } \\
\text { птицы) }\end{array}$ & 1145 & 1460 & 2928 & 3932 & 4223 & 3322 & 2824 & 3211 \\
\hline $\begin{array}{l}\text { Мясо птицы свежее } \\
\text { и мороженое }\end{array}$ & 542 & 651 & 1367 & 1609 & 1764 & 1430 & 1412 & 1582 \\
\hline $\begin{array}{l}\text { Рыба свежая и } \\
\text { мороженая }\end{array}$ & 383 & 1039 & 2137 & 2999 & 2997 & 2562 & 2736 & 2658 \\
\hline $\begin{array}{l}\text { Масло сливочное } \\
\text { и прочие молочные } \\
\text { жиры }\end{array}$ & 1389 & 1845 & 3751 & 4835 & 4936 & 3245 & 3815 & 5365 \\
\hline $\begin{array}{l}\text { Цитрусовые плоды, } \\
\text { свежие или сушеные }\end{array}$ & 285 & 508 & 859 & 984 & 899 & 775 & 767 & 760 \\
\hline Koфpe & 1551 & 1789 & 3254 & 3598 & 3699 & 3263 & 3012 & 3369 \\
\hline Злаки & 118 & 170 & 522 & 418 & 563 & 439 & 334 & 484 \\
\hline $\begin{array}{l}\text { Масло подсолнеч- } \\
\text { ное, сафрлоровое } \\
\text { или хлопковое и их } \\
\text { фракции }\end{array}$ & 591 & 878 & 1042 & 1304 & 1256 & 1135 & 853 & 667 \\
\hline $\begin{array}{l}\text { Готовые или консер- } \\
\text { вированные продук- } \\
\text { ты из мяса }\end{array}$ & 1344 & 1724 & 4248 & 4761 & 4719 & 3738 & 3192 & 4236 \\
\hline Сахар-сырец & 152 & 257 & 555 & 484 & 420 & 378 & 426 & 644 \\
\hline Сахар белый & 297 & 428 & 745 & 598 & 628 & 364 & 533 & 475 \\
\hline $\begin{array}{l}\text { Руды и концентраты } \\
\text { алюминиевые }\end{array}$ & 50,8 & 68,9 & 285 & 210 & 198 & 161 & 140 & 344 \\
\hline $\begin{array}{l}\text { Обувь кожаная, } \\
\text { за пару }\end{array}$ & 12,7 & 14,9 & 22,6 & 25,1 & 26,4 & 23,9 & 28,3 & 29,9 \\
\hline $\begin{array}{l}\text { Трубы из черных } \\
\text { металлов }\end{array}$ & 535 & 1033 & 1398 & 1847 & 1738 & 1630 & 1485 & 1453 \\
\hline $\begin{array}{l}\text { Комбинированные } \\
\text { холодильники-моро- } \\
\text { зильники, за шт. }\end{array}$ & & 262 & 341 & 378 & 339 & 273 & 265 & 275 \\
\hline $\begin{array}{l}\text { Телефонные аппа- } \\
\text { раты для сотовых } \\
\text { сетей связи или дру- } \\
\text { гих беспроводных } \\
\text { сетей связи, за шт. }\end{array}$ & & & 74,0 & 87,8 & 92,5 & 69,3 & 89,6 & 113 \\
\hline $\begin{array}{l}\text { Автомобили легко- } \\
\text { вые, за шт. }\end{array}$ & 6259 & 9988 & 16234 & 19010 & 18693 & 18556 & 22578 & 25019 \\
\hline $\begin{array}{l}\text { Автомобили грузо- } \\
\text { вые, за шт. }\end{array}$ & 18127 & 20719 & 31234 & 33110 & 33696 & 37793 & 50872 & 62839 \\
\hline
\end{tabular}


25.24. СРЕДНИЕ ИМПОРТНЫЕ ЦЕНЫ НА ОСНОВНЫЕ ТОВАРЫ В ТОРГОВЛЕ СО СТРАНАМИ СНГ (долларов США за тонну)

\begin{tabular}{l|r|r|r|r|r|r|r|r}
\hline & 2000 & 2005 & 2010 & 2013 & 2014 & 2015 & 2016 & 2017 \\
\hline $\begin{array}{l}\text { Мясо свежее и моро- } \\
\text { женое (без мяса птицы) }\end{array}$ & 1284 & 2376 & 3550 & 3898 & 4179 & 2957 & 3020 & 3540 \\
Мясо птицы свежее & & & & & & & & \\
и мороженое & 814 & 1655 & 2024 & 2009 & 2279 & 1498 & 1492 & 1558 \\
Рыба свежая и моро- \\
женая
\end{tabular}

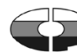


25.25. СРЕДНИЕ ИМПОРТНЫЕ ЦЕНЫ НА ОСНОВНЫЕ ТОВАРЫ В ТОРГОВЛЕ СО СТРАНАМИ ДАЛЬНЕГО ЗАРУБЕЖЬЯ

(долларов США за тонну)

\begin{tabular}{l|r|r|r|r|r|r|r|r}
\hline & 2000 & 2005 & 2010 & 2013 & 2014 & 2015 & 2016 & 2017 \\
\hline $\begin{array}{l}\text { Мясо свежее и моро- } \\
\text { женое (без мяса }\end{array}$ & & & & & & & & \\
птицы) & 1072 & 1355 & 2850 & 3936 & 4229 & 3436 & 2764 & 3123 \\
Мясо птицы свежее & & & & & & & & \\
и мороженое & 535 & 643 & 1328 & 1488 & 1608 & 1363 & 1325 & 1615 \\
Рыба свежая и мо- & & & & & & & & \\
роженая & 373 & 1053 & 2145 & 2988 & 2986 & 2575 & 2776 & 2683 \\
Масло сливочное и & & & & & & & & \\
прочие молочные & & & & & & & & \\
жиры & 1454 & 1891 & 3282 & 4587 & 4920 & 3586 & 3654 & 5150 \\
Цитрусовые плоды, & & & & & & & & \\
свежие или сушеные & 284 & 517 & 860 & 987 & 903 & 788 & 775 & 766 \\
Коре & 1521 & 1785 & 3250 & 3545 & 3696 & 3258 & 3006 & 3368 \\
Злаки & 159 & 237 & 630 & 681 & 916 & 925 & 859 & 853 \\
Масло подсолнеч- \\
ное, сафолоровое
\end{tabular}




\section{6. МЕЖДУНАРОДНЫЕ СРАВНЕНИЯ}

Раздел содержит показатели экономического и социального развития России в сравнении с зарубежными странами. Материалы подготовлены на основе статистических публикаций международных организаций (ООН, ОЭСР, Евростата, Статкомитета СНГ и др.) и национальных статистических органов. Данные по России и зарубежным странам приведены к сопоставимому виду с учетом особенностей расчета отдельных показателей в различных странах. Данные по ряду показателей зарубежных стран являются предварительными.

По большинству зарубежных стран индекс промышленного производства - агрегированный индекс по видам экономической деятельности (отраслям) «Горнодобывающая промышленность и разработка карьеров», «Обрабатывающая промышленность», «Снабжение электроэнергией, газом, паром и кондиционированным воздухом», «Водоснабжение, системы канализации, удаление отходов и меры по восстановлению окружающей среды» в соответствии с Международной стандартной отраслевой классификацией всех видов экономической деятельности (4-й пересмотренный вариант).

В целях обеспечения международных сопоставлений макроэкономических показателей, характеризующих уровень развития экономики, в конце 1960-х годов Статистическим отделом $\mathrm{OOH}$ в сотрудничестве с другими международными организациями, национальными статистическими службами и исследовательскими организациями был разработан Проект (с 1989 г. Программа) международных сопоставлений (ПМС ООН), который основан на расчете паритетов покупательной способности (ППС) национальных валют.

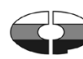


Пересчет ВВП по валютному курсу приводит к искажению данных за счет многих факторов: не все товары и услуги являются товарами внешней торговли, спрос и предложение на валюту не фрормируются целиком за счет внешней торговли товарами, разный уровень налогообложения в странах, ежедневные колебания валютного курса носят спекулятивный характер и т.п.

Предыдущие раунды ПМС проводились за базисные 1970, 1973, 1975, 1980, 1985, 2005 и 2011 гг. В связи с ростом числа участников сопоставлений с 1980 г. международные сопоставления проводятся по региональному принципу один раз в 3-5 лет. Европейские страны участвовали в Европейской программе сопоставлений (ЕПС, раунды 1980, 1985, 1990, 1993, 1996, 1999 гг.). С конца 90-х годов XX века большинство стран Европы стали членами EC, и сопоставления в ЕС, координируемые Евростатом, стали ежегодными в силу административного использования результатов сопоставлений. Неевропейские страны-члены ОЭСР оставались на трехлетнем цикле - 2002, 2005 , 2008, 2011, 2014 гг. В этой связи объединенные сопоставления ОЭСР - Евростата осуществлялись каждые 3 года. Начиная с данных за 2014 г. ОЭСР осуществляет внедрение годовых сопоставлений в силу расширения использования результатов сопоставлений, включая их административное использование.

Начиная с 1993 г. Российская Федерация участвовала в международных сопоставлениях ВВП за 1993, 1996, 1999, 2002, 2005, 2008, 2011 и 2014 годы. В настоящее время осуществляется участие России в годовых сопоставлениях ОЭСРЕвростата.

Одновременно в соответствии с решением Статистической комиссии ООН осуществляется Глобальный раунд ПМС за 2017 год.

Базовый подход международных макроэкономических сопоставлений заключается в следующем: 
1. ВВП каждой страны разбивается на ряд однородных товарных групп («первичные группы») по компонентам конечного использования (фактическое конечное потребление домашних хозяйств, фрактическое конечное потребление государственного управления, валовое накопление основного капитала, изменение запасов материальных оборотных средств и чистое приобретение ценностей, чистый экспорт товаров и услуг). В сопоставлениях ОЭСР - Евростата выделяются 202 первичные группы, в сопоставлениях стран-участников СНГ - 183 первичные группы, в Глобальном раунде сопоставлений - 155 первичных групп.

2. В рамках каждой товарной группы производится регистрация национальных цен на отобранные репрезентативные товары и услуги по согласованному списку товаров-представителей. Согласно процедуре каждой стране предлагается включить в перечень продуктов для каждой первичной группы по меньшей мере один продукт, репрезентативный для структуры ее национального потребления. При расчете паритетов первичных групп учитывается информация о характерности для внутреннего рынка товаров-представителей. Окончательный список товаровпредставителей в сопоставлениях за 2014 г. включал около 3000 наименований потребительских и инвестиционных товаров и услуг. Для расчета ППС на уровне первичных групп соотношения цен на эти отдельные товары в различных странах подвергаются агрегированию. Затем эти ППС взвешиваются с использованием весов структуры расходов для расчета ППС по всем уровням агрегирования, вплоть до уровня ВВП. Используемая методология расчетов результатов сопоставлений позволяет получать результаты сопоставлений, независимые от выбора счетной единицы (денежной единицы) и базовой страны.

3. Стоимостные показатели конечных расходов по ВВП в национальной валюте по всем уровням агрегирования пере-

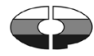


считываются в «международно-сопоставимые» показатели с помощью соответствующих ППС.

В рамках проведения международных сопоставлений ВВП рассчитывается несколько показателей.

Одними из основных показателей являются паритеты покупательной способности (ППС). В своей самой простейшей форме ППС являются соотношениями цен. ППС рассчитываются не только по индивидуальным продуктам, но также по группам продуктов и по каждому из различных уровней агрегирования расходов, вплоть до уровня ВВП. Тем не менее, они попрежнему являются соотношениями цен, будь то на уровне групп продуктов, агрегатов или ВВП. ППС являются одновременно и дефляторами, и инструментами пересчета стоимостных показателей в национальной валюте в единую валюту. Например, если цена 1 Биг Мака в России составляет 130 российских рублей и в США - 5,3 долларов, то ППС Биг Мака между Россией и США равен соотношению 130/5,3 или 24,53 российских рубля за 1 доллар США. Это означает, что за каждый доллар США, потраченный в США за Биг Мак, нужно потратить 24,53 рубля в России, чтобы получить одинаковое количество Биг Мака. Соответственно, если на уровне ВВП ППС между Россией и США в 2014 г. составляет 21,01 рублей за 1 доллар, то нужно потратить 21,01 рублей в России и 1 доллар в США, чтобы купить одинаковое количество товаров и услуг. В сопоставлениях ОЭСР - Евростата ППС традиционно выражаются в долларах, в Европейском союзе в стандарте покупательной силы (СПС) (эквивалентно евро).

Для выявления «более дешевых» или «более дорогих» стран рассчитывается сопоставимый уровень цен как отношение ППС к валютному курсу. Сопоставимые уровни цен рассчитываются по каждому компоненту расходов ВВП. Этот показатель применяется при разделении стран на «дешевые» 
(с низкими значениями показателя) и «дорогие» (с высоким национальным уровнем цен). Этим показателем широко пользуются туристы на бытовом уровне. Выявлена закономерность, что более высоким значениям ВВП на душу населения соответствуют более высокие сопоставимые уровни цен.

Показатели индексы физического объема ВВП и физического объема ВВП на душу населения представляют собой соответственно отношение ВВП и отношение ВВП на душу населения сопоставляемой страны к ВВП и к ВВП на душу населения базовой страны (группы стран). Стоимостные показатели в национальной валюте пересчитываются с помощью паритетов покупательной способности в реальные величины.

Результаты сопоставлений рассчитываются и публикуются международными организациями после их согласования со странами-участницами.

В сборнике приведены уточненные оценки ВВП Российской Федерации, осуществленные ОЭСР при проведении годовых сопоставлений.

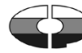




\section{1. СРАВНИТЕЛЬНЫЕ ДАННЫЕ ПО НЕКОТОРЫМ СТРАНАМ МИРА ${ }^{1)}$}

\begin{tabular}{|c|c|c|c|c|c|c|c|}
\hline & $\begin{array}{c}\text { Средне- } \\
\text { годовая } \\
\text { числен- } \\
\text { ность на- } \\
\text { селения }{ }^{2)} \text {, } \\
\text { млн. } \\
\text { человек }\end{array}$ & $\begin{array}{c}\text { Числен- } \\
\text { ность } \\
\text { занятых, } \\
\text { млн. } \\
\text { человек }\end{array}$ & $\begin{array}{c}\text { Валовой } \\
\text { внутрен- } \\
\text { ний про- } \\
\text { дукт }^{3)} \\
2010=100\end{array}$ & \begin{tabular}{|c|} 
Индекс \\
расходов \\
на конеч- \\
ное по- \\
требле- \\
ние до- \\
машних \\
хозяйств \\
$2010=100$ \\
\end{tabular} & \begin{tabular}{|c|} 
Индекс \\
промыш- \\
ленного \\
произ- \\
водства \\
$2010=100$
\end{tabular} & \begin{tabular}{|c|} 
Индекс \\
произ- \\
водства \\
продук- \\
ции сель- \\
ского хо- \\
зяйства \\
$2010=100$
\end{tabular} & $\begin{array}{c}\text { Индекс } \\
\text { потреби- } \\
\text { тельских } \\
\text { цен } \\
2010=100\end{array}$ \\
\hline Россия & 146,8 & 72,3 & $105,0^{4)}$ & $105,5^{4)}$ & $113,4^{5)}$ & 141,1 & 168,2 \\
\hline $\begin{array}{c}\text { Страны СНГ } \\
\text { из них: } \\
\text { Азербай- } \\
\text { джан }\end{array}$ & 9,9 & 4.8 & 109 & $152^{6)}$ & 92 & 131 & 150 \\
\hline Армения & 3,0 & 1,0 & $119^{7 ; 8)}$ & $101^{7 ; 8)}$ & 172 & 144 & 124 \\
\hline Беларусь & 9,5 & 4,9 & $106^{7)}$ & $124^{6 ; 7)}$ & 111 & 118 & 459 \\
\hline Казахстан & 18,0 & 8,6 & $132^{7)}$ & $144^{7)}$ & 112 & 129 & 169 \\
\hline $\begin{array}{l}\text { Киргизия } \\
\text { Республика }\end{array}$ & 6,2 & & 138 & 138 & 133 & 118 & 152 \\
\hline Молдова ${ }^{9}{ }^{2}$ & 3,5 & 1,2 & 132 & 129 & 135 & 138 & 154 \\
\hline Таджикистан & 8,8 & & 161 & $144^{6)}$ & 200 & 155 & 159 \\
\hline Узбекистан & 32,4 & 13,5 & 167 & & 167 & 152 & 160 \\
\hline Украина & 42,3 & 16,2 & $93^{7)}$ & $107^{7)}$ & 83 & 231 & 235 \\
\hline $\begin{array}{l}\text { Страны } \\
\text { БРИКС }\end{array}$ & & & & & & & \\
\hline $\begin{array}{c}\text { из них: } \\
\text { Бразилия }\end{array}$ & 206,1 & $\ldots$ & 102 & $108^{10)}$ & 83 & 111 & 150 \\
\hline Индия & 1269 & & 148 & $151^{10)}$ & $120^{11)}$ & 117 & 155 \\
\hline Китай & 1379 & & 156 & $164^{10)}$ & - & 116 & 117 \\
\hline & & & & & & & \\
\hline $\begin{array}{l}\text { ская Рес- } \\
\text { публика }\end{array}$ & 55,9 & 16,4 & 112 & $115^{10)}$ & $\cdots$ & 99,9 & 139 \\
\hline $\begin{array}{c}\text { Страны EC } \\
\text { из них: }\end{array}$ & & & & & & & \\
\hline Австрия & 8,7 & 4,2 & 107 & 103 & 113 & 102 & 112 \\
\hline Бельгия & 11,3 & 4,6 & 106 & 105 & 109 & 101 & 111 \\
\hline Болгария & 7,2 & 3,0 & 112 & 112 & $110^{12)}$ & 108 & 106 \\
\hline Венгрия & 9,8 & 4,4 & 112 & 110 & 122 & 110 & 112 \\
\hline Германия & 82,2 & 41,3 & 110 & 108 & 112 & 104 & 107 \\
\hline Греция & 10,8 & 3,7 & 82 & 82 & 91 & 99 & 99,9 \\
\hline Дания & 5,7 & 2,8 & 107 & 106 & 108 & 100,1 & 107 \\
\hline Ирландия & 4,7 & 2,1 & 144 & 107 & 160 & 108 & 105 \\
\hline Испания & 46,4 & 18,3 & 102 & 98 & 97 & 100,4 & 106 \\
\hline Италия & 60,7 & 22,8 & 98 & 97 & 94 & 94 & 107 \\
\hline Нидерланды & 17,0 & 8,4 & 106 & 102 & 95 & 106 & 110 \\
\hline Польша & 38,0 & 16,2 & 119 & 115 & 123 & 112 & 108 \\
\hline Португалия & 10,3 & 4,6 & 97 & 96 & 99 & 103 & 108 \\
\hline
\end{tabular}


Продолжение табл. 26.1

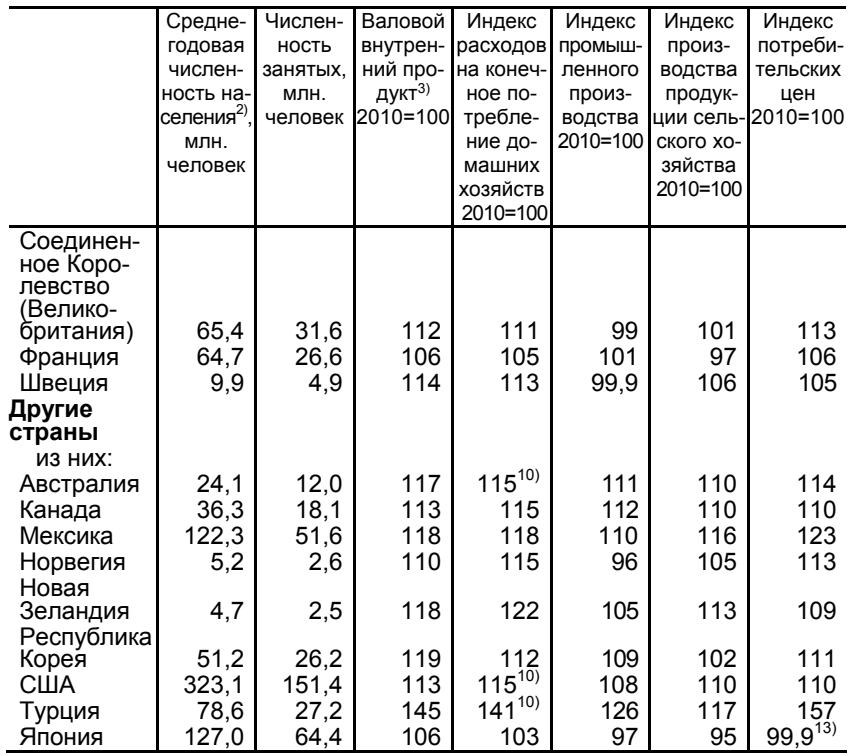

1) По России и странам СНГ данные приведены за 2017 г. По другим странам данные представлены за 2016 г.

2) По большинству стран приведена численность постоянного населения.

3) При расчете индексов валового внутреннего продукта (ВВП) использованы данные Организации экономического сотрудничества и развития (ОЭСР), Международного валютного фонда, Статкомитета СНГ, а также данные национальных источников.

4) $2011=100$. См. Сноску на стр. 179.

5) Агрегированный индекс производства по видам экономической деятельности «Добыча полезных ископаемых», "Обрабатывающие производства», "Обеспечение электрической энергией, газом и паром; кондиционирование воздуха», «Водоснабжение; водоотведение, организация сбора и утилизации отходов, деятельность по ликвидации загрязнений» (ОКВЭД2).

6) Данные за 2016 г.

7) С учетом отдельных положений СНС 2008.

${ }^{8)}$ В \% к 2012 г.

9) Без данных по территории левобережья р. Днестр и г. Бендеры.

10) Индекс расходов на конечное потребление домашних хозяйств и некоммерческих организаций, обслуживающих домашние хозяйства.

11) Агрегированный индекс производства по видам экономической деятельности (отраслям) «Горнодобывающая промышленность и разработка карьеров», «Обрабатывающая промышленность», «Электроэнергия, газ и водоснабжение».

12) 2015 г. в \% к 2010 г.

13) $2015=100$. 


\section{2. МЕСТО, ЗАНИМАЕМОЕ РОССИЕЙ В МИРЕ ПО ПРОИЗВОДСТВУ ОТДЕЛЬНЫХ ВИДОВ ПРОМЫШЛЕННОЙ И СЕЛЬСКОХОЗЯЙСТВЕННОЙ ПРОДУКЦИИ В 2016 Г.}

\begin{tabular}{l|c}
\hline \multicolumn{1}{c|}{ ииды промышленной } & $\begin{array}{c}\text { Место, } \\
\text { занимаемое } \\
\text { Россией }\end{array}$ \\
\hline Сахарная свекла & 1 \\
Нефть добытая (включая газовый конденсат), & 2 \\
газ природный и попутный & 3 \\
Картофель & \\
Электроэнергия, чугун, зерновые и зернобобовые & 4 \\
культуры, скот и птица на убой (в убойном весе) & 5 \\
Сталь, вывозка древесины & 6 \\
Уголь, молоко коровье & 7 \\
Хлопчатобумажные ткани & 8 \\
Цементы гидравлические & 12 \\
Шерстяные ткани, обувь с верхом из кожи & 13 \\
Бумага и картон & 14 \\
Легковые автомобили (включая сборку) & \\
\hline
\end{tabular}

26.3. ЕЖЕГОДНЫЕ ОЦЕНКИ ОТДЕЛЬНЫХ ПОКАЗАТЕЛЕЙ ВВП В СОПОСТАВИМОЙ ВАЛЮТЕ ${ }^{1)}$

\begin{tabular}{|c|c|c|c|c|c|c|c|c|c|}
\hline & \multicolumn{3}{|c|}{$\begin{array}{c}\text { Паритет } \\
\text { покупательной } \\
\text { способности } \\
\text { (единиц националь- } \\
\text { ной валюты } \\
\text { за доллар США) }\end{array}$} & \multicolumn{3}{|c|}{$\begin{array}{c}\text { ВВП по ППС } \\
\text { (млрд. долларов } \\
\text { США) }\end{array}$} & \multicolumn{3}{|c|}{$\begin{array}{c}\text { ВВП по ППС } \\
\text { на душу населения } \\
\text { (долларов США) }\end{array}$} \\
\hline & 2014 & 2015 & 2016 & 2014 & 2015 & 2016 & 2014 & 2015 & 2016 \\
\hline $\begin{array}{l}\text { Россия } \\
\text { Страны БРИКС } \\
\text { из них: }\end{array}$ & 21,01 & 23,02 & 23,67 & 3768,8 & 3621,7 & 3640,3 & 25797 & 24738 & 24819 \\
\hline Бразилия & 1,751 & 1,866 & 1,996 & 3300,2 & 3216,6 & 3140,5 & 16160 & 15617 & 15124 \\
\hline Индия & 16,97 & 17,06 & 17,45 & 7331,9 & 8021,0 & 8700,6 & 5667 & 6127 & 6571 \\
\hline $\begin{array}{l}\text { Китай } \\
\text { Южно- } \\
\text { Африканская }\end{array}$ & 3,519 & 3,478 & 3,476 & 18300,1 & 19814,3 & 21409,4 & 13414 & 14450 & 15529 \\
\hline $\begin{array}{c}\text { Республика } \\
\text { Страны ЕС } \\
\text { из них: }\end{array}$ & 5,367 & 5,564 & 5,879 & 709,4 & 727,9 & 739,2 & 13008 & 13164 & 13197 \\
\hline Австрия & 0,799 & 0,799 & 0,800 & 417,0 & 431,1 & 441,4 & 48801 & 49959 & 50503 \\
\hline Бельгия & 0,800 & 0,801 & 0,804 & 500,2 & 512,2 & 526,4 & 44743 & 45577 & 46607 \\
\hline Венгрия & 129,4 & 133,4 & 135,2 & 251,8 & 257,4 & 262,0 & 25525 & 26148 & 26701 \\
\hline Германия & 0,769 & 0,779 & 0,780 & 3813,7 & 3905,5 & 4030,4 & 47092 & 47811 & 48943 \\
\hline Греция & 0,611 & 0,610 & 0,604 & 292,3 & 288,9 & 288,4 & 26839 & 26697 & 26765 \\
\hline Дания & 7,329 & 7,328 & 7,356 & 270,3 & 276,6 & 280,8 & 47905 & 48688 & 49021 \\
\hline Ирландия & 0,819 & 0,813 & 0,812 & 237,5 & 322,4 & 339,5 & 51468 & 69459 & 72485 \\
\hline Испания & 0,662 & 0,668 & 0,663 & $\mid 1566,9$ & $\mid$ | 1617,1 & \begin{tabular}{|l|}
1687,6 \\
\end{tabular} & 33728 & 34844 & 36332 \\
\hline
\end{tabular}


Продолжение табл. 26.3

\begin{tabular}{|c|c|c|c|c|c|c|c|c|c|}
\hline & \multicolumn{3}{|c|}{$\begin{array}{c}\text { Паритет } \\
\text { покупательной } \\
\text { способности } \\
\text { (единиц националь- } \\
\text { ной валюты } \\
\text { за доллар США) }\end{array}$} & \multicolumn{3}{|c|}{$\begin{array}{c}\text { ВВП по ППС } \\
\text { (млрд. долларов } \\
\text { США) }\end{array}$} & \multicolumn{3}{|c|}{$\begin{array}{c}\text { ВВП по ППС } \\
\text { на душу населения } \\
\text { (долларов США) }\end{array}$} \\
\hline & 2014 & 2015 & 2016 & 2014 & 2015 & 2016 & 2014 & 2015 & 2016 \\
\hline Италия & 0,740 & 0,743 & 0,722 & 2192,7 & 2225,2 & 2326,9 & 36071 & 36640 & 38380 \\
\hline Латвия & 0,498 & 0,502 & 0,497 & 47,5 & 48,5 & 50,1 & 23802 & 24513 & 25589 \\
\hline Литва & 0,443 & 0,448 & 0,451 & 82,6 & 83,6 & 85,7 & 28174 & 28784 & 29862 \\
\hline Люксембург & 0,884 & 0,892 & 0,889 & 56,5 & 58,4 & 59,6 & 101275 & 102554 & 102019 \\
\hline Нидерланды & 0,809 & 0,815 & 0,816 & 819,7 & 839,0 & 860,7 & 48612 & 49551 & 50551 \\
\hline Польша & 1,767 & 1,781 & 1,788 & 973,2 & 1010,2 & 1039,7 & 25288 & 26271 & 27058 \\
\hline Португалия & 0,579 & 0,588 & 0,586 & 299,0 & 305,9 & 316,6 & 28747 & 29532 & 30658 \\
\hline Словакия & 0,485 & 0,493 & 0,491 & 156,7 & 160,1 & 165,4 & 28928 & 29530 & 30460 \\
\hline Словения & 0,591 & 0,598 & 0,598 & 63,6 & 64,9 & 67,6 & 30857 & 31472 & 32730 \\
\hline $\begin{array}{l}\text { Соединенное } \\
\text { Королевство } \\
\text { (Великобрита- }\end{array}$ & & & & & & & & & \\
\hline ния) & 0,698 & 0,697 & 0,702 & 2630,2 & 2708,0 & 2798,1 & 40717 & 41592 & 42622 \\
\hline Финляндия & 0,907 & 0,909 & 0,905 & 226,5 & 230,5 & 238,4 & 41463 & 42064 & 43378 \\
\hline Франция & 0,808 & 0,814 & 0,806 & 2659,4 & 2696,2 & 2765,5 & 40117 & 40489 & 41364 \\
\hline Чехия & 12,70 & 13,02 & 13,00 & 339,6 & 353,0 & 367,2 & 32265 & 33479 & 34753 \\
\hline Швеция & 8,727 & 8,949 & 9,077 & 451,1 & 469,3 & 485,3 & 46524 & 47891 & 48853 \\
\hline Эстония & 0,527 & 0,539 & 0,539 & 37,5 & 37,7 & 39,1 & 28511 & 28735 & 29741 \\
\hline $\begin{array}{l}\text { Другие страны } \\
\text { из них: }\end{array}$ & & & & & & & & & \\
\hline Австралия & 1,452 & 1,471 & 1,486 & 1116,3 & 1128,4 & 1181,2 & 46921 & 46761 & 48178 \\
\hline Израиль & 3,940 & 3,865 & 3,833 & 280,0 & 300,8 & 318,4 & 34101 & 35902 & 37270 \\
\hline Исландия & 138,5 & 142,2 & 144,1 & 14,6 & 15,7 & 17,0 & 44544 & 47502 & 50752 \\
\hline Канада & 1,230 & 1,247 & 1,252 & 1617,6 & 1599,8 & 1625,4 & 45508 & 44627 & 44793 \\
\hline Мексика & 8,045 & 8,541 & 8,869 & 2171,6 & 2170,3 & 2266,4 & 18140 & 17935 & 18535 \\
\hline Новая & & & & & & & & & \\
\hline Зеландия & 1,441 & 1,464 & 1,468 & 169,1 & 175,1 & 181,0 & 37301 & 37879 & 38346 \\
\hline $\begin{array}{l}\text { Норвегия } \\
\text { Республика }\end{array}$ & 9,278 & 9,733 & 10,13 & 339,1 & 320,4 & 307,8 & 66018 & 61713 & 58792 \\
\hline Корея & 871,9 & 870,9 & 874,6 & 1704,5 & 1795,9 & 1872,1 & 33587 & 35204 & 36532 \\
\hline США & 1,000 & 1,000 & 1,000 & 17427,6 & 18120,7 & 18624,5 & 54651 & 56420 & 57591 \\
\hline Турция & 1,105 & 1,203 & 1,299 & 1851,0 & 1944,6 & 2007,5 & 24159 & 25112 & 25655 \\
\hline Чили & 367,2 & 394,3 & 402,6 & 405,4 & 402,3 & 415,4 & 22727 & 22294 & 22727 \\
\hline Швейцария & 1,282 & 1,240 & 1,232 & 506,9 & 527,2 & 534,9 & 61902 & 63648 & 63889 \\
\hline Япония & 103,1 & 102,8 & 100,3 & 4986,6 & 5176,8 & 5369,5 & 39183 & 40727 & 42293 \\
\hline
\end{tabular}




\title{
РОССИЯ В ЦИФРАХ. 2018 \\ Краткий статистический сборник
}

\author{
Ответственные за выпуск: \\ Н.С. Бугакова \\ И.В. Воронина \\ Т.А. Михайлова \\ Тел.: (495) 607-4071 \\ $632-9224$ \\ $632-9221$
}

Компьютерная верстка Информационно-издательского

центра «Статистика России»

Подписано в печать 29.05.2018 г.

Формат $70 \times 901 / 32$

Печать офсетная

Тираж 460 экз.
Гарнитура журн.- рубл.

Объем 16,4 п.л.

Заказ №

Отпечатано в типографии «Август Борг»

107497, Москва, ул. Амурская, 5, стр. 2 


\section{ОФИЦИАЛЬНЫЕ СТАТИСТИЧЕСКИЕ ИЗДАНИЯ РОССТАТА 2018*}

\section{Периодические издания}

Статистическое обозрение (журнал на русском языке; 2 раза в год)

Статистическое обозрение (журнал на английском языке; 2 раза в год)

Информация о социально-экономическом положении России

(ежемесячный краткий доклад)

Социально-экономическое положение России (ежемесячный доклад)

Социально-экономическое положение федеральных округов

(ежеквартальный бюллетень)

Вопросы статистики (ежемесячный научно-информационный журнал)

\section{Статистические сборники}

Рабочая сила, занятость и безработица в России

(по результатам выборочных обследований)

Цены в России

Строительство в России

Транспорт в России

Охрана окружающей среды в России

Беларусь и Россия

Россия и страны мира

Российский статистический ежегодник (на русском и английском языках)

Женщины и мужчины России

Финансы России

Регионы России. Социально-экономические показатели

Регионы России. Основные характеристики субъектов Российской

Федерации

Регионы России. Основные социально-экономические показатели городов

В 2018 году официальные статистические издания Росстата, кроме сборников «Россия в цифрах», «Российский статистический ежегодник» и журнала «Вопросы статистики», выпущены только в электронном виде.

Более подробную информацию об изданиях Росстата и условиях их приобретения Вы можете получить в Информационно-издательском центре "Cтатистика России»:

Россия, 107450, г. Москва,

ул. Мясницкая, 39, стр.1

Телефон: (495) 607-4941, 607-4252

Факс: (495) 607-4941

E-mail: shop@infostat.ru 